\title{
A Cultural Approach to Foreign Policy Analysis: The Role of Political Ideologies in Shaping Israeli Policy Toward the Peace Process
}

by

Hamed Mousavi

A thesis submitted to the Faculty of Graduate and Post Doctoral Affairs in partial fulfillment of the requirements for the degree of

\author{
Doctor of Philosophy \\ in \\ Political Science
}

\author{
Carleton University \\ Ottawa, Ontario \\ (C)2015 \\ Hamed Mousavi
}




\section{Abstract}

Why was Israeli policy toward the peace process in the 1990s conflicted, inconsistent and even erratic? This study suggests that in order to understand Israeli foreign policy, we must analyze the country's domestic political movements. The dissertation takes a theoretically informed approach, which seeks to 'bring back' ideology to cultural frameworks of foreign policy analysis, to examine the Israeli case. The study argues that the political movements within Israel interpreted and reacted differently to the regional and global developments of the 1980 s and early 1990 s. These various perspectives were due to the fact that the ideologies of these movements were constructed in relation and opposition to each other, and as a result they differed on what it meant to be "Israeli," as well as what they considered the "national interest." Both the rise and the fall of the peace process should be seen as part of a larger ideological struggle between the Labor movement on the one hand and the religious and revisionist Zionist movements on the other, each of which sought to redefine Zionism and Israel in its own image and according to its own ideology. Israel's drive to peace in the early nineteen nineties was the result of the interaction between a new liberal Zionist ideology of the Labor movement and regional and global developments. In contrast the religious Zionist movement saw the peace process as part of the "Hellenization" of Israeli state and society and the abortion of the "divine redemptive process." The revisionists also opposed the peace process based on the movement's ideology that portrayed Israel as an isolated and vulnerable nation, which could only rely on military power, rather than 
political agreements, against an "anti-Semitic" and hostile gentile world. The shifts in Israeli foreign policy in the nineteen nineties were thus the result of the confrontation between these contrasting worldviews. 


\section{Acknowledgements}

One of the propositions of this dissertation is that ideas are not formed in vacuums. This project is the result of my time at Carleton and the knowledge imparted to me by its experienced faculty members. I am greatly indebted to my committee members who provided invaluable ideas and suggestions throughout the research process. First and foremost I would like to thank my supervisor Dr. Mira Sucharov who not only helped me learn the ins and outs of Israeli politics but also was always available for support and advice. Our lengthy and engaging discussions helped me clarify my arguments and prevented me from drifting off course. In fact it was her constant exhortations to "stay focused" that helped me finish the dissertation in a timely manner. The number of graduate students $\mathrm{Dr}$ Sucharov is currently supervising is a testament to her reputation as a "great supervisor" in the faculty. Dr. Elinor Sloan provided very useful criticism of my theoretical framework and helped me formulate my research question and plan the research process. Dr. Farhang Rajaee not only gave valuable feedback on the dissertation but also on numerous occasions provided me with guidance and support on how to survive and thrive in the academic world. I would also like to thank Dr. Hans-Martin Jaeger who was always available to chat about IR theory and world politics.

None of this would have been possible without the loving support of my wife Fatemeh. She was the source of my sustenance through long research hours, which according to her would turn me into a "zombie." Her constant "you can do it" reminders was what helped me plow through. Finally I would like to 
thank my baby daughter Zainab. When she was born nine months ago my world lit up like never before! 


\section{Table of Contents}

Chapter 1: Introduction

Question and Thesis 12

$\begin{array}{ll}\text { Theory and Methodology } & 14\end{array}$

Israeli Identity and Political Ideologies $\quad 20$

The Construction of the Israeli Identity 20

$\begin{array}{ll}\text { Labor Zionism } & 25\end{array}$

$\begin{array}{ll}\text { Revisionist Zionism } & 29\end{array}$

Religious Zionism 34

Israeli Public Opinion 38

Plan of Dissertation 40

Chapter 2: Theoretical Framework 43

The Limits of Realist IR Theory 43

Cultural Approaches to Foreign Policy Analysis 51

A New Cultural Approach to Foreign Policy Analysis 60

The Inter-Relational Character of Ideological Identities 62

Ideology as a Lens Into the World 64

Political Crisis and Ideological Change $\quad 65$

The Contested Nature of Ideological Change 68

Where Does Ideology Reside? $\quad 69$

The Influence of Public Opinion $\quad 70$

$\begin{array}{ll}\text { Rhetoric Change and Ideological Transformation } & 72\end{array}$

$\begin{array}{ll}\text { Pragmatism Vs. Realist IR Theory } & 73\end{array}$

The Impact of External Factors on Domestic Ideologies 75 
The Consequences of Foreign Policy on Domestic Ideologies

Theoretical Contributions

Chapter 3: The Hegemony of Labor Zionism and the Creation of the Sabra

Negating "Exile" $\quad 81$

The Creation of the Sabra $\quad 83$

$\begin{array}{ll}\text { Indoctrination Through Education } & 88\end{array}$

Identity Formation Through Military Service 95

$\begin{array}{ll}\text { The Yishuv and the Holocaust } & 101\end{array}$

$\begin{array}{ll}\text { Labor's hegemony } & 103\end{array}$

$\begin{array}{ll}\text { The Pioneers of the Yishuv } & 106\end{array}$

The Power of the Union 110

Dominance of Educational and Military Institutions 113

$\begin{array}{ll}\text { The Lack of Strong Rivals } & 119\end{array}$

$\begin{array}{ll}\text { Labor's Foreign Policy } & 127\end{array}$

$\begin{array}{ll}\text { The Primacy of Security } & 127\end{array}$

Self-Reliance and Independence 132

$\begin{array}{ll}\text { Pragmatism } & 137\end{array}$

$\begin{array}{ll}\text { Favoring Partition } & 142\end{array}$

$\begin{array}{ll}\text { Conclusion } & 150\end{array}$

Chapter 4: The Rise of Israel's Right 156

$\begin{array}{ll}\text { Revisionist ldeology } & 157\end{array}$

The Principle of Monism 158

$\begin{array}{ll}\text { The Primacy of Militarism } & 161\end{array}$

$\begin{array}{ll}\text { Opposition to partition } & 167\end{array}$ 
The Failures of Revisionist Zionism in the Yishuv

The Decline of Labor 180

The Holocaust and 'Negating the Exile' 181

The New Immigrants 186

The Advent of Western Individualism and Multiculturalism in Israeli Society

The Yom Kippur War and the Decline of 'Mamlachtiut' 193

From Fringe to Center: The Transformation of Revisionist Ideology 195

The 1967 War and the Rise of Israel's Right 202

The Ascendance of Messianic Religious Zionism 212

Messianic Zionism and Rabbi Kook 218

Messianic Zionism and the Six-Day War 223

$\begin{array}{ll}\text { Conclusion } & 229\end{array}$

Chapter 5: The Road to Oslo 236

Gush Emunim: The 'New Zionists' 237

$\begin{array}{ll}\text { Pioneering and Collectivity } & 242\end{array}$

Religiosity 246

Ties to the land 248

The People of Israel Are Not 'Normal' 252

Morality Subservient to the Larger Cause 258

The Reasons Behind the Gush's Success 261

Labor: From a State of Crisis to the Rise of the 'Peace Movement' 270

Labor's Instrumentalist Approach to the Captured Territories 270

Labor's 'End of Zionism' Crisis and the Need for a New Ideological Message 
The Rise of the Peace Movement Within Labor

The Reification of the Two Camps 285

The 1982 War of Lebanon 285

The Jewish Underground $\quad 292$

$\begin{array}{ll}\text { The Palestinian Intifada } & 297\end{array}$

$\begin{array}{ll}\text { Conclusion } & 305\end{array}$

Chapter 6: The Rise and Fall of The Peace Process 311

The Rabin Government and the Oslo Peace Process 312

$\begin{array}{ll}\text { The } 1992 \text { Elections } & 312\end{array}$

A New Balance of Power or a New Liberal Zionist Identity? 317

Labor's New Liberal Ideology 324

The Interaction Between Political Identity and External Events 332

The New liberal Zionist Identity and Palestinian Rights 334

The Polarization of Israeli Society 339

The Fall of the Peace Process: Religious Zionists and the Rabin Government

Shimon Peres and the Settlers 375

The Emergence of a New Political Actor: Israel's ultra-Orthodox Community and the Peace Process

Oslo and the Ideological Crisis of Revisionist Zionism 386

The 96 Elections and the Change in Revisionist Rhetoric 390

Netanyahu's One Step Forward, Two Steps Back Approach 396

The Ideological Dilemma of the Revisionist Zionist Movement 402

The Fundamental Differences Between Revisionist and Religious Zionist Views of the Territories and the Peace Process 
Labor: From Militarism to Peace

Revisionist Zionism: From Ideological 'Purity' to Ideological Crisis

Religious Zionism: The Persistence of a Messianic Ideology

The Merits of 'Bringing Back' Ideology Into Foreign Policy Analysis 


\section{Table of Figures}

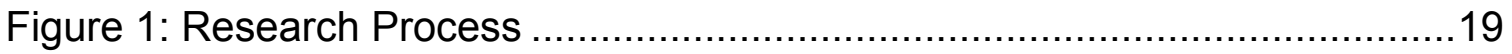

Figure 2: A New Cultural Approach to Foreign Policy Analysis .........................61

Figure 3: Opinion Regarding the Oslo Accords Based on Political Movements 344

Figure 4: Haredi Vs. Religious Zionist Opposition to the Peace Process ...........383

Figure 5: Revisionist Zionist Opposition to the Peace Process .......................408

Figure 6: The Evolution of Labor Zionist Ideology .......................................430

Figure 7: The Evolution of Revisionist Zionist Ideology ..................................433

Figure 8: The Evolution of Religious Zionist Ideology ....................................439

Figure 9: Opposition to the Peace Process ……............................................457 


\section{Chapter 1: Introduction}

This dissertation analyzes Israeli foreign policy towards the peace process using a cultural approach that pays special attention to the role of political ideologies in shaping government policy. Doing so will serve a double objective: first, to explain and analyze Israeli foreign policy; and second, to contribute to the development of cultural theories of foreign policy, using Israel as a case study. To achieve this, the construction of Israeli identities and the evolution of the political ideologies of the Labor, Revisionist and Religious Zionist movements are studied.

The Middle East is arguably the most volatile and yet the most strategic region of the $21^{\text {st }}$ century. It is a main source of the globe's energy needs and at the same time it has been plagued by instability and war. Israel is one of the region's powerhouses and is a close ally of the United States. Nevertheless understanding and analyzing Israeli foreign policy has been challenging for Western scholars. ${ }^{1}$ This has been particularly the case with the rise and fall of the 'peace process' in the last two decades. Israel made a sharp turn in its policy on Palestinian nationalism and statehood by recognizing the PLO and engaging in the Oslo negotiations in the early nineties, leading to optimistic analysis on the chances for peace. However with the rise of right wing Israeli political parties in

\footnotetext{
${ }^{1}$ See Raymond Cohen, "Israel's Starry-Eyed Foreign Policy," Middle East Quarterly 1, no. 2 (June 1994).
} 
subsequent years, the country's policy largely went back to its former prenegotiation position. These developments have also negatively affected the country's relationship with the United States, making it "dysfunctional" in the last few years according to one senior American diplomat. ${ }^{2}$

IR scholars have offered various explanations for the puzzling changes in Israeli foreign policy. Jonathan Rynhold argues that a cultural shift towards postmaterialism that led to the rise of a new generation of Israeli Left was the primary driving factor in the country's decision to pursue a negotiated settlement. This rise resulted in the success of the Labor party in the 1992 elections, giving the new Left an opportunity to change the country's foreign policy. Rynhold explains the collapse of the peace process as the effects of "domestic and international constraints," which eventually led to the marginalization of the liberal Left, ${ }^{3}$ although a sufficient description of these constraints is not provided.

Arie Kacowicz explains the rise and fall of the peace process by examining the conflicting narratives of both the Israelis and the Palestinians. Narratives shape identities and norms, creating self-fulfilling prophecies that provide a moral justification to the actions of each party. From the Israeli side the narrative was that territory and political authority was being relinquished to the Palestinians in exchange for security, however with the onset of suicide

2 See Lee Smith, "Have Obama and Bibi Made Up?," December 5, 2012, http://www.tabletmag.com/jewish-news-and-politics/118288/have-obama-and-bibi-made-up.

${ }^{3}$ See Jonathan Rynhold, "Cultural Shift and Foreign Policy Change: Israel and the Making of the Oslo Accords," Cooperation and Conflict 42 (2007): 419-40. 
bombings this narrative was replaced with the "myth that 'Barak gave them [the Palestinians] almost everything and Arafat responded with terror,"' as one Israeli negotiator in the Oslo process put it. According to Kacowicz this has become one of the deepest narratives in Israel, ultimately informing and legitimizing the actions of decision makers. ${ }^{4}$

Michael Barnett has argued that Israel's embrace of the Oslo accords was due to the construction of a new Israeli identity that was tied to the peace process, and that the fall of the process has been due to an "identity crisis in Israeli politics." Barnett also brings in institutional factors such as Israel's proportional representation parliamentary system and the need to build coalitions with smaller parties into the equation. He argues that an important electoral reform introduced in 1996, which for the first time allowed the direct election of the Prime Minister, encouraged split-ticket voting and resulted in the rise of smaller parties with localized narrow interests. The emergence of this "cultural tribalism" coupled with the identity crisis mentioned earlier diminished the country's capacity to achieve peace. ${ }^{5}$

On the other hand Mira Sucharov argues that the pursuit of peace with the Palestinians was aimed at realigning state policies with a "defensive-warrior" Israeli role identity that had been challenged by the 1982 Lebanon war and the

\footnotetext{
${ }^{4}$ See Arie M. Kacowicz, "Rashomon in the Middle East: Clashing Narratives, Images, and Frames in the Israeli-Palestinian Conflict," Cooperation and Conflict 40, no. 3 (2005): 343-60.

${ }^{5}$ See Michael Barnett, "Culture, Strategy and Foreign Policy Change: Israel's Road to Oslo," European Journal of International Relations 5 (1999): 5-36.
} 
first Intifada, both of which cast Israel as an aggressor unlike past wars which were seen as defensive. Sucharov asserts that these two wars created strong unconscious counter narratives to the conscious Israeli role-identity, which could only be addressed by seeking peace with the Palestinians. ${ }^{6}$

The role of Israeli public opinion is another factor that played an important part in the peace process. This issue is examined by Tamar Hermann and Ephraim Yuchtman-Yaar who conclude that the stability of the Peace Index, an ongoing survey of Israeli public opinion on the peace process, from 1994 to 2001 suggests the emergence of two highly divided camps that hold consistently opposing views on a peace deal with the Palestinians. ${ }^{7}$ At any particular time, the question of which party holds the greatest numbers will play an important role in determining which party will win the elections and set the state's foreign policy. As a result, the peace process is highly dependent on Israeli public opinion.

Zeev Maoz on the other hand explains Israeli foreign policy through the existence of a militaristic culture among key decision makers who prescribe military solutions to the challenges facing the Jewish state, as a result of which the country has faced numerous wars and has been unable to reach a negotiated settlements with the Palestinians as well as its Arab neighbors. ${ }^{8}$ Avi Shlaim also

\footnotetext{
${ }^{6}$ See Mira Sucharov, The International Self (Albany: State University of New York Press, 2005).

${ }^{7}$ See Tamar Hermann and Yuchtman-Yaar Ephraim, "Divided yet United: Israeli-Jewish Attitudes Toward the Oslo Process," Journal of Peace Research 39, no. 5 (2002).

${ }^{8}$ See Zeev Maoz, Defending the Holy Land: A Critical Analysis of Israel's Security \& Foreign Policy (Ann Arbor: University of Michigan Press, 2009).
} 
examines Israeli foreign policy and comes to a similar conclusion. The Oxford IR scholar and historian asserts that Israeli foreign policy with regards to the Palestinians has been inspired by revisionist Zionist ideology as laid out by Ze'ev Jabotinsky, which emphasizes the territorial integrity of Eretz Israel and argues that Israel's opponents would see any relinquishing of territory as a weakness and that an iron fist policy is necessary in order to deal with them. ${ }^{9}$ Jabotinsky wrote in his highly influential 'Iron Wall' article:

I do not mean to assert that no agreement what so ever is possible with the Arabs of the Land of Israel. But a voluntary agreement is just not possible. As long as the Arabs preserve a gleam of hope that they will succeed in getting rid of us, nothing in the world can cause them to relinquish this hope, precisely because they are not a rabble but a living people. And a living people will be ready to yield on such fateful issues only when they have given up all hope of getting rid of the alien settlers. ${ }^{10}$

All the above explanations of Israeli foreign policy are based on the study of ideas and norms. On the other hand a second group of scholars look at how domestic politics and institutions shape the country's foreign policy. A noted scholar who uses Innen-politik to explain Israeli foreign policy is Yoram Peri who argues that both in extending an olive branch to the Palestinians in the early 1990s and in reversing that decision in the early twenty-first century, the military played a major role in setting policy. Israel's turbulent relationship with its

\footnotetext{
${ }^{9}$ See Avi Shlaim, The Iron Wall: Israel and the Arab World (New York: Norton and Company, 2001).

${ }^{10}$ Ze'ev Jabotinsky, Writings: On the Road To Statehood (Jerusalem, 1959).
} 
neighbors and the constant threat from terrorism and war has opened the way for the Israeli Defense Forces (IDF) to influence government policy. ${ }^{11}$ In fact the IDF's intelligence arm is tasked with advising the government on a broad range of foreign policy issues. In the words of General Aviezer Yaari, the former head of Military Intelligence Directorate's (MID) research division, "the global threats hovering over Israel force the Military Intelligence Directorate to deal with political and ideological issues as well." ${ }^{12}$ According to Peri the MID's dominant position in Israel's intelligence structure has provided it with a unique opportunity to portray Israel's opponents in a particular light and set the country's foreign policy agenda.

Democratic peace theory has also been used to explain the rise and fall of the Oslo Accords. Claudia Baumgart-Ochse argues that the Labor governments of 1992-1996 explicitly linked democracy and peace and used liberal and democratic arguments of democratic peace theory to justify their actions. Baumgart-Ochse asserts that the peace process was part of a larger democratization platform that also aimed to improve the conditions of the Arab citizens of Israel and more importantly enhance the differentiation between religion and state. The goal was to change Israel from an "illiberal, partly exclusive democracy to a fully-fledged liberal democracy." However the religious

\footnotetext{
${ }^{11}$ See Samuel W. Lewis and Yoram Peri, "Generals in the Cabinet Room: Foreword," in Generals in the Cabinet Room (Washington: United States Institute of Peace Press, 2006).

${ }^{12}$ Quoted in Ibid, 48.
} 
settler movement, which saw these changes as existential threats, launched a campaign against the peace process and the larger democratization process and eventually succeeded in taking back the government and reversing its earlier decisions. ${ }^{13}$

The above constructivist, Innen-politik, institutionalist and liberal approaches provide important insights on the role of ideas, norms, narratives, domestic politics and local institutions in shaping Israeli foreign policy. Moreover scholars such as Shlaim and Maoz provide rich and detailed accounts of Israeli foreign policy history. Nevertheless most of these approaches are mostly successful in explaining either the policy to pursue peace in the early nineties (Barnett and Ryhnhold) or the decline and abandonment of the peace process (Kacowicz, Shlaim and Maoz). Only a few authors seek to account for both policies (Baumgart-Ochse and Peri), and even then the explanations are not satisfying. Peri explains the shift in policy by emphasizing the role of the military, while no adequate answer is provided as to why the viewpoint of the military changed. Baumgart-Ochse on the other hand blames the fall of the peace process on the settler movement, however there is no explanation about the goals of this movement and why it succeeded.

A noted work that seeks to account for this deficiency by attempting to explain both the rise and the fall of the peace process through a constructivist

\footnotetext{
${ }^{13}$ See Claudia Baumgart-Ochse, "Democratization in Israel, Politicized Religion and the Failure of the Oslo peace process.," Democratization 16, no. 6 (2009): 1115-42.
} 
framework is Dov Waxman's The Pursuit of Peace and The Crisis of Israeli Identity. Waxman argues that Israel's conflicted policy toward the peace process was due to a crisis of national identity. He defines two Israeli identities that have emerged as a result of Oslo: 'Israelis' and 'Jews,' the former adhering to a civic conception of Israeli national identity and the latter to an ethno-religious conception. ${ }^{14}$ While Waxman's approach addresses some of the deficiencies of past ideational analysis of the issue, by completely disregarding the role of political ideologies in identity formation and focusing solely on the role of religion he does not take his improvement far enough. This is further discussed in chapter seven of this dissertation.

Moreover, Realists have criticized these ideational approaches for not taking into account the strategic security needs of the Jewish state. More specifically these explanations do not amply address why Israel decided to compromise with the Palestine Liberation Organization (PLO) in 1992. Many of the ideational and domestic factors these scholars present existed long before the turning point of 1992. Thus it is important to ask, what was so special about this particular time period that suddenly made these factors salient? This question can be answered by looking at the structural incentives and constraints facing Israel and the dramatic changes in the balance of power in the Middle East during the early nineties. Neorealist IR theory provides a framework for such

\footnotetext{
${ }^{14}$ Dov Waxman, The Pursuit of Peace and the Crisis of Israeli Identity (New York: Palgrave, 2006), 4.
} 
an analysis, although as it will be discussed later on, it suffers from its own set of weaknesses.

Neorealists argue that in the aftermath of the Iraq War of 1990-1991 and the demise of the Soviet Union, the power of the US and Israel increased, strengthening their position to pursue a settlement that was in their favor. On the other hand the new balance of power left the PLO very weakened. Not only had the PLO lost the Soviet Union as one of its main allies, but it had also lost most of the support it enjoyed from the Arab world due to Arafat's support for Saddam during the war. ${ }^{15}$ President Bush correctly stated after the war that the PLO had "backed the wrong horse. ${ }^{16}$ Moreover the PLO, expelled from Lebanon and now based in Tunisia, had virtually no control over the Palestinian Intifada, resulting in the rise of Palestinian competitors such as Hamas. Israeli Prime Minister Yitzhak Rabin believed that the PLO was "on the ropes" and was therefore highly likely to drop some of its main principles and demands. ${ }^{17}$ As a result, the time was set for Israel and the US to move in and use the window of opportunity to establish a favorable settlement before the balance of power in the Middle East changed.

From the Israeli perspective the ordeal had the potential to be a political,

\footnotetext{
${ }^{15}$ See for example Naseer H. Aruri, Dishonest Broker: The U.S. Role in Israel and Palestine (Massachusetts: South End Press, 2003); John Mearsheimer and Stephen M. Walt, The Israel Lobby and US Foreign Policy (London: Allen Lane Books, 2007).

${ }^{16}$ Naseer H. Aruri, Dishonest Broker: The U.S. Role in Israel and Palestine (Massachusetts: South End Press, 2003), 70.

${ }^{17}$ Shlaim, The Iron Wall: Israel and the Arab World, 515.
} 
economic and public image success. The peace process allowed Israel to sign a peace deal with Jordan, with which Israel shares a long border. Also the negotiations ended the Palestinian Intifada, which Israel had been unable to quash for nearly six years even though it had used a variety of methods. In the economic realm, by 1995 and partly as a result of the peace process, Israel had a GDP growth rate of $7.1 \%$ (one of the highest among Western economies at the time). The GDP per capita of Israel reached sixteen thousand dollars per year, almost the same as Great Britain. In the 1990-1995 period the economy had grown by $40 \%$ while export had grown by a whopping $54 \% .{ }^{18}$ Moreover the peace process strengthened Israel's alliance with the US and increased its prestige in the West. Typical headlines after the signing of the Oslo Accord were: "Israel agrees to quit West Bank", "Israel Ends Jews Biblical Claim on the West Bank," "Rabin's historic trade with Arabs," "A historic compromise" and the "Israelis find a painful peace."19

Realist IR theory emphasizes the role of global and regional balances of power, as well as the security and power interests of the Jewish state in determining its foreign policy. However, even though this framework is successful in explaining Israeli policy in the early 90 s and the decision to launch the peace process, it is of less use when analyzing the dramatic changes in policy that

\footnotetext{
${ }^{18}$ Aruri, Dishonest Broker: The U.S. Role in Israel and Palestine, 104.

${ }^{19}$ Noam Chomsky, The Fateful Triangle: The United States, Israel and the Palestinians (London: Pluto Press, 1999), 915.
} 
started to take shape with the rise of the Israeli right and the collapse of the peace process in the late nineties. Specifically if the external factors cited above resulted in the launch of the peace process, how can they also account for its decline in the late nineties and eventual collapse in September 2000? When we consider the fact that these external incentives and constraints, as well as the balance of power in the Middle East, did not change in any significant way during this period, we can conclude that neorealism is able to provide only a very partial explanation of Israeli policy towards the peace process. This shortcoming is due to neorealism's sole focus on structural factors, at the expense of ignoring domestic variables, in explaining international relations. ${ }^{20}$ In the case of Israel, had external elements such as the decline of Soviet and Arab power and the rise in the power of the US and Israel been the sole factors determining the country's foreign policy, then such policy should have remained constant throughout the nineteen nineties.

Thus, both approaches provide only a partial analysis of Israeli foreign policy. Realists have focused on power politics without considering the role of Israeli domestic politics as well as the ideological leanings of the state, while another group of scholars have looked at the influence of norms and domestic factors at the expense of overlooking the strategic security interests of Israel. Moreover only a few of the above authors use a theoretical framework to study

\footnotetext{
${ }^{20}$ Neoclassical Realist theory attempts to remedy this deficiency by accounting for internal variables, however as the next chapter will demonstrate it is only partially successful in this effort.
} 
the topic. ${ }^{21}$ Indeed the lack of theoretical approaches to the study of Israeli foreign policy is a major gap of the literature. Dov Waxman for example complains that "only a small number of books and articles have explicitly examined Israeli foreign policy through the lens of International Relations theories. Of these, most have used realist theory to explain Israel's foreign policy." ${ }^{22}$ This dissertation seeks to provide a theoretically informed analysis of Israeli foreign policy toward the peace process, as well as to contribute to the development of a cultural theory of foreign policy. The main question and hypothesis of this study are summarized in the following section.

\section{Question and Thesis}

Question 1: How can Israel's conflicting foreign policy behavior regarding the peace process be explained?

> Thesis 1: The political ideological movements within Israel interpreted and reacted differently to the events of the 80 s and early 90 s. These various perspectives were due to the fact that these ideologies differed on what it meant to be "Israeli," as well as what they considered as "national interests." Both the rise, and the fall of the peace process, should be seen as a result of the ideological struggle between the Labor movement on the

\footnotetext{
${ }^{21}$ For a discussion on the lack of theoretical frameworks in studies of the Middle East see Rex Brynen, "The State of the Art in Middle Eastern Studies: A Research Note on Inquiry and the American Empire," Arab Studies Quarterly 8 (1986): 404-19.

${ }^{22}$ Waxman, The Pursuit of Peace and the Crisis of Israeli Identity, 143.
} 
one hand and the religious and revisionist Zionist movements on the other, each of which sought to redefine Zionism and Israel in its own image and according to its own ideology. Israel's drive to peace in the early nineties was the result of the interaction between the new liberal Zionist ideology of the Labor movement and regional and global developments. In contrast the religious Zionist movement saw the peace process as part of the "Hellenization" of Israeli state and society and the abortion of the "divine redemptive process." The revisionists also opposed the peace process based on the movement's ideology that portrayed Israel as an isolated and vulnerable nation, which could only rely on military power rather than political agreements, against an "anti-Semitic" and "hostile" gentile world. As a result of the showdown between these contrasting worldviews, and depending on which of these movements was controlling government policy, Israeli policy towards the peace process became inconsistent, conflicted and even contradictory.

Question 2: How do political ideologies influence and shape foreign policy?

> Thesis 2: External events, including new structural constraints and incentives as well as war and peace, are interpreted differently by domestic political movements, which form policy decisions based on how they understand the new external environment as well as what they define as "state interests." These understandings are a result of ideologies, which are composed of coherent systems of symbols, values, and beliefs that are used to make sense of the external world and also provide a 
normative political action program. Therefore a state's foreign policy is shaped through the interaction between external material developments and internal ideological constructions. As a result, in cases where there is no single domestic hegemonic political ideology, foreign policy becomes deadlocked, contradictory and on the surface haphazard. Moreover in democratic societies public opinion can change the country's foreign policy by empowering one political ideology over its competitors.

\section{Theory and Methodology}

This dissertation uses a new cultural framework that attempts to bring "ideology back" into foreign policy analysis. This approach ties domestic political ideologies to national identities and subsequently to foreign policy behavior. Ideology is here defined as the coherent set of beliefs and ideas that are used to make sense of the external world and that explicitly dictates political behavior, as well as provides rhetoric that justifies such action. This theoretical model is explained in chapter two.

To study the role of ideology and partisanship in foreign policy, four methodological approaches have been taken. The first group of scholars uses large statistical models. These include Therien and Noel, ${ }^{23}$ Calin,${ }^{24}$ Arena and

\footnotetext{
${ }^{23}$ See Jean P. Thérien and Alain Noel, "Political Parties and Foreign Aid," The American Political Science Review 94, no. 1 (2000): 151-62.

${ }^{24}$ See Costel Calin, "Hawks versus Doves: The Influence of Political Ideology on the Foreign Policy Behavior of Democratic States" (PhD Dissertation, University of Tennessee., 2010).
} 
Palmer, ${ }^{25}$ Schultz, ${ }^{26}$ London et $a^{27}$ and Fordham. ${ }^{28}$ Another group of scholars, including Delaet and Scott, ${ }^{29}$ Bartels, ${ }^{30}$ McCormick and Wittkopf, ${ }^{31}$ study the legislative voting behavior of politicians. A third group of scholars, including Holsti, ${ }^{32}$ Wittkopf, ${ }^{33}$ Holsti and Rosenau, ${ }^{34}$ rely on elite surveys. Finally some

${ }^{25}$ See Philip Arena and Glenn Palmer, "Politics or the Economy? Domestic Correlates of Dispute Involvement in Developed Democracies," International Studies Quarterly 53 (2009): 955-75.

${ }^{26}$ See Kenneth Schultz, "The Politics of Risking Peace: Do Hawks or Doves Deliver the Olive Branch?," International Organization 59 (2005): 1-38.

${ }^{27}$ See Glenn H. Palmer, Tamar R. London, and Patrick M. Regan, "What's Stopping You?: The Sources of Political Constraints on International Conflict Behavior in Parliamentary Democracies," International Interactions 30 (2004): 1-24.

${ }^{28}$ See Benjamin Fordham, "Partisanship, Macroeconomic Policy, and the U.S. Uses of Force, 1949-1994," Journal of Conflict Resolution 42 (1998): 418-39.

${ }^{29}$ See James C. Delaet and James M. Scott, "Treaty-Making and Partisan Politics: Arms Control and the U.S. Senate, 1960-2001," Foreign Policy Analysis 2, no. 3 (2006): 177-200.

${ }^{30}$ See Larry Bartels, "PartisanshipandVotingBehavior,1952-1996," American Journal of Political Science 44 (2000): 35-50.

${ }^{31}$ See James M. McCormick and Eugene R. Wittkopf, "Bipartisanship, Partisanship, and Ideology in Congressional-Executive Foreign Policy Relations, 1947-1988," Journal of Politics 52 (1990): 1077-1100.

${ }^{32}$ See Ole R. Holsti, Public Opinion and American Foreign Policy. (Ann Arbor: University of Michigan Press, 2004).

${ }^{33}$ See Eugene R. Wittkopf, Faces of Internationalism: Public Opinion and American Foreign Policy (Duke University Press, 1990).

${ }^{34}$ See Ole R. Holsti and James N. Rosenau, "The Domestic and Foreign Policy Beliefs of American Leaders," The Journal of Conflict Resolution 32, no. 2 (1988): 248-94. 
scholars such as Schultz ${ }^{35}$ and Klingeman et $\mathrm{al}^{36}$ analyze political documents such as political party manifestos. ${ }^{37}$

This dissertation will use a combination of the first and last category. Statistical models will be used to analyze Israeli public opinion and political statements and documents will be used to study the construction and evolution of political ideologies. This will be accomplished by examining a wide range of documents including the public rhetoric of political leaders, party pronunciations, as well as symbols and images used in campaign and propaganda material. More importantly, as discussed earlier the creation and evolution of Israeli political ideologies will be analyzed through a constructivist lens. To achieve this particular attention will be paid to discourse analysis. Discourse plays an important role in shaping practice. This is because the ways in which politicians talk about the world tend to define the ways in which they act in that world, inclining them toward some options and away from others.

Discourses are constituted by symbolic orders that help create an interpretive community. A characteristic of every discourse is that it is recurrent, helping it become inscribed in society and giving it dominance over other

\footnotetext{
${ }^{35}$ See Kenneth Schultz, Democracy and Coercive Diplomacy. (Cambridge: Cambridge University Press, 2001).

${ }^{36}$ See Hans-Dieter Klingemann, Richard Hofferbert, and lan Budge, Parties, Policies, and Democracy (Boulder: Westview, 1994).

${ }^{37}$ For more information see Calin, "Hawks versus Doves: The Influence of Political Ideology on the Foreign Policy Behavior of Democratic States."
} 
discourses. Most ideological discourse is information about "Us" vs. "Them." Discourse also outlines who belongs to the group ("us"). In the context of this dissertation it is important to study the discourse of Israeli leaders in regards to Palestinians and the peace process as well as in relation to other domestic rival groups, since the "self" can only be created in relation to the "other." This dissertation argues that the "other" is not restricted to other states, rather group identity can also be formed based on domestic divisions.

One of the difficulties of studying ideological discourse is being able to distinguish between real ideological positions and speech used for short term tactical objectives. An example related to the topic of this dissertation will make this clear: Is Benjamin Netanyahu's unprecedented June 2009 speech at BarIlan University in which he stated that he would conditionally accept a Palestinian state, represent an ideological change in the Likud party? Or is the speech simply a tactical ploy aimed at deflecting US pressure and gaining political advantages over domestic rivals? In order to be able to make such a distinction it is important to look at a variety of sources over time so that an overall pattern of articulation can be identified, rather than looking at a particular speech or text in isolation. Moreover this dissertation argues that if short-term tactical rhetoric that runs counter to a movement's ideology is continuously repeated, it creates a strong impetus for ideological transformation that will lead to actual policy changes. Moreover tactical discourse might lead to unintended legitimization of alternative ideological narratives. For example Netanyahu's rhetorical acceptance of a Palestinian state inadvertently leads to the legitimization of the 
"two-state solution," which the revisionist movement has long opposed. This is discussed further in subsequent chapters.

Also in order to differentiate between tactical maneuvers and ideological change it is important to study political discourse in settings in which politicians are under less pressure to dissemble, in addition to discourse that is aimed at "external consumption" such as public speeches and media interviews. Thus, while language use, text, talk and verbal communication will be studied under the broad label of discourse; it is beneficial to also focus on some discourse genres that have the explicit goal of ideological indoctrination. These include the discourse used in political propaganda, party rallies, closed leadership meetings and indoctrination material used to "teach" ideologies to group members and newcomers. ${ }^{38}$

Although discourse is often crucial to the expression and reproduction of ideologies, it is not a sufficient mechanism for the reproduction and evolution of ideologies. Rather external developments and events should also be examined when studying ideological evolution. Thus unlike post-modern approaches which reduce the study of ideologies to only discourse, arguing that there is nothing outside of text, this study assumes that discourse cannot be isolated from the wider socio-political and historical context. Thus for example the Six Day War of

\footnotetext{
${ }^{38}$ Nadav Shelef, Evolving Nationalism: Homeland, Identity, and Religion in Israel, 1925-2005 (Ithaca: Cornell University Press, 2010).
} 
1967 represents an exogenous shock that had a tremendous impact on the discourse of religious Zionist ideology.

In order to understand the ideological evolution of the Labor, Revisionist and Religious Zionist movements and how they impacted Israeli foreign policy, we must examine how each ideology was created, how they evolved in the lead up to the peace process and finally how they impacted the country's foreign policy, as shown in the diagram below:

Figure 1: The Research Process

1. What are the

ideologies of the

three movements?

(How were they

constructed?)

2. How have these
ideologies evolved?

3. How have these

ideologies shaped

Israeli foreign policy

toward the peace process?

Chapter three and part of chapter four focus on the first step, while chapters four and five examine the evolution of Israel's domestic political ideologies. Finally chapter six studies how the three political ideologies shaped Israeli foreign policy during the nineteen nineties. As a result, the evolution of the three ideologies is examined from the early nineteen hundreds up until the fall of the peace process at the end of the twentieth century. Studying the ideological discourse of the three movements and how they reacted to external events for nearly a century, allows for a richer and more comprehensive analysis of their approach to the peace process in the nineteen nineties. 
Finally to examine the attitudes of each of three ideological movements' constituents towards the peace process, statistical analysis of the Peace Index will be conducted. The Peace Index is an ongoing monthly public opinion survey started in 1994 and led by Ephraim Ya'ar of Tel Aviv University and Prof. Tamar Hermann of the Israel Democracy Institute, which follows opinion trends in Israel concerning the peace process. For the purposes of this research the data sets for January and July of each year from 1994 to 2013 were obtained. ${ }^{39}$ With the help of SPSS software, these 41 data sets were then recoded and analyzed using advanced statistical methods such as Multinomial Logistic Regression. The full results of this study are presented in the appendix and are used in the analyses of chapters six and seven.

\section{Israeli Identity and Political Ideologies}

\section{The Construction of the Israeli Identity}

Michael Barnett explains that Israeli identity is composed of four major elements: religion, nationalism, the Holocaust and liberalism. First Israel is a Jewish state, and while there are differing views about the place of faith in public life, Judaism is undeniably part of Israeli identity. Secondly Zionism, the Jewish nationalist movement that emerged in response to Jewish persecution in Europe near the end of the nineteenth century, was the movement that created the state of Israel and its various versions still form the core ideology of the major political

\footnotetext{
${ }^{39}$ In addition to the six-month interval datasets, three opinion polls conducted several days after, several weeks after and a month after Yitzhak Rabin's assassination were also analyzed.
} 
parties of the country. Thirdly the Holocaust is the most blatant historical instance of the oppression of Jews, creating a strong and continuous perception of being under existential threat among Israelis. ${ }^{40}$ Such historical experiences have reified the belief that Israelis and Jews more broadly are "a people that dwells alone." Asher Arian labels these beliefs as the "People Apart Syndrome." ${ }^{41}$ Lastly liberalism has become a common feature of debates regarding Israeli identity in recent years, however unlike Barnett's association of liberalism with the entire Israeli society, subsequent chapters will show that more correctly it is part of the identity of only a segment of Israeli society.

The influence of militarism on Israeli identity should also be added to Barnett's list. Numerous scholars have shown how the ongoing conflict with the Palestinians has been instrumental in forming a security culture in Israeli politics and society. For example Uri Ben-Eliezer who calls Israel a "nation in arms" explains that the country suffers from a "national culture that sanctifies the military solution to political problems and that places the military and the soldiers at society's center." ${ }^{42}$ Military service in Israel is an important requisite for positions of power and importance, and plays a key socializing role for Israeli

\footnotetext{
${ }^{40}$ Michael Barnett and Shibley Telhami, "The Israeli Identity and the peace process.," in In Identity and Foreign Policy in the Middle East (Ithaca: Cornell University Press, 2002), 58-87.

${ }^{41}$ See Asher Arian, Security Threatened: Surveying Israeli Opinion on Peace and War (New York: Cambridge University Press, 1995), Chapter 6.

${ }^{42}$ Lewis and Peri, "Generals in the Cabinet Room: Foreword." 29.
} 
youth. ${ }^{43}$ Israel's universal dual-gender conscription and the frequent wars Israel has fought have made the military an important avenue for the creation of a national identity. ${ }^{44}$ Also military service is the rite of passage to adulthood for many Israeli youth. ${ }^{45}$ Many Israeli university students tend to begin their studies after serving in the military. Moreover even after their mandatory military service, Israelis must report for reserve duty until the age of $40-49$, depending on their rank and area of work. ${ }^{46}$ This is why it is said, "Israelis are soldiers on eleven months' leave" (The phrase was originally coined by former Chief of Staff Yigael Yadin).

Jewish experiences of persecution and most importantly the tragedy of the Holocaust have also led to what is commonly referred to as the "Massada complex" in Israeli society, in which Jews have "no choice" but to defend themselves militarily or otherwise be "slaughtered like sheep." Based on such a belief, the actions of the IDF and the Israeli state more generally are seen as "necessary" in order to ensure the country's survival. Prime Minister Golda Meir once responded to a reporter: "We do have a Masada complex. We have a

\footnotetext{
${ }^{43}$ Sucharov, The International Self. 69

${ }^{44}$ Ibid, 72-73.

${ }^{45}$ Uta. Klein, "Our Best Boys': The Gendered Nature of Civil-Military Relations in Israel," Men and Masculinities 2, no. 47 (1999).

${ }^{46}$ See Barry Rubin, Israel: An Introduction (New Haven: Yale University Press, 2012), 175-178.
} 
pogrom complex. We have a Hitler complex." ${ }^{47}$ This perceived sense of insecurity and isolation has become a crucial part of the Israeli narrative. As such it is imperative that any study on Israeli identity also examines the military culture of the country.

Although the above five elements continue to be a major part of Israeli identity, with the onset of the peace process, what it meant to be an "Israeli" was challenged to its core and deep divisions, which had long existed in Israeli society, were now fully exposed. In the view of Haaretz columnist Gideon Samet, what was occurring was the "collapse of the common denominator...the Israeli identity is becoming increasingly blurred." ${ }^{48}$ The peak of such divisions came with the assassination of Israeli Prime Minister Yitzhak Rabin in 1995 and the 1996 electoral success of Benjamin Netanyahu. For secular leftists, Israel had to withdraw from the territories if it were to maintain its Zionists and democratic identity, which they saw as being connected to Western liberal values. On the other hand for Religious Zionists "Judea and Samaria" constituted part of Israel's "Jewish Soul" which could never be abandoned, while according to the militant revisionist Zionist identity, territorial withdrawal would only be seen as a sign of weakness by the "Arab enemy." As a result, the peace process is not simply a foreign policy issue for Israelis but is also a question of national identity.

It is important to point out that there are still common elements in what it

\footnotetext{
${ }^{47}$ Waxman, The Pursuit of Peace and the Crisis of Israeli Identity, 49.

${ }^{48}$ Gideon Samet, "The Collapse of the Common Denominator," Haaretz, April 10, 1998.
} 
means to be Israeli among the majority of the country's public. Nevertheless the point is that the internal conflict about what it means to be Israeli has become much more intense in the lead up and after the signing of the Oslo accords. The major political parties within Israel whose ideology can be categorized as Labor, Revisionist and Religious Zionist spearhead these differences. All the five elements of Israeli national identity pointed earlier have played a role in the construction and evolution of these ideologies to some degree, nevertheless what differentiates the three is how they order the importance of these elements, so for example while liberalism has ranked high in Labor Zionist identity since the eighties, religion is much more dominant in Religious Zionist identity. As pointed out earlier, peace with the Palestinians has become a source of divergence among the three. In order to understand Israeli policy towards the peace process it is necessary that we study how these three ideologies were constructed and how their viewpoints regarding the territories and Palestinian nationalism evolved, rather than take them as given. The next three sections give a brief overview of the political ideologies of the Labor, Revisionist and Religious Zionist movements. ${ }^{49}$

\footnotetext{
${ }^{49}$ It should also be pointed out that that two other sizable political groups in Israel, the ultraOrthodox community and Arab-Israelis, are largely excluded from the present study. The reason for this omission is that both groups played little to no role in shaping Israeli security and foreign policy up until the 1990s. As such, they are only mentioned in chapter six. The "non-Zionist" Haredi (ultra-Orthodox) community is primarily concerned about its specific group interests such as military exemption for "Torah Study" and financial allocation for Yeshivot and other Haredi institutions and takes little interest in other issues of the state, while Arab parties have not been part of any government coalition in Israeli history. For a comprehensive overview of the Haredi community see Aviezer Ravitzky, Messianism, Zionism, and Jewish Religious Radicalism, trans. Michael Swirsky and Jonathan Chipman (Chicago: University Of Chicago Press, 1996), Chapters
} 


\section{Labor Zionism}

'Labor Zionism,' which can be described as the main stream of left wing Zionism, seeks liberal and progressive goals internally and usually adopts a 'pragmatic' approach to foreign policy. The Labor movement and the Israeli left more generally were heavily influenced by Theodor Herzl's liberal values, which were based on European enlightenment. In Der Judenstaat, the central book of political Zionism, Herzl advocates a state for the Jews that is "modern", "tolerant", "neutral" in world affairs and more importantly where Jews are "free men" on their own soil and everyone is treated equally before the law. Herzl also envisioned the new state as completely secular, where freedom of religion and language was ensured. ${ }^{50}$

Labor Zionists, at least theoretically, saw accommodation with the native Palestinians and Israel's Arab neighbors as possible and even desirable. Labor's pragmatism means that foreign policy issues such as peace with the Palestinians are measured by a cost-benefit analysis. This is why political analysts routinely describe Labor's foreign policy approach as "realist" in its worldview. ${ }^{51}$ Such pragmatism is a norm in itself in which state interests are seen as overriding

1, 2 and 4. For a discussion of the relationship between Israel's Jewish majority and Palestinian minority see: Ilan Peleg and Dov Waxman, Israel's Palestinians: The Conflict Within (Cambridge: Cambridge University Press, 2011).

${ }^{50}$ Theodor Herzl, The Jewish State. (New York: Dover Publications, 1896).

${ }^{51}$ This dissertation challenges the notion of labeling the foreign policy orientation of any of the three movements as "realist." This issue is discussed in chapters two and seven. 
other interests and considerations. Moreover members of this group, particular in more contemporary times, also identify with liberal norms such as freedom, democracy, self-determination and human rights. In the case of the Oslo peace process, the two sets of norms pointed in the same direction, building a strong impetus to pursue it.

A look at the history of foreign policy decisions made by Labor Zionists reveals numerous instances of such pragmatism. For example, following the establishment of the state of Israel, Labor Zionists allied with the US, instead of the USSR, and gradually backed away from their original socialist goals in the sixties and seventies. In 1952 Ben-Gurion's government reached a reparations agreement with West Germany over the persecution of Jews in the Holocaust. The controversial move resulted in a massive riot spearheaded by Menachem Begin in Jerusalem. After the 1956 Suez War, Ben-Gurion's government quickly withdrew from the captured Sinai desert after being pressured from the US. Even after the 1967 war, a large part of the Labor party was ready to withdraw from the captured territories in principle. Raymond Cohen also points out how during Labor's reign in Israeli politics, alliances were sought on "ruthlessly objective grounds; no one was excluded a priori," including the Hashemite kingdom of Jordan, the outer tier states of Turkey, Iran and Ethiopia, the Federal Republic of Germany and even Apartheid South Africa. ${ }^{52}$ It is under the light of such pragmatism that Labor's decision to seek peace with the Palestinians should be

\footnotetext{
${ }^{52}$ Cohen, "Israel's Starry-Eyed Foreign Policy."
} 
seen.

Israel and the region more broadly, experienced important developments in the late 80 s and early 90s. In 1987 the Palestinian Intifada broke out, during which Israel was unable to halt the riots even after using lethal force, leading to widespread criticism from the international community. Moreover the Intifada provided an avenue for the rise of militant Islamist groups, particularly Hamas. Also the significant rise in the population of Palestinian Arabs both inside Israel as well as in the territories meant that the annexation of the West Bank and Gaza Strip would seriously jeopardize Israel's Jewish majority. The result of such an annexation would be that Israel could be either Jewish or democratic, but not both. As pointed out earlier, territorial maximization was never a priority in Labor Zionist ideology. This is why Labor presented withdrawal from the territories in the 1992 elections as a decision between "absorbing a million immigrants from Russia or a million Gazans. ${ }^{\text {"53 }}$

Moreover any analysis of Israel's decision to seek peace with the Palestinians must take into account changes in the balance of power of the late eighties and early nineties. The period saw the collapse of the USSR, the most serious Arab ally, the utter defeat of Iraq, a serious threat to Israel, as well as a significant rise in US troops and power in the region. These developments meant that Israel's power status vis-à-vis its opponents had greatly improved, to the point where it was now in a position to withdraw from the territories based on its

\footnotetext{
${ }^{53}$ Shelef, Evolving Nationalism: Homeland, Identity, and Religion in Israel, 1925-2005, 139.
} 
own terms. Moreover these developments should not be seen only through a power lens. Labor leaders have always been very conscious of Israel's strategic security needs. From a security perspective, the period arguably marked the first time where Israel was not under the threat of a major external army. These changes in the balance of power led Labor leaders such as Rabin and Peres to conclude that Israel's "security predicament" had greatly improved, to the point where it could now "afford" to make peace with the Palestinians.

The above material developments however were not the only impetus behind Labor's decision to seek peace with the Palestinians. Indeed limiting the foreign policy ideology of the Labor movement to cold cost-benefit calculations would be an oversimplification. Rather, important elements of the Israeli identity were challenged in the 1980s. Mira Sucharov for example provides a compelling case that Israel's "defensive-warrior" role identity was challenged by the 1982 Lebanon war and the first Intifada, both of which cast Israel as an "aggressor," unlike past wars which were seen as "defensive." As a result, these two wars created strong unconscious counter narratives to the conscious Israeli roleidentity, which could only be addressed by seeking peace with the Palestinians. ${ }^{54}$

As chapter five will demonstrate, the rise of a militant settler identity within Israeli society and the traumatic developments of the 1980 s resulted in a soulsearching endeavor within Labor that led to a redefinition of the movement's ideology. In fact it was this transformation that enabled the movement to

\footnotetext{
${ }^{54}$ Sucharov, The International Self.
} 
understand the global developments of the late eighties and early nineties the way it did, and adjust the country's foreign policy accordingly.

Yitzhak Rabin fully used the rise of the movement's new ideology as an opportunity to create a national identity that was tied to the peace process. ${ }^{55}$ Rabin openly criticized the old Israeli identity: "We lost trust in others. We were suspicious of everyone. We developed a siege mentality. We lived in a kind of political, economic, and mental ghetto. We secluded ourselves. We distanced ourselves. We became skeptical and harbored reservations. We developed patterns of obstinacy and of seeing the world in somber colors." ${ }^{56}$

This dissertation argues that the important changes in Israeli foreign policy during the nineteen nineties should be seen as a result of the interaction between a new and emerging liberal Zionist identity within the Labor movement and the country's greatly improved security status. The combination of these two factors compelled Labor leaders that a political compromise with the Palestinians was now "affordable."

\section{Revisionist Zionism}

Ze'ev Jabotinsky originally developed revisionist Zionism in competition to Labor Zionism, with aims of territorial maximization, as well as more assertive postures and actions against both Western and Arab control of the region. The primary goal of early Revisionist Zionists was to maintain the territorial integrity of

\footnotetext{
${ }^{55}$ Barnett, "Culture, Strategy and Foreign Policy Change: Israel's Road to Oslo."

${ }^{56}$ Yitzhak Rabin, The Rabin Memoirs. (Berkeley: University of California Press, 1996), 397.
} 
the historical land of Israel and to establish a Jewish state with a Jewish majority on both sides of the River Jordan. Moreover as Waxman points out, their model of the ideal Israeli was not the pioneering Jewish worker, as championed by Labor, but the "heroic Jewish fighter." ${ }^{57}$ This militaristic identity had far reaching consequences on the group's ideology and behavior. The school's paramilitary wings, the Irgun and the Lehi, went as far as orchestrating terrorist attacks against the British during the mandate period. Nevertheless the ideology of revisionist Zionists has witnessed important changes since its early days.

As pointed out earlier, the territorial integrity of Eretz Yisrael has always been on top of the revisionist Zionist agenda and as a result parties such as the Likud as well as its predecessor Herut, have always been opposed to any form of partitioning of the "Jewish Homeland." This is why revisionist Zionists led by Menachem Begin strongly opposed the UN partition plan of 1947. After that, in every election until 1959 Herut campaigned for the "liberation" of Eretz Yisrael, which according to them included the lands of Transjordan and southern Lebanon. ${ }^{58}$ Starting from the late $50 \mathrm{~s}$, the inclusion of Transjordan as part of the homeland was slowly dropped in Herut's rhetoric and campaign platforms, and a new understanding of the boundaries of Israel which included only the West Bank, the Gaza Strip, the Golan Heights and the Sinai, but not Transjordan, rose after the Six Day War and was reified in the 70s. By the 80 s, a consensus had

\footnotetext{
${ }^{57}$ Waxman, The Pursuit of Peace and the Crisis of Israeli Identity, 20.

${ }^{58}$ Shelef, Evolving Nationalism: Homeland, Identity, and Religion in Israel, 1925-2005.
} 
emerged among revisionist Zionists that saw only the territories that Israel occupied as part of the homeland. This is why in 1991 Benny Begin said that "in the last years a wide political understanding has crystallized, according to which the state of Israel does not have and will not have in the future, territorial demands and plans for territorial expansion, to determine borders beyond the ceasefire line or beyond today's international borders. I don't know of another assessment, even in the margins." ${ }^{59}$

In a similar vein, Likud's policy towards the West Bank and the Gaza Strip was severely challenged with the onset of the peace process, as a result of which the movement's ideology came under threat of transformation. As future chapters will demonstrate the crisis of revisionist ideology is still ongoing and has not reached a firm conclusion. A look at the history of the group's viewpoints regarding the territories will confirm this. In 1973 Herut's election platform called for the annexation of the West Bank and Gaza Strip. In fact to make clear that the West Bank and the Gaza Strip were unlike other territories such as Transjordan, whose claim had been dropped by the party, the Herut central committee said in 1973 that the slogan of Af-Sha'al ("not a single step"), only applied to "Judea and Samaria" and not to other territories. ${ }^{60}$ Based on such an ideology Begin swore in 1981 that as long as he was prime minister there would

\footnotetext{
${ }^{59}$ Ibid, 213.

${ }^{60}$ Ibid.
} 
be no withdrawals from the West Bank and Gaza Strip. ${ }^{61}$

Likud's viewpoint regarding the borders of Israel and subsequently its policies regarding the territories evolved in the 1990s, culminating in Ariel Sharon's 2005 unilateral withdrawal from the Gaza Strip. The most important development in this path took place during the 1996 elections, in which Netanyahu advocated a tougher approach with the Palestinians as part of a "Peace With Security" plan that nevertheless accepted, at least in rhetoric, the Oslo accords and promised further negotiations. Indeed after Netanyahu became Prime Minister he was responsible for Israeli withdrawal from 80 percent of Hebron.$^{62}$ Not only was this the first time that a Likud leader was withdrawing from "Jewish land" but also the city had a significant place in biblical and Jewish history and as such was often cited by Jabotinsky as well as Begin as an "essential part" of the homeland. Moreover Netanyahu's "Allon Plus Plan" proposed that Israel withdraw from roughly half of the West Bank and the entire Gaza Strip, which would effectively mean the abandonment of some Jewish settlements. ${ }^{63}$

The point of these examples is not to dismiss the role of Netanyahu's

\footnotetext{
${ }^{61}$ Jonathan Rynhold and Dov Waxman, "Ideological Change and Israel's Disengagement from Gaza," Political Science Quarterly 123, no. 1 (2008): 11-37.

62 Ibid.

${ }^{63}$ Charles Krauthammer, "Momentous Move By Netanyahu's Likud Government Is Largely Ignored By The West Some Say The Plan Is Not Forthcoming Enough. But They Miss The Principles Conceded," Philly.com, June 16, 1997, http://articles.philly.com/1997-0616/news/25526459_1_netanyahu-plan-land-of-israel-party-benjamin-netanyahu.
} 
government in derailing the peace process, but rather to demonstrate that Likud's position regarding the territories has changed in important ways. Indeed it seems that the question inside Likud has transformed from whether Israel should withdraw from the territories to how and to what extent it should withdraw. Based on this analysis, Netanyahu's June 2009 speech at Bar-Ilan University in which he stated that he would accept a Palestinian state if the new state would be demilitarized, the Palestinian right of return would be dropped and Jerusalem would remain the undivided capital of Israel, should be seen as a significant departure from past Likud policies, since it showed that the question about a Palestinian state had also changed from a categorical denial to a conditional and reluctant acceptance. As noted earlier, even if such moves are only seen as tactical policy maneuvers, rather than real ideological changes, in the long run they will affect the movement's ideology by changing the group's discourse.

The above discussion however does not mean that there has been a definitive and widely accepted change in Likud's ideology. In January 2013 for example, Likud member and government minister Yuli Edelstein and two other Likud members of the Knesset openly called for the annexation of the West Bank and the Gaza Strip. ${ }^{64}$ Moreover the Israeli website 'Sixtyone' revealed that in the 2013 Israeli elections, 15 of the Knesset candidates nominated by the Likud,

\footnotetext{
${ }^{64}$ Harriet Sherwood, "Likud Members Call for Israeli Annexation of West Bank Territories," The Guardian, January 2, 2013.
} 
supported the annexation of large parts of the West Bank. ${ }^{65}$ These examples show that the ideological change within Likud regarding the territories is far from successful and complete; rather it is a point of contestation within the party. Moreover it is important to point out that such ideological changes do not apply to religious Zionist parties such as the Jewish Home and its predecessor the National Religious Party as well as the religious settler movement. In fact religious Zionists, as part of the government coalition of 1996, were able to successfully use the internal divisions inside the Likud to shift Israeli policy away from the peace process initiated by the preceding Labor government.

\section{Religious Zionism}

One of the areas this dissertation seeks to illuminate is the increasingly divergent ideology of religious Zionists and revisionist Zionists, which are sometimes mistakenly assumed to be similar by existing literature. According to religious Zionists, the "sacred land" of Israel could never be relinquished to people who they believe do not belong there in the first place. As Rabbi Abraham Isaac Cohen Kook, the founder of Messianic Religious Zionism, describes: "the state of Israel is a divine entity," and that settlement of the land by Jews was hastening the coming of the Messiah and as a result that the enemies of Israel were in fact the enemies of God, trying to impede the "Lord's divine plans." ${ }^{66}$ The identity of religious Zionists is deeply tied to the belief that they are playing an

\footnotetext{
${ }^{65}$ Elisheva Goldberg, “Likud: The Party of Annexation," The Daily Beast, November 27, 2012.

${ }^{66}$ Ravitzky, Messianism, Zionism, and Jewish Religious Radicalism, Chapter 3.
} 
important part in the process of divine redemption. ${ }^{67}$

This is in complete contrast with Israel's Haredi or ultra-Orthodox community who believe that the Jewish people are still living in the age of exile, even if they are physically living in the Holy Land, and who see the state of Israel as a secular state similar to European states in which Jews had been living for the past two millennia. Moreover Zionism is seen as a secular nationalist movement that is completely devoid of any religious significance. This is why the ultra-Orthodox are routinely categorized as "non-Zionist," with some branches even considered as "anti-Zionist." 68

Religious Zionists on the other hand see the settling of the Holy Land as an act that hastens the coming of the Messiah. Nevertheless it should also be pointed out that territorial settlement and expansion has not always been the primary goal of religious Zionism. In the years of the Yishuv and the early years of the state, the goal of religious Zionists was the creation of a "Torah State," which would serve as an integral phase of the redemption process. This viewpoint was unlike that of the ultra-Orthodox, who did not want to have anything to do with the new state. Religious Zionists sought to achieve their goals by allying with the left wing Mapai. As a result of this coalition, some aspects of religion in public life were relegated to the religious Zionists who sought to shape

${ }^{67}$ Ehud Sprinzak, The Ascendance of Israel's Radical Right (Oxford: Oxford University Press, 1991).

${ }^{68}$ See Ravitzky, Messianism, Zionism, and Jewish Religious Radicalism, Chapter 4. 
"the character of the state according to the Torah."

The turning point in the ideology of Religious Zionists was the Six Day War of 1967. Israel's "miraculous" victory ${ }^{69}$ in the war convinced the group that the sacred land of Israel as "promised to Abraham by God" was being returned to its rightful owners and that during the current age of redemption all the land recovered by "the Joshuas of our time," had to be settled and retained. It is important to note however that this ideological shift did not happen overnight. In fact the National Religious Party did not officially announce a position regarding the territories until 1973 due to internal divisions. The result of this division however was the victory of the "young guard" who in the following year formally established the Gush Emunim movement, and who successfully changed the priorities of the party by making the newly captured territories as its primary focus. These changes also meant the end of the alliance with the Labor movement.

The religious Zionists interpreted the events of the 80 s and 90 s, which significantly altered the ideology of labor Zionists and to a much lesser extent revisionist Zionists, and resulted in the will to withdraw from the territories and allow the creation of a Palestinian state, very differently. According to the religious right, the "shameful escape" from Lebanon could have been prevented

\footnotetext{
${ }^{69}$ The Religious Zionists saw Israel's decisive victory in the Six Day War as nothing short of miraculous. In fact one of the myths of the movement is that Rabbi Kook had "foretold" the miracle several weeks before the war. See lan Lustick, For the Land and the Lord: Jewish Fundamentalism in Israel (New York: Council on Foreign Relations Press, 1988), Chapter 2.
} 
had the state not been filled by "leftist" politicians. ${ }^{70}$ In fact even the revisionist Zionists could not be trusted after the Likud led 1978 Camp David Accords, which resulted in Israel's withdrawal from the Sinai desert. According to these religious radicals, left wing Zionists had become "corrupt," "soft," "too liberal and pluralistic," with an "excessive obsession" with democracy. They believed that in this age of redemption in which God supported Israel, there was no reason to be weak toward Israel's enemies. This is why Rabbi Meir Kahane equated fear of the gentiles to Hillul Hashem, the desecration of the name of God. This is also why some groups in the religious Zionist camp have even gone as far as to argue that they should resist the government of Israel when it acts against the interests of Jews, just like when the British were resisted in the 1930s and 1940s by some Zionists. ${ }^{71}$ It is under this light that the assassination of Yitzhak Rabin by a religious Zionist and the vehement opposition to the Oslo accords by religious Zionist parties should be understood.

In fact religious Zionists did not need to revert to violence to advance their cause. The rise of religious parties in the past two decades as junior coalition partners to governments led by the revisionists has made them kingmakers in Israeli domestic politics, and has heavily influenced the state's worldview and its foreign policy direction. This is largely due to the political

\footnotetext{
${ }^{70}$ See Sprinzak, The Ascendance of Israel's Radical Right, 19-21 and 114-116.

${ }^{71}$ Idith Zertal and Akiva Eldar, Lords of the Land: The War Over Israel's Settlements in the Occupied Territories, 1967-2007 (New York: Nation Books, 2007), Chapter 1.
} 
system of Israel, which provides great influence to even small political parties, a topic that is briefly discussed in the following section.

\section{Israeli Public Opinion}

Israel's proportional representation parliamentary political system has resulted in the formation of a large number of parties, with no party being able to win a majority of seats in the Knesset (Israeli parliament) in the country's entire history. This has created a strong need for coalition building while at the same time fostering factional disputes. As a result of the fragility of many government coalitions, the average life span of Israeli governments has been about 22 months. ${ }^{72}$ This system has also increased the influence of junior coalition partners, which in the past decade has been largely restricted to ultra-Orthodox religious parties such as Shas and the religious Zionist Jewish Home (formerly National Religious Party). These domestic constraints have made Israeli foreign policy decision-making decentralized and complex. This is why in the words of Henry Kissinger, "Israel has no foreign policy, only a domestic political system."73

As explained earlier, since consecutive Israeli governments have been formed as a result of coalition building, they are especially vulnerable to public opinion, with even junior coalition partners being able to hold the government hostage to their interests. Moreover unlike other democracies where pressure

\footnotetext{
72 Jim Zanotti, Israel: Background and U.S. Relations (Congressional Research Service, 2012).

${ }^{73}$ Michael Kramer, "The Political Interest Nobody Does Nothing Better Than Shamir," Time Magazine, September 30, 1991.
} 
from public opinion usually builds up in the next election cycle, in Israel the impact and force of public opinion is almost immediate since even small parties regularly have the power to oust the government and call for early elections. Because of this in many instances elections in Israel have not been held in regular intervals, rather their timing has been erratic and unexpected. As a result of this, Israeli political leaders are in danger of losing their office much more frequently than other democracies, making them more responsive to their constituents.

Moreover many scholars have pointed out that Israel has a highly opinionated citizenry with regards to the peace process. ${ }^{74}$ These viewpoints were important reasons behind the high levels of participation in the 1992, 1996, and 1999 elections when issues of security and foreign policy played a major role. Also numerous Israeli leaders including Yitzhak Rabin, Benjamin Netanyahu and Ehud Barak have indicated that any peace deal with the Palestinians must be ratified by the Israeli public in a nationwide referendum. ${ }^{75}$ Indeed this approach to foreign policy is uncommon even among Western democracies, a fact that points to the importance of public opinion in Israel.

The Israeli public has been highly divided regarding the peace process,

\footnotetext{
${ }^{74}$ Ilan Peleg, "The peace process and Israel's Political Kulturkampf," in In The Middle East peace process: Interdisciplinary Perspectives (New York: SUNY Press, 1998), 237-63; Gabi Sheffer, In the Wake of the peace process: Changes in Ideology and Political Orientation in Israel and the Palestinian Community., Tel-Aviv: Tami Steinmetz Center for Peace Research (Tel-Aviv University., 2000).

${ }^{75}$ Hermann and Ephraim, "Divided yet United: Israeli-Jewish Attitudes Toward the Oslo Process."
} 
with the share of the population that is in favor of the negotiations hovering between 40 to 60 percent during most of the past two decades. ${ }^{76}$ Israelis have also been split on the desirability of the "two-state solution." ${ }^{77}$ Nevertheless even small changes in public support for the peace talks and the two-state solution have had important consequences in election results and subsequently Israeli foreign policy. Thus it is necessary that this study examine how Israeli public opinion was shaped during the peace process, how it evolved and how it enabled and disabled various political ideologies to steer state policy.

\section{Plan of Dissertation}

The dissertation is divided into seven chapters. The second chapter expands upon the theoretical framework briefly discussed earlier by presenting a new cultural approach that "brings back ideology" into foreign policy analysis.

\footnotetext{
${ }^{76}$ See The Israel Democracy Institute's monthly public opinion reports for the past two decades at: http://www.peaceindex.org.

${ }^{77}$ While the Democracy Institute has continuously polled the level of public support for negotiating with the Palestinians, no similar data exists regarding support for a two-state solution. Nevertheless there are many 'one-time' polls regarding this issue, particularly in recent years. For example the Democracy Institute reported in April 2012 that around 40 percent of the Israeli public believed in the feasibility of the two-state solution while 58 percent did not believe that it would resolve the conflict. A March 2013 Gallup reported that 52 percent of Israelis were in favor of a two-state solution, while 40 percent opposed such an initiative. A joint poll by the Dialog Institute and Tel-Aviv University in July 2014 found that sixty percent of the Israeli public supported a two-state solution. Another poll conducted in December 2014 and reported in January 2015 by the Israel-Palestine Center for Creative Regional Initiatives and +972 Magazine reported that 56 percent of Israeli public supported a two-state framework. See: The Israel Democracy Institute, The Peace Index Report: April 2012, April 2012; Lydia Saad and Elizabeth Mendes, "Israelis, Palestinians Pro Peace Process, but Not Hopeful," Gallup, March 21, 2013; Nir Hasson, "Despite It All, Most Israelis Still Support the Two-State Solution," Haaretz, July 7, 2014; Dahlia Scheindlin, "Are Israelis Ready for a Confederated Two-State Solution?," +972 Magazine, January 4, 2015.
} 
The new theoretical framework examines how domestic political ideologies, which are shaped in contrast and opposition to each other, compete to shape the state's foreign policy. The third chapter argues that during the Mandate period the Labor Zionist movement created a powerful Sabra identity in opposition to the presumed characteristics of Jews living in "exile." Labor's success in establishing the Sabra as an ideal image of the "new" Jew, which a majority of the public sought to resemble, was one of the primary reasons for its political hegemony. Finally the movement's ideology and the Sabra identity it created translated into a security oriented foreign policy that heavily relied on military strength and internal power, but which was also pragmatic and practical in its approach and tactics.

Chapter 4 begins by arguing that revisionist Zionist ideology was created in contrast to the presumed characteristics of Labor Zionists. The chapter then analyzes the developments that led to the decline of the Labor movement and the ascendance of revisionist Zionism, arguing that the Holocaust, the arrival of new oriental immigrants, the rise of multiculturalism in Israeli society and finally the 1973 War led to the decline of the Labor movement, while Herut's ideological evolution in favor of political pragmatism coupled with the increasing popularity of the "Greater Israel" idea in the wake of the Six Day War were the two most important reasons behind the rise of the revisionist movement. Finally the Six Day War resulted in a significant ideological transformation of religious Zionism from a movement mainly concerned with the implementation of Halacha in Israeli society, into a messianic settler movement that is primarily concerned with the 
settlement of biblical lands in accordance with the Lord's "divine plan."

Chapter 5 examines how the formation of Gush Emunim signified the first attempt to enshrine the ideology of Rabbi Kook into a centralized political movement that sought to redefine the very basis of Zionism and what it meant to be an "Israeli." The rise of the Gush and the events of the 1980s, particularly the Lebanon War, the exposure of the Jewish underground and the first Palestinian Intifada, led to the transformation of Labor's ideology in favor of Western liberal values and the construction of a 'liberal Zionist' identity. Chapter 6 argues that this development empowered Labor to interpret the international developments of the late eighties and early nineties in a new positive light, allowing it to reassess Israel's "security dilemma" and adopt a new foreign policy framework accordingly. In contrast the religious Zionists, together with their revisionist allies, prevented the "Hellenization" of the Israeli state by bringing down the government of Yitzhak Rabin and the peace process with it. Finally the chapter argues that the peace process has brought about a severe challenge to the ideology of the revisionist movement, which has yet to be resolved in a conclusive manner. Chapter 7 concludes the dissertation by providing a summary of the research's findings and situating them in the broader context of international relations theory. Finally recent developments in the peace process are discussed and recommendations for future research avenues are presented. 


\section{Chapter 2: Theoretical Framework}

In order to understand Israeli foreign policy toward the peace process in a more complete and comprehensive manner, a new theoretical framework that goes beyond the limits of past approaches is needed. To achieve this, a new framework that ties political ideologies with national identities and analyzes its impacts on the state's foreign policy is presented. The chapter begins by outlining the limits of realist approaches to Israeli foreign policy analysis. Alternative cultural approaches to foreign policy analysis are subsequently discussed. Finally a new cultural approach to foreign policy study is suggested. Subsequent chapters will use this theoretical framework to analyze Israeli foreign policy towards the peace process.

\section{The Limits of Realist IR Theory}

Neorealist IR theory emphasizes the role of global and regional balances of power in shaping the foreign policy of states. As discussed earlier however, Neorealism's sole focus on structural factors has come at the expense of ignoring domestic variables such as political ideology, in explaining international relations. This has severely hampered the framework's ability in explaining foreign policy change during periods when structural factors have remained largely static. For example it was pointed out how neorealists present a compelling case of why Israel sought to seek peace in the early nineties, but are unable to account for the decline of the peace process and the changes in Israeli policy. 
Other non-structural realists acknowledge the role of domestic political ideologies in influencing foreign policy, however rather than analyze such influence they have dismissed them as temporary "obstructions" over the realist non-ideological pursuit of national interests. George Kennan for example asserted that ideological and moralistic outlooks had repeatedly obstructed an effective pursuit of national interests and advocated that foreign policy decision makers should detach themselves from ideological dogma and see the "realities" of the international system. ${ }^{78}$ Similarly, Walter Lippmann complained about the unconscious ideological considerations that drove US foreign policy. ${ }^{79}$ Other realist scholars such as Norman Graebner and Arthur Schlesinger have also denounced the mixing of ideology with real-politik in US foreign policy. ${ }^{80}$ Schlesinger for example calls ideology a "curse" that "converts politics into a branch of theology." This is why he asserts that foreign policy should be separated from ideology and instead should be based on "practical" considerations. $^{81}$

While these scholars have acknowledged the role of ideology in foreign

\footnotetext{
${ }^{78}$ George F. Kennan, American Diplomacy (Chicago: University of Chicago Press, 1985), Chapter 5.

${ }^{79}$ Walter Lippmann, The Cold War: A Study In U.S. Foreign Policy (New York: Harper, 1947).

${ }^{80}$ Norman A. Graebner, America As a World Power: A Realist Appraisal from Wilson to Reagan (Lanham: Rowman \& Littlefield Publishers, 1984); Arthur Schlesinger, "Foreign Policy and the American Character," Foreign Affairs 62, no. 1 (Fall 1983).

${ }^{81}$ Schlesinger, "Foreign Policy and the American Character," 16.
} 
policy making, they have taken a pejorative stance towards it, claiming that ideology is interfering with the cool-headed pursuit of national interests. The problem with such an approach is that it does not explain when and how ideology affects policy. Moreover, this dissertation will argue that ideology cannot be separated from policy making in the first place because the belief system of politicians will determine how they define the country's national interests as well as how they should be pursued. ${ }^{82}$

Another realist alternative that seeks to account for internal variables shaping policy is neoclassical realism. Neoclassical realists assert that a state's foreign policy is driven primarily by its place in the international system and its relative material capabilities. This is a major area of commonality with neorealist theory. Where they differ from structural theory is that they argue that a state's relative power in the system is not directly translated into foreign policy. Rather its impact is dependent on unit level "intervening variables" which act in between the independent (relative power capabilities) and dependent (foreign policy) variables. Neoclassical realists for example stress that the perception of decision makers and domestic state structures are key to how states view the international system and how they define their country's interests. By accounting for intervening variables that "translate" the independent variable, realist theory becomes more complex but at the same time results in greater accuracy and

\footnotetext{
${ }^{82}$ As future chapters will demonstrate, the belief systems of politicians are constructed based on the political ideologies of the movements they are raised in.
} 
specificity. ${ }^{83}$ Neoclassical Realism also differs from constructivism in that the main driver of a state's foreign policy is its relative power capabilities and the other factors pointed earlier only act as intervening variables, whereas constructivism sees norms as constituting the very identity and interests of states. Also there are objective structural constraints and incentives on state behavior in neoclassical realism and as a result "anarchy is not what states make of it."

While neoclassical realism claims to explain why states are unable to adapt to systemic constraints and incentives by using domestic "intervening" variables that explain deviation from neorealist expectations, in effect the theoretical approach is only able to account for minor "deviations" from systemic predictions and "ideal" foreign policy. As noted earlier, based on neorealist assumptions, Israel's pursuit of the peace process in the early nineties was a result of the significant changes of relative power in that period which saw the rise in power of Israel and the US on the one hand and the decline of the power of their opponents on the other, creating a window of opportunity which allowed the pursuit of a settlement that was in their favor. Neoclassical realism would explain the subsequent change in Israeli foreign policy following the late nineties as a typical case in which domestic variables such as the perception of state leaders and factional politics led to deviation from the ideal foreign policy

\footnotetext{
${ }^{83}$ Ole R. Holsti and James N. Rosenau, "The Domestic and Foreign Policy Beliefs of American
} Leaders," The Journal of Conflict Resolution 32, no. 2 (1988): 248-94. 
behavior of the earlier period.

Neoclassical realism accepts the role of ideas in distorting the decision making process, in which ideas prevent state leaders from seeing the distribution of power objectively. Thus if states perceived objectively then their foreign policies would correspond to the predictions of neorealist theory. Therefore neoclassical realism's use of ideas is limited to decision makers' subjective perceptions and miscalculations of power relations. As Rathbun explains this distorted view is not due to the social construction of reality based on norms and identities, as constructivism would explain, but rather because power calculations are a "complicated business." For example "nowhere does Wohlforth indicate that if other actors with a similar set of information but different norms and values had been in place, the balance would have been perceived differently, which is what a constructivist would maintain." ${ }^{84}$ This is why standard neoclassical realist works only make "very limited use of ideas." Neoclassical realism does not advocate an expanded use of ideas, quite the contrary as Rathbun explains neoclassical realism "puts limits on its use of ideas. It problematizes perception but not the objective nature of reality. States must often fall back on perception not because reality is socially constructed but rather because they lack complete information." 85

\footnotetext{
${ }^{84}$ Brian Rathbun, "A Rose by Any Other Name: Neoclassical Realism as the Logical and Necessary Extension of Structural Realism," Security Studies 17 (2008): 294-321.

${ }^{85}$ Ibid.
} 
This limited use of ideas however does not allow a sufficient explanation of the changes in Israeli policy towards the peace process. Revisionist Zionist ideology and religious Zionism based on divine revelations, a long brutal history of persecution and forced exile resulting in a unique and strong feeling of insecurity and distrust of other countries, which are all important ideational driving factors behind the policies of right wing Israeli parties and leaders, cannot be reduced to only "miscalculation" and "misinformation" about changes in the distribution of power. Moreover as future chapters will demonstrate these ideational frameworks have shown remarkable continuity in defiance of changes in the balance of power. Therefore ideas, rather than being limited to misunderstanding and misinformation, form the very identity of the state and define its 'interests' and how they should be pursued. Thus, neoclassical realism's view of ideas risks misrepresenting and oversimplifying a complicated topic.

Moreover neoclassical realism emphasizes that systemic pressure determined by relative power shapes the broad and general contours of foreign policy, making certain options possible while eliminating others, thus narrowing the sets of possible courses of actions, and domestic intervening variables accounting for which specific policy is chosen within this narrowed set of options. In the specific case under examination in this project we must ask: if the independent variable (relative power) is so permissive that it allows for such a wide array of policies, some of which are in complete contradiction to each other (for example supporting and opposing the peace process), and identity and 
ideology determining which of these contradicting policies are in fact chosen, then can we still call identity and ideology an "intervening" variable?

The ideas and norms influencing decision makers such as Benjamin Netanyahu are different than for example Chamberlain's miscalculation of Germany's rising power in the run up to the Second World War. Indeed neoclassical realism asserts that such "misperceptions" are corrected in the long run. This is because when domestic intervening variables deviate a country's behavior from what structural factors predict (ideal foreign policy) the system punishes the state, resulting in the realization of past misperceptions and a correction of policy. This is why Rose asserts that even if the foreign policy of states might not track objective material power trends over the short to medium term, over the "long run a state's foreign policy cannot transcend the limits and opportunities thrown up by the international environment." ${ }^{186}$ Thus for example Britain and France corrected their foreign policy after the system punished them for failing to balance against Germany. These consequences led them to realize their misperceptions and lack of information and as a result to correct their miscalculations. In the case of Israel however, religious Zionist political parties and their leaders have not reassessed their policy towards a Palestinian state even after substantial "costs" to the Jewish state.

Realists claim that the lack of progress in the peace process has brought about substantial consequences for Israel such as security challenges due to

\footnotetext{
${ }^{86}$ Rose, "Neoclassical Realism and Theories of Foreign Policy," 151.
} 
Palestinian violence manifested in the Second Intifada, straining of peaceful settlements with regional rivals Egypt and Jordan, threatening the strategic alliance with the United States, damaging the country's economic growth of the early nineties, increased emigration from Israel (an important issue from a Zionist perspective), diplomatic and public image challenges and pressures, the latest of which was the Palestinian bid for observer status at the UN. Most importantly the collapse of the peace process has led to the strengthening of Israel's regional opponents such as Iran as well as Islamic groups such as Hezbollah and Hamas, by providing them with an avenue to pressure the Jewish state and giving them a rallying cry that is popular in the Arab and Muslim world and is a major source of legitimization for such groups. Israeli policy has also brought about "distinct challenges" to US interests in the region. ${ }^{87}$ Moreover the spread of the "Arab Spring" in the Middle East has increased such costs. ${ }^{88}$

Even if one agrees with these claims about the implications of Israeli policy, one cannot ignore the fact that right wing groups in Israel have stood their ground even with the high costs associated with their policies and as such the "punishment" of the international system has not resulted in the correction of their "misperceptions" and "miscalculations," largely because these policies were not

\footnotetext{
${ }^{87}$ David Petraeus, Statement of General David H. Petraeus, Before the Senate Armed Services Committee (Senate Armed Services Committee, March 16, 2010).

${ }^{88}$ Stephen M. Walt, "News Flash: WINEP Defends the 'Special Relationship," Foreign Policy, $\begin{array}{llll}\text { November } & 9 & 2011, & \text { November }\end{array}$ http://walt.foreignpolicy.com/posts/2011/11/08/news_flash_winep_defends_the_special_relations hip.
} 
based on incorrect or incomplete information about relative power to begin with, rather identity politics and ideology were the driving force behind these policies. This points to another important shortcoming of neoclassical realism in the study of this case: A strong argument can be made that the aim of these policies was not solely the maximization of power, or influence maximization as neoclassical realist theory would assert.

As a result, the need for a non-materialist based approach that looks at the role of identity and ideology in shaping Israeli policy and even constituting the very "interests" the state pursues becomes more apparent. Indeed a key constructivist insight is that a state's identity shapes its interests and thus its foreign policy. ${ }^{89}$ As future section will discuss, the theoretical framework of this dissertation will try to remedy the above weaknesses by using Constructivist theory to study how ideologies and identities are constructed in relation to the domestic "other" and how this in turn impacts the state's foreign policy.

\section{Cultural Approaches to Foreign Policy Analysis}

Cultural approaches to foreign policy study the role of shared sets of beliefs, ideologies and values in shaping a country's foreign policy. Culture helps define the goals of the country and shapes perceptions of the environment by providing a lens through which external events are interpreted and understood.

\footnotetext{
${ }^{89}$ See Peter J. ed. Katzenstein, The Culture of National Security. Norms and Identity in World Politics (New York: Columbia University Press, 1996); Alexander Wendt, Social Theory of International Politics. (Cambridge: Cambridge University Press, 1999).
} 
Moreover culture influences which options are "available" by determining which sets of actions are legitimate, and affects which of the choices is taken, by deeming some responses as more "appropriate." Moreover as Brian Rathbun explains, "culture is not objectively given but is rather a particular interpretation of historical experience that becomes institutionalized." Rathbun emphasizes that once consolidated however, shared cultures are "extremely stable," transcending partisan divides so that any government turnover is only "cosmetic change." ${ }^{90}$ In contrast this dissertation argues that as a result of contrasting domestic ideologies there is no dominant "shared culture" that transcends party divisions. Moreover these ideologies can in fact evolve and change in important ways, in turn affecting the state's foreign policy.

The word Ideology was first used during the French Revolution by Antoine Destutt de Tracy who defined it as a "science of ideas," literally an idea-ology, which stressed the importance of human sensation in the formation of knowledge.${ }^{91}$ As a result ideology was considered a new science that explained the relationship between ideas and experience. The word "ideologue" acquired a derogatory meaning by Napoleon who associated it with doctrinaire and utopian ideas. Such a negative view of ideology is also seen in the works of Marx, Arendt and Talmon.

\footnotetext{
${ }^{90}$ Rathbun, "A Rose by Any Other Name: Neoclassical Realism as the Logical and Necessary Extension of Structural Realism."

${ }^{91}$ Andrew Heywood, Political Ideologies: An Introduction, Fifth (New York: Palgrave Macmillan, 2012), 5; Hans Barth, Truth and Ideology (Berkeley: University of California Press, 1976), 1-3.
} 
This negative description of ideology is well summarized by Christenson et al: "a bad odor surrounds the word ideology, it suffers from ill repute.... And is characterized as false, delusory and highfalutin propaganda." Moreover one rarely sees oneself as an ideologue, rather it is always someone else that is a victim of ideology. "We have a political philosophy, they have an ideology; we have cherished values, they have dogma; we have founding fathers and leaders, they have false prophets and tyrants; we are steadfast and true to our principles, they are fanatics." 92

The most critical view of ideology comes from Marxist writers who see it as masking the true nature of capitalism and imperialism. According to Marxists, ideology paints a false and distorted view of social relations in order to facilitate the dominance of the ruling class. Both Marx and Engels assert, "The ruling ideas of each age have ever been the ideas of its ruling class." ${ }^{93}$ Ideology legitimates, perpetuates, and reifies contingent social relations and presents them as unchanging and fixed. Moreover the propagation of ideology is largely done unconsciously. As a result ideology is seen as an important instrument of the domination of the ruling class. ${ }^{94}$

Starting from the 1960s however the word ideology has lost its negative connotations and has become a neutral and objective concept. Ideology in

\footnotetext{
${ }^{92}$ Reo M. Christenson et al., Ideologies and Modern Politics (New York: Harper Collins, 1975), 5.

${ }^{93}$ Karl Marx and Friedrich Engels, The Communist Manifesto (New York: Penguin Classics, 2011), 86.

${ }^{94}$ See John Torrance, Karl Marx's Theory of Ideas (Cambridge: Cambridge University Press, 2008), Chapters 6 and 7.
} 
modern times is used to refer to "a set of closely related beliefs or ideas, or even attitudes, characteristics of a group of community." ${ }^{95}$ Johnston defines an ideology as a "more or less consistent set of beliefs about the nature of society in which individuals live, and about the proper role of state in establishing or maintaining that society." 96

Michael Hunt, one of the premier researchers on the role of ideology in foreign policy, defines ideologies as "integrated and coherent systems of symbols, values, and beliefs" arising from "socially established structures of meaning." These sets of ideas and beliefs are "relatively coherent, emotionally charged, and conceptually inter-locking.." ${ }^{97}$ Moreover ideologies are not just used to make sense of the external world, but also provide normative criteria for value judgment and a prescriptive program that dictates actions, as well as a rhetoric that justifies it and mobilizes followers. Hunt for example argues that American national ideology is marked by a vision of national greatness, territorial expansion, the exportation of liberal political values, a sense of Anglo-Saxon racial superiority as well as negative attitudes towards revolutions. Hunt uses this ideological framework to explain US policy during the Cold War, particularly the

\footnotetext{
95 John Petrov Plamenatz, Ideology (London: Macmillan, 1971), 15.

${ }^{96}$ Larry Johnston, Ideologies: An Analytic and Contextual Approach (Peterborough, Ontario: Broadview Press, 1995), 13.

${ }^{97}$ Michael Hunt, Ideology and U. S. Foreign Policy . (New Haven: Yale University Press, 1987), p14.
} 
Vietnam War. ${ }^{98}$ Therefore while ideas are the constitutive elements of an ideology, ideas only become an ideology once a consistent and well-organized system of relationship among them emerges, resulting in an ideational framework that has clear and specific goals and a political action program to achieve them.

Political scientists have long studied the role of ideology in domestic politics, yet the role of political ideologies in shaping foreign policy has been neglected. This is why many scholars have called for more attention to this promising approach to international relations. Kenneth Schultz argues that little systematic attention has been paid to the relationship between ideology and foreign policy. ${ }^{99}$ Sasson Sofer complains about the "invisibility" of ideology in international relations, ${ }^{100}$ while Costel Calin explains that "the present international relations literature lacks an in-depth analytical debate on the relationship between a government ideology and a country's foreign policy."101

When compared to the main theoretical schools of IR such as realism, liberalism and constructivism, one can conclude that the role of ideology in foreign policy and international relations has been overlooked. Nevertheless there has been a recent surge to remedy this deficiency in the past two and half

${ }^{98}$ Ibid.

${ }^{99}$ Schultz, "The Politics of Risking Peace: Do Hawks or Doves Deliver the Olive Branch?"

100 Sasson Sofer, "International Relations and the Invisibility of Ideology.," Millennium: Journal of International Studies 16, no. 3 (1987): 489-521.

${ }^{101}$ Calin, "Hawks versus Doves: The Influence of Political Ideology on the Foreign Policy Behavior of Democratic States." 
decades. Scholars who have used ideology to explain foreign policy include Foster and Palmer (2006), Schultz (2005), Rathbun (2004), Hunt (1987), Therien and Noel (2000), Holsti and Rosenau (1988 and 1990), Klingemann et al. (1994), Sulfaro (1996), DeLaet and Scott (2006), Haas (2003), Russett (1990), Eichenberg (1989), Hurwitz and Peffley (1987), Calin (2010), Cassels (1996), Sofer (1987), Schonberg (2009), Fordham (1998), London, Palmer, and Reagan (2004). The existing literature on the role of ideology in foreign policy however suffers from several important gaps, which the current study seeks to fill. These can be listed as follows:

a) The large majority of studies that examine the role of ideology in foreign policy, concentrate only on the US case. This includes Schonberg, Fordham, London, Palmer and Reagan, Hunt, DeLaet and Scott, Russett, Foster and Palmer, Holsti and Rosenau, Sulfaro. ${ }^{102}$ Although an interesting case study, drawing empirical generalizations from the US, which has a distinct position in international affairs, would be unreliable.

\footnotetext{
102 See Karl K. Schonberg, Constructing 21st Century U.S. Foreign Policy (New York: Palgrave Macmillan, 2009); Fordham, "Partisanship, Macroeconomic Policy, and the U.S. Uses of Force, 1949-1994"; Palmer, London, and Regan, "What's Stopping You?: The Sources of Political Constraints on International Conflict Behavior in Parliamentary Democracies"; Hunt, Ideology and U. S. Foreign Policy .; Delaet and Scott, "Treaty-Making and Partisan Politics: Arms Control and the U.S. Senate, 1960-2001"; Bruce Russett, "Doves, Hawks, and U.S. Public Opinion," Political Science Quarterly 105, no. 4 (1990): 515-38; Dennis M. Foster and Glenn Palmer, "Presidents, Public Opinion, and Diversionary Behavior: The Role of Partisan Support Reconsidered," Foreign Policy Analysis 2 (2006): 269-87; Holsti and Rosenau, "The Domestic and Foreign Policy Beliefs of American Leaders"; Ole R. Holsti and James N. Rosenau, "The Structure of Foreign Policy Attitudes among American Leaders," The Journal of Politics 52, no. 1 (1990): 94-125; Valerie A. Sulfaro, "The Role of Ideology and Political Sophistication in the Structure of Foreign Policy Attitudes.," American Politics Research 24 (1996): 303.
} 
For example one of the results of this overemphasis on the US has been the categorization of foreign policy belief systems along an internationalistisolationist continuum, which does not necessarily apply to other countries. Moreover, as a result of this exclusive focus, many scholars have mistakenly limited political ideology to liberalism and conservatism. In the Israeli case for example such an approach would severely limit our understanding of the country's political ideologies, where different forms of Zionism are at play. In the few instances where scholars have studied other countries, the focus has been on Western European countries. This exclusive focus on "great powers" has limited the utility of such an approach to the study of other regions.

b) As it currently stands, the vast majority of ideological approaches, and cultural approaches to foreign policy more generally, are utilized to explain continuities in foreign policy. This is because culture and ideology are assumed to be static. Rathbun for example asserts, "Shared cultures are extremely stable." ${ }^{103}$ Duffield stresses, "culture promotes continuity in behaviour. Continuity follows from the relative stability in culture." ${ }^{104}$ Similarly Hunt explains the tendency of ideologies to persist. The assumption that ideologies and cultures are static has limited the

\footnotetext{
${ }^{103}$ Brian Rathbun, "Contesting the National Interest" (PhD Dissertation, University of California at Berkeley, 2002), 10.

104 John S. Duffield, "Political Culture and State Behavior: Why Germany Confounds Neorealism," International Organization 53, no. no. 4 (1999): 772.
} 
application of such approaches. This research project on the other hand will use the Israeli case to demonstrate that ideologies themselves can evolve and change in important ways and how these changes can influence foreign policy, and as such cultural approaches can be effectively used to study foreign policy change.

c) Ideology is usually seen as homogeneous and unitary. The case study of this dissertation on the other hand will demonstrate that ideologies within a country can be fragmented and highly opposed to each other. The literature wrongly assumes that there is a single dominant culture that the vast majority of society adheres to and that rejectionists groups are forced to compromise with the hegemonic culture and ideology.

d) In instances where ideological divisions are acknowledged, they are divided into stereotypical categories. Another division of ideology, which is widely used in the literature, are "doves" and "hawks," where dovish parties are associated with multilateralism and anti-militarism and hawks seek to export democracy and liberal values abroad, with the power of force if necessary. Such stereotypical simplifications of ideologies are due to the excessive focus on the US and its foreign policy. Indeed such categorization can be misleading when applied to other countries. For example the Israeli Labor party is not necessarily in favour of multilateralism, and the right wing Likud is not necessarily in support of unilateral intervention in support of liberal goals. These approaches lead to the neglect of important factors shaping political ideologies, such as a 
group's historical experience and the role of religion. This research project will examine how ideologies are constructed and how they evolve, rather than taking them as given and making broad generalizations such as "doves" and "hawks."105

e) One of the main criticisms of cultural approaches to foreign policy has come from positivists who question whether the research results of the school can be applied to other cases. In response some scholars have resorted to using large-N statistical analysis on a wide range of countries to overcome the "shortcomings" of the approach. Therien and Noel for example examine how the political orientation of parties affects foreign aid in 16 OECD countries using statistical analysis. ${ }^{106}$ Calin on the other hand uses statistical analysis to analyze the relationship between party ideology and foreign policy behaviour in 22 OECD countries. ${ }^{107} \mathrm{~A}$ weakness of such approaches is that in order to successfully conduct large-N statistical analysis, party ideology as well as foreign policy outcomes need to be categorized and overgeneralized. The advantage of these approaches is that they provide results that are applicable to a wide set of countries; on the other hand they can only explain a limited set of foreign policy

\footnotetext{
${ }^{105}$ Within the context of the Peace Process, such generalizations arguably lead to the loss of the nuances and complexities of each ideology's approach to the conflict.

106 Thérien and Noel, "Political Parties and Foreign Aid."

${ }^{107}$ Calin, "Hawks versus Doves: The Influence of Political Ideology on the Foreign Policy Behavior of Democratic States."
} 
behaviour. Therien and Noel for example conclude that social democratic parties positively affect the level of a country's foreign aid budget, while Calin concludes, "the further right a government is, the higher the propensity to behave more aggressively. Conversely, the further left a government is, the more likely it is to behave more cooperatively." ${ }^{108}$ The point is not to dismiss the results of these researchers, but rather to show that in order to come up with parsimonious general theories, the depth and detail of how party ideology affects foreign policy is lost. Instead this dissertation seeks to use statistical analysis in conjunction with interpretive methods to come up with a mid-level foreign policy theory, which while providing a generalizable model that can be applied to other countries does not provide universal categories of political ideologies and their foreign policy agendas. Such an approach allows the researcher to account for the distinct characteristics of the case under study.

\section{A New Cultural Approach to Foreign Policy Analysis}

This dissertation proposes a theoretical framework that ties political ideologies to national identities. This is because ideologies are not created in a vacuum, rather their political agendas are based on beliefs, values and symbols that are deeply rooted in national identity. Thus how "we see the world" and our goals within it are dependent on who "we" are. Moreover the relationship

\footnotetext{
${ }^{108}$ Ibid., 5.
} 
between ideology and identity is mutually constitutive. Ideology, as the set of ideas that explicitly dictate political behavior, is the politically normative component in the cognitive framework of national identity. Thus it is necessary to analyze both the political ideologies of a given society as well as the broader national identity/identities underpinning them. ${ }^{109}$ This relationship is demonstrated in the figure below.

Figure 2: A New Cultural Approach to Foreign Policy Analysis

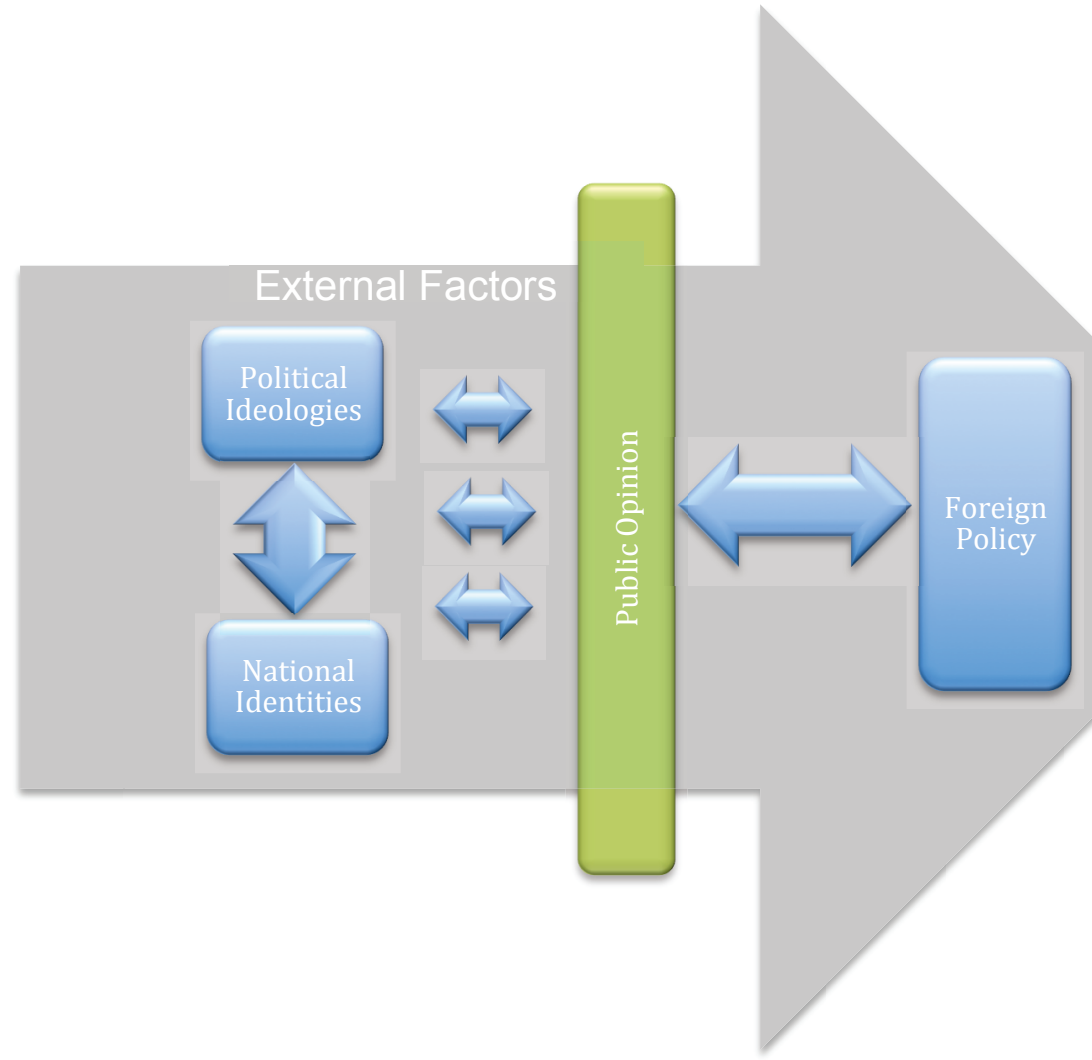

The relationships depicted in figure 2 are in no way causal relationships as defined by positivist frameworks. Rather they are complex constitutive

${ }^{109}$ Schonberg, Constructing 21st Century U.S. Foreign Policy, chapter 1. 
relationships that influence but do not firmly decide foreign policy. This is because culture is in no way deterministic, rather it helps explain why some options are more likely to be chosen by political groups by explaining which goals are considered to be "legitimate" and which options are "available."

This dissertation makes several theoretical claims. These include: ideologies and identities are often created in relation to the domestic "other," that ideologies are like a lens that are used to make sense of the world, that ideological change usually take place during times of political crisis and that such change is usually contested within political movements, that public opinion plays an important part in the rise and fall of ideologies, that changes in rhetoric might lead to unintended ideological transformations, that ideologies are affected by external events and developments, and finally that the relationship between ideology and foreign policy is not unidirectional, rather a country's foreign policy can also have important effects on domestic political ideologies. These arguments are discussed below.

\section{The Inter-Relational Character of Ideological Identities}

Hopf explains that "identities categorize people according to common features, making the other's actions intelligible and an individual's own actions vis-à-vis them intelligible to himself." ${ }^{\text {110 }}$ Therefore it is important to understand identity relationally, since there can be no "we" if there is no "they." This

\footnotetext{
${ }^{110}$ Ted Hopf, Social Construction of International Politics: Identities \& Foreign Policies, Moscow, 1955 and 1999 (Ithaca: Cornell, 2002), 5.
} 
relationship plays a central role in the construction of political ideologies and as such must be studied in any discussion of ideological foreign policy decisionmaking. This study shows that much like identities, key characteristics of political ideologies are also formed in relation to their ideological rivals. This is due to the fact that the ideology and identity of a movement are mutually constitutive of one another.

This dissertation uses Constructivist theory to study the relational construction of political ideologies. By constructivism I mean the meta-theory that examines the relationship between structures and agents and the role of ideas and norms in this relationship, not the body of literature that has specific claims and propositions regarding international politics. Such use of constructivism is inline with many scholars such as Hopf, Wendt and Barkin who define Constructivism as a meta-theory akin to Rational Choice that is compatible with various IR theories.

Constructivists assume that identities are created intersubjectively. Most of the existing literature however mistakenly assume that the "other" used in identity formation are solely other states. Hopf sees this as a consequence of an overemphasis on the third-image in constructivist writing which leads to the investigation of the "Self and Other as if the only other for a state were another state." ${ }^{111}$ In contrast this dissertation does not assume that identity formation solely takes place at the international level, rather it argues that domestic political

\footnotetext{
${ }^{111}$ Ibid., 9.
} 
divisions and cultural differences also shape it. To use the Israeli case as an example, the identity and political ideology of Religious Zionists has partly been shaped by contrasting themselves with Labor Zionists who are portrayed as "corrupt" and "soft elitists" who are "too liberal and pluralistic," who oppose Judaism and instead are "over obsessed with pleasing the gentiles." ${ }^{112}$ This relational construction of identity is elaborated in future chapters.

Furthermore the case study of this dissertation will demonstrate that ideological identities become more salient and pronounced during times of high ideological polarization. Ideological identities also become more prominent when it is presumed that the other is "acting ideologically" and not based on the country's "national interests."

\section{Ideology as a Lens Into the World}

Ideology is usually contrasted to national interests, and the competition and conflict between the two is studied. However this is not a helpful distinction since ideology, rather than being in competition with national interests, provides a lens through which "national interests" are defined to begin with. This is because national interests are not objectively given, rather it is contested by political ideologies. As such, far from being unresponsive to international factors and

\footnotetext{
${ }^{112}$ For example Yaakov Weinrot, a religious Zionist leader, declared in the court of the 'Jewish Underground": "They [the religious settlers] see the hatred of the elite in the State of Israel, of the fashionable and phony intellectualism...that each time strikes at religious Jewry in competition... The state of Israel today is bourgeois and disgruntled where as the entire essence of these people [the religious Zionist defendants] is constant sacrifice and giving...they will be the first to answer any call, and it is they who will ascend the mountain." Zertal and Eldar, Lords of the Land: The War Over Israel's Settlements in the Occupied Territories, 1967-2007, 90.
} 
material interests, ideologies define what these interests are and how they should be pursued, as well as determining friend and foe, threat and opportunity in the process. The difference between the responses of Labor and Likud to the new international environment of the late eighties demonstrates how political ideologies see the world, and changes within it, differently.

This is because political actors cannot determine what their interests are until they know "who they are." This issue becomes more pronounced when one considers that developments within the international system are often ambiguous, complex and even contradictory, making a variety of understandings and explanations plausible. As a result, the ideologies of political parties running the state become important since they determine the beliefs about the international system and the "interests" the country should pursue. Even developments that may be considered straightforward by realists can be interpreted differently be domestic political ideologies. For example the secular Labor movement and the messianic religious Zionist movement understood Israel's victory in the Six Day War very differently.

\section{Political Crisis and Ideological Change}

This dissertation argues that ideological change generally take place during times of political crisis. Ideological change is defined as significant alterations to a movement's worldview that is accepted by a majority of its members, including party elites as well as supporters within the general public. Ideological change can be difficult to distinguish from short-term policy changes that are frequently adopted by parties due to political expediency. Nevertheless 
real ideological change manifests itself in the adoption of new policies and rhetoric that are consistent and long-term. An example will make this clear: the revisionist movement's exclusion of Transjordan from the land of Eretz Israel in the late fifties, which will be discussed in chapter four, heralded a real ideological change since claims to Transjordan began to dissipate both from the movement's rhetoric and from its policy proposals from then on, so that by the sixties the movement had completely dropped Zionist claims to the area. As a result of this ideological change, the grand majority of the revisionist movement has not called for the "liberation" of Transjordan from the sixties until today.

On the other hand, as chapter six will demonstrate, Likud's acceptance of the Oslo Accords during the 1996 elections was a political ploy aimed at attracting the centrist voter. As a result once the elections were over the Likud attempted to renege on its earlier promises. This is because the change in the movement's behavior was not the result of a new understanding and discourse of the conflict. Nevertheless it is also important to point out that changes in policy platforms that diverge significantly from a movement's ideology will eventually weaken that ideology and create momentum for actual ideological change.

The results of this study suggest that political movements are usually more prone to ideological change when they experiences turmoil in the form of a severe loss during elections, or when the movement fails to perform as expected during several election cycles. In such circumstances, frequently a group of elites seeks to change the movement's ideology in order to rehabilitate its political prospects. Nevertheless other members of the movement who insist on 
ideological consistency and "purity" almost always resist such process. As such, not all political crises that create a drive for ideological change result in actual transformation. Aside from the role of party elites, external events and public opinion are also factors that impact the success of ideological change.

External events and international developments can confirm the ideas and beliefs of an ideology or they can challenge them. As a result domestic political ideologies are continuously tested by actual events. When external events contradict the ideational principles of a political movement, they are usually reevaluated and reinterpreted by elites in order to lessen their negative impact on the movement. Nevertheless if such events are powerful and reoccurring, they increasingly lead to pressure for ideological change. In the context of the case under study here for example, Yitzhak Rabin's successful signing of a peace agreement with Yasser Arafat brought about a significant challenge to revisionist ideology, which explained that only force could deter the "eternal" Arab enemies of the Jewish people. As a result, revisionist leaders such as Netanyahu had to reinterpret the event for the movement's followers by explaining that the Palestinians were using the peace negotiations as a "tactic" to weaken Israel before they could deliver their "final blow." This is why the Oslo Accords were routinely referred to a "Trojan horse" in revisionist discourse.

Even though political turmoil and unforeseen external events that run counter to a belief system affects all political movements, the results of this research show that some movements are more accepting of change, while others show extreme resilience and defiance in the face of political decline and 
unwanted external developments. Movements whose ideologies contain elements of political pragmatism and who value electoral success are more prone to ideological change. For example this is why the Labor movement has been more successful in refining its ideology according to times and political circumstances. In contrast, movements that have a high capacity for interpreting and reframing external events in ways that make them fall in line with their ideologies, are better equipped to hold on to their ideational principles. In the context of this research the religious Zionist movement has shown surprising ideological consistency throughout its history. This issue is further discussed in chapters six and seven.

\section{The Contested Nature of Ideological Change}

When a political crisis does in fact result in ideological change, such transformation is usually not accepted by all of the movement's members, some of which will lead a campaign to stop and rollback such change. This is because ideological transformation is usually not fully complete and does not affect all members equally. For example while the Labor movement dropped many of its socialist-Marxist principles during the fifties and sixties, there were many dissenters within the movement who went as far as breaking away from the movement and forming their own independent parties. More importantly chapter six will show how some Labor leaders were sympathetic to the settler movement during the seventies and eighties on some levels because Labor's ideology had originally valued a pioneering spirit that was rooted in settlement activity, even though such ideas and attitudes had largely dissipated from the movement's 
worldview by then, and even though the "new" settlers were the chief rival of Labor at the time.

Ideological transformation in this dissertation is defined as when significant changes to the movement's worldview are accepted by a majority of its members. Nevertheless it should be pointed out that ideological change is usually not a smooth process and the establishment of minority views after such change is commonplace. Moreover the results of the present study show that ideological change regularly takes around a decade to complete, from its inception until a majority of the movement is won over. After such transformation, it sometimes takes a further decade for the change to manifest itself in tangible policy modifications. Thus the process of ideological crisis, transformation, and change in actual behavior, typically takes two decades to complete.

\section{Where Does Ideology Reside?}

The results of this study suggest that ideology is used both by a movement's elites as well as its members and followers as an ideational lens that is used to make sense of the world. As such, while typically it is party elites who play the leading role in devising political ideologies, prescribing political actions in accordance with them, and coming up with discourse and rhetoric that justifies such action and mobilizes followers, ordinary party members and even a movement's constituents are far from "cultural dupes," rather they have the power to reject or alter such elite decisions. More importantly, this dissertation's research findings suggests that while ideological change is usually initiated and 
carried out by a movement's elites, less frequently such a transformation can also be led by the rank and file of a movement.

The prime example of such change is the rise of the Peace Movement within Labor in which ordinary party members played a leading role in transforming the movement's ideology in favor of Western liberal values and a negotiated political settlement with the Palestinians. This issue is discussed in chapters five and six. Thus ideological change does not always take place from the top-down but can also be initiated and fought for by the masses. Furthermore political movements are constantly under pressure to refine their ideologies in

order to make them attractive to their constituents. These issues make it necessary to factor in the role of public opinion in foreign policy making, particularly when studying democracies.

\section{The Influence of Public Opinion}

In democratic political systems public opinion determines which ideology influences foreign policy by voting for warring political parties during election cycles. As with identity and ideology, the relationship between ideology and public opinion is also mutually constitutive. Political ideologies help shape public opinion. They help the public make sense of the external world and dictate political action. On the other hand public opinion decides which ideology becomes dominant in a certain time period. This creates the need for political parties to reform their ideologies in order to have more resonance among the public.

Public opinion is rarely used explicitly as a variable in foreign policy 
analysis. Some scholars such as Randall Schweller see the role of society in foreign policy as episodic and rare, others like Colin Dueck assert that societal forces do not affect the substance of policy but rather influence its style and form. Nevertheless scholars such as Steven Lobell, Benjamin Fordham and Mark Brawley have emphasized the role of societal forces such as public opinion in shaping a state's foreign policy agenda. ${ }^{113}$

With regards to the role of domestic interest groups, including public opinion as well as privileged interest groups, Norrin Ripsman argues that they are far more likely to influence the "timing and style" of a state's national security policy rather than its main interests. ${ }^{114}$ Nevertheless, Ripsman acknowledges "when national leaders feel their hold on power is slipping, they may be more responsive to domestic preferences and may choose riskier security policies in order to secure themselves politically." ${ }^{" 15}$ Such pressures on political leaders are especially acute in democracies such as Israel. More importantly when there is a lack of a domestic hegemonic discourse on how to deal with a specific foreign policy issue, public opinion determines which approach is adopted as state policy. As apparent in Figure 2, public opinion is acting like a filter that

\footnotetext{
${ }^{113}$ Steven E. Lobell, Norrin M. Ripsman, and Jeffrey W. Taliaferro, Neoclassical Realism, the State, and Foreign Policy (Cambridge: Cambridge University Press, 2009), 32.

${ }^{114}$ Norrin M. Ripsman, "Neoclassical Realism and Domestic Interest Groups.," in Neoclassical Realism, the State, and Foreign Policy, by Steven E. Lobell, Norrin M. Ripsman, and Jeffrey W. Taliaferro (Cambridge: Cambridge University Press, 2009), 192.

${ }^{115}$ Ibid., 173.
} 
determines which ideological orientation takes over government in a particular time period.

\section{Rhetoric Change and Ideological Transformation}

A movement's discourse of "us" vs. "them" plays an important role in the indoctrination of its members and is used in understanding and explaining external events and developments. Ideological discourse, which is made up of coherent symbolic orders, is also used to legitimize policy and mobilize followers. Furthermore ideological discourse needs to be consistent and recurrent in order for it to become inscribed in society and compete with other ideological discourses. As a result when the political rhetoric of a movement's leaders diverges from its accepted ideology, naturally a tension arises that if left unaddressed will build up pressure for ideological change. While politicians regularly use political rhetoric for "tactical" short-term objectives, if such rhetoric runs counter to the movement's ideology, it weakens its discourse over competing narratives. This situation becomes especially heightened when the contradicting rhetoric is recurrent.

The present study demonstrates for example how a change in revisionist rhetoric regarding the Oslo peace process starting with the campaign of the 1996 elections, led to the legitimization of the peace talks and the undermining of the "Greater Israel" doctrine, which formed the backbone of revisionist ideology. In fact as chapter 6 will discuss, the movement soon found that rhetorical change was ultimately leading to policy change and eventually to ideological transformation. As noted earlier, this is because the ways in which politicians talk 
about the world tend to define the ways in which they act in that world, inclining them toward some options and away from others. Moreover political rhetoric also affects a movement's constituency, who may not be able to differentiate between tactical political speech and real transformation in ideological discourse. As a result when party rhetoric diverges in significant ways from ideology for a considerable length of time, an impetus for ideological change builds up.

\section{Pragmatism Vs. Realist IR Theory}

The political ideology of some movements value pragmatism, which is essentially defined as increased practicality in reaching the movement's objectives. For example the next chapter will demonstrate how the Labor movement was very pragmatic in its goal of establishing a Jewish State. Such pragmatism meant that the movement used a diverse array of tools to reach its objectives and showed increased flexibility in the means and methods it adopted. Labor's pragmatism was also due to its leaders' understanding of the Yishuv's limits and weaknesses. In post-independence years this pragmatism led to a foreign policy approach that was very flexible and dynamic in securing the "interests" of Israel and did not rule out alliances with other countries based on presumptions. While such an approach shows some similarities with a Realist view to international relations and indeed is the reason why Labor's foreign policy is commonly described as "realist," this dissertation will demonstrate how such pragmatism should not be confused with Realist international relations theory.

Realist international relations theory is based on the assumption that the nature of reality is objective. Realists claim that the international environment is 
marked by anarchy, regardless of whether international actors see it as such. This "objective reality" means that states should primarily seek to ensure their own survival. As such if states are able to understand international power relations objectively, they would be better equipped to pursue their national interests, which is defined as either increased security or power, depending on the realist school. Moreover Realists see these conditions as immutable and fixed. ${ }^{116}$

In contrast to the above materialist approach, the present dissertation argues in favor of an ideational approach in which the external world is not an external objective reality that is independent from its actors. Rather ideologies serve as lenses that actors use to understand the international environment and determine their place and role in it. Furthermore ideologies decide what "national interests" are and how they should be pursued. Therefore while some international actors might value political pragmatism due to their ideologies, this does not necessarily entail the acceptance of the much more profound assumptions of Realist international relations theory. As a result, labeling Labor's foreign policy approach as "Realist"117 and its rivals as "Idealist" is completely unfounded. Also while the results of this study suggest that political movements

\footnotetext{
${ }^{116}$ Defensive Realism defines state interest as the maximization of security, while Offensive Realism sees the maximization of power as the ultimate national interest.

117 In line with 'Realist international relations theory,' not the term 'realism' that is defined as "the attitude or practice of accepting a situation as it is and being prepared to deal with it accordingly." In the context of this dissertation, ideologies determine the "situation," regardless of whether the ideology values pragmatism or not.
} 
show increased pragmatism when in power compared to when they are in opposition, this does not mean that they become "Realists" once they gain power.

\section{The Impact of External Factors on Domestic Ideologies}

Another important issue to consider is that the influence of ideologies on foreign policy does not takes place in a vacuum but is under the influence of external events. Group identity is partly shaped as a result of historical and ongoing experiences with the external world, political ideologies have roots in shared ideas, beliefs and values, but they are also influenced by external events and developments. Indeed ideologies are defined as how these shared cognitive frameworks help interpret the external world, thus it would be meaningless to study ideologies without looking at the external environment in which they are created and the conditions of their evolution. For example domestic political ideologies within Israel not only interpreted events such as the Six Day War, the end of the Cold War and the Oslo Accords differently, but each ideology was in turn affected by these developments in distinct ways.

Public opinion is also affected by external events. For example suicide bombings by Palestinian militants in the mid-nineties played a crucial role in the shift of Israeli public opinion away from the peace process and the subsequent collapse of Shimon Peres' government and Likud's ascendance to power. This example shows how external events can play an important role in empowering one political ideology over its domestic rivals. As such it is imperative that any study that uses a cultural approach to foreign policy analysis takes into account 
external events, constraints and incentives.

\section{The Consequences of Foreign Policy on Domestic Ideologies}

In this theoretical approach the relationship between ideology and political action runs both ways. There is widespread agreement among scholars about the existence of a relationship between ideology and action. As Zbigniew K. Brzezinski states, "ideology is the link between theory and action" and that everybody agrees that ideology is "action-related." ${ }^{118}$ However there is disagreement among scholars about the nature of this relationship. Some scholars such as Skidmore and Donaldson claim that ideology shapes political action, while others including Balaban, Seliger, and Funderburk argue that ideology is primarily used to legitimize action and manipulate social consciousness and thus instead of ideology shaping political action, it is action that influences ideology. Balaban for example argues that ideology is a "system of ideas and beliefs that politicians create for the purpose of persuading people to support or reject a given policy."119

In this dissertation the relationship between ideology and foreign policy runs both ways. Ideology helps shape foreign policy, while foreign policy, which is also influenced by other factors such as external events, also ultimately affects ideology. This is because in the process of legitimizing political action, ideology

\footnotetext{
${ }^{118}$ Zbigniew K. Brzezinski, Ideology and Power in Soviet Politics (Westport: Greenwood Press, 1976), 98.

${ }^{119}$ Oded Balaban, Politics and Ideology: A Philosophical Approach (London: Avebury, 1995), xvii.
} 
might need to be refined and altered. This is particularly the case when political action has swayed away from the movement's established ideology. For example in the Israeli case the peace process highly influenced the ideological evolution of the revisionist movement.

\section{Theoretical Contributions}

This new theoretical framework provides an improvement over both realist as well existing cultural approaches to foreign policy. Realist approaches to foreign policy either completely ignore the role of domestic ideologies or reduce them to "interferences" to "ideal" decision-making. In the case of neoclassical realism, which seeks to account for domestic variables such as ideology, they are categorized as "intervening" variables and are effectively reduced to miscalculations and misperceptions about the relations of power. As a result neoclassical realism is not able to account for major changes in foreign policy due to domestic factors. Moreover the theory assumes that there is a single "ideal" national interest that should be pursued without considering that the ideology that drives political parties in the domestic political arena also leads them to define national interests in different ways.

Compared to existing cultural approaches to foreign policy, this new theoretical framework is able to account for changes in foreign policy behavior in addition to policy continuities, which has been the main focus of cultural approaches to international relations thus far. This is because culture and ideology are no longer assumed to be static and stable, rather they are being 
affected from multiple directions (as seen in figure 2) including from national identity, public opinion and external events and developments. Moreover by not assuming that there exists a dominant and homogeneous domestic political ideology that dictates policy, this framework allows the study of how rival ideologies differ and fight over government policy.

Also as mentioned earlier, in this approach identity formation does not solely take place at the international level, rather domestic political divisions and cultural differences also shape it, therefore the "self" is not shaped only in relation to the international "other" but to the domestic "other" as well. Therefore this theoretical framework attempts to shift constructivism's overemphasis on the third image to the second image by "bringing back" ideology to the study of national identities and foreign policy decision-making. These theoretical contributions are further elaborated in chapter seven.

As a result of these modifications to existing approaches to foreign policy analysis, more complex foreign policy behavior such as Israeli policy toward the peace process can be explained much more effectively. The next chapter will begin the path to such an explanation by demonstrating how the Labor movement, which played a hegemonic role in shaping Zionism in its early days and which would emerge as the "other" of the revisionist and religious Zionist movements, molded a popular national identity from its own ideology and how this led to the establishment of a power oriented foreign policy framework. 


\section{Chapter 3: The Hegemony of Labor Zionism and the}

\section{Creation of the Sabra}

This chapter will demonstrate how in line with the theoretical framework presented in the previous chapter a political ideology can form a distinct national identity that in turn will have important influences on the state's foreign policy. The chapter argues that during the Mandate period the Labor movement was able to successfully create a Sabra identity that was constructed in opposition to the presumed characteristics of the "exile Jew." While the creation of the Zionist enterprise on the myth of the "exile Jew" is well documented by Yael Zerubavel and Anita Shapira, ${ }^{120}$ the present chapter builds on existing literature by examining how the Labor movement was successful in constructing the Sabra identity through key institutions such as the military and the education system based on its own ideology, and how this would play an instrumental role in the formation of the movement's cultural and political hegemony during the mandate period and the early years after the founding of the state. Furthermore it is argued that Labor's ideology, manifested in the Sabra identity, played a central role in the formation of a security oriented foreign policy that was pragmatic in its approach but reliant on military power nonetheless. Such an orientation would

\footnotetext{
${ }^{120}$ See Yael Zerubavel, Recovered Roots: Collective Memory and the Making of Israeli National Tradition (Chicago: University Of Chicago Press, 1997); Anita Shapira, "Whatever Became of 'Negating Exile'?," in Israeli Identity in Transition (Westport: Praeger, 2004).
} 
form the basis of Israeli policy for years to come and is thus a crucial element in solving the puzzle of the country's inconsistent approach to the peace process in the nineteen nineties.

In the early years of the Zionist movement, the entire success of the Jewish nationalist effort was dependent on how it would be able to address two main challenges: How to create a state for the Jews, an issue that has received much attention, and the understudied challenge of creating a nation to correspond with the new state. The challenge of creating a new uniform national identity from a diverse multitude of diaspora cultures was no easy task, yet the Zionist movement was able to create an image of a "new Jew" that presented a very powerful discourse which was able to assimilate new immigrants, and advance Zionist goals such as "love of the land," as well as defending the new Jewish community in Palestine (the Yishuv) and in later years the newly-born Israeli state. The movement to create "new Jews" or Sabras was able to form a melting pot that constructed a hegemonic identity out of the "ingathering of the exiles."

Constructivism argues that the construction of identity is relational, meaning that the creation of a "national identity" is only possible in relation to people who are different or "Other." ${ }^{121}$ Based on such a framework some scholars have argued that Israeli identity was created in opposition to "the Arab"

\footnotetext{
${ }^{121}$ See Lene Hansen, Security as Practice: Discourse Analysis and the Bosnian War (London: Routledge, 2006).
} 
who was seen as "the adversary" which personified "eternal hatred towards the Jew." ${ }^{122}$ While some aspects of the new Jewish identity might have been created in opposition to the assumed characteristics of Arabs living in Palestine, this chapter begins by arguing that major aspects of this new identity were created in contrast to the assumed characteristics of Jews living in "exile." Indeed the main reason why this identity was commonly referred to as "new" was to signify its departure from the "old" Jewish identity, which Zionism argued had been created as a result of the conditions of the galut (exile).

\section{Negating "Exile"}

Zionism was primarily a rebellion against the "degeneration" of Jews in Europe. The leaders of the Zionist movement argued that Jewish life in the diaspora had become flawed, anomalous and even "diseased" and "polluted," as a result of which Jews had recurrently become the targets of anti-Semitism, manifested in oppression, humiliation, pogroms and expulsion by the hands of the gentiles. The conditions of 1,800 years of exile had made Jews into a "passive," "weak," "submissive," "impotent" and "fearful" people who had come to accept their persecution and only hoped to be either saved "by God or by the Gentiles," ${ }^{123}$ rather than actively resist it. Zionism, inspired by the Jewish

\footnotetext{
122 See Nurith Gertz, Myths in Israeli Culture: Captives of a Dream (London: Valentine Mitchell, 2000).

${ }^{123}$ Zerubavel, Recovered Roots: Collective Memory and the Making of Israeli National Tradition, 19.
} 
Enlightenment, was a movement that aimed to transform traditional, religious "ghetto Jews" living in exile into a modern, secular, developed, European and strong nation in Palestine. This is why many Zionist leaders saw the relocation of Jews from exile into Palestine as only a first step in the political, spiritual, mental and cultural revival of Jews.

Disdain for Jewish culture and mentality in exile was very strong among Zionist leaders. The more the founding fathers of Zionism had a utopian vision of a new, model Jewish society, the harsher and stronger their criticism of the preZionist conditions of Jews. Herzl for example said about "ghetto Jews" (offensively called mauschel or yid in English): "The Jew is a human being like any other, no better and no worse...the Yid, on the other hand, is a hideous distortion of the human character, something unspeakably low and repulsive."124 Herzl was so convinced that the mauschel was not a real Jew that he even suggested, "at some dark moment in our history some inferior human material got into our unfortunate people and blended with it." ${ }^{\text {125 }}$ Yitzhak Ben-Zvi explained that the "spirit of heroism and courage disappeared in the Jewish ghetto in which it had no place," ${ }^{126}$ while Ze'ev Jabotinstky argued that the starting point in

\footnotetext{
${ }^{124}$ Quoted in Glenn Bowman, "A Place for Palestinians in the Altneuland: Herzl, Anti-Semitism, and the Jewish State.," in In Surveillance and Control in Israel/Palestine: Population, Territory and Power, by David Lyon, Elia Zureik, and Yasmeen Abu-Laban (New York: Routledge, 2010), 7.

125 Ibid.

${ }^{126}$ Quoted in: Zerubavel, Recovered Roots: Collective Memory and the Making of Israeli National Tradition, 19.
} 
creating a new Jew was "to take the typical Yid [the derogatory Russian term for Jew] of today and to imagine his diametrical opposite ... because the Yid is ugly, sickly, and lacks decorum, we shall endow the ideal image of the Hebrew with masculine beauty." ${ }^{127}$ Leon Pinsker on the other hand called Jews in Europe as the "living dead," everywhere as a "guest people" and nowhere as "hosts."128

Zionist discourse argued that Aliyah to Israel was the first step to becoming a "real" Jew, the later steps of which was to transform oneself and one's family according to how Jews supposedly behaved during the years of antiquity. In this discourse the Jews of the antiquity were brave, strong and active, and had great love for the Holy Land and the fate of the Jewish people and as a result were successful and glorious as a nation. Eighteen centuries of exile had "derailed" the course of Jewish history and had led to the deterioration of the "true" Jewish identity. Thus the movement to "become Hebrew" and raise one's children as Sabras among Jewish immigrants to Palestine was part of an effort into recovering the "lost roots" of the Jewish people. ${ }^{129}$

\section{The Creation of the Sabra}

The word Sabra comes from the word Sabre that translates into prickly

\footnotetext{
${ }^{127}$ Quoted in: Waxman, The Pursuit of Peace and the Crisis of Israeli Identity, 25.

128 Leon Pinsker, Auto-Emancipation, https://www.jewishvirtuallibrary.org/jsource/Zionism/pinsker.html.

${ }^{129}$ See Zerubavel, Recovered Roots: Collective Memory and the Making of Israeli National Tradition.
} 
pear, which is tough on the exterior while soft and sweet on the interior, ${ }^{130}$ is commonly used to refer to Jewish people who are born in Israel. Sabra however goes beyond biological, racial and geographic definitions. The Sabra is a culture, an ideal image, something to strive for. The Sabra image was created by Yishuv leaders based on the Zionist discourse discussed above, and in contrast to the identity of the exile Jew. This negation of the exile was a move from the spiritual to the earthly, instead of alienation from the land, agriculture, and instead of individual materialism, the mobilization of pioneering tasks for the common good of the new Jewish nation. Moreover the Sabra was able and willing to defend himself and his community from adversaries.

The discourse within the Yishuv presented the Sabra as a Jew who was well versed in Hebrew, instead of the Yiddish spoken in exile, loved his people and his land, instead of the past homelessness and landlessness of Jews, was strong, able, muscular and handsome, instead of the short, dirty and weak Jews of the exile, and more important of all sacrificed his own interests and well-being for the nation (and later on the country) and was able to successfully defend his community from external enemies seeking to eliminate it. It is important to point out that Sabra discourse was not limited to men. In fact Sabra women were also presented as strong, independent and even rebellious, playing an equal role to men in the defense of the Jewish people. Moreover the movement to create the

\footnotetext{
${ }^{130}$ As future sections will explain being strong and tough on the outside, while soft and kind on the inside is in fact in line with the image of the Sabra.
} 
Sabra was more than just the creation of an ideal image, rather it had its own language, literature, values and customs, equating it to a full-blown cultural revolution. In fact historians describe the Sabra as the product of a "Hebrew revolution." ${ }^{131}$ This Cultural Revolution started to take shape in the 1930s with the rise in the Labor movement's cultural and political hegemony in the Yishuv, even though Zionist pioneers had established the roots of the revolution in earlier decades. The Sabra revolution peaked during and after the $1948 \mathrm{War}^{132}$ and began to decline in the 1960 s and 1970 s.

"Becoming Hebrew" was a complex mechanism, which sought to reconstruct the identity and ideology of immigrants coming to Palestine in the mold of the Sabra. In a 1946 article Uri Avneri explained the approach: "This is the most glorious victory of the Israeli generation-to see the sons of the Diaspora cured and made upright as they are absorbed and assimilated into his way of life." 133 The word "cured" was often used in the Cultural Revolution to indicate how life in exile had "diseased" the minds of Jews.

Sabra characteristics included intimate knowledge of the land, hatred of

\footnotetext{
${ }^{131}$ See Oz Almog, The Sabra: The Creation of the New Jew, trans. Haim Watzman (Berkeley and Los Angeles: University of California Press, 2000).; Arieh Bruce Saposnik, Becoming Hebrew: The Creation of a Jewish National Culture in Ottoman Palestine (Oxford: Oxford University Press, 2008).

${ }^{132}$ In Zionist discourse the 1948 War is described as "Israel's War of Independence," while Palestinians refer to it as the "al-Nakba" ("The Catastrophe" in Arabic) in which around 800,000 Palestinian Arabs were expelled from their homes. See Ilan Pappe, The Ethnic Cleansing of Palestine (Oxford: Oneworld Publications, 2007).

${ }^{133}$ Quoted in: Almog, The Sabra: The Creation of the New Jew, 6.
} 
the diaspora, a sense of supremacy, fierce adherence to Zionist idealism, Hebrew as their native language, skilled in manual agricultural work, being nontraditional and to a large extent non-religious, and most of all being a strong, fit and heroic fighter, ready to sacrifice his or her life for the new nation. These characteristics where carefully selected to correspond to Labor Zionism's ideology, which at the time constituted mainstream political Zionism. The main components of this ideology included socialism, secularism, communal agricultural work of the land, and most important of all the unflinching defense of the Yishuv from its enemies. Labor's ideology also resulted in a foreign policy that was practical yet security oriented, an issue that will be discussed in later sections.

The Sabra identity was thus created in order to serve the ideology of Labor Zionism. As noted in the theory chapter, the term 'ideology' here does not have any negative connotations, rather it is defined as a coherent system of beliefs that is used to not only make sense of the world but also to provide a criteria for value judgment and a prescriptive program that dictates actions. It is important to point out that while the Sabra identity was shaped according to Labor Zionism's ideological mold, it is difficult to see how the Zionist movement would have been successful in creating a nation-state without the creation of a national identity that emphasized self-reliance and sufficiency in both economics (primarily agriculture at the time) as well as in military and defense.

This becomes more apparent when one considers that the first Aliyah, which had little success in creating a national identity, also had little success in 
advancing Zionist goals. Moreover the Yishuv faced serious economic challenges in the 1920s, resulting in the increase of Jewish emigration from Palestine ${ }^{134}$ also a major problem of the first Aliyah. This is why "love of the land" was strongly emphasized in addition to agriculture and defense. Thus the Labor elites of the second Aliyah had correctly understood that the road to Zionism's success was through a renewed ideological commitment to the Jewish national struggle. The idealized Sabra identity was created in order to revive this struggle. The point is not to argue in favor or against the Hebrew revolution and its child, the Sabra, but rather to demonstrate that it is difficult to imagine how the Zionist enterprise could have been successful without the creation of such an idealistic identity in order to address the many challenges it faced during its initial years.

By examining Labor's ideology and the Sabra identity it created we can better understand the ideological changes the movement witnessed in the $1980 \mathrm{~s}$ leading to the peace process of the 1990s. Moreover future chapters will demonstrate how the very Sabra image Labor created was manipulated and hijacked by the religious settler movement in its struggle against Labor during the 1980s. By molding the national identity according to its own ideational principles, a movement is able to gain both internal political hegemony and exclusive control

\footnotetext{
${ }^{134}$ According to Schwartz, Zerubavel and Barnett: "In 1926, 56 people left Palestine for every 100 who entered. In 1927 every 100 newcomers were offset by 187 emigrants. In 1928, the emigration-immigration ratio was 99.5: one person left the country for every person who arrived." See Barry Schwartz, Yael Zerubavel, and Bernice Barnett, "The Recovery of Masada: A Study in Collective Memory," Sociological Quarterly 27, no. 2 (1986): 156.
} 
over external state policy. Future sections in this chapter will demonstrate how Labor's ideological hegemony within the Yishuv and the early days of the state, allowed it to set the key foundations of the country's international orientation for several decades.

The Sabra identity and the ideology it represented were established and reified through several key institutions namely the educational system, youth movements, the military and finally the Hebrew language and literature. The educational system was arguably the most effective weapon for the creation of the Sabra in the days of the Yishuv, with the military becoming a more important arena after the creation of the Israeli state. We will first discuss the role of education in the creation of Sabra identity and subsequently the role of military service.

\section{Indoctrination Through Education}

Oz Almog points out how the fictional character of Yaron Zehavi, a Jewish commander that defies the "evil" British, embodied the new Jew that was "born and bred on his own land, free of the inhibitions and superstitions of earlier ages;

even his physique was superior to that of his cousins in the old country." ${ }^{135}$ What is interesting is that Zehavi was the hero of a popular adventure novel for children called the Hasamba series. The books, which were produced by the new Israeli state and sold over a million copies, chronicle how a group of children from Tel-Aviv help the underground Haganah in its struggle for the establishment

\footnotetext{
${ }^{135}$ Almog, The Sabra: The Creation of the New Jew, 1.
} 
of the Jewish state. Books written after Israel's independence tell the story of how the group of children assists Israeli security forces particularly the IDF. In such series the boy fighter, also called the "boy Palmachnik" (after the elite Palmach unit of the Haganah ${ }^{136}$ ) would fight against Arab, British and Nazi enemies. ${ }^{137}$ Scholars such as Yael Dar have demonstrated how the Hasamba series played a crucial role in the creation of a generation of militant Sabra youth. ${ }^{138}$

The Hasamba series is just one of many examples of how the education of young children through both formal institutions as well as informal means was a prime area for the building of the Sabra generation. ${ }^{139}$ Indeed members of the second Aliyah were commonly referred to as the "pioneer generation" while their children were called the "Sabra generation," which shows that the children of immigrants were the primary target of the Sabra ideology, rather than the

\footnotetext{
${ }^{136}$ The Palmach (the Hebrew acronym for Pelugot Hamahatz, meaning striking force) was an elite unit of the Haganah that was formed in 1941. The highly regarded Palmach, which was closely associated with the Kibbutz movement, embodied many Sabra values and would play a central role in shaping Israeli identity. Many Palmach commanders would later occupy top positions within the newly formed Israel Defense Forces. See the website of the 'Palmach Museum' at: http://info.palmach.org.il/show_item.asp?itemld=8096\&levelld=42798\&itemType $=0$

${ }^{137}$ See Almog, The Sabra: The Creation of the New Jew, 134.

${ }^{138}$ See Yael Dar, "The Militarization of the Sabra: Hebrew Children's Literature Mobilized to Militarizing Its Readers.," in Battle Cry and Morning After: Representations of the War of Independence in Israeli Literature, by Oded Menda-Levy and Hanna Naveh (Tel Aviv University, 2002).
}

${ }^{139}$ Other examples include: "Eight on the Heels of One" written in 1945 by Yemina TchernovitzAvidar and "A Gang Like This" written in 1950 by Yisrael Visler. Moreover institutions such as the Palmach also directly published their own books for children and youth such as the Heroic Heritage and Undercover Defense 
parents. Sabra indoctrination began very early in a child's life. Even the lullabies that pioneers sang to their toddlers were rife with elements of the Hebrew revolution. ${ }^{140}$ The songs and stories used to educate children in school textbooks as well as by texts published by the Jewish National Fund (JNF) glorified the advantages and success of the Zionist immigration and settlement projects and the heroic work of soldiers and settlers in defending the settlement and the Yishuv, and later on the new nation-state in the 1948 War. For example in a famous children's poem called Prayer written in 1940, eight year old Dani asks God to make him a "valiant hero" so that he could "build an airplane... with guns" and "to bring immigrants to the Land of Israel."141

Textbooks prepared for Yishuv schools were strongly ideological and usually published with the support of the Council of Israeli Teachers for the Jewish National Fund. These textbooks glorified the values of the Hebrew revolution, presented the Zionist enterprise as a continuum of Jewish success during antiquity and portrayed life in exile as not only miserable but also as a deviation from the place of Jews in human history. Moreover diaspora Jews were described as cowardly, servile and soft. One textbook explained, "[The Jews of the Diaspora] became accustomed to fear a driven leaf, began to be unmindful of

\footnotetext{
140 Yael Dar, "The Militarization of the Sabra: Hebrew Children's Literature Mobilized to Militarizing Its Readers.," in Battle Cry and Morning After: Representations of the War of Independence in Israeli Literature, by Oded Menda-Levy and Hanna Naveh (Tel Aviv University, 2002).
}

\footnotetext{
${ }^{141}$ Miriam Yellen-Shtaklis, "Prayer," Davar Le-Yeladim 10, no. 8 (1940): 9. Quoted in Almog, The Sabra: The Creation of the New Jew, 24.
} 
their dress and their gait; their aesthetic sense degenerated, and they lost all sense of respectable appearance."142 On the other hand Sabras were presented as handsome, well dressed, self-confident, strong and full of courage. Aside from the textbooks, teachers played a crucial role in creating the Sabra identity. Muki Tzur, a historian, states that the "teachers were not professors of the history of the revolution, they were its spokesmen." ${ }^{\text {143 }}$ Because of this critical role, teaching positions in the Yishuv were held in very high regard. Usually the best and the brightest of immigrants became teachers, and teaching was considered a "calling." 144

Sabra indoctrination didn't only take place using formal instruction but also involved becoming emotionally attached to the Zionist enterprise, its national events as well as its national heroes. For example teachers often encouraged their students to write letters to soldiers fighting in the front line and in some instances entire classrooms would write such letters. Preschools and elementary schools had a "JNF corner" or "Blue Box" in which children put their contributions to the JNF. It even became custom for children to contribute some or all of their birthday money to the JNF. The JNF would in return send the child a certificate

\footnotetext{
${ }^{142}$ Ruth Firer, Agents of Zionist Education (Oranim, 1985): 95. Quoted in Almog, The Sabra: The Creation of the New Jew, 77.

${ }^{143}$ Almog, The Sabra: The Creation of the New Jew, 25.

${ }^{144}$ In contrast, today Israeli teachers are underpaid and Israeli classrooms are among the most crowded in the world. See Rubin, Israel: An Introduction, 179-180; Tamar Trabelsi-Hadad, "Israeli Classrooms among World's Most Crowded," Ynet News, May 10, 2009; Yaheli Moran Zelikovich, "OCED Report Paints Bleak Picture of Israeli Education," Ynet News, September 9, 2008.
} 
decorated with pictures of pioneers doing agricultural work and a text that read: "To ... You have remembered the JNF on your birthday and have contributed to the redemption of the land. Take this blessing from us: may you grow up into Torah, labor, and good deeds and be a delight to your parents and a blessing to your people. Amen." ${ }^{145}$ Children and youths were also encouraged to collect money for the JNF from the general public. There was even an official day for this called the "ribbon day" in which children and youth would collect money in blue boxes in city streets from passersby. Menachem Ussishkin, a JNF leader, explains: "The coin that the child gives or that he collects for the redemption of the land is not important in and of itself...but it is important as a foundation of education- it is not the child who gives to the JNF, but the JNF that gives him.... a hold on a sublime ideal for all the days of his life."146

Moreover ideological indoctrination didn't only take place in classrooms, but also included campfires, singing at social events and particularly in youth movements, something that was very common during the Yishuv and the early days of Israel. Many popular early Zionist youth movements both inside the Yishuv and abroad such as Hashomer Hatza'ir, Hanoar Ha'oved, Hapoel Hatza'ir, Habonim, Blau-Weiss, Dror, Hamahanot Ha'olim and Gordonia were

\footnotetext{
${ }^{145}$ Almog, The Sabra: The Creation of the New Jew, 52.

${ }^{146}$ Ibid., 53.
} 
affiliated with the Labor movement and preached socialist Zionist ideology to the young. ${ }^{147}$

The Kibbutzim and the Moshavim were also two of the primary institutions where the Sabra identity was created. The residents of these settlements would work the land, establishing a direct relation with it, live in a communal system, advancing the socialist goals of the Labor ideology, and guard the nation's frontiers from its enemies. Volunteering to work and live at the kibbutzim was popular in Israel for many years. Moreover many educational institutions and youth movements sent their pupils to the settlements to get "trained." Even the Palmach had a special unit called the Hachsharot that sought "agriculturalmilitary training" by sending its members to live for a while in various kibbutzim. The kibbutz was an excellent arena for ideological indoctrination since children and youth in the kibbutz were there 24 hours a day with little contact with the outside world. Moreover children in the kibbutz lived separately from their parents and special consideration was given to their education and training. Also many children and youth arriving after the Holocaust were orphans as a result of which they joined kibbutz families and fully embraced their culture.

Immigrants making Aliyah to Palestine, and later on to Israel, took new Hebrew names. Shedding one's old name signified the first step in breaking apart from one's own diasporic culture and past, and taking on a new Hebrew name

\footnotetext{
${ }^{147}$ For an overview of early Zionist youth movements see "Youth Movements," Israeli Ministry of Foreign Affairs, August 4 , 1998, http://mfa.gov.il/mfa/aboutisrael/history/pages/youth\%20movements.aspx.
} 
was a step into becoming a "new Jew." Changing one's name was essentially the first step into giving up one's previous identity and adopting a new identity. Changing one's name was never mandatory for immigrants, yet it was highly encouraged. As explained by a character in The Sermon by Chaim Hazaz, an important text used in school, "Ordinary people here [in the Yishuv] are embarrassed to go by ordinary Jewish names. They would rather be called Artsieli or Avnieli or something Hebrew sounding like that. Haimovitz you'll admit is a very Jewish name- Far too Jewish.... where as Avnieli that's something else again, although the devil only knows what. The main thing is that it sounds different, not Jewish, so they can feel proud of it. That's also the reason of course that you'll find so many rare biblical names among us: Gideon, Ehud, Yigal, Tirzah." 148 Not coincidentally many of these "new" names came from biblical warriors that fought hard against the enemies of the people of Israel.

Interestingly the IDF was also very committed to assigning new names to immigrants, even going as far as appointing a names committee, which issued a booklet that suggested Hebrew names that were distributed to soldiers. The most popular names adopted by immigrants were those that were associated with the Sabra in Hebrew culture, such as Dani, Uzi and Uri. For example the original name of Dahn Ben-Amotz, a famous journalist and author, was Moshe Tehilimzeiger. Ben-Amotz, who later became a Sabra icon in Israeli society,

\footnotetext{
${ }^{148}$ Haim Hazaz, The Sermon and Other Stories (Toby Press, 2005), 248.
} 
himself acknowledges that in order to be considered a Sabra by society as well as himself he had to change his name. ${ }^{149}$

\section{Identity Formation Through Military Service}

A prime arena for the creation of the Sabra identity was the Haganah, the Jewish paramilitary organization of the British Mandate period that served as the precursor to the Israel Defense Forces (IDF). Serving in the paramilitary organization, and later on in the IDF, served as the entry passage from youth to adulthood for many members of the Jewish community. As a result many members of the Haganah and later on the IDF were very young. In fact even some of the military's commanders were in their twenties. As noted earlier, the epitome of the Sabra image was the Sabra fighter who bravely defended the nation and even sacrificed his or her life for Zionist ideals.

One of the primary myths of early Zionism was the defense of Tel Hai. In 1920 the settlement of Tel Hai located in the Upper Galilee was attacked by an Arab mob resulting in the death of eight Zionist settlers. At the heart of this myth was the brave fight that Yosef Trumpeldor and his group of men put up against the attackers. Trumpeldor who died as a result of wounds from the battle reportedly said just before he died "It is worth dying for the country" (Kedai lamut be'ad ha'aretz). The sentence was quickly improvised into "It is good to die for our country" (Tov lamut be'ad artsenu) and soon became a national slogan with a

\footnotetext{
${ }^{149}$ See Almog, The Sabra: The Creation of the New Jew, 91-95.
} 
deep ideological message. ${ }^{150}$ The defense of Tel Hai by Trumpeldor and his outnumbered men played very well into the ideological discourse surrounding the Sabra. Labor Zionist author Yosef Chaim Brenner wrote about the battle: "The small clutch of people who devoted their lives to guarding the north, alone and neglected, tattered and ragged, hungry and frozen won the right from Hebrew history to be honored after their deaths with the aura and glory of the nation's heroes." ${ }^{151}$ Trumpeldor and his men's readiness to bear arms to fight rather than submit, was seen as the prime example of the change the Hebrew revolution sought. It provided an early example of how new Jews had been created from the passive and defenseless Jews of the exiles.

The battle of Tel Hai mirrored two other instances of Jewish resistance: the fall of Massada and the Bar Kokhba revolt, both of which were also important myths of the Zionist movement. In all three instances Jewish fighters were outnumbered and outgunned, yet they decided to stand their ground and sacrifice their lives rather than to surrender and submit. Such fierce commitment to the nation and the land was the centerpiece of the Sabra ideology. Moreover by linking Tel Hai to Massada and Bar Kokhba the Zionist movement sought to connect the new Jewish identity to its glorious past of the antiquity and therefor

\footnotetext{
150 See Zerubavel, Recovered Roots: Collective Memory and the Making of Israeli National Tradition, Chapters 3, 6 and 9.

${ }^{151}$ Quoted in Almog, The Sabra: The Creation of the New Jew, 38.
} 
presenting itself as a movement that sought the "redemption" of Jews from the conditions of the exile. ${ }^{152}$

The battle of Tel Hai served as an important ideological rallying cry in the Jewish community and elevated membership in military groups to an unparalleled prestige. This was especially true for elite units such as the Palmach, the elite fighting unit of the Haganah. Members of the Palmach were seen as the prime examples of the new Sabras and the unit's newsletter (HaPalmach), which was read in many Jewish youth movements, became one of the main literatures disseminating Sabra ideology in the Yishuv. Moreover many members of elite military units wrote about their battle experience, creating legends that became an important part of Israeli folklore. As a result of this, members of elite military units became larger than life Sabra figures. These included figures such as Yitzchak Rabin, Yigal Allon, Avraham Eden, Ehud Barak, David Elazer, Chaim Bar-Lev, Moshe Dayan and Ariel Sharon. These Sabra figures became so famous that many of them later assumed high political office.

The fierce military defense of the Yishuv and later on the Israeli nationstate from outsiders was the central component of Sabra ideology, thus its association with military activism was a natural extension which helped the Haganah and later on the IDF to recruit almost all youths entering adulthood

\footnotetext{
152 See Schwartz, Zerubavel, and Barnett, "The Recovery of Masada: A Study in Collective Memory"; Zerubavel, Recovered Roots: Collective Memory and the Making of Israeli National Tradition.
} 
willingly and without interruption. Moreover many youth movements as well as the Kibutzim started to train youths before the age of adulthood when boys and girls could formally join the military. In 1939 the Chagam program (the Expanded Physical Education Program) formally institutionalized preliminary military training for high-school students. Also many youth movements, city schools as well as Kibbutz schools took children and youth to field trips to the sites of Tel Hai and Massada, further increasing their knowledge and admiration for Sabra warriors.

The glorification of the Sabra warrior and as a result the militarization of Israeli society intensified in the wake of the 1948 War. The success of the newly born state was seen as the result of the courageous fighting of Sabras. Moreover the war resulted in heavy casualties, deepening the gratitude for fallen soldiers. After the war the term Sabra was constantly repeated in anthologies of fallen soldiers, including the ones put out by the Ministry of Defense. Following the war the image of the Sabra soldier appeared in art, fiction, poetry, camp fire sing along, theater and cinema. Also in 1951 the Ministry of Defense created a Memorial Day for fallen soldiers. In 1954 it became a national holiday and one of the most sacred days of the Zionist movement.

The 1948 War and the 1956 Sinai war brought great pride for Israelis who saw the Sabra warrior as the reason for the war's success, even though Israelis perceived themselves as outnumbered and isolated by the international community. The striking military success of Israel in both wars meant that the Zionist movement had been successful in its drive to create a "new Jew," and after two thousand years of persecution and victimization, Jews were once again 
capable of defending themselves against stronger and larger enemy forces. These victories were seen as reminiscent of the battles of David, Joshua and Gideon during antiquity. Thus the 1948 War was the peak of the Labor Zionist movement's success in creating the Sabra identity to serve its ideology. Not only had the Sabras been able to defend the Jewish community but they had also been able to impose humiliating defeats on their enemies, something that was seen as unprecedented in nearly 2 millennia of Jewish exile. In contrast to the "defeated" and "humiliated" Jews of the exile period culminating in the Holocaust, the Sabras had allowed the people of Israel to reconnect with their glorious past. It is no wonder that the Sabra generation became known as the "1948 generation."

As a result of the 1948 War many "Sabra warriors" became national symbols who embodied Sabra ideals. An example of this is the photograph of Avraham Eden, a Sabra Palmach commander, raising an improvised Israeli flag in Eliat in 1949, which became the symbol of the young nation and the Sabra warrior. The photograph also signified the ending of the 1948 War with Israel's success. Like many early Sabra figures, Eden later on went to become an important IDF general. The famous photograph was Israel's equivalent to the photograph depicting US marines raising the American flag in Iwo Jima in World War $2 .{ }^{153}$

\footnotetext{
${ }^{153}$ See Ofer Aderet, "Former IDF General Israeli Icon Avraham Adan Dies at 86," Haaretz, September 29, 2012, http://www.haaretz.com/news/national/former-idf-general-israeli-iconavraham-adan-dies-at-86-1.467408.
} 
The image of the fallen Sabra also became ingrained in Israeli culture and became a source of pride and admiration. Emmanuel Sivan estimates that 80 percent of memorial books of fallen soldiers were devoted to Sabras and near Sabras. ${ }^{154}$ If the fallen Sabra was a commander then the glorification of his life and service became even more pronounced. Fallen commanders were evidence of how they declared to their soldiers: "Follow me!" and thus put themselves at greater danger than their soldiers, emphasizing their sacrifice and service to the nation even further. ${ }^{155}$ In fact "Follow me" stories became a major theme of IDF legends and Israeli culture and literature. In this narrative the Sabra commander was humane and down to earth, asking for no special privilege compared to ordinary soldiers. This is why he would sacrifice his life before he allowed his soldiers to sacrifice theirs. A popular poem after the Sinai war for example says "The commander is always the first to surge forward, 'Follow me!' he lets out a cry, Like a pillar of fire rising and shining, Like the pillar of God in Sinai.."156

As a result of the Sabra ideology, military service became the pinnacle of the Israeli experience. Demand for membership in groups such as the paratroopers and Ariel Sharon's 101 commando-unit was so high that many youths competed to be selected. Once a part of these units the soldiers were so

\footnotetext{
${ }^{154}$ Almog, The Sabra: The Creation of the New Jew, 122.

${ }^{155}$ See Sucharov, The International Self, 85.

${ }^{156}$ Dan Almagor, "The Commander Who Calls 'Follow Me!"," in Man at War: A Selection of Literary Chapters, 1975, 213 (Hebrew). Quoted in Almog, The Sabra: The Creation of the New Jew, 130.
} 
keen on participating in combat operations that "if you were on one operation, then you had to give up your place in the next operation to your comrade," according to one paratrooper. ${ }^{157}$ Moreover Sabra folklore became an important part of elite military units and the Sabra image became associated with a Sten submachine gun and later on an Israeli made Uzi submachine gun, as well as a military style backpack and a jeep vehicle.

\section{The Yishuv and the Holocaust}

The Yishuv had an uneasy and somewhat contradictory view of the Holocaust. Nevertheless, the mass slaughter of Jews by the Nazis inadvertently strengthened the Sabra identity, and Zionist ideology more generally, in the short term. ${ }^{158}$ While many members of the Yishuv felt compassion and solidarity with the victims of the Holocaust, at the same time the European genocide reinforced the Sabra ideology which stated that diaspora Jews had become weak victims who were unable both mentally and physically to defend themselves against antiSemitism. As a result, feelings of empathy and sorrow were accompanied with an "I told you so" attitude. In this narrative the diaspora Jews where somewhat responsible for their fates since they had rejected the call of Zionism to join Aliyah and become "reborn" again in Palestine.

\footnotetext{
${ }^{157}$ Quoted in Almog, The Sabra: The Creation of the New Jew, 69.

${ }^{158}$ In the next chapter I will argue that in the long run the Holocaust led to the decline of the Labor movement and the Sabra identity.
} 
The events of the Holocaust "proved" many of Zionism's claims. Not only did anti-Semitism in Europe not subside, but also it culminated in mass genocide, which sought to eliminate the Jewish race once and for all. Moreover the diaspora Jew had failed to understand that even though his or her ancestors had lived for centuries in a country, he or she was still regarded as a "guest" who would not be protected by the host government or people. Even worse, the diaspora Jew had failed to gather the mental and physical strength to put up a fight against the persecution they had to withstand. From the Yishuv's point of view most of the victims of the Holocaust embodied the stereotypical "exile Jew" image that had been created in contrast to the Sabra. While holocaust victims neatly stood in line to be killed in Nazi gas chambers like "lamb to the slaughter," without resistance or effective objection, the Sabra was mentally and physically superior to his enemies and was able to heroically defend Jewish honor as displayed in the war of 1948. Even the fallen Sabra was different than most holocaust victims since he died "with honor," on the other hand in the holocaust only the Jewish ghetto rebels who fought the Nazis had died with honor. Yitzhak Tabenkin, the leader of Kibbutz Me'uhad, explains this: "Had the entire Diaspora been taught to stand up in this way [like the ghetto resistance], perhaps they would have changed something, saved something, at least their honor and selfworth." ${ }^{159}$

\footnotetext{
${ }^{159}$ Quoted in Almog, The Sabra: The Creation of the New Jew, 84.
} 
This differentiation between ordinary holocaust victims who had "failed" to resist Nazi crimes and members of the ghetto resistance who had put up a fight was given official sanctity by the Israeli state when in 1953 it introduced an annual memorial day to commemorate Holocaust victims titled "Holocaust and Heroism Remembrance Day" on the anniversary of the Warsaw ghetto uprising. Thus tying the holocaust with the "heroism" of those who fought, and consequently making the majority who did not as invisible.

The Sabra ideology of negating the exile and its embodiment in discourses such as the differentiation between the "helpless" victims of the Holocaust and the brave ghetto rebels did not come without costs however. In 1944 for example, Labor leader Berl Katznelson voiced significant concerns about how Yishuv youths were completely alienated from diaspora Jews and their lack of empathy for victims of the Holocaust. Katznelson explained that local youth were only able to identify with members of the ghetto uprising, whose members they saw as sharing some similarities with themselves. ${ }^{160}$ Also a majority of the Yishuv came to see Holocaust survivors who had immigrated to Israel as "wrecked people" (avak adam) with a "diaspora mentality."161

\section{Labor's hegemony}

The start of the twentieth century saw the rise of nationalism, modern anti-

\footnotetext{
${ }^{160}$ See Shapira, "Whatever Became of 'Negating Exile'?."

${ }^{161}$ See Baruch Kimmerling, The Invention and Decline of Israeliness: State, Society, and the Military (Berkeley: University of California Press, 2001), Chapter 3.
} 
Semitism and socialist utopianism in Europe. These forces played an important role in the creation of Labor Zionist groups in Eastern Europe. On the one hand as a result of the Haskalah, the Jewish enlightenment, to become "emancipated" became a major objective of many leading Jews in Europe, resulting in the call for secularism and better education to achieve it, and ultimately leading to the creation of modern Jewish political movements for the first time in European history. On the other hand events such as the pogroms in Russia and the Dreyfus affair in France were used by Zionists to demonstrate that the road towards emancipation was not through better integration and assimilation in European societies but through the creation of a Jewish national home. Labor Zionism synthesized this Jewish nationalism with socialist goals by arguing that the creation of a Jewish working class was essential in the establishment of a national home. ${ }^{162}$

European Jews played a major role in the creation and advancement of socialist ideologies in Europe. Many important socialist figures such as Karl Marx, Moses Hess and Leon Trotsky were Jewish. Moreover many important figures and intellectuals of the Zionist movement were either open advocates of various forms of socialism or had strong sympathies with socialist causes. These

\footnotetext{
${ }^{162}$ For the history of the Zionist movement see: Arthur Hertzberg, The Zionist Idea: A Historical Analysis and Reader (Philadelphia: Jewish Publication Society, 1997); Shlomo Avineri, The Making of Modern Zionism: Intellectual Origins of the Jewish State (New York: Basic Books, 1981); David Vital, Origins of Zionism (New York: Oxford University Press, 1980); David Vital, Zionism: The Formative Years (New York: Oxford University Press, 1989); Walter Laqueur, A History of Zionism: From the French Revolution to the Establishment of the State of Israel (New York: Tauris Parke Paperbacks, 2003).
} 
included Nachman Syrkin, Dov Ber Borochov, Aaron David Gordon, Franz Oppenheimer and Max Simon Nordau. Nevertheless it is important to point out that in its early days the Zionist movement was in no ways a socialist movement. In fact Theodor Herzl strongly rejected any Zionist ties to socialism and sought to distance Zionism from the domestic politics of Europe. Moreover many Zionists were apprehensive about tying Zionism to socialism since this would effectively hurt their diplomatic efforts with tsarist Russia and the Ottoman Empire. As a result many of the more radical socialists such as Birnbaum, Landau, Lazare, and Bahar, soon left the World Zionist Organization in protest of this policy. ${ }^{163}$

The power of Labor Zionist groups only began to rise with the building of the New Yishuv following the second and third Aliyahs to Palestine. After the First World War and the demise of the Ottoman Empire, Labor Zionists successfully created organizations that were responsible for the immigration, settlement, employment, health and defense of European Jews coming to Palestine. By the 1930s, Labor Zionists not only controlled the Yishuv government but were also a major force in the WZO and the Jewish Agency. The supremacy of Labor Zionist groups in the pre-state years continued for nearly three decades after the establishment of the Israeli state in 1948. This provided

\footnotetext{
${ }^{163}$ See Ben Halpern and Jehuda Reinharz, Zionism and the Creation of a New Society (New York: Oxford University Press, 1998), 8-25 and 120-145. Also for a discussion on the relation between Zionism and Socialism see Allon Gal, Socialist Zionism (Cambridge, Massachusetts: Schenkman Publishing Company, 1973). For a discussion of Marxism and Zionism see Joel Beinin, Was the Red Flag Flying There? Marxist Politics and the Arab-Isræli Conflict in Eqypt and Isræl 1948-1965 (Berkeley: University of California Press, 1990).
} 
the Labor Zionist movement the opportunity to create and establish the hegemonic Sabra identity discussed earlier based on the movement's ideology. The supremacy of Labor Zionism in the formative years of the Yishuv and the state of Israel can be attributed to the group's pioneering status in the Yishuv, its capacity in organization and bureaucracy, its dominance of educational and military institutions and finally the lack of any strong rivals.

\section{The Pioneers of the Yishuv}

Labor Zionists were among the first Zionists to formally organize into groups and unions both in Palestine and in Europe. Between 1900 and 1904 chapters of the Po'alei Zion (Workers of Zion) was established in Russia, the Austro-Hungarian Empire and the United States. In 1906, second Aliyah members Yitzhak Ben-Zvi, who would later serve as the second president of Israel, and David Ben-Gurion, who would later serve as the country's first prime minister, established a branch of Po'alei Zion in Palestine. In the same year another group of Labor Zionists led by A.D. Gordon, Yosef Ahronowitz and Yosef Sprinzak established Hapoel Hatzair, which saw the labor movement in Palestine as unique and non-Marxist and as a result rejected European socialist doctrines. Thus the second Aliyah had barely begun when Labor Zionists established two Zionist workers organizations. Indeed this tendency to organize and centralize decision-making and political power was one of Labor Zionism's most important qualities.

In 1907 a World Union of Po'alei Zion was founded and in the same year Ben-Zvi went to the sixth Zionist congress as the delegate of the Po'alei Zion in 
Palestine. Po'alei Zion would later join other non-partisan groups in setting up Ahdut Ha'avodah (Unity of Labor) in 1919. Ahdut Ha'avodah would later join Hapoel Hatzair in 1930 to from the Mapai party in 1930, which from then on served as the primary center of Labor power in the Yishuv and the Israeli state. Labor Zionists were also quick to organize in the World Zionist Organization. In 1905 at the $7^{\text {th }}$ Zionist congress, Labor Zionists for the first time appeared as a unified faction. ${ }^{164}$

In comparison, the founding conference of Revisionist Zionism, Labor Zionism's main ideological rival, did not take place until 1925, and the New Zionist Organization (NZO) was established by Jabotinsky in 1935. This discrepancy becomes even more pronounced when one looks at the time period of when the two groups established themselves in Palestine. Many leading Labor Zionists were members of the second Aliyah to Palestine, which took place between 1904-1914. While technically they were the second group of Zionist Jews immigrating to Palestine, with the first Aliyah taking place between 18821903, they were the first group of immigrants to successfully establish the seeds of the Zionist movement in Palestine. The first Aliyah had largely ended in disaster. The members of the first Aliyah were mostly youthful idealists who lacked funding and were inexperienced in farming. They soon became depended

\footnotetext{
${ }^{164}$ For an overview of early Labor history see: Yonathan Shapiro, The Formative Years of the Israeli Labour Party: The Organization of Power, 1919-1930 (New York: SAGE Publications, 1976); Halpern and Reinharz, Zionism and the Creation of a New Society.; Neill Lochery, The Israeli Labor Party: In the Shadow of the Likud (Berkshire: Ithaca Press, 1997), Chapter 1.Myron Aronoff, Power and Ritual in the Israel Labor Party (New York: M.E. Sharpe, 1993).
} 
on the investment of Baron Edmond de Rothschild who effectively turned them into serfs. Many of these first settlers succumbed to the pressures of living in Palestine and eventually returned back to Europe. Members of the second Aliyah on the other hand came much more prepared to Palestine and were able to quickly establish "Jewish only" farming settlements that did not depend on capitalist investment or Arab labor. Very soon second Aliyah Jews became the primary force within the New Yishuv.

Labor Zionism's early presence in Palestine effectively turned its members into the "pioneers" of practical Zionism. In contrast to political Zionism, which at the time put most of its efforts into diplomatic negotiations with world powers in order to secure a Jewish homeland, "practical" Zionism resorted to more actual efforts such as immigration to Palestine as well as land acquisition and settlement in the Holy Land. ${ }^{165}$ Although it should be pointed out that both efforts were simultaneously pursued and supported by the WZO, and the organization set up an office in Jaffa headed by Arthur Ruppin to manage Zionism's practical efforts. $^{166}$

With the complete demise of the Ottoman Empire following the First World War, settling in Palestine became the primary objective of the Zionist movement.

\footnotetext{
${ }^{165}$ In comparison during this period Revisionist Zionism hadn't even taken shape, and even when it did it took it more than a decade to translate ideas into action. This is discussed in the next chapter.

${ }^{166}$ See Mordecai Naor, Zionism The First 120 Years 1882 - 2002 (The Jewish Agency, 2014), Chapter 3 http://www.jafi.org.il/JewishAgency/English/Jewish+Education/Compelling+Content/Eye+on+lsrae l/120/Chapter+Three+From+Political+Zionism+to++Synthetic+Zionism.htm.
} 
Under the leadership of Chaim Weizmann starting in 1921, the primary strategy of the WZO focused on building an economically viable Jewish community on extended territories in Palestine, which would eventually claim an independent national status. The dominance of Labor Zionism in the New Yishuv put it in charge of the two most critical aspects of the Zionist enterprise: Jewish immigration, and land acquisition and occupation. By the late 1920s, due to an economic downturn Jewish emigration surpassed Jewish immigration to mandate Palestine. Making Zionism's efforts even more difficult was a turn in British policy that sought to limit Jewish immigration for political and economic reasons. Moreover hostilities with Palestinians had become much more violent. All these development meant that Zionism's success became entirely dependent on Jewish immigration and successful settlement in Palestine, difficult tasks that almost completely fell on the shoulders of the Labor Zionist movement. Moreover these conditions meant that Labor Zionism's ideology, which called for immediate Aliyah to Palestine as Halutzim (pioneers) with the capacity and skills to independently work the land, became the primary solution for the challenges the Zionist movements faced in the 1920 s and 1930s.

The relegation of Zionism's practical efforts to the Labor Zionists was not only due to the group's early arrival in Palestine, but more importantly to the group's skillful management of immigration and settlement during difficult times. The successful creation of Kibbutzim and Moshavim, the reliance on "Jewish only" labor that effectively protected them against Arab strikes and hostilities, economic independence from the likes of Rothschild, the acquisition of lands 
through purchasing, the recruitment of Jews abroad for Aliyah and training them for the challenges of settlement through Hehaluz, ${ }^{167}$ the provision of jobs to new immigrants by securing contracts from the British government and Jewish agencies, as well as the final task of providing military defense for Jewish settlements, meant that the process of immigration and settlement in Palestine had changed from a disorganized, risky and perilous enterprise to a much more orchestrated and centralized effort which sought to eliminate the challenges of immigrating and settling in the Holy Land thanks to the Labor Zionist movement. Thus while Labor Zionism was effectively leading the practical efforts of Zionism in Palestine, Revisionist Zionism was still largely based in Europe. The practical usefulness of Labor organizations within the Yishuv also strengthened their ties to the WZO and the JNF and gradually increased their power within these organizations.

\section{The Power of the Union}

Labor Zionism's successful creation of a viable community in the Holy Land was partly as a result of the movement's organizational and bureaucratic capacity. As noted earlier Labor Zionists were very quick to organize themselves into organizations and unions. Moreover these unions took over a vast array of tasks not commonly associated with worker unions elsewhere. This was particularly true with the establishment of the Histadrut (the General Federation of Laborers) in 1920 and the election of David Ben-Gurion as its general

\footnotetext{
167 The diaspora organization of 'pioneers-in training.'
} 
secretary. The Histadrut soon took over a wide array of tasks in the Yishuv. In addition to functioning as a trade union, the Histadrut operated the Kupat Holim (the Sick Fund) that developed a wide network of comprehensive hospitals and health clinics, a complete system of primary and secondary schools, Bank Hapoalim, the community's largest bank, the Davar newspaper and the Am Oved publishing house, manufacturing plants and construction firms such as Solel Boneh and the Koor consortium, insurance organizations for particular crafts, $\mathrm{Ha}$ Poel athletic and sports organization, a theater, as well as a wide range of subordinate trade unions and rural communes. ${ }^{168}$

By providing for the vast majority of the political, educational, cultural, social and economic needs of the population, the Histadrut quickly became a state building institution. Through the Histadrut the Labor movement was essentially able to create a centralized quasi-government organization during the British mandate that the Jewish population in Palestine became increasingly dependent upon. As a result the union which started with less than 5,000 workers, or less than 7 percent of the Yishuv population, by 1927 its membership increased to 25,000 workers, encompassing 75 percent of the entire Jewish labor force, and by 1936 membership soared to 90,000 workers and workers' wives.

\footnotetext{
168 See Michael Shalev, "The Labor Movement in Israel Ideology and Political Economy," in The Social History of Labor in the Middle East, Edited by Ellis J. Goldberg. (Boulder Colorado: Westview, 1996), 131-61. For an overview of the Labor Movement's organizational structure decision making process see: Peter Y. Medding, Mapai in Israel: Political Organisation and Government in a New Society (Cambridge: Cambridge University Press, 1972).
} 
Moreover a majority of newly arriving immigrants would join the Histadrut. ${ }^{169}$

The Histadrut played an important role in the absorption and settling of new immigrants. The Histadrut directed Hehaluz on behalf of the WZO, which gave it a considerable role in the immigration process. According to statistics published by the Histadrut, in 1927 , Hehalutz had trained $43 \%$ of all workers in the Yishuv and $80 \%$ of the members of kibbutzim before making Aliyah. ${ }^{170}$ After making Aliyah, the Histadrut, as the Yishuv's largest employer played an important role in providing jobs for the newly arriving immigrants. The Histadrut's capacity for providing employment was largely the result of gaining control of the distribution of the WZO's funds in the Yishuv. As the Histadrut grew in size so did its representation in the Jewish Agency and as a result the amount of funds it was allocated. ${ }^{171}$ Also once Mapai took over control of the WZO and the Jewish agency, it had the power to ration entry visas into Palestine in favor of potential supporters of the party ideology. ${ }^{172}$

The two major parties that controlled the Histadrut were both Labor Zionist parties: Ahdut HaAvorah (which won 40 to 50 percent of the Histadrut's electorate in the 1920s), and Hapoel Hazri (which won 20 to 30 percent of the

\footnotetext{
${ }^{169}$ Halpern and Reinharz, Zionism and the Creation of a New Society, 223.

170 Jewish $\quad$ Virtual "HE-HALUTZ," 2008, http://www.jewishvirtuallibrary.org/jsource/judaica/ejud_0002_0008_0_08655.html.

${ }^{171}$ Laobr 6.

${ }^{172}$ Michael Shalev, Labor and the Political Economy in Israel (Oxford: Oxford University Press, 1992), 96.
} 
vote). After the two parties joined to form Mapai, they won four-fifths of the total Histadrut electorate in the December 26, 1932, elections. ${ }^{173}$ The Histadrut's achievements were undoubtedly a central factor to the success of Zionist statemaking enterprise, yet it also brought considerable influence and power for the Labor Zionist movement. The Histadrut not only made the Labor Zionist movement the de-facto provider of government services to the Jewish population but also gave it an avenue to indoctrinate new immigrants with its ideology and create "new Jews" or Sabras out of them. Labor Zionism's control over the Yishuv's dominant ideology and ideal identity became especially powerful with the creation of its schooling system and the establishment of the Jewish defense organization of Hashomer and later on Haganah.

\section{Dominance of Educational and Military Institutions}

The Zionist movement saw Hebrew education as the flagship of the national revival process and the creation of a "new Jew." As a result the educational system was managed independently of the Mandate government, even though this came at the price of a lack of funding from the government. Nevertheless there was no consensus about the curricula and content of the education and as a result three different school "streams" operated in the Yishuv, each affiliated with a political or religious group: The "general" stream affiliated with "general" Zionism which by 1948 accounted for half of all Jewish students and teachers, the "labor" stream operated by the merkaz le'chinuch (Education

\footnotetext{
${ }^{173}$ Halpern and Reinharz, Zionism and the Creation of a New Society, 224.
} 
Center) of the Histadrut which about a third of all Jewish students attended, and finally the orthodox Mizrachi Stream which was affiliated with the two religious parties of HaMizrachi, and HaMizrachi Laborer and educated about 20 percent of the student population. It is also worth mentioning that the non-Zionist ultraOrthodox Agudat Israel operated their own schools system, which only focused on religious studies, independent from the three streams. ${ }^{174}$

While the Labor movement did not directly control the majority of Hebrew schools in the Yishuv however it held considerable influence in most schools of large cities and in the Kibbutzim. In fact the Sabra ideology was used in the educational content of both the general and labor streams, with the main difference between the two being the explicit socialist educational orientation of the later. The goal of the Labor stream was "[to] create a Jewish, pioneering, autonomous personality, committed to the Zionist-Socialist vision, and willing to fulfill in body and soul the missions of the Hebrew Labor Movement." ${ }^{175}$ Moreover the Labor movement was able to expand its educational institutions so that by 1953 it became the largest stream with about two-fifths of the students and the General Stream attracting only one-third of the students.

During the Yishuv period, education was an ideological and political

\footnotetext{
174 See: Orit Ichilov, The Retreat from Public Education: Global and Israeli Perspectives (New York: Springer, 2009), 55-75. Also see: Kimmerling, The Invention and Decline of Israeliness: State, Society, and the Military, 105-107.

${ }^{175}$ Hanna Yablonka and Zvi Zameret, The first decade - 1948-1958 (Jerusalem: Yad Ben-Zvi, 1997), 125 (Hebrew). Quoted in Ichilov, The Retreat from Public Education: Global and Israeli Perspectives, 56.
} 
enterprise, and this is why all the schools were affiliated or identified with a political or Ideological movement. As a result these school streams fought hard with each other to attract new immigrant children and increase their ideological base. The use of the educational system as factional power bases was also the main reason why different political groups strongly tried to resist the incorporation of their schools into a unified state system in 1953. The influence of the Labor movement in this highly prized avenue should not come as a surprise since the movement controlled many of the Yishuv's key political positions as well as a majority of the funding. Moreover by the time of the creation of the unified state educational system in 1953, the Labor movement was deeply entrenched in key Israeli government positions and thus had the power to decide the content and curricula of the country's educational system. As discussed earlier, the educational system along with military service served as the primary avenues for the creation and reification of the Sabra identity.

In the early years of the Yishuv only organized labor groups had the capacity to mobilize and train groups capable of defending Jewish settlements. Their ability to fulfill this critical function was one of the most decisive reasons for the rise in Labor's power. In line with the movement's tendency to organize and centralize activities, Hashomer (The Watchman) organization was created in 1909 by second Aliyah members Izhak Ben-Zvi, Israel Giladi, Alexander Zeid and Israel Shohat, and most of its members belonged to Ahdut HaAvoda. Many second Aliyah members had first hand experiences of the pogroms in Russia and thus understood the importance of military power for the survival of the Jewish 
community. Hashomer was disbanded in 1920 in favor of the creation of the Haganah (The Defense) which later formed the core of the Israeli Defense Forces (IDF) after the establishment of the state.

The Haganah was essentially a sectarian army affiliated and under the command of the Labor movement and the Histadrut. The Haganah played a very important role in maintaining the predominance of the Labor Zionist movement in the Yishuv, particularly due to its identity building capacity, which was used primarily in the service of the creation of the Sabra. Most Labor leaders had emigrated from Russia and had been influenced by Bolshevik concepts, one of which was that an armed force must be unequivocally subordinate to the party. As a result the Labor movement sought full control of Jewish military groups in Palestine.

The central figure behind this control was David Ben-Gurion who centralized control of the Haganah and later on the IDF in his own office. During the pre-Haganah period Ben-Gurion was the primary opponent of Hashomer members who did not accept the authority of the party. When the Haganah was formed and came under the direction of the Histadrut, as secretary general of the union he dismissed Haganah commanders who defied his authority. Moreover he was the fiercest opponent of breakaway groups from the Haganah, specifically the revisionist Irgun. Even the professionalization of the Haganah did not diminish the Labor movement's and Ben-Gurion's influence in the military 
organization. ${ }^{176}$

The riots of 1936-1939 convinced Yishuv leaders that the Haganah needed to be transformed into a centralized and professional army with a clear hierarchical structure. The General Staff was established in 1939 in line with this goal. Also in order to widen Haganah's reach and strengthen it, control over the military organization was passed to the Jewish Agency, by now however Labor Zionists already dominated the agency. In fact Ben-Gurion, who at the time was chairman of the executive committee of the Jewish Agency, was the primary person behind the transition. Even after the establishment of the state and the creation of the IDF in 1948, Ben-Gurion, as prime minister, concurrently served as Defense minister almost uninterrupted until 1963.

Even though the Yishuv lacked sovereignty during the British mandate, Ben-Gurion sought to give the Haganah a monopoly of violence in the Jewish community. The centralization of military forces under one organization gave the Jewish community a much better chance of success in the 1948 War, at the same time however it helped the Labor movement become the de facto ruler of the Yishuv. To achieve this Ben-Gurion isolated and repressed rival groups particularly the Irgun. These clashes culminated in the 'Altalena Affair' shortly after the foundation of the state in which Ben-Gurion demanded that the cargo of a ship carrying arms by the Irgun be handed over to the IDF. When the Irgun led

\footnotetext{
176 See Yoram Peri, Between Battles and Ballots: Israeli Military in Politics (Cambridge: Cambridge University Press, 1983); Ze'ev Drory, The Israel Defence Force and the Foundation of Israel:Utopia in Uniform (New York: Routledge, 2005).
} 
by Menachim Begin refused Ben-Gurion ordered the IDF to take it by force and to shell the ship, which resulted in clashes killing sixteen Irgun fighters and three IDF soldiers.

The appointment and promotion of senior officers in the Haganah was also carried out at the political level, as a result Labor Zionists occupied many military ranks. In fact many of the most prominent members of the Haganah had already been ideologically trained before joining the military organization. For example many Haganah commanders had been schooled at the "Herzliya Gymnasium Tel Aviv," known as the "gymnasists" in the organization. When separation between the political and military spheres increased, particularly after 1948, many of the "gymnasists" were appointed to civilian positions responsible for military decision making while a younger generation of Sabras who had become experienced in the 1936-39 revolt and the 1948 War were promoted to commandership. These two groups of military elites dominated the IDF until the early 70 s. ${ }^{177}$ Nevertheless it is important to point out that ordinary Haganah members were recruited from all segments of society making it a popular militia. This was particularly true following the professionalization of the Haganah in the wake of the Arab revolt of 1936, after which the Haganah essentially became the sole legitimate military organization of the Yishuv that was accepted and respected by a majority of the Jewish community. During this time control of the Haganah was formally given to Zionist organizations rather than party factions,

\footnotetext{
${ }^{177}$ See Peri, Between Battles and Ballots: Israeli Military in Politics, Chapter 2.
} 
as indicated earlier however by this time Labor was in control of most of these organizations operating in the Yishuv. Ben-Gurion himself later admitted "the Zionist Organization had authority over the Haganah. However, this authority was to a large extent fictitious." 178

One of the reasons for the continuous success of the Labor movement in controlling the Haganah was the firm establishment of the principle of civilian control over the military by the movement's founding fathers. For example all military actions in the Haganah had to be approved by the civil National Command. In comparison local Irgun commanders made their own decisions and this resulted in several crises for the Revisionist movement. Moreover as discussed earlier the Haganah and later on the IDF were a principle avenue for Sabra ideological indoctrination. As a result many members of the military organization willingly accepted the authority of the leaders of the "pioneer generation" who were seen as the "founding fathers of Israel." Thus the military, as an important identity building institution for many young Jews, was a primary source for the continuation of Labor's hegemony. This is also one of the reasons why the Revisionist Zionist movement sought to create, albeit somewhat unsuccessfully, its own independent military organizations.

\section{The Lack of Strong Rivals}

In the 1920 s and 1930s, which were the formative years of the Yishuv, Labor Zionism lacked potent ideological rivals. Labor Zionism's main rival was

\footnotetext{
178 Ibid., 37.
} 
the Revisionist Zionism movement led by Ze'ev Jabotinsky. The revisionists however suffered from several fundamental setbacks. First of all their charismatic leader was based in Europe rather than Palestine, as a result most revisionist activities at the time were based in Europe and the movement's struggle in Palestine took off very late. By that time the Labor Zionists were well established in Palestine and had formed powerful and successful organizations and unions. Jabotinsky immigrated to Palestine in 1928, however he left following the Arab riots of 1929, and was subsequently barred from returning by the Colonial Office of the British Government. This lack of physical presence of the movement's leader effectively hampered their chances of overcoming their ideological rivals. Moreover the revisionists three main bodies, the youth movement Betar, The New Zionist Organization (N.Z.O) and the Irgun military organization were respectively created in 1923, 1935 and 1937, over a decade later than Labor's main organizations. In fact by the mid thirties Mapai had become the main political power center in the Yishuv and the Haganah had been established as the community's military organization. As a result the organizational power of the revisionists was no match for the labor movement during the Yishuv period.

The economic structure of the Yishuv also presented a barrier to the revisionists' ideological challenge of the Labor movement. The class structure of the Yishuv included a large number of laborers, as well as small-scale artisans, shopkeepers and manufacturers. The economic needs of these groups depended much more on organized labor than on the bourgeoisie. Non-socialist middle class families from Eastern Europe dominated the Fourth Aliyah, which 
took place from 1924 to 1928 and added 80,000 people to the Yishuv's population. This fact emboldened the revisionist movement to appeal to the economic interests of the middle class and challenge Labor's hegemony. In reality however few members of the fourth Aliyah were part of the upper-middle class and the wealthy. Most became small rentiers and small shop owners and workshops and had little capital. To make matters worse, the Yishuv was hit by a significant economic crisis in 1926. As a result many members of the fourth Aliyah either left Palestine or became dependent on organized labor for their economic well-being. Add to that their individualist outlook and their economic dispersion, they never collectively mobilized like the workers did and thus they never formed an organized class which the revisionists could exploit as a base to challenge the Labor movement. ${ }^{179}$ Moreover in the 1930 s Mapai consciously moved to the center of the political sphere and appealed to all classes within the Yishuv, therefore preemptively attracting economic classes that could potentially become allies of the right.

Revisionist Zionism's main criticism of the Labor movement was its supposed lack of explicit and clear commitment to the founding of a Jewish state in the short future and its weak and passive performance in military and defense matters. Yet in reality it was the Labor movement, not the revisionists, who set the outer limits of the Jewish presence in Palestine through the Kibbutzim and who organized and ran the Haganah, which played a much bigger role than the

\footnotetext{
${ }^{179}$ See Shalev, Labor and the Political Economy in Israel, Chapter 3.
} 
Irgun in defending Jewish villages and cities. In fact even though the Labor movement catered to the interests of the worker, its main and overarching commitment was to Jewish nationalism. This commitment to Jewish settlement, defense and nationalism was the basis for Labor's hegemony. As a result the revisionists were never able to win the sympathy of a large segment of the Jewish population during the Yishuv period. This allowed Labor Zionists to actively isolate their rival, effectively forcing the Revisionists to withdraw from the World Zionist Organization in 1935.

In contrast to Labor Zionism's approach to the revisionists, its approach to Religious Zionism, its other ideological rival, was much different during the Yishuv period. The hegemonic movement was able to incorporate religious Zionists by giving them authority in some spheres. This included vesting control of issues such as marriage, divorce, and burial to rabbinical courts, and upholding halachic ${ }^{180}$ laws of Shabbat and Kashrut in the public sphere and using halachic definitions to determine Jewish nationality. Labor's partnership with religious parties, both Zionist and non-Zionist, continued well into 50s and 60 s, which allowed it to form coalitions without the inclusion of the revisionists. The religious groups' sectarian interests such as religious education and the keeping of the Sabbath and the Kashrut was served, and in return they refrained from intervening in foreign and security policy, as well the management of public affairs not related to religion. This subject will be further examined in the next

\footnotetext{
${ }^{180}$ Halacha is Jewish religious law.
} 
chapter.

By effectively accommodating the religious Zionists and isolating the revisionists, Labor Zionism made sure that its ideological rivals were not able to overtake the movement's predominant position in the Yishuv. The main threat to Labor's hegemony however was the challenge of internal strife. From the early days of Labor's activity in the Yishuv they were separated into different groups (the main ones being Po'alei Zion and Hapoel Hatzair). The formation of Mapai in 1930 united most Labor groups in Palestine, soon however a group of Ha'Avodah members broke away from the party and created the Siah-Faction B, which would later form Mapam. Differences within the Labor movement were thus never relieved and in fact broke the popular vote of the movement so that no faction was able to win a majority of the community's vote.

A great majority of Labor's leaders were second Aliyah members who were Ashkenazi Jews who had grown up in Russia prior to immigrating. As a result the "founding fathers" generation of Israelis had largely experienced the same process of socialization. They were influenced by socialist and Marxist principles, had experienced the historical events at the eve of the Russian revolution and had seen first hand Jewish pogroms. As a result most of this generation were committed to various forms of socialism as well as to the Jewish nationalist enterprise. Tension and conflict however arose precisely because they sought to combine socialism and class goals with nationalism, with some groups being more committed to the former while others emphasized the primacy of Zionism. As time went on factions more committed to Zionism led by Ben-Gurion 
became the dominant stream in Labor Zionism, yet they never commanded the loyalty of the entire movement.

During the 1920s the struggle between socialism and nationalism was clearly won in favor of the later with class struggle objectives becoming secondary to the Labor Zionist project of national revival and political sovereignty. To achieve this they redefined their socialist ideology as "constructivist socialism" that stressed the development of the Yishuv as a whole rather than the Marxist goals of European socialist movements at the time, which advocated a workers revolution. In this new "constructivist" approach socialism became in the service of the nation and the workers became the primary agents of national resurrection. ${ }^{181}$ Ben-Gurion explained this form of socialism as follows: "Our movement has always had the socialistic idea that the party of the working class, unlike the parties of other classes, is not only a class party solely concerned with matters affecting the class but a national party responsible for the future of the entire people. It regards itself not as a mere part of the people but as the nucleus of the future nation." ${ }^{182}$ In practice whenever classic socialist principles came into conflict with nationalism, it was the later that won. Thus for example Mapai emphasized class co-operation and reached out to the bourgeoisie and capitalists, sanctioned joint business projects with private capital

\footnotetext{
${ }^{181}$ See Zeev Sternhell, The Founding Myths of Israel: Nationalism, Socialism, and the Making of the Jewish State (Princeton: Princeton University Press, 1998), Chapter 3.

182 Ibid., 225.
} 
and would even reign down on strikes and union militancy in favor of employers when it believed that nation building was coming under jeopardy.

The primacy of the nation went into full force with the rise of Ben-Gurion to Labor's leadership. Ben-Gurion had a famous principle of mamlachtiut (Statism) that emphasized the importance of the nation and the state over civil society and the priority of political power over social action. The foundations of mamlachtiut were set in place in the 20s, and by the 30s Ben-Gurion's statist system was in effect governing the Yishuv. This is one of the main reasons why Israel had such a strong state immediately after its independence. The drive for organization and the centralization of power in the Labor movement and its organizations such as the Histadrut should be seen in line with the principle of mamlachtiut.

This new form of socialism however was not without its opponents. The most important dissenters of such policies were influential Kibbutz based groups as well as a group of individuals within the Labor movement. Even though the Labor movement was able to isolate and eliminate some of these groups such as the Gdud Ha'avoda (Labor Corps), others would unite to form a united group against Labor in the 40s as a result of which the opposition Left's vote in the Histadrut would rise from around 7 percent in 1920 to 38 percent in $1944 .{ }^{183}$ In 1948 these groups joined to form Mapam, which was largely as a result of merger between Hashomer Hatzair Workers Party and Ahdut HaAvoda Poale

\footnotetext{
${ }^{183}$ For Histadrut election results from 1920-1989 see Shalev, Labor and the Political Economy in Israel, 95.
} 
Zion Movement and had a Marxist outlook.

The left wing critics of the Labor movement thus became its most important ideological and political rival due to the impotence of the right, yet although their ranks rose during the 30 s and 40 s, they were never able to unseat the more "mainstream" Labor movement from power. This is apparent in the results of the first Israeli Knesset elections in which Mapam won 19 seats, a distant second place to Mapai's 46 votes, with the revisionist Herut only winning 14 seats and becoming fourth place. ${ }^{184}$

One of the main reasons for Labor's success was that although the transition from revolutionary socialism to "constructivist" socialism came with a price, specifically the breakaway of groups with Marxist and communist worldviews, it also brought its advantages, allowing the Labor movement to move to the political center and transition from a workers movement to a popular movement that could now legitimately represent a wider array of Yishuv's members and could better accommodate business leaders and the middle class and thus rob the revisionists of a potential base. Also this reorientation of the Labor movement to the nation as a whole arguably left them much more prepared to deal with the serious challenges the Yishuv faced both economically, especially during the Arab revolts, politically, particularly in dealings with the British mandate government, as well as successfully defending the newly formed

\footnotetext{
${ }^{184}$ For official results of all Knesset elections since 1949 see the official Knesset Website at: https://www.knesset.gov.il/description/eng/eng_mimshal_res.htm
} 
state in the 1948 War.

\section{Labor's Foreign Policy}

As the remainder of this chapter will demonstrate, the same ideology that led to the creation of the Sabra identity also shaped the foreign policy pillars of the Labor movement. This approach to international relations, which emphasized the role of the state, the primacy of security and power, as well as pragmatism and independence, set the foundations for the Jewish state's foreign policy in its first three decades of existence. Labor's hegemony effectively allowed its leaders to make these principles the foundations of the country's international orientation.

\section{The Primacy of Security}

The primary purpose and goal of the Sabra was to defend the Yishuv and later on Israel. This was also mirrored in Labor's foreign policy. During preindependence years the supreme objective of Labor, particularly David BenGurion, who was the ideological and political powerhouse of the movement, was the establishment of a Jewish nation-state and its protection through military means. ${ }^{185}$ After Israel's independence, the state's foreign policy was in effect an extension of its security policy. The role of Ben-Gurion in shaping such an international perspective cannot be overstated. It is no wonder that Peres refers

\footnotetext{
${ }^{185}$ While on the surface Labor's security oriented foreign policy approach might seem very similar to the revisionist position, in reality there are important differences between the two, due to their different ideological underpinnings. This is fully discussed in the next chapter.
} 
to him as "our Washington, and our Jefferson." ${ }^{186}$ As the movement's capable leader he played a critical role in isolating the rival revisionists from security and foreign policy making within the Zionist movement as well as sidelining left wing Mapam members. This allowed Ben-Gurion to lay down the building blocks of a coherent and consistent framework for Israeli security and foreign policy.

Since the very early days of the Yishuv, Ben-Gurion's primary concern was with defense. Throughout his career he would repeatedly criticize the Turks and later on the British for failing to defend the Jewish community. His main criticism was however reserved for the Yishuv itself for failing to protect itself. In one of his first articles in Ha'achdut newspaper, the official paper of the Poalei Zion party, he asked:

Who is to blame if not the Hebrew public, which reacts apathetically to the murder of one of its own? When a German is killed, all the Germans immediately bombard the Turkish authorities...whereas in our villages there have been assaults, brawls, armed attacks, and six murders, and what have we done to protect our persons and property? Nothing!

We Jews don't have a foreign government to come to our aid. But precisely because we don't, precisely because our existence and our future depend on ourselves alone, we absolutely must be more active politically, always on guard to assert our national and political interests and to demand our legal rights from the central government in Constantinople. ${ }^{187}$

As indicated in the quote, the main aim of diplomacy with the Turks and later on the British was to ensure the defense of the Yishuv, yet Ben-Gurion

\footnotetext{
${ }^{186}$ Shimon Peres, Ben-Gurion: A Political Life (New York: Schocken Book, 2011), 3.

${ }^{187}$ Quoted in Ibid., 19.
} 
strongly believed that such negotiations, even if successful, would only be halfmeasures and the defense of the Jewish community ultimately rested on their own shoulders. As a result he was one of the architects of the Haganah and later on the IDF. He also believed that Jewish settlement and defense ultimately relied on the creation of an independent Jewish state. Such a belief was strengthened among other leaders of the Labor movement by repeated let downs by both the British as well as the Soviet Union, which was assumed to be sympathetic to the Zionist cause due to the common socialist worldviews of the two. Because of this Ben-Gurion, during his political career, would negotiate and compromise on many matters including territory and borders but never yielded with regards to the establishment of a Jewish state and the defense of the Jewish community.

In Ben-Gurion's perspective the Arab world was fundamentally hostile to Israel. Making matters worse was the wide asymmetries that existed between Israel and the Arab world. Moreover the international community was seen as an unreliable ally. As a result the Yishuv would have to guarantee its own survival by increasing its power. This would be achieved by increasing the community's population, through facilitating Aliyah, economic independency, ${ }^{188}$ diplomatic maneuvering and most important of all military superiority. Such an approach however was not supported by the entire Labor movement. Most notably the worldview of A.D. Gordon and his disciples was in complete contrast to statist and militaristic approaches. Gordon viewed the state as an entity based on

\footnotetext{
${ }^{188}$ The drive for 'Hebrew only labor' can be seen as part of this effort.
} 
militarism and expansionist aspirations that threatened the humanist approach that emphasized the brotherhood between national communities including between Jews and Arabs. As a result of this Gordon's followers, which formed the Ha Po'el Ha-Tza'ir, rejected partition, advocated equality in a bi-national state and accused the British of fostering hostility between Jews and Arabs. BenGurion and his allies who effectively took control over the security and defense policy of the Yishuv and later on the Israeli state however defeated such currents within the Labor movement.

Ben-Gurion's drive to amass military power for the Yishuv particularly intensified after his talks with the Palestinians collapsed in 1936. The subsequent Arab uprising made Ben-Gurion more determined than ever to strengthen the Haganah. In 1937 when the Yishuv was under attack from the riots and Europe was engulfed in its own turmoil, he commented: "We, who are the children of Jewish distress, suffering and sorrow", must establish "power, we must have power." ${ }^{189}$ Yet long before such events, Ben-Gurion's thinking had been set, which he explained during a series of articles he wrote in 1915. In these articles he argued that diplomacy should be subordinate to nation-building and achieving sovereignty. Moreover he again stressed the vital importance of the community to rely on its own strength, explaining, "political rights and legal guarantees are

\footnotetext{
189 Quoted in Sasson Sofer, Zionism and the Foundation of Israeli Diplomacy (Cambridge: Cambridge University Press, 1998), 101.
} 
the result and function of actual, physical conquest, not a precondition for it." ${ }^{190}$ Moreover this power-politics approach to international relations was not just limited to Ben-Gurion. For example Moshe Sharett, the head of the Jewish Agency's political department and Israel's second Prime Minister, who was much more sympathetic to the idea of arriving at a diplomatic compromise with the Palestinian Arabs, believed that the only path forward for the Yishuv was to gain power, stating that "once we are stronger, we will be able to forge an alliance with the Arabs, as one force with another."191 Thus even the path to diplomacy was through power.

The circumstances in which Yishuv leaders were trying to establish a Jewish state in Palestine allows one to better understand why reliance on domestic military power became a major principle of Israeli foreign policy ideology. On the one hand with the onset of the Arab uprising of 1936, Yishuv leaders, particularly Ben-Gurion, saw the chances of a diplomatic compromise with the Palestinians as very bleak. In fact in the lead up to 1948, Ben-Gurion would repeatedly tell the party that war with the Arabs was inevitable. On the other hand starting with the White Paper of 1939, British policy towards the Zionist cause seemed antagonistic or at least in serious conflict with its other interests, namely to win the alliance of the Arabs during the Second World War. It

\footnotetext{
${ }^{190}$ Quoted in Ibid., 104.

${ }^{191}$ Quoted in Ibid., 109.
} 
is also important to note that during the turbulent years of the 40s the Yishuv was not allied with any major power.

Nevertheless it is critical to consider that as a result of this power-driven international orientation by Yishuv leaders, Israel would effectively become a "nation in arms" with a security doctrine that emphasized military power over diplomatic overtures, particularly with regards to dealings with Palestinian Arabs as well as Israel's Arab neighbors, an approach that would only change in the early 90s. Such a worldview is highlighted in the words of Ben-Gurion who stated that "peace cannot be achieved until the Arabs, or rather the Arab leaders, will be persuaded they cannot destroy Israel either by economic boycott or by political pressures or by military offensives." 192

\section{Self-Reliance and Independence}

Just as the Sabra identity emphasized the role of the new Jew in settling, developing and protecting the nation, in Ben-Gurion's international perspective international diplomacy would only be successful when the Yishuv realized its own internal power. He famously said "The Land of Israel will be ours not when the Turks, the English or the peace committee agree to it and sign a diplomatic treaty to that effect, but when we, the Jews, build it." ${ }^{193}$ To achieve this internal power the Labor movement institutionalized the concepts of self-reliance and

\footnotetext{
192 Quoted in Michael Brecher, The Foreign Policy System of Israel: Setting, Images, Process (New Haven: Yale University Press, 1972), 282.

${ }^{193}$ Quoted in Sofer, Zionism and the Foundation of Israeli Diplomacy, 105.
} 
independence. In the early days of the Yishuv the movement emphasized "Jewish only labor" to make the community economically independent. ${ }^{194}$ Soon however the concept of self-reliance was extended to a wide variety of areas. As Hayyim Nahman Bialik, Israel's first national poet, explained: "We will be a normal state only when we have the first Jewish prostitute, the first Hebrew thief, and the first Hebrew policeman." 195

The movement's emphasis on self-reliance was particularly strong regarding issues of defense and military. Such a view was rooted in a belief that saw the Jewish nation as different from other nations and as isolated and abandoned by the international community. Asher Arian calls this this belief system the "People Apart Syndrome" and explains that "there is a fundamental belief that in the final analysis the world will do nothing to protect Jews, as individuals, as a collectivity, as a state."196

This feeling of abandonment by the international community and the need for self-reliance particularly when it came to the survival of the nation was very strong among the movement's leaders. Ben-Gurion for example stated, "Do not forget that although Israel enjoys the friendship of many nations it is the only country which has no self-governing 'relatives' from the point of view of religion,

\footnotetext{
194 See Zachary Lockman, Comrades and Enemies: Arab and Jewish Workers in Palestine, 19061948 (Berkeley: University of California Press, 1996), chapter 2.

${ }^{195}$ Quoted in Rex Weiner, "Extradited to L.A., the Abergils Get Ready To Face the Music," Forward, March 2, 2011.

${ }^{196}$ See Arian, Security Threatened: Surveying Israeli Opinion on Peace and War, 161.
} 
language, origin or culture.... The only permanent loyal 'relatives' we have is the Jewish people." ${ }^{197}$ Moreover such a perspective was not limited to preindependence years but strongly continued after 1948, even when Israel became a military powerhouse. On the eve of the 1967 war for example Abba Eban, Israel's foreign minister and a prominent member of the Labor movement, noted "when we looked out at the world we saw it divided between those who wanted to see us destroyed and those who would not raise a finger to prevent it from happening." 198

Such a worldview stems from centuries of persecution in Europe that culminated in the Holocaust. In fact the Holocaust represents the ultimate historical instance of the persecution of Jews, creating a constant perception of being under existential threat, which continues to exist to this day among Israelis. The Holocaust also serves as an example of a deep belief that Israel is isolated and will be abandoned in its hour of need. Such historical experiences have reified the belief that Israelis and Jews more broadly are "a people that dwells alone." The impact of the Holocaust cannot be overstated in the creation of such a belief system among Zionist leaders. Shimon Peres recalls how Ben-Gurion, after visiting Nazi death camps in Germany after World War 2, returned "shocked to his core, both by what he had seen in the camps and by a more thorough understanding of how the reaction of the rest of the world had contributed to the

\footnotetext{
${ }^{197}$ Quoted in Brecher, The Foreign Policy System of Israel: Setting, Images, Process, 276.

${ }^{198}$ Waxman, The Pursuit of Peace and the Crisis of Israeli Identity, 48.
} 
fate of Europe's Jews. Not only had the Allies failed to save them; not only had they failed to bomb the death camps or the railway lines; but British warships had kept the gates of Palestine shut to any Jews who managed to escape from the European hell. His conclusion was stark and unequivocal: We must have our independent state at once." ${ }^{199}$ The Holocaust was a stark reminder to Labor leaders that the survival and security of the Jewish nation could not be trusted to the gentiles. ${ }^{200}$

It is important to point out however that such feelings of isolation and abandonment weren't only as a result of Jewish persecution in the diaspora, particularly during the Shoah, but also due to the actions of great powers in regards to the Zionist cause both before and after the Holocaust. Britain, which was initially believed to be the primary patron of the Zionist cause after the Balfour declaration, was seen to be backtracking on its promises and even turning against the idea of a Jewish state. Even before the White paper of 1939, which severely restricted Jewish immigration to Palestine, Ben-Gurion was warning Mapai leaders of England's "treachery." The Soviet Union's policy was even more disappointing. The left wing of the Labor movement had very high hopes regarding Bolshevik Russia, in practice however the Soviets were seen as

${ }^{199}$ Quoted in Peres, Ben-Gurion: A Political Life, 7, (emphasis added).

${ }^{200}$ For the effects of the Holocaust on Israeli society and politics see: Tom Segev, The Seventh Million: The Israelis and the Holocaust, trans. Haim Watzman (New York: Holt Paperbacks, 1991); Idith Zertal, Israel's Holocaust and the Politics of Nationhood (Cambridge: Cambridge University Press, 2005). 
more supportive of Arab nationalism. Ben-Gurion believed that the Soviets supported the Arabs based on cold realpolitik calculations, since the Arabs were more powerful than the Jews. As Shimon Peres explains: "[The Soviets] made a mathematical calculation: how many people were there on our side, how many on the Arab side." 201 Thus the behavior of the Soviets reaffirmed the realpolitik, power driven, belief system of Labor leaders.

Israel's alignment with the US after the Second World War didn't produce the results it wanted in the short term either. For example in 1955 Israel became worried about an arms deal Egypt had secured with the Eastern bloc made through Czechoslovakia. In response Israel put a lot of effort and lobbying to secure arms from the United States. These efforts were fruitless however. On October 12, 1955, Abba Eban the Israeli ambassador to Washington wrote to Moshe Sharett, the Israeli Prime Minister at the time, that Israel could not count on the United States to balance the Soviet arms deal with Egypt by selling arms to Israel. He recommended to the Prime Minister to attack Egypt before it became too strong. Even after intense lobbying efforts the US refused to sell arms to Israel. In response to this policy Ben-Gurion wrote a letter to President Eisenhower on $14^{\text {th }}$ February 1956, protesting the denial of arms to Israel and stating that if Israel got a negative reply to its arms request, "then we have only one task: to look to our security."202

\footnotetext{
${ }^{201}$ Peres, Ben-Gurion: A Political Life, 137.

${ }^{202}$ Quoted in Shlaim, The Iron Wall: Israel and the Arab World, 158.
} 
Looking after its own security is exactly what Israel did. Such an overemphasis on self-reliance and power politics however deeply affected Israeli foreign policy. It made Israeli leaders deeply suspicious of the international system and as a result of this, the country's foreign policy became subordinate to its security policy and deeply dependent on military action. This worldview is well encapsulated in the words of Yitzhak Rabin, who as the country's Prime Minister, stated after the 1973 War, "Israel shall dwell alone and only our military might guarantees our existence." ${ }^{203}$ Two years later when the United Nations adopted an anti-Zionist resolution he stated, "The whole world is against us-when was it not so!"204

\section{Pragmatism}

As discussed above, Ben-Gurion's political outlook can be described as strategically consistent. During his entire political career Ben-Gurion's was determined to realize the ideal of an independent Jewish state capable of defending itself. As Shimon Peres describes, "Ben-Gurion was a man of one idea, to create a state. Everything else was secondary...Even after he had created the state, he never saw it as created but as in the ongoing process of creation. And he continued to be wholly preoccupied with it." ${ }^{205}$ Yet in terms of

\footnotetext{
${ }^{203}$ Quoted in Efraim Inbar, "Israeli National Security, 1973-96," Annals of the American Academy of Political and Social Science 555 (1998): 66.

204 lbid.

${ }^{205}$ Peres, Ben-Gurion: A Political Life, 42.
} 
tactics, the means used to achieve this ideal, he adopted very diverse and varied ways. Above all else Ben-Gurion was very pragmatic in his approach to international relations, and this is why he is commonly labeled as a "realist." Although future chapters will argue that Labor's pragmatism should not be confused with Realist international relations theory. ${ }^{206}$

Ben-Gurion asserted that the fate of the nation could not be determined by suppositions. The words "fact" and "reality" were the ones used most frequently by the Zionist leader in discussing policy. Ben-Gurion was a fan of realpolitik and according to Shimon Peres had read Thucydides' Peloponnesian War sixteen times, "and he made us all read it too." ${ }^{207}$ Ben-Gurion's political pragmatism was not only restricted to his rhetoric but can be seen in his actions throughout his career. Prior to World War I Ben-Gurion believed that it was in the interests of the Yishuv to establish an alliance with Turkey. In fact Ben-Gurion and Yitzhak BenZvi, another labor leader who would later serve as the second president of Israel, moved to Constantinople in 1912 to study law and learn Turkish. Ben-Gurion explained: "I intended to go to Turkey to study law, and thus acquire the necessary professional training to be a candidate for parliament... At the same time, I would be able to help the Jewish liberation movement in various ways, so that it could obtain some autonomy initially, and full independence in the final

\footnotetext{
${ }^{206}$ See the current chapter's concluding section, as well as chapter 7.

${ }^{207}$ Peres, Ben-Gurion: A Political Life, 39.
} 
event." ${ }^{208}$ During the initial phases of World War I, Ben-Gurion wanted the Yishuv to join the Ottoman cause in the war. He and Ben-Zvi even joined the Ottomanization Committee of the Yishuv established in Jerusalem. The Turks however rejected Jewish help. Before the end of the war Ben-Gurion had understood that the allies were more likely to win the war, as a result he sought to realign the Yishuv's alliances accordingly. This is why Ben-Gurion himself now joined the Jewish legion of the British Army. The affair shows that from very early on, Ben-Gurion believed in diplomacy primarily based on power and the necessity for policy to be flexible in order to attain Jewish nationalist aims.

In subsequent decades Ben-Gurion sought the alliance of various powers. During most of the mandate period he sought to improve relations with Britain, which he mistrusted but rightly believed would play an important role in the Yishuv's path to statehood. His approach to the British was usually a combination of diplomacy and alliance, as well as pressuring them using various ways in order for them to accept the Yishuv's demands. His famous 1939 statement: "We must help the [British] Army [fight the Nazis] as if there was no White Paper, and the White Paper as if there was no war" is an example of this approach. Before the 1936 revolt Ben-Gurion even negotiated with the Palestinians in regards to the Yishuv joining an Arab Federation in the Middle East. He believed that such an agreement would strengthen the position of the Yishuv in relations to

\footnotetext{
${ }^{208}$ Quoted in Sofer, Zionism and the Foundation of Israeli Diplomacy, 93.
} 
Britain. ${ }^{209}$ This approach again demonstrates the Labor leader's pragmatic perspective to foreign relations.

After the Second World War America's international standing quickly began to rise and Ben-Gurion was quick in trying to form an alliance with the US, even though it would take a while before the relationship would become strategic. Ben-Gurion had also become aware of the importance of American Jewry to the Zionist cause, as a result he made lengthy visits to the US to seek their help in establishing the Jewish state. Ben-Gurion openly discussed his power-politics orientation at the Fifth Mapai Conference held in 1942, asserting "an orientation towards the forces of tomorrow means that we must act in such a way that we ourselves become the force of tomorrow, that we become the focus and that others turn to us." ${ }^{210}$

The majority of the Mapai party shared Ben-Gurion's pragmatic approach to foreign policy that was primarily concerned with achieving Zionist goals. Nevertheless foreign policy was precisely the area in which different groups within the Yishuv strongly disagreed. Ben-Gurion however, through the mamlachtiyut doctrine, successfully centralized power and decision-making in regards to security and foreign policy long before 1948. Ben-Gurion effectively isolated the revisionists, who advocated territorial maximization and the utter rejection of plans that would partition Eretz Israel, from decision-making. This

\footnotetext{
${ }^{209}$ Quoted in Sofer, 100-101.

${ }^{210}$ Quoted in Ibid., 135.
} 
effort was helped by the rise of Fascism in Europe. Ben-Gurion openly called Jabotinsky a "Zionist dictator" and even went as far as calling him "Il Duce" (the term used for Italian dictator Benito Mussolini). ${ }^{211}$

Labor's domination of the Yishuv's policy-making organizations effectively allowed it to largely limit revisionist influence in foreign policy decision-making. The main challenge to Labor however came from disagreements on major foreign policy issues within the movement. The newly formed Mapam was the second largest party in the first Israeli Knesset. Ben-Gurion however effectively isolated the group by excluding it from the ruling coalition. After the 1948 War Ben-Gurion even disbanded the Palmach, the elite fighting force of the Haganah, which he correctly believed was a source of Mapam power and influence. ${ }^{212}$

The main difference between the international outlook of these breakaway groups and the majority of the movement led by Ben-Gurion was that they strongly advocated a Marxist world outlook and sought to ally the Yishuv and subsequently the Israeli state with the Soviet Union. They also strongly rejected any form of partition and argued in favor of a bi-national state with Arab Palestinians as equal citizens. The Mapai leadership led by Ben-Gurion had long abandoned sympathies with the Bolsheviks, who they believed were against the Zionist cause and had persecuted the Zionist movement in Russia. In fact the

${ }^{211}$ Peres, Ben-Gurion: A Political Life, 52.

${ }^{212}$ When asking the Histadrut's Executive committee for the disbanding of the Palmach, BenGurion noted that sixty-two of its sixty-four officers were members of Mapam. See Sofer, Zionism and the Foundation of Israeli Diplomacy, 156-159. 
disillusionment with Soviet policy was one of the reasons why the movement had rejected its former Marxist principles in favor of a centrist and nationalist "constructive socialism." On a theoretical level these developments are an interesting example of how international events and foreign policies can also affect domestic political ideologies.

\section{Favoring Partition}

Pragmatism led the majority of the Labor movement to accept and even support partition plans that would allow a Jewish state in only part of Eretz Israel. In the early years of the Yishuv, the Labor movement's concept of the homeland largely corresponded to that of revisionist Zionists, but as time went on the leaders of the movement, particularly Ben-Gurion, came to the conclusion that maximalist territorial demands would hinder efforts to realize a Jewish state. As a result the Labor movement, with the exception of the breakaway left wing groups, came to accept partition both in rhetoric and in practice.

A 1918 book by Ben-Gurion and Ben-Zvi defined the boundaries of the homeland as the Litani River in the north, the "Syrian desert" in the east and the international border with Egypt in the south. The leaders of the labor movement, particularly Ben-Gurion, emphasized the inclusion of Transjordan as part of Eretz Israel. Ben-Gurion famously said in 1934 that he was in complete agreement with Jabotinsky regarding the boundaries of the homeland, while Ben Zvi insisted that the border of the homeland "does not end at the line at which the Jordan 
passes." ${ }^{213}$ Such definitions of the homeland were also featured in children's books and the movement's propaganda material. These viewpoints weren't limited to rhetoric either. Mapai leaders supported and implemented settlement projects to the East of the Jordan River until the 1930s despite their economic costs.

Starting in the late thirties, the position of Mapai started to change. Not only did claims to Transjordan start to disappear from party rhetoric and propaganda material, but it also led to changes in policy. After the introduction of the Peel Commission's partition plan in 1937 by the British, the question of partition became a primary source of division within the movement. The strongest opposition to the plan came from the Kibbutz Ha-Me'uhad led by Yitzhak Tabenkin. ${ }^{214}$ In the end however Ben-Gurion and his allies who favored partition were able to lead the day within the movement. Ben-Gurion, despite his earlier rhetoric in favor of territorial integrity, was unequivocally in support of partition, even though the Peel partition plan would allow a Jewish State in less than 20 percent of the territory of Mandatory Palestine. Ben-Gurion correctly believed that under the circumstances that were the best a new Jewish State could receive, and that this could serve as a beginning for the acquisition of more territories.

\footnotetext{
${ }^{213}$ Quoted in Shelef, Evolving Nationalism: Homeland, Identity, and Religion in Israel, 1925-2005, 28.

${ }^{214}$ See Sofer, Zionism and the Foundation of Israeli Diplomacy, 106-107.
} 
The liberal faction of Mapai led by Moshe Sharett also favored partition, as well as Yosef Sprinzak and Eliezer Kaplan who headed another faction of the party that were pro-British and supported Chaim Weizmann. Eventually the World Zionist Congress accepted the principle of partition, but rejected the plan put forth by the commission. From 1937 forward, partition became an idea supported by the majority of the Labor movement. ${ }^{215}$ Ben-Gurion would comment 20 years later: "Had [Peel] partition been carried out, the history of our people would have been different and six million Jews in Europe would not have been killed-most of them would be in Israel."216

The acceptance of partition in principle led to the movement's acceptance of the UN's partition proposal despite the important misgivings they had about it. The main reason behind the movement's adoption of partition in contrast to its earlier approach was the realization of the necessity for compromise in order to fulfill Jewish nationalism by Labor leaders, particularly by Ben-Gurion. The charismatic Zionist leader would always stress the right of the Jewish people to the whole of Eretz Yisrael yet he would explain: "we are prepared to discuss a

\footnotetext{
${ }^{215}$ See Eyal Chowers, "Peel Back Time: Should Israelis Revisit the Partition Plan of 1937?," Haaretz, September 6, 2012.; Sofer, Zionism and the Foundation of Israeli Diplomacy, Chapter 5; Shelef, Evolving Nationalism: Homeland, Identity, and Religion in Israel, 1925-2005, Chapter 1.

${ }^{216}$ Quoted in Tom Segev, One Palestine, Complete: Jews and Arabs Under the British Mandate (New York: Holt Paperbacks, 2001), 414.
} 
compromise arrangement if, in exchange for the reduction of territory, our rights are immediately granted and we are given national independence."217

Thus the ideological change of the movement regarding the territorial boundaries of the homeland was rooted in its pragmatism. Labor leaders believed that the establishment of a Jewish state over all of Eretz Israel, which included Transjordan, was very unrealistic. For one thing it would be strongly rejected by the international community, particularly by Britain, which at the time was the main power in the Middle East. At the time Transjordan was a British protectorate and after independence would become a British ally. More importantly the Yishuv lacked the necessary population and military resources to settle and defend the vast land. At the time the Haganah found it even difficult to defend the meager territories Jewish immigrants had settled in. Therefore Labor leaders saw the establishment of a Jewish state over "all of Eretz Israel" as wishful thinking rather than something that could be achieved, at least for the time being.

It is also important to consider the priorities of the movement's ideology, since it could be noted that Labor leaders did not compromise on other goals even if they also seemed unrealistic at the time. Indeed the whole Zionist enterprise could have been categorized as "wishful thinking" in the early years of the twentieth centuries when the Yishuv struggled to provide even the basics of

\footnotetext{
${ }^{217}$ Quoted in Peres, Ben-Gurion: A Political Life, 96.
} 
life to the incoming immigrants. Yet people like Ben-Gurion never faltered in their ideological commitment.

To solve this puzzle we must consider the contradictions that arose in the late 1930s in Labor's ideology. On one hand the movement strongly sought the establishment of a Jewish state, on the other hand, Labor leaders such as BenGurion increasingly came to see demands for maximalist territorial borders, which was also part of the movement's ideology, as hindering and contradicting the earlier goal. This is why he and his allies actively excluded the revisionists and the left wing of his own movement from the Yishuv's decision-making. This allowed the movement to sacrifice territorial borders in favor of the more central and important part of the movement's ideology, which was to establish an independent Jewish state and significantly expand Aliyah. Moreover in the 1940s Ben-Gurion correctly believed that the world as well as the Middle East was being reshaped, creating a window of opportunity to create a Jewish state before it was too late. Two other external shocks led the movement to speed up its ideological evolution and support partition with more vigor. These two external events were the Holocaust and Jordan's independence.

From the very early stages of World War 2 the Yishuv had heard about Germany's Jewish persecution programs, yet it was only after the war that the full scale of Nazi atrocities became known. The Holocaust created a strong sense of urgency in opening up Aliyah for Jewish refugees in Europe. Yet at the time the British, through the implementation of the recommendations of the 1939 White Paper, had severely curtailed Jewish immigration to Palestine. Moreover the 
Yishuv lacked the appropriate resources to respond to the Holocaust, even in terms of evacuating some Jews from war torn areas. Labor leaders such as BenGurion believed that the only remedy to this predicament was the establishment of a Jewish state as soon as possible. As a result the earlier "gradualist" approach, which emphasized the realization of Zionist goals through incremental steps, was abandoned in favor of more urgent solutions. Therefore the movement became more willing to compromise on other matters, specifically the borders of such a state.

Also in 1946 the Hashemite Kingdom of Jordan was established after the British granted independence to the Arab Emirate. This development further complicated any claim the Zionist movement had toward the area west of the river. After this event, Labor leaders decided to secretly negotiate with the Hashemite rulers for the establishment of a Jewish state on parts of the western land of the river in exchange for the recognition of the Kingdom's rule over other parts of this area, now called the West Bank. ${ }^{218}$ These negotiations were intended to increase the chances of the Jewish state's survival once it came into existence. The Labor movement believed that after the declaration of independence the newly established state would have to fight in a simultaneous war with all of its Arab neighbors and that its chances of winning such a war and surviving were slim if the Jordanian army attacked it with its full strength. As a

\footnotetext{
${ }^{218}$ These negotiations are well documented in Avi Shlaim, Collusion Across the Jordan: King Abdullah, the Zionist Movement, and the Partition of Palestine (New York: Columbia University Press, 1988).
} 
result of the prewar negotiations, Jordan refrained from attacking areas that are now considered as Israel-proper, even though it did enter the conflict on the side of the Arabs. ${ }^{219}$ As in previous examples, Labor leaders were willing to compromise on the extent of the new state in favor of its quick realization and subsequent survival.

Another factor that encouraged the territorial evolution of Labor's ideology was the emphasis on the new state being both Jewish and democratic. Most of Labor's leaders, particularly Ben-Gurion, despised dictatorships. Indeed even though Labor sought hegemony within the Yishuv as noted earlier, it did respect democratic processes and as a result allowed the inclusion of its ideological revisionist rivals in Yishuv elections and democratic institutions. As a result of the inclusion of democracy as a central component of the movement's ideology, the new state could be either Jewish or democratic, but not both if the maximalist territorial borders advocated by the revisionists and others such as Kibbutz HaMe'uhad and Ha-Shomer Ha-Tza'ir were to be realized. This paradox was clearly explained by Ben-Gurion on various occasions.

For example a day after Israel signed an armistice agreement with Jordan that formally allowed the Arab kingdom to annex the West Bank on April 3, 1949, the new Israeli Knesset held a meeting in which Ben-Gurion was strongly criticized by the right as well as the far left for partitioning the Land of Israel. BenGurion replied: "A Jewish state, or Shleimut Haaretz [the integrity of the biblical

\footnotetext{
${ }^{219}$ See Shlaim, The Iron Wall: Israel and the Arab World, Chapter 1.
} 
Greater Israel]? Well, a Jewish state...over the entire country can only be a dictatorship of the minority. A Jewish state, even just in western Palestine [not including Transjordan] cannot possibly be a democratic state because the number of Arabs in western Palestine is larger than the number of Jews."220

Another important issue to point out is that the change in Labor's ideology was not the result of a fully conscious decision by its leaders. While people like Ben-Gurion had openly started to advocate partition in the 1930s due to the reasons cited above, to some extent they saw partition as a short-term tactical compromise, rather than a strategic ideological change that would effectively limit the territorial borders of the Jewish state. Ben-Gurion himself repeatedly explained this: "A partial Jewish state is not the end, but only the beginning.... We shall bring into the state all the Jews it is possible to bring... and then I am certain that we will not be prevented from settling in other parts of the country, either by mutual agreement with our Arab neighbors or by some other means."221 Ben-Gurion would repeatedly stress to members of the movement that the real territorial borders of the new state would be formed based on the realities of the battlefield, something that did in fact happen.

Ben-Gurion was also well aware that war would provide a perfect disguise to change the demographics of the region. For example in 1937 he wrote a letter to his son explaining: "The Arabs will have to go, but one needs an opportune

\footnotetext{
${ }^{220}$ Quoted in Peres, Ben-Gurion: A Political Life, 132.

${ }^{221}$ Quoted in Ibid., 68.
} 
moment for making it happen, such as war."222 In fact the Labor movement would play the leading role in the expulsion of around 800,000 Palestinians from their homes by Zionist forces under the cover of the 1948 War. $^{223}$

Nevertheless Labor's acceptance of partition in principle resulted in the acceptance of the 1949 armistice border agreements as the legitimate borders of Israel. Thus the realities created by the war of 1948 coupled with the slow but real change in the rhetoric, tactics and policies of the movement starting from the 30s regarding partition, in effect institutionalized the armistice borders, which excluded Transjordan as well as the West Bank and the Gaza Strip, as the new ideological status-quo. This is apparent by the fact that Mapai's Political Committee did not hold a single meeting regarding Israel's borders between 1949 and $1952 .{ }^{224}$

\section{Conclusion}

Labor Zionism's creation of the Sabra through the Hebrew revolution can be considered as one of the most successful episodes of the twentieth century in which a new identity was created in order to serve ideological goals. Labor's Zionist ideology, which sought to create a "new Jew" that would form the basis of the Jewish national movement, was translated into an identity that in contrast to

\footnotetext{
${ }^{222}$ Quoted in Pappe, The Ethnic Cleansing of Palestine, 23.

${ }^{223}$ See Pappe, The Ethnic Cleansing of Palestine, Chapters 1-8.

${ }^{224}$ Shelef, Evolving Nationalism: Homeland, Identity, and Religion in Israel, 1925-2005, 43-49.
} 
the diaspora Jew relied on collectivism, agriculture, secularism, and most important of all physical strength and sacrifice in defense of the Jewish nation. This translated into a security oriented foreign policy that heavily relied on military force and emphasized internal power and strength, which Labor elites argued could only be achieved through self-reliance and independence particularly in regards to defense issues.

According to Labor Zionist discourse, unlike the Jews in the diaspora who had been powerless to defend themselves in the face of persecution and attacks, Israeli Jews had a powerful state and military to defend them. Therefore, just as the Sabra negated the weaknesses and passivity of the diaspora Jews, the Israeli nation as a whole also achieved this through its military power. Nevertheless Labor's foreign policy ideology also contained an important pragmatic element, which sought to achieve Zionist aims through practical ways that relied on cost-benefit calculations and was attuned to regional and global constraints and incentives. Accepting the partition of the Jewish homeland can be analyzed in this regard.

Labor's success was due to its political hegemony in the Yishuv as well as its dominance of the fields of education and military, the two most important identity-building institutions of the Jewish society. The movement's success was also partly due to its powerful discourse in which the new Jewish nation was presented as the "revival" of the "glorious" past of Jews during the years of antiquity. As a result, the process of shedding one's diasporic identity and the adoption of Sabra values and culture became a secular experiment in the 
process of redeeming the Jews from the conditions of exile, an aspiration that had deep roots within Jewish religion and history. Thus the Hebrew revolution sought to recover the "lost roots" and success of the Jewish people and therefore the Sabra was understood as the embodiment of the continuation of Jewish values and culture during the antiquity into the modern period, in contrast to the aberration of the period of exile.

The creation of myths is particularly important during the formative years of a nation and as a result has long term consequences on the national consciousness and ideology of a nation. This is why while Sabra identity and culture faded as Labor's political hegemony waned in the sixties and seventies leading to the 1977 elections, many of its values and principles continued to form a key part of Israeli identity and culture well beyond the rule of Labor. Thus for example while the negative images associated with life in the diaspora have faded in Israeli culture, Jewish life in Eretz Israel is still understood by the Israeli public as "unique" and more "genuine" to Jewish roots. More importantly Israeli identity continues to be influenced by a "Jewish warrior" image that emphasizes military strength and sacrifice for the nation. As a result of this ideology, the Labor movement also set the foundations of Israel's foreign policy approach, which continued to influence Israel's international orientation long after Labor's hegemony in the first two decades after Israel's independence.

From a theoretical perspective the success of the Labor movement in establishing Israeli foreign policy according to its ideological commitments provides strong evidence of how domestic political ideologies can shape the 
worldview of a state. Moreover the continued influence of this ideology on Israel's foreign policy, even after the decline of the movement that created it, seems to confirm the continuity of culture and ideology as emphasized by scholars such as Hunt, Rathbun and Duffield. Yet it is important to point out that the present chapter only provides a partial picture of the influence of domestic ideologies on Israeli foreign policy. As the next chapter will demonstrate, in the sixties and seventies other ideological movements within Israel successfully undermined Labor's hegemony, and while they accepted and even strengthened the security and self-reliance aspects of Israel's foreign policy as set out by Labor, they challenged and rejected its pragmatism and acceptance of partition.

Important developments in the sixties and seventies including the Six Day War, the rise of the revisionist movement and 1973 War would lead to the evolution of the ideologies of all the three movements discussed in this dissertation, a development that would have undeniable effects on Israeli foreign policy making. Thus while ideology can be a source of continuity in foreign policy behavior, it can also be a source of change. Therefore while persistence in domestic ideologies and identities helps to explain underlying regularities in foreign and national security policy, ideological and identity change can account for policy change, an issue that has been disregarded in theoretical literature, which assumes that national ideologies and identities are largely static.

Also the evolution of the proper territorial extent of Eretz Israel in Labor's ideology is an example of how tactical decisions, and the rhetoric used to justify them, can lead to ideological change in the long run. As discussed earlier many 
Labor leaders including Ben-Gurion saw the acceptance of partition as only a short term tactical consideration, yet such decisions eventually made their way into the ideology of the movement. This is because the rhetoric of a movement's leaders, even when used to legitimize and rally support for short-term tactical decisions, plays an important role in setting the ideological discourse which in turn shapes the norms and identity of the group.

Scholars have labeled Labor's approach to foreign policy as "realist," "interest based" and "civic" in contrast to the approach of revisionist and religious Zionists that are seen as "ideological" and "Jewish." Even if one accepts the categorization of Labor foreign policy as a realist approach that puts Israeli "interests" above all else, this does not necessarily make it less ideological than that of its competitors. If one defines ideology as a coherent system of beliefs and values that is used to make sense of the world and provide a prescriptive action program, then a "realist" worldview is actually also an ideology. Indeed the present chapter discussed how such a power-driven worldview was constructed within Labor based on the movement's ideology. The next chapter for example will demonstrate that while the revisionists also had a power-driven approach to foreign policy, in fact more so than Labor, the movement had a completely different idea of what the nation's "interests" were and how they should be pursued.

Therefore, rather than labeling Labor's foreign policy as "realist," more correctly it can be described as the result of the interaction between the movement's ideology and the Sabra identity it created and external events and 
power relations. This is because international developments, including new structural constraints and incentives, were interpreted based on the movement's worldview. Finally the present chapter demonstrates the merits of using a neutral definition of ideology. An unbiased and impartial view of ideology allows for the study of the role of ideas and beliefs in shaping foreign policy of not just right wing, Marxist and radical groups, but a much wider range of political movements. 


\section{Chapter 4: The Rise of Israel's Right}

Revisionist Zionism since its inception in the 1920s by Ze'ev Jabotinsky has been the founding ideology of the non-religious Zionist right and the main ideological and political rival of the Labor Zionist movement. The birth of the Revisionist movement took place in 1922 when Jabotinsky, then an executive of the Zionist Organization, openly and strongly opposed the 1922 British White Paper that excluded Transjordan from the "Jewish national home." After the Zionist body accepted the British position, Jabotinsky resigned from his position in 1923 and established the 'Revisionist Zionist Alliance' two years later, and ultimately formed the New Zionist Organization in 1935 in opposition to the Zionist Organization, which had come under the influence of the Labor movement. It is important to point out that the opposition of Jabotinsky and his followers to the decisions adopted by the Zionist establishment did not stem from tactical political considerations in order to gain power. Neither did the movement see these "mistakes" as the result of a lack of correct judgment by the Zionist elite dominated by Labor Zionists, rather the movement gets its name from Jabotinsky's demand for a complete revision of Labor Zionist ideology. In fact the revisionists offered an alternative ideology and identity which they believed stayed "true" to the "real" Zionism established by Theodore Herzl, and in opposition to the "deviance" of the Labor movement from Jewish nationalism. ${ }^{225}$

\footnotetext{
${ }^{225}$ For a detailed yet sympathetic biography of Jabotinsky see Shmuel Katz, Lone Wolf: A Biography of Vladimir (Ze'Ev) Jabotinsky (New Jersey: Barricade Books, 1996).
} 
This chapter sheds new light on the rise of the revisionist movement within Israeli politics by bringing in the study of ideology into the analysis. The chapter argues that revisionist Zionist ideology was created in relation and in contrast to Labor's ideology. Moreover while militarism forms a core part of the ideology of both movements, key differences differentiate the two, a topic that has been overlooked in existing literature. The chapter then seeks to answer why the hegemonic Labor movement declined and how the ideological evolution of revisionist Zionism led to its rise. Finally it is argued that as a result of the Six Day War, the religious Zionist movement witnessed a substantial ideological transformation, from one concerned with the implementation of the Halacha, to a messianic ideology concerned with the settlement of biblical lands in order to hasten the coming of "the Messiah."

\section{Revisionist Ideology}

In line with Labor Zionism, the revisionists also sought to establish an independent Jewish state in Eretz Israel. They also accepted the "negating the exile" discourse discussed in the previous chapter and the need to create a "new Jew." Where they differed from their ideological rival was their absolute and unconditional emphasis on the territorial integrity of Eretz Israel and the need for militarism in order to achieve it. In fact many of the building blocks of revisionist ideology and identity where formed in opposition to Labor Zionists who were seen as "soft" and "corrupt," "degenerates" who had bastardized Zionism with their "communist" worldviews. In contrast the Revisionists saw themselves as "pure" Zionists, since they had not corrupted it with socialism, and the sole group 
able to establish the Jewish state and restore "Jewish honor" using military means. The main ideological tenets of the movement are explained below.

\section{The Principle of Monism}

The principal attack revisionists laid against the Labor movement was the mixing of socialism and class struggle with Zionism. Because of this the revisionists adopted the principle of had-ness (one flag or single banner in Hebrew), which emphasized the supremacy of Jewish nationalism and subordination of individual and class goals to the one aim of establishing a Jewish state. Revisionists believed that Herzl's Zionism only had one goal: the achievement of sovereignty over all of historic Eretz Israel and that all other aims were secondary to this one aim. As a result the Revisionists saw the Labor movement with its socialist roots as a deviation from Zionist ideology. ${ }^{226}$

Moreover the revisionists saw the Russian revolution and the Soviet Union as the biggest threat to Zionism. According to revisionist ideology Communism and socialism were considered as essentially the same and inherently antiZionist. Socialists were internationalists that sought to break up the nation in favor of its class oriented goals. Because of this Jabotinsky and other revisionist leaders constantly accused the Labor movement of dividing the Yishuv along class lines and sympathizing with the international labor revolution, which was

\footnotetext{
${ }^{226}$ For a discussion on the political philosophy of the Revisionist movement see Sarig Mordechai, Shimshon Feder, and Daniel Carpi, The Political and Social Philosophy of Ze'ev Jabotinsky: Selected Writings (Portland: Vallentine Mitchell, 1999); Yaacov Shavit, Jabotinsky and the Revisionist Movement 1925-1948 (London: Frank Cass and Co., 1988).
} 
seen as anti-nationalist. In a famous article which influenced a generation of revisionists, titled Sha'atnez ${ }^{227}$ Jabotinsky explained:

Socialism and Communism have their principle characteristics in common: the idea of social revolution has only one standard bearer, the working class, particularly the manual workers. The path to reform leads via the victory of this class and their domination of all other classes. The decisive step in this process of domination will be taken in the name of 'Socialist Revolution' - in other words not by common consent, but by an act of violence. ${ }^{228}$

Jabotinsky repeatedly accused that the Labor movement was more concerned with building a Labor economy and their own socialist rural settlements, a socioeconomic model that weakened inter-class solidarity and weakened the national economy, than the Zionist cause. As a result of this socialism was incompatible with Zionism, which was essentially a nationalist ideology. Revisionists emphasized that any synthesis of the two ideologies would result in behavior that was dualistic, hypocritical and erratic. Unlike in Europe, capitalists and the middle class had not exploited the working class in the Yishuv, Jabotinsky correctly argued, and that it was in fact the middle class that was the "true proletariat." Moreover socialist ideology had prevented the private sector of the Yishuv from flourishing and middle class and entrepreneurial Jews from making Aliyah.

${ }^{227}$ Sha'atnez is "a ritually forbidden mixture of linen and wool." See Shavit, Jabotinsky and the Revisionist Movement 1925-1948, 342.

${ }^{228}$ Quoted in Philip Arena and Glenn Palmer, "Politics or the Economy? Domestic Correlates of Dispute Involvement in Developed Democracies," International Studies Quarterly 53 (2009): 95575. 
Such criticisms were intensified after the Labor movement manipulated immigration certificates to only allow followers of its own ideology to make Aliyah. When in the 1930s the Labor movement moved to the political center by shedding its original Marxist principles and adopting "socialist constructivism" accompanied with the slogan of "from a class to a people," the revisionists cynically saw this as nothing more than the domination of the entire nation by the working class led by the "authoritarian" Mapai. ${ }^{229}$

Mapai's efforts in the 1930s to appeal to the entire Yishuv furthered revisionist criticism that accused it of "hypocritically" using the lower classes to further its own hegemony and dominance. In Revisionist discourse Labor was presented as a "philistine party" that dominated the majority in order to reap its own narrow interests, and totally lacking in "reliability" and "honesty." The Histadrut was especially despised because of its catering to Labor members and supporters and its role in the isolation of revisionists in the Yishuv, who accused the Union of barring them from employment opportunities.

Antagonism to socialism was one of the main rallying cries of revisionist leaders and as such it became a focal point of the movement's ideology. Abba Achimeir a founder of the revisionist Brit HaBirionim (The Strongmen Alliance) in the Yishuv, commented in 1932 that socialism was one of the most negative developments in human history since Tamerlane and Ghengis Khan, adding that "the people of Israel, after giving birth to Christianity, had turned its back on it

\footnotetext{
${ }^{229}$ See Shavit, Jabotinsky and the Revisionist Movement 1925-1948, Chapter 11.
} 
after first foisting it on the cruel Romans. Now history was repeating itself: the people of Israel had given birth to Socialism, and after using it to punish the cruel Russians, it was also turning its back on this deceitful doctrine." Yehoshua Heshel Yevin commented that Marxism was a "diabolic entity which if it should succeed in controlling our lives, would wipe the image of God from the human face and drown it in the abyss of pollution." 230

In contrast to the alleged class orientation of the Labor movement, the revisionists emphasized the primacy of the nation. In their ultra-nationalist ideology, which was also inspired and influenced by Polish nationalism between the two World Wars as well as Italian Fascism, all spheres of life including economics, culture and politics had to be in the service of the nation-building process. Above all else, the revisionists emphasized the necessity and supremacy of militarism and war in this process.

\section{The Primacy of Militarism}

What differentiated the revisionists from other Zionists groups in terms of policy and tactics was their willingness to use organized violence and political terror to achieve their aims. Militarism was the pillar of revisionist ideology due to their extreme Hobbesian view of international affairs. Jabotinsky explained that relations between nations was based on homo homini lupus (man is a wolf to [his fellow] man) and "that isolation, distrust, a stand of 'being on watch' always, stern

\footnotetext{
${ }^{230}$ Quoted in Ibid., 341.
} 
treatment at all times is the only means to hold one's own in this wolfish confrontation." 231

As a result of this extreme Hobbesian view, revisionists believed that the only path to statehood was through war, as a result, strengthening the military power of the Jewish nation was considered as the only path for the success of Zionism. In contrast to the Labor Zionists which relied on the plow and on an ideology that sought to "bloom the desert," the revisionist relied on the sword, and adopted the motto "In blood and fire Judea fell; in blood and fire she will rise again." As Greenberg explained the "eternity of the plough" would only be secured by "the eternity of the sword, and not the reverse." 232 In revisionist ideology the nation-building process would not be achieved by the plow or through diplomacy, but by fire and blood. As Uri Zvi Greenberg wrote in 1937, in what would become one of the most important poems of the movement:

"Double blood for blood

Double fire for fire!.....

For thus races repay their enemies

Throughout the generations and throughout times.....

A country is conquered in blood ... from the River of Egypt to the Euphrates." ${ }^{233}$

\footnotetext{
${ }^{231}$ Quoted in Yonathan Shapiro, The Road to Power: Herut Party in Israel (Albany: State University of New York Press, 1991), 11-12.

${ }^{232}$ See Shavit, Jabotinsky and the Revisionist Movement 1925-1948, 149.

${ }^{233}$ Quoted in Scott Atran, "Stones against the Iron Fist, Terror within the Nation: Alternating Structures of Violence and Cultural Identity in the Israeli-Palestinian Conflict," Politics and Society 18 (1990): 493.
} 
Military strength was what would determine the success or failure of the Zionist enterprise. Even more importantly, Jabotinsky believed that war was a crucial and necessary stage in the psychological transformation of the Jewish people and the creation of the "new Jew." The violence of war and the struggles and sufferings it entailed would transform the passive and weak Jews to a unified and strong nation. Jabotinsky's was especially fond of militarism for its ability to unify and organize a nation. As such military education was the focal point of revisionist activities, and national and military symbols were very dominant in its discourse. Also the Betar youth militia served as the principle avenue for the movement's ideological indoctrination and source of power.

The role of militarism in Zionist Revisionism has been well documented in academic scholarship ${ }^{234}$ and there is no point in repeating it here, yet what is missing in the literature is how it differs from the militarism of the Labor movement discussed in the previous chapter. In fact, the increasing militarism of the Labor movement starting in the late 1930s, and especially Ben-Gurion's reliance on military strength after independence to solve Israel's problems with its Arab neighbors, has led prominent scholars such as Avi Shlaim and Ze'ev Moaz to conclude that the Labor movement essentially adopted the "Iron Wall" ideology

\footnotetext{
${ }^{234}$ See for example Lenni Brenner, The Iron Wall: Zionist Revisionism From Jabotinsky to Shamir (London: Zed Books, 1984), Chapter 8.; Ofira Seliktar, New Zionism and the Foreign Policy System of Israel (Carbondale: Southern Illinois University Press, 1986), Chapter 3.; Eran Kaplan, The Jewish Radical Right Revisionist Zionism and Its Ideological Legacy (Madison: The University of Wisconsin Press, 2005).; Sofer, Zionism and the Foundation of Israeli Diplomacy, Chapters 10 and 11.
} 
of the revisionists. ${ }^{235}$ The following pages will argue however that even though some of the tactics and policies of the movements seem similar on the surface, they stem from completely different ideological frameworks. As a result of this, even though the two movements adopted the same tactics in some time periods, they behaved completely different in other times and circumstances. This is why the study of a movement's ideology is so crucial in understanding its behavior.

The Labor movement's view of military force was that it was a "necessary evil" in the path to nationalism. This view especially became potent in the years prior to independence during which Labor leaders such as Ben-Gurion came to the conclusion that war with the Arabs was inevitable. Thus war was seen as a "last resort" and even then only in a "defensive" capacity. This position was not entirely rhetoric either. Labor leaders such as Ben-Gurion negotiated with their Arab neighbors including Palestinian Arabs on numerous occasions, particularly prior to the Arab revolt of 1936. Even after the Arab revolt, the Haganah ("defense" in Hebrew) was believed to be operating in a strictly "defensive" capacity while upholding "purity of arms" and high "ethical standards." On the other hand the revisionists openly and proudly celebrated militarism and sought to establish military battalions that would "conquer" Eretz Israel. In fact the prime goal of the Betar and the Irgun was to achieve this very invasion.

\footnotetext{
${ }^{235}$ See Shlaim, The Iron Wall: Israel and the Arab World; Maoz, Defending the Holy Land: A Critical Analysis of Israel's Security \& Foreign Policy.
} 
The Labor movement saw military power as one of the instruments to achieve Jewish independence and subsequently to ensure Israeli security in the post-independence era, yet it was not seen as the sole instrument to achieve such aims. Ben-Gurion explained that the state's staying power was not solely measured through military strength but "in the total moral, professional and economic resilience of the nation." ${ }^{\text {236 }}$ As a result, Labor leaders spent a lot of effort on building in their eyes an egalitarian and well-functioning society, and Labor leaders including Ben-Gurion made many efforts at diplomacy with Britain and other world powers in order to secure the alliance of at least one great power. Also Labor efforts to win world sympathy are also manifest of this ideology. This is also why even though Labor youth and Kibbutz members were trained in military training, they also received other forms of training such as how to cultivate the land. This is also why the Labor movement's training of diaspora Jews preparing for Aliyah was largely non-military. Moreover as discussed in the previous chapter, while militarism was a central component of the Sabra identity, being a Sabra also entailed intimate knowledge of the land, Hebrew as the native language and skills in manual agricultural work. Moreover the Sabra was a "heroic" Jew ready to sacrifice his or her life in the "defense" of Jewish settlements.

${ }^{236}$ Quoted in Shapiro, The Road to Power: Herut Party in Israel, 153. 
In contrast militarism and war were seen as the only path forward in the revisionist movement. Moreover Jabotinsky saw the instilment of a "psychology of shooting" in the Jewish people as the only way to negate their exile mentality. This ideology is clearly seen in the movement's actions. The revisionists' principle organization was the Betar and later on the Irgun, both aimed at military training. In fact for a very long time the movement lacked any other significant organizations, institutions or a bureaucracy that could compete with powerful labor organizations such as the Histadrut and the Kibbutzim association. Moreover unlike the "universal humanistic" principles and moral guidelines that Labor's militarism proclaimed its adherence to, the revisionists believed that nationalist considerations trumped all other considerations.

David Raziel, the commander of the Irgun, explained, "From the standpoint of national morality, everything which has the good of nation at heart will be considered good, even if it brings misfortune to an individual or to many individuals; and everything which is detrimental to the nation will be considered bad, even if it brings happiness to a multitude of individuals. National military morality stands at a far higher level than private morality. ${ }^{237}$ Based on such a worldview the Irgun openly called for and carried out numerous terrorist operations against Arab civilians as well as British authorities, much to Jabotinsky's dismay. As power passed down from intellectual figures such as

\footnotetext{
237 Ibid., 55.
} 
Jabotinsky to younger military figures such as Begin, the militarism of the movement intensified even further. The young guard of the revisionist movement, led by Begin, emphasized that political Zionism had to give way to military Zionism. The differences between the militarism present in the two movements was especially apparent in their approach to the "Arab question" and proposals of partition.

\section{Opposition to partition}

One of the fundamental building blocks of revisionist ideology was the territorial integrity of Eretz Israel, which was considered as including the land on both banks of the Jordan River. This position became one of the central points of contention between the revisionist and labor movements. When in 1937 the Jewish agency and the majority of Mapai accepted in principle the partitioning of the land proposed by the Peel Commission, it was seen by revisionists as nothing short of treason. According to the revisionists, by accepting to divide the homeland, the Zionist leadership had in effect lost all legitimacy. The revisionist movement argued that the Jewish people had an unbreakable bond with the entire land of historic Eretz Israel and moreover by accepting partition, the new state would be bound by a tiny and narrow piece of land that would be insufficient to accommodate Jewish immigrants and would be indefensible to outside invasion. ${ }^{238}$

\footnotetext{
${ }^{238}$ See Shavit, Jabotinsky and the Revisionist Movement 1925-1948, 332-334.
} 
The onward acceptance of partition by the Labor movement from 1937, leading to the acceptance of the UN partition plan of 1947, led to many heated and emotional attacks by revisionists who labeled labor leaders as "traitor defeatist" who had lost all connections to the Zionist cause. Moreover they believed that the Labor movement was subduing the Jewish national movement and defeating its national glory and honor by "deferring to the goyim" instead of relying on inner strength and power. It is also important to point out that the revisionists' stance on partition also partly stemmed from their views regarding the "Arab question." The fundamental assumption of the revisionist movement on the Arab question was the Iron Wall concept that explained:

We cannot promise anything to the Arabs of the Land of Israel or the Arab countries. Their voluntary agreement is out of the question. Hence those who hold that an agreement with the natives is an essential condition for Zionism can now say "no" and depart from Zionism. Zionist colonization, even the most restricted, must either be terminated or carried out in defiance of the will of the native population. This colonization can, therefore, continue and develop only under the protection of a force independent of the local population - an iron wall which the native population cannot break through. This is, in toto, our policy towards the Arabs. To formulate it any other way would only be hypocrisy. ${ }^{239}$

The fundamental premise of the Iron Wall ideology was that voluntary agreement with Palestinian Arabs was unattainable and as such the Zionist movement should rely on the power of force to achieve its aims. It is also important to point out that Jabotinsky and other revisionist leaders had a very negative view of the Arabs and the "East" in general. They believed that the

${ }^{239}$ Ze'ev Jabotinsky, The Iron Wall, trans. Lenni Brenner, 1923. 
native Arab population was alien to the Jewish nation, that Arabs were essentially deceitful and uncivilized, and that they only understood force. Also Arabs were seen as savages that were bent on slaughtering Jews. It is important to point out that in revisionist discourse Arab behavior, such as mass strikes and riots were not seen to be the result of reaction to Jewish policies but rather because the eternal essence of the Arab was to "kill the Jews." As a result people like Achimeir concluded that the Arab "only understands power."

Revisionism's stance on the "Arab question" also undermines the argument of scholars such as Shlaim and Maoz who argue that the Labor movement also adopted the approach of the revisionists to the Palestinians. Even though Labor also prepared for an "inevitable" war with the Arabs, as the revisionists argued they should, they saw the conflict with the Palestinian Arabs as the struggle and rivalry between two national movements. As a result, partition and compromise was seen as necessary and even beneficial, and war was seen as only one tool, among others such as direct negotiations with Arabs and diplomacy with Britain, in order to deal with the "Arab question." In contrast to the practical approach of the Labor movement, revisionists saw Islam as the "essential and eternal foe" of the Jewish people, and its values and norms in complete contradiction to their own. In revisionist literature Islam is described as "tyrannical," "extremist," "violent," "treacherous" and even "inhumane." 240

\footnotetext{
${ }^{240}$ Shavit, Jabotinsky and the Revisionist Movement 1925-1948, 246-247.
} 
Jabotinsky declared, "We Jews, thank God, have nothing to do with the East...The Islamic soul must be broomed out of Eretz-Yisrael...[Muslims are] yelling rabble dressed up in gaudy, savage rags." ${ }^{241}$ Moreover Jabotinsky described Islam as a "paper tiger" that needed to be defeated. ${ }^{242}$

In the movement's literature, the history of the Jews in Islamic territories is painted as similar to the oppressive conditions of Jews in medieval Europe. Moreover giving up any part of Eretz Israel was equivalent to giving up the whole of Eretz Israel, and the Palestinians were "Canaanites" that had to be overcome through force just "like the Children of Israel campaigned in the day of Yehoshua Bin-Nun." ${ }^{243}$ Greenberg explained "I say: A land is taken by blood. Only what is taken with blood weds the people in a holy bond of blood..... blood will decide who rules here." ${ }^{244}$ As a result of this ideology, coexistence with the Palestinians became difficult if not impossible. Jabotinsky himself explained that he saw "no prospect of a political compromise," and that he foresaw a "lengthy, violent and bloody struggle." ${ }^{245}$ Such an approach to the "Arab question" partly stemmed from the revisionists very cynical and extreme Hobbesian view of the

\footnotetext{
${ }^{241}$ Nur Masalha, Expulsion of the Palestinians: The Concept of "Transfer" in Zionist Political Thought, 1882-1948 (Washington D.C.: Institute for Palestine Studies, 1992), 29.

${ }^{242}$ Shavit, Jabotinsky and the Revisionist Movement 1925-1948, 250.

243 lbid., 269.

${ }^{244}$ Quoted in Ibid., 268.

${ }^{245}$ See Ibid., 253-260.
} 
international system which meant that the conflict with the Arabs was seen as a zero-sum game.

\section{The Failures of Revisionist Zionism in the Yishuv}

Prior to independence, the Revisionist movement was never able to seriously challenge the hegemony of Labor in the Yishuv. Unlike Labor, the revisionists were not in a position to create a comprehensive political, social and cultural system according to their ideology, akin to that of the Labor movement. Also, while the revisionists created the Hadar identity to serve their ideological goals and challenge Labor's Sabra, they were never able to make this a mainstream identity, or an ideal that a majority of people sought.

Hadar, which means glory or splendor in Hebrew, was the central concept used to indoctrinate members of Betar. Hadar entailed self-esteem, chivalry, politeness, physical cleanliness, social manners and discipline. Jabotinsky explained that Hadar is comprised of many small actions, such as "eat noiselessly and slowly.... in the streets give right of way to a lady, to an elderly person," which taken together would restore the "respect" and "honor" of Jews. National honor was a supreme principle of the revisionist movement. As Kalman Katznelson explained, “Jabotinsky's Jewish state.... was intended to exalt Jewish honor." ${ }^{246}$ The immaculate organization and discipline in Hadar was intended to

\footnotetext{
${ }^{246}$ Quoted in Shapiro, The Road to Power: Herut Party in Israel, 17.
} 
achieve this. In the Yishuv, Brit Habirionim developed the concept of Hadar into a psychology of "conquer or die."247

In order to analyze the rise of the revisionists in Israeli politics and society it is imperative to first examine their initial weaknesses and failures. The most important weakness of the revisionists was that even though their ideology had important differences with Labor Zionism, they were unable to translate this into a comprehensive belief system that was a striking alternative to that of the Labor movement. As a result they were seen as only differing on a tactical and policy level. The most important manifestation of this failure was the Hadar identity that lacked any significant difference or perceived superiority to the Sabra and as a result of this, as well as the lack of identity building institutions within the Yishuv that were controlled by the revisionists, it never had a serious influence within the Yishuv, unlike the Sabra which affected an entire generation of Israelis.

The Hadar philosophy was used to construct a disciplined and militant identity by the revisionists particularly in the Betar movement. The youth organization was in effect the clearest organizational and ideological expression of revisionist Zionism. The influence of the Hadar idea however never extended from the revisionist organization into general society. The intellectual leaders of the revisionist movement such as Jabotinsky were thus never able to translate

\footnotetext{
${ }^{247}$ For a discussion of the goals of Brit Habirionim see: Nachman Ben-Yehuda, Masada Myth: Collective Memory and Mythmaking in Israel (Madison: The University of Wisconsin Press, 1995), 139-142; Leonard Weinberg and Ami Pedahzur, Religious Fundamentalism and Political Extremism (London: Frank Cass and Co., 2004), 100-103; Shapiro, The Road to Power: Herut Party in Israel, 84-85.
} 
their ideological principles into a concrete, everyday and accessible identity that was available to the general masses. This failure partly stemmed from the absence of mass identity building institutions akin to that of Labor.

The revisionists did enjoy some success in Europe, particularly among the Jews of Poland. The number of Betar members for example rose from around ten thousand in the 1920s to nearly eighty thousand on the eve of the Second World War. ${ }^{248}$ Nevertheless these advancements were never matched with success inside the Yishuv. Betar and Irgun membership within the Yishuv was relatively small and even then many members left the organizations due to the lack of a financial support mechanism, as well as their isolation from employment markets operated by the powerful Histadrut. In 1934, the revisionists tried to rectify this by establishing their own union titled National Labour Federation. While the revisionist union weakened the domination of the Histadrut, it was never able to penetrate the general public the way the Labor union did, rather its members were largely drawn from revisionists. This in turn was largely as a result of the revisionists' late entry into the politics of the Yishuv.

During the pre-independence years the revisionists were largely based in Europe, particularly in Italy and Poland. As a result their organizational capacity and activity within the Yishuv was much smaller than the Labor movement. In fact the movement's leader such as Jabotinsky were not involved in the everyday politics of the Yishuv. The revisionist leader, aside from a short period in 1928-

\footnotetext{
${ }^{248}$ Shavit, Jabotinsky and the Revisionist Movement 1925-1948, 37.
} 
1929, spent all his life in Europe. Menachim Begin, his successor, only made Aliyah in 1942. As a result, revisionism had a very small presence in the Yishuv when compared to the Labor movement, which effectively governed the Jewish community in Mandatory Palestine. As noted in the previous chapter the centralized educational system and military organization (Haganah) of the Labor movement were imperative in building the Sabra identity and propagating the movement's ideological principles. Moreover these identity-building institutions were supported and funded by the Histadrut and the Jewish Agency. In contrast, the revisionists had no matching bureaucracy and while its leaders such as Jabotinsky articulated their ideology in eloquent articles, they lacked the necessary organizations to institutionalize their belief system within the Yishuv.

The immediate consequence of this was a lack of support for the movement within the Yishuv. For example in the 1931 elections of the $17^{\text {th }}$ Zionist congress, the Labor bloc won 22,487 votes in Poland and 18,513 votes in the Yishuv, while the revisionists received 20,496 votes in Poland and only 5,024 votes in the Yishuv. ${ }^{249}$ The movement's lack of presence and support in the Yishuv became a source of weakness even further as the center of gravity of the Zionist movement gradually shifted from Europe to the Yishuv. Moreover World War Two and the Holocaust resulted in the eradication of revisionist bases in Europe and the elimination of a large number of revisionist supporters in Europe.

\footnotetext{
${ }^{249}$ Ibid., 39.
} 
The failure of the revisionist movement to win over the majority of the Yishuv however cannot be solely ascribed to its lack of bureaucratic and organizational capacity. Rather it is also important to consider the negative image of the movement within the Yishuv. As indicated earlier, while the revisionist movement was much more militant than Labor Zionists, its branches within the Yishuv were even more militant and extreme than their European counterparts as well as Jabotinsky himself. Ultra-nationalist activists such as Abba Achimeir, Y.H. Yevin and Uri Greenberg who had been highly influenced by Italian Fascism led the revisionist movement within the Yishuv. These individuals not only sought a militant and activist approach to Arabs and Britain, but even against Labor leaders. Achimeir for example led a group of revisionists who called themselves the Sikarikin, named after a group of knife-wielding rebels during the first Jewish revolt in the first century who were known for not only insurgency against the Romans but also their willingness to kill Jews who had collaborated with the enemy. ${ }^{250}$ Such extremist approaches were not restricted to rhetoric either. For example in 1933 Chaim Arlosoroff a Mapai leader who was negotiating with the German government on behalf of the Jewish Agency regarding the transfer of Jewish property to Mandate Palestine was assassinated in Tel Aviv. Although revisionists leaders such as Achimeir were acquitted in court due to lack of evidence, there was little doubt that their inflammatory rhetoric against Arlosoroff had led to his murder. The British mandate government eventually arrested and

\footnotetext{
${ }^{250}$ See Shapiro, The Road to Power: Herut Party in Israel, 47.
} 
deported many revisionist leaders, nevertheless the revisionists particularly through the Irgun, the movement's military organization, carried out numerous terrorist attacks against Palestinian civilian targets, such as the marketplace bombings of Jerusalem, Haifa and Jaffa, all resulting in heavy civilian casualties, as well against the British, such as the bombing of the King David Hotel which served as British administrative headquarters for Palestine and the assassination of Lord Moyne, British minister of state in the Middle East, in Cairo by Lehi members. ${ }^{251}$

These terrorist tactics led to a campaign by the Haganah in cooperation with British authorities to arrest and kill Irgun and Lehi militants from November 1944 to February 1945, also known as the "Hunting Season." The tactics used by the revisionists led not only to their suppression by the Labor movement and the British but also to a negative image among the general public in the Yishuv, which came to see the revisionists at best as a radical right wing underground movement and at worst as a terrorist extremist group. Thus while the revisionists presented provocative and engaging criticisms of the Labor movement and its failure to defend the Yishuv during the Arab riots, as well as its gradualist and "defeatist" approach to establishing a Jewish state, and its "subservience" and "deference" to the British, instead they offered no realistic alternative and only

${ }^{251}$ See Colin Shindler, Triumph of Military Zionism: Nationalism and the Origins of the Israeli Right (London: I.B. Tauris, 2006). For a history of the Lehi group see Joseph Heller, The Stern Gang: Ideology, Politics and Terror, 1940-1949 (Abingdon: Routledge, 1995).; For a history of the use of violence by various Zionist groups see Anita Shapira, Land and Power: The Zionist Resort to Force, 1881-1948 (Stanford: Stanford University Press, 1999). 
relied on rebellious militant tactics that would often have negative affects for the Zionist cause. This failure was partly as a result of the revisionists' lack of a strong political party in mandatory Palestine and their complete reliance on military organizations and tactics, as well as a more fundamental disregard of pragmatic considerations within the movement.

While Labor leaders, particularly Ben-Gurion, were highly disposed to pragmatic considerations, the revisionists largely functioned at the level of symbols and myths. Jabotinsky was known for oversimplifying complex problems and relying more on the "superiority of the human will" rather than the meansends rationality of the Labor Zionists. As a result many contradictions and anomalies can be observed in the approach of revisionists in the early days of the movement. For example even though Jabotinsky strongly pushed for a Jewish state on both sides of the river Jordan with a Jewish majority, he staunchly refused to endorse plans that called for the transfer of Arabs from their lands. He simply stated that the new state would have 5 million Jews and 1 million Arabs, without any specific course of action of how such magical numbers could be achieved and how British opposition to mass Jewish immigration could be overcome.

Interestingly enough, within the revisionist movement Jabotinsky was actually much more realistic than other senior members. In the 1938 conference for example Begin strongly called for an invasion of Eretz Israel by the Irgun, an idea that Jabotinsky believed was completely unrealistic, since the Irgun with its 
two thousand membership was no match for the British army as well as the Haganah, which at the time was fighting Irgun members in the Yishuv. The difference between Jabotinsky and Begin led to an open and heated exchange. ${ }^{252}$ In fact Jabotinsky's opposition to the planned invasion led many younger members of the movement to criticize his reluctance to turn words into action.

This lack of realistic and pragmatic considerations in revisionist ideology translated into very few notable achievements for the movement. Also while the revisionists had grandiose schemes, they lacked the necessary tools to implement them such as financial resources, organizational power and even military strength which was the focal point of emphasis within the movement. As a result, critics commented that revisionism was more about "comic" marches and parades than real work, and revisionist plans for an "invasion" of the

\footnotetext{
252 In the movement's 1938 convention in Warsaw Jabotinsky and Begin got into an argument after Begin proposed the Irgun's plan to conquer Eretz-Israel from the podium at which point Jabotinsky intervened from his seat:

Jabotinsky: "Would the gentleman please tell me how he will get the Betari soldiers into the country without the support of foreigners."

Begin: "If the force is created, help will come also from the Diaspora..."

Jabotinsky: "Has the gentleman taken note of the proportions of the Jewish military force and the Arab force in Eretz-Israel?"

Begin: "We will win by virtue of our own moral strength."

In fact Jabotinsky later called the plan "absurd" and likened Begin's speech to "the squeaking of a door" that needed to be suppressed. See Shapiro, The Road to Power: Herut Party in Israel, 5859.
} 
homeland was ridiculous. Nahum Sokolow, president of the Zionist Organization, for example commented that "Nobody in his wildest imagination could conceive that this Legion could ever rise up and fight against Britain, the Arab world, Islam or anybody else. And it is this absurdity which is so attractive and simulating: Credo quia absurdum ('I believe it because it is absurd') and this is where the faith of fools lends a hand."253

In contrast, while the revisionists repeatedly called the Labor movement the "philistine" party that had abandoned Zionist goals and sold Jewish nationalism to the British government and the Arabs, in reality the Labor movement had played a significantly greater role than the revisionists in building and expanding Zionist settlements in Palestine, forming centralized military and welfare organizations, and leading negotiations with the British and world powers, eventually leading to the foundation of the Jewish state. The fact that the Labor movement was the primary force behind the success of the Jewish nationalist struggle was highly detrimental to revisionist propaganda and severely limited their ability to win support within the Yishuv.

As a result of all the above factors, the revisionist movement was at a great disadvantage in relation to the much larger and better organized Labor movement which went on to dominate nearly all state institutions in the postindependence period. The fact that the revisionists were to take over the Israeli

\footnotetext{
${ }^{253}$ Quoted in Shavit, Jabotinsky and the Revisionist Movement 1925-1948, 40.
} 
government in the 1977 elections, known as Ha Mahapakh (the revolution in Hebrew) due to its immense consequences for Israel, seemed highly improbable at the time. As the following sections will demonstrate the decline of the Labor movement and the ascendance of the revisionists cannot be attributed to any single factor. Neither did this complex transformation take place in a short period of time. Rather it was the result of various gradual political and cultural developments as well as major external shocks namely the 1967 and 1973 wars. Since the ascendance of Israel's right had a significant effect on the country's foreign policy toward the peace process, it is imperative for this study to examine its root causes. For the sake of simplicity, the decline of the Labor movement and the ascendance of the revisionists are analyzed in separate sections and presented in that order.

\section{The Decline of Labor}

The Labor movement was successful in propagating a comprehensive ideology and winning over the support of the majority of the Yishuv as well as the Israeli population post-independence, yet by the early seventies its hegemony began to dissolve and in 1977 it officially lost control of government to its revisionist rivals. While these developments became apparent in the 70 s, their roots began to take shape in the 50 s and $60 \mathrm{~s}$. This section will examine some of the most important causes behind Labor's decline. 


\section{The Holocaust and 'Negating the Exile'}

Labor's ideology and the Sabra identity it created suffered from several paradoxes that would strain the movement and eventually result in its decline. The first of these was the conflict between the concept of "negating the exile" and the rise of feelings of sympathy and solidarity with Holocaust survivors as well as other diaspora Jews. As discussed in chapter three, negating the exile was the basis of the Sabra identity, as such criticizing and even ridiculing the conditions of the galut Jew, who was seen as the "other" of the "new Jew," was commonplace in the movement's narrative. As a result of this, many members of the Sabra generation saw diaspora Jews with disdain. Such contempt was even apparent in the way some segments of the Yishuv reacted to the Holocaust.

As discussed earlier the Holocaust brought about an "I told you so" attitude in the Yishuv since the tragedy had "demonstrated" the Sabra narrative about the diaspora Jew being weak, submissive and unable to protect himself from the persecutions of the gentiles. The view of the Yishuv regarding the tragedy was summarized by Elad Peled, a Palmach commander, who wrote "I see before my eyes the beaten Jewish child, the tortured woman, and the cowardly man of the Diaspora at the time of the pogroms, and in contrast to Rozka and her friends in the ghettos." 254

In this narrative diaspora Jews, by not accepting the call of Zionism to join Aliyah, had been responsible for their own demise. Shimon Peres once noted

\footnotetext{
${ }^{254}$ Quoted in Almog, The Sabra: The Creation of the New Jew, 85.
} 
regarding Holocaust victims: "We disagreed with the way they were living, so we disagreed with the way they were dying." ${ }^{255}$ Such estrangement with the fate of diaspora Jews was especially acute in native youth who had been born and raised in Sabra culture in Mandatory Palestine.

The alienation of native youth from the Jewish tragedy was to such an extent that they could only identify with the ghetto rebels who they saw as sharing similar traits to their own identities. ${ }^{256}$ Yishuv members even had feelings of inferiority towards survivors of the Holocaust who made Aliyah after the war. Ben-Gurion called these people "a mixed multitude of human dust without a language, without education, without roots, and without any roots in the nation's tradition and vision," adding that "turning these people of dust into a cultured, independent nation with a vision will be no easy task." 257 Others labeled these refugees to Israel as agadim (the Hebrew acronym for "people of the mournful Diaspora"). In Sabra discourse only the Jews who had taken part in the ghetto uprising had done their duty. For example on the fifth anniversary of the Warsaw ghetto uprising, which was commemorated every year in Israel, the order of the day issued to Palmach soldiers stated: "The victory in the ghetto, the victory of the Jewish person, was to die with honor, weapon in hand, and not as sheep led

\footnotetext{
${ }^{255}$ Shimon Peres and Robert Littell, For the Future of Israel (Baltimore: Johns Hopkins University Press, 1998), 41.

${ }^{256}$ See Shapira, “Whatever Became of 'Negating Exile'?,” 79-81.

${ }^{257}$ Quoted in Almog, The Sabra: The Creation of the New Jew, 87.
} 
to the slaughter.." ${ }^{258}$ As a result of this many natives had patronizing attitudes toward arriving survivors.

Ideas that cast Holocaust victims and survivors as inferior however were challenged in the 50 s and 60 s. Some of the intellectual founders of the Labor Zionist movement such as Berl Katznelson were deeply troubled by the negative portrayal of Holocaust victims, stating, "even if there had been no uprising in the ghetto, I would not say a single word against the Jews of the ghetto." Katznelson would later write "This indifference to our agony- it's frightening $\ldots$ the youth in Palestine had grown up detached from the Jewish people and its suffering." 259 Katznelson used his influence within the Yishuv to change this. For example when commenting on the fact that the brother of the rabbi of Gur had asked for some water to purity himself before his death, he stated "To me, this is an incredible demonstration on one's day of death. And I know that it is the Jewish death of kiddush hashem [martyrdom]."260

Such pronouncements challenged the dominant discourse of the Sabra culture that only designated "honor" to the few Jews who had actively resisted and fought against the Nazis. Also the challenging of Sabra discourse did not take place only among intellectuals. Many holocaust survivors were able to integrate themselves well into Israeli society and even reach high ranks within

\footnotetext{
${ }^{258}$ Quoted in Ibid., 85.

${ }^{259}$ Shapira, “Whatever Became of 'Negating Exile'?,” 79.

${ }^{260}$ Quoted in Ibid.
} 
the IDF and the Palmach. As a result of this mixing between the "immigrants" and the "natives" many of the stereotypes regarding the "diaspora Jew" began to disappear, or at least brought about ambivalent feelings among the Sabra generation. This was especially true after the experience of the 1948 War in which many of the new immigrants fought alongside the "natives." The war was a unifying experience between the Sabra and its "other." In fact the war pitted the sabras and the immigrants against a new Arab "other" that was now seen as the enemy of both groups.

The turning point of Israeli views on the Holocaust and its victims came with the trials of Nazi officer Adolf Eichmann. The prominent Israeli historian Anita Shapira explains that "the Eichmann trial has become a decisive juncture: it was responsible for Holocaust memory penetrating Israel consciousness and becoming a national myth as well as a point of contact between world Jewry and the Jews of the State of Israel." 261 The Eichmann trials received massive media attention inside Israel. Many Israelis heard the trials through radio and read the court proceedings in local newspapers.

The most important aspect of the trials which concerns the discussion here was the breaking of stereotypes regarding both the Nazis as well as their Jewish victims. Before the trials Nazi officers were seen as strong master killers, while the Jews were seen as passive, defenseless and weak. In contrast to this image, Eichmann was shattered in both body and soul and many journalists

\footnotetext{
${ }^{261}$ Shapira, "Whatever Became of 'Negating Exile'?," 91.
} 
commented on how "ordinary" he was. In contrast Yizhak Zukerman who appeared as a witness was strong, handsome, tall and had a long history of military resistance against European anti-Semitism. Uri Avneri summed up the image coming out from the trials and its effect nicely, "The Nazis were far from being heroes, and many Jews were far from being cowards-the evaporation of the resistance to hearing about the Holocaust was conditional on this realization. The emotional windows opened up-and once they did, it was virtually impossible to shut them."262

The consequences of the Holocaust and the subsequent Eichmann trial were that they weakened the strength of the Sabra identity created by the Labor movement in the long run. This is because the core of this identity depended on negating the exile. After the trials broke away some of the stereotypes regarding diaspora Jews and as Holocaust survivors became a more integral part of Israel society, the distinction between the "new Jew" and the "exile Jew" became blurred. As a result of this change, many Israelis became interested in studying Jewish history in the diaspora and Holocaust history, as well as learning about their traditions and roots in the diaspora.

From the Eichmann trials forward, Israeli Jews increasingly identified with Jews living in the diaspora. Also the Labor narrative, which emphasized the discontinuity of Jewish history and the omission of two millennia of exile, was slowly being replaced with a narrative that emphasized the continuity of Jewish

\footnotetext{
${ }^{262}$ Quoted in Ibid., 93.
} 
history. Moreover the experience of the Holocaust renewed perceptions of the "great threat" Jewish survival faced, as a result creating a bond between Israeli Jews and those of the diaspora. As Yael Zerubavel explains: "Underlying this renewed emphasis on historical continuity is the perception of a great threat to Jewish survival throughout Jewish history, which also applies to the State of Israel... Israeli collective memory has thus lost much of its oppositionist stance vis-à-vis traditional Judaism, now embracing a lesson deeply ingrained in Jewish memory: the experience of a persecuted group struggling to survive against all odds." 263

\section{The New Immigrants}

A comprehensive study, conducted by Moshe Lissak, of 602 of the Yishuv's highest elites, shows that 73 percent of them came from Eastern Europe, while the remainder were mostly born either in central Europe or in Palestine. ${ }^{264}$ The fact that a majority of the community's elites came from the same backgrounds as Labor Zionist leaders greatly helped them establish the movement's hegemony. Yet it is also important to point out that prior to independence, aside from the elites, the Yishuv's society at large was also largely homogenous. In 1948, 58.7 percent of the population was from Eastern

\footnotetext{
${ }^{263}$ Zerubavel, Recovered Roots: Collective Memory and the Making of Israeli National Tradition, 195.

${ }^{264}$ See Sofer, Zionism and the Foundation of Israeli Diplomacy, 25-26.
} 
Europe and Russia, 18.5 from Western Europe and only 15 percent from Muslim countries. ${ }^{265}$

After the establishment of the state, the composition of Aliyahs was very different from its predecessors. From 1948 to the mid 1950s a vast number of immigrants came from post-Holocaust Europe and Arab and Muslim lands. Not only did Mizrahi Jews ${ }^{266}$ have a major share in post-independence Aliyah, but also these immigration waves were much larger in terms of numbers from preindependence immigration waves. As a result from 1948 to 1954, the Jewish population of Israel more than tripled, reaching nearly two million and many Israeli citizens were now originally from Iraq, Yemen, Egypt, Libya, Morocco, Tunisia, and Algeria. The "natives" saw these new immigrants with contempt. As Baruch Kimmerling explains "the mass immigration of non-European Jews threatened to 'Levantinize' the Yishuv, downgrading it to the 'low quality' of the surrounding Arab states and societies. In stereotypical terms, these immigrants were perceived as aggressive, alcoholic, cunning, immoral, lazy, noisy, and unhygienic." 267

While in the first years of Israel's existence the Mizrachim were in no position to put up any meaningful resistance to Labor's hegemony, in the long run and due to Israel's democratic system they were able to form a strong force

\footnotetext{
${ }^{265}$ Ibid., 15-16.

${ }^{266}$ Mizrahi Jews are descendants of the Jewish communities of the Middle East.

${ }^{267}$ Kimmerling, The Invention and Decline of Israeliness: State, Society, and the Military, 95.
} 
against the Labor movement in Knesset elections. Moreover the ability of the revisionist movement to attract the votes of these disenfranchised Israelis meant that their voting power was coupled with a strong and established political movement. It should come as no surprise that Ehud Barak, the Labor candidate for the Prime Minister's office and a high profile Sabra figure, publicly apologized in 1997 for the movement's treatment of the Mizrachim. ${ }^{268}$ The apology was very significant, as Daniel Gutwein, a history professor at the University of Haifa explains: "Barak, the ultimate Israeli, a kibbutz-born commander of the most prestigious elite unit of the Israeli Defense Forces (IDF), and leader of the party veteran European middle class (the Ashkenazim), actually accepted the Mizrachi lower-class narrative of oppression and exclusion and publicly recognized the responsibility of his movement." 269 Indeed by this time the Labor movement had become aware, albeit very late, of the power of the Mizrachim in Israeli politics.

The primary reason why the Mizrachim where cast out in the first few decades of Israel's existence was less due to government policies, and more to

\footnotetext{
${ }^{268}$ In September 1997 Ehud Barak told a crowd of Oriental Jews in Netivot: "We must admit to ourselves [that] the inner fabric of communal life was torn. Indeed, sometimes the intimate fabric of family life was torn. Much suffering was inflicted on the immigrants and that suffering was etched in their hearts, as well as in the hearts of their children and grandchildren. There was no malice on the part of those bringing the immigrants here-on the contrary, there was much goodwill-but pain was inflicted nevertheless. In acknowledgement of this suffering and pain, and out of identification with the sufferers and their descendants, I hereby ask forgiveness in my own name and in the name of the historical Labor movement." Quoted in Zion Zohar, Sephardic and Mizrahi Jewry: From the Golden Age of Spain to Modern Times (New York: New York University Press, 2005), 300.

${ }^{269}$ See Daniel Gutwein, "From Melting Pot to Multiculturalism; Or, the Privatization of Israeli Identity," in Israeli Identity in Transition (Westport: Praeger, 2004), 215-33.
} 
do with Labor's ideology and the Sabra identity it created, which essentially made it impossible for traditional and oriental Jews to identify with. Due to their cultural background and physical characteristics the new immigrants were completely inferior to the Sabra identity. In contrast to the first few immigration waves of the Yishuv, which were composed of mostly young, single educated Jews who had already been trained in the principles of socialism and secularism prior to Aliyah and were thus very ready to become "new" Jews, the immigrants from the Middle East already possessed an identity that was different from that of the Sabra.

Many of the new immigrants were religious compared to the Sabra who was secular and modern, they were "oriental" in both looks and culture, while the Sabra was European in both physical and personal characteristics. The new immigrants were traditional, while the Sabra was modern. Moreover the new immigrants were seen as having many characteristics of the Arabs. Because of this wide gap between original Mizrahi identities and that of the Sabra, the change being asked from the new immigrants in order to become a "new" Jew was too great, unlike Ashkenazi immigrants, many of who were already leading a secular modern lifestyle before leaving Europe. It is also important to point out that while many young Ashkenazi Jews coming to Palestine after the Second World War were orphans as a result of the Holocaust, most Mizrahi immigrants came together with their extended families. ${ }^{270}$ As a result, while these Ashkenazi

\footnotetext{
${ }^{270}$ For example 46 percent of all youths immigrating to Palestine from Eastern Europe after the war were orphans compared to only one percent of youths coming from Iraq and Morocco. See Almog, The Sabra: The Creation of the New Jew, 98.
} 
youth were immersed and raised in the Kibbutz and according to Sabra culture, most Mizrahi Jews kept their pre-Aliyah relationships and cultures. ${ }^{271}$

Moreover the patronizing attitude of Labor elites, which saw the "Arab Jew" as in need of "curing," did not facilitate a transition toward a Sabra identity. As a result many Mizrahi Jews found it difficult to assimilate into the Sabra culture set up by Ashkenazi Jews. For years these new citizens of Israel had trouble climbing up the ladder of success and occupying high positions in government, which was dominated by the Labor elite, and sometimes were even actively excluded and discriminated against. As a result of this many Mizrahi Jews were unable to integrate into Israel society and came to despise the ruling Labor hegemony.

Thus Labor's failure in altering its ideology and the identity it prescribed, based on the new makeup of Israeli society can be considered as one of the main reasons for the decline in the movement's hegemony. Labor elites wrongly assumed that the new immigrants, despite their inferiority, could be molded into the Sabra ideal despite the contrary evidence at the time. For example while most pre-independence immigrants willingly adopted new Hebrew names, which as discussed in the previous chapter was an important step in the process of "becoming Hebrew," Mizrahi immigrants largely resisted such pressures for years

\footnotetext{
${ }^{271}$ For a discussion of the difficulties Mizrahi Jews faced in assimilating into Israeli culture see: Sami Shalom Chetrit, Intra-Jewish Conflict in Israel: White Jews, Black Jews (New York: Routledge, 2010), Chapter 1; As'ad Ghanem, Ethnic Politics in Israel: The Margins and the Ashkenazi Centre (New York: Routledge, 2010), Chapter 3.
} 
and kept their traditional Jewish first names and their last names, which usually identified their family group in their countries of origin. ${ }^{272}$

\section{The Advent of Western Individualism and Multiculturalism in Israeli Society}

It is also important to note that in the late 50 s and during the 60 s Israeli society increasingly came to reject the "melting pot" approach, which sought to reshape and assimilate all new immigrants to a single ideology and identity. At the same time, the concept of multiculturalism started to gradually become accepted in Israeli society so that by the time of the immigration of Russians in the 1990s it was largely accepted that the new immigrants could keep their original language and culture. ${ }^{273}$ This trend in Israeli society can be attributed to the increasing influence of Western culture and ideas on Israeli society. As a result, with the rise of multiculturalism and individualism in Western societies, Israeli society also became affected. ${ }^{274}$

The increasing urbanization and individualization of Israeli society directly challenged a Labor ideology that emphasized agriculture and collectivism. A study by Eaton and Chen shows that that since the mid 50s Israeli youngsters

\footnotetext{
${ }^{272}$ Such as Wazana, Bokobza, Der'l and Ohana. See Almog, The Sabra: The Creation of the New Jew, 95.

${ }^{273}$ For a discussion of this immigration wave see Theodor $\mathrm{H}$. Friedgut, "Immigrants from the Former Soviet Union: Their Influence and Identity," in Israeli Identity in Transition, by Anita Shapira (Westport: Praeger, 2004).

${ }^{274}$ See Gutwein, "From Melting Pot to Multiculturalism; Or, the Privatization of Israeli Identity."
} 
increasingly adopted individualistic and consumption-oriented Western values. ${ }^{275}$ Moreover the Kibbutz, which served as the ideological role model of the movement, started to lose its status as the vanguard of Zionism "pioneering" in Israeli society. Polls taken in 1976 and 1978 show that a majority of Israelis thought that the Kibbutzim were not paying enough taxes and 66 percent believed that the Kibbutz was not helping the lower classes of Israeli society. Even inside the Kibbutzim themselves studies show that in the early 70 s there had been a marked decrease in the ideological commitment of members and a shift from collectivism to consumerist and individualist values. This shift can be partly attributed to the increasing industrialization of the Kibbutzim and the employment of outside labor. The Histadrut, another Labor institution used for ideological indoctrination, also lost its socialist ideological function and largely became an institution that simply provided welfare services. A 1963 poll for example found that only $28 \%$ of Israelis joined the Histadrut for ideological reasons. ${ }^{276}$

The arrival of immigrants from various geographical and cultural backgrounds was one of the reasons behind the rise of multiculturalism in Israel. Nevertheless such a trend cannot be solely ascribed to changes within Israeli society, rather the decline of socialist ideologies and movements around the

\footnotetext{
${ }^{275}$ See Joseph W. Eaton and Michael Chen, Influencing Youth Culture: Study Youth Organizations in Israel (Beverly Hills: SAGE Publications, 1970).

${ }^{276}$ See Seliktar, New Zionism and the Foreign Policy System of Israel, 115-121.
} 
world and the rise of individualism and consumerism in the West highly affected Israeli society. Israel should not be seen as a cultural island, rather it is affected by global trends particularly those in the West.

\section{The Yom Kippur War and the Decline of 'Mamlachtiut'}

On October 6, 1973, Israel was taken by surprise when Egypt and Syria attacked Israeli forces in the Sinai Peninsula and the Golan Heights. During the war, which came to be known as the Yom Kippur War due to the timing of the attack that coincided with the Yom Kippur Jewish holiday, Israel sustained heavy casualties and nearly lost. ${ }^{277}$ The war also caused a diplomatic fiasco after Arab countries announced an oil embargo on the United States. Unlike the Six Day War, which demonstrated Israeli military supremacy, the war of 1973 deeply injured the prestige and perceived power of the Israeli Defense Forces and the Israeli state in general. In fact a commission of inquiry headed by Supreme Court Simon Agranat was formed to examine the military, intelligence and policy failures of the state.

The main consequence of the 1973 war for the Labor movement was that Israel's failures and setbacks in the war were seen as a result of the inefficiency of the IDF and the state. As discussed in the previous chapter, one of the central components of Labor's ideology was the concept of mamlachtiut (the centrality of the state) as well as the capability of the Sabra, which formed the backbone of

\footnotetext{
${ }^{277}$ Israel suffered 2,838 casualties, 8,800 wounded and lost 103 aircrafts and 840 tanks. See Shlaim, The Iron Wall: Israel and the Arab World, 321.
} 
the IDF, to protect the Jewish nation. Thus when the war challenged the efficacy of state and the IDF, it was indirectly challenging the ideology and identity established by the Labor movement. Only two months after the war, in the December 1973 Knesset elections, the Labor Alignment's Knesset seats fell to 51, from the previous 56. The newly formed Likud party won the lost votes, winning 39 seats (after gaining $30 \%$ of the votes, compared to Labor's $39 \%$ ). In comparison all the parties that had joined to form Likud had a total of 32 seats in the previous Knesset. ${ }^{278}$

Also in the aftermath of the war, Israel saw the rise of mass protests as a result of growing discontent with the Israeli government. The protests eventually led to the resignation of Golda Meir from the premiership. The mass protests however had deeper impacts on Israeli society and politics. On the one hand after the war and the subsequent protests, the Gush Emunim movement was established in 1974, which sought to build Jewish settlements in the West Bank and Gaza Strip (referred to as "Judea and Samaria") and to reassert Israeli power and dominance. On the other end of the political spectrum the lesson taken from the war was that Israel should withdraw from the territories in exchange for peace. The creation of the "Peace Now" movement in 1978 should be seen in this light. These developments are examined in the next chapter.

It is also important to point out that the Labor movement had relinquished the most important sources of its ideological power to the state after

\footnotetext{
278 Ibid., 323.
} 
independence. After 1948, Mapai in accordance with the concept of mamlachtiut gave up control of some of its most important institutions to the state. These included Labor schools as well as the Haganah and the Palmach. Even some of the functions and organizations of the Histadrut, such as the Labor exchanges, were nationalized even though the Histadrut's social services were allowed to continue independent of the state. In the short term the nationalization of the movement's power bases did not affect the movement since it was firmly in control of the state. It even provided an avenue for the dominant current in the movement led by Ben-Gurion to takeover control of institutions that had become a power base for the left opposition. In theory however, the take over of Labor's two most prized ideology building institutions, the military and the education system, by the government meant the loss of exclusive control of these institutions and the possibility of these institutions falling into rival hands in the future. The decline in Labor's hegemony culminating in the period after the 1973 war turned this possibility into reality. Instead of right wing educational and military institutions competing for power with their left wing rivals, as was the case during the Yishuv period, now the revisionists only needed to defeat the left in national elections.

\section{From Fringe to Center: The Transformation of Revisionist}

\section{Ideology}

The rise of the revisionists was partly as a result of a gradual but significant evolution in the movement's ideology, which empowered the group to 
move from the fringes of Israeli politics to its center. This transformation forever changed the movement from an underground militant organization to a legitimate political actor. This shift allowed the revisionists to be in a better position to accumulate power in the wake of Labor's decline and the 1967 and 1973 wars.

In June 1948 Begin established the Herut ('Freedom') party, setting in motion a gradual shift in the movement's ideology, perhaps unknowingly. With the creation of the state of Israel in 1948, the revisionist movement had no choice but to disband its military organizations. The Altalena Affair which took place only several weeks after Israel's independence was a stark reminder to the revisionists that military activity was now under the sole authority of the state, which was dominated by Labor. This development meant a significant change to the realities revisionists faced, since militarism had been the primary avenue of activity for the movement.

Furthermore the movement had lost almost its entire support base among European Jews, particularly in Poland, due to the Holocaust. Moreover radical right movements in Europe had been defeated as a result of the war and therefore right-wing nationalist ideologies were increasingly seen in a negative light. Most important of all the movement was at an ideological impasse since the founding of the Jewish state had robbed the revisionists of their sole ideological goal. All of this meant that the situation of revisionists looked very bleak in 1948. In the first Knesset elections of 1949 , Herut only won $11.5 \%$ of the vote, coming in fourth after Mapai, Mapam and the United Religious Front. In the second 
Knesset elections of 1951 Herut performed even worse, gaining only $6.6 \%$ of the vote and reducing its seats from 14 to $8 .{ }^{279}$

After 1948 , the only way to power for the revisionists was to attain control of government. This became even more important when it was understood that the IDF was to be the sole military force of the nation, and when other services and institutions such as the educational system came under the control of government. In fact Ben-Gurion's mamlakhtiut policy turned the state into an all powerful and unrivaled force within Israeli politics and society. As a result the revisionists had no choice but to turn from a loose and largely military movement to a centralized political party whose only aim now was to gain power through elections. On the other hand, Herut's humiliating election performance demonstrated to Begin and other revisionist leaders that they were working under a new political situation widely different from pre-independence years and that they needed to adjust their tactics and become more practical and more attuned to public opinion. Nevertheless such an understanding came slowly and subsequent change in party policy and ultimately ideology took place gradually.

The first sign of such change appeared in Herut's initial party platform, which was adopted shortly after the party was formed, stating: "the Herut movement declares itself to be an anti-Fascist movement because Fascism is

\footnotetext{
${ }^{279}$ For official results of all Knesset elections since 1949 see the official Knesset Website at: https://www.knesset.gov.il/description/eng/eng_mimshal_res.htm
} 
based on the principle of force." ${ }^{280}$ Herut was also "non-Communist." Rather it was a democratic party, "and the principle of democracy is liberty." This signified an important change from the movement's initial Fascist leanings, which legitimized and even glorified the use of force. Of course such change did not happen overnight. For several years there was widespread disagreement within the party about whether the party should avoid the use of violence and limit itself to democratic means. The issue however was put to rest in 1954 when at the party's third convention it was decided that power would only be achieved through elections. Begin also tried to present the party as a defender of liberal rights. In his speeches he outlined the party's three liberal principles: freedom of the individual, the improvement of society and the supremacy of the law. Moreover the party's Knesset faction sought to preserve civil rights by opposing the extension of the Emergency Regulations of the mandate period. ${ }^{281}$

While the changes in the movement's operation and approach in the first years after Israel's independence outlined above are significant, nevertheless they should not be seen as a complete ideological transformation. In fact the revisionist were steadfast in their most important ideological principle: the territorial integrity of Eretz Israel. Begin strongly criticized Mapai's "deliberate" failure in "liberating" the entire land of Eretz Israel during the 1948 War. The Herut opposed armistice agreements with Jordan and called for a renewed war

\footnotetext{
${ }^{280}$ Shapiro, The Road to Power: Herut Party in Israel, 68.

${ }^{281}$ See Ibid., 68-79.
} 
to conquer the remainder of the homeland. Prior to the 1951 Knesset elections, Begin even called for the "evacuation of women and children" from Israel in preparation for the war. Such rhetoric was assessed to be as one of the main reasons behind Herut's failure in the elections. The image of Herut as the "war party" was strongly criticized within the revisionist movement, ultimately resulting in the resignation of Begin as party chairman, even though he came back less than two years later to lead the party against the Israeli government's reparations agreement with Germany.

During the 1960s, Herut's pragmatism further developed when the party agreed to a joint bloc with the General Zionists, forming the 1965 Gahal party. On the eve of the 1967 war Gahal joined a national unity government. This was the first time that the revisionist movement had officially become part of government. Begin became minister without portfolio. Becoming part of the coalition governing the country significantly increased the prestige and legitimacy of the revisionist movement. In two decades the movement had turned itself from a small underground militant organization that used terrorist tactics into a legitimate political party that was considered the main political contender to Labor's hegemony.

The increased pragmatism of the movement affected many of its policies and behaviors. For example Herut, like other radical right political parties, had avoided seeking the support of different sectors and classes of Israeli society since it saw itself as a "national party." As mentioned earlier one of the movement's primary criticisms of the Labor movement was its catering to 
sectorial and class interests, which according to revisionist ideology harmed the national interest. Moreover revisionist ideology had deep orientalist roots that had a very negative view of the East. ${ }^{282}$ Yet starting in the mid 1960s Herut started to seek the support of the oriental communities who until then had consistently voted for Mapai even though they had been marginalized and disenfranchised since their arrival in Israel. ${ }^{283}$ Even more surprising was the party's decision to join the Histadrut in 1963. Joining the Labor union went completely against the movement's anti-socialist ideology and almost split the party in two. The idea of joining the Histadrut was rejected in the 1961 convention and was only narrowly approved two years later.

The shedding of the movement's anti-socialist ethos as well as the irrelevance of the "principle of monism" (since the Zionist goal of establishing a nation-state had already been achieved) meant that the core of the movement's ideology was now the fulfillment of the territorial integrity of Eretz Israel. Arguably the movement's move to pragmatism was a bid to attain control of government, which was now only possible through elections, in order to fulfill the greater Israel promise. Yet it is important to point out that even this part of the movement's ideology did not go untouched during this period.

\footnotetext{
282 Jabotinsky for example declared, "everything that is oriental, is doomed," and claimed that the East was completely alien to the Jewish people, stating: "The East, and everything associated with this concept, is alien to me.... Even among the Eskimos in the Far North I would feel more at home." Quoted in Shavit, Jabotinsky and the Revisionist Movement 1925-1948, 245.

${ }^{283}$ See Seliktar, New Zionism and the Foreign Policy System of Israel, 129-141.
} 
Efforts at alliance between Herut and the General Zionists had started from 1955, yet they had failed due to the latter's opposition to the principle of Greater Israel. In the ten years it took to eventually form the Gahal bloc, Herut gradually changed its position from promoting a war to "liberate" the land to affirming only "in principle" the inalienable "right of the Jewish people to EretzIsrael in its historical wholeness." ${ }^{284}$ Even the definition of the boundaries of "historic Eretz-Israel" started to shift. While revisionism as a movement had started in opposition to Labor's rejection of the idea of a Jewish state on both sides of the River Jordan, the revisionists themselves slowly started to abandon their claim to Transjordan. Until 1959 Herut had campaigned for the "liberation" of Eretz Israel in every election, which included the lands of Transjordan and southern Lebanon. Starting from the late 50s the "Both Banks of the Jordan" slogan slowly started to change to the new slogan of the "Whole Land of Israel," which included the West Bank and the Gaza Strip as part of the homeland, but not Transjordan, in the party's propaganda material. ${ }^{285}$

One important question that might arise out of the arguments presented in this chapter is why Herut's abysmal election performance continued even after adopting pragmatism and becoming more attuned to public demands. The reason for Herut's failure in winning public support can be ascribed to the failure

\footnotetext{
${ }^{284}$ See Shapiro, The Road to Power: Herut Party in Israel, 126-129.

${ }^{285}$ See Shelef, Evolving Nationalism: Homeland, Identity, and Religion in Israel, 1925-2005, Chapter 3.
} 
of its ideology to present an alternative to Labor's rule. In the first decade after independence, the movement's call for war in order to accomplish Greater Israel was seen as impractical and dangerous adventurism. In the second decade when the movement gradually shed such calls in line with the public mood, there was essentially no difference between the existing foreign policy of Israel led by Labor and that of the revisionists. As a result the movement became much more pragmatic but lacked a new ideological message.

This dilemma is captured well by a 1959 Haartez article, which explained that Herut had "to move from being a raucous opposition to a substantive opposition," but if it were to do this then it wouldn't be any different than the General Zionists. ${ }^{286}$ The fundamental challenge of the movement was that the founding of the state and the realities of Israel's borders had effectively robbed the movement of its main ideological rallying cry, which meant that the movement could offer very little that was strikingly different than the status quo. This was all changed with the Six Day War of 1967, which effectively changed not only Israeli borders but also the political and cultural landscape of the country.

\section{The 1967 War and the Rise of Israel's Right}

In the 1967 War, in only six days Israel was able to capture the West Bank including East Jerusalem from Jordan, the Gaza Strip and the Sinai from Egypt and the Golan Heights from Syria, effectively tripling the size of the territory

\footnotetext{
${ }^{286}$ Quoted in Shapiro, The Road to Power: Herut Party in Israel, 123.
} 
under its control. Yet the war did not only result in territorial expansion, rather the capture of the biblical territories of "Judea and Samaria" (the West Bank) particularly East Jerusalem, deeply affected many Israelis. Dov Waxman explains this well: "When Israeli paratroopers triumphantly entered the gates of the Old City of Jerusalem and arrived at the Western Wall (Judaism's holiest site), few, if any, Israeli Jews were not filled with a sense of the miraculous, of a feeling that divine providence had returned 'the children of Israel' to their holy city and the lands of their biblical ancestors. The spectacle of battle-weary, hardened Israeli soldiers reverently bowing their heads before the hallowed stones of the Western Wall, eyes filled with tears and wonder, is perhaps the most resonant symbol of the rapprochement that took place between the 'new Jew' created by secular Zionism and the Jewish tradition: the new in awe of the old and reconnecting with their once-buried Jewishness." 287

For the ailing revisionist movement the 1967 war was like a gift from heaven. Not only did it revitalize and strengthen the movement internally, but it also changed the public's view of the group almost overnight. After decades of being seen as irresponsible radical militants, the general public now saw the movement's platform as legitimate and even favorable. With the capture of the above mentioned territories the movement was no longer advocating a war to "liberate" them, which could be dangerous and risky, rather it was only advocating keeping the status quo, a much more acceptable and even attractive

\footnotetext{
${ }^{287}$ Waxman, The Pursuit of Peace and the Crisis of Israeli Identity, 39.
} 
proposal. Not only was the idea of Greater Israel seen as within arms reach but the whole idea started to become more appealing to the Israeli public as a result of the cultural-religious affects of the war.

For example right after the war in September 1967 a movement called the Greater Land of Israel (Hatnuah Lemaan Eretz Israel Hashlemah) was established, which declared in its manifesto that "the whole of Eretz Israel is now in the hands of the Jewish people, and just as we are not allowed to give up the State of Israel, so we are ordered to keep what we received there from its hands: the Land of Israel." What is interesting from the signatories of the movement's manifesto is its widespread reach from intellectuals, such as Nobel Laureate S.Y. Yagon, to poets and writers, such as Moshe Shamir and Natan Alterman, to military generals, such as former air force commander Dan Tolkovsky and veteran commanders such as Abraham yaffe and Eliezer Livneh. Even among politicians the movement received widespread support, including from prominent Labor leaders such as Yosef and Moshe Tabenkin and Rachel Ben-Zvi, widow of former Israeli president and Labor leader Yitzhak Ben-Zvi. ${ }^{288}$

Moreover such a shift in opinion was not only restricted to the elite. According to the polls of the Israel Institute of Applied Social Research, which conducted the most comprehensive public opinion survey after the war, in 1968 only $6 \%$ of the Israeli public supported the return of the entire West Bank in

\footnotetext{
${ }^{288}$ See Sprinzak, The Ascendance of Israel's Radical Right, 38-43.; Seliktar, New Zionism and the Foreign Policy System of Israel, 92-93.
} 
return for peace. $21 \%$ of respondents supported a partial return, while $72 \%$ did not want any part of it returned. The poll numbers were similar for the Gaza Strip and the Golan Heights with only a minority of Israelis supporting the exchange of the territories for peace. Only regarding the Sinai desert was the public split, with $28 \%$ supporting a full withdrawal, $30 \%$ supporting a partial withdrawal and $42 \%$ being against any withdrawal whatsoever. ${ }^{289}$

The shift in Israeli public opinion cannot be solely attributed to a renewed emotional attachment to the biblical territories as a result of their capture, even though this was a contributing factor. Rather deeper shifts in Israeli perceptions should also be examined. Studies of Israeli public opinion at the time showed that the lead up to the Six Day War as well as the war itself led to an increasingly pessimistic outlook to international affairs. This was partly due to the intense period of uncertainty in the weeks before the war that led to a high perception of threat in the Israeli public. During those uncertain and fateful weeks, Israelis felt that there was a chance that their entire existence might be jeopardized. This feeling was compounded as a result of the renewed relationship with the Holocaust prevalent in the Israeli public after the Eichmann trials.

On the eve of the Six Day War, the Israeli public as well as leading politicians believed that Israel's very existence was under threat and that a victory by Egypt would lead to the complete extinction of Jewish society in the

\footnotetext{
${ }^{289}$ See Russell A Stone, Louis Guttman, and Levy Shlomit, Social Change in Israel: Attitudes and Events, 1967-1979 (New York: Praeger, 1982).
} 
Holy Land and that the international community, including Western allies, would not prevent it, just as they had decided not to prevent the Holocaust. On the eve of the Six Day War, Israel's liberal Foreign Minister Abba Eban noted that "there would be a ghastly sequel [to the Holocaust], leaving nothing to be discussed...ending with no renewal and no consolation." ${ }^{290}$ Prime Minister Levi Eshkol, another Labor leader, explained after the war that "if the Arabs had won, Hitler's million victims of World War 2 would have been joined by another two and a half million victims of the Arab lust for destruction." ${ }^{291}$ Michael Brecher, a veteran professor of Israeli foreign policy, argues that this Holocaust psychology was the "universal" Israeli view during the 1967 war. $^{292}$

Interestingly, after the war and Israel's decisive victory, not only did the threat perception of Israelis not decrease, but in fact it gradually rose. Studies of Israeli public opinion have argued that the main reason behind this was the rise in guerilla warfare tactics of the PLO after the war. For example studies by Peled and Levy and Guttman found that the Israeli's "worry score" increased after 1967 due to "terrorism against Israel." This trend continued well into the 70s. For example a 1979 poll found that 93 percent of Israelis were worried about

\footnotetext{
${ }^{290}$ Quoted in Brecher, The Foreign Policy System of Israel: Setting, Images, Process, 93.

${ }^{291}$ Quoted in Terence Prittie, Eshkol; the Man and the Nation (New York: Putman, 1969), 263.

292 See Michael Brecher, Decisions in Israel's Foreign Policy (London: Oxford University Press, 1974), Chapter 7.
} 
terrorism and 73 percent indicated that they were worried that they or their families might be hurt as a result of terrorism. ${ }^{293}$

The rise in the threat perception of the Israeli public coupled with the fear of terrorism resulted in an increasingly negative view of "the Arabs." A 1965-1968 study by Benjamini found that the Six Day War created twelve negative and only one positive change in the image of the Arabs. ${ }^{294}$ Numerous studies have shown how the Six Day War led to the radicalization of the image of the "enemy" among the Israeli public. For example while 45 percent of the Israeli public believed that Arabs were interested in peace before the war, the number went down to only 10 percent following the war, and remaining well below 30 percent until 1977. Another study found that in the 1973-1979 period an average of only 18.5 percent of Israelis believed that territorial concessions would result in peace. ${ }^{295}$ Also a poll in 1974 found that 95 percent of the Israeli public believed that the Palestinians should not be granted a state due to the "terrorist activity" of the PLO. ${ }^{296}$

The Israeli public's increasingly pessimistic view of the international system, particular in regards to Arab intentions, and the adoption of more

\footnotetext{
${ }^{293}$ See Seliktar, New Zionism and the Foreign Policy System of Israel, 165-166.

${ }^{294}$ Ibid.

${ }^{295}$ Stone, Guttman, and Shlomit, Social Change in Israel: Attitudes and Events, 1967-1979, 21 \& 35.

${ }^{296}$ Seliktar, New Zionism and the Foreign Policy System of Israel, 167.
} 
"hawkish" foreign policy approaches including the annexation of the captured territories in response to the renewed sense of threat, created a dissonance between public attitudes and Labor's foreign policy behavior. While some Labor leaders openly voiced support of the Greater Israel idea, the movement as a whole looked at the captured territories largely instrumentally, specifically as a powerful bargaining chip in dealing with its Arab neighbors. Nevertheless there was disagreement within the movement about the territories and as a result the movement's behavior in the years after the war was marked with confusion and reluctance. Officially the Labor government adopted the American Rogers Plan that proposed Israeli withdrawal from the captured territories in return for peace. This decision led to the collapse of the National Unity Government after Begin decided to leave the government. ${ }^{297}$ In practice Labor saw at least some parts of the territories as strategic military and economic assets and seemed ready to partially withdraw from other parts of the captured territories. The most significant Labor plan that never materialized was the Allon plan that would entail Israeli withdrawal from $70 \%$ of the West Bank and the annexation of the remainder. ${ }^{298}$

The capture of the biblical territories in effect reopened the territorial debates of the Yishuv period between the two competing Zionist movements. Even though in the decade preceding the war, a tacit consensus regarding Israeli borders had emerged where even Begin no longer advocated any meaningful

\footnotetext{
${ }^{297}$ See Brecher, Decisions in Israel's Foreign Policy, Chapter 8.

${ }^{298}$ See Shlaim, The Iron Wall: Israel and the Arab World, 250-264.
} 
plan to capture territories outside the state's internationally recognized borders, the Six Day War brought the ideological differences of the two movements into sharp perspective again. While Labor's view of the territories was largely an instrumental one, seeing the land as a source of power, a military asset, a source of economic vitality and finally as a bargaining chip in negotiation with its neighbors and great powers, the view of the revisionist movement led by Begin was a normative one which emphasized the eternal bond of the Jewish people to the "Holy Land." Immediately after the war in a meeting of the central committees of Herut, Begin declared: "Neither in our hearts nor on our lips can we imagine the possibility that a single inch of our land will be restored to alien rule." ${ }^{299}$ In fact the party adopted a resolution containing this exact wording. Various studies on the view of the Israeli elite regarding the territories found that members of Likud and the National Religious Party were the main supporter of the annexation of the West Bank regardless of considerations for peace or security. ${ }^{300}$

The ideological differences of the two movements regarding the proper territorial boundaries of Eretz Israel had existed from pre-independence years as discussed in this chapter. What had changed however were the perceptions of the public regarding the issue. Labor's "pragmatic" foreign policy approach was no longer seen as such by the public, instead the revisionists who had

${ }^{299}$ Quoted in Shapiro, The Road to Power: Herut Party in Israel, 158.

${ }^{300}$ See for example Noel Kalpowitz, "Psycho Political Dimensions of the Middle East Conflict," Journal of Conflict Resolution 20 (1976). 
ideologically remained largely consistent regarding the territorial integrity of Eretz Israel became much more popular. The revisionist approach was also seen as more appropriate in dealing with the increasingly negative image of the enemy. For example Asher Arian's 1969 study of voting behavior found that 72 percent of Israelis wanted an aggressive stance towards the Arabs. ${ }^{301}$ Moreover the study showed that foreign policy had become the single most important factor in shaping rightist and leftist political orientation among the Israeli public. Another study by Eva Etzioni-Halevy found that from 1969 to the mid 1970s a significant gap had risen between the new rightist orientation of the public and Socialist Zionist ideology. ${ }^{302}$

As a result of this dissonance between public opinion and Labor's foreign policy ideology, the movement faced yet another challenge in addition to the factors cited earlier that led to its decline. Moreover because Labor was reluctant to build settlements in the occupied West Bank, it lost its original image of "pioneering" and "settlement" building which formed the core of the Sabra identity. While Labor's instrumentalist view of the territories was partly due to the pragmatic foundations of its ideology, such an approach contradicted other tenets of its ideology, namely Zionist pioneering. This development hurt the movement's image as the revolutionary founders of the Zionist cause. A 1974

\footnotetext{
${ }^{301}$ See Asher Arian, The Elections in Israel -- 1969 (Jerusalem: Jerusalem Academic Press, 1972).

${ }^{302}$ See Eva Etzioni-Halevy and Rina Shapira, Political Culture in Israel: Cleavage and Integration among Israeli Jews (London and New York: Praeger, 1977).
} 
poll of Israeli youth for example found that 54 percent of participants saw Likud as the "most Zionist party" compared to 36 percent that saw Labor as such. More interesting, only 31 percent of participants identified their parents as Likud supporters compared to 56 percent who identified their parents as voting for Labor. ${ }^{303}$ The results of the poll made bare the declining status of Labor. Even though the movement had played a central role in the foundation of the Jewish state, and even though revisionist Zionism had been a weak and unpopular opposition, the Six Day War completely changed this dynamic. It was now the revisionists who were seen as Zionist pioneers settling and defending the biblical land. The revisionist movement used these developments to portray itself as the only group capable of protecting the Jewish state against its enemies, particularly in the wake of the 1973 War.

The Six Day War would also highly impact the religious Zionist movement, transforming it from a movement largely concerned with domestic religious issues and allied with Labor Zionists to a messianic movement which became increasingly involved and influential in the country's foreign policy making, a development that would have far reaching consequences for Israel. This ideological transformation also meant the convergence of the policy orientation of religious Zionists with that of secular revisionists in the post-1967 period.

\footnotetext{
${ }^{303}$ Seliktar, New Zionism and the Foreign Policy System of Israel, 181.; Also see Ofira Seliktar, "Socialization of National Ideology: The Case of Zionist Attitudes among Young Israelis," Political Psychology 2, no. 3-4 (1980): 66-94.
} 


\section{The Ascendance of Messianic Religious Zionism}

The founding of Zionism at the end of the nineteenth century was met with fierce opposition from the grand majority of rabbis and orthodox communities. For centuries prominent Jewish rabbis had forbade Jews from returning to the Holy Land, since according to the orthodox tradition, exile would only end with the coming of the Messiah and the salvation of the Jewish people. As a result any attempts to bring salvation through human means rather than waiting patiently for God to initiate the redemption would be "forcing God's hand," and would only result in disaster. Vital explains this succinctly:

Orthodoxy's fundamental objection to Zionism was theological. It followed from the Zionists' intention to reverse the course of Jewish history and remake the Jewish people-in effect, to redeem them-through mere human agency. It was the settled Orthodox view that the condition of the Jews in their Exile, with its attendant miseries, had been divinely ordained and that to seek to alter it without divine sanction was blasphemous and, of course, futile. The Jews were, on the contrary, under a primary religious obligation to await redemption at the hands of the Messiah, in God's good time, with patience and submission. ${ }^{304}$

Moreover according to the "Three Vows" of the Talmud, God made an oath with the people of Israel so that they would not leave exile and immigrate en masse to the Land of Israel as well as not to rebel against the nations of the world. ${ }^{305}$ The combination of the Talmudic oaths plus the orthodoxy's

${ }^{304}$ David Vital, Zionism: The Formative Years (Oxford, England: Clarendon Press, 1982) p.209

${ }^{305}$ For a discussion of the 'Three Vows' see Reuven Firestone, "Holy War in Modern Judaism? 'Mitzvah War' and the Problem of the 'Three Vows,'” Journal of the American Academy of Religion 74, no. 4 (December 2006): 954-82. 
understanding of the Messianic Age and the process of its achievement provided a strong basis for the denunciation of the Zionist movement and its leaders. To make matters worse the Zionist movement was led by "unbelievers" who had abandoned the Halacha, or at best by secularist who saw religious traditionalism as one of the reasons for the regression and decay of Jews in the diaspora. As a result, their conception of the future Jewish state was a secular and modern one. In fact on this issue there wasn't much difference between the views of the founders of political Zionism particularly Herzl, and later on the leaders of the Labor and Revisionist movements, namely Ben-Gurion and Jabotinsky.

As a result of the above reasons, many orthodox circles in Europe saw the Zionist movement as a rebellion against the Jewish religion and came out strongly against it. For example Rabbi Haim Soloveichik, the most prominent Talmudic scholar of the late nineteenth century, wrote in 1899 regarding Zionists: "each and everyone [sic] of them is of an evil reputation in his own locality...And their purpose, as they have already announced and published it, is the uprooting of the foundations of the religion." ${ }^{306}$

Religious support for the Zionist cause dwindled even further, when the majority of a small number of orthodox rabbis, who had initially supported the movement, left the Zionist Organization when secular educational and cultural programs where added to the agenda of the organization, since these were seen as areas which should be under the sole jurisdiction of religious leaders.

\footnotetext{
${ }^{306}$ Quoted in Lustick, For the Land and the Lord: Jewish Fundamentalism in Israel, 26.
} 
Nevertheless religious Jews were not completely absent in the Zionist movement. The earliest and most significant support of Zionism from a group of orthodox rabbis came in an open letter published in 1900 under the leadership of Rabbi Yitzhak Ya'akov Reines. Two years later Reines would form the religious HaMizrachi $^{307}$ faction within the WZO.

While the religious Zionist faction within the WZO was a strong supporter of Herzl's movement, it is important to carefully examine their ideology in order to expose their sharply different understanding of Zionism from the messianic Zionism espoused by most religious Zionists today. Rabbi Reines completely differentiated between the Zionist movement and Jewish messianism. In fact according to HaMizrachi movement Zionism in no way replaced or fulfilled the messianic expectations of the Jewish people. Rather Zionism was a mundane, rather than divine, approach that sought to relieve Jewish suffering in the diaspora using practical and pragmatic means. Reines claimed that there was nothing holy or miraculous about Zionism, rather it was an earthly effort to prevent Jewish persecution in the diaspora. ${ }^{308}$ Such a position is even clearly articulated in the aforementioned 1900 letter of support for the Zionist movement:

Anyone who thinks the Zionist idea is somehow associated with future redemption and the coming of the Messiah and who therefore regards it as undermining our holy faith is clearly in error. [Zionism] has nothing whatsoever to do with the question of redemption. The entire point of this

\footnotetext{
${ }^{307}$ An acronym for Merkaz Ruhani (Religious center in Hebrew).

${ }^{308}$ See Dov Schwartz, Religious Zionism: History and Ideology (Boston: Academic Studies Press, 2009), Chapter 2.
} 
idea is merely the improvement of the condition of our wretched brethren. In recent years our situation deteriorated disastrously, and many of our brethren are scattered in every direction, to the seven seas, in places where the fear of assimilation is hardly remote. ${ }^{309}$

As a result of the above view, it can be argued that in its early days HaMizrachi movement lacked a distinct political ideology that differentiated it from Labor Zionists and the Revisionists, particularly when it came to issues of foreign policy. This is because Reines and other Mizrachi members did not use religion to form a normative view of political issues that would lead to specific courses of action, which forms the foundation of religious ideologies. The HaMizrachi movement in its early days is thus better characterized as Zionists who happened to be religious rather than the commonly used term of Religious Zionism which would require a clear political program in contrast to other branches of Zionism. This fact had far reaching consequences in the positions HaMizrachi took within the Zionist movement. Their approach can be categorized best as a moderate and pragmatic approach that largely followed the lead of the Zionist executive. Examples of such moderations are too numerous to name, suffice to say that HaMizrachi was the major faction in the WZO that supported and voted in favor of the "Uganda option"310 in the Sixth Zionist Congress, a move that would be unthinkable in the post-1967 religious Zionist movement.

${ }^{309}$ Quoted in Ravitzky, Messianism, Zionism, and Jewish Religious Radicalism, 34.

${ }^{310}$ At the Sixth Zionist Congress in 1903, Herzl proposed the 'British Uganda Program' which would allow Russian Jews to settle in the East African land as a refuge against anti-Semitic pogroms. The opposition however favored Palestine for Jewish settlement. See Schwartz, Religious Zionism: History and Ideology, 15-17. 
Interestingly enough it was the largely secular Russian delegations of the Congress, many of whom would later become affiliated with the Labor movement, who opposed the proposal and eventually voted it down. ${ }^{311}$

This pragmatism allowed the religious Zionists, which formed the National Religious Party in 1956, as a result of a merger between HaMizrachi and HaPoel- HaMizrachi, ${ }^{312}$ to take part in almost all the governing coalitions in Israel from 1949 to $1977 . .^{313}$ In fact the "historic alliance" with Labor had started from the mid 1930s. With the establishment of the state, HaMizrachi's main concern and demand became the institutionalization of the Halacha in society. This was mainly achieved by closing the gap between state laws and the Halacha. Although the new Jewish state was far from the "Torah State" religious Zionist sought however they were able to win some major concessions from the ruling Labor governments. These included the suspension of public transportation and services during Sabbath, the state definition of "who is a Jew" according to the Halacha, military service exemption for Yeshiva students, as well as rabbinical control of marriage and divorce..$^{314}$

311 See "Sixth Zionist Congress: Basel 23 - 28 August 1903," Herzl Museum, n.d., http://www.herzl.org/english/Article.aspx?ltem=543.

${ }^{312}$ Hapoel HaMizrachi was formed in 1922 by religious Zionists who also supported socialist goals with the Torah va'Avodah (Torah and Labor) slogan.

${ }^{313}$ Except for short periods in $1958-1959$ and in 1974.

${ }^{314}$ For a detailed discussion on these concessions see Menachem Friedman, "The Structural Foundation for Religio-Political Accommodation in Israel: Fallacy and Reality," in Israel: The First Decade of Independence, by Ilan Troen and Noah Lucas (Albany: State University of New York Press, 1995), 51-82.; Also see Schwartz, Religious Zionism: History and Ideology, Chapter 10. 
In return HaMizrachi largely followed the lead of Labor, particularly in the realm of foreign policy. The alliance was also highly convenient and even beneficial for the Labor movement since HaMizrachi did not pose an ideological threat to Labor's hegemony. In fact through the partnership, Labor was in effect successful in luring them away from joining or allying with the revisionists. Thus the alliance was also a useful tool in isolating the revisionists who were considered the main opposition to the Labor movement at the time.

HaMizrachi's conception of the territorial borders of the Land of Israel was varied since the biblical borders of the land is also not clear-cut within the Bible and Jewish history. In the early years of the HaMizrachi movement many religious Zionists adopted a maximalist stance on this issue which demanded that "From the River of Egypt to.... the great river, the River Euphrates," as promised by God to Abraham, belonged to the People of Israel. As time went on however the majority of the group adopted a more practical definition of the homeland that excluded Transjordan. Nevertheless in the years both before and after the founding of the state many members within the movement continually criticized partitioning the land based on religious grounds. In practice however, the religious Zionists continued with their alliance with Labor and tacitly approved partitioning the Holy Land especially after the Holocaust and the destruction of European Jewry. ${ }^{315}$

\footnotetext{
${ }^{315}$ For a discussion on the evolution of the concept of the 'Homeland' in the Religious Zionist movement see Shelef, Evolving Nationalism: Homeland, Identity, and Religion in Israel, 19252005, Chapter 2.
} 
Moreover HaMizrachi never joined the revisionists who were adamant in their opposition to partition during those years. The primary reason for the grudging acceptance of partition was that prior to the Six Day War, territorial integrity of the homeland was not the main concern of the movement, rather the movement primarily sought to shape the religious character of the public realm and the new state, as well as cater to the needs of religious groups within Israel such as securing funds for religious education. The religious Zionists could only secure such concessions by having a seat at the decision making table which was dominated by Labor. As a result, prior to 1967 the movement played little role in Israeli foreign policy. The main dissenters to HaMizrachi's approach were a small messianic movement led by a little known Rabbi.

\section{Messianic Zionism and Rabbi Kook}

While the majority of religious Zionists followed the "pragmatic" approach of HaMizrachi that saw Zionism devoid from any form of religious meaning, there were dissenters, the most important of whom was Rabbi Abraham Yitzhak Hacohen Kook and his disciples. Kook was an obscure rabbi from Lithuania who immigrated to Palestine in 1904 to take the position of Rabbi of Jaffa. In the years following his appointment he started to become a powerful figure in the Yishuv, becoming Ashkenazi chief Rabbi of Palestine in 1921, a title he held until his death in 1935. The significance of Kook's ideas was that he unapologetically defined Zionism as a divine movement towards redemption. In response to Orthodox critiques of such a position, Kook claimed: "No, it is not we who are 
forcing the End, but the End that is forcing us." ${ }^{316}$ Rabbi Kook saw Jewish nationalism not as a mundane, earthly and secular enterprise, but a movement ordained by Heaven and led by God. He famously proclaimed that the only nationalism is that of the Torah ${ }^{317}$ and that "Zionism is a heavenly matter." Such a worldview would eventually find its way in the political ideology of the religious Zionist movement and would transform it in the process.

While Kook's ideas were wide-ranging and diverse, several of his viewpoints were to form the pillars of religious Zionist ideology later on. ${ }^{319}$ The first of these ideas was that the secular activists of the Zionist movement were in fact carrying out God's plans, even if this was done unknowingly. Kook asserted that the secular pioneers "do not realize what they want. The divine spirit informs their strivings in spite of them." This is because the Zionist movement had been established through a holy source and its activists were walking in the "footsteps of the Messiah." The significance of such a view was that it was in complete contradiction to the views of the ultra-Orthodox community who saw Zionists as secular unbelievers. In fact Kook drew links between Theodore Herzl and the Messiah ben Joseph, a legendary figure that according to religious tradition

\footnotetext{
${ }^{316}$ Quoted in Zertal and Eldar, Lords of the Land: The War Over Israel's Settlements in the Occupied Territories, 1967-2007, 202.

317 See Schwartz, Religious Zionism: History and Ideology, Chapter 4.

${ }^{318}$ Quoted in Ravitzky, Messianism, Zionism, and Jewish Religious Radicalism, 82.

${ }^{319}$ For a discussion of Kook's philosophy see Ezra Gellman, Essays on the Thought and Philosophy of Rabbi Kook (London: Cornwall Book, 1991).
} 
would pave the way for the main Messiah, also known as Messiah ben David. ${ }^{320}$ Thus according to Kook, secular Jews and the believers were both working toward the same end, even if this was done unconsciously. This viewpoint would later on pave the way for religious Zionists to become more involved in politics and work side by side with secular politicians. In contrast for example, the ultraOrthodox Agudat Yisrael community limited its interaction with Zionists who had "abandoned the Halacha."321

Another important facet of Kook's ideas was his deterministic and utopian view of the world. According to the Rabbi, with the onset of Zionism world history was moving in a one-way direction in accordance with the divine will of the Lord whose objective were the redemption of Israel and subsequently the perfection of the world. ${ }^{322}$ In fact no force could stop such a development. Moreover while the process might be fraught with difficulties and challenges, the inevitable end result would be the establishment of the Messianic age in which world peace and harmony would endure. Thus while mortals could hasten or delay this process,

${ }^{320}$ Ravitzky, Messianism, Zionism, and Jewish Religious Radicalism, 98-99.

${ }^{321}$ For a discussion on the beliefs of Agudat Israel see Sofer, Zionism and the Foundation of Israeli Diplomacy, Chapter 16.

322 In fact Kook believed that the return of the Jewish people to the Land of Israel was already ushering in the utopian age. In 1907 he wrote about the Yishuv: "Let us examine their moral level in relation to that of the multitude of other people that well on their own land....The serious crimes so common among the multitude-robbery, theft, murder, and the like-are unknown, the integrity of the family is respected, doors can be left open at night without fears. Is this not an oasis of peace? Is it not the tent of the upright?" Quoted in Ravitzky, Messianism, Zionism, and Jewish Religious Radicalism, 121. According to the Rabbi even secularism would come to pass and the Land of Israel would be ruled according to the Torah. 
support or oppose it, the ultimate result would still be the same. Also as a result of such a view all the events that the Jewish people faced were explained as part of the "redemptive process." For example when the news of the Holocaust reached the Yishuv, Kook's son, Rabbi Zvi Yehuda Kook who became the champion of his father's ideas after his death, declared that the Shoah had been a "heavenly surgery," a "deep hidden, divine therapy aimed at purging [us] of the impurity of exile." According to the Rabbi, God had lost hope in the Jewish people returning to the Land of Israel out of their own free will, therefore the Holocaust was his way of forcing them to make Aliyah. The Holocaust with all its cruelty was explained as "the angry blow of the Lord's hand [aimed at] removing us from the nations and their worthless culture!"323

Also Kook believed, in line with his deterministic view of history, that secular Zionism was only a "transient stage" toward the restoration of Judaism in the Holy Land according to the laws of the Torah. As a result not only should religious people not "stay away" from politics, as ultra-Orthodox communities in the Yishuv argued, but should lead the way in order to fulfill God's plans. This viewpoint forms one of the bases of religious Zionist activism in the aftermath of the Six Day War. Moreover when in the 80s and 90s Labor Zionists, who had once been the Zionist "pioneers," began to contemplate a withdrawal from the occupied territories, religious Zionists saw this as a natural development in the

${ }^{323}$ Quoted in Schwartz, Religious Zionism: History and Ideology, 78; Also see Ravitzky, Messianism, Zionism, and Jewish Religious Radicalism, 109 and 127-128. 
redemptive process in which the secular activists had only been responsible for the "transient" stage and the final steps of the process could only be completed by religious Jews. ${ }^{324}$

The above ideas would form the core of the activist religious Zionist identity that formed in post-1967 Israel. Yet it is important to note that Abraham Kook's ideas had little following during his lifetime, even among the religious Zionist camp. Also although Kook was an influential rabbi within the Yishuv and even though he was considered close to HaMizrachi movement, his ideology had little influence on the religious Zionist movement. In line with the political ideology Kook developed he asserted that HaMizrachi's moderate and reluctant approach to be entirely wrong. This is why he kept himself apart from officially becoming affiliated with HaMizrachi movement and instead established Degel Yerushalayim ('Flag of Jerusalem' in Hebrew), a federation of observant Jews who he hoped would aggressively settle the land and impose religion on the Jewish national movement. Yet due to lack of following this movement quickly declined and eventually faded. ${ }^{325}$ Had it not been for Israel's "miraculous" victory in the Six Day War the late Rabbi's ideas would have been just the worldviews of a religious scholar among a multitude of Zionist intelligentsia whose ideas never impacted the Zionist movement in any significant way. Perhaps the Rabbi's

\footnotetext{
${ }^{324}$ See Richard L. Hoch, "Sovereignty, Sanctity, and Salvation: The Theology of Rabbi Zvi Yehudah Ha-Kohen Kook and the Actions of Gush Emunim," Shofar: An Interdisciplinary Journal of Jewish Studies 13, no. 1 (Fall 1994): 90-118.

${ }^{325}$ Schwartz, Religious Zionism: History and Ideology, 31-32.
} 
greatest achievement during his lifetime was the established of the Merkaz $\mathrm{Ha}$ Rav religious seminary (Yeshiva) in Jerusalem in 1923. After the Rabbi's death, and particularly after 1967, the institution would become the primary center for the propagation of his ideas under the leadership of his son and would later on serve as the foundation of the Gush Emunim settler movement.

\section{Messianic Zionism and the Six-Day War}

Many religious Zionists saw Israel's lightning victory in 1967 as "proof" of the correctness of the late Rabbi Abraham Kook's messianic characterization of the Zionist movement. His son, who was now the spiritual leader of his father's disciples, explained that Israel's victory was the work of God and that the redemption was near. Moreover Rabbi Zvi Yehuda Kook gained prophetic status after the war when many religious Zionists found out that three weeks before the war he had "predicted" the capture of the territories when he had told his students: "Of course, know that this is the army of Israel that will liberate the Land of Israel." ${ }^{326}$

Israel's victory in 1967 was not only "evidence" that God was bringing about the redemption of the Jewish people, but also the war had brought a "reunion" with many biblically significant monuments and lands such as the Western Wall in the Old city of Jerusalem, as well as the cities of Hebron, Beit-El and others. The fact that after nearly two millennia the people of Israel were now in control of the most holy places of the Jewish faith had a profound effect on

\footnotetext{
${ }^{326}$ Quoted in Lustick, For the Land and the Lord: Jewish Fundamentalism in Israel, 36.
} 
religious Zionists and even secular Israelis.

While before 1967, religious Zionists, aside from Kook and his followers, rarely suggested that Zionism was a divine plan that would bring about the coming of the Messiah, after the war many prominent religious figures gave such interpretations. Rabbi Sholomo Aviner, the chief rabbi of Beit-El and the dean of the Ateret Kohanim religious school (Yeshiva) for example stated: "We declare the absolute certainty of our imminent redemption...All the troubles, delays, and complications we have endured are merely momentary and cannot obscure this mighty overall trend, this Messiah, whose power has been concealed since ancient times in the treasure house of history and who is now being revealed in actuality." ${ }^{327}$ While Rabbi Shelomo Zalman Shragai a leading HaMizrachi leader and the first elected mayor of Jerusalem declared that the 1967 War "shows that the Three Vows no longer exist.... We were witnesses in the Six Days War that God heard our prayers on Hoshana Rabba: 'Hoshana of Three Hours,' for in the first three hours of the war we merited to get the better of our enemies, who said (Ps. 83:5) Come let us wipe them out as a nation, but after the war the people were awakened and said (Ps. 118:23) This was from God." ${ }^{328}$ As Rabbi Reuven Firestone explains: "Immediately after the victory, it seemed as if a dam had burst and everyone in the Religious Zionist camp was writing about the beginning

\footnotetext{
${ }^{327}$ Quoted in Ravitzky, Messianism, Zionism, and Jewish Religious Radicalism, 81.

${ }^{328}$ Quoted in Firestone, "Holy War in Modern Judaism? 'Mitzvah War' and the Problem of the 'Three Vows,'” 969.
} 
of messianic redemption." 329

The Six Day War effectively transformed the political ideology of the religious Zionist movement, which primarily focused on protecting the Halacha and religious values and combating secularism, into a messianic worldview that would highly affect the peace process in later decades. This ideological transformation also made Rabbi Zvi Yehuda Kook the most important figure of this new religious Zionist movement. The "prophetic" Rabbi even became highly influential in the revisionist movement so that when Menachim Begin, who had become Prime Minister as a result of the 1977 elections, went to see the Rabbi at Merkaz HaRav Yeshiva. One student of the Yeshiva described the moment:

He [Begin] came as if to Canossa, ${ }^{330}$ as if this man, Zvi Yehuda, was God's representative. Suddenly the Prime Minister kneels and bows before Zvi Yehuda. Imagine for yourself what all the students standing there and watching this surrealistic scene were thinking. I'll never forget it. I felt that my heart was bursting within me. What greater empirical proof could there be that his fantasies and imaginings were indeed reality? You could see for yourself that instead of treating him as if he were crazy, people looked upon him as upon something holy. And everything he said or did became something holy as well. ${ }^{331}$

Rabbi Zvi Yehuda used his newfound status to aggressively propagate the messianic Zionism advocated by his father. However whereas the late Rabbi

\footnotetext{
329 Ibid., 965.
}

330 The term refers to Henry IV 'Walk to Canossa' in which the king went to Canossa in order to beg the revocation of the excommunication imposed on him by the Pope Gregory VII, however he was humiliated when the pope made him wait on his knees for three days and three nights before opening the gates of the castle.

${ }^{331}$ Quoted in Lustick, For the Land and the Lord: Jewish Fundamentalism in Israel, 37. 
Kook was mostly a man of grand ideas and visions, his son sought to translate these ideas into political action. As Rabbi Ya'akov Ariel one of the rabbi's leading students described later, "the late Rabbi Zvi Yehudah's greatness lay in his translation of the broad, deep teachings of his father into the language of action." ${ }^{332}$ Zvi Yehuda's first prescription immediately after the war was to settle on every inch of the newly occupied territories. Moreover he declared that returning the new territory was a "sin," and that the idea was "a stupidly illicit thought harbored by haters of the people of Israel." ${ }^{333}$

Settling the occupied territories particularly the West Bank soon became the primary focus of the religious Zionist movement. This marked a sharp turn from the pre-war ideology of the movement. As noted earlier, while HaMizrachi movement did declare the Jewish right over the entire land of Israel according to scripture, it compromised on this issue with the Labor movement in order to achieve its more primary aims of shaping the religious character of state and society. As a result territorial expansion was never a priority of the movement after the establishment of the state, and the movement came to accept the post1948 territorial status quo. For example the movement's Bnei Akiva youth faction,

${ }^{332}$ Ravitzky, Messianism, Zionism, and Jewish Religious Radicalism, 123.

${ }^{333}$ Quoted in Chaim Levinson and Yair Ettinger, "Rabbi Kook's Followers Are Still Debating His Legacy," Haaretz, March 11, 2012, http://www.haaretz.com/print-edition/features/rabbi-kook-sfollowers-are-still-debating-his-legacy-1.417753. 
which would later become a hub of the settler movement, not once used the border issues for mobilization in the 1961-1967 period. ${ }^{334}$

After the war, this lack of ideological discourse regarding the border of the homeland took the movement completely by surprise. Yitzhak Meltzer stated that before the war "the only movement that spoke of the wholeness of the land was Herut. In Bnei Akiva they only spoke of the Nahal and the Kibbutz. The Six-Day war changed the reality. All of Eretz Israel was before us.... We were not ready for this question in Bnei Akiva and in the [religious] schools." ${ }^{335}$ Rabbi Kook and his followers, who using their messianic conceptions of Zionism provided a new goal for religious Zionists, quickly filled this void within the movement.

The Rabbi quickly understood that the Israeli state would come under international pressure in order to return the captured territories. Because of this he unequivocally argued that the people of Israel should follow the orders of God who was in the process of redeeming the Jewish people by returning them the holy lands that was rightfully theirs, rather than "deferring to the gentiles." When U.S. Secretary of State Henry Kissinger began his shuttle diplomacy in efforts to persuade Israel to accept territorial compromise, Kook rejected his efforts by calling him "the Goy woman's husband," and when foreign diplomats withdrew from attending 'Independence Day' festivities due to Israel's decision to stage a military parade in Jerusalem, he declared:

\footnotetext{
${ }^{334}$ See Shelef, Evolving Nationalism: Homeland, Identity, and Religion in Israel, 1925-2005, 71.

${ }^{335}$ Quoted in Ibid., 72.
} 
How happy are we! Now we have this sacred day without the "in-laws," the goyim. Thank God! These "in-laws" are not appearing at our wedding, at our celebration. All these years we have requested [God] to break the yoke of the goyim that is around our necks and He will lead us with proud bearing into our land. ${ }^{336}$

While Kook unequivocally called for settling the occupied territories particularly in "Judea and Samaria" (the West Bank) right after the Six Day War, however it wasn't until after the 1973 Yom Kippur war, in which Israel paid dearly and nearly lost, that the Rabbi and his followers started to turn their words into action. The war, which caught Israel by surprise, resulted in nearly three thousand casualties, the resignation of Golda Meir as Prime Minister, as well as a reevaluation of the costs of holding on to the territories. As a result the idea of returning the territories captured six years earlier in exchange for peace became much more serious among the Labor movement as well as a segment of the Israeli population.

Polls after the war showed that 20 percent of Israelis supported a full withdrawal from the West Bank and 35 percent supported a partial withdrawal, compared to 8 and 18 percent support respectively for full and partial withdrawal right before the war. ${ }^{337}$ Also several years after the war a group of left wing activists established the Peace Now movement that sought to realize a withdrawal from the occupied territories. The war also brought renewed

\footnotetext{
${ }^{336}$ Quoted in Hoch, "Sovereignty, Sanctity, and Salvation: The Theology of Rabbi Zvi Yehudah Ha-Kohen Kook and the Actions of Gush Emunim," 18.

${ }^{337}$ Stone, Guttman, and Shlomit, Social Change in Israel: Attitudes and Events, 1967-1979.
} 
international pressure for a territorial compromise after an Arab oil embargo quadrupled the price of oil resulting in a global economic crisis. In response to this rising possibility of Israeli territorial withdrawal, the Rabbi and his followers, which formed the Young Guard within the NRP, established the Gush Emunim ("Bloc of Faithful" in Hebrew) movement that began establishing numerous settlements in the West Bank. The rise of this militant settler identity in the 70s and 80 s in contrast and in opposition to the emerging "liberal" identity among Labor Zionists is the topic of the next chapter.

\section{Conclusion}

The revisionists formally took over the Israeli government in the 1977 elections, yet their ascendance and the decline of Labor had started much earlier. The Labor movement, which had been the dominant force within the Yishuv and post-independence Israel, lost its status as a result of the decline of its ideology. As indicated in the previous chapter, the core aspects of the Sabra identity that the movement created were negating the presumed characteristics of the "exile Jew." However as a result of the Holocaust, a majority of diaspora Jews in Europe perished resulting in the elimination of the ideological "other" of the Sabra. While the results of this development did not immediately become clear, Israeli public opinion's views on the "exile" Jew started to shift in the fifties, culminating in the Eichmann trials of 1961 which fundamentally challenged the Sabra's narrative of the diaspora Jew. Moreover the widespread immigration of Mizrahi Jews from the Middle East resulted in a major shift in the demographics of the Jewish state, yet the Labor movement was unwilling to change the Sabra 
ideal in order to accommodate these communities who had completely different backgrounds and cultures than eastern European Jews which formed the elite cadres of the movement.

In addition to these two developments, an important segment of Israeli society began to adopt Western individualism and multiculturalism. This meant that the hegemony of any one ideology became increasingly difficult to accomplish in Israeli society, let alone the Labor movement whose ideology had become increasingly out of touch with the new demographic realities of society. While the above developments seriously challenged Labor's hegemony, in the end the movement's decline was a result of its ideological stagnation. The elites of the Labor movement were unable or unwilling to face the discrepancy between its ideology and the new realities of society and adjust the movement's worldview accordingly.

Unlike Labor, the revisionists successfully changed their ideology according to the new realities of society. The revisionists led by Begin quickly understood that the founding of the state had completely changed the political game from the Yishuv years. This is why the movement transformed itself from a fringe underground militant movement to a legitimate political party that sought to attain power only through elections, although this transformation did not happen overnight, nor did all the factions within the movement accept such change easily. Nevertheless during the fifties and sixties revisionist ideology experienced steady yet important changes which included increasing pragmatism, the shedding of the movement's anti-socialist philosophy, the exclusion of 
Transjordan from the "Land of Israel," and the acceptance of political alliances and compromises.

It can be argued that some of these changes in the revisionist movement's behavior were a result of tactical maneuvering in order to gain votes and assume power. Nevertheless what is important is that even if such changes were a result of short-term tactics, they still resulted in fundamental changes in the ideology of the movement. The shedding of the movement's anti-socialist ethos, the partnership with Mizrahi communities, and most important of all the redefinition of the boundaries of Eretz Israel have all persisted well beyond the short-term political environment they were intended for. Mizrahi Jews continue to form the backbone of the revisionist movement within Israeli politics and the claim to Transjordan never returned to the party's ideology. Moreover by understanding the movement's history, one realizes that these changes represented fundamental alterations to the movement's beliefs. Jabotinsky established the revisionist movement primarily in opposition to the exclusion of Transjordan from the Jewish homeland. Moreover in its pre-independence years the leaders of the movement were very orientalist in their worldview. Yet during the seventies the movement was able to integrate and accommodate the increasing population of Mizrahi Jews, unlike the Labor movement, which refused to alter its ideology.

Interestingly enough such dramatic changes in the ideology of the revisionists only resulted in minor increases in the movement's share of the electorate. The main reason behind this lackluster success was that the founding of the state and the realities of Israel's borders had effectively robbed the 
movement of its main ideological rallying cry, which was the Greater Israel concept. This meant that the movement could offer very little that was strikingly different than the status quo offered by the Labor movement. Thus while the movement had made important changes that had allowed it to become the legitimate political opposition in Israel, it lacked a potent ideological message that would differentiate it from the Labor movement. This was all changed with the Six Day War of 1967, which effectively reshaped not only Israeli borders but also the political and cultural landscape of the country.

The Six Day War did not alter the ideology of the revisionist movement in any significant way, rather it dramatically changed the views of the Israeli public regarding the Greater Israel concept. This empowered and revitalized the revisionist movement and added a new challenge facing the Labor movement. Most importantly, it fundamentally transformed the religious Zionist movement, which up until then was not an important ideological contestant in Israeli politics. As future chapters will demonstrate the rise of messianic religious Zionism would have far reaching consequences for Israel.

On a theoretical level, the examination of Labor's decline and the rise of revisionism reveal that domestic political ideologies do not operate in a vacuum, rather they are strongly influenced by external developments. In contrast to postmodern frameworks that reduce the study of ideas to only discourse, arguing that there is "nothing outside of text," this study suggests that discourse cannot be isolated from external developments. External events such as the founding of a state, mass immigration, and most important of all external wars, can significantly 
challenge a political discourse. These events have the power to both reassert and confirm certain beliefs and values within an ideology as well as to challenge and refute other claims. In the Six Day War for example, the war confirmed and strengthened messianic and religious interpretations of Zionism, while on the other hand the Eichmann trials helped disaffirm negative stereotypes of diaspora Jews and the negative portrayal of their actions during the Holocaust.

When external events confirm ideological beliefs they seem to strengthen and revitalize the corresponding political movement. On the other hand when external events contradict the belief structure of a movement, a significant challenge arises in which if the movement is unable or unwilling to change its ideology in order to eliminate or at least reduce the gap between its belief structure and the new emerging realities, then its power and influence diminishes. Indeed the case under study in the present chapter proves that an important element in the rise and continued success of political ideologies is their sensitivity and flexibility to changing realities. Also external events can also affect the beliefs and values of the general public, as a result of which certain political ideologies might become more popular, while their rivals might suffer. The case of the Six Day War and the growing popularity of the revisionist movement is a prime example of this argument.

Another important lesson that can be drawn from studying the evolution of the revisionist movement is that tactical changes can lead to ideological change in the long run. Thus in many instances party leaders might not be aware that their rhetoric and actions will result in fundamental changes in their movement's 
beliefs and values. Rather they will be focused on short-term benefits and electoral success. The case of the revisionist movement shows however, that if practical political considerations significantly diverge from the party's ideology, then an ideological crisis will emerge within the party. In the case of the revisionists, such crisis persisted and eventually a majority of the movement adopted and incorporated the changes to their belief system, eventually resulting in an ideological transformation.

Finally the 1973 Yom Kippur War is a prime example of how political ideologies and identities are shaped in opposition to the domestic "other" in contrast to the majority of Constructivist literature which assumes that the "other" used in identity formation are solely other states. Although it is important to point out that Constructivist theory does not necessarily entail a sole focus on the third image or the assumption that there exists a single, homogeneous national identity, rather this is how the theory has been mostly used. In contrast this dissertation attempts to shift constructivism's focus on the third image to the second image by studying the role of domestic ideologies in shaping the state's foreign policy.

In the Israeli case, even though messianic religious Zionism had been revitalized as a result of the Six Day War, the "religious settler" identity only started to emerge after the 1973 War and the formation of a liberal identity in the Labor movement that sought to withdraw from the occupied territories. This is why religious Zionists turned their words into action, through the establishment of the Gush Emunim settler movement and the takeover of the National Religious 
Party, only after the 1973 War when the Labor movement began to seriously consider "land for peace" proposals. After the war a religious Zionist identity emerged which sought to implement the Lord's "divine plan" by settling the territories and fighting against the "Godless" secular Jews. The Yom Kippur war thus brought the struggle over the very meaning of Zionism into the forefront of Israeli politics. The next chapter examines how these two ideological camps diverged even further in the lead up to the Oslo peace process. 


\section{Chapter 5: The Road to Oslo}

The Six Day War immensely impacted Israel, even if some of these influences became apparent gradually. The rise of messianic religious Zionism as set forth by Rabbi Kook following the war revitalized the religious Zionist movement that up until then had largely followed Labor's lead in foreign affairs in exchange for domestic concessions on religious matters. While it took the messianic Zionist movement nearly a decade after the war to establish itself within Israel's domestic political scene, once there, it rose to become the main ideological contender to the Labor movement and a political force to be reckoned with. Even though Rabbi Kook's ideas gained widespread acceptance within the religious Zionist community after the 1967 war, as indicated in the previous chapter, it wasn't until after the Yom Kippur war that his ideas where translated into the Gush Emunim ideological movement that in turn led to the creation of a religious militant settler identity that identified Jewish settlement in the captured territories as the most vital step in the process of "divine redemption."

This chapter does not provide a historical account of the settlement of the occupied territories, an issue that has been well documented by other researchers. ${ }^{338}$ Instead the chapter attempts to contribute to existing knowledge

\footnotetext{
${ }^{338}$ See Robert I. Friedman, Zealots for Zion: Inside Israel's West Bank Settlement Movement (New Brunswick: Rutgers University Press, 1994); Zertal and Eldar, Lords of the Land: The War Over Israel's Settlements in the Occupied Territories, 1967-2007; Yigal Kipnis, The Golan Heights: Political History, Settlement and Geography since 1949 (New York: Routledge, 2013);
} 
of the settler movement by arguing that in the wake of the Yom Kippur war a religious settler identity emerged primarily in opposition to a perceived "liberal leftist" identity which was seen as threatening the core essence of the entire Zionist enterprise. On the other hand the rise of this increasingly militant and religious messianic movement led to a slow but firm ideological change within the Labor movement in favor of Western liberal values such as democracy, freedom of expression and political pluralism. The ideological confrontation that ensued between the two camps, leading up to Oslo, was much more than a difference of opinion over what to do with the newly occupied territories, rather it was a fullscale struggle over the very meaning of Zionism and what it meant to be an "Israeli," a development whose full implications would only become apparent in the nineteen nineties.

\section{Gush Emunim: The 'New Zionists'}

Gush Emunim (which translates into Block of Faithful) was created in 1974 by a group of Merkaz HaRav graduates in order to coordinate settlement activities in the captured territories. The Gush was created in the wake of the Yom Kippur War that badly shook Israel. Not only did Israel suffer heavy casualties as a result of the surprise Arab attack, but also it nearly lost the war. Moreover the conflict demonstrated the inefficiency of Israel's intelligence agencies, the IDF and the Israeli government more generally. More importantly, 
the war ended the euphoria after the Six Day War and perceptions of the "invincibility" and "indestructability" of the IDF. The war had demonstrated the limits of Israel's military power and the need for political settlements with its neighbors. In the wake of the war, the Peace Movement, which had been established right after 1967 but which had failed to win any significant gathering, started to reassert itself. The peace movement now argued that had a settlement with the Arabs been reached after 1967, the Yom Kippur War never would have happened. ${ }^{339}$ Moreover it appeared that the Labor government of Yitzhak Rabin, which took over in June 1974, was increasingly inching towards a significant territorial concession in exchange for peace, as advocated by Henry Kissinger's "shuttle diplomacy." Rabin famously stated shortly after becoming Prime Minister: "a piece of territory for a piece of peace."340

All these events deeply disturbed the messianic religious movement, which came to believe that unless it acted quickly the biblical lands of "Judea and Samaria" would be given back to the gentiles and the redemptive process would be hampered. The Yom Kippur War also presented an ideological challenge to the religious Zionist movement. In the wake of the Six Day War, Rabbi Kook had repeatedly claimed that the redemptive process was in quick progress and the coming of the Messiah was very near. In contrast, in reality not only had the

\footnotetext{
${ }^{339}$ Quoted in Rael Jean Isaac, Israel Divided: Ideological Politics in the Jewish State (Baltimore: Johns Hopkins University Press, 1976), 2-6.

${ }^{340}$ Steven L. Spiegel, The Other Arab-Israeli Conflict: Making America's Middle East Policy, from Truman to Reagan (Chicago: University Of Chicago Press, 1986), 289.
} 
Messiah not come but also Israel had just faced a war it had nearly lost. If anything it seemed that "God's divine plan" had been interrupted or even halted. Interestingly enough not only did the movement not experience a crisis from this ideological anomaly but also the war actually revitalized the movement.

To understand how religious Zionists were not challenged by the 1973 War it is necessary to study Rabbi Abraham Kook's deterministic ideas. The late rabbi, whose work was now being followed by his son, not only tied Zionism with the divine redemption of Jews but also firmly asserted that the process of redemption was irreversible. The rabbi claimed that since Israel's redemption was a divine process ordained in heaven, therefore human attempts to prevent it were futile. As a result of such a view, the messianic Zionist movement since its inception has seen all challenges as "temporary setbacks" that ultimately would have no effect on the divine outcome. In fact many of these challenges were not really hampering the redemptive process at all but were in fact part of the "Lord's plan." It was noted earlier for example that the rabbi even described the Holocaust as God's way of teaching the Jews the necessity of fighting back and ultimately to force them to migrate to the Holy Land. In essence, Kook's ideology sees all external events as part of the redemptive process and any setbacks as unimportant and temporary. The rabbi would state:

The divine historical imperative, clearly revealed to us, to put an end to the Exile, cannot be changed or distorted, either by the wickedness and stubborn resistance of the nations or by our own mistakes and un-Jewish deviations. The brief delays all these can occasion do not have the power 
to reverse the movement, which proceeds onward and upward with utmost certainty. ${ }^{341}$

In line with such a narrative, a leading rabbi of Gush Emunim described the Yom Kippur war as the final attempts of the gentiles to prevent the preordained redemption of Israel. Moreover the war, which was almost lost by the "weak leftists," demonstrated the need for religious Jews to take over the Zionist enterprise. Rabbi Kook had expressed long ago that Zionism would be handed down from secular Jews to religious Jews who were its "true" heirs. As such, the 1973 War and the crisis that befell on the Labor movement were to be "expected" according to Kook's students. In fact signs of Labor's ideological decline were usually explained within the emerging messianic Zionist movement as, "of course secular Zionism cannot in and by itself endure." ${ }^{132}$ Thus, not only was the 73 War not a setback to the movement, rather it energized and vitalized the movement, in contrast to Labor.

After the war when the possibility of a political settlement with Israel's Arab neighbors became a real possibility, the movement quickly organized to settle the territories and block any peace agreement. As one Gush leader would later comment, "At that time we came to the realization that the games were over. No more political negotiations and no more love affair [sic] with Israel Galili - we're

\footnotetext{
${ }^{341}$ Quoted in Zertal and Eldar, Lords of the Land: The War Over Israel's Settlements in the Occupied Territories, 1967-2007, 201.

${ }^{342}$ See Sofer, Zionism and the Foundation of Israeli Diplomacy, Chapter 15.
} 
heading for the territories!" ${ }^{343}$ It was at this stage that Kook's messianic ideas were translated into a fully-fledged ideological movement with a concrete political action program. As noted in the theory chapter ideologies are not just coherent systems of values and ideas that are used to make sense of the external world, but rather they also provide a normative program that dictates specific political goals and actions. Thus the creation of the Gush heralded the manifestation of Kook's ideas into an ideological movement.

The central component of the religious Zionist movement's ideology was to transform the "decayed" state of the Zionist movement and Israeli society into its "true" and "rightful" place. This was clearly articulated in Gush Emunim's 1974 manifesto:

The purpose is to bring about a grand movement of reawakening within the people of Israel in order to fulfill the Zionist vision in its entirety, with the recognition that the origins of the visions are rooted in Israel's tradition and in the foundation of Judaism and its goal - the full redemption of the people of Israel and the rest of the world. ${ }^{344}$

The key words of the above paragraph being "reawakening," hinting that the Israeli people had fallen asleep and had deviated from the Zionist path, as well as defining Zionism as rooted in "tradition" and "Judaism," in contrast to the secular and modern Zionism established by Labor, and finally tying the Zionist movement to the redemption of the Jewish people and the human race in

\footnotetext{
${ }^{343}$ Quoted in Zertal and Eldar, Lords of the Land: The War Over Israel's Settlements in the Occupied Territories, 1967-2007, 31.

${ }^{344}$ Quoted in Sprinzak, The Ascendance of Israel's Radical Right, 66.
} 
general. According to the Gush, the Labor movement had become degenerate and corrupt and had abandoned Zionist objectives. The religious Zionists sought to rectify the state of Zionism and Israeli society by "reviving" the "original" pioneering Jewish identity, albeit with a religious and messianic twist. By analyzing the narrative of the movement, one can discern several important principles on which the collective settler religious identity was created. Once created this identity far outlasted the Gush as an organized political group, which began to decline in the late 1980s.

\section{Pioneering and Collectivity}

From the beginning of its inception, the Gush tried to capitalize on the cherished status of settlement and pioneering among Israelis. The movement's narrative criticized Israeli society for becoming engulfed in materialism, individualism, political and economic greed, as well as softness and hesitancy in dealing with the Arabs. These "social ills" had eroded the best qualities of Zionism. Moreover the decline of Israel and the negative developments cited above were all seen as embodied by the Labor movement, a group of "rich," "selfish," "elites" who had forgotten their Zionist roots and had traded the welfare and security of Jews for the approval of the gentiles and the welfare of Israel's Arab enemies. In opposition to the above dissolute image of the "diseased" Israeli, the Gush presented themselves as the only "true" Israelis who were reviving Zionism back to its glorious days of pioneering, self-sacrifice, communal work, "self-defense" as well as a spiritual and religious rebirth. 
This is why Gush members saw themselves as following in the footsteps of the pioneers who had played a crucial role in the progress of Zionism during the Yishuv years. In fact Hanan Porat, one of the primary founders of the Gush, would often use Yosef Trumpeldor's definition of a "pioneer" to characterize the new identity the movement sought to create: "A pioneer is an individual who is prepared for everything. If he is told to carry bricks, he carries bricks, if he is told to plow, he plows; if he is told to teach, he teaches. In short, he is like a piece of iron, which is wrought as needed."345 Gush leaders even started to wear faded blue shirts, shabby trousers, sandals and khaki carryalls, all of which were the clothing style of original Labor Zionist pioneers. ${ }^{346}$

By connecting current settlement activity to the Jewish pioneers of Israel's "glorious" days, the Gush was able to instill a sense of rootedness in its members. Rather than depicting this identity as new, the movement portrayed it as a continuation of the past, with deep roots in Zionism. Gush literature indicated how the new settlers were "ascending in the rich-in-deed road of the fathers and the realizers of the Zionist movement, whose devotion, determination, and persistence had ignited the torch of settlement in the Land of Israel. ${ }^{347}$ As a result many of the values the Gush promoted were, at least on the

\footnotetext{
${ }^{345}$ Quoted in Zertal and Eldar, Lords of the Land: The War Over Israel's Settlements in the Occupied Territories, 1967-2007, 8.

${ }^{346}$ Ibid., 9.

${ }^{347}$ Ibid., 185.
} 
surface, the same values of the Sabra identity created by the Labor movement in the 30 s and 40 s. According to the Gush, the ideal Israeli was a settler who put the national mission above his or her welfare. To achieve this the settlers needed to make great self-sacrifices. This was in contrast to the increasing individualism and materialism of Israeli society of the 50 s and 60 s. One Gush leader explained that, "when pleasure seeking and personal gratification become the focus of one's life, egotism and avarice dominate both the individual and society." ${ }^{348}$

According to the Gush the Westernization of Israeli society had been the main culprit behind such corruption and the fading of pioneering ethos. The movement's manifesto declared "contemporary Western culture with all its attitudes, its materialism, its violence and decadence," coupled with a desire of an "easy and confortable life" had ruined Israeli society. ${ }^{349}$ Moreover the Labor movement was seen as the primary perpetrator of such decay.

The fear of Westernization and secularization has been a continuous concern of religious settlers to this day. Yisrael Harel, an important leader of the movement explained in a 1997 interview that Israel was turning into a replica of the "decadent West" by becoming "materialistic, hedonistic, and spineless," showing two palms moving in the opposite direction, with one representing Israel

${ }^{348}$ Quoted in Yael Yishai, Land or Peace: Whither Israel? (Stanford: Hoover Institution Press, 1987), 131.

${ }^{349}$ Gadi Taub, The Settlers and the Struggle over the Meaning of Zionism (New Haven: Yale University Press, 2011), 56. 
and the West, while the other was Judaism, Zionism and settlement. ${ }^{350}$ This is why, as the next section will explain, the Judaization of Israeli society has always been a primary goal of the settler movement.

The Gush movement also portrayed the Labor movement as old, conservative, degenerate and static, in contrast to the young, resourceful, energetic and dynamic image of the new religious pioneers. Such a narrative further justified the passing of Zionist pioneering responsibilities from its creators to the religious Zionists. Nekuda, the influential settler magazine, declared that "the pioneering of the 80 s does exactly what the Labor movement did in the days when it gained its enormous credit" in building the Jewish homeland. Moreover Labor's antagonism for the Gush was nothing more than "jealousy" of the old for the young who had taken over the leadership of Zionist pioneering: "Isn't this the hatred of the wrinkled old man for the reflection of his young countenance looking back at him in a magic mirror? Why should the mirror be shattered in a fit of rage?"351

Thus the rise of the Gush was not only a drive to settle the territories, but rather it was a direct ideological challenge to the hegemonic Labor ideology. Ironically the new religious settlers used many of the symbols and values used by Labor to create the Sabra identity. In fact Gush's drive to create a new pioneer settler identity can be characterized as the hijacking of Labor's early ideological

\footnotetext{
350 lbid., 1-2.

${ }^{351}$ Ibid., 63.
} 
narrative, which defined Zionism in terms of communal work, self-sacrifice, self defense, independence and resistance to international pressure. The Gush's only major change to this narrative was to infuse it with religious messianism.

\section{Religiosity}

Judaism forms the backbone of Gush ideology and the movement openly declares its desire to redefine Zionism in religious terms. While religious Zionists acknowledge the secular roots of Zionism, according to Kook secular Zionism was only a "temporary phase" in the process of divine redemption, and that Zionism would return to its true heirs: religious Jews. Thus the transfer of the leadership of the Zionist enterprise from secular Labor elites to religious Zionists was seen as a natural and foretold progression of Zionism, and the redemptive process more generally. The Gush's manifesto declared that "in the Jewish tradition lies the key to the understanding of the uniqueness and mission of the people and the Land of Israel...Forfeiting Jewish roots puts into question the very value of the Israelis' survival and their adherence to Eretz Israel." ${ }^{352}$

Even the pioneering identity whose many characteristics had been adopted by the Gush was now redefined in religious terms. Gush leader Hanan Porat would declare: "Here am I,' just as Abraham had replied to God, 'here am I - for priesthood, for kingship, to kill, to be killed. Lord of the Universe, here am I for all that is required...this, with thousands upon thousands of differences, is

\footnotetext{
${ }^{352}$ Yishai, Land or Peace: Whither Israel?, 131.
} 
how I understand the true meaning of the concept of pioneer" ${ }^{353}$ (emphasis added). Thus while Gush "pioneers" shared many characteristics with Labor "pioneers," their ultimate objective was different. Rather than solely being concerned about settling the land and establishing Jewish sovereignty, which were not seen as ultimate aims, settlement was a means towards the fulfillment of divine redemption. While Labor pioneers can be characterized as soldiers of Jewish nationalism, the new religious pioneers saw themselves as "soldiers of God."

Religious elements were even added to the pioneering clothing style that was adopted by the Gush. Specifically Gush members would have Tzitzit ritual fringes hanging from their shirts and knitted skullcaps on their heads. The skullcaps were especially a symbol of differentiation from secular Israelis who didn't wear a cap, as well as from ultra-Orthodox Jews who usually wore black caps. ${ }^{354}$ The Sabra pioneers were thus recreated in a new religious mold. Such an identity was particularly propagated using the Yeshivat Hesder system that combined Talmudic studies with military service in which young Israelis would spend five to six years alternating between yeshiva religious study and military service, rather than the normal three-year conscription program. The religious Zionist educational system thus became the focal point for the creation of the

${ }^{353}$ Zertal and Eldar, Lords of the Land: The War Over Israel's Settlements in the Occupied Territories, 1967-2007, 8-9.

${ }^{354}$ See David Newman, Impact of Gush Emunim: Politics and Settlement in the West Bank (London: Croom Helm, 1985), 17-19. 
"new Zionists" the settlers strived to create. Such efforts were to a large extent successful as well. In fact media pictures of soldiers praying next to their Merkava tanks became a symbol of the "new" IDF. ${ }^{355}$

The Gush's drive to create a new identity based on messianic religious Zionist ideology was again largely a reaction to the perceived "de-Judification" and "Hellenization" of state and society by the Labor movement. In the Gush's discourse "the left" were modern day Hellenized Jews who had abandoned Judaism in favor of Western liberal values. Moreover the Labor movement had formulated Jewish redemption in a secular framework in which diaspora Jews would be redeemed by migration to Palestine and the creation of a Jewish state. This was in contrary to the Gush, which saw redemption as essentially a divine and religious process. This fundamental difference on the essence of Zionism resulted in two very different understandings of the "land of Eretz Israel."

\section{Ties to the land}

Like the original Sabra the "new Sabra" had deep ties to the land, however this new identity based its relationship to the land on strongly ingrained religious beliefs, strengthening it even further. In the original Zionist discourse, as set by the Labor movement, toiling the land was an important part of the process of individual and national rebirth. In Gush discourse however the land of Israel was much more than an instrument in the process of a secular redemption, rather,

\footnotetext{
${ }^{355}$ For a comprehensive discussion of this phenomenon see: Elisheva Rosman-Stollman, For God and Country?: Religious Student-Soldiers in the Israel Defense Forces (Austin: University of Texas, 2014). Also see Schwartz, Religious Zionism: History and Ideology, 90-92.
} 
settling the land was the integral component of a heavenly redemption that would transform the entire world, in which according to Rabbi Kook the Kingdome of Israel would act as the "Kingdome of Heaven on earth." As a result, the settlement of Eretz Israel was exalted beyond secular understandings. Benny Katzover, a Gush leader, explains:

In every age and time, there is one point, a special point, through which all that is good sheds light...in the beginning of the messianic age, the critical point is Eretz Israel and everything else derives from it. Without its settlement no holiness operates in the world. ${ }^{356}$

Such sentiments were the prime reason why Gush members were willing to make great sacrifices in order to settle the territories. For example one settler explained, "My husband and I are convinced that we are living in a most fateful period. If we prove to be the exclusive proprietors of Eretz Israel, of the parts we have already managed to liberate, it will hasten redemption." ${ }^{\text {357 }}$ Moreover in the religious Zionist discourse the land of Israel was beyond political compromise since it was a divine entity. Thus the Israeli government had no legitimacy to negotiate Israel's borders since God had set these borders. This is why the Gush movement saw itself and its activities as above mundane politics and not subject to political pragmatism and expediency. Rabbi Kook stated: "The Master of the Universe has His own political agenda, according to which politics here below are

\footnotetext{
${ }^{356}$ Quoted in Sprinzak, The Ascendance of Israel's Radical Right, 18.

${ }^{357}$ Quoted in Lilly Weissbrod, "Gush Emunim Ideology: From Religious Doctrine to Political Action," Middle Eastern Studies 18, no. 3 (1982): 269.
} 
conducted. Part of this redemption is the conquest and settlement of the land. This is dictated by divine politics, and no earthly politics can supersede it." ${ }^{358}$

Thus the Gush movement, in contrast to the Greater Land of Israel lobby that opposed withdrawal from the captured territories based on strategic and political reasons, opposed withdrawal based on divine revelation. According to Rabbi Kook withdrawal would be equivalent to opposing God's intentions and forfeiting redemption. This very difference was why the Rabbi refused to sign the Greater Land of Israel's manifesto, even though he strongly supported the agenda of the group. Moreover the Rabbi played an instrumental role in issuing Halacha rulings regarding withdrawal from the territories. Kook argued that withdrawal from the territories fell under the Halacha rulings of Yehareg Uval Yaavor ("be killed rather than sin"), according to which a Jew must die rather than commit three great sins: idolatry, incestuous relations, and the shedding of blood. The Rabbi believed that withdrawal from the territories was equivalent to Avodah Zarah (worship of other Gods) and as such Jews had to resist withdrawal even if this endangered their lives. As Sprinzak points out, Kook's rulings was taken very seriously by the settler movement and led to a whole interpretive literature that explained and justified the Rabbi's ruling. ${ }^{359}$ The religious rulings also provided an avenue for further denunciation of the Labor movement. In fact

\footnotetext{
${ }^{358}$ Quoted in Ravitzky, Messianism, Zionism, and Jewish Religious Radicalism, 131.

${ }^{359}$ Sprinzak, The Ascendance of Israel's Radical Right, 43-51.
} 
the Nekuda article mentioned earlier which accused the "wrinkled old" Labor movement of jealousy had the incriminating title: Avodah Zarah. ${ }^{360}$

It is under such Halacha rulings that the settler movement came to believe that withdrawal was punishable by God. For example when Prime Minister Ariel Sharon fell into a coma only months after ordering the evacuation of Gaza in 2005, the settler movement and its leading rabbis explained it as a "punishment from God," even though the general turned politician had previously played such a leading role in the expansion of the settlements in the occupied territories that he had come to be known as "Gush Emunim's custodian." In fact several conservative rabbis led by Yossef Dayan, had held a Pulsa Dinura prayer ceremony asking God to kill the Prime Minister. Interestingly, the same rabbi had also led a Pulsa Dinura ceremony asking for the death of Yitzhak Rabin, just days before he was assassinated. ${ }^{361}$ Such events demonstrate the gravity of the "sin" of withdrawal in influential circles of the settler movement.

A final point worth mentioning is that according to the Gush every inch of Eretz Israel was holy. As such, while the movement placed the settling of "holy sites" such as Hebron in high regard, many of the settlements the movement built were deep inside Palestinian territory and not necessarily at religious sites. The Gush's settlement strategy was based on a careful plan, which would prevent the

\footnotetext{
${ }^{360}$ See Taub, The Settlers and the Struggle over the Meaning of Zionism, 194, Footnote number 37.

${ }^{361}$ See Zertal and Eldar, Lords of the Land: The War Over Israel's Settlements in the Occupied Territories, 1967-2007, XII and 228.
} 
establishment of a viable Palestinian state that would have territorial continuity. Moreover while the divine status of the captured territories was the central part of the settler movement's foreign policy ideology, two other ideas also played an important role in the group's international orientation: the belief that Israel was not "normal" and the subservience of morality to the larger cause of redemption.

\section{The People of Israel Are Not 'Normal'}

Originally Zionism as set forth by its founders such as Theodore Herzl and Leo Pinsker sought "Jewish normalization," in which the establishment of a Jewish state would allow Jews to become "normal" like other nations and would eradicate anti-Semitism that was the result of the "abnormality" of diaspora Jews. Thus Israel's declaration of independence states that it is "the natural right of the Jewish people to be masters of their own fate, like all other nations, in their own sovereign state." ${ }^{362}$ Therefore Jews deserved to establish a state in the Holy Land not because they were different or special but rather because they were "like all other nations." Also the Gush correctly believed that the Labor movement was slowly adopting a foreign policy agenda that sought to make Israel a normal member of the international community. More precisely Labor leaders such as Yitzhak Rabin sought to make Israel an accepted member of the Western world in order to rectify "a people that dwells alone" syndrome. This greatly alarmed the

\footnotetext{
${ }^{362}$ Declaration of Establishment of State of Israel (Israel Ministry of Foreign Affairs, May 14, 1948),

http://www.mfa.gov.il/mfa/foreignpolicy/peace/guide/pages/declaration\%20of\%20establishment\% 20of\%20state\%20of\%20israel.aspx.
} 
rising messianic religious movement that believed that there was nothing "ordinary" about Israel.

Therefore the new Religious Zionism advocated by the Gush fundamentally differed from the political Zionism of the early twentieth century which sought to make Jews a nation like all other nations. Rabbi Yehuda Amital, a Gush leader, wrote in an influential essay after the Yom Kippur war: "The dreams of normalization have been exposed as hollow. The state of Israel is the only state in the world that faces destruction...the vision of the prophet - 'a people that dwells alone and that shall not be reckoned among the nations' - is fulfilled in front of our eyes in the most physical sense." ${ }^{\text {363 }}$ Moreover according to the Gush's ideological narrative, the Zionist enterprise should not and cannot be aimed at the normalization of the Jewish people, quite the opposite Zionism was an important step in the redemptive process that differentiated and exalted the Jewish people above all others. This was clearly articulated by the Rabbi:

This Zionism [of redemption] has not come to solve the Jewish Problem by the establishment of a Jewish state but is used, instead, by the High Providence as a tool in order to move and to advance Israel towards its redemption. Its intrinsic direction is not the normalization of the people of Israel in order to become a nation like all the nations, but to become a holy people, a people of living God, whose basis is in Jerusalem and a king's temple is its center. ${ }^{364}$

\footnotetext{
${ }^{363}$ Quoted in Sprinzak, The Ascendance of Israel's Radical Right, 116.

${ }^{364}$ Ibid.
} 
This belief, which sees Israel as a "special" nation destined to lead the divine redemption, is the central component of the international orientation of the messianic Zionists. This is why the settler movement is rarely interested in realpolitik, great-power diplomacy and particularly international law. This is because they believe that Israel is essentially a different nation from all other nations of the world. It is an entity beyond time and place and as such should not be held to the same norms and laws of other nations. Moreover the settler movement is angered by the lack of recognition of the "uniqueness" of Israel by international organizations as well as other countries, including the United States. This is why the Gush's manifesto states:

Any framework or international organization whose resolutions imply the humiliation of the honor of Israel has no right to exist and we consequently do not belong there. We must leave that organization and wait for the day when the honor of Israel would rise again and the truth among the nations will be uncovered. ${ }^{365}$

The "day" mentioned in the above quote is referring to the day when the redemptive process will lead to the rise of the Third Temple and the "truth" that Israel is a special nation chosen by God will be revealed to the entire world. As a result of this ideology, not only is the settler movement not concerned with the possible isolation of Israel, but also it advocates withdrawal and separation from the international community. Also the opinion and concerns of the "gentiles" is

\footnotetext{
${ }^{365}$ Atran, "Stones against the Iron Fist, Terror within the Nation: Alternating Structures of Violence and Cultural Identity in the Israeli-Palestinian Conflict," 504; Sprinzak, The Ascendance of Israel's Radical Right, 115.
} 
irrelevant and their meddling in the affairs of Israel is illegitimate. This is why when Labor leaders such as Rabin maintained a close relationship with Western countries such as the United States and were influenced by their peace proposals, they were seen as "traitors" who were deferring to the gentiles instead of the "authentic" Jews of the Gush.

Moreover the settler movement saw efforts at normalization as inevitably leading to failure since they went against the will of the Lord, explaining: "It [Zionism] failed because it tried to make the Jewish people into what it is notthat is, a normal people, one people among the peoples of the world, and thereby make the land of Israel into what it is not-i.e. what every state constitutes for the people that live in it." ${ }^{\text {366 }}$

It is important to note however that feelings of inferiority from other nations is widespread among most of Israel's political spectrum, including the Labor movement which in Israel's early years sought to rectify such isolation by relying on internal military power rather than the international community to save Israel in its hour of need. For example as mentioned earlier on the eve of the 1967 war Abba Eban, Israel's foreign minister and a prominent member of the Labor movement, noted "when we looked out at the world we saw it divided between those who wanted to see us destroyed and those who would not raise a finger to

\footnotetext{
${ }^{366}$ Zertal and Eldar, Lords of the Land: The War Over Israel's Settlements in the Occupied Territories, 1967-2007, 217.
} 
prevent it from happening. ${ }^{367}$ Such attitudes have been labeled a "Holocaust psychology," which has been described as the "universal" Israeli view during the 1967 war. ${ }^{368}$ Indeed the "people apart syndrome" is widely mentioned as an intrinsic feature of Israeli politicians and society.

As a result, on the surface the "special" status that the settler movement talks about seems very similar to the assumed inferiority of the Israeli nation by other political movements including Labor. The study of the ideology of these movements however allows us to discern the subtle yet important differences in the values and beliefs of each group. While Labor leaders, including Ben-Gurion, saw Israel as isolated and alone, this was largely due to the external circumstances Israel was living in, including being surrounded by "enemy" states, the perception of being outnumbered and outgunned by the enemy, as well as not having any "reliable" allies. As a result, changes in external circumstances particularly the balance of power in the region, would also result in changes to the long-held Labor view that Israel was isolated and alone. Thus events such as Israel's surprise victory in the Six Day War, the strengthening of the "special relationship" with the US, the peace accords with Egypt, the fall of the Soviet Union, etc. all led to reassessment of the "Holocaust psychology" in the Labor movement so that by the late 80 s Israel was no longer seen as a small, fragile

\footnotetext{
${ }^{367}$ Quoted in Aviezer Ravitzky, Messianism, Zionism, and Jewish Religious Radicalism, trans. Michael Swirsky and Jonathan Chipman (Chicago: University Of Chicago Press, 1996), 131.

${ }^{368}$ See Michael Brecher, Decisions in Israel's Foreign Policy (London: Oxford University Press, 1974), Chapter 7.
} 
and isolated nation that was constantly under threat. It is also important to note, that Labor's move towards Western values such as liberalism, capitalism and individualism, also helped in this re-assessment and the move toward normalization. These developments are further discussed in future sections of this chapter.

In contrast, the messianic religious movement sees the exceptionalism of the Israelites as a result of divine intervention and not as a consequence of earthly events such as balances of power, diplomatic relations and wars. Therefore the isolation and distinction of the Israeli people is beyond time and space and thus immutable. Such a view is an integral part of the movement's ideology and there are many signs of this belief in the group's discourse. For example during the first Rabin government when the settler movement sought to prevent a withdrawal from Sinai, in contrast to international pressure and American diplomacy, a group of religious professors published a statement which argued:

When we ponder the root causes of Israel's difficulties, we find ourselves of necessity entertaining a sense of loneliness, in keeping with the biblical saying, "People that shall dwell alone and among the nations it shall not be reckoned," beginning with Abraham the Hebrew, "All the world on one side and Abraham on the other side" until our very days, this period of Holocaust and Revival. Our situation resembles that of the Children of Israel standing on the shore of the Red Sea, surrounded on all sides by enemies. ${ }^{369}$

\footnotetext{
${ }^{369}$ Quoted in Amnon Rubinstein, From Herzl to Rabin: The Changing Image of Zionism (New York: Holmes \& Meier Publishers, 2000), 126.
} 
What is significant in the above statement is not the "loneliness" of Israel, but rather the fact that such isolation is seen as continuing from the time of Abraham until today. As a result of this ideology, standing up to international and American pressure has become a hallmark of the settler movement's foreign policy orientation. Another point of differentiation between the religious Zionists and Labor was the place of morality in the two movements' ideologies and the issue of how to "deal with the Arabs."

\section{Morality Subservient to the Larger Cause}

Rather than relying on international institutions and foreign allies, the settler movement firmly believes on the necessity of inner strength and military power. As discussed in previous chapters however, this has been a hallmark of Labor's foreign policy ideology as well. Where the two ideologies differ however is the lack of any consideration for universal morality and ethics in the ideology of the settler movement. This is in complete contrast to the peace movement that emerged in Israeli society partly in order to defend "universal humanistic values" that they felt were coming under attack. Although Labor's foreign policy turn in the 1990s in favor of a political solution to the "Palestinian question" was not due primarily to humanistic considerations, a topic that is discussed in the next chapter, the construction of a liberal Zionist identity within Labor, which was partly built on humanistic values, facilitated the movement in interpreting global developments of the late eighties and early nineties in a positive light. The rise of this new liberal identity is examined in future sections of this chapter. 
On the other hand Gush Emunim openly rejects universalistic values such as equal rights for all, including non-Jews, and is absolutely convinced regarding the exclusive "right" of the Jewish people to "Judea and Samaria." When this "right" comes into conflict with the rights of the native population living in these areas, the movement has no qualms to downplay and even completely ignore the latter. As David Newman explains, "Had the Gush Emunim people developed a guilt feeling about the moral and psychological damage that their settlements have inflicted upon the local population, we might not have witnessed their radicalized attitude vis a vis their new neighbors and the resulting terrorism. But this never happened." 370

Aviezer Ravitzky, an expert on Jewish religious extremism, explains the rationale behind such an approach: "When you are in the midst of a divine process, and God is on your side, you gradually lose your sensitivity to the suffering of the other. You become impervious, you see the big picture and little things like human beings disappear. A person with a redemptive outlook like that is satisfied only by the whole and the perfect. Anything that is not whole is perceived as treason." ${ }^{371}$ Yigal Amir, the religious Zionist assassin of Yitzhak Rabin, for example told his interrogators after his arrest "Once something is a [Halachic] ruling, there is no longer a question of moral issue. If I were now

\footnotetext{
${ }^{370}$ Newman, Impact of Gush Emunim: Politics and Settlement in the West Bank, 43.

${ }^{371}$ Zertal and Eldar, Lords of the Land: The War Over Israel's Settlements in the Occupied Territories, 1967-2007, 4.
} 
involved in the biblical conquest of the land, and, as it says in Joshua, I would have to kill babies and children, I would do so regardless of the issue of morality. Once something is a ruling, I don't have a problem with it." ${ }^{372}$

Such a viewpoint allowed the Gush to internally legitimize the occupation of the territories and its consequences. As Rabbi Shlomo Aviner put it, the settlements were "above moral-human considerations." ${ }^{373}$ The settlers were especially weary of humanistic considerations in times of war. The movement's manifesto for example commanded that the military "not flinch because of 'moral' and political considerations. ${ }^{374}$ What is interesting is that morality is mentioned in quotation marks, signifying that the movement does not even accept the criteria that are cited by other political groups.

The subservience of morality in the Gush's ideology was in part due to their discourse of Jewish history in which the non-Jewish inhabitants of Palestine during biblical times were accorded only limited rights not equal to that of the Jews. Moreover some settler authorities even likened the Palestinians to that of the biblical Amalekites, who were annihilated by the Israelites on "God's orders" as described in the Hebrew Bible. The Palestinians were referred by settler leaders as "deadly foes," a term reserved for the Amalekites, which meant that

\footnotetext{
${ }^{372}$ Ehud Sprinzak, "Israel's Radical Right and the Countdown to the Rabin Assassination," in The Assassination of Yitzhak Rabin (Stanford: Stanford University Press, 2000), 124.

${ }^{373}$ Taub, The Settlers and the Struggle over the Meaning of Zionism, 9.

${ }^{374}$ Quoted in Ibid., 57.
} 
they could not be negotiated and compromised with. As one settler leader explained the struggle with "deadly foes" was a "struggle in which there are no compromises, for life and death. The aggressive side, that is the deadly foe, has as his aim to destroy, to kill and to exterminate."375 Such analogies were used to dehumanize Arab Palestinians while legitimizing the settlers' violent struggle against them as rooted both in Judaism and Jewish history. While in its early years the settler movement largely tried to avoid any explicit mention of ideas regarding the expulsion of the Palestinians from the territories, in principle their strategy was the "purification of the land from its defilement."

\section{The Reasons Behind the Gush's Success}

The above-discussed principles were used by the Gush to create a unique religious settler identity in contrast to the presumed characteristics of the "degenerate liberal" identity that was seen as growing within Israeli society, however the religious settler identity never gained widespread acceptance akin to that of the Sabra identity during the Yishuv years. Actually the Gush was never able to demand the loyalty of a majority of Israeli citizens. Nevertheless the settler movement was able to insert itself as an influential force in Israel's political arena. In fact the settler movement has been able to claim a much bigger role in Israeli politics than their numbers would suggest. Several reasons can be cited for the Gush's success.

\footnotetext{
${ }^{375}$ Zertal and Eldar, Lords of the Land: The War Over Israel's Settlements in the Occupied
} Territories, 1967-2007, 219. 
The first and probably most important reason for the settler movement's success, to this day, is their intense determination and devotion to their cause. Indeed the Gush's claim that the Labor movement had become old and fatigued cannot be dismissed as empty rhetoric. When compared to their domestic rivals, Gush members were young, energetic, persistent and resourceful when dealing with obstacles and challenges. Their absolute belief in the righteousness of their goals and their faith in the ultimate victory of their cause gave them an unmatched willpower to stubbornly pursue the movement's objectives, in defiance of domestic and international opposition. In contrast, as will be explained in following sections, the peace camp within the Labor movement was slow to develop and reluctant in dealing with the settlers. The main reason behind the Gush's determination was the indoctrination of its members with Kook's ideas and the successful construction of a settler-religious identity as outlined earlier, even if such an identity was adopted by only a segment of the population.

One of the principle strategies the Gush employed to build such an identity was to invest in educational institutions. Religious Zionists have long operated their own kindergartens, the Mamlachti-Dati religious primary and high schools, ${ }^{376}$ Yeshivas for boys and Ulpanas for girls, a growing number of

\footnotetext{
${ }^{376}$ Mamlachti-Dati (state religious schools) has been one of the major streams of Israel's public educational system since the state's founding. In the 2002-2003 academic year, $18.8 \%$ of Israeli primary students when to these schools.
} 
Yeshivat Hesders and finally advanced Yeshivas. ${ }^{377}$ As a result, the Gush was able to employ and expand a complete educational system, which indoctrinated students from a very young age up to adulthood. For example Merkaz Harav graduates established the Noam Elementary Schools, which provided a firstclass education while also disseminating Kook's "Eretz Yisrael" message. In fact over the years the high quality of the schools have attracted many non-Gush parents to enlist their children. Another Gush institution is the Machon Meir, which provides religious classes for adults. ${ }^{378}$ More importantly the movement established the Judea and Samaria College in the settlement of Kedumim, which would later move to the settlement of Ariel and be renamed Ariel University. Today the university has a student population of 14 thousand and offers undergraduate and graduate degrees in a wide range of disciplines. ${ }^{379}$

Aside from their resoluteness, Gush members were also very skillful in lobbying and using domestic political rivalries in their own favor. In fact the settlers were surprisingly flexible and pragmatic in their political tactics. For example Gush members held numerous meetings with Labor officials and negotiated even with leaders such as Yitzhak Rabin whom they resented and opposed. In fact the settler movement had a representative party in every

\footnotetext{
377 See Robert Jackson and Satoko Fujiwara, Peace Education and Religious Plurality: International Perspectives (New York: Routledge, 2008), 52.

${ }^{378}$ See Sprinzak, The Ascendance of Israel's Radical Right, 132-135.

${ }^{379}$ See “Adelsons Pledge \$25 Million to Ariel University," Israel Hayom, June 24, 2014.
} 
government coalition from 1977-1992. This demonstrates that while the movement's ideological goals were idealistic, utopian and messianic, it's approach in advancing these goals were very practical and based on real-world politics. Moreover the settler movement does not only rely on contacts with high echelons of power, but has also established a wide range of contacts with civil servants in the Israeli bureaucracy, particularly in ministries of importance to them such as the Ministry of Agriculture and the Rural Settlement Department of the WZO, as well as military officials responsible for the West Bank. ${ }^{380}$ Another source of strength was the fact that the Gush translated its ideology into a single political issue, namely the settlement and annexation of the West Bank and Gaza Strip. This extreme focus on a single goal arguably strengthened their hand in Israel's domestic political arena, allowing them to lobby, pressure and compromise with political leaders with only one objective in mind, and ready to compromise on other issues.

The capture and settlement of the West Bank and Gaza Strip also brought the movement much closer to the revisionist movement whose ideology had long argued for a "Greater Israel." Now a movement had risen which was willing to do the dirty work necessary for such a goal. As a result the religious Zionists found natural allies in revisionist parties and constituents. More importantly the settler movement did not contend itself with only an alliance with the revisionists, rather

\footnotetext{
${ }^{380}$ See Myron J. Aronoff, Israeli Visions and Divisions (New Brunswick: Rutgers University Press, 2004), 81-85.
} 
it successfully penetrated revisionist parties such as the Likud. Sprinzak estimated in 1991 that around a quarter of Likud members viewed the world through the prism of the religious right. This penetration of larger revisionist parties such as Likud as well as traditional religious Zionist parties such as the National Religious Party granted the settler movement a much larger influence than their numbers would suggest. A good measure of their power was demonstrated in the formation of the "Eretz Yisrael Front," established in 1989 and consisting of over 30 members of the Knesset, more than one fourth of the seats, to block any compromise regarding the occupied territories. ${ }^{381}$ Sprinzak estimated that in 1987 the Gush lobby in the Knesset had nearly 50 members. ${ }^{382}$

Moreover Gush members were exceedingly learning to present their ideological message in a framework that was appealable to the general public. This is why they repackaged their goals and activities using traditional Zionist values, beliefs and symbols, including Sabra ideals, such as settlement, pioneering, self-defense, sacrifice and toiling the land. Considering their extremist and expansionist ideological goals, the settler movement has been surprisingly sensitive to its internal public image and has thus refined its public relations campaign over the years. The result was that a large segment of the Israeli public sympathized and supported the activities of the movement even if they were not part of the movement and did not take part in settlement activities.

\footnotetext{
${ }^{381}$ Sprinzak, The Ascendance of Israel's Radical Right, 13-14.

382 Ibid., 147.
} 
Annual opinion polls show that in the 1974 to 1982 period, on average 61 percent of the Israeli public strongly supported settlement activity in "Judea and Samaria." ${ }^{383}$ Such support was especially true regarding the Israeli right. Sprinzak has argued "for the entire Israeli right, about half of the nation, Gush Emunim especially, represents the idealism and self-sacrifice of the good old days. In many respects it fulfills for them the same role the tiny Kibbutz movement once fulfilled for the Labor movement." 384 This is why even among the leaders of the left who opposed Gush activities, it brought about a sense of nostalgia, with Yaakov Hazan, leader of the left-wing Mapam, commenting that "they [Gush Emunim] are not fascists but rather young religious people who have faith in the justice of their way.... And they believe in their way of settlement just as the people of Hashomer Hatzair [the precursor and the youth movement of Mapam] believed in their way in the 1920s." 385

In fact the new pioneering spirit revived a sense of purpose and brought about a sense of nostalgia for many Israelis, including members of Labor, during a time when Zionism had become mundane and static. Moreover the Gush successfully utilized the euphoria following the Six Day War during which the Greater Israel idea became much more accepted in elite circles as well as the

${ }^{383}$ Quoted in Yishai, Land or Peace: Whither Israel?, 178.

${ }^{384}$ Sprinzak, The Ascendance of Israel's Radical Right, 15.

${ }^{385}$ Quoted in Zertal and Eldar, Lords of the Land: The War Over Israel's Settlements in the Occupied Territories, 1967-2007, 224. 
general public. This included Labor leaders such David Ben-Gurion, ${ }^{386}$ Shimon Peres, ${ }^{387}$ Moshe Dayan and Yigal Allon. A group of Labor activists even established an organization in support of Gush activities named the Ein Vered Circle, which pressured government officials on behalf of the settlers. ${ }^{388}$ In fact Labor support for the Gush's settlement activities in the sixties and seventies, in complete contrast to the movement's later approach, points to the important changes Labor's ideology witnessed during the eighties and nineties, which will be discussed in future sections of this chapter. It is important to point out however that in the years after the Six Day War the idea of settling and annexing the territories enjoyed widespread consensus among Israeli elites.

This is why the prime focus of the Gush's lobbying efforts was politicians who were sympathetic to the Greater Israel idea and to settlement activities. Moreover in its initial years, the Gush was not asking the general public to leave

\footnotetext{
${ }^{386}$ Ben-Gurion had told a Rafi meeting in June 1967, "We now control Jerusalem, and that is one of the greatest of events- one of the first things that must be done is to build neighborhoods...To immediately settle the Jewish Quarter. If there are empty Arab houses, we'll put Jews into them as well. The same is true for Hebron...I am sure that with the current mood, the people will go." In another example Ben-Gurion had asked the head of the Hebron Yeshiva in Jerusalem, "Why we haven't yet gone there [to settle in Hebron]" and had added "we must do so at once." See Ibid., 17.

${ }^{387}$ During the 70 s Peres, as defense minister, played an instrumental role in allowing the Gush to establish the first settlements of the West Bank. In a 1975 Labor-led Alignment Knesset group meeting in which the settlers were heavily criticized, he defended them and added that "As someone who does not scorn the desires and pressure of Gush Emunim- I think that they are good citizens and good settlers- [however] I do not think that Gush Emunim should dictate policy to the government." Ibid., 49.

${ }^{388}$ Samuel Peleg, Zealotry and Vengeance: Quest of a Religious Identity Group (Lanham: Lexington Books, 2002), 123.
} 
their comfortable life styles in Tel-Aviv and Jerusalem and move to the West Bank, rather it only asked for political backing. As a result supporting the Gush was not seen as a costly endeavor, especially since the ramifications of settling the captured territories was not fully understood at the time by most of the public as well as the political elite.

It has been this support from important segments of the political elite as well as the general public that has made the whole settler initiative possible. As Idith Zertal argues "it is the Israeli government and society that through their support have made the settlements possible, if they withdraw this support the settlement project will fall like a house of cards." ${ }^{389}$ The result has been that consecutive Israeli governments have supported settlement activities by creating financial incentives to move to the settlements, including heavily subsidized apartments and houses, as well as a significant investment in settlement infrastructure such as water, hydro and "Jewish only" roads connecting the settlements together and to major Israeli urban centers.

One such program was titled the "build your own home" program, which offered homes similar to American suburbs using government grants as well as special low-interest mortgages. The Israeli government even led promotional campaigns to persuade people to move to the West Bank. ${ }^{390}$ Moreover under the

\footnotetext{
${ }^{389}$ Zertal and Eldar, Lords of the Land: The War Over Israel's Settlements in the Occupied Territories, 1967-2007, XV.

${ }^{390}$ Newman, Impact of Gush Emunim: Politics and Settlement in the West Bank, 24, 64-65.
} 
sponsorship of the Jewish Agency, programs were created to attract potential immigrants from abroad to settle in the occupied territories. In addition, the World Zionist Organization heavily invested in communal settlements established by the Gush, so that by 1988 the WZO had invested $\$ 80,000$ per family in these settlements. ${ }^{391}$ Over the years these unmatched financial subsidies and incentives have played an instrumental role in convincing non-religious Israelis to move to the West Bank and have thus been a primary reason for the steady growth of the settlement population. In fact in the 2015 Knesset elections only about half of settlers voted for religious Zionist and ultra-Orthodox parties. ${ }^{392}$

Another reason the settlers have been able to play such an influential role regarding the issue of peace with the Palestinians is their location. Since any withdrawal from the territories and a peace deal with the Palestinian will necessarily impact the settlers, as a result their involvement and cooperation is seen as essential by most Israeli politicians. This has granted the settler movement a greater influence than their numbers would suggest, in regards to peacemaking with the Palestinians. Moreover settlers in the West Bank are the Israelis that are in regular contact with the Palestinians, in contrast to many Israelis who rarely deal with Palestinians, especially after the Second Intifada. As a result in many instances the settlers have had the power to calm or heighten

${ }^{391}$ Sprinzak, The Ascendance of Israel's Radical Right, 130.

392 The religious Zionist Jewish Home party won 25 percent of the settler vote, while the ultraOrthodox United Torah Judaism and Shas parties winning 17 and 7 percent respectively. See Tovah Lazaroff, "More Settlers Voted for Bayit Yehudi, Data Shows," The Jerusalem Post, March 22, 2015. 
tensions with the Palestinians, with or without the approval of the Israeli government.

In contrast to the Gush, the peace camp was very slow to develop and even when it did, it took some time before a majority of the Labor movement was won over. As a result the Labor movement was very ambivalent in dealing with the Gush. This allowed the settler movement to firmly establish itself in the West Bank before any serious opposition to its activities formed. In the end, Gush Emunim's successful exploitation of cherished Zionist symbols and values helped delay the rise of an opposition to its settlement activities. As Aharon Megged, a liberal Israeli author, would write:

With all my intellectual opposition to the way of Gush Emunim, it is hard for me to find in my heart (or to enlist within myself) hatred towards them...I do not find the courage in my heart to scorn them...perhaps this is some accursed legacy from the far-off days of the youth movement: not to scorn people who bodily fulfill the commandment of settling the land, even if their belief is different from yours. ${ }^{393}$

\section{Labor: From a State of Crisis to the Rise of the 'Peace}

\section{Movement'}

\section{Labor's Instrumentalist Approach to the Captured Territories}

After the Six Day War, Israel's Labor led government adopted a policy in which Israel would not withdraw from the territories regardless of international

\footnotetext{
${ }^{393}$ Quoted in Zertal and Eldar, Lords of the Land: The War Over Israel's Settlements in the Occupied Territories, 1967-2007, 224.
} 
pressure. After the war, Israeli Prime Minister and Labor leader Levi Eshkol told the Knesset, "Throughout the generations the People of Israel maintained their spiritual and material bonds with this land which were never cut off even when they were driven into exile. Simultaneously the land has been faithful to us and did not give herself to an alien nation. She remained waiting for the return of her sons and for the ingathering of her exiles. Today the whole world has become aware of the fact that there is no power capable of uprooting us from this land." 394

As noted earlier after the Six Day War support for holding the captured territories and even settling and annexing them was widespread both among the Israeli public as well as among political elites including many Labor leaders. Yet the government also adopted a resolution declaring its readiness to conclude peace deals with Egypt and Syria based on territorial withdrawal on June 19, 1967, a decision that was not supported by all Labor leaders. Moshe Dayan famously declared, "Sharm al-Sheikh ${ }^{395}$ without peace is better than peace without Sharm al-Sheikh." ${ }^{396}$ In fact in October 1968 the government rescinded its earlier decision. A year later the central committee of the Labor alignment approved an "oral doctrine" which stated that that Israel would keep the West Bank, the Golan Heights, the Gaza Strip and the Straits of Tiran. ${ }^{397}$

\footnotetext{
${ }^{394}$ Yishai, Land or Peace: Whither Israel?, 3.

${ }^{395}$ Sharm al-Sheikh Is an Egyptian city on the southern tip of the Sinai Peninsula

${ }^{396}$ Akiva Eldar, "Peace Is Israel's Best Security Guarantee," Almonitor, August 19, 2013.

${ }^{397}$ Sprinzak, The Ascendance of Israel's Radical Right, 63.
} 
Israel also initially rejected the American Rogers Plan of 1970, which called for Israel to withdraw from all captured territories as outlined in Security Council Resolution 242, and for Arab states to accept a permanent peace deal. Several weeks later however Israel reversed its position on the proposal after intense American pressure and the increasing involvement of the Soviet Union in the ongoing War of Attrition. In response to the government's acceptance, in principle, of the American proposal, the revisionist Gahal party withdrew from the governing coalition. Labor's adoption of the American proposal was the first sign that the movement differed with the revisionists and the religious Zionists on what to do with the captured territories. Prime Minister Golda Meir explained to the Knesset:

There are fundamental issues over which all of us are united. That is, no withdrawal from the armistice lines until peace arrives and no Israeli return to the 1967 borders. But contrary to Gahal, the other parts of the government do not view the secure and agreed borders, achieved within the framework of a peace treaty as necessarily identical with the present armistice borders in all the fronts. ${ }^{398}$

As Israeli historian Yael Yishai documents, Labor's willingness to negotiate the fate of the territories at the time was only in principle and not in practice, with the exception of the Sinai. This argument is corroborated by the fact that the Labor alignment's central committee approved the Galili Document of September 1973, which detailed a four-year settlement plan in the Golan

\footnotetext{
${ }^{398}$ Quoted in Yishai, Land or Peace: Whither Israel?, 8.
} 
Heights, the Jordan Valley and northern Sinai. ${ }^{399}$ Although on surface these policies were in line with those of the revisionists and the religious Zionists, the examination of the three movement's ideologies point to the different underlying motives behind them. The root difference between the Labor movement's view of the territories and that of the religious Zionists was that it had an instrumentalist view of them, rather than a normative one. The Labor movement had no qualms about settlement activity following the Six Day War, however it saw the settlement of the captured territories as a powerful military, political and economic tool, rather than a vital step in the process of "divine redemption," as the religious Zionists saw it.

In fact after 1967, Labor's Kibbutz movement took the lead in establishing settlements in the Golan Heights, the Jordan Valley and the Sinai. By 1982 there were 20 Labor affiliated settlements in the Golan Heights compared to 7 settlements in the area affiliated with the revisionist and religious movements. There were also more Labor affiliated settlements within the Sinai and the Jordan Valley than the settlements of the other two movement combined. The only area where the Labor movement did not initiate settlement activities was exactly the place where Gush Emunim placed all its emphasis. By 1982 the Gush had established 36 settlements in "Judea and Samaria" while the Kibbutz movement had none. ${ }^{400}$

\footnotetext{
${ }^{399}$ Ibid., Chapter 1, and 89-95.

${ }^{400}$ Ibid., 34.
} 
The above figures point to the instrumentalist-normative divide between the movements. While the Labor movement targeted strategically important geographical areas such as near the borders of the armistice lines, and avoided building settlements close to Arab urban centers, the Gush initiated a long-term plan that targeted areas that they considered "holy." Furthermore the Gush had no reservations about evicting the Arab residents of the captured territories. Also while Labor insisted that it was ready to dismantle the settlements and withdraw from the captured territories, aside from East Jerusalem and some other "strategic" parts of the West Bank, the religious Zionists saw any withdrawal as fundamentally against "God's will." As a result they systematically planned their settlements so as to thwart the establishment of a viable Palestinian state.

The fact that some of Labor's most important leaders sympathized with the Gush, even if they did not take part in its activities, coupled with the strong support of the Israeli public for settlement activities, as well as the skillfulness and political power of the Gush discussed earlier, all resulted in a very ambivalent Labor policy in the 1967-1977 period toward the religious settlers. Labor leaders were very reluctant in confronting the Gush, even when the settlers took explicit action in opposition to government policy. This included Labor leaders who were strongly opposed to the Gush such as Yitzhak Rabin, who would call them "a cancer in the body of Israeli democracy." 401

\footnotetext{
${ }^{401}$ Shlomo Ben Ami, Scars of War, Wounds of Peace : The Israeli-Arab Tragedy: The Israeli-Arab
} Tragedy (Oxford: Oxford University Press, 2006), 150. 
Moreover many opponents of the Gush underestimated the settlers' resolve and determination. For example when Gush members settled in Sebastia, in defiance of the government, Rabin told a government meeting "The evictions just strengthen them. Let's give them permission to go into the Qadum camp and three weeks later they'll all go home." 402 Thus testifying to the perception in Labor that saw the Gush movement as something temporary, failing to see to grand strategy of the new messianic movement and its long-term implications for Israel.

\section{Labor's 'End of Zionism' Crisis and the Need for a New Ideological Message}

One of the principle reasons why the settler movement was able to win the sympathy of politicians as well as the Israeli public in the post 1967 period was the ideological crisis within the Labor movement. The original goal of secular political Zionism had been to solve the problem of European anti-Semitism by establishing a nation-state in Palestine, a goal that had been achieved, largely due to the efforts of the Labor Zionist movement. However even though the movement had played the main role in the creation of Israel, it had no further goals to strive for. As a result the Labor movement had in effect reached the "end" of Zionism, in the sense that the secular Zionist enterprise had been completed. A Jewish nation-state had been created in Palestine, a significant number of Jews had made Aliyah from Europe, and finally the Jewish state had

\footnotetext{
402 Zertal and Eldar, Lords of the Land: The War Over Israel's Settlements in the Occupied Territories, 1967-2007, 47.
} 
become a major military force, even having nuclear weapons in its arsenal in case the "Samson option" ${ }^{403}$ would ever become necessary.

While this all meant that the Labor movement had been greatly successful in fulfilling Zionist objectives, it also meant that the movement had reached the end of the list of its idealistic goals. As a result the movement no longer had an ideological message that could mobilize and energize the masses. In fact the stagnation of Labor's ideology was one of the main reasons for its political decline in the 1970s. Moreover the lack of ideological energy also undercut the movement's ability to confront the settlers.

In contrast, the Gush saw the Zionist enterprise as still incomplete. This was because Zionism was seen as an essential part of a much larger process of divine redemption. Since the redemption would only be achieved with the coming of the Messiah, then Zionism still had things to do. As a result while the Gush's Zionism still provided something to strive for, namely the settlement and annexation of the newly occupied territories, the Zionism of Labor seemed complete and consequently dead. The Gush's ideological message became even more powerful when its adherents were convinced that their actions was hastening the coming of the Messiah, the "real" goal of Zionism, while Labor adherents had little to struggle towards.

\footnotetext{
${ }^{403}$ The Samson Option is the name of a military strategy that would entail massive nuclear retaliation as a "last resort" if military attacks ever threatened the very existence of Israel. See Seymour M. Hersh, The Samson Option: Israel's Nuclear Arsenal and American Foreign Policy (New York: Random House, 2013).
} 
This reinterpretation of the Zionist enterprise is the very reason why the emergence of the Gush should not be seen solely as a rise of a political movement, but rather as a challenge to the core identity of many Israelis. In reality the Gush sought to redefine what it meant to be a "Zionist" and an "Israeli." This brought it into a full ideological conflict with the Labor movement, which until then had played the dominant role in Israeli society. Rabbi Yehuda Amital, a leader of the settlers, explains this well: "There is another Zionism, a Zionism of redemption. It is not here to solve the Jewish question by founding a Jewish state, it is rather an instrument of Providence to prepare Israel for redemption...Its inner thrust is not normalization of the people of Israel, making it a people like all others," as Herzl had argued, rather Israel was "to be a holy people, a people of the live God, whose center is in Jerusalem and the temple of the King within it...The time has come for Zionism to make way for a Zionism of redemption in our minds as well." 404

This is how the Gush was able to create a discourse that painted Labor as a "betrayer" to the Land of Israel and even to Zionism, and the settlers as the "true" Zionists. Unlike the Gush who believed that the "real phase" of Zionism led by religious Jews had just begun, the Labor Zionists had unknowingly reached the "end" of Zionism and as a result many components of their ideology such as pioneering, communal work, socialism and even the Sabra identity were well in decline by the 1970s. This weakness allowed the Gush to manipulate to its own

\footnotetext{
${ }^{404}$ Quoted in Taub, The Settlers and the Struggle over the Meaning of Zionism, 56.
} 
advantage many Labor Zionist symbols such as pioneering, settlement and selfdefense.

The ideological crisis within the Labor movement, coupled with the quick ascent of the religious right to power following the 1977 elections, led to the evolution of Labor's ideology in favor of a political settlement with the Palestinians. The rise of the "peace camp" within Labor and the subsequent peace process of the 1990s in effect revitalized the movement and gave it a new ideological message and a corresponding identity for its followers. The new "liberal Zionist" identity had something to strive for: peace. Also the new identity defined itself as moderate, free, democratic, secular, modern, tolerant of others and striving to make Israel as part of the Western world, as opposed to the perceived "bigotry", "racism", "illiberalism" and the "undemocratic" and "backward" tendencies of the settler movement, which was trying to "hijack" the country away from its original foundations.

\section{The Rise of the Peace Movement Within Labor}

Following the Six Day War several organizations emerged that advocated for peace, none of which however was affiliated with the Labor movement. One such group was the Movement for a Federation of Israel-Falastin, which was initiated by Uri Avnery. The group's primary demand was the immediate creation of a Palestinian state in the West Bank and the establishment of a "federation" between Israel and the newly created state, an idea that was highly unpopular both among the political elite as well as the general public in the post-67 atmosphere. As a result the group was never able to lift itself from the fringes of 
Israeli politics. Another notable group was the Movement for Peace and Security that was created by a group of academics in response to the Movement for Greater Israel and warned about the serious implications of occupying the territories. However the Labor movement shunned these groups, and these groups were never able to mobilize popular support. For example when these groups put forward a Peace List in the 1969 Knesset elections they gained a depressing 5,138 votes, winning no seats in the process. Hebrew University professor Gad Yatsiv, who headed the list, bitterly said after the elections that they had failed because the Labor led government had pushed them into an opposition position. ${ }^{405}$

In fact Labor's policy in the 1967-1973 period, which included support for settlement activity and opposition to peace groups, proves the hypothesis of this chapter which is that the movement's ideology evolved in response to the religious Zionist movement, not due solely to the latter's settlement activities but rather to its much larger drive to redefine Zionism and the very identity of Israelis, an area which until then had been heavily influenced by Labor's hegemony. As a result the rise of the peace movement within Labor is best understood as a reactionary response to the perceived "negative turn" Zionism and Israeli society was taking.

In the wake of the 1973 War when the Labor movement began contemplating the return of part of the territories in exchange for peace, the Gush

\footnotetext{
${ }^{405}$ Isaac, Israel Divided: Ideological Politics in the Jewish State, 15.
} 
movement was established and the struggle to redefine Zionism began. Even though the Gush was established in 1974 and the Labor government of Yitzhak Rabin reluctantly began confronting it, it wasn't until the 1977 elections that the Labor movement understood its own ideological crisis and the full implications of the religious settler challenge. The elections which came to be known as the revolution (HaMahapakh) badly shook the Labor party which until then had played the leading role in Zionism and had led all Israeli governments since 1948. The surprise victory of Likud and its allies meant that things began to change overnight. The first act of Menachem Begin after winning the elections was to visit the Gush settlement of Eilon Moreh, which had been a major source of conflict between the Labor government of Rabin and the setter movement. In fact under the orders of Rabin, the IDF had evicted the Gush settlers seven times from the area. Now Begin openly promised to the settlers that many more such settlements would be built. Moreover, instead of visiting the Chief Rabbi of Israel upon becoming Prime Minister, as is custom in Israel, Begin visited Rabbi Kook as soon as he took office..$^{406}$

The reversal in policy wasn't only limited to settlement building in the West Bank. The religious Zionist movement quickly used its newfound influence to alter many social and religious laws. By passing a series of bills in the Knesset, the movement was able to ban abortions, autopsies and archeological digs.

\footnotetext{
${ }^{406}$ Tamar Hermann, The Israeli Peace Movement: A Shattered Dream (Cambridge: Cambridge University Press, 2009), 14.
} 
Moreover new laws made the upholding of the Sabbath stricter. For example El Al flights were now suspended on Saturdays. ${ }^{407}$ While marriage and divorce laws had come under the jurisdiction of the religious establishment since 1948, in a compromise deal between the Labor movement and the religious Zionists, the new laws seemed to seriously infringe upon the secular foundations that the Labor movement had laid for Israeli state and society. Moreover the growing Westernization of the Labor movement in the 60 s and 70 s, which was discussed in the previous chapter, meant that the new changes were even more cause for alarm. The Labor movement was also deeply troubled by the fact that the Gush had "stolen" many Sabra symbols to reach its objectives. As Amos Oz, a Labor activist and a principle founder of the Peace Now movement, explained:

The appearance of Gush Emunim was also a blow to the ego of the youth in the kibbutzim and the Labor movement. A part of society that had been accustomed to being regarded as the standard bearer, accustomed to being looked up to by the country, had then been swindled - it, the firstborn- by people who were masquerading their sloppy army jackets, running around hilltops with submachine guns and walkie-talkies, who had adopted the mannerisms and the slang of the kibbutz. ${ }^{408}$

The victory of the Israeli right, composed of the revisionist movement and the emerging religious Zionist movement, in the 1977 elections brought a real fear within Labor that Zionism and Israel was being "hijacked." Moreover the new government was now led by Menachem Begin, the arch nemesis of Labor and

\footnotetext{
${ }^{407}$ David Hall-Cathala, The Peace Movement in Israel, 1967-1987 (Houndmills: Macmillan, 1990), 16.

${ }^{408}$ Amos Oz, In the Land of Israel (Orlando: Harcourt Book, 1993), 134.
} 
the biggest supporter of the Gush, which he referred to as his "darling children." ${ }^{409}$ Ben-Gurion famously said in 1963 that if Begin ever came to power he would "replace the army and command with his ruffians and rule the way Hitler ruled Germany, using brute force to suppress the Labor movement." ${ }^{410}$

These conditions created a deep ideological crisis within the Labor movement, the result of which was a new ideological drive to make Zionism and Israel "humane," democratic and secular, and to make Israel a "normal" member of the "civilized" Western world. An objective that seemed deeply in contrast to the direction the country was now headed towards, with the revisionists and the religious Zionists in charge. These sentiments were manifested in the sudden establishment of Shalom Achshav (Peace Now) less than a year after the 77 elections, when peace negotiation with Egypt seemed to be failing. ${ }^{411}$ With the painful memories of the Yom Kippur War still fresh among many left-wing Israelis, the new movement felt that the new right-wing Israeli government was purposefully subverting peace talks with Egypt, who under the direction of Sadat

${ }^{409}$ Roger Friedland and Richard Hecht, To Rule Jerusalem (Berkeley: University of California Press, 2000), 170.

${ }^{410}$ Aronoff, Israeli Visions and Divisions, 24.

${ }^{411}$ The movement was initiated when 348 reserve soldiers of the Israel Defense Forces published an open letter to the Prime Minister, denouncing "a government that prefers existence of settlements beyond the Green Line to elimination of this historic conflict with creation of normalization of relationships in our region will evoke questions regarding the path we are taking. A government policy that will cause a continuation of control over million Arabs will hurt the Jewish-democratic character of the state, and will make it difficult for us to identify with the path of the State of Israel." See: "The Officers' Letter - March 1978" (Peace Now), accessed September 22, 2014, http://peacenow.org.il/eng/content/officers-letter-march-1978. 
seemed to be genuinely interested in reaching a political settlement with Israel. Moreover Labor activists had finally woken up to the long-term consequences of the Gush's settlement drive that was now in full gear thanks to the new allied revisionist government. The new peace movement openly rejected the "Greater Israel" idea and stated its deep concerns with "the path" the state of Israel was taking.

Labor's ideological evolution toward a more "dovish" foreign policy approach should thus be seen as the result of a combination of factors. On the one hand the Yom Kippur War had demonstrated the high costs of not reaching a political compromise with the Arabs. The war had also shattered the "invincibility" of Israel's military and had shown the limits of military power in solving Israel's problems. On the other hand and more importantly, the rise of the settler religious movement brought about a serious challenge to the secular roots of Labor, bringing about grave doubts of where Israel was headed. The shattering results of the 1977 elections heightened such fears, making the prospects of Israel becoming a "religious Sparta" ever more real. In contrast the Labor movement believed that Israel was now in a position to achieve peace by reaching a compromise with its neighbors, an outcome that would not only improve Israel's security, but would also make Israel part of the "civilized" and "humane" Western world. This is why the traditionalism and religiosity of the Begin government was seen with such alarm. Yitzhak Shamir the revisionist leader who served after Begin as Prime Minister of Israel from 83 to 84 and again 
from 86 to 92, and who was one of the chief opponents of Peace Now, wrote in his diary:

[Peace Now] was seen by its followers and even the general public (on whom its impact was minor) as the diametric opposite of Gush Emunim. Not overtly political, it was nonetheless distinctly leftist, basked in the support of the Labour Alignment, especially the kibbutz movement which supplied many of its members, and found favor, automatically, in Israeli's academic and literary circles in which the loathing of the Likud was both traditional and endemic. ${ }^{412}$

It is important however to point out that in the 70s Labor activists, including Peace Now members, did not advocate for Palestinian nationalism, or for a "two-state solution." In fact during the 70 s and early 80 s even talking and negotiating with the Palestinians was highly taboo in Israeli society, even inside the "peace camp," a situation that only began to change following the important developments of the 1980s including the Lebanon War, the exposure of terrorist activities within the Gush and finally the Palestinian Intifada. These developments led to the reification of the emerging liberal identity within a segment of Israeli society while also heightening the tension and conflict between the Labor movement on the one hand and the religious and revisionist movements on the other.

\footnotetext{
${ }^{412}$ Yitzhak Shamir, Summing Up: An Autobiography (London: Weidenfeld and Nicholson, 1994), 152-153.
} 


\section{The Reification of the Two Camps}

\section{The 1982 War of Lebanon}

Israel's invasion of Lebanon in June 1982 came on the heels of its withdrawal from the Sinai Peninsula. In March 1979, Israel signed a peace treaty with Egypt and as part of that deal it completed its withdrawal from the Sinai in April 1982. In fact Prime Minister Begin sent the army to forcibly remove Gush protesters from the northern Sinai settlement of Yamit. These events were deeply traumatic for the settler movement. Not only was Israel withdrawing from an important part of territories captured in 1967, but also it was willing to dismantle and fight Jewish settlers in the process. Even worse was the fact that this was being done by a government that had been perceived as an ideological ally. While the Sinai desert had not been part of the land of the ancient Kingdom of Israel and while it was arguably not part of the Promised Land given by God to the Children of Israel, ${ }^{413}$ the settlers correctly believed that a withdrawal from Sinai could set a precedent for withdrawal from other territories, particularly the West Bank. Indeed, the Camp David accords had specifically called for Palestinian autonomy in the West Bank and Gaza Strip. Because of these reasons Rabbi Kook had publicly called the peace agreement a "government betrayal. ${ }^{.414}$

\footnotetext{
${ }^{413}$ For the various biblical accounts of the territorial border of the Land of Israel see: Shelef, Evolving Nationalism: Homeland, Identity, and Religion in Israel, 1925-2005, 50-51.

${ }^{414}$ See Colin Shindler, The Land Beyond Promise: Israel, Likud and the Zionist Dream (London and New York: I.B. Tauris, 2002), Chapter 7.
} 
Moreover, while the Yamit settlement was primarily a project initiated and supported by Moshe Dayan and not the Gush, its dismantlement and the eviction of its Jewish inhabitants could set an example for the dismantling of Gush settlements that had been built in the West Bank during the past decade. This is why Rabbi Yoel Bin-Nun would comment that "in the struggle for Yamit I saw a struggle for Judea and Samaria," while Elyakim Haetzni, another settler leader, argued that "quite a few of our enemies wish to see the evacuation of Sinai and the dismantling of the settlement as a precedent that will spread to Yesha, the Golan and even Jerusalem." ${ }^{415}$ When the Gush failed to prevent the evacuation as it had planned, it began to intensify its settlement activities following the peace accords and lobbied the government more forcefully, all in the hopes that a similar evacuation from the West Bank would be prevented. The group also started to better organize by establishing a powerful and central organization named the Yesha Council as well as the Nekudah publication.

The Lebanon War, which was designed and executed by Defense Minister Ariel Sharon, the Gush's most important ally in government, was seen by the settlers as a legitimate move by the Begin government to "redeem" itself from its past actions. ${ }^{416}$ The Gush openly declared that southern Lebanon was where the

\footnotetext{
${ }^{415}$ Both quoted in Zertal and Eldar, Lords of the Land: The War Over Israel's Settlements in the Occupied Territories, 1967-2007, 71.
}

${ }^{416}$ For historical accounts of the war see Maoz, Defending the Holy Land: A Critical Analysis of Israel's Security \& Foreign Policy, Chapter 6; Benny Morris, Righteous Victims: A History of the Zionist-Arab Conflict 1881-2001 (New York: Vintage Books, 2001), Chapter 11; Shlaim, The Iron Wall: Israel and the Arab World, Chapter 10. 
Jewish tribes of Asher and Naftali had lived during biblical times and as such needed to be annexed, even if the Begin government insisted that the aims of the war were limited to "self-defense" in order to "avoid another Treblinka." ${ }^{417}$ In fact Gush leaders stated that the war was part of the divine redemptive process. When criticism of the war and its aims began to be voiced by the left, Hanan Porat, one of the Gush's two main leaders, candidly stated:

Even according to the position of the minimalists, southern Lebanon is part of Eretz Yisrael. Not only is it included in the Promise's borders, but also in the territories we are obliged to conquer and settle, the lands of the tribes of Asher and Naftali, which were mostly in present-day southern Lebanon. It makes no difference whether it is convenient for us and close to our conscience. The Providential truth does not change and will never change. ${ }^{418}$

In fact the Lebanon war and the rise of Gush allies such as Defense Minister Ariel Sharon and Minister of Science and Energy Yuval Newman, made the 1982-1984 years the peak of the movement's power. Ehud Sprinzak notes that during these years "the most confidential state secrets were discussed and debated in Yesha's internal councils, and most of the ministerial doors were open to the settlers. ${ }^{419}$ Also during this period settlement development saw a boom, partly due to the fact that domestic and foreign opposition was largely focused on Lebanon, giving the Gush a perfect opportunity to settle the West Bank. In fact

\footnotetext{
417 Treblinka was a Holocaust extermination camp operated by the Nazis in occupied Poland.

${ }^{418}$ Sprinzak, The Ascendance of Israel's Radical Right, 114.

${ }^{419}$ Ibid., 146.
} 
critics argue that the Lebanon War was intended to block the creation of a Palestinian state in the West Bank and Gaza and the facilitation of their annexation to Israel. As such the war rekindled the relationship between the Gush and the Begin government. In settler discourse Begin the "criminal" and the "Judenrat" of Yamit had redeemed himself and had become a "new Jew," the Jew "who no longer has feelings of inferiority and a psychological need to prove dignity, the pursuit of peace and suchlike. ${ }^{\prime 420}$ Gush efforts to settle the West Bank were also very successful during Begin's tenure. From 1977 to 1983 the Israeli government approved the establishment of 103 settlements, compared to 22 settlement approvals during the first decade of the occupation. ${ }^{421}$

While the Lebanon war strengthened the religious Zionist movement and deepened its ties with their revisionist allies in government, it simultaneously reinforced the emerging liberal Zionist identity in favor of peace within the Labor movement. This is an example of how various groups interpret external events differently and how they are also affected by them differently. As discussed in chapter two, the relationship between ideology and foreign policy is not a oneway street, rather external developments and the foreign policy of a state also affect its domestic political ideologies.

\footnotetext{
${ }^{420}$ Zertal and Eldar, Lords of the Land: The War Over Israel's Settlements in the Occupied Territories, 1967-2007, 75.

${ }^{421}$ Ibid., 97.
} 
Opposition to the Lebanon war within Israeli society was unprecedented from several different aspects. First of all there was opposition to the war from its very commencement, ${ }^{422}$ a first in Israeli history. ${ }^{423}$ Secondly opposition to the war drew unparalleled mass demonstrations, particularly Peace Now's September 1982 demonstration that called for a national inquiry into the Sabra and Shatila massacres and the resignation of Ariel Sharon, which was attended by 400 thousand Israelis, approximately ten percent of the country's population at the time. Thirdly the massive demonstration and subsequent protests to the war were coordinated with the Labor Alignment. Indeed Labor leaders including Yitzhak Rabin and Shimon Peres had officially attended the September demonstration. Lastly the protests were successful in significantly changing government policy, namely Israel's withdrawal from most of Lebanon, the establishment of the Kahan Commision and the resignation of Ariel Sharon as Defense Minister. ${ }^{424}$

The emerging peace movement was deeply distraught about the "aggressiveness" of Israel's "offensive" military operation, unlike past wars that were seen as "defensive wars of no alternative" that ensured the country's existence. Indeed even Begin had called it a "war of choice." Furthermore when

\footnotetext{
${ }^{422}$ Although Peace Now stayed silent for the first ten days of the war, however other peace groups protested from the beginning.

${ }^{423}$ Hermann, The Israeli Peace Movement: A Shattered Dream, 91.

${ }^{424}$ Tamara Zieve, "This Week In History: Masses Protest Sabra, Shatila," The Jerusalem Post, September 23, 2012.
} 
Israel's Phalangist allies committed atrocities in the Sabra and Shatila Palestinian refugee camps, killing hundreds of women and children, many left-wing Israelis came to the conclusion that Israel had turned from a "victim" into a "victimizer." 425 In fact concern about "what Israel had become" turned into a routine feature of the peace movement's activity from then on. The rising liberal identity within the Labor movement saw these actions as separate and in contrast to "their" Israel versus the transformed Israel that had been shaped by the Gush and its revisionist allies in government. When Shimon Peres, then the head of the Labor party, addressed the massive Peace Now demonstration of September 1982, he stated: "there is another Israel, living on its conscience not only on its sword, a country of constructiveness and human dignity." ${ }^{426}$ Indeed bringing back the "other" Israel, which relied on force only when there was "no alternative," which sought "peace" with its neighbors, which was part of the "civilized" Western world and adhered by "international human rights norms," slowly became the core ideological goal of the Labor movement.

The perception of religious and right wing Zionists as the "other" by liberal Zionists, whose identity was still in development, became more acute when Yona Avrushmi, a right wing activist, threw a hand grenade into a 1983 rally, killing Peace Now activist, Emil Grunzweig, and wounding nine others. The act, which

\footnotetext{
${ }^{425}$ See Sucharov, The International Self, Chapter 5.

${ }^{426}$ William E. Farrell, "Israelis, at Huge Rally in Tel Aviv, Demand Begin and Sharon Resign," The New York Times, September 26, 1982.
} 
signified the extreme right's willingness to use violence even against fellow Jews, was deeply troubling to the peace camp. Indeed the use of violence gradually became a commonplace tactic of Israel's right against its opponents. Avrushmi would brag years later that by throwing the hand grenade he had "killed the Israeli Left." ${ }^{427}$ However while the Lebanon war was deeply distressing for Labor, in retrospect it can be considered as a victory point for the movement in its ideological struggle against its religious and revisionist rivals. Not only did the war strengthen an emerging liberal Zionist identity as well as provide an avenue for Labor to create a new ideological message in favor of peace, after years of ideological crisis and stagnation, but also as a result of the movement's peace activities, both Begin ${ }^{428}$ and Sharon stepped down and Israel withdrew from most of Lebanon, events that weakened both the revisionist movement as well as its settler allies.

The withdrawal from Lebanon brought resentment and anger from the settlers who believed that the "shameful" retreat could have been prevented had the government been more committed to the war and had the "leftists" not "betrayed" the country. In Gush discourse the Lebanon war held great potential in becoming a great victory and the annexation of more biblical territories, events

\footnotetext{
427 In the same interview he stated that: "People in the street want to kiss both my hands, the hand that pulled out the pin and the hand that threw the grenade. I go to synagogues all over the country, with friends and acquaintances, and I am greeted with admiration everywhere. Even Ashkenazis tell me, "congratulations, we admire you." Quoted in Richard Silverstein, Emil Grunzweig's Assassin: "I Killed the Israeli Left” (Tikun Olam, July 26, 2011).

${ }^{428}$ Begin explained his resignation by saying: "I could not face the daily anti-war vigils outside my home in Jerusalem." Quoted in Sucharov, The International Self, 100.
} 
which would have "hastened" the divine redemptive process. The settler movement now saw the new left as not only responsible for the failure of the Lebanon war, but also as a dangerous opponent which must be held in check if Israel was not to lose any more of the Holy Land. Such fears where explained by Hanan Porat during the Lebanon war when he told Nekuda, "I want to stress that he who does not clearly rely on the foundations of the Godly command regarding the conquest and settlement of Eretz Yisrael is bound, at the end, to disregard not only Israel's north but also to be ready to make concessions even in its very heart. $^{.429}$

\section{The Jewish Underground}

The use of violence and terror tactics was one of the Gush's main strategies in preventing the peace process with Egypt. For example at a Yesha Council meeting aimed at halting the Sinai withdrawal, Hanan Porat, then a Knesset member, proposed the creation of "an acute, large and weighty balance of terror. A balance of terror that will force the government to come to the realization that evacuation is impossible. Only such a realization will guarantee the prevention of a civil war. However taking a lukewarm path could lead to a clash." ${ }^{430}$ Other settler leaders also threated the government with "civil war" and "national trauma." While the Gush's threats regarding Yamit never materialized,

${ }^{429}$ Sprinzak, The Ascendance of Israel's Radical Right, 114.

${ }^{430}$ Quoted in Zertal and Eldar, Lords of the Land: The War Over Israel's Settlements in the Occupied Territories, 1967-2007, 71. 
the rhetoric it used inadvertently opened the door to violence, even against fellow Jews.

In the wake of the Gush's struggle to prevent the peace process with Egypt, a faction of the settler movement secretly began to use terrorist tactics in what came to be known as the Jewish Underground. Menachem Livni, a leading member of the group, would testify later in court that as early as 1977 , and after Sadat's trip to Israel, the group were contemplating "rehabilitating" the temple mount by blowing up the Dome of the Rock, "in order to stop the evacuation of the Yamit Region settlements, in fact so that no precedent would be created for evacuating Hebrew settlements and abandoning them willingly." ${ }^{231}$

The group, whose members came from the Gush's leading families, attacked the mayors of Nablus and Ramallah by planting explosives in their cars, as a result of which both Palestinian figures lost their legs. The group was also responsible for the 1983 attack on a Palestinian college in Hebron, which killed three students and wounded 33, as well as other attacks on Arab civilian targets. The settlers would later explain that since the government had "abandoned them," they needed to personally take action. They would also claim that their plans were according to Halacha law and verified by leading settler Rabbis. ${ }^{432}$

\footnotetext{
${ }^{431}$ Ibid., 76.

${ }^{432}$ See Yair Sheleg, The Political and Social Ramifications of Evacuating Settlements in Judea, Samaria and the Gaza Strip (The Israel Democracy Institute, October 2004);
} 
More importantly the group began the "purification of the Temple Mount" by planning the explosion of the Dome of the Rock in order to derail the peace process with Egypt. The group's leaders believed that such an attack would start the dynamic process of divine redemption. Yehuda Etzion, one of the group's leaders, explained that blowing up the Dome of the Rock, was "the only way for Israel to become, ultimately, the proper Kingdom of Israel, worthy of the one that is promised" ${ }^{\prime 33}$ The group planned the attack for several months and prepared the required explosives for the operation, however a last minute illness by one of the leading people of the task team resulted in the completion of the Sinai withdrawal before the group could carry out the plan. Finally Israeli security forces arrested the group's members immediately after they planted bombs in six buses that would be packed with Arab passengers on April 27, $1984 .{ }^{434}$

As with other Gush actions, the Jewish Underground saw its actions as in line with the founders of the state of Israel. Livni for example declared after arrest, "we reject in disgust the desire to bring us to trial like criminals. We are no worse than Yitzhak Shamir, Menachem Begin, and their colleagues who went forth to defend their people and their homeland in the 1930s and the 1940s." ${ }^{\prime 43}$

\footnotetext{
${ }^{433}$ Zertal and Eldar, Lords of the Land: The War Over Israel's Settlements in the Occupied Territories, 1967-2007, 84.

${ }^{434}$ Ami Pedahzur, and Arie Perliger, Jewish Terrorism in Israel (New York: Columbia University Press, 2009), Chapter 3.

${ }^{435}$ Quoted in Jennifer L. Jefferis, Religion and Political Violence: Sacred Protest in the Modern World (New York: Routledge, 2010), 160-161.
} 
Thus not only were the Gush members not repentant of their deeds, they actually took pride in them. More importantly the Jewish Underground squarely placed the blame for its actions on the footsteps of the Labor movement who had played the leading role in the decline of Zionism and the corruption of Israel. Yaakov Weinrot, a leading activist within the religious Zionist movement who acted as the group's attorney, declared in court, "of a hundred measure of hypocrisy, the Zionist left has taken ninety-nine. It has left the religious a small living space, like the nature reserves for the Indians. Gradually the left eroded the heartstrings and distanced the religious youth...Indeed, even today, behind bars, disappointed, frustrated, hurting, and becoming wiser, they [the defendants] will be the first to answer any call, and it is they who will ascend the mountain." ${ }^{436}$ Even the Gush's official secretariat publicly maintained that the real culprit was the government, whose mistakes had "forced" the Habachurim Hatovim ("the good guys") of the underground movement to act in their erroneous ways. ${ }^{437}$

The trial of the Jewish Underground is a prime example of how the settler movement was able to use Zionist as well as religious symbols and myths to win the sympathy of the non-settler public, as discussed earlier. During their trial, Judge Bazak would note how the accused were "good people imbued with faith,"

\footnotetext{
${ }^{436}$ In Psalm 24 it is said: "Who may ascend the mountain of the LORD? Who may stand in His holy place? The one who has clean hands and a pure heart, who has not set his mind on what is false, and who has not sworn deceitfully." Weinrot quoted in Zertal and Eldar, Lords of the Land: The War Over Israel's Settlements in the Occupied Territories, 1967-2007, 89-90.

${ }^{437}$ Sprinzak, "Israel's Radical Right and the Countdown to the Rabin Assassination," 158.
} 
while another judge noted how "most of them are people of Torah and work, and who left behind them a comfortable way of life and set out with their families to establish a Hebrew settlement, work it, and guard it." Even Judge Zvi Cohen, who believed the defendants were guilty, commented how "among them are those who have written glorious pages in settlement, defense, and help to the needy. It is untenable that these should not stand them in good stead at this difficult hour of theirs." ${ }^{\text {"38 }}$

Out of the 20 convicted members of the group only three ${ }^{439}$ were given life sentences (the compulsory sentence for premeditated murder) and even then President Chaim Herzog reduced their sentences first to 24 years, then to 15 years and then to ten years. ${ }^{440}$ Finally, after serving only six and a half years, the men were freed in 1990 on the order of the Israeli President. Interestingly enough Herzog was a Labor politician who in 1983 had become the sixth President of Israel, when the Labor movement presented him for candidacy against Menachem Elon, the candidate of the revisionists. The example shows the extent to which the settlers have been able to penetrate Israeli society, including their political opponents.

\footnotetext{
${ }^{438}$ Zertal and Eldar, Lords of the Land: The War Over Israel's Settlements in the Occupied Territories, 1967-2007, 91-93.

${ }^{439}$ Menachem Livni, Uzi Sharbaf and Shaul Nir,

${ }^{440}$ See Chaim Levinson, "Former Jewish Underground Convict Receives More than NIS 1.3 Million from State," Haaretz, February 13, 2013.
} 
Most Labor leaders however were unsympathetic to the actions of the group, which they saw as a dangerous form of terrorism. More important than the group's attacks against the Palestinians, was their plan to blow up the Dome of the Rock, an operation that would have great yet unpredictable consequences for Israel, including a possible war with Islamic countries as well as widespread international condemnation. Moreover the actions of the Jewish Underground had "proved" the worst fears of the emerging peace movement within Labor. The religious extremists together with their revisionist allies were "turning Israel" into an "undemocratic", "violent", "racist" and "isolated" country. The exposure of the Jewish Underground revealed the gravity of the situation to the peace movement and the urgent need to stand up to the settlers. The exposure of the Jewish underground also badly hurt the settler image among the general public, which the Gush had invested greatly to create. The event also led to internal strife within the Gush, with some groups unhappy about the actions of the underground. ${ }^{441}$ In the long run the exposure weakened the group.

\section{The Palestinian Intifada}

The Palestinian uprising that began in December 1987 did not result in a reassessment of the "Palestinian question" by the religious Zionist movement,

\footnotetext{
${ }^{441}$ It was widely perceived that Rabbi Moshe Levinger, who Sprinzak calls the "most influential leader" of Gush and who was initially arrested for two weeks following the exposure of the underground, was intimately involved with the groups terrorist activities. Other Gush leaders such as Hanan Porat and Yoel Ben-Nun wanted Levinger to denounce the underground publicly to limit the damage to the image of the Gush, however the Rabbi never did so. This issue became a major source of contention within the settler movement. See Sprinzak, The Ascendance of Israel's Radical Right, 156-159.
} 
which until then had largely tried to ignore the problem and avoid explicit discussions of it. The uprising had shattered any image of a "benign" and "enlightened" occupation that some Israelis had. ${ }^{442}$ As a result the settler movement could now be more open and public about its strategies and tactics. Hanan Porat would comment after the uprising that the settlers should be "suppressing with a heavy hand any attempts at terror and damaging our sovereignty," otherwise the conflict "will reach a stage at which either we will be expelled, or they will. We will have to see to it that they are the ones who will be expelled." ${ }^{443}$ Similarly Rabbi Yitzhak Shilat of the Ma'aleh Adumim settlement explained that "anything we do as a result of distress and anger, even killing, is good, is acceptable and will help. Killing is just a matter for the Kingdom." ${ }^{444}$

Such an approach wasn't limited to rhetoric either, as many settler leaders such as Rabbi Levinger took the lead in suppressing the uprising using force. The Gush also used the opportunity to put its drive to redefine Zionism into full swing. Rabbi Moshe Levinger declared that it was time to transform the nation, since the Mashiach Ben-Yoseph (Messiah the son of Joseph) phase, which was

\footnotetext{
442 For the effects of the occupation on Palestinians see Raja Shehadeh, "Israel and the Palestinians: Human Rights in the Occupied Territories," in Echoes of the Intifada: Regional Repercussions of the Palestinian-Israeli Conflict, ed. Rex Brynen (Boulder Colorado: Westview Press, 1991); Rex Brynen and Neil Caplan, "The Palestinian Uprising," in Echoes of the Intifada: Regional Repercussions of the Palestinian-Israeli Conflict, ed. Rex Brynen (Boulder, Colorado: Westview Press, 1991); Zachary Lockman and Joel Beinin, eds., Intifada (Cambridge, Massachusetts: South End Press, 1989).

${ }^{443}$ Quoted in Zertal and Eldar, Lords of the Land: The War Over Israel's Settlements in the Occupied Territories, 1967-2007, 104-105.

444 Ibid., 105.
} 
a prequel to the era of redemption was over and the Mashiach Ben-David (Messiah the son of David) stage, which was the actual era of the Messiah, had begun. ${ }^{445}$

In the initial period of the Intifada there seemed to be little difference between the approach of the Labor movement and that of the revisionist and religious Zionists. In fact Yitzhak Rabin, who served as defense minister in the unity government, would lead the cause in suppressing the uprising with force, commenting in January 1988 that the Intifada should be crushed using "force, might, and beatings." ${ }^{446}$ Such feelings were also shared by the general public, which agreed with the Gush that Arab "terrorism" had to be dealt with harshly. ${ }^{447}$ Moreover more centrist peace groups, particularly Peace Now, were caught in a dilemma. On the one hand they wanted to support the government and the IDF in response to "Palestinian violence." This is why, in line with the national consensus, Peace Now never called for its members to refuse to serve in the armed forces during the Intifada, like some smaller peace groups had done. On the other hand the need to withdraw from the territories was felt even more acutely than when the group was established a decade earlier. Dedi Zuker, one of the movement's leaders, explained, "The intifada put forward a difficult

\footnotetext{
${ }^{445}$ Quoted in Sprinzak, The Ascendance of Israel's Radical Right, 163.

${ }^{446}$ Lamis Andoni, "Searching for Answers: Gaza's Suicide Bombers," Journal of Palestine Studies 26, no. 4 (1997): 36.

${ }^{447}$ Sprinzak, The Ascendance of Israel's Radical Right, 160.
} 
dilemma: between patriotism and political logic...this was a real trial by fire and Shalom Achshav [Peace Now] was not really able to get through it unharmed." ${ }^{448}$ However as the uprising dragged on and the IDF was unable to suppress the protests, it became increasingly clear that the Intifada was much larger than the violence of a few disgruntled Palestinians. As a result, right wing propaganda, which portrayed Palestinians as largely content with the status quo mainly due to their "improved living standards," was proven false by the uprising. ${ }^{449}$ A poll conducted in the summer of 1989 found that 73 percent of the Israeli public was unhappy about the settler acts of violence and revenge against the Palestinians, while 85 percent believed these efforts could lead to war between Jews. ${ }^{450}$ The peace activists within Labor also started to strongly voice their criticism of the settler movement. In a June 1989 article, Peace Now founder, Amos Oz, declared that the settlers were "a gang of armed gangsters, criminals against humanity, sadists, perpetrators of pogroms and murderers." ${ }^{.41}$

${ }^{448}$ Quoted in Hermann, The Israeli Peace Movement: A Shattered Dream, 99.

${ }^{449}$ Mark A. Tessler, A History of the Israeli-Palestinian Conflict (Bloomington: Indiana University Press, 1994), Chapter 11.

${ }^{450}$ Zertal and Eldar, Lords of the Land: The War Over Israel's Settlements in the Occupied Territories, 1967-2007, 111.

${ }^{451}$ Amos Oz, "In the Name of Life and Peace", Yediot Aharonot, June 8, 1989. Quoted in Nativ, Volume 19, Number 6 (113) (Ariel Center for Policy Research, November 2006), www.acpr.org.il/nativ_e/113-nativ-toc.htm. 
More important than the renewed animosity the Intifada brought between the peace camp and the settler movement, was the fact that the uprising brought in full view the unavoidable implications of occupation and annexation of the territories. As a result of the Intifada the settler movement could no longer downplay the consequences of holding on to the territories for Israel. Even more moderate leaders of the Gush began to realize this. Rabbi Ben-Nun, who was one of the Gush's original founders, declared: "The majority of the public is for [keeping] Eretz Yisrael but opposes the annexation of 1.5 million Palestinian Arabs, and it is no longer possible to think that you can annex the territory and at the same time deny Israeli citizenship to its inhabitants. And do not live with the illusion that you can expel them. ${ }^{452}$ In fact several Gush members would leave the group in the 1989-1990 period, in protest of the movement's increasing violent tactics against the Palestinians. ${ }^{453}$

The Intifada had effectively exposed the high price of holding on to the territories, an issue that had been inadequately examined by political elites and the public until then. Not only was Israel's international image being tarnished, but also the IDF, which was essentially shaped to defend Israel against foreign armies, was being used to suppress civil unrest. Moreover the Intifada had been disastrous for Israel's economy, which was now in a recession. Not only had Israeli businesses largely lost the Palestinian market but they were also now

\footnotetext{
${ }^{452}$ Quoted in Sprinzak, The Ascendance of Israel's Radical Right, 163.

453 Ibid., 164.
} 
deprived of cheap Arab labor due to the widespread Palestinian strikes. The Intifada was thus a much needed proof for the peace movement's claim that the occupation was far from benign and enlightened and that in the end it would also be harmful to Israel's "moral essence" as well as to its "national interests."

More importantly, the Intifada, which was widely covered in Israeli media, strongly revived the narrative of the Lebanon War, which cast Israel as the victimizer rather than the victim. When the IDF began using increasingly harsh tactics and as the Palestinian civilian death toll began to climb, narratives that cast Israeli actions as "oppressive" and in line with an "apartheid" regime began to rise in the Labor movement. A segment of the Israeli public was again deeply concerned with what "Israel had become," an Israel that was very different from their cherished values and from what they perceived the founders of Zionism had envisioned. Also such sentiments were no longer limited to the peace camp but were spreading to other segments of the Israeli public.

Israeli historian Benny Morris explains, "Israelis liked to believe, and tell the world, that they were running an 'enlightened' or 'benign' occupation, qualitatively different from other military occupations the world had seen. The truth was radically different. Like all occupations, Israel's was founded on brute force, repression and fear, collaboration and treachery, beatings and torture chambers, and daily intimidation, humiliation and manipulation." ${ }^{\text {"54 }}$ This is why Yossi Beilin commented that "[t]he small, sophisticated, moral Israel of the 1950s

\footnotetext{
${ }^{454}$ Morris, Righteous Victims: A History of the Zionist-Arab Conflict 1881-2001, 341.
} 
and 1960s was transformed in the eyes of the young generation of television viewers from David into Goliath, while the stone-throwers became the modernday Davids." ${ }^{\not 55}$ Moreover the Green Line separating Israel from the West Bank and Gaza Strip, which had disappeared in the Israeli consciousness in the two decades prior to the Intifada, had now firmly reappeared. The Palestinian uprising effectively reestablished these borders within the Israeli psyche by turning the territories into an inaccessible and dangerous "outside" land. ${ }^{456}$

Nevertheless it is important to point out that not all Israelis shared the above views of the Intifada. In fact the majority of the religious Zionists and revisionists supported adopting even harsher measures to quell the protests. According to these movements the Intifada had "proven" their worst fears and suspicions of the Arabs. As a result they became even less willing to consider making concessions and withdrawing from the territories. Thus the Intifada strengthened the position of the territorial maximalists within the revisionist and religious Zionist movements. Moreover as a result of widespread international condemnation of Israeli actions during the intifada, the concept of "Israel dwells alone" was once again reminded to these groups, making them even less

\footnotetext{
${ }^{455}$ Quoted in Sucharov, The International Self, 132.

${ }^{456}$ Mark A. Tessler, "The Intifada and Political Discourse in Israel," Journal of Palestine Studies 19, no. 2 (Winter 1990): 43-61.
} 
sympathetic to the Labor movement's drive to make Israel a "normal" member of the "international community." 457

Moreover as Tessler points out, during the Intifada the forcible removal, or "transfer" of Palestinians from the territories was no longer a taboo topic and was now part of the legitimate political discourse of right wing parties. Such a trend was not limited to the political elite either. A Jerusalem Post survey conducted in August 1988 found that 49 percent of Israelis leaned toward transfer as a solution to the problem of the occupied territories. ${ }^{458}$ The rise of the right wing extremist Kach party led by Rabbi Meir Kahane also displays the increasing hawkish views of right wing Israelis. The party which had won just one Knesset seat in the 1984 elections, was projected to win 4 seats in the 1988 elections, before being disqualified by the Supreme Court. ${ }^{459}$

Therefore as a result of the developments of the 1980s, particularly the war in Lebanon, the exposure of the Jewish underground and the eruption of the Palestinian Intifada, the construction of a liberal Zionist identity within the Labor movement that was a result of its changing ideology was accelerated. At the same time such events did not weaken the resolve of the religious settlers, rather the religious Zionist movement increasingly came to the conclusion that the

\footnotetext{
${ }^{457}$ Zertal and Eldar, Lords of the Land: The War Over Israel's Settlements in the Occupied Territories, 1967-2007, Chapter 2.

${ }^{458}$ Tessler, "The Intifada and Political Discourse in Israel."

${ }^{459}$ Samuel G. Freedman, Jew Vs. Jew: The Struggle for the Soul of American Jewry (New York: Simon \& Schuster, 2000), 196.
} 
Labor movement needed to be confronted and defeated if the group's vision of a "new Israel" were to be fulfilled.

\section{Conclusion}

While the decline of Labor's ideology in the 60 s and 70 s led to the political rise of the revisionist movement, as discussed in chapter 4 , on another more important level it provided an opportunity for the religious Zionist movement to attempt to redefine Zionism in its own image. The creation of Gush Emunim in 1974 signified the first attempt to enshrine the ideology of Rabbi Kook into a centralized political movement to achieve this aim. The goals of the new religious settlers were much larger than the settlement of the newly captured territories, rather the movement sought to redefine the very basis of Zionism and what it mean to be an "Israeli."

The rise of the Gush was thus a direct ideological challenge to the Labor movement and a threat to the core identity of its members. Even though Labor had led the way in the creation of the Israeli state and the creation of a hegemonic Sabra identity, it now saw the fundamentals of Zionism under attack from the religious Zionists. If in the first decades of Zionism, the Labor movement saw Jewish life in the diaspora as "diseased" and sought to "cure" it through the creation of the Sabra warriors, the religious Zionists saw the current state of Israel and its people as "diseased." They believed that Israelis had become soft, pluralistic, secular, liberal, and over obsessed with democracy and that the Labor government was weak and often in pursuit of pleasing the gentiles. According to 
the Gush the Labor led westernization of Israeli society had eradicated the pioneering principles of Zionism.

In contrast the religious Zionists portrayed themselves as the only "true" Israelis who were resuscitating the "dead" Zionism of Labor back to its original status by engaging in pioneering and settlement in "Judea and Samaria." These settlements without which "no holiness operated in the world" were needed in order to remind the increasing individualistic and materialistic Israeli society of original Zionist values such as self-sacrifice, communal work and self-defense. Yet while the religious Zionists used many of the symbols and values of Labor's early days, their aim was not to revitalize the Sabra but to create a new "religious Sabra" or a "Jewish-warrior" identity which included many of the characteristics of the original Sabra such as strength, self-sacrifice and above all else unbending dedication to the "defense of the Jewish people," however while the original Sabra was secular and devoid of religion, the new Sabra was not only a practicing Jew but was a religious scholar trained at Yeshivas. In religious Zionist discourse the new Sabras were the "soldiers of the Messiah."

On the other hand the rise of the Gush and the events of the 1980s, specifically the Lebanon War, the exposure of the Jewish underground and the first Palestinian Intifada, facilitated the evolution of Labor's ideology in favor of liberal Western values, which increasing came to see the settler movement and its role in the events cited above as turning Israel into an undemocratic, illiberal and racist pariah state, that was isolated and shunned by the international community. The rise of the Peace Movement within Labor was thus a response 
to the fear of what "Israel was becoming." This development led to the rise of a liberal Zionist identity inside the Labor movement, which saw Israel as part of the democratic, secular and modern West and saw territorial withdrawal as in line with these values. This is why the struggle over territorial policy and peace negotiations in the 1990s within Israel's domestic political scene should not be seen simply as a policy dispute, but rather the manifestation of a much larger ideological battle, with contrasting values, beliefs and discourses.

The future of the territories as well as the issue of how to deal with opponents such as the PLO as well as allies like the United States were thus important parts of the emerging religious Zionist and liberal Zionist identities that were created in opposition and conflict to each other during the seventies and eighties. By the time of the Oslo negotiations in the early nineties, these two identities had become reified and highly opposed to each other. The events of the nineties were thus the result of the ideological conflict between two camps that that had been established and nourished in the earlier two decades.

From a theoretical perspective, the events of the 1980s and how they affected the religious Zionist and Labor movements demonstrates how different ideological groups interpret and react to external events and international developments in different and sometimes opposing ways. The eruption of the Palestinian Intifada for example led religious Zionists to conclude that the territories needed to be controlled and annexed sooner rather than later due to Palestinian "violence." The movement also called for more extensive use of brute force to suppress the uprising, while also seeing criticism by the international 
community as anti-Semitic and irrelevant. At the same time the Labor movement saw the uprising as proof of its earlier fear of what "Israel had become." Furthermore the crisis showed that the occupation was far from "benign" and "costless," increasing calls for a negotiated settlement with the Palestinians. The emergence of two opposing understandings of international developments also took place in the wake of the 1973 Yom Kippur War and the Lebanon War of 1982. The case study under discussion here thus demonstrates how international events are not "objective" developments as realists argue, but are rather understood through ideological lenses, which provide an ideational framework used to make sense of world events and prescribe normative action programs in response to them.

This chapter also provides evidence of how a movement's ideological change and evolution can be initiated from the bottom-up rather than from the elite. The rise of peace movement within Labor provides an example of how the constituents and low to mid level members of a political movement can exert change, even when the elites of the movement are opposed or reluctant about such change. In the case of Labor, which initially supported the settlement of the territories, the peace movement initially sprang up outside and separate from it. However the rise of the Gush and its revisionist allies and their expansionist policies led to the emergence of a pro-peace liberal identity within the ranks of the Labor movement. Interestingly such change, including the establishment of Peace Now, was not initiated and managed by the party elite, who were arguably the last group within the movement to embrace it. For example during the run up 
to the 1992 elections and during Labor's internal primaries that were held to decide the party's candidates list, many new, young and dovish candidates, who were much more pro-peace than the older elite of the party, were selected by the party membership. ${ }^{460}$ In fact the list, which had many new faces, that were much more liberal than the party's earlier generation, was downplayed by the party's campaign machine during the 1992 elections out of fear that the list was "too dovish." ${ }^{.61}$

The rise of the peace movement within the ranks of Labor thus provides a real world example of how ideological change does not always take place from the top-down but can also be initiated and fought for by the masses. This forms an important part of the answer to the theoretical question, 'Where does ideology reside?' presented in chapter 2. Ideology is the ideational framework of both a movement's elites as well as the masses that support it. While ideological change is usually initiated and managed by party elites, in some cases the rank and file of a movement take the front seat in driving such transformation.

Up to now this dissertation has examined how the ideology of Israel's political movements were constructed in relation and opposition to each other in the decades leading up to the peace process. Such a study is imperative to

${ }^{460}$ Daniel J. Elazar and Shmuel Sandler, Israel At The Polls, 1992 (Lanham: Rowmand \& Littlefield Publishers, 1995), 4; Asher Arian and Michal Shamir, The Elections in Israel, 1992 (Albany: State University of New York Press, 1995), 13.

${ }^{461}$ Efraim Inbar, "Labor's Return to Power," in Israel at the Polls, 1992, by Daniel J. Elazar and Shmuel Sandler (Lanham: Rowmand \& Littlefield Publishers, 1995), 34. 
understand Israel's conflicting foreign policy behavior regarding the peace process during the nineteen nineties, the dissertation's main aim and the topic of the next chapter. The next chapter will demonstrate how Labor's new liberal Zionist ideology would lead to important changes in Israel's policy towards the "Arab question" in the 1990s, a development that would forever change the nature of both the Israeli-Palestinian conflict and raise a significant challenge to the ideology of the revisionist movement 


\section{Chapter 6: The Rise and Fall of The Peace Process}

If the seventies and eighties saw the emergence of a struggle between Israel's political movements to redefine Zionism and "Israeliness" according to their respective ideologies, the nineties were the ultimate showdown in this battle, leading to turbulent events that would affect Israel and the region in unprecedented ways. The most important of these developments was the signing of the Oslo Accords in September 1993. The agreement was akin to the Six Day War in that it would immensely impact Israel's political movements and as a result influence both the domestic and external politics of the country.

Thus far this dissertation has examined the ideological evolution of Israel's three main political movements in the decades leading up to the peace process. As the following pages will demonstrate this will allow us to take a fresh look at Israel's pursuit of a peace deal with the Palestinians in the early nineties, and the country's subsequent decision to formally continue with the negotiations, while halting or slowing down its progress in practice. This chapter argues that the political agreement signed with the Palestinians was the result of the interaction between Labor's new liberal ideology, discussed earlier, and the international events of the late eighties and early nineties. Labor's new ideology effectively allowed the movement to interpret global developments in an optimistic light, allowing it to reassess Israel's "security dilemma" and adopt a new foreign policy approach to the "Palestinian question." In contrast the religious Zionists, together with their revisionist allies, would prevent the "Hellenization" of the Israeli state by bringing down the government of Yitzhak Rabin and the peace process with it. 
Finally this chapter makes the unconventional argument that the peace process has brought about a significant ideological crisis within the revisionist movement, which has yet to be resolved in a conclusive manner.

\section{The Rabin Government and the Oslo Peace Process}

In order to understand the Labor movement's drive to peace we must first analyze the 1992 elections. As Asher Arian notes, it was the results of the 1992 elections that made the breakthrough in negotiation with the PLO in the summer of 1993 possible. ${ }^{462}$

\section{The 1992 Elections}

As a result of the 1992 elections, Likud lost 8 of its seats bringing its Knesset share to 32 , while Labor won 5 seats bringing its share of seats to 44 . This marked a significant turning point in Israeli politics, since as a result of the elections the 15-year rule of Likud was now over. ${ }^{463}$ In fact the 1992 elections was the second government turnover in the 44 years since Israel's founding, with the first one being the 1977 elections. This is why the election came to be known as the Mahapach ("reversal" or "turnabout"), signifying the reversal of the 1977 election results. In fact up until then the term Mahapach was primarily used to refer to the 1977 elections. After the elections, the Labor party was able to form a

${ }^{462}$ Arian and Shamir, The Elections in Israel, 1992, 1.

${ }^{463}$ In the 1984 and 1988 Knesset elections neither Labor nor Likud was able to win a meaningful advantage over the other, and as a result the two parties had to agree to a power sharing arrangement. 
coalition government with the secular Meretz party, which now had 12 Knesset seats, and the "non-Zionist" ultra-Orthodox Shas party. This was the most "dovish" coalition in Israeli history, with no party to the right of Labor as part of the coalition. More importantly, for the first time in Israeli history the religious Zionists were not part of a governing coalition for a considerable length of time. ${ }^{464}$

During the elections the Labor party, which was unambiguously in support of some sort of territorial withdrawal and political compromise with the Palestinians, correctly understood that the peace movement, which had emerged in the past decade and a half, including within its own ranks, would not provide it with sufficient numbers to defeat the reigning Likud. As a result the party tried hard to move to the center of the political spectrum and attract centrist voters. As part of this effort, the whole idea of territorial compromise in the West Bank was dropped from the party's campaign. In fact Rabin would explicitly state that there would be no withdrawal from the West Bank during his first term in office. ${ }^{465}$ Instead the party said that it would adopt Menachim Begin's Camp David "autonomy plan" for the Palestinians, a much more conservative position which was in fact also Likud's official position during the elections.

\footnotetext{
${ }^{464}$ From 1948-1992, except for very short periods in $1958-1959$ and in 1974, Religious Zionist parties were part of every single governing coalition. In the first Israeli government the religious Zionists were part of the 'United Religious Front' alliance. In the second to sixth governing coalitions the Mizrachi party represented them. From the seventh Israeli government formed in 1955 to the $24^{\text {th }}$ Israeli government that ruled until 1992, the religious Zionists were part of almost every government coalition as the National Religious Party.

${ }^{465}$ Elazar and Sandler, Israel At The Polls, 1992, 12-13.
} 
To differentiate himself from Shamir, Rabin promised the Israeli public that he would reach an agreement with the Palestinians regarding autonomy arrangements within six to nine months after taking office. ${ }^{466}$ In contrast, Labor argued that the Likud had "failed" in such negotiations, which had started nearly a year earlier in Madrid. The centrist position Labor took was ultimately successful in giving it a meaningful edge over the Likud. In fact Labor was even successful in attracting the votes of people who had voted in the 1988 elections for Likud. Polls of such individuals found that the main reason they changed their vote was because of Likud's policy of diverting state funds in favor of the settlements. ${ }^{467}$

The main reason why Labor was able to attract the center vote was because of Yitzhak Rabin's exemplary security background. In fact the Labor leader was never considered a "dove" and was usually associated with the "hawkish" wing of the Labor movement. ${ }^{468}$ The center vote in Israel has always been worried about the "softness" of Labor on national security issues. To combat this, the party constantly utilized Rabin's impeccable security credentials during the election campaign, with the party's main slogan during the elections being "Israel is waiting for Rabin," which reminded the voters of the once popular

\footnotetext{
${ }^{466}$ Inbar, "Labor's Return to Power," 35.

${ }^{467}$ Arian, Security Threatened: Surveying Israeli Opinion on Peace and War, 154.

${ }^{468}$ Inbar, "Labor's Return to Power," 30.
} 
1967 war song "Nasser is Waiting for Rabin." ${ }^{469}$ Indeed not only was Rabin chief of staff during the fateful Six Day War, but he was also defense minister during the Intifada. Rabin was perceived to have a "tough" stance regarding "the Arabs." During the elections he declared that he would not invite Arab parties to the coalition, a promise he kept after the elections when he formed the new government. ${ }^{470}$ Moreover, according to Labor's elections campaign, Rabin was not timid when force was "necessary." In fact during the first weeks of the Intifada he had reportedly directed soldiers to "break their bones." Although Rabin later denied ever saying the three words, ${ }^{471}$ they were enough to give him an image that portrayed him as "tough on security matters." The Labor leader's history effectively placed him in the middle of Israel's political spectrum. In fact Rabin's campaign advertisement had Rabin's picture with a caption on each side of the Labor leader, saying "no to the extreme right" and "no to the extreme left." 472

The fact that Rabin, the ultimate Sabra, was going to lead the peace talks reinforced the discourse that even though he was seeking political arrangements with the Palestinians, he would never "endanger Israeli security." This is why

\footnotetext{
${ }^{469}$ Hassan A. Barari, Israeli Politics and the Middle East peace process, 1988-2002 (New York: Routledge, 2005), 65.

${ }^{470}$ Inbar, "Labor's Return to Power," 35.

${ }^{471}$ Libby Hughes, Yitzhak Rabin: From Soldier to Peacemaker (Lincoln: iUniverse, 2005), 95.

472 Inbar, "Labor's Return to Power," 33-34.
} 
Rabin came to be known as a "soldier for peace." ${ }^{\text {"73 }}$ In fact one of the main goals of the peace process in the eyes of many Israelis was to increase security. A Gallup poll a month before the elections revealed that 39 percent of Israeli voters ranked security as their highest priority during the elections compared to 22 percent who identified the peace talks as their highest priority. Even among people who said they were going to vote for Labor in the upcoming elections, security and peace negotiations both stood at 39 percent. ${ }^{474}$

This is why Labor's slogan during the elections was "Peace with Security." Even on the highly polarizing settlement issue, Rabin claimed that he was against Likud's "political settlements," and that he in fact supported "security settlements" that protected Israel, such as those in the Jordan valley. In contrast, Rabin argued that the "political settlements" did not contribute to Israel's security and in cases where they were very close to Palestinian population centers, they actually put a burden on Israel's security apparatus. ${ }^{475}$

The reason why the preceding discussion is very important is because it displays that the peace camp in Israel never included a majority of the Israeli public, including in the 1991-1993 period, which was the pinnacle of the group's

\footnotetext{
${ }^{473}$ Leslie Derfler, Yitzhak Rabin: A Political Biography (New York: Palgrave Macmillan, 2014), $177-178$.

${ }^{474}$ Gerald M. Steinberg, "A Nation That Dwells Alone? Foreign Policy in the 1992 Elections," in Israel at the Polls, 1992, by Daniel J. Elazar and Shmuel Sandler (Lanham: Rowmand \& Littlefield Publishers, 1995), 185.

${ }^{475}$ See Sven Behrendt, The Secret Israeli-Palestinian Negotiations in Oslo: Their Success and Why The Process Ultimately Failed (New York: Routledge, 2007), 64-65; Inbar, "Labor's Return to Power," 34-35.
} 
power and success. Rather the movement was only able to influence Israeli foreign policy after winning the support of the Israeli center by promising increased security and stability as a result of the peace process. This is critical in understanding the fall of the peace process, which is addressed in future sections. At the same time Israel's new security status during the early nineties is also crucial in understanding why important Labor leaders, including "hawks" such as Rabin, came to adopt new slogans and policies.

\section{A New Balance of Power or a New Liberal Zionist Identity?}

As discussed in the introductory chapter of this dissertation, realist international relations scholars argue that in the early nineties the power of the US and Israel soared while the Arabs and particularly the PLO were at their weakest. Therefore the time was set for Israel to achieve a favorable settlement before the balance of power in the Middle East changed. This new balance of power was a result of the collapse of the USSR, the chief ally of Arab countries and the main global rival to American power. Moreover the Iraq War of 19901991 had badly humiliated and weakened the Arabs. Even worse was the fact that the PLO had supported Saddam's invasion of Kuwait, the result of which was the breakdown of the organization's relationship with Arab countries, which until then had funded and supported the group. These events had left the PLO very weakened. In contrast the period was the peak of American power in the region.

This is why Avi Shlaim argues that Israeli Prime Minister Yitzhak Rabin believed that the PLO was "on the ropes" and was therefore highly likely to drop 
some of its main principles and demands. ${ }^{476}$ The new balance of power would effectively allow Israel to seek peace according to terms that were highly in its favor, bringing the country significant political, economic and public image success in the years after the agreement. For example Israel was able to reach a peace deal with Jordan, end the Palestinian Intifada, boost its economy and repair its relations with the United States. In response, other scholars have argued that the rise of a new "post-material" or liberal identity within Israeli society that was deeply tied to the peace process was responsible for Israel's decision to negotiate with the Palestinians. ${ }^{477}$

Explaining Labor's decision to engage in the Oslo peace process however does not necessarily have to be an either-or decision between identity politics and the new realities of the balance of power in the Middle East. Rather this chapter argues that it was the interaction between the new and emerging liberal identity within the Labor movement and Israel's new security situation that allowed and compelled Labor leaders to engage in a political compromise with the Palestinians. Had Labor not witnessed the ideological embrace of Western liberal values discussed in the previous chapter, it is doubtful that the movement

${ }^{476}$ Avi Shlaim, The Iron Wall: Israel and the Arab World (Updated and Expanded) (New York: W.W. Norton, 2014), 533.

${ }^{477}$ See for example Barnett, "Culture, Strategy and Foreign Policy Change: Israel's Road to Oslo"; Rynhold, "Cultural Shift and Foreign Policy Change: Israel and the Making of the Oslo Accords." 
would have ever engaged in the peace process, which signified a dramatic shift from Israeli policy up until then.

This is why the 1992 elections were a turning point in Israeli history. The elections were not simply about which party would lead the country, rather more accurately they can be described as a referendum about not only the future of the territories, but also about the kind of Israel people envisioned for the future. The Israeli public's answer was not overwhelmingly in one direction. Indeed the Labor movement was only able to win a slight majority over its opponents, and even then by shifting its discourse to the middle of the political spectrum. Nevertheless as discussed earlier, the Labor movement undeniably witnessed an ideological evolution during the late $70 \mathrm{~s}$ and $80 \mathrm{~s}$ in response to the rise of a militant religious settler movement. Future sections provide more evidence of Labor's ideological evolution. It was this ideological change that enabled Labor to interpret external developments differently from the revisionist and religious Zionist movements.

Not only had the balance of power changed in the Middle East during the late eighties and early nineties, but also there were other important developments. In August 1988, Jordan officially renounced its claims to the West Bank and designated the Palestine Liberation Organization as the "sole legitimate representative of the Palestinian people." 478 The change in the

\footnotetext{
478 John Kifner, "Hussein Surrenders Claims on West Bank to the PLO; US Peace Plan in Jeopardy," The New York Times, August 1, 1988.
} 
Hashemite Kingdom's position regarding the West Bank, a territory it had ruled over from 1948 to 1967 , was very significant in that it completely closed the "Jordanian Option" in Israeli political circles, an option which entailed handing the West Bank back to the Jordanians, as opposed to allowing the creation of a Palestinian state, which was believed to be a much more "negative" scenario.

The following December, Yasser Arafat, the chairman of the PLO, addressed the United Nations, renouncing terrorism and calling for negotiations with the Israelis to agree to a territorial partition that would settle the decades old conflict. While inside Israel many criticized Arafat's lack of sincerity, the United States formally commenced dialogue with the PLO, a dramatic change in American foreign policy regarding the conflict and a move that signified the beginning of unprecedented pressure on Israel to reach a political settlement with the Palestinians. These pressures reached their peak when the Bush administration suspended a 10 billion dollar loan to the Jewish state in protest of settlement activity in the territories.

In fact the above developments were so significant that they forced the Israeli revisionist government of Yitzhak Shamir to very reluctantly participate in the Madrid Peace Conference of 1991. While the participation of Israel in the American sponsored conference held important symbolic value, it is important to note that it did not lead to any tangible progress in resolving the Israeli- 
Palestinian conflict. In fact Shamir candidly stated during an interview with Ma'ariv newspaper right before leaving office in 1992, "What is this talk about 'political settlements'? I would have carried on autonomy talks for ten years and meanwhile we would have reached half a million people in Judea and Samaria. ${ }^{\not 79}$ It is interesting to note that the Israeli Prime Minister doesn't even talk about stonewalling a Palestinian state, but rather about stonewalling "autonomy talks." In fact "waiting out" international pressure would become a cornerstone of revisionist strategy regarding the peace process, a topic that is discussed in future sections.

Had the "objective" changes in the balance of power in the Middle East cited by realist international relations scholars, coupled with the important external developments cited above been the prime reason behind Israel's decision to pursue a peaceful resolution of its conflict with the Palestinians, then such a policy should have been pursued by the revisionist government of Shamir. In fact all the external changes cited thus far took place during the reign of the revisionists and not during the Labor government of Yitzhak Rabin. In reality however the important international developments of the late eighties and early nineties did not result in any significant reassessment of policy by the revisionist government. This is why a more accurate explanation of Israeli foreign policy behavior during the early nineties can only be achieved when we consider the

\footnotetext{
${ }^{479}$ Quoted in Shlaim, The Iron Wall: Israel and the Arab World, 500.
} 
ideological orientation of Israel's domestic political movements and how they interpreted external events.

The revisionist movement saw the developments of the late 80 s and early 90s as only temporary and superficial. After the Iraq War of 1990-1991 for example, Shamir declared in a Jerusalem Post interview, "there is a constant threat to our existence. ${ }^{480}$ In his 1992 Independence Day message, the Israeli Prime Minister declared: "The dangers facing us and the threats to our security have not abated. A host of terrorist organizations continue to attack Israel, its citizens, and missions abroad. And Arab governments are making every effort to acquire massive quantities of arms and weapons of mass destruction. In spite of the end of the Cold War, our region has not become safer." ${ }^{481}$ Yossi Ahimeir, an aid to the Prime Minister, summarized the point by saying that Shamir saw the end of the Cold War as "belonging to another world," and as far as he was concerned, the "rules of the game" in the Middle East remained the same. ${ }^{482}$

Therefore revisionist ideology, which constantly emphasized the existential danger facing Jews, distrust of an "anti-Semitic gentile world", the "eternal" and "intrinsic" hostility of the Arabs, and the need for military power and

\footnotetext{
${ }^{480}$ Quoted in Waxman, The Pursuit of Peace and the Crisis of Israeli Identity, 87.

481 Independence Day Message by Prime Minister Shamir- 7 May 1992, Volume 11-12: 19881992 (Israel Ministry of Foreign Affairs, May 7, 1992), http://mfa.gov.il/MFA/ForeignPolicy/MFADocuments/Yearbook8/Pages/271\%20Independence\%2 0Day\%20Message \%20by\%20Prime\%20Minister\%20Sha.aspx.

${ }^{482}$ Quoted in Waxman, The Pursuit of Peace and the Crisis of Israeli Identity, 87.
} 
force as the only viable solution, saw the aforementioned global developments as part of the "same old" world Jews had been living in for centuries. Even more cynically, some revisionist saw recent events as unprecedented proof of their ideological belief system. When American pressure on Israel increased for example, Bush and Baker were repeatedly cast as "anti-Semitic" in revisionist discourse, particularly in regards to the freezing of the $\$ 10$ billion loan Israel wanted. ${ }^{483}$ Moreover when Israel was asked to stay out of the Persian Gulf War even after being attacked with scud missiles, the revisionists saw this as further evidence of Israel being thrown under the bus by the Americans. In fact the war demonstrated that Israel could "no longer rely" on the Americans for strategic deterrence..$^{484}$

In regards to the Palestinians, their new "peaceful" approach was seen as only a tactic to force Israel to withdraw from the strategic territories it held, making it weaker politically and militarily, and ready for the "final destruction" of the Jewish state by the Arabs. Shamir who had lost most of his family in the Holocaust, much like Menachem Begin, believed that not much had changed in the world since the dark days of the Shoah. That's why he openly declared that Israel would never relinquish "Judea and Samaria." 485

${ }^{483}$ See Steinberg, "A Nation That Dwells Alone? Foreign Policy in the 1992 Elections," 184.

${ }^{484}$ See Vipin Narang, Nuclear Strategy in the Modern Era: Regional Powers and International Conflict (Princeton: Princeton University Press, 2014), Chapter 7.

${ }^{485}$ Yael S. Aronoff, The Political Psychology of Israeli Prime Ministers (New York: Cambridge University Press, 2014), Chapter 2. 
In the religious Zionist camp the developments of the late 80 s and early 90s only emboldened the resolve of the settler movement to prevent any relinquishing of territory and the creation of a Palestinian state. Moreover such sentiments weren't only limited to the leaders of the revisionist and religious Zionist movements. For example a 1993 poll found that 60 percent of Israelis believed that the ultimate goal of the Arabs was the destruction of Israel, in spite of the ongoing peace negotiations. ${ }^{486}$ This is why the changes in Labor's ideology during the seventies and eighties, resulting in the emergence of a liberal Zionist identity, are so critical in understanding the movement's different understanding of external developments and subsequent alternative approach than that of Likud and the religious Zionists.

\section{Labor's New Liberal Ideology}

Labor's new approach to the territories and the Palestinians in the nineties cannot be simply categorized as merely a different policy approach in response to Israel's new circumstances. When analyzing the behavior of political movements it can be difficult to differentiate between real ideological change and policy changes adopted because of political necessities. To differentiate between the two we must look at the behavior of a movement throughout time and in different areas and under various circumstances. Real ideological change is defined as significant alterations to a movement's worldview that is accepted by a

\footnotetext{
${ }^{486}$ Steinberg, "A Nation That Dwells Alone? Foreign Policy in the 1992 Elections," 178.
} 
majority of its members. As a result ideological change manifests itself in the adoption of new policies and rhetoric that are consistent and long-term. In contrast when a movement adopts new policies for tactical advantages and expediencies, the policies and the rhetoric used to justify them are dropped as soon as the circumstances change.

There is ample evidence to prove that Labor's drive to peace during the 90s was a result of the evolution of its ideology, rather than a mere tactical adoption of a new policy. As the previous chapter discussed, during the 80 s the Labor movement's ideology evolved in favor of Western liberal values that sought to make Israel more democratic and inclusive. It also sought to make Israel a "normal" member of the Western world. In contrast to the religious Zionist movement that emphasized Israel's "uniqueness" and "divine right" to the territories and in contrast to the revisionist worldview that saw Israel as pitted alone against a hostile gentile world, a view that was shared to a large extent by the Labor movement before the transformation of its ideology. This is why Yitzhak Rabin, in his first address to the Knesset as Prime Minister on July 13, 1992, declared that

No longer are we necessarily "a people that dwells alone" and no longer is it true that the "whole world is against us." We must overcome the sense of isolation that has held us in its thrall for nearly half a century. We must join the international movement toward peace, reconciliation and cooperation that is spreading over the entire globe these days. Lest we be the last to remain, all alone, in the station. The new government has 
accordingly made it a prime goal to promote the making of peace and take vigorous steps that will lead to the resolution of the Arab-Israeli conflict. ${ }^{487}$

It was this new worldview that allowed Labor leaders to understand international developments in a new light and seek a political compromise with the Palestinians. Moreover the Labor movement has been consistent and unbending in its new approach starting from the early nineties until today. Such consistency for over two decades, despite the many challenges the peace process has witnessed and despite the political turmoil the movement has faced, allows us to understand Labor's shift of policy as the result of a change in ideology and not a mere tactical policy adoption. Had Labor's drive for peace in the nineties been the result of policy adjustments based on political circumstances, rather than actual ideological change, then the movement would have dropped the approach following the decline of the peace process and the movement's consecutive electoral defeats. Moreover Labor's domestic policies during 1992-1996 period also provides evidence of its new liberal ideology.

In the lead up to the 1992 elections, Labor for the first time opened up the selection process of its Knesset candidate list as well as its nominee for prime minister to its entire party membership of around 160,000. Reforming the party's

\footnotetext{
${ }^{487}$ Yitzhak Rabin, Address to the Knesset by Prime Minister Rabin Presenting His Government13 July 1992 (Israel Ministry of Foreign Affairs, July 13, 1992), http://www.mfa.gov.il/mfa/foreignpolicy/mfadocuments/yearbook9/pages/1\%20\%20address $\% 20$ to $\% 20$ the $\% 20$ knesset $\% 20$ by $\% 20$ prime $\% 20$ minister\%20rabin.aspx.
} 
primaries mechanism was aimed at democratizing the party internally. ${ }^{488}$ The new selection process also energized and empowered the rank and file of Labor, which until then had been regularly criticized by its opponents as being very "elitist." Moreover Rabin promised the Israeli public that upon winning the elections he would pass a law in the Knesset that would entail the direct election of the prime minister. In line with his promise and in a move to make Israeli politics more democratic and stable, the Labor leader was successful in passing The Direct Election Law for Prime Minister several months after taking office. ${ }^{489}$ As a result of the new law separate elections for the premiership would be held in 1996, 1999 and 2001 before the law was scrapped in favor of the previous pure parliamentarian system. ${ }^{490}$

Labor's new liberal ideology also manifested itself in the movement's drive to reform Israel's educational system in favor of liberal values such as democracy, human rights and multiculturalism. After taking office, Rabin appointed Shulamit Aloni, the staunchly secular and feminist Meretz leader, as the new Minister of Education. Aloni together with labor leader Micha Goldman, who was appointed as deputy minister, initiated a wide-ranging reform of state-

\footnotetext{
${ }^{488}$ See Arian and Shamir, The Elections in Israel, 1992, 13; Elazar and Sandler, Israel At The Polls, 1992, 4.

489 See Assaf Meydani, Political Transformations and Political Entrepreneurs: Israel in Comparative Perspective (New York: Palgrave Macmillan, 2009), 92-93.

${ }^{490}$ Michael Omer-Man, "This Week in History: Israel's Last Direct Election," The Jerusalem Post, February 5, 2012.
} 
issued textbooks that was aimed at including the country's non-Jewish citizens in the country's historical and cultural discourse. Goldman also unsuccessfully sought to change the country's national anthem, titled as Hatikva ("The Hope"), in favor of a new anthem "in order to give expression to citizens who are not Jews." In 1995 Labor initiated a controversial revision of the highly important State Educational Law in order to teach Israeli students "democratic values," "the love of mankind," "the equality of fundamental rights of all citizens of Israel," as well as "the language, culture and unique heritage of the various population groups of the country." Religious Zionists pointed out that the new law had purposefully removed the three main pillars of the previous law which were "the values of Jewish culture," "loyalty to the Jewish people," and "love of the homeland." ${ }^{491}$ The government-endorsed reform bill passed a preliminary vote in the Knesset, however before it would become law, it was scrapped after Likud took over government following the 1996 elections.

Not all of Labor's efforts at reforming the educational system would end up fruitless however. For example in 1994 the Education Ministry was successful in mandating the teaching of "high school civics" to all students which included goals such as "to work to realize" democratic values, human rights and civil

\footnotetext{
491 See Yoram Hazony, "The Zionist Idea and Its Enemies," Commentary, May 1, 1996; Amnon Rubinstein, "Post-Zionism," Commentary, October 1, 1996; Yoram Hazony, The Jewish State: The Struggle for Israel's Soul (New York: Basic Books, 2001), 41-43.
} 
rights. ${ }^{492}$ A new "civics curriculum" was also introduced to create a common core curriculum for all state schools including Arab and religious schools. The Ministry openly declared that the objective was to "inculcate a common Israeli civic identity, together with the development of distinct national identities, and to impart to students the values of pluralism and tolerance, educate students to accept the diversity that exists within Israeli society." ${ }^{493}$ The Religious Zionist movement however was deeply troubled with such moves and charged that during Rabin's tenure the Education Ministry was seeking to deemphasize Judaism and even Zionism from the educational system. This is discussed in future sections of this chapter.

Also while Rabin refused to invite Arab parties to his coalition, shortly after taking office he appointed two Arab-Israelis as deputy ministers. ${ }^{494}$ Also the Labor led government increased state funding for educational and welfare services and benefits for Arab citizens. The Labor led government also built dozens of health clinics in Arab-Israeli communities. Palestinian critics of the government however argued that these moves did little to improve the economic well-being of Arab citizens and only made them more dependent on the

\footnotetext{
${ }^{492}$ Kenneth Levin, The Oslo Syndrome: Delusions of a People Under Siege (Smith and Kraus, 2005), 373.

${ }^{493}$ Quoted in Orit Ichilov, Dan Inbar, and Avriel Salomon, "Citizenship Education in Israel - A Jewish-Democratic State," Israel Affairs 11, no. 2 (April 2005): 314.

494 "Cabinet Picks Israeli Arabs for High Posts: Mideast: Two Are Named Deputy Ministers. Appointments Are First of Their Kind in 19 Years.," Los Angeles Times, August 3, 1992.
} 
government. ${ }^{495}$ At the same time these initiatives, which Labor hoped would fulfill the rights of Arab-Israelis, were strongly criticized by religious Zionists, who essentially believed that Israel should only cater to Jews, to which Rabin replied, "It is time, once and for all, to decide whether the Israeli-Arab public is an integral part of Israel. Those who claim that it is not should come out and apologize to those Arabs whose votes they had solicited." ${ }^{496}$ The Rabin government was also successful in passing a series of amendments to Israel's Basic Laws, which serve as substitutes for a constitution, that focused on 'citizens' rights and human dignity." The introduction of the new laws which came to be known as the "constitutional revolution" increased civil liberties and rights, especially for women. ${ }^{497}$ Rabin would also state that his ultimate goal was to "forge a constitution for the state." 498

Although many of the above progresses were halted and even reversed when Likud took power in 1996, the above examples demonstrate that Labor's behavior in the early 90 s was not limited to only new policies in the foreign policy

${ }^{495}$ See Derfler, Yitzhak Rabin: A Political Biography, 172-173.

${ }^{496}$ Quoted in Myron J. Aronoff and Pierre M. Atlas, "The Peace Process and Competing Challenges to the Dominant Zionist Discourse," in The Middle East Peace Process: Interdisciplinary Perspectives, ed. Ilan Peleg (Albany: State University of New York Press, 1998), 45.

${ }^{497}$ See Daniel J. Elazar and Shmuel Sandler, Israel at the Polls, 1996 (New York: Routledge, 2013), 10; Kimmerling, The Invention and Decline of Israeliness: State, Society, and the Military, 54-55; Itamar Rabinovich and Jehuda Reinharz, Israel in the Middle East: Documents and Readings on Society, Politics, and Foreign Relations, Pre-1948 to the Present (Lebanon: Brandeis University Press, 2008), Chapter 7.

${ }^{498}$ Quoted in Rabin, The Rabin Memoirs., 393. 
realm, but was rather driven by an entire worldview based on liberal Western values that manifested itself in wide ranging areas from culture and politics to education and law. Labor's new ideology was a significant departure from its earlier hegemonic approach of the 40 s and 50 s, discussed in chapter 4 , in which even Mizrahi Jews were not tolerated, let alone Arab-Israelis who under Labor's leadership suffered under an oppressive martial law that lasted from 1949 until 1966.

Therefore Labor's new foreign policy approach should be seen as the result of a larger ideological transformation in favor of liberalism that empowered the movement to seek a political settlement with the Palestinians. Three important points however need to be mentioned about this new liberal approach: first, while the new liberal identity that had emerged in the Labor movement was imperative in the decision to seek peace, it was the interaction of this new identity with external developments that led to a new foreign policy direction. Secondly this new liberal identity was not primarily about granting Palestinian rights, rather the occupation of the territories was turning Zionism and Israel into the opposite of what the movement envisioned. Finally, while this new ideology and the liberal identity it entailed influenced a large and important segment of the Labor movement, it would be incorrect and misleading to attribute such a transformation to Israeli society as a whole. If anything the peace process, from its inception, highly polarized Israeli society as never before, a society that had never ascribed to a single ideology and identity, even during the hegemony of Labor in the pre-state period. These three issues are discussed below. 


\section{The Interaction Between Political Identity and External Events}

The events of the $80 \mathrm{~s}$, including the Lebanon War, the terrorism of the Jewish underground and finally the Intifada had been traumatic for the Labor movement in the sense that they had challenged the narrative of Israel as the weak and alone "David" pitted against the more powerful "Arab Goliath," a narrative that had played an important role in the shaping of the movement's ideology up until then. No longer was Israel a weak and isolated state, and no longer were its adversaries numerous Arab armies. As previously discussed this led to a reassessment of the movement's ideology in favor of democratization, normalization and Westernization. As a result of this change, the movement adopted a new foreign policy worldview in which Israel was no longer required to constantly "live by the sword," rather it was now empowered to rely on political negotiation and compromise to ensure its security and interests.

This new worldview allowed the Labor movement to interpret the important developments of the early nineties, such as the collapse of the USSR and the emergence of a new unipolar world in favor of the US, to reassess Israel's security situation. In the early nineties the Labor movement believed that an attack by an Arab army on Israel was highly improbable, a condition completely unlike their security assessment of the past decades. In fact Labor leaders believed that for the first time in its history Israel faced no real existential threats. These sentiments weren't limited to the party elite either. In 1987, 57 percent of the Israeli public believed that a war with Israel's Arab neighbors was probable or 
very probable in the next three years, compared to 43 percent in $1994 .{ }^{499}$ Arian also reports that the Security Index, a scale made up of nine items measuring the security attitudes of Israelis in which a higher number signifies lower feelings of security and more "hawkish" approaches to ensuring it, decreased from 3.1 in 1987 to 2.6 in $1993 .{ }^{500}$

Labor's new liberal ideology effectively empowered it to reassess Israel's strategic security needs based on recent regional and global developments. Labor leaders such as Rabin and Peres now believed that Israel could "afford" a partial withdrawal from the territories and the granting of Palestinian autonomy. ${ }^{501}$ Rabin himself declared, "We live today in a period in which the threat to the very existence of Israel has been reduced." ${ }^{502}$ It is based on this new strategic assessment that Rabin openly declared that he was willing to negotiate a withdrawal from the Golan Heights captured from Syria in 1967, even though holding on to these territories in no way challenged the values of the new liberal Zionist identity of the Labor movement. There was no "occupation" or Intifada in the Golan Heights, nor was there much international pressure regarding it.

${ }^{499}$ Arian, Security Threatened: Surveying Israeli Opinion on Peace and War, 55.

500 Ibid., 92.

501 The transition of Peres from a hawk to a dove serves as a perfect example for the influence of perception of increased security in this change. He himself explains that he only changed his position after Israel became capable of building nuclear weapons, adding, "because until Dimona, the Arabs were sure they could destroy us." Quote in Patrick Martin, "We Are the Only Country That Is Threatened to Be Destroyed," The Globe and Mail, May 5, 2012.

${ }^{502}$ Quoted in Efraim Inbar, Rabin and Israel's National Security (Washington D.C.: The Woodrow Wilson Center Press, 1999), 135. 
Rather Labor's new worldview had allowed it to interpret new international developments in a positive light. In an important address to the IDF in 1993 Rabin declared "The world is no longer against us...States that never stretched their hand out to us, states that condemned us, that assisted our bitterest enemies...regard us today as a worthy and respectable address...This is a new reality." 503

The Labor movement effectively came to the conclusion that the new state of affairs had ended centuries of isolation and persecution, that Israel was no longer facing an existential threat and that it had become a nation like all others. Research by Asher Arian has shown that when perceived threat is lower among Israelis, there is greater willingness to cede land and to grant civil rights to the Palestinians. ${ }^{504}$ This why we must understand the turn in Israeli foreign policy during the early nineties as the interaction between the new liberal Zionist identity of the Labor movement and the new positive external conditions Israel now lived in. Had any of these two factors been missing, it is improbable that the Labor movement would have negotiated a withdrawal from the territories.

\section{The New liberal Zionist Identity and Palestinian Rights}

While the new liberal Zionist identity was a critical element in Labor's new peacemaking endeavor, which would effectively result in granting Palestinians political rights in the territories, it is important to note that this new identity was

\footnotetext{
${ }^{503}$ Quoted in Waxman, The Pursuit of Peace and the Crisis of Israeli Identity, 98.

${ }^{504}$ See Arian, Security Threatened: Surveying Israeli Opinion on Peace and War, 29.
} 
not primarily based on such a goal or even on a withdrawal from the territories. Thus it would be incorrect to characterize this new identity as intrinsically "tied" to the peace process. Rather the liberal identity was primarily shaped in opposition to the religious settler identity, which sought to turn Israel into a religious, unique and messianic nation. In contrast the new liberal identity increasingly came to value democracy, ${ }^{505}$ inclusiveness, and good relations with the West, particularly the United States. The reason a withdrawal from the territories became a core demand of the movement was because the policies of the settler movement and their revisionist allies had resulted in the creeping annexation of the territories, as a result of which Israel would essentially become a bi-national state. Such a scenario would mean that Israel would either have to deny the new Palestinian residents of Israel citizenship rights, effectively turning it into an apartheid state, or to cease being a Jewish majority state, considering the higher birth rate of Palestinian Arabs. In a September 1995 interview, shortly before his death and after the signing of the West Bank Agreement, which came to be known as Oslo II, Rabin clearly explained this:

I believe that dreams of Jews for two thousand years to return to Zion were to build a Jewish state, not a bi-national state. Therefore I don't want to annex the 2.2 million Palestinians who are a different entity from us politically, religiously, nationally... Therefore I see peaceful coexistence between Israel as a Jewish State - not all over the land of Israel, on most of it, its capital the United Jerusalem, its security border the Jordan river -

\footnotetext{
${ }^{505}$ For example the 1992 elections were significant within the Labor itself, since they marked the first time in the party's history when the leader of the party and the Knesset list was determined using a democratic primary system in which voting was open to all 160 thousand members of the party.
} 
next to it a Palestinian entity, less than a state, that runs the life of the Palestinians. ${ }^{506}$

As Efraim Inbar notes, while Rabin was vague and conflicted about his goals in the Oslo process, "the only thing Rabin continued to insist on was his reluctance to rule over a large number of Arabs, which could lead to a bi-national state." ${ }^{507}$ Moreover the Labor movement highly emphasized the need for "separation" between Israelis and the Palestinians in the territories. Not only was this needed to preserve the "Jewish character" of Israel but also Rabin and other Labor leaders emphasized that it would also improve the security of Israeli citizens, which had been threatened by the nearly five-year-old Intifada. Not only were the settlements blocking such separation, but they were also endangering Israeli security by preventing the political settlement of the conflict. The settlements had also become the major point of contention in US-Israel relations. The breakdown of this relationship during the tenure of Shamir and the withholding of $\$ 10$ billion dollars of loan was highly utilized by the Labor movement in its attack against the revisionists during the elections. ${ }^{508}$

Thus the settlement and eventual annexation of the territories threatened Israel's democratic character, since granting voting rights to the new Palestinian

\footnotetext{
${ }^{506}$ Quoted in Efraim Karsh, From Rabin to Netanyahu: Israel's Troubled Agenda (Abingdon: Frank Cass and Co., 2004), 138.

507 Inbar, Rabin and Israel's National Security, 153.

${ }^{508}$ See Asher Arian and Michal Shamir, "Two Reversals: Why 1992 Was Not 1977," in The Elections in Israel, 1992, n.d., 46-49.
} 
citizens would effectively mean the end of political Zionism, which was established to achieve a "Jewish State," it also threatened the value of "inclusiveness" since it would bring an overwhelmingly large population with a foreign culture, religion and history into the Jewish nation. Instead the new ideology of the Labor movement sought inclusiveness of suppressed political groups within Israeli society such as Mizrahi Jews and Israeli-Arabs.

Finally the settlements were barring Israel from becoming a "normal" member of the democratic West and were bringing US-Israel relations to a breaking point. Hypothetically speaking if the population of the territories was small, and there was no international pressure to withdraw from them, it would be difficult to see how the occupation of the territories would clash with the new ideology of the Labor movement. This does not preclude the fact that some specific individuals within the Labor movement cared about Palestinian nationalism, nevertheless such concerns were not the primary driving force of Labor's ideology and were never shared by a majority of the movement. Rather, Labor's main concern was the nature of Israel and Zionism, which had come under "threat" due to the policies of the revisionist and religious Zionist movements during the past one and a half decades.

Thus the pursuit of the peace process should not be seen as a result of any fundamental changes in Israeli views towards the Palestinians. A 1994 poll conducted by Asher Arian for example reported that over 80 percent of Israelis said that their attitude toward the Palestinians had either not changed or had 
worsened after the signing of the Oslo Accords. ${ }^{509}$ As Dov Waxman notes, even after the onset of the peace process "many Israeli Jews were accustomed to regarding the Palestinians- long their collective enemy—with suspicion and even hatred (and vice versa)." 510

Moreover Labor leaders such as Rabin leaned heavily toward the "autonomy option" rather than allowing the creation of a Palestinian state. The late Israeli leader repeatedly stressed such a position. Moreover neither the Oslo Declaration of Principles, nor the Interim Agreement on the West Bank and the Gaza Strip (Oslo II), both of which were signed on the Israeli side by Rabin, stipulated the creation of a Palestinian state, regardless of the understanding of the Palestinian side. In fact the lengthy Oslo II document does not refer to a "Palestinian state" even once, rather it sets forth the conditions for an "Interim Self-Government" run by an elected "Palestinian Council."

Shlomo Ben-Ami, a notable Labor leader and Foreign Affairs Minister during the government of Ehud Barak, wrote years later in his book that neither Rabin nor Shimon Peres "wanted autonomy to usher in a Palestinian state," adding that in 1997, four years after the onset of the Oslo negotiations, when he, as the chairman of the party's foreign affairs committee, proposed that Labor

\footnotetext{
${ }^{509}$ Arian, Security Threatened: Surveying Israeli Opinion on Peace and War, 89.

${ }^{510}$ Waxman, The Pursuit of Peace and the Crisis of Israeli Identity, 106.
} 
adopt the idea of a Palestinian state, it was Peres that strongly opposed it. ${ }^{511}$ Such views were not limited to the party elite either. Polls by Asher Arian show that while support for the creation of a Palestinian state as part of a peace treaty had more than doubled from 1990 to 1994 , however the percentages still remained small, going from $7 \%$ in 1990 to $15 \%$ in 1994 . In comparison and according to the same poll, the annexation of the territories and the "transfer" of its inhabitants as the "preferred solution" also stood at 15\%, while "annexation, no transfer, no full rights for Arabs" also gained $15 \%$. The highest ranked solution was "autonomy" with $36 \%$ (up from $24 \%$ in 1990). ${ }^{512}$ These numbers point to the third point regarding Labor's new ideology: the fact that its new liberal worldview was never shared by a majority of the Israeli public.

\section{The Polarization of Israeli Society}

Another important point about Labor's drive for peace in the early nineties is the fact that the movement was not able to attract a majority of the Israeli public to its new ideology, nor was the movement able to make the new liberal Zionist identity the dominant identity of Israeli society, in contrast to the 40 s and 50s when Labor's Sabra identity had been largely hegemonic. For example a 1991 poll of the Israeli public found 40 percent support for the annexation of the territories. Support for the "transfer" of Palestinian Arabs out of the territories also

\footnotetext{
${ }^{511}$ Ben Ami, Scars of War, Wounds of Peace: The Israeli-Arab Tragedy: The Israeli-Arab Tragedy, 220.

${ }^{512}$ Arian, Security Threatened: Surveying Israeli Opinion on Peace and War, 99.
} 
stood at 40 percent. ${ }^{513}$ It is interesting to note that during the 70 s even the Gush very rarely mentioned the eviction of the inhabitants of the territories. Even in the 80 s the idea was highly taboo, with only extreme radical right groups such as the outlawed Kach party of Rabbi Meir Kahane supporting the idea. Thus the support of 40 percent of the Israeli public for the idea, at the same time when the Madrid negotiations were being conducted, displays how polarizing the peace process was in Israeli society.

Moreover in the 1992 elections, which was a resounding success for Labor, the radical right, composed of religious Zionists and secular parties to the right of Likud, also increased their Knesset share by going from 12 seats in the 1988 elections ${ }^{514}$ to 17 seats in $1992 .^{515}$ Thus if we consider the parliamentary share of the revisionist and religious Zionist movements together, it only dropped by a mere three seats, going from 52 seats in 1988 to 49 seats in 1992 . The point of these numbers is not to downplay the importance of the 1992 elections, but rather to demonstrate that the election was far from a "transformation" or "turnaround" of Israeli politics and society. More correctly the 1992 elections

${ }^{513}$ Ibid., 109.

${ }^{514}$ (5 NRP +3 Tehiya +2 Tzomet +2 Moledet) For the official results of the 1988 Knesset elections see: The Knesset, Elections to the Twelfth Knesset, November 1, 1988, http://knesset.gov.il/description/eng/eng_mimshal_res12.htm.

${ }^{515}$ (6 NRP + 8 Tzomet +3 Moledet) For the official results of the 1992 Knesset elections see: The Knesset, Elections to the Thirteenth Knesset, June 23, 1992, http://knesset.gov.il/description/eng/eng_mimshal_res13.htm. 
brought the Labor camp, with a new ideology and worldview, into power. This was a very significant development on its own, however this was achieved with a razor sharp and fragile lead over its rivals.

Moreover Labor's lack of widespread support meant that it had to significantly water down its policy proposals. For example while the issue of settlements was a "wedge issue" during the 1992 elections, with 81 percent of Israelis saying the issue would greatly or very greatly affect their vote ${ }^{516}$ with one camp increasingly in support of the costly endeavor and another opposed to it, it should also be noted that opposition to settlement expansion was not primarily because of the settlement's impact on a possible peace process or its impact on Palestinian life in the territories, but rather because of the heavy burden the enterprise put on Israel's economy. Arian notes how surveys before the elections demonstrated that the issue of settlement expenditure was more important, and the main cause of contention, rather than issues regarding the "future of the territories." ${ }^{n 17}$

This is why during the elections Labor did not criticize the settlements on ethical or moral reasons, or even based on the fact that they were impeding a political compromise with the Palestinians, but rather by pointing how they were a drain on the country's economy. Labor promised that instead of spending money

\footnotetext{
${ }^{516}$ Arian, Security Threatened: Surveying Israeli Opinion on Peace and War, 24.

517 See Arian and Shamir, "Two Reversals: Why 1992 Was Not 1977," 44; Arian, Security Threatened: Surveying Israeli Opinion on Peace and War, 157.
} 
on settlement construction in the territories, as past Likud governments had done, it would redirect resources into infrastructure, education and employment. This approach arguably helped Labor in the elections, since Likud's prosettlement policy was unpopular with the centrist voter, at a time when unemployment was already high and in danger of becoming even higher due to a large wave of immigrants from the Soviet Union. Moreover the issue of settlements was blocking the granting of a 10 billion dollar American loan, heightening concerns regarding the economic and political costs of the settlements. ${ }^{518}$

As the previous chapter indicated the events of the 1980s did not have a unified effect on the Israeli public, if anything they hardened the polarization of Israeli society between the emerging liberal Zionist identity of the Labor movement and the militant religious identity of the settler movement. For example three years into the Intifada, a 1990 poll found the Palestinian uprising had not changed 53 percent of the Israeli public's views on security and politics. On the other hand 20 percent of participants said their views had softened, while 28 percent had hardened. ${ }^{519}$ Such polarization of Israeli society was furthered with the 1992 elections and the onset of the peace talks after the elections. For example in 1994 only 43 percent of the Israeli public supported Rabin's "Gaza-

\footnotetext{
${ }^{518}$ See Glenn Frankel, Beyond the Promised Land: Jews and Arabs on the Hard Road to a New Israel (New York: Touchstone, 1994), Chapter 13; David Horovitz, Shalom, Friend: The Life and Legacy of Yitzhak Rabin (New York: Newmarket Press, 1996), 130-137.

${ }^{519}$ Arian, Security Threatened: Surveying Israeli Opinion on Peace and War, 79.
} 
Jericho first" plan. ${ }^{520}$ The polarization of Israeli society was heightened as a result of the efforts of the religious Zionist movement following the elections, reaching a boiling point with the assassination of Rabin in 1995.

Statistical analysis of the Peace Index ${ }^{521}$ conducted in this research project highly confirms the polarization of Israeli society based on political ideologies during the peace process. Analysis of the July 1994 poll shows that there is a very strong relationship between the political movement one supported in the previous elections and opinion regarding the peace process. ${ }^{522}$ The graph below portrays the viewpoints of each of the movements' constituents regarding the peace talks:

520 lbid., 58.

${ }^{521}$ The data/the questionnaires were provided by the Guttman Center under the auspices of the Israel Democracy Institute (R.A.).

${ }^{522}$ Model fitting evaluation yielded a chi-square value of 200.569 , at 15 degrees of freedom and a significance value of 0.000 . See appendix, page 469 . 


\section{Figure 3: Opinion Regarding the Oslo Accords Based on Political}

\section{Movements}

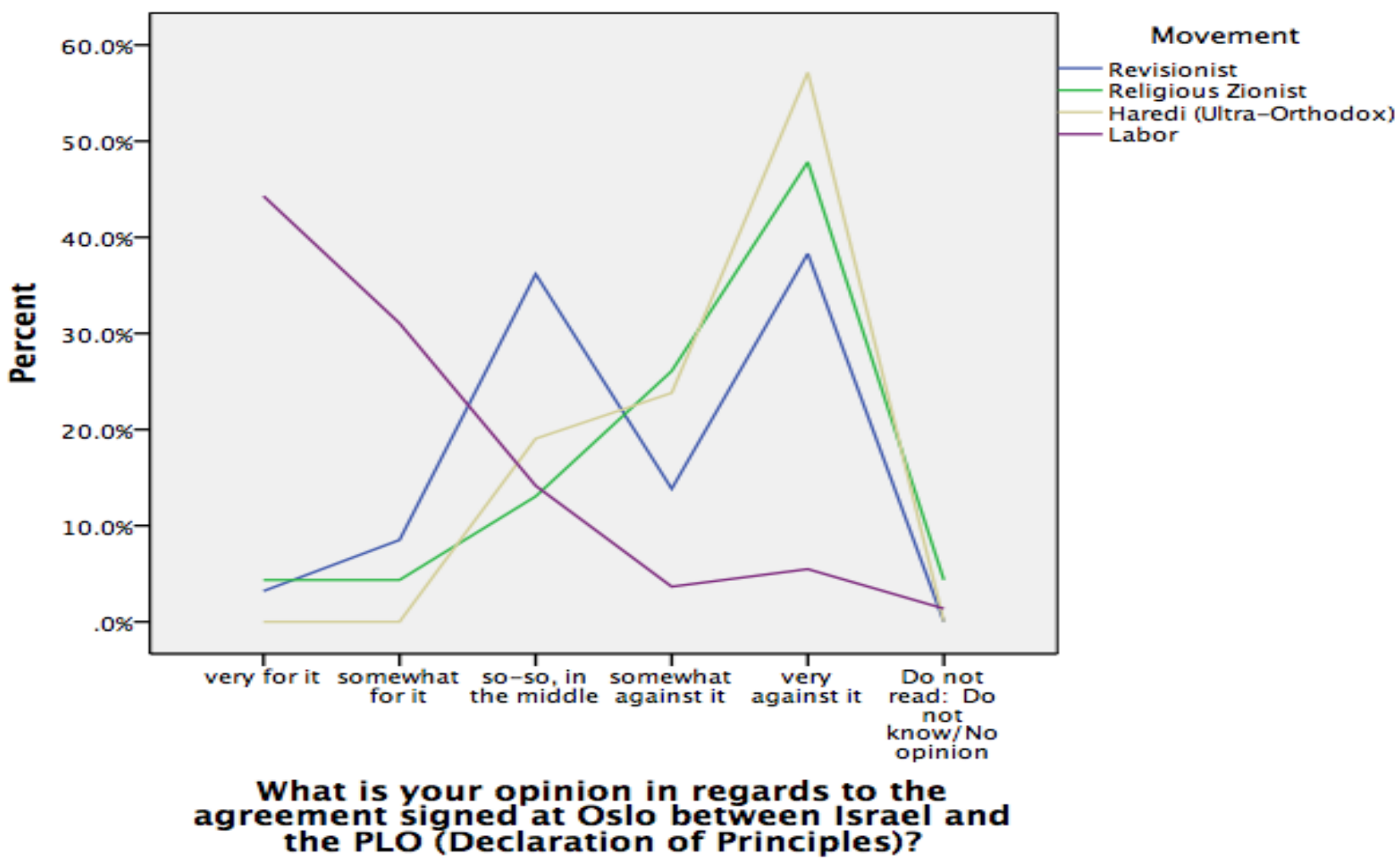

By running a Multinomial Logistic Regression of the data we can discover some very interesting facts. The regression's parameter estimates demonstrate that out of the three movements under study in this dissertation, supporters of the revisionist movement are the most likely to "strongly oppose" the peace process, with an odds ratio of 97 when compared to Labor supporters, followed by the supporters of the Religious Zionist, with an odds ratio of $88.9 .^{523}$ This means that

${ }^{523}$ The parameter estimates demonstrate that in July 1994, voters of revisionist parties are more likely to 'strongly oppose' rather than 'strongly support' the peace process (with an odds ratio of 97 and a sig value of .000) when compared to Labor voters, followed by voters of religious Zionist voters with an odds ratio of 88.917 and a sig value of .000 . For Haredi voters the estimates are 
revisionists were 97 times, and religious Zionists 88.9 times, more likely to oppose Oslo when compared to Labor supporters. While the attitudes of each of the movements' supporters are not surprising, the magnitude of the difference between them is. These numbers point to the very strong and significant relationship between a participant's political ideology (measured based on the party he or she voted for in the last elections) and support for peace negotiations with the Palestinians. The full results of the dissertation's statistical analysis are presented in the appendix. ${ }^{524}$

\section{The Fall of the Peace Process: Religious Zionists and the Rabin}

\section{Government}

The second tenure of Yitzhak Rabin from 1992 to 1995 was increasingly seen with optimism by the Labor movement. Not only was the peace process bringing Israel and Zionism back to its "rightful" path after fifteen years of moving towards illiberalism, racism and isolation, but also the historic agreement with the Palestinians was a significant diplomatic and economic success. As a result of Israel's new improved international standing, the country now had formal diplomatic relations with 150 countries, up from a hundred. This included diplomatic relations with ten Arab countries. The country's relationship with the US, which had been threatened during Shamir's tenure, was also healed.

inconclusive (sig value of .995) due to the empty cells of Haredim support for the peace process. See the appendix, pages 470-471.

${ }^{524}$ For analysis of the July 1994 data set see pages $467-471$ of the appendix. 
Economic indicators were even more impressive. Foreign Investment had increased to 2 billion dollars, up from fifty million before the Oslo Accords. GNP per capita reached 15 thousand dollars in 1995, from 8 thousand only a decade earlier. The number of annual tourists to the country dramatically increased by 67 percent, going from 1.5 million in 1992 to 2.5 million in $1995 .{ }^{525}$ It seemed that during the 90 s Israel was increasingly embracing globalization both economically as well as culturally. The religious Zionists and the revisionists however did not share such optimistic analysis of Israel's "progress" during Rabin's tenure.

As indicated in earlier sections, the rise of the peace process should be understood as a result of the transformation of Labor's ideology in favor of creating a liberal identity, which allowed it to interpret global developments in a new positive light and adopt a new foreign policy framework accordingly. The successful struggle to halt the peace process should also be understood as the result of the efforts of a messianic religious ideology, which created a militant settler identity tied to the territories. During the 1980s these two ideologies clashed with each other, creating opposing identities and value systems. By the 1990s however the two camps were reified and highly entrenched and their conflict over the meaning of Zionism and the "path of Israel" took a violent turn. As stressed throughout this dissertation, the conflict over Israel's territorial policy

\footnotetext{
${ }^{525}$ Yoram Peri, "The Assassination: Causes, Meaning, Outcomes," in The Assassination of Yitzhak Rabin (Stanford: Stanford University Press, 2000), 26.
} 
should be seen as part of a much larger struggle over the very meaning of Zionism and the character and identity of the Israeli nation-state.

Religious Zionists saw the actions of the Rabin government as a confirmation of their worst fears regarding the Labor movement. The liberalization and secularization of Israeli society in the 90 s was seen as the "abandonment of the Halacha" and the elimination of the role of the Torah in society. Integration into the world community was seen as assimilation into a "decayed" Western culture and the renunciation of Jewish uniqueness and specialness. A better relationship with the US was seen as equivalent to "referring to the gentiles," and the preference of gentile interests over Jewish ones. Finally handing back the territories was seen as a "sin" against divine commandment and as hampering the redemptive process. Moreover negotiating with Arafat and his "terrorist" associates was seen as colluding with the "eternal" enemies of the Jewish people. It was also argued that peace with the Arabs might lead to cultural and religious interaction and integration, something seen as a very negative outcome by the religious Zionists. As Chaim Peles, an educator of the movement explained:

The reason for the prohibition to make a pact of friendship and love with the goyim is that we should not fraternize with them too much, so as not to learn from their ways. The people of Israel are presently in such a state that a formal peace with the Arabs will bring about assimilation of large parts of our people in the Semitic region. Consequently, we may see in the state of war between us and the Arabs the hand of providence which sees to it that the integrity of the people is maintained. ${ }^{526}$

\footnotetext{
${ }^{526}$ Quoted in Rubinstein, From Herzl to Rabin: The Changing Image of Zionism, 123.
} 
The peace process particularly came as a shock to the settler community since its initial stages were a well-kept secret and only when an agreement was reached did the breakthrough become public. This was all the more concerning for them when we consider the fact that before 1992, as a result of being coalition partners in almost every government since the inception of the state, the religious Zionists had access to the most sensitive security and foreign policy information.

While withdrawing from the territories was the most sensitive issue concerning the religious Zionists, it should be seen in relation and as part of Labor's other policies. First of all as indicated earlier this was the first time religious Zionists were kept out of the governing coalition for a considerable length of time. In fact some of the most important leaders of the movement such as Hanan Porat wanted the NRP to join the government in 1992. Rabin had even invited the NRP to the coalition, ${ }^{527}$ however negotiations quickly failed as it became increasingly clear that Labor's new approach was in complete contrast to religious Zionist ideology. It is worth noting that before 1992 the two movements had formed numerous government coalitions together, which displays why the ideological evolution of the two movements discussed in the previous chapter are so important in understanding the turbulent events of the 90s.

527 Inbar, “Labor's Return to Power," 37-41. 
As a result of the exclusion of the NRP from the governing coalition, the religious Zionists lost control over the ministry of Religious Affairs, which had been traditionally in their control since Israel's inception and which had served as one of the movement's main sources of power. The ministry was now run by Rabin himself, who served as acting Minister of Religious Affairs, simultaneously while serving as Prime Minister. A member of Shas was initially given the position of deputy minister, however this did not last as the Shas withdrew from the governing coalition on the eve of the signing of the Declaration of Principles in Washington. ${ }^{528}$ The "take over" of the religious ministry by the secular Labor party, led by the "anti-religious" Rabin was highly alarming for the religious Zionist movement. As pointed out in chapter 3, upon Israel's inception in 1948 religious affairs was relegated to the religious and ultra-Orthodox communities in return for their non-meddling in security and foreign policy issues. While the later part of the bargain had effectively been abandoned, until 1992 policy on religious issues had been in the firm control of the religious Zionists and the ultraOrthodox community.

Another highly controversial decision was Rabin's selection of Meretz leader Shulamit Aloni as minister of education. The selection of the outspoken Aloni to the sensitive and ideological ministry was a severe cause for alarm for the religious Zionists as well as the ultra-Orthodox community who saw her as an

\footnotetext{
${ }^{528}$ Yusuf Sarfati, Mobilizing Religion in Middle East Politics: A Comparative Study of Israel (Routledge, 2014), Chapter 6.
} 
"enemy" of religion. As minister, the liberal feminist Aloni proposed a reduced emphasis on religious studies in Israel's educational system. She even suggested the omission of the name of God from a memorial prayer. Aloni also criticized organized tours by high school students to Holocaust concentration camps in Europe saying such programs were turning Israeli youth into aggressive xenophobes, adding that students "march with unfurled flags, as if they've come to conquer Poland." ${ }^{529}$ Most controversial of all however was her questioning of the biblical account of creation in state-issued textbooks and her view that Darwin's theory of evolution should replace it. ${ }^{530}$ As a result religious Zionists hated Aloni and came to refer to her as "Lilith," the queen of demons in Jewish mythology. ${ }^{531}$ In response to such criticisms Aloni shot back, declaring that she was against a "religious establishment which sees the women as an object to be fruitful and multiply, which is xenophobic, which is afraid of progress, culture, science and even afraid to talk about evolution." ${ }^{532}$

\footnotetext{
${ }^{529}$ Tom Hundley, "2 Views Of A Horror Jews In US, Israel Split Over Holocaust Lesson," Chicago Tribune, May 9, 1993.

${ }^{530}$ See Michael Parks, "Israel's Rabin Scolds Official for Call to Give Up Golan : Politics: To Retain Parliamentary Majority, Prime Minister Stops Short of Firing Education Minister.," Los Angeles Times, September 28, 1992; Mualem Mazal, "Israel Mourns Shulamit Aloni, Champion of Feminism in Israeli Politics," Al-Monitor, January 24, 2014; Gideon Levy, "Shulamit Aloni: The Great Woman of the Dreams," Haaretz, January 26, 2014.

531 Motti Inbari, Messianic Religious Zionism Confronts Israeli Territorial Compromises (Cambridge: Cambridge University Press, 2012), 83.

${ }^{532}$ Kevin Boyle and Juliet Sheen, Freedom of Religion and Belief: A World Report (London: Routledge, 1997), 438.
} 
It is important to point out that Aloni was not a peripheral figure in the new government, rather she was the leader of the second biggest party in government, with 12 Knesset seats. Moreover with the withdrawal of Shas from the government in September 1993, Rabin's coalition was effectively left with no religious or ultra-Orthodox party whatsoever, an unprecedented development in Israeli politics. Rabin's government was now left with only 56 Knesset seats and had to rely on the five votes of Arab parties, which were not invited to the coalition but would vote in favor of government proposals in the Knesset. The unwritten agreement would allow Rabin's minority government to rule without the need for an alliance with the religious parties.

This was the first time in Israeli history that a government relied on Arab support in the Knesset and according to Baruch Kimmerling was "hitherto considered unthinkable in the ethnocentric discourse of Israeli political culture. ${ }^{533}$ This allowed the religious Zionists to argue that the Rabin government was "illegitimate," considering the fact that it no longer had the support of the majority of Israel's Jewish population. ${ }^{534}$ Rabbi Shlomo Aviner, one of the spiritual leaders of the movement, declared: "The nihilist forces in the nation, together with our Arab enemies [are members of the government] and if we count the Arab Knesset members who support this government, even you will see that this

${ }^{533}$ Kimmerling, The Invention and Decline of Israeliness: State, Society, and the Military, 53.

${ }^{534}$ Baruch Kimmerling, "The Elections as a Battleground over Collective Identity," in The Elections in Israel, 1996, by Asher Arian and Michal Shamir (New York: State University of New York Press, 1999), 30. 
government does not have a majority among the nation in Israel," adding that these "enemies of Zionism and settlement must be stricken from the blessing [of the state]." ${ }^{535}$ Such arguments, which resonated with many non-religious Israelis including Revisionists as well as non-Zionist Haredi voters, were quite ironic given the religious Zionists' consistent lack of regard for democratic principles. The religious Zionists were also angered by the Rabin government's adoption of secular based "citizens' rights" and "human dignity" laws in Israel's Supreme Court as discussed earlier. ${ }^{536}$

More severely Labor's new approach, which included territorial withdrawal from parts of the West Bank and Gaza, was working against the "Lord's plan" to redeem the Jewish people as set out by Rabbi Kook and his son, which formed the core of the religious Zionist movement's ideology since 1967. In religious Zionist discourse, the Oslo Accords was tantamount to giving parts of the indivisible holy land to "impure gentiles." The settlement movement warned that the peace process would lead to the fall of the "Third Temple" and would result in a "new Holocaust." The new approach of the Labor movement also further proved that the religious Zionists were the only "real Zionists" able to show the

\footnotetext{
${ }^{535}$ Zertal and Eldar, Lords of the Land: The War Over Israel's Settlements in the Occupied Territories, 1967-2007, 130.

${ }^{536}$ See Rabinovich and Reinharz, Israel in the Middle East: Documents and Readings on Society, Politics, and Foreign Relations, Pre-1948 to the Present, Chapter 7; Kimmerling, The Invention and Decline of Israeliness: State, Society, and the Military, 54-55.
} 
Jewish people "the light." ${ }^{537}$ Opposition to the peace process was not only limited to the movement's leaders either. This project's statistical analysis shows that only 8.6 percent of religious Zionist voters were either "strongly" or "somewhat" supportive of Oslo in July $1994 .^{538}$

According to the religious Zionists, the "left" had to be stopped even if "martyrdom" and religious based "suicide" was necessary. This is why the movement began a widespread and well-coordinated effort to delegitimize and undermine the Rabin government. As a result of this effort, the mixing of politics with the Halacha reached new heights in the history of the movement, culminating in the assassination of Yitzhak Rabin in November 1995, shortly after the Oslo II agreement and in a massive Tel-Aviv rally tragically titled "Yes to peace, No to violence." The assassination was an extreme manifestation of the intense rivalry between the two camps and a violent approach to halt the left's jeopardizing of "the divine redemptive process." Yet the assassination did not take place in a political vacuum, rather it was preceded by months of inflammatory rhetoric and extreme measures by the settler movement.

The first reaction of the religious Zionists against the peace process was a 200 thousand strong demonstration against the Rabin government in Jerusalem a week before the signing of the Declaration of Principles. In the following

\footnotetext{
${ }^{537}$ Zertal and Eldar, Lords of the Land: The War Over Israel's Settlements in the Occupied Territories, 1967-2007, 136, 178, 185.

${ }^{538}$ See appendix page 467.
} 
months settlers would get involved in numerous violent clashes with the Palestinians, a strategy that effectively radicalized both sides and jeopardized the standing of more moderate factions engaged in the peace talks. Moreover the religious Zionist movement highly intensified its settlement activities after Oslo, as a result of which settlement construction saw a boom during the peace talks so that in the seven period of 1992-1999, the settler population in the West Bank and Gaza Strip increased by 70 percent. ${ }^{539}$ By 1999, there were over 350 thousand settlers living in the West Bank and Gaza. ${ }^{540}$ For reasons that will be discussed in following sections, neither the Rabin government, nor the Peres government that followed it, demanded a full halt to settlement expansion even though such growth was severely undermining Arafat's position among Palestinian factions.

The religious Zionist movement also began a well-synchronized campaign of character assassination against Rabin, who was seen as an arch nemesis. In fact the Gush Emunim movement was initially found in opposition to the first Rabin government which took office in 1974 and which signed the interim agreements with Egypt and Syria that would entail a withdrawal from some of the

\footnotetext{
${ }^{539}$ Going from 109,784 in 1992 to 186,935 in 1999 (these figures do not include the settler population in East Jerusalem).

${ }^{540}$ In 1999 the settler population was 357,335 that includes 170,400 living in East Jerusalem. See Settlement Populations in the Occupied Territories, 1972-2000 (Foundation for Middle East Peace), accessed June 2, 2014, http://www.fmep.org/settlement_info/settlement-info-andtables/stats-data/settlement-populations-in-the-occupied-territories-1972-2000.
} 
territories. During Rabin's first tenure as Prime Minister the messianic movement had been able to pressure his government to roll back on its policies. In fact the "defeat" of Rabin served as one of the Gush's central myths. This time around the situation was even more critical and the threat even more dangerous, since Rabin was now seen as compromising "Judea and Samaria," whose annexation and settlement had formed the core objective of the settler movement. This is why religious Zionists saw the Oslo accords as a roll back of two decades of their relentless efforts to assist the "divine process." As a Nekuda article explained the Rabin government "threatens to destroy, in every sense of the word, truths in the light of which many have walked and in the name of which thousand have given their lives." ${ }^{541}$ This is why their attacks on Rabin increasingly became personal and without limits.

In settler discourse the Rabin government was referred to as "evil", "traitorous", "sick" and "submissive" and Rabin was compared to Marshal Petain, who had betrayed France in favor of the Nazis, since the Israeli Prime Minister had also "betrayed" Jews for the non-Jewish enemy. Some even hinted that a just punishment for such a crime was death, like the sentence Petain received. As time went by the character assassination of Rabin intensified, going beyond being compared to the treachery of Petain to being likened to the Nazis themselves. In an infamous demonstration a month before Rabin's assassination

\footnotetext{
${ }^{541}$ Quoted in Zertal and Eldar, Lords of the Land: The War Over Israel's Settlements in the Occupied Territories, 1967-2007, 130.
} 
held in Jerusalem, the Israeli Prime Minister was depicted in a Nazi SS uniform. The massive demonstration was attended by Likud leaders Benjamin Netanyahu and Ariel Sharon. ${ }^{542}$ Meanwhile Nekuda declared that the government was "shrinking Israel to the size of Auschwitz." ${ }^{443}$ In another demonstration held against the government posters were distributed which portrayed Rabin wearing Arafat's Kefiya headdress with captions that called Rabin "assassin" and "murderer." Other posters depicted Rabin as an Arab that was washing his hands in Jewish blood. ${ }^{544}$

Furthermore the settlers warned against forced evacuation of the settlements by the government. Elyakim Ha'etzni for example declared that "an IDF soldier, though Jewish, who would pull us, our wives, our children, and grand children from our houses and make us refugees - will, in our view, be conducting a pogrom. We shall look upon him as a violent thug behaving like a Cossack," referring to the Cossack rebellion in Ukraine during the seventeenth century which led to the destruction of several hundred Jewish communities. ${ }^{546}$

\footnotetext{
${ }^{542}$ Raphael Cohen-Almagor, Liberal Democracy and the Limits of Tolerance: Essays in Honor and Memory of Yitzhak Rabin (Ann Arbor: University of Michigan Press, 2000), 85-87.Zertal and Eldar, Lords of the Land: The War Over Israel's Settlements in the Occupied Territories, 19672007, 152-153.

${ }^{543}$ Quoted in Peri, "The Assassination: Causes, Meaning, Outcomes," 4.

${ }^{544}$ Such posters were trying to implicate Rabin in Hamas's attacks against Israelis. Sprinzak, "Israel's Radical Right and the Countdown to the Rabin Assassination," 99.

${ }^{545}$ Quoted in Ibid.

${ }^{546}$ See Jewish Virtual Library, CHMIELNICKI (Khmelnitski), BOGDAN, accessed September 20, 2014, http://www.jewishvirtuallibrary.org/jsource/judaica/ejud_0002_0004_0_04259.html.
} 
While the settlers got engaged in violent confrontation with Palestinians, held various demonstrations, executed roadblocks and tried hard to delegitimize the government, none were enough to derail the peace process in any significant way. This all changed on February 25, 1994, when Dr. Baruch Goldstein, a settler physician and Brooklyn native, opened fire on Muslim worshipers in the Ibrahim Mosque in Hebron. The attack, which took place during the month of Ramadan and while the worshippers where prostrating, killed 29 Palestinians and wounded $125 .{ }^{547}$ In response to the attack, Arafat suspended all peace talks with Israel and a major Palestinian protest erupted in the West Bank and Gaza, as a result of which IDF forces killed 25 more Palestinians and imposed a two month long curfew on the city. ${ }^{548}$ Moreover in the wake of the incident, Hamas adopted the strategic decision to carry out suicide attacks against Israeli targets, ${ }^{549}$ a move that would severely undermine Labor's ability to win the consent of the Israeli public for the peace process.

\footnotetext{
547 Elhanan Miller, "Two Decades after Massacre, Hebron Is Still Hurting Read More: Two Decades after Massacre, Hebron Is Still Hurting | The Times of Israel," The Times of Israel, February 25, 2014.

${ }^{548}$ Elhanan Miller, "Two Decades after Massacre, Hebron Is Still Hurting Read More: Two Decades after Massacre, Hebron Is Still Hurting | The Times of Israel," The Times of Israel, February 25, 2014; 972Mag, "20 Years since Cave of the Patriarchs Massacre," February 25, 2014, http://972mag.com/photos-20-years-since-cave-of-the-patriarchs-massacre/87599/.

${ }^{549}$ Zertal and Eldar, Lords of the Land: The War Over Israel's Settlements in the Occupied Territories, 1967-2007, 122; Sprinzak, "Israel's Radical Right and the Countdown to the Rabin Assassination," 102.
} 
Rabin was quick to denounce the massacre and argued "the murderer from Hebron opened fire on innocent people, but intended to kill the making of peace. His aim was political." In a heated speech to the Knesset Rabin proclaimed:

You [Goldstein] are not part of the community of Israel. You are not part of the national democratic camp to which we in this house all belong, and many of the people despise you. You are not partners in the Zionist enterprise. You are a foreign implant. You are an errant weed. Sensible Judaism spits you out. You placed yourself outside the wall of Jewish Law. You are a shame on Zionism and an embarrassment to Judaism. ${ }^{550}$

The speech exposed the clashing identities within Israeli society like never before, when Rabin claimed that the settler was not part of "us," the "community of Israel" and the Zionist enterprise. Counter to Rabin's claim however Goldstein was not an outsider "weed" or a "foreign implant." While the Kiryat Arba settler had allegedly acted alone in the attack, there was widespread support among religious Zionists for his actions in the wake of the massacre. As Idith Zertal and Akiva Eldar explain, "Rabin and his colleagues did not understand, or refused to believe" that Goldstein's views were not limited to a fringe movement. ${ }^{551}$ In fact many religious Zionist leaders openly praised the attacker, with Dov Lior, an influential rabbi, declaring that "Baruch Goldstein is a holier martyr than all the

\footnotetext{
${ }^{550}$ Yitzhak Rabin, Statement in the Knesset by Prime Minister Rabin on the Hebron Murders- 28 February 1994 (Israel Ministry of Foreign Affairs, February 28, 1994), http://www.mfa.gov.il/MFA/ForeignPolicy/MFADocuments/Yearbook9/Pages/168\%20Statement\% 20in\%20the $\% 20$ Knesset\%20by\%20Prime\%20Minister\%20Rab.aspx.

${ }^{551}$ Zertal and Eldar, Lords of the Land: The War Over Israel's Settlements in the Occupied Territories, 1967-2007, 122.
} 
holy martyrs of the Holocaust, ${ }^{, 552}$ and fellow settlers defending the act as an instance of mesirut nefesh (total devotion) as well as kidush hashem (sanctification of God's name). Even the Yesha Council, the official settler body, which sought to distance itself from the event, explained that it was the blunders of the Rabin government that had led to the attack. ${ }^{553}$ According to Ehud Sprinzak "a surprisingly large number of people had come to consider Baruch Goldstein a holy man and an exemplary figure." ${ }^{554}$

Arguably the aftermath of the incident was more damaging to the peace process than the actual attack, since it signified the first major victory of the settler movement over Labor led by Rabin. While the Prime Minister initially planned to seriously confront the settlers, he eventually backed down, demonstrating to the religious Zionist movement that with the right amount of pressure and lobbying, they could advance their cause even if they no longer had a seat in government and even if the majority of the Israeli public did not support them.

After the attack, Rabin allies such as Shulamit Aloni encouraged him to use the opportunity created by the uproar over the massacre to finally uproot the Jewish settlement in the heart of Hebron. Similar calls were heard inside Labor. For example Yossi Beilin, Deputy Foreign Minister and one of the architects of

\footnotetext{
${ }^{552}$ Sefi Rachlevsky, “The Extremist Rabbi Who Reigns Unobstructed," Haaretz, May 11, 2013.

${ }^{553}$ Sprinzak, "Israel's Radical Right and the Countdown to the Rabin Assassination," 101.

${ }^{554}$ Ibid., 111.
} 
the Oslo Accords, stressed that evicting the settlers would strengthen the peace process as well as law and order. It was also argued that the evacuation was no longer only a Palestinian demand but rather in accordance with Israeli interests. Indeed even before the massacre Rabin knew that the presence of 500 settlers among more than 130 thousand Palestinians was a recipe for disaster and a possible avenue for undermining the peace process. Now members of his cabinet argued that future massacres would be expected if the settlers would be allowed to remain. ${ }^{555}$

For several weeks Rabin contemplated dismantling the Hebron settlement or at least the small Tel Rumeida enclave, in which seven religious settler families had started to live since the 1980s on a hill in the heart of Hebron surrounded by 30 thousand Palestinians. ${ }^{556}$ During this period the religious Zionist movement led a massive campaign to prevent any settlement evacuation. Aside from lobbying against a possible evacuation in the Knesset as well as with the Prime Minister himself, the movement began a well-coordinated mobilization effort. Plans were made to bring tens of thousands of settler activists to Hebron and even to plant their own bodies in the ground in case of an evacuation. Prominent rabbis also issued Halachic rulings prohibiting the dismantling of any Jewish settlements. Rabbi Shlomo Goren, formerly Chief Rabbi of Israel and one

\footnotetext{
${ }^{555}$ Zertal and Eldar, Lords of the Land: The War Over Israel's Settlements in the Occupied Territories, 1967-2007, 123-125.

${ }^{556}$ Sprinzak, "Israel's Radical Right and the Countdown to the Rabin Assassination," 104-105.
} 
of the country's most respected Halachic authorities, issued a religious ruling which read:

The criminal initiative to evacuate Hebron should be met with messirut hanafesh [utmost devotion]. The ruling on such a heinous crime, like the ruling of saving life, is yehareg uval ya'avor [be killed but do not trespass]...According to the Halacha, the meaning of the destruction of Hebron, God forbid.... is like the killing of people, which requires kria for the dead...This is why we must give our life in the struggle against this vicious plan of the government of Israel, which relies on the Arabs for its majority, and be prepared to die rather than allow the destruction of Hebron. ${ }^{557}$

Goren's ruling was followed by Halacha rulings against any sort of settlement evacuation from the three most prominent rabbis of the religious Zionist movement. ${ }^{558}$ Moreover the rulings called on IDF soldiers to disobey evacuation orders. Other rabbis such as Dov Lior made rulings that called on Jews to give their lives to prevent an evacuation from Hebron. Ultra-Orthodox rabbis further supported such Halachic rulings. On March 19, nearly a month after the massacre, Rabin in defiance of the above pressure finally decided to evacuate the seven families at Tel Rumeida hill and yeshiva students from the settlement in Hebron. A delegation was also sent to Tunisia to inform Arafat of the decision and to argue for a renewal of the peace talks. By the evening of the

${ }^{557}$ Quoted in Ibid., 105.

${ }^{558}$ Rabbis Abraham Shapiro, Shaul Yisraeli and Moshe Tzvi Neria. 
same day however Rabin retreated from his decision. ${ }^{559}$ Subsequently the deputy defense minister was sent to Israel's chief Rabbinate assuring him that the government was not evacuating any settlers. In response the state rabbis issued a public statement that read:

The Council of the Chief Rabbinate acknowledges with great satisfaction the announcement of Deputy Defense Minister Mota Gur that the government of Israel has no intention of evacuating either Jewish settlers or Jewish settlements...It is therefore clear that the question of military orders to evacuate settlers or settlements - which are against the Halacha - is not on the agenda and the army must be kept out of the political debate. ${ }^{560}$

The Chief Rabbinate of Israel, which consists of two Chief Rabbis, one Ashkenazi and one Sephardic, is recognized by law "as the head of religious law and spiritual authority for the Jewish people in Israel." The two rabbis are chosen by 150 of the country's top rabbis and hold considerable influence. What is significant about the above statement is that it demonstrates the success of the settler movement in convincing Israel's top rabbinical authorities, including rabbis outside the religious Zionist camp, that any form of settlement evacuation is against Jewish law. While the mixing of Halacha with politics had long been a cornerstone of the religious Zionist movement, it had never been so explicitly used against government policy and even against the sanctified IDF. The

559 Zertal and Eldar, Lords of the Land: The War Over Israel's Settlements in the Occupied Territories, 1967-2007, 124.

${ }^{560}$ Quoted in Sprinzak, "Israel's Radical Right and the Countdown to the Rabin Assassination," 106-107. 
Halacha rulings following the Hebron massacre set a new precedent and brought about a wave of rabbinical meddling in Israeli politics. For example shortly after the struggle over the Hebron settlement was over, one thousand rabbis from all over the country denounced the Rabin government when it implemented the Gaza-Jericho plan. Even though the handover of the two cities, which was a part of the Oslo Accords, did not involve the dismantling of any settlements, the rabbinical statement read:

The so-called peace agreement, made by a government supported by a tiny majority dependent on the Arab vote, is a complete contradiction to peace. The implementation of the agreement may lead, God forbid, to great danger to human life. This is why anyone who can stop this "agreement" and does not do so breaks the rule "you shall not stand idle when your brother is in danger." 561

When Rabin signed the Oslo II agreement in September 1995, which if implemented would hand over autonomy of seven West Bank cities and many more villages to the Palestinians, influential Israeli rabbis again issued religious rulings. Even though the government was not planning on evacuating any settlements in the short term, it was planning on moving several military installations. ${ }^{562} \mathrm{~A}$ Halachic ruling by fifteen prominent rabbis was issued saying "a permanent military camp is a Jewish settlement in the full sense of the term. Its uprooting and abandonment into the hands of the gentiles is subject to the

${ }^{561}$ Quoted in Ibid., 107.

${ }^{562}$ For Oslo II implementation see David Newman, "Territorial Discontinuity and Palestinian Autonomy: Implementing the Oslo II Agreement," IBRU Boundary and Security Bulletin, Winter 19961995. 
same rule as the uprooting of an Eretz Israel settlement, which is prohibited by law. It is therefore clear that no Jew is allowed to take part in any act that assists the evacuation of a settlement, camp, or military compound." ${ }^{563}$ Thus, the religious establishment was now interfering even in military policy not related to the settlements. The development made Rabin furious, declaring:

It is unheard of that the democratically elected government will be coerced by rabbis, using the Halacha to allow soldiers to disobey orders. There has never been anything like this in Israel's history. It is one of the worst things possible that a small number of rabbis, who do not represent the majority of Israeli rabbis, can make such a decision. It is unthinkable that we turn Israel into a banana republic. The entire Knesset, not just the government, ought to reject this matter. ${ }^{564}$

By now however, the settler movement had already weakened Rabin. The struggle over the Hebron settlement was the first major victory of the religious Zionists over the Labor led government. Not only had the Prime Minister backed down but also there was now increasing support for the settlements among the leaders of the religious and ultra-Orthodox communities in Israel. ${ }^{565}$ The event demonstrated to the religious Zionist movement that Rabin would back down when pressured. While Rabin's retreat from the Hebron evacuation plan seriously

\footnotetext{
${ }^{563}$ Quoted in Sprinzak, "Israel's Radical Right and the Countdown to the Rabin Assassination," 116.

${ }^{564}$ Quoted in Ibid., 117.

${ }^{565}$ See Gideon Doron and Rebecca Kook, "Religion and the Politics of Inclusion: The Success of the Ultra-Orthodox Parties," in The Elections in Israel, 1996, by Asher Arian and Michal Shamir (Albany: State University of New York Press, 1999), 78-81; Asher Arian and Michal Shamir, The Elections in Israel, 1996 (Albany: State University of New York Press, 1999), 52-53; Sprinzak, "Israel's Radical Right and the Countdown to the Rabin Assassination," 115-120.
} 
damaged his ability to follow through with the peace process, it should not come as a surprise. Like other Labor leaders, even though Rabin loathed the settlers calling them "non-Zionist kugelagers" (a part of the car wheel that makes squeaking noises) and "Jewish Hamas," "566 like other Labor leaders he was highly hesitant in confronting them with actual action. During Oslo, Rabin refused to endorse a full settlement freeze. Indeed settlement expansion was widely allowed in the Jordan Valley and the "Greater Jerusalem area," a term that allowed considerable flexibility in allowing settlement construction outside of Jerusalem. An "exceptions committee" was formed to allow settlement construction even outside of the above parameters. ${ }^{567}$

In response to American and Palestinian pressure over the settlements, Rabin repeatedly insisted that the fate of the settlements would only be decided in the 'final-status agreement.' The Palestinians indicated that such an approach would cut the success chances of the peace process. Hanan Ashrawi for example argued "we know that they will exploit their power as occupier to the hilt and by the time you get to permanent status, Israel would have permanently altered realities on the ground." ${ }^{568}$ Moreover data obtained by the Hadashot

\footnotetext{
${ }^{566}$ Zertal and Eldar, Lords of the Land: The War Over Israel's Settlements in the Occupied Territories, 1967-2007, 136; Sprinzak, "Israel's Radical Right and the Countdown to the Rabin Assassination," 108.

${ }^{567}$ See Edward W. Said, Peace and Its Discontents: Essays on Palestine in the Middle East peace process (London: Vintage Books, 1996), 153-154; Zertal and Eldar, Lords of the Land: The War Over Israel's Settlements in the Occupied Territories, 1967-2007, 133-135.
}

${ }^{568}$ Hanan Ashrawi, This Side of Peace: A Personal Account (New York: Touchstone, 1995), 261. 
newspaper showed that the Rabin government had paid the settlers $\$ 32$ million for equipment purchases, while $\$ 85$ million was paid to settler local councils. Also the settlers were given $\$ 25$ million in tax breaks. Moreover none of these sums included the government's $\$ 700$ million spending in East Jerusalem. ${ }^{569}$ As indicated earlier settlement construction saw a boom during the Rabin era. In its first year in office, the government itself completed six thousand housing units in the Pisgat Zeev area of East Jerusalem. In fact Rabin told the Knesset, "I explained to the president of the United States that I wouldn't forbid Jews from building privately in the area of Judea and Samaria...I am sorry that within united Jerusalem construction is not more massive. ${ }^{\text {"570 }}$

While Rabin's behavior might seem contradictory on the surface, they can be understood when one considers the severe consequences he would have faced if he were to confront the settlers head on. ${ }^{571}$ For example during the period when he was contemplating evacuating the settlers from Hebron, Yaakov Peri, the head of the country's security service Shin Bet, warned him of a settler revolt in case of an evacuation. Meanwhile Noah Kinarti, Rabin's aid on settlement matters, told Rabin of an "operational team" the Yesha Council had

\footnotetext{
${ }^{569}$ Zertal and Eldar, Lords of the Land: The War Over Israel's Settlements in the Occupied Territories, 1967-2007, 133-134.

570 Steven J. Rosen, "Israeli Settlements, American Pressure, and Peace," The Jerusalem Center for Public Affairs, May 4, 2012, 35.

${ }^{571}$ It should also be noted that Rabin never indicated that Israel would hand over all of the West Bank and East Jerusalem to the Palestinians, thus the construction of settlements was not necessarily seen on lands that would be allocated to the Palestinians in the future.
} 
formed to bring in 10 thousand supporters into Hebron in case of an evacuation. In fact Noam Arnon, the spokesman for the Jewish settlers in Hebron, explicitly warned of booby-trapped cooking gas balloons. Ehud Sprinzak who was called into the Prime Minister's office to advise Rabin on the matter, told him that an evacuation was "liable to ignite a conflagration in the territories." 572

In fact one of the main strategies of the settler movement since its inception has been to threaten consecutive Israeli governments with a "civil-war" and the spilling of "Jewish blood" in case of a forced removal from the territories. For example Gershon Shafat, a Gush parliamentarian and spokesperson, would explain years later that during Rabin's struggle to evacuate settlers from Sebastia in 1975 (only a year after the Gush's founding), the settlers made sure that "there were quite a number of exaggerations, and these helped us later in creating the impression of impeding fraternal strife, a civil war. ${ }^{573}$ While settler threats might have been exaggerated to force the government to back down, the events of the 90s showed that the movement was willing to go to great lengths, including the use of violence on Jews, to keep its hold on the territories.

As a result of the extreme problems the religious Zionists would cause in case of any settlement dismantling, Rabin's approach was two-pronged. On the one hand he would pursue a political compromise with the Palestinians,

\footnotetext{
572 Zertal and Eldar, Lords of the Land: The War Over Israel's Settlements in the Occupied Territories, 1967-2007, 126-127.

573 lbid., 223.
} 
determined and unabashed, on the other he would minimize any deliberate confrontations with the religious Zionists. Rabin arguably believed that by caving in to some settler demands he would be empowered to follow through on other more important aspects of the peace process. In retrospect the approach failed, since the settlers did not reciprocate Rabin's moderate approach. If anything the settlers became emboldened after each governmental retreat. For example in the months following Rabin's reversal from his plans to evacuate some settlers from Hebron, not only were verbal attacks on the government not reduced, but also rhetoric against the Prime Minister became increasingly personal and extreme. Religious Zionist attitudes to the peace process did not soften either. This research's statistical analyses shows that while 8.6 percent of religious Zionist voters supported the peace talks in July 1994, as pointed out earlier, this number dropped to zero in July 1995. In comparison 16 percent of revisionist voters supported the peace talks in the same month. ${ }^{574}$

The hateful attacks on Rabin ultimately led to his death on November 4, 1995. Yigal Amir, Rabin's assassin, would later tell his interrogators "Maybe physically I acted alone, but what pulled the trigger was not only my finger, but the finger of this whole nation, which for 2000 years yearned for this land and dreamed of it." Amir would further explain that he killed Rabin because "he came up with ideas like a Palestinian state. Together with Yasser Arafat, the murderer, he was awarded the Nobel Peace Prize, but he failed to address his people's

\footnotetext{
${ }^{574}$ See appendix, pages 467 and 475.
} 
problems. He divided the people. He marginalized the settlers and didn't care about them." ${ }^{.575}$

In the months preceding the assassination the religious Zionists explicitly called for "bringing down" the government. Nekuda declared that "a government of blood...wicked and cruel...that could create a new Tiananmen Square in Israel...All means are kosher to bring it down." ${ }^{576}$ Soon calls of "death to Rabin" became commonplace. Radio Seven, a settler media outlet, argued "Rabin is leading the state to civil war. If he's not careful, he's liable to get killed...Things can get so bad that just as Goldstein killed 40 Arabs, someone will kill 40 leftwingers...You have no idea how many people feel contempt for the government, and they have no qualms about doing something about it." ${ }^{\text {"577 }}$ The government's selective approach to the settlements, in which some settlement construction were approved and other's were rejected, was compared to the "Nazi selection at the death camps" by rabbi Zalman Melamed, head of the Beit El Yeshiva, adding that if Jews had risen up "against their Nazi oppressors...the Germans would not have been able to carry out their deeds as they had planned. This is the case with this government. ${ }^{\text {"578 }}$

\footnotetext{
${ }^{575}$ Quoted in Sprinzak, "Israel's Radical Right and the Countdown to the Rabin Assassination," 121.

${ }^{576}$ Quoted in Peri, “The Assassination: Causes, Meaning, Outcomes," 4.

577 lbid., 5-6.

${ }^{578}$ Quoted in Zertal and Eldar, Lords of the Land: The War Over Israel's Settlements in the Occupied Territories, 1967-2007, 135.
} 
Even more severe was the naming of Rabin as a Rodef and a Moser. The term Rodef, which comes from Jewish law, is used for a "Jew who leads to the death of other Jews, and thus should be killed." ${ }^{579}$ According to the Jewish law of din rodef ("law of the pursuer"), the extrajudicial killing of the rodef is permitted since it is in self-defense. ${ }^{580}$ The term Moser comes from Talmudic times and refers to a Jew who betrays the Jewish community in favor of the gentiles by spying for the enemy. According to Jewish law, the penalty of a moser is also death. ${ }^{581}$ Both terms were used to describe Rabin in the lead up to the assassination. The ultra-Orthodox HaShavua publication declared that Rabin was a "murderer" and "traitor" and as a result din rodef applied to him. ${ }^{582}$ Also Rabbi Nachum Rabinowitz declared on Israeli radio that Rabin was a moser, adding that the Prime Minister "owed his life." ${ }^{583}$ In fact Amir would later tell his interrogators:

\footnotetext{
${ }^{579}$ Aviezer Ravitzky, “'Let Us Search Our Path': Religious Zionism After the Assassination," in The Assassination of Yitzhak Rabin, by Yoram Peri (Stanford: Stanford University Press, 2000), 151.

580 See Louis E Newman, Jewish Choices, Jewish Voices: War and National Security (Philadelphia: Jewish Publication Society, 2010), 120-124; Johan D. Van Der Vyver and John Witte, Religious Human Rights in Global Perspective: Religious Perspectives, Volume 1 (Cambridge: Kluwer Law International, 1996), 206.

581 "Moser," Jewish Encyclopedia, accessed October 25, 2014, http://www.jewishencyclopedia.com/articles/11047-moser.
}

${ }^{582}$ Quoted in Peri, "The Assassination: Causes, Meaning, Outcomes," 43; Sprinzak, "Israel's Radical Right and the Countdown to the Rabin Assassination," 111.

${ }^{583}$ Quoted in Zertal and Eldar, Lords of the Land: The War Over Israel's Settlements in the Occupied Territories, 1967-2007, 155. 
If not for a Halachic ruling of din rodef made against Rabbin by a few rabbis I knew about, it would have been very difficult for me to murder. Such a murder must have backing. If I had not had backing and the support of many people, I wouldn't have done it. ${ }^{584}$

While according to the authorities Amir had acted alone, the religious Zionist movement had attacked Rabin so viciously that in numerous instances extremists had indicated that they were ready to harm Rabin physically. For example two months before the murder, demonstrators against the government would carry Rabin's mock coffin. Less than a month before the fateful day, Natan Ophir, the rabbi of the Hebrew University of Jerusalem, assaulted Rabin at Netanya. A week before the assassination dead doves were sent to Rabin's office with the words: "We're going to rub you out, your end is near." before the assassination, demonstrators outside Rabin's home shouted to Leah Rabin, the Prime Minister's wife, "next year we'll hang you in the city square like Mussolini and his mistress." ${ }^{586}$ In fact the Shin Bet had warned Rabin of the increased potential for an attempt on his life and a top-secret memo had said that there were approximately 100 people with the "potential to carry out an assassination." ${ }^{587}$ Thus while Amir may have acted alone in the physical assassination of Rabin, the character assassination that preceded it was a well-

\footnotetext{
${ }^{584}$ Quoted in Sprinzak, "Israel's Radical Right and the Countdown to the Rabin Assassination," 121.

${ }^{585}$ Peri, The Assassination of Yitzhak Rabin (Stanford: Stanford University Press, 2000), 6.

${ }^{586}$ Ibid., 5.

${ }^{587}$ Ibid., 8-9.
} 
coordinated effort by the religious Zionist movement. In fact Rabbi Bin-Nun, one of the very few religious Zionist leaders that sought a reassessment of the movement's approach after the assassination, demanded the resignation of "every person who said rodef...not fools, not weeds, not the marginalized, but Torah authorities." ${ }^{588}$ In fact Bin-Nun even went as far giving the names of the rabbi agitators to the chief rabbis of Israel. ${ }^{589}$

If Yitzhak Rabin was the ultimate Sabra, Yigal Amir was on the path of becoming the ultimate "religious Sabra," an identity created by the religious Zionist movement. He came from a devout religious family, attended an ultraOrthodox elementary school and went to a Yeshiva ${ }^{590}$ for his secondary school. After school he attended the highly respected Kerem Deyavneh Hesder yeshiva. As discussed earlier the Yeshivat Hesder system that combined Talmudic studies with military service was the primary institution of religious Zionist ideological indoctrination and the site of the creation of the "religious Sabra" or "Jewish-warrior" identity. After graduating and at the time of the assassination, Amir was studying law and Jewish studies at Bar-llan University, the foremost religious Zionist educational institution in the country. As a result it was very difficult for the movement to portray Amir as an outsider in the wake of the

\footnotetext{
${ }^{588}$ Ravitzky, “Let Us Search Our Path': Religious Zionism After the Assassination,” 151.

${ }^{589}$ Zertal and Eldar, Lords of the Land: The War Over Israel's Settlements in the Occupied Territories, 1967-2007, 156.

${ }^{590}$ Amir went to HaYeshuv HeHadash Yeshiva. See Sprinzak, "Israel's Radical Right and the Countdown to the Rabin Assassination,"122.
} 
assassination. This is why Rabbi Aharon Lichtenstein, the head of a Hesder Yeshiva, declared, "this man [Amir] was nurtured in our best institutions. Ten days ago we would have pointed to him as a symbol of success." ${ }^{591}$ In fact Amir had become close to Rabbi Moshe Levinger, a senior leader of the religious Zionist movement, in the lead up to the murder. ${ }^{592}$

While the assassination of the Prime Minister came as a deep shock to many Israelis, including some religious Zionists, the incident had no lasting effect on the religious Zionist movement. A minority of religious Zionist leaders, the most important of which was Rabbi Bin-Nun ${ }^{593}$ and Rabbi Lichtenstein, called for a reassessment of the movement's ideology as well as it tactics. The majority of the movement however was dismissive of such calls and in fact blamed the Labor government for the assassination. Four days after the murder, settler leader Israel Harel declared, "not only has our way of life not been proven mistaken, but it is the way. The King's road of religious Zionism.. ${ }^{594}$ In the wake of the assassination, Gush Emunim founder Hanan Porat, who at the time served as Knesset member for the NRP party, declared:

${ }^{591}$ Ravitzky, “'Let Us Search Our Path': Religious Zionism After the Assassination,” 148.

${ }^{592}$ Michael Karpin and Ina Friedman, Murder in the Name of God: The Plot to Kill Yitzhak Rabin (New York: Henry Holt and Company, 1998), 17.

${ }^{593}$ In fact such critical leaders were sidelined and renounced. For example Rabbi Bin-Nun was threatened with libel suits and was forced to leave his home in the Orfa settlement. See Zertal and Eldar, Lords of the Land: The War Over Israel's Settlements in the Occupied Territories, 1967-2007, 156.

${ }^{594}$ Quoted in Ibid., 154. 
A person who lifts his hand to uproot Jewish settlements from their land... is not raising his hand against Hanan Porat and Rabbi Druckman; he is raising his hand against the word of God that ordains 'that thy children shall come again to their own border' (Jeremiah 31:17)...Anyone who wants to do a reckoning of conscience must stand in that place, regard the dark abyss and say: Anyone who walks in this abyss, and anyone who thinks that in this way he can save the people - is simply stupid and wicked. ${ }^{595}$

Thus far from being a unifying experience, the assassination of Rabin was the peak of the ideological battle between the Labor movement and the religious Zionists. Some have even called the assassination of Rabin "the first shot in the Israeli Civil War." ${ }^{596}$ Among the Israeli public, the assassination, while highly surprising and even traumatizing, did not have any long-term affects on opinions regarding the peace process. This is especially true regarding the attitudes of religious Zionists, which as the next chapter will discuss has shown remarkable consistency from 1967 until today. To examine the affects of the assassination on opinions regarding the peace talks, statistical data of polls conducted several days after the assassination, three weeks after and finally more than a month after the event was analyzed. ${ }^{597}$

The results of the statistical analysis show that while attitudes to the peace process changed dramatically after the assassination, they returned to their preassassination levels just a month after the attacks. Four days after the attack, 30

\footnotetext{
${ }^{595}$ Quoted in Ibid., 156.

${ }^{596}$ Peri, “The Assassination: Causes, Meaning, Outcomes," 57.

${ }^{597}$ See the appendix, pages $477-490$.
} 
percent of religious Zionist constituents and 28 percent of revisionist constituents indicated they were either very or somewhat supportive of the peace process, a dramatic rise from before the murder. By November 29, just over three weeks after the attack, this number had dropped to 6 percent for religious Zionists and 27.5 for revisionists. By the month of December, the level of support for the peace talks dropped to zero for religious Zionists and 17.6 percent for revisionists.

\section{Shimon Peres and the Settlers}

By the time Shimon Peres took over government, the Labor movement was already on the retreat and the peace process was already in trouble, even if it was not apparent at the time. Peres mistakenly believed that by taking a conciliatory approach to the settlers he would be able to mend relations. This is why he took very little action against the religious Zionist movement and in response to the murder of Rabin. For example in the wake of the assassination some Labor leaders called for the shut down of Hesder yeshivas and government religious schools. Some of these proposals even had support from revisionist leaders. ${ }^{598}$ Peres however took little action against the settlers. In fact government funding and approval of settlement expansion continued unabated. ${ }^{599}$ This is why Idith Zertal and Akiva Eldar have argued that as a result

\footnotetext{
${ }^{598}$ Ravitzky, “'Let Us Search Our Path': Religious Zionism After the Assassination,” 152.

${ }^{599}$ Zertal and Eldar, Lords of the Land: The War Over Israel's Settlements in the Occupied Territories, 1967-2007, 157.
} 
of the actions of the Peres government, "the meaning of Rabin's assassination was betrayed." 600

During the 1996 elections, Labor made the fateful decision of downplaying and even ignoring the assassination, in the hopes of attracting the center vote. Labor's decision was partially based on poll numbers that indicated that few people cared about the assassination any longer. ${ }^{601}$ In fact two weeks prior to the 1996 elections, Peres signed an agreement with the more "moderate" elements of the settler movement, which guaranteed that the government would not uproot any Jewish settlements and that "Israeli sovereignty in essential parts of Judea and Samaria would be ensured." Peres misguidedly hoped that the agreement would compel the settlers to vote for him. ${ }^{602}$ Also settler leader Pinchas Wallerstein revealed later that during the short tenure of Peres, the Prime Minister had allocated 350 million shekels (approximately $\$ 85$ million) for settler roads in the West Bank and during the tenures of Rabin and Peres, settler population had increased by 40 percent. ${ }^{603}$ Such policies however did not result in the winning of any significant votes from the religious Zionists for Peres.

\footnotetext{
600 Ibid., 158.

${ }^{601}$ Arian and Shamir, The Elections in Israel, 1996, 13.

602 Zertal and Eldar, Lords of the Land: The War Over Israel's Settlements in the Occupied Territories, 1967-2007, 156-158.

${ }^{603}$ See lbid., 157-158.
} 
Neither did settler leaders tone down their inflammatory rhetoric against the Labor led government, the new Prime Minister, or the peace process.

In the ideological struggle between the religious Zionist movement and Labor, the former had won, at least for now, even before the defeat of Labor in the 1996 elections. This is why in 2000, Shulamit Aloni would bitterly state: "They won...the assassin and his senders...the assassination, the violent demonstration which preceded it, the incitement in the streets...all of these protested not only the Oslo accords...they primarily turned against democracy and the judicial and governmental order."

\section{The Emergence of a New Political Actor: Israel's ultra-Orthodox}

\section{Community and the Peace Process}

Until now this dissertation has not discussed the role of Israel's Haredi, or ultra-Orthodox, community in the shaping of the country's foreign policy. This is because the Haredim have traditionally rejected modernity and Zionism, and view Israeli state and society as "secular" and even "sacrilegious." As a result, during the Yishuv years as well as after 1948, the Haredim have largely segregated and isolated themselves from general Israeli society, to the point that they even have their own separate legal system. Moreover while they have established independent political parties, they have largely avoided the

${ }^{604}$ Quoted in Nadav Gabay, "Peace Begins at Home: Toleration, Identity Politics and the Changing Conception of Peacemaking in Israel after Yitzhak Rabin's Assassination," Social Identities 12, no. 3 (May 2006): 360. 
"mundane" politics of the state. Since the inception of Israel, the Haredi's engagement with the state and its politicians has almost exclusively focused on ensuring special privileges for the group. One prime example of this has been the Tal Law, which provides exemption from mandatory military service for the ultraOrthodox so that they may spend their time exclusively on "studying the Torah." Unlike The religious Zionists who had successfully tied Judaism with Zionism, the Haredi saw the Jewish nationalist movement as similar to the various political ideologies of the gentiles, and completely devoid of any divine or religious significance. ${ }^{605}$

As Aviezer Ravitzky, an orthodox professor who specializes on the group explains, "The majority of ultra-Orthodox Jews utterly reject both of these ideological stances [Zionism and its critics] and dismiss their judgments regarding these questions. From this Haredi point of view, the State of Israel is a neutral entity, part of the secular realm still belonging to the age of exile." ${ }^{" 606}$ This is why Haredi parties are usually categorized as "non-Zionist" and sometimes even described as "anti-Zionist."607

Haredi parties such as Agudat Yisrael have in fact joined both Labor and Likud led coalitions, but as noted earlier this has been only to ensure the group's particular religious needs. As a result the ultra-Orthodox have very rarely

${ }^{605}$ See Ravitzky, Messianism, Zionism, and Jewish Religious Radicalism, Chapter 4.

${ }^{606}$ Ibid., 145.

${ }^{607}$ Kimmerling, "The Elections as a Battleground over Collective Identity," 34. 
involved themselves with issues of security and foreign policy. This century old tradition however seems to be changing. The sparks of such a change began with the establishment of the Shas party in 1984 under the relationship of Rabbi Ovadia Yosef. The party, which caters almost exclusively to the needs of Sephardic and Mizrahi ultra-Orthodox Jews, had a very modest beginning but today is the fifth biggest party in the Knesset with 11 seats. In fact together with United Torah Judaism, the other main Haredi party, today the ultra-Orthodox have 18 seats out of the 120 seats of the Knesset, which is more than the 12 seats of the religious Zionists. ${ }^{608}$.

While the Shas party is not opposed to the peace process "in principle" however in the wake of Oslo it has increasingly moved to the right of the political spectrum and in support of the settler movement. As indicated earlier Shas left Rabin's coalition right before the signing of the Declaration of Principles, as a result of which the coalition was left with only 56 seats in the Knesset and had to rely on Arab parties in order to maintain the majority it needed. After the accords were signed the ultra-Orthodox community played an important role in organizing anti-Oslo demonstrations together with the religious Zionists. Moreover Haredi rabbis, who had traditionally ignored politics, now played the leading role in issuing Halacha rulings against the peace process as well as against the Prime Minister. In fact the ultra-Orthodox were full partners with the religious Zionists in

\footnotetext{
${ }^{608}$ Represented by 'The Jewish Home' party
} 
branding Rabin a rodef ${ }^{609}$ The Haredim also played a major role in the 1996 electoral success of Benjamin Netanyahu. This represents a significant ideological change within the ultra-Orthodox community, a development that would have important consequences for Israeli foreign policy during the nineteen nineties. Several reasons can be cited for this ideological transformation.

Following the Six Day War, the religious Zionist movement rose as a successful political movement while also firmly holding on to its religious foundations. The religious Zionists were thus successful in effectively combining Zionism and Judaism into a single ideology. Not only had the religious Zionists successfully redefined Zionism using Jewish scriptures, but also their newly obtained status gave them much more power and influence in demanding religious concessions from the Israeli government. This development had undeniable effects on the Haredi movement. No longer were all of Israel's politicians "secular" Jews who had "abandoned the Halacha." In fact while the religious Zionists' primary objective was the settlement of the territories in order to facilitate divine redemption, they were also concerned with the role of Halacha in society and had used their influence to successfully sideline the secular Labor movement in favor of the more traditional and religious Likud. The rise of the religious Zionist movement in the 80 s thus challenged the image of the Zionist movement as a secular nationalist movement influenced by European Jewish enlightenment. In the new religious Zionist ethos, Zionism was part and parcel of

\footnotetext{
${ }^{609}$ See Peri, "The Assassination: Causes, Meaning, Outcomes," 43.
} 
Judaism. As a result, while the Haredi community rejected the claimed ties between Zionism and Jewish redemption, it began to accept the positive consequences of a strong Jewish state for the life and security of Jews during the "exile" period.

A second factor that facilitated the transition of the orthodox community from indifference to foreign policy issues to opposition to the peace process was the xenophobic attitudes of the group toward the "gentile world," an attitude that was shared with the religious Zionists and to some extent with the revisionists. Ovadia Yosef, the highly revered rabbi and leader of Shas, famously said in a sermon "Goyim were born only to serve us. Without that, they have no place in the world - only to serve the People of Israel," even going as far as to compare the gentiles to "donkeys" who were created by God to serve their Jewish masters. It should then come as no surprise that views regarding Palestinian Arabs who were the "enemies" of the Jewish people were even harsher. Yosef would comment in 2000 that "Those evildoers, the Arabs - it says in the Gemara [Talmud] that God is sorry he ever created those sons of Ishmael," adding "How can you make peace with a snake?" ${ }^{610}$ These sentiments among the ultra-Orthodox became especially widespread after violent Palestinian attacks against Jews. For example one of the primary reasons why the Haredi community started to use inflammatory language against Rabin and later against

${ }^{610}$ Quoted in Lazar Berman, "5 of Ovadia Yosef's Most Controversial Quotations," The Times of Israel, October 9, 2013. 
Peres was in reaction to the spilling of "Jewish blood." Such views became even more extreme with the start of the second Palestinian Intifada. In 2001, Yosef would declare, "it is forbidden to be merciful to them [Palestinians]," adding "you must send missiles to them and annihilate them. They are evil and damnable." ${ }^{611}$ The increasing xenophobic attitude of the ultra-Orthodox community would naturally lead to more hawkish views regarding the peace process. $^{612}$

A third important factor in support of change in Haredi policy was the discrepancy between the viewpoints of ultra-Orthodox leaders and their constituents regarding the peace process. While the leaders of Shas and United Torah Judaism, unlike religious Zionist leaders, were not against the peace talks in principle, ultra-Orthodox Israelis were among the most adamant opponents of Oslo. This can be partly explained as the result of the inflammatory language of Haredi rabbis such as Yosef against non-Jews. Thus while the Haredim make clear that there is nothing holy about Zionism and the Israeli state, a worldview that is fundamentally different from that of religious Zionists, at the same time their claim about the superiority of Jews over other nations has led to the disregard of Palestinian rights among the ultra-Orthodox community. The

${ }^{611}$ Quoted in "Rabbi Calls for Annihilation of Arabs," BBC News, April 10, 2001.

612 In 2010 for example, just before peace negotiations were set to start between Israeli Prime Minister Benjamin Netanyahu and Palestinian Authority President Mahmoud Abbas, also known as Abu Mazen, Yosef delivered a sermon saying, "Abu Mazen and all these evil people should perish from this world.... God should strike them with a plague, them and these Palestinians." Quoted in "Shas Spiritual Leader: Abbas and Palestinians Should Perish," Haaretz, August 29, 2010. 
statistical analysis of this research project demonstrates that ultra orthodox voters were only slightly less opposed to the peace talks than the religious Zionists.

Figure 4: Haredi Vs. Religious Zionist Opposition to the Peace Process ${ }^{613}$

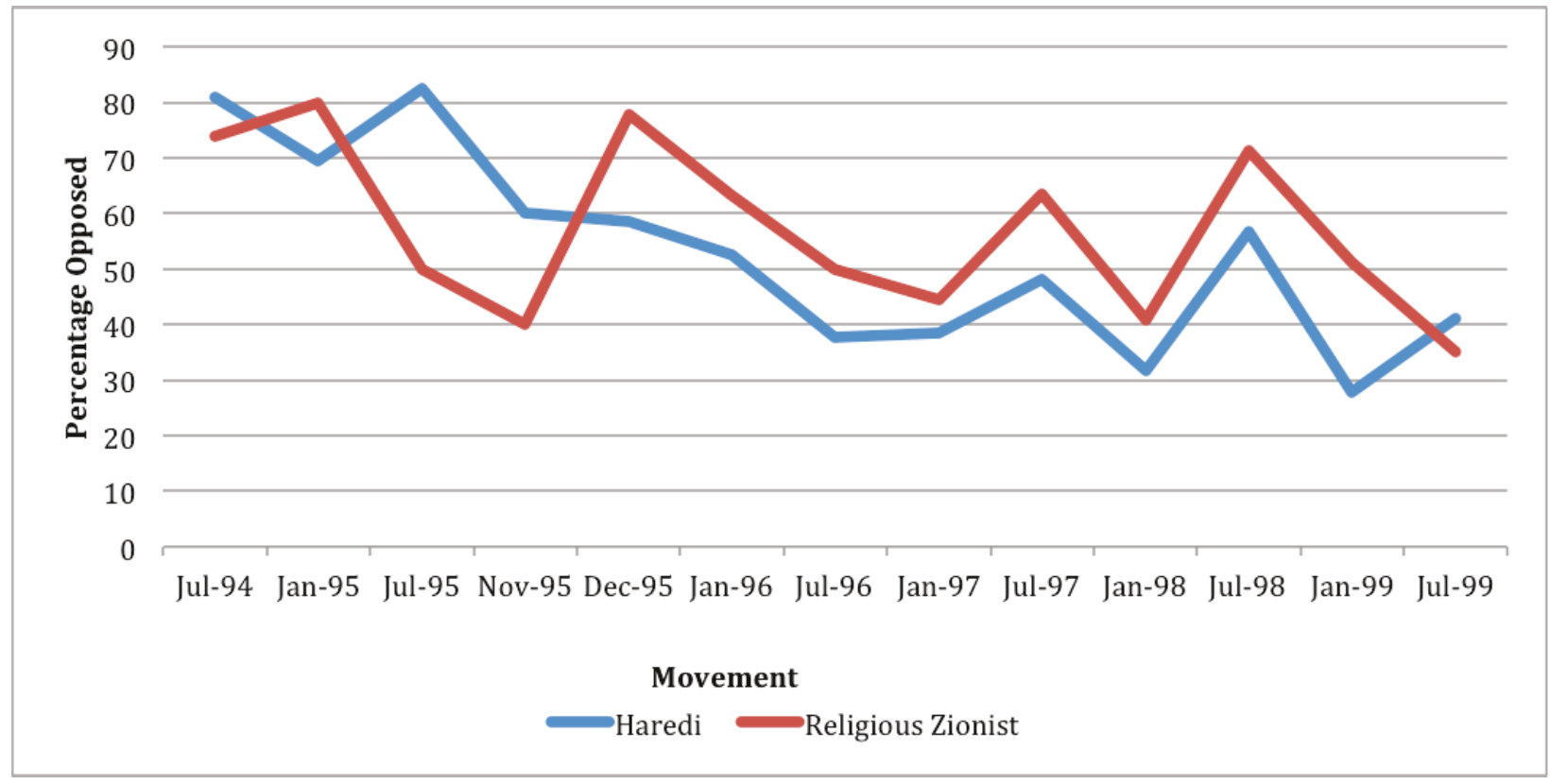

Another factor that has led to the transformation of Haredi ideology has been cooperation and integration with the religious Zionist movement. During the 1980s several religious Zionist yeshivas underwent a process of "haredization" in which pure commitment to life-long Halachic studies began to be preached. From

\footnotetext{
${ }^{613}$ Method of Calculation: Each data point in the graph is the total percentage of those "very opposed" and "somewhat opposed" to the peace process for each movement. The percentage points are the result of cross tabulation statistical analysis of this dissertation for the 94-99 period, presented in pages 467-526 of the appendix. For example in July 1994, 57.1 percent of Haredi voters were "very opposed" to Oslo, 23.8 percent were "somewhat opposed," while 19 percent were neutral, and zero percent were in support of the peace talks. This is translated into 80.9 percent $(57.1+23.8)$ in the graph.
} 
the Haredi side, some groups such as the Lubavitch ultra-Orthodox group began to adopt some of the nationalist beliefs of the religious Zionists. The emergence of the "Messiah Now" movement should be seen under such light. While the Haredi never adopted the messianic zeal of the religious Zionists, the interaction between the two groups assisted the ultra-Orthodox to become more accepting of nationalist ideas while also making the religious Zionists more observant of the Halacha. ${ }^{614}$ This converging of attitudes and viewpoints of the two groups' followers is apparent in the above graph as well, with the two movements' attitudes to the peace process rising and falling together. The creeping acceptance of Zionist nationalism among the Haredi turned into policy when in 2010 the Shas party became the first ultra-Orthodox party to join the World Zionist Organization, and Shas Knesset members explicitly declaring that the party was Zionist. ${ }^{615}$

Finally the association of the Labor movement during the Rabin era with the "de-Judification" and "Hellenization" of Israeli state and society was deeply concerning for the ultra-Orthodox. Especially worrying were the inclusion of the "anti-religious" Meretz party in the coalition and the takeover of the influential ministries of education and religious affairs by secular Israelis. One of the main reasons the ultra-Orthodox had largely avoided politics until then was that the

${ }^{614}$ Arian and Shamir, The Elections in Israel, 1996, 53.

${ }^{615}$ See Sarfati, Mobilizing Religion in Middle East Politics: A Comparative Study of Israel, Chapter 6. 
religious Zionists had limited, at least to a degree, the secularization of Israeli society through such institutions. The takeover of these institutions by "Hellenized Jews" such as Aloni and the appointment of two Israeli-Arabs as deputy ministers by Rabin were seen as highly threatening by the religiously conservative haredim. ${ }^{616}$ The ultra-Orthodox community thus became inclined to align itself with the religious Zionists in order to roll back the elimination of "Torah in society." This is why the Likud slogan of "only Netanyahu is good for the Jews" was well received among the haredim.

The entrance of the haredim into the struggle to shape Israeli foreign policy was a vital factor behind Israel's erratic and inconsistent behavior during the nineties. While the haredim initially accepted the peace negotiations in principle and even joined Rabin's coalition, their later withdrawal from government and subsequent attacks on Labor would badly damage the peace process. This shift of haredi viewpoints regarding the talks played an important role in shifting the balance of power in favor of the opponents of the negotiations. In the crucial 1996 elections for example, 244 thousand haredim voted, a number that equated to 11.7 percent of total votes cast. Considering the fact that 95 percent of the ultra-Orthodox voted for Benjamin Netanyahu as opposed to Shimon Peres, in an election that was won by less than 30 thousand votes, it becomes clear how in Israel even small groups can play a vital role in politics.

\footnotetext{
616 "Cabinet Picks Israeli Arabs for High Posts: Mideast: Two Are Named Deputy Ministers. Appointments Are First of Their Kind in 19 Years."
} 
Due to the fact that Israeli society is highly polarized, groups such as the Haredi can play a pivotal role in tipping the balance of power in favor of either side. After winning the elections, Netanyahu rewarded the religious Zionist-Haredi alliance by giving them exclusive control over the Ministry of Religious Affairs and the Ministry of Education and top posts in the Ministries of Interior, Labor and Housing, which they used to their full extent to reverse the secularization that had begun during Labor's rule. ${ }^{617}$ As one senior rabbi declared after the 96 elections, "God willing we will change the Knesset into a Beit Knesset [Hebrew for synagogue]." ${ }^{618}$

\section{Oslo and the Ideological Crisis of Revisionist Zionism}

The negotiations that led to the Oslo Accords were one of the best-kept secrets in Israeli history. This is why the agreement came as a complete shock to the revisionist movement. The opposition led by Likud was unable to prevent the passing of the accord in the Knesset, which was approved by 61 votes in favor. Benjamin Netanyahu, who had recently succeeded Shamir as Likud leader, came strongly against the agreement and indicated that it would be canceled as soon as Likud took over the government. While the revisionist movement had long seen Labor as a threat to its Greater Israel ideology, the Rabin government

\footnotetext{
617 Gideon Doron and Rebecca Kook, "Religion and the Politics of Inclusion: The Success of the ultra-Orthodox Parties," in The Elections in Israel, 1996, by Asher Arian and Michal Shamir (Albany: State University of New York Press, 1999), 78-79.

618 Ibid., 67.
} 
had effectively changed theory into practice by signing an agreement with the "terrorist" Arafat that entailed Israeli withdrawal from the territories. As discussed earlier, unlike the Labor movement whose ideological transformation in the 80s allowed it to see the global and regional events of the late 80 s and early 90 s as highly improving Israel's "security dilemma" and thus enabling it to seek peace, the revisionist movement throughout this period continued to strongly hold to the idea that the "entire world" was against Israel, as it had been throughout history. In the revisionist binary view of the world in which the Jews were pitted against an eternally hostile gentile world, there was little difference between the threat from the PLO in the $80 \mathrm{~s}$ and $90 \mathrm{~s}$ and the threat from the Nazis in the $30 \mathrm{~s}$ and 40s. As Baruch Kimmerling explains, in this worldview "there are no substantial differences between all the historical enemies of the 'Jewish people,' such as the Assyrians, Romans, Christians, Nazis, Arabs, etc." ${ }^{1619}$

Revisionist discourse in the post Cold War period can be summarized into the slogan: "Nothing has changed." This is why Shamir declared in 1992 "the dangers facing us and the threats to our security have not abated," adding that nothing had changed since the war of 1948 and that "we need to accept that war is inescapable, because, without this, the life of the individual has no purpose and the nation has no chance of survival." ${ }^{620}$ If anything the revisionists saw the post Cold War developments as a dangerous path in which the "anti-Semitic"

\footnotetext{
${ }^{619}$ Kimmerling, "The Elections as a Battleground over Collective Identity," 27.

${ }^{620}$ Quoted in Shlaim, The Iron Wall: Israel and the Arab World (Updated and Expanded), 518.
} 
Americans were cynically pushing Israel to submit to a plot that would see the erection of a "PLO state" on the "land of Eretz Israel," a development that would ultimately lead to the destruction of the Jewish people. This is why Netanyahu in his 1993 book, titled A Place Among the Nations: Israel and the World, declared, "a PLO state on the West Bank would be like a hand poised to strangle Israel's vital artery along the sea." ${ }^{621}$ In the book Netanyahu compares the Arabs to the Nazis and Israel to the small and vulnerable Czechoslovakia, which had to pay the brunt of Chamberlain's appeasement of Hitler. Moreover the revisionists believed that the Palestinians saw the peace agreements as only a "phase" during which they would regroup and strengthen themselves in order to serve a fatal blow to Israel. According to Netanyahu the "PLO is a Pan-Arab Trojan horse, a gift that the Arabs have been trying to coax the West into accepting for over twenty years, so that the West in turn can force Israel to let it in the gates." ${ }^{122}$ In the words of Ariel Sharon the creation of a Palestinian state would only serve as a front for terrorists in which "the terrorists will be acting from behind a cordon of UN forces and observers." ${ }^{\text {"23 }}$

This is why even though it was the Religious Zionists who took the leading role in bringing down the Rabin government, the bigger revisionist movement

\footnotetext{
${ }^{621}$ Benjamin Netanyahu, A Place Among the Nations: Israel and the World (New York: Bantam Books, 1993), 282.

${ }^{622}$ Quoted in Shlaim, The Iron Wall: Israel and the Arab World (Updated and Expanded), 588.

${ }^{623}$ Quoted in Robert Fisk, “Ariel Sharon,” The Independent, January 6, 2006.
} 
became full partners in the endeavor. Netanyahu repeatedly warned that the agreement signed by Rabin was equal to the "dismembering of the nation" and that the Labor government was leading the country into "the abyss." ${ }^{624}$ Netanyahu, Sharon and other revisionist leaders attended and even delivered speeches to the most vicious anti-Rabin rallies. When after one such rally the head of the Shin Bet, Israel's internal security organization, asked Netanyahu to tone down his rhetoric because of an emerging plot to kill Rabin, the Likud leader did the opposite by ordering one of his top advisors to step up the protests. ${ }^{625}$ In fact the revisionist attacks against Rabin had become so heated and personal that when after the assassination Netanyahu went to pay her respects to Leah Rabin, the wife of the late Prime Minister, she refused to shake his hand. ${ }^{626}$ In contrast she shook the hand of Arafat and explained, "Sometime I feel we can find common language with Arabs more easily than we can with the Jewish extremists. It seems that we live in different worlds." 627

In the wake of the assassination, while Likud had not been directly responsible for the killing, the Israeli public saw it as fully complicit. Polls showed that if elections were to be held following the assassination only 23 percent of

\footnotetext{
624 Jonathan Mendilow, "The Likud's Double Campaign: Between the Devil and the Deep Blue Sea," in The Elections in Israel, 1996 (Albany: State University of New York Press, 1999), 194.

${ }^{625}$ Aronoff, The Political Psychology of Israeli Prime Ministers, 58.

${ }^{626}$ Interestingly, Yitzhak Shamir never even said a single word of condolence to Leah Rabin. See Ibid., 34.

${ }^{627}$ Quoted in Shlaim, The Iron Wall: Israel and the Arab World, 548.
} 
voters would support Netanyahu as prime minister. ${ }^{628}$ The revisionists who accused Labor of "McCarthyism" and turning the Rabin assassination into a "witch hunt" had no choice but to tame their rhetoric. The damage however was done and Netanyahu was increasingly criticized within his own party for associating himself with radical religious extremists, with one senior Likud member saying that "If you don't want to get fleas, don't go around with dogs." 629 An important segment of the party was even considering replacing Netanyahu with the more moderate Dan Meridor. ${ }^{630}$ The assassination of Rabin thus marked the turning point of the transformation of revisionist rhetoric, even if such change took place gradually.

\section{The 96 Elections and the Change in Revisionist Rhetoric}

In the months following the assassination of Rabin, the Likud continued to attack the Oslo Accord and portrayed Peres as Neville Chamberlain willing to make a "Munich appeasement," however the tone and intensity of the attacks became notably more moderate when compared to the attacks against Rabin. More importantly in the seven months between the Rabin assassination and the fateful elections of 1996, Likud's position regarding the peace process evolved from strong opposition to reluctant acceptance of its principles, and criticism of its form and content. In the lead up to the election, Netanyahu declared, "the Oslo

628 Ibid., 552.

\footnotetext{
${ }^{629}$ Mendilow, “The Likud's Double Campaign: Between the Devil and the Deep Blue Sea,” 196. 630 Ibid., 195-197.
} 
accord endangers Israel, but one cannot ignore reality." Furthermore he promised that if elected he would abide by the peace agreements signed by Rabin, however he would "freeze" them by not taking the Israeli concessions any further. ${ }^{631}$ The reasons behind such a dramatic change will be discussed in detail in future sections, at this stage, suffice to say that the revisionist movement's only hope for winning the elections was to tame its position regarding the peace process.

In the race for the 1996 elections, in which for the first time in Israeli history the Prime Minister was to be elected directly, Netanyahu indicated that he would accept the Oslo accords in principle and was willing to negotiate with the Palestinians. This new position was reflected in the party's official policy guidelines published a month before the elections. Moreover the steering committee of the Likud-Gesher-Tzomet list approved Netanyahu's position in a paper titled "The Principles of the Netanyahu Government for Continued Negotiations with the Palestinians." The transformation of Likud's rhetoric was so dramatic that the radical Moledet party, which has long advocated the "voluntary transfer" of the Arab population in the territories, adopted the slogan: "Only Moledet is on the Right," during the election race. ${ }^{632}$ Indeed in the weeks prior to the election, when the race seemed very close, Netanyahu declared that he was

${ }^{631}$ Shlaim, The Iron Wall: Israel and the Arab World, 568.

${ }^{632}$ Reuven Y. Hazan, "The Electoral Consequences of Political Reform: In Search of the Center of the Israeli Party System," in The Elections in Israel, 1996 (Albany: State University of New York Press, 1999), 179. 
willing to meet Arafat and that "a Likud government will recognize the facts created by the Oslo accords." Even more dramatic was his declaration that "we are ready to negotiate.... in full knowledge that there will be concessions. There is no choice; in negotiations there must be concessions."

The change in revisionist rhetoric on the peace process was so severe that it was difficult to differentiate the movement's position from that of Labor. This is why during the election campaign the Likud adopted the slogan "Peace with Security" supposedly in contrast to Labor's peace initiatives that had "endangered" Israeli security. Likud's emphasis on security came in the wake of a deadly wave of suicide bombings by Palestinian militants a few months before the elections. The events gave Netanyahu ample ammunition to attack Peres who was portrayed as willing to pursue peace at "any price" and was bent on "dividing Jerusalem." In contrast Netanyahu adopted the slogan "Peace with Jerusalem. ${ }^{634}$ In reality Peres had no plan to divide Jerusalem, ${ }^{635}$ an idea that has been constantly opposed by a majority of Israelis. ${ }^{636}$ Moreover the suicide attacks had been carried out by Hamas and Islamic Jihad militants who were

\footnotetext{
${ }^{633}$ Quoted in Mendilow, "The Likud's Double Campaign: Between the Devil and the Deep Blue Sea," 201.

${ }^{634}$ Friedland and Hecht, To Rule Jerusalem, 504.

${ }^{635}$ In fact the Labor movement has arguably done more to annex East Jerusalem into Israel than the revisionists.

${ }^{636}$ See Stacie E. Goddard, Indivisible Territory and the Politics of Legitimacy: Jerusalem and Northern Ireland (New York: Cambridge University Press, 2010), Chapter 6.
} 
opposed to the peace process and aimed to undermine Arafat's Palestinian Authority. Nevertheless the undermining of the security of Israeli citizens, which was in complete contrast to Rabin's promise that the peace process was going to improve the country's security, badly hurt Peres' elections prospects. Although somewhere between 58 to 64 percent of the Israeli public continued to support the peace process, support for Peres continued to decline. ${ }^{637}$ In line with public sentiment, Netanyahu promised to continue the peace talks while being "tough" on security. This is why "Netanyahu! Creating Peace with Security" became the party's main slogan during the elections. Likud declared that it would increase IDF presence in the territories in contrast to Labor's "soft" approach to the Palestinians, in which Israeli security was "relegated to Arafat." 638

The entire revisionist movement however was not willing to accept the movement's change of rhetoric. In fact many of the movement's leaders harshly criticized Netanyahu for backtracking on his earlier opposition to the peace process. Benny Begin, son of Menachem Begin and at the time the chief rival of Netanyahu in Likud, declared that "coming to terms with [Oslo]...this means giving in to a submissive frame of mind, to the victory of evil, and to the abandonment of any hope of averting catastrophe," adding in another speech that "a government that conducts negotiations with the PLO is not worthy of trust,

\footnotetext{
${ }^{637}$ See Mendilow, "The Likud's Double Campaign: Between the Devil and the Deep Blue Sea," 199.

${ }^{638}$ Ibid., 199-202.
} 
irrespective of who is at its head." 639 Yitzhak Shamir was also sharply critical of Netanyahu's approach, declaring, "We have to stop Oslo...that was a big mistake, a terrible mistake. In Oslo we had a disaster for Israel. Anyone going on that path will fail, will cause Israel to lose everything she has." ${ }^{640}$

Such divisions were not limited to the party elite either. Only a month after the Oslo Accords, the Party Center met, with over a thousand members present. However, it was not able to reach a conclusive decision on how to deal with Oslo. The views expressed in the meeting can be categorized into three groups. A first group was comprised of ideological purists who emphasized the need to stand firm in defense of revisionist principles and against the Oslo challenge, no matter the cost. Begin and Shamir can be counted among the leaders of this group. A second group believed that the movement had to show flexibility in light of the development, otherwise it would become irrelevant. Likud Knesset member Meir Sheetrit argued, "the [movement's] platform was not drawn up by God, and so it can be changed if reality demands it," warning "to try to restore the Likud to power by pure negation is to condemn it to many years in the wilderness of the

\footnotetext{
${ }^{639}$ Quoted in Ibid., 197 and 206.

${ }^{640}$ Quoted in Aronoff, The Political Psychology of Israeli Prime Ministers, 41.
} 
opposition." ${ }^{641}$ Others within this group even suggested opening up a dialogue with the PLO in order to influence the peace process. ${ }^{642}$

A third group led by Netanyahu and Sharon believed that the movement should win the backing of the biggest possible margin of Israelis in order to oppose a withdrawal, while changing only a limited number of the movement's principles and instead focusing on adapting new tools and tactics. Netanyahu explained, "the question to be determined is not whether the Likud platform should be changed but how to adjust its principles to reality... if the Likud seeks to return to government it must present a clear-cut alternative. The platform alone is insufficient. We must sharpen the principles, because in the platform they are abstract and insufficiently clear." ${ }^{643}$ The view of this group was thus based on coming up with a practical action plan that would in effect implement revisionist ideological goals albeit with a new rhetoric and with new tactics. This approach increasingly became the dominant position within the revisionist movement and the other two groups were marginalized.

Based on such a framework, Likud leaders such as Netanyahu and Sharon would accept the American led peace talks in "principle" and would even conduct face-to-face negotiations with the Palestinian "enemy"; however all of

\footnotetext{
${ }^{641}$ Quoted in Mendilow, "The Likud's Double Campaign: Between the Devil and the Deep Blue Sea," 191.

642 Ibid., 190-191.

${ }^{643}$ Quoted in Mendilow, "The Likud's Double Campaign: Between the Devil and the Deep Blue Sea," 191.
} 
this would be done in order to prevent any Israeli withdrawal from the territories and the establishment of a Palestinian state. These revisionists believed that if the movement were to declare a complete and uncompromising opposition to the peace process then the Israeli government would be handed over to the Labor party, which would make irreversible concessions. This approach of sticking with revisionist ideological principles in terms of the overall strategy and adopting new rhetoric and tactics, which on the surface seemed to be in line with the peace process, became more apparent during Netanyahu's tenure from 1996 to 1999.

\section{Netanyahu's One Step Forward, Two Steps Back Approach}

Once Netanyahu took over government it became clear that the earlier change in rhetoric was a tactical ploy to win votes rather than signifying a real ideological change within the revisionist movement. For the first three months after taking office he froze the peace process with the excuse that his first priority was to "unite" Israeli society, saying, "peace begins at home." ${ }^{\text {"44 }}$ Moreover, if there was any hope that Netanyahu would follow the path set out by Rabin, it was shattered with the introduction of official government policy to the Knesset on the same day the new government took office. The document presented a sharp contrast to the policies of the previous Labor government as well as Netanyahu and Likud's rhetoric during the election campaign. The new policies included explicit opposition to a Palestinian state, Palestinian right of return and the dismantling of Jewish settlements. In fact the document explained that the

\footnotetext{
${ }^{644}$ Shlaim, The Iron Wall: Israel and the Arab World, 571.
} 
government would continue settlement expansion, declaring, "Settlement in the Negev, the Galilee, the Golan Heights, the Jordan Valley, and in Judea, Samaria and Gaza is of national importance to Israel's defense and an expression of Zionist fulfillment. The Government will alter the settlement policy, act to consolidate and develop the settlement enterprise in these areas, and allocate the resources necessary for this." ${ }^{645}$ Moreover the document did not reference Oslo even once. Thus it seemed that now that the election race was over, the Likud had gone back to its original revisionist ideological roots, both in terms of policy and in rhetoric.

Several months after taking office, in an important interview, Ari Shavit of Haaretz asked the Prime Minister whether Israel still needed to continue with the "Iron Wall policy," to which Netanyahu responded "Until further notice, we are living in the Middle East in an era of iron walls. What iron walls do is buy us time." ${ }^{" 46}$ Furthermore he criticized the previous Labor government for neglecting Israel's military power, explaining, "Military might is a condition for peace. Only a very strong deterrent profile can preserve and stabilize peace." The interview demonstrated that Netanyahu's revisionist ideological principles were well intact.

${ }^{645}$ Guidelines of the Government of Israel, 17 June 1996 (Israel Ministry of Foreign Affairs, June 17 , 1996), http://www.mfa.gov.il/mfa/foreignpolicy/mfadocuments/yearbook11/pages/2\%20address $\% 20 \mathrm{in} \% 2$ 0the $\% 20$ knesset $\% 20$ by $\% 20$ president $\% 20$ weizman $\% 20$ on $\% 20$ t.aspx.

646 "Interview with Prime Minister Netanyahu in Ha'aretz," Israeli Ministry of Foreign Affairs, November 22, 1996, Historical Documents, Volume 16: 1996-1997 edition, http://www.mfa.gov.il/MFA/ForeignPolicy/MFADocuments/Yearbook11/Pages/38\%20Interview\%2 Owith\%20Prime\%20Minister\%20Netanyahu\%20in\%20Haa.aspx. 
In fact Shavit would ask the Prime Minister whether he was gradually abandoning his "ideological positions," to which Netanyahu would reply "No, not at all." ${ }^{\text {"47 }}$

The revisionist movement's struggle to hold on to its ideology and roll back previous Labor policies on the one hand, while also dealing with the realities created by the peace process on the other, was one of the main reasons behind Israel's inconsistent and erratic foreign policy behavior during the late nineteen nineties. The revisionist strategy regarding the peace process, which has arguably continued to this day, was to slow and subvert the talks by delaying and canceling Israeli withdrawals, while at the same continuing with settlement expansion. Netanyahu's tactic in implementing this strategy was to declare that Israel would only negotiate with the PA "on the condition that it will fulfill all of its obligations." ${ }^{\prime 48}$ However with little progress in the peace process and with living conditions in the territories deteriorating, Arafat was finding it increasingly difficult to control and rein in Islamic militants who had been opposed to Oslo from its inception. Nevertheless Netanyahu slowly began to understand that Oslo had opened a door that could not be easily closed.

As the months passed the Clinton administration became frustrated with the Israeli government and international pressure dramatically increased on

647 Ibid.

${ }^{648}$ Address in the Knesset by Prime Minister-Elect Netanyahu Presenting His Government to the Knesset (Israel Ministry of Foreign Affairs, June 18, 1996), http://www.mfa.gov.il/MFA/ForeignPolicy/MFADocuments/Yearbook11/Pages/4\%20Address\%20i n\%20the\%20Knesset\%20by\%20Prime\%20Minister-elect\%20N.aspx. 
Israel to continue with the peace process as set out by Rabin. Netanyahu constantly called off scheduled Israeli withdrawals even though the head of Israel's security services warned the Prime Minister that the conditions in the territories were quickly deteriorating, increasing the chances for the eruption of violent confrontations. These predictions turned into reality when on September 25 , barely three months after taking office, Netanyahu ordered the opening of an archaeological tunnel close to the Al-Aqsa mosque. The controversial move had great symbolic value, as Avi Shlaim explains opening the tunnel "blasted away the last faint hopes of a peaceful dialogue with the Palestinians." ${ }^{649}$ In the three days of protests that erupted after the incident, fifteen Israeli soldiers and eighty Palestinians were killed.

The clashes led to an intensification of American pressure on Israel to abide by Oslo II provisions, under which Israel was to hand over 3 percent of the West Bank to exclusive Palestinian control and was to redeploy from 27 percent of the West Bank, that would come under the jurisdiction of PA authority in civilian and administrative affairs while Israel would be responsible for security. ${ }^{650}$ These pressures led to a resumption of peace talks, which after several months

${ }^{649}$ Shlaim, The Iron Wall: Israel and the Arab World, 576-577.

${ }^{650}$ According to the Oslo II agreement the West Bank would be divided into three zones: A, B and C: In area A comprising of around 3\% of the West Bank the Palestinian Authority would be fully responsible for internal security, public order and civil affairs. In area B comprising of around $27 \%$ of the West Bank Israel would be in charge of "security" while the PA would be responsible for civil affairs. In the remaining $70 \%$, designated as area C, Israel would enjoy complete authority (security, public order and civil affairs). See Aruri, Dishonest Broker: The U.S. Role in Israel and Palestine, 99-100. 
led to the Hebron Protocol agreement in January 1997 in which Israel was to redeploy from 80 percent of the town. While critics of the agreement from the Palestinian side pointed out that less than a thousand settlers had been given 20 percent of the city's best areas, while 130,000 Palestinians were given 80 percent, the agreement signified a dramatic shift in revisionist policy towards "Judea and Samaria." In fact some even hailed the event as the end of revisionist Zionism. ${ }^{651}$ Netanyahu was strongly criticized for the withdrawal from the religious Zionists and within his own party. He responded by clarifying "we are not leaving Hebron, we are redeploying from Hebron. In Hebron, we touch the very basis of our national consciousness, the bedrock of our existence." ${ }^{652}$ Moreover he authorized a new wave of settlement construction in the territories, the most important of which was the construction of 6,500 houses in the Har Homa area of East Jerusalem, declaring, "The battle for Jerusalem has begun.

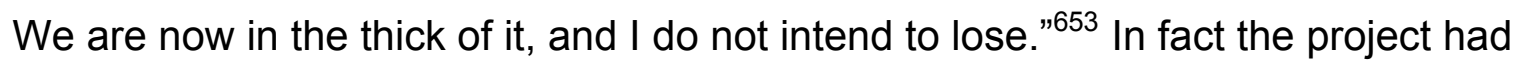
previously been suspended for two years due to the fateful impact it would have on the peace process. As a result of the decision, the peace talks were suspended. Such contradictory moves would become a hallmark of Netanyahu's approach to the peace process.

${ }^{651}$ Shlaim, The Iron Wall: Israel and the Arab World, 581.

652 Ibid., 580.

${ }^{653}$ Quoted in Emily L. Hauser, "Netanyahu's Fake Jerusalem Stalls Peace," The Forward, March 24, 2014; Also see Mitch Abrams, "Construction at Har Homa Could Begin in Two Weeks," JTA, June 5, 1997. 
A similar two-pronged approach was taken with the Wye memorandum in October 1998. After nineteen months of stagnation in the peace talks and after immense pressure from the Clinton administration, Israel agreed to withdraw from a further thirteen percent of the West Bank over three months. In return the $\mathrm{PA}$, in coordination with the CIA was to track down and apprehend Hamas and Islamic Jihad militants. Moreover the PA agreed that it would revise its national charter that called for the destruction of Israel. ${ }^{654}$ Only 8 out of 17 Israeli cabinet ministers ratified the Wye agreement. In fact the religious Zionists threatened to pull out of the governing coalition, a move that would result in the collapse of Netanyahu's government. In reaction Netanyahu tried to balance the agreement with the confiscation of Palestinian land for the construction of new settlements. Moreover the Prime Minister declared that Israeli withdrawal would be dependent on the PA meeting a set of five demands that had not been part of the original agreement. Ultimately even though Netanyahu promised his coalition partners that the Wye agreement would be abandoned and even though Israel effectively withdrew from only 1 percent of the West Bank, with the rest of the agreement being scrapped, the affair led to the collapse of the Likud led government and early elections being scheduled for May $1999 .{ }^{655}$

${ }^{654}$ The clause was expunged in a Palestine National Council meeting on December 14, 1998.

${ }^{655}$ See Anthony H. Cordesman and Jennifer Moravitz, The Israeli-Palestinian War: Escalating to Nowhere (Westport: Praeger, 2005), Chapter 1; Jonathan Mendilow, Ideology, Party Change, and Electoral Campaigns in Israel, 1965-2001 (Albany: State University of New York Press, 2003), 192. 
Netanyahu's approach of proceeding with the peace talks during some periods and keeping the Americans happy on the one hand, and holding on to his revisionist ideological principles and keeping his coalition with the religious Zionists intact on the other, had ultimately failed. The Likud leader's approach was succinctly captured when Thomas Friedman wrote: "Bibi's strategy was to swim laps in the Rubicon. He crossed the river in some important ways by signing the Hebron and Wye agreements, but then crossed back, when he confronted the wrath of his original right-wing constituency." ${ }^{\text {"656 }}$ The important question to be asked here is whether the contradictory approach of the Netanyahu government to the peace process was only a tactical ploy to maintain power or was it the result of real and substantive changes to revisionist ideology?

\section{The Ideological Dilemma of the Revisionist Zionist Movement}

The change in the revisionist movement's position regarding the peace process, which it had so fiercely opposed during the tenure of Rabin, was mostly limited to rhetoric and several tactical concessions, however the new approach would ultimately challenge the ideology of the movement, even though this would not result in a decisive ideological transformation. Initially the change in rhetoric was a ploy to win the 1996 elections. Various polls before the elections showed that a majority of the Israeli public supported the continuation of the peace process. As a result, even though a determined minority continued to oppose the

\footnotetext{
${ }^{656}$ Thomas L. Friedman, "Foreign Affairs; A River Runs Through It," The New York Times, May 25, 1999.
} 
peace talks, they were not enough to give Likud an advantage over Labor. ${ }^{657}$ The situation was made more acute with the implementation of an electoral reform law that stipulated that voters would directly elect the Prime Minister.

As a result of the new mechanism, Netanyahu now needed to attract the votes of a majority of Israelis. In contrast, in the past the Likud had been able to form governments by winning a plurality of seats in the Knesset by only catering to its own social base, and largely ignoring outsiders. The direct election of the Premiership meant that Likud was now forced to battle for undecided "floating voters," which in Israel's highly polarized politics is usually limited to centrist voters. Netanyahu and other Likud leaders initial acceptance of Oslo in "principle" can thus be analyzed as a move to win the center, most of which supported the peace talks. This was done by promising peace with the Palestinians, like Labor had done in the 1992 elections, while also assuring the public that unlike previous years there would be no more suicide attacks. Thus Likud was promising the attractive option of peace without its undesired negative side effects. Even then Netanyahu's victory over Peres was razor thin, with a difference of 30 thousand votes. In the Knesset race the party won only 32 seats, 2 seats less than Labor, even after providing a joint list with Gesher and Tzomet. ${ }^{658}$

\footnotetext{
${ }^{657}$ Mendilow, "The Likud's Double Campaign: Between the Devil and the Deep Blue Sea," 199 200.

${ }^{658}$ Even though Labor won more seats in the elections, Likud would form the new government based on the new law in which the Prime Minister was directly by the people. For official results of
} 
After taking over government, the Likud no longer needed to support the peace process as it had during the elections, as was discussed earlier. Soon however the movement found that what had started under Rabin was very difficult to roll back or even stop. On the one hand the agreements had led the international community led by the US to become more determined in solving the conflict via a political compromise, on the other hand the tenure of Rabin had solidified a strong pro-peace camp in Israel that was no longer a small minority of the Israeli population, as it had been in the 70 s and 80 s. While the core activists of the peace camp remained small, they were now able to claim the support of a significant number of the Israeli public. ${ }^{659}$ Interestingly enough, support for the peace process did not dramatically decrease even after suicide attacks by Palestinians. For example in February and March 1996 polls showed that between 58 to 64 percent of the Israeli public supported the continuation of the peace process. ${ }^{660}$ The next chapter will argue that while these attacks increased Likud's election prospects, they did not result in a significant decrease in support for the peace talks in the long run.

Even more important than the above factors, was the irreversible rise in Palestinian nationalism following the first Palestinian Intifada and the subsequent

the 1996 Knesset elections see The Knesset, Elections to the Fourteenth Knesset, May 29, 1996, http://knesset.gov.il/description/eng/eng_mimshal_res14.htm.

${ }^{659}$ For a discussion on how the peace camp, despite its small numbers, was able to win the sympathy of a significant number of the Israeli public see Hermann, The Israeli Peace Movement: A Shattered Dream, Chapter 4.

${ }^{660}$ Mendilow, “The Likud's Double Campaign: Between the Devil and the Deep Blue Sea," 199. 
Oslo Accords. The agreements made by Rabin and the Israeli withdrawal from most of Gaza and some cities of the West Bank had allowed Arafat to leave Tunisia for the territories and set up a Palestinian self-government. These unprecedented moves meant that turning the clock back on Palestinian nationalism was increasingly becoming difficult. No longer was the option of annexing the territories a practical option. Neither was it possible to follow the policies of the 1967-1987 period in which the territories were relatively calm and stable. In the post Oslo period it seemed that the Palestinians would settle for nothing less than a sovereign independent state with territorial borders based on UN Security Council Resolution 242. As a result while many revisionists were deeply upset about the Oslo developments, they had very few options in reversing them. The only practical option at their disposal was to slow down the peace process so that it would lose its momentum and ultimately collapse. Netanyahu explained this during an internal Likud meeting when he compared Oslo to an accordion that had inflated Palestinian expectations so that they had assumed that they would get back around 90 percent of the West Bank, while he was deflating such expectations and making sure they only got around ten percent through the Wye agreement. ${ }^{661}$

The revisionist movement's approach to wait out Oslo was thus adopted only because there were very few options beside it. Through Oslo, Rabin had opened a genie's bottle that was very difficult to close. The revisionist

\footnotetext{
${ }^{661}$ See Aronoff, The Political Psychology of Israeli Prime Ministers, 65.
} 
movement's other option would have been to continue to abide by its ideological principles both in rhetoric and practice at the cost of losing power to Labor, in which case the movement would take a back seat while its rival made further concessions to the Palestinians. In retrospect the adoption of the tactics proposed by Netanyahu and Sharon at the height of Oslo, which entailed going along with the peace process in theory and "freezing" or subverting it as much as possible in practice, was successful in leading to the collapse of the talks. Indeed while the withdrawal from most of Hebron and 1 percent of the West Bank during the first phase of the Wye agreement are very important when discussing the ideological development of the revisionist movement, they were a far cry from the initial time table the Oslo agreements had set. According to the Oslo Accords the final status agreements had to be completed by May 4, 1999, while during Netanyahu's tenure these talks never even started. ${ }^{662}$ Meanwhile settlement construction doubled during the Likud led 96-99 period. ${ }^{663}$ The revisionist movement's two-pronged and on the surface contradictory approach to the peace process was thus highly successful in leading to the ultimate collapse of the peace process, however it also unintentionally led to the rise of fundamental tensions within the movement's ideology.

While the changes in the revisionist movement's rhetoric were to the most part tactical, ultimately they led to an ideological crisis. Change in rhetoric

\footnotetext{
${ }^{662}$ Shlaim, The Iron Wall: Israel and the Arab World, 588.

${ }^{663}$ Aronoff, The Political Psychology of Israeli Prime Ministers, 67.
} 
gradually results in a change of discourse, which is a central element of an ideology. When the discourse of a movement becomes contradictory and inconsistent then its ideology becomes contested and under the threat of transformation or even elimination. As discussed in earlier chapters discourse plays an important role in shaping political practice since the ways in which politicians talk about the world tend to define the ways in which they act in that world, inclining them toward some options and away from others. Moreover discourses are constituted by symbolic orders that help create an interpretive community. In ideological discourse these symbols are especially useful in defining "Us" vs. "Them."

When the ideological discourse of a movement becomes confusing and contradictory, even if done for tactical reasons, then the interpretive framework of its followers becomes contested and open to ideological change. Moreover a movement's followers might not be able to differentiate between tactical rhetoric and ideological rhetoric. As a result they might interpret any change in rhetoric as a change in the movement's belief system. The results of the statistical analysis of this dissertation shows that the change in revisionist rhetoric following the assassination of Rabin and in the lead up to the 1996 elections affected the attitudes of its constituents as shown in the graph below: 
Figure 5: Revisionist Zionist Opposition to the Peace Process ${ }^{664}$

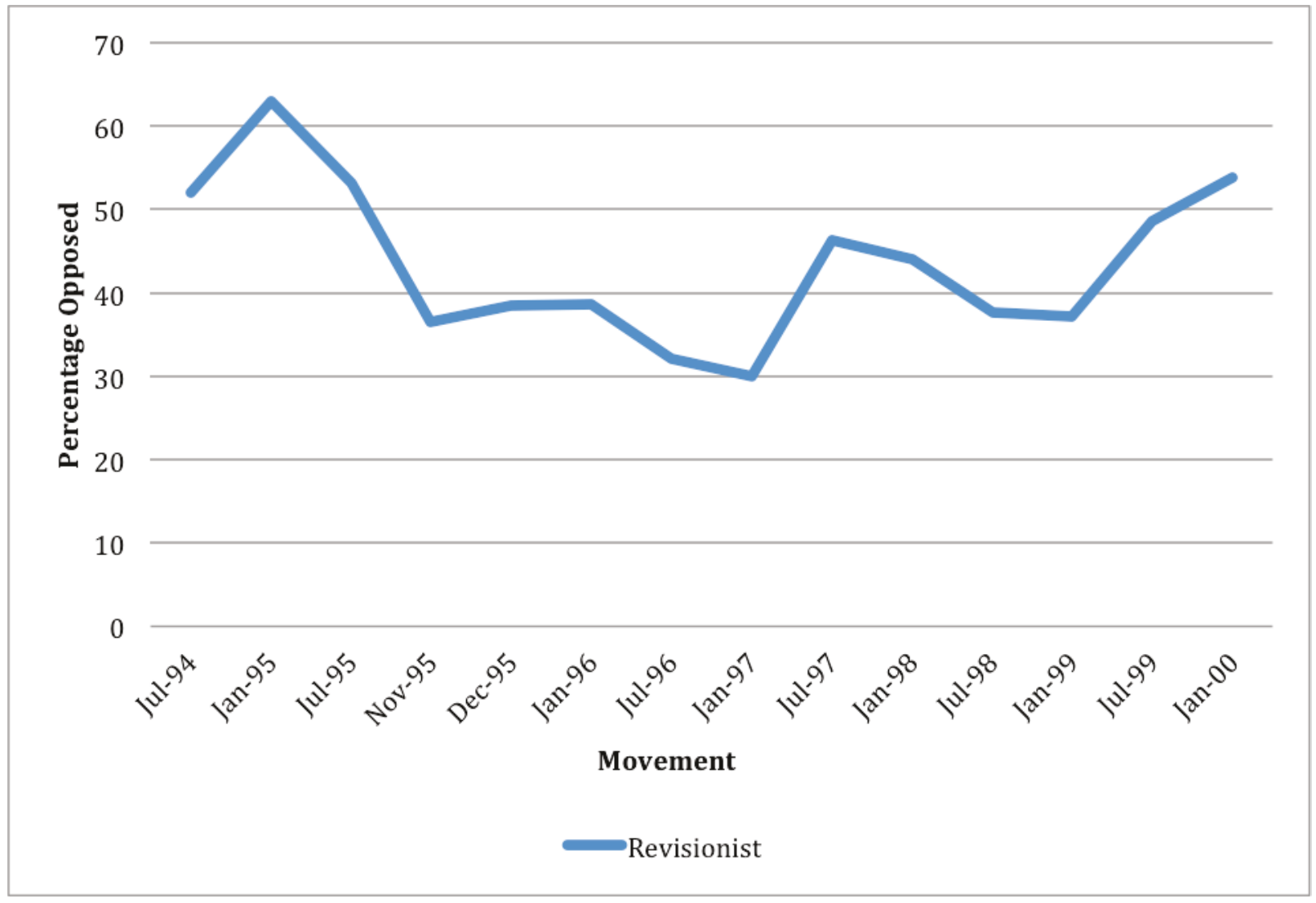

As apparent in the above graph, revisionist opposition to the peace process lessened from around 50-60 percent to around 30-45 percent, following the change in the movement's rhetoric. Interestingly when the movement began to reassert its opposition to the peace process in the wake of Ehud Barak's victory in the May 1999 elections, opposition to the peace talks among the movement's constituents also increased. This is why political rhetoric is so

\footnotetext{
${ }^{664}$ Method of Calculation: Each data point in the graph is the total percentage of revisionist voters who are either "very opposed" or "somewhat opposed" to the peace process. The percentage points are the result of cross tabulation statistical analysis of this dissertation for the 1994-2000 period, presented in pages 467-530 of the appendix.
} 
important. The results of multinomial logistic regression also demonstrate an important change. In July 1994, revisionists were 97 times, and religious Zionists 88.9 times, more likely to strongly oppose the Oslo Accords when compared to Labor voters. ${ }^{665}$ By July 1998 , this number had dropped to 16.5 for revisionists, while for religious Zionists it increased to $101 .^{666}$ Thus while revisionist opposition to the peace process still remained significant, it had dropped considerably from four years earlier.

These changes can be explained by the fact that the change in revisionist rhetoric effectively legitimized negotiating with the Palestinian "enemy" when such talks were highly taboo just a decade earlier. By accepting the continuation of the peace process in its discourse, the revisionist movement was effectively putting the fate of the territories up for negotiations. This was in complete contradiction to its ideology whose central element was the territorial integrity of Eretz Israel. Moreover Netanyahu, who was now leading the movement, soon found out that rhetoric had policy consequences. While the revisionist led government successfully put on hold any territorial withdrawal for half a year after taking office, it was forced into accepting a compromise over Hebron. Even though the Hebron agreement was highly in favor of Israel, and according to Netanyahu a much better deal than what Labor would have agreed, it still

\footnotetext{
${ }^{665}$ The odds ratio is computed as the probability of revisionists being strongly opposed to Oslo rather than strongly in support, when compared to Labor.

${ }^{666}$ See pages 470 and 517 of the appendix.
} 
signified the first withdrawal from "Jewish Land" by a revisionist leader in the history of the movement and the first agreement between a Likud government and the "terrorist" PLO. ${ }^{667}$ This was amplified by the fact of Hebron's association with Abraham the prophet and its very special place in biblical history. Netanyahu himself referred to Hebron as the "first Jewish community in history." ${ }^{668}$ Also the Wye memorandum, while mostly canceled in practice, meant that a revisionist government had agreed to withdraw from a further 13 percent of the West Bank. $^{669}$

These developments signaled important changes in revisionist policy, which was a result of a more fundamental ideological challenge. Yet, this change should not be seen as a complete ideological transformation of the movement similar to that of the 50 s and 60 s discussed in chapter 4 . First, the ideological tension and change described thus far cannot be ascribed to the whole revisionist movement. Indeed, aside from the religious Zionists, the Netanyahu government was criticized mostly from within his own party. Many influential Likud members were highly critical of the change in the party's approach to the territories and the Palestinians. Shamir for example was unrelenting in his

\footnotetext{
667 Sinai was not seen as part of Eretz Israel by the revisionists. See Shelef, Evolving Nationalism: Homeland, Identity, and Religion in Israel, 1925-2005, Chapter 3.

${ }^{668}$ Aronoff, The Political Psychology of Israeli Prime Ministers, 65.

${ }^{669}$ Up until then Rabin and Peres, in line with the Oslo agreements, had withdrawn from $27 \%$ of the West Bank. Had the Wye memorandum been implemented the Palestinians would have had around $40 \%$ of the West Bank.
} 
criticism of Netanyahu's direction of the party. After the Wye agreement he declared "With Netanyahu as Prime Minister I don't sleep well at night...there is no Likud today. No ideology. Almost nothing is left." ${ }^{670}$ Likud Knesset members Benny Begin, Michael Kleiner and David Re'em left the party in protest of the Hebron withdrawal and reformed the Herut party that they claimed would stay true to revisionist Zionism in contrast to the changing Likud. Even the more practical Sharon voted against his government's decision to withdraw from 80 percent of Hebron.

Netanyahu himself seemed to ignore the ideological dilemma rather than deal with it, picking both sides of the debate based on the circumstances. ${ }^{671}$ While such an approach was doable rhetorically, in practice it was difficult to implement, with the Prime Minister coming under attack from both sides of the debate. In fact these ideological tensions, which manifested in haphazard and contradictory government rhetoric and behavior, were arguably the main reason why his coalition collapsed in 1999. In fact Likud's loss in the elections were the most dramatic in the party's history going from 32 Knesset seats to only 19. Netanyahu's two-pronged approach had thus alienated both the center and the hawkish right.

${ }^{670}$ Rynhold and Waxman, "Ideological Change and Israel's Disengagement from Gaza," 20.

${ }^{671}$ There are numerous examples of such contradictory statements by Netanyahu in the past two decades. In September 2013 for example Netanyahu declared in regards to Hebron: "Anyone who tries to uproot us from the city of our patriarchs will achieve the opposite... We will continue to fight terrorism . . . with one hand, while strengthening the settlement with the other," (Quoted in Aronoff, The Political Psychology of Israeli Prime Ministers, 66) while ignoring the fact that he himself ordered the Hebron withdrawal sixteen years earlier. 
At the same time it would be incorrect to dismiss the changes in the revisionist movement during the 1990s as superficial tactical maneuvers. The events of the past two decades provide ample evidence for the argument that Oslo raised a serious challenge to revisionist ideology and affected it in unimaginable ways, an ideological challenge that has yet to be resolved in any decisive way. The most important event signaling the ideological crisis of the movement was the Gaza withdrawal of 2005 and the subsequent formation of Kadima by moderate revisionists in support of further withdrawals.

In September 2005 the Likud led government of Ariel Sharon, formerly known as the "father of the settlements," implemented a unilateral withdrawal from the Gaza Strip. The plan included the dismantling of 21 settlements in the Gaza Strip and four small settlements in the West Bank and the evacuation of over 8 thousand settlers residing in them. ${ }^{672}$ The unprecedented move exposed significant rifts within the revisionist movement. While Sharon's ideological commitment to revisionist Zionism has been questioned, ${ }^{673}$ he was not alone in his desire to withdraw from the Gaza strip and parts of the West Bank. In fact many influential Likud members such as Ehud Olmert, Tzipi Livni, Tzachi Hanegbi, Gideon Ezra, Avraham Hirchson and Meir Sheetrit also defected from Likud to form the new "centrist" Kadima party. Moreover an internal referendum

\footnotetext{
672 Jefferson Morley, "Israeli Withdrawal From Gaza Explained," The Washington Post, August 10, 2005.

${ }^{673}$ Aronoff, The Political Psychology of Israeli Prime Ministers, Chapter 4.
} 
within Likud found that 40 percent of party members were in support of Sharon's disengagement plan. ${ }^{674}$ As Olmert explained the reason for the defections and the formation of Kadima was that Sharon was "prepared for a major accommodation in the territories that Likud could not accept." ${ }^{1675}$ Interestingly, it was Netanyahu, who had effectively steered the movement in its current direction a decade earlier, who led the opposition within Likud against Sharon's plans. Moreover during the 90s Netanyahu himself had presented his "Allon Plus" plan to the party, which entailed withdrawal from the Gaza Strip and around 40 percent of the West Bank. ${ }^{676}$

The Gaza withdrawal and its fall out within Likud exposed the deep ideological crisis of the revisionist movement as a result of the Oslo process. Yet it is important to point out that two decades after Oslo, this impetus for ideological change has still not resulted in a transformation of revisionist ideology in favor of a political compromise with the Palestinians as many had hoped. The concluding chapter of the dissertation further discusses this point. Before closing the present chapter it is worth noting how the peace process exposed the fundamental differences between revisionist Zionist views of the territories and those of religious Zionists, a contrast that stems from their dissimilar ideological roots.

\footnotetext{
${ }^{674}$ Ron Dermer, Why the Likud Voted No to Sharon's Disengagement Plan (Jerusalem Issue Brief, May 3, 2004).

${ }^{675}$ Daniel Tauber, "The Rise and Fall of Kadima: A Cautionary Tale," The Jerusalem Post, October 31, 2012.

${ }^{676}$ Shlaim, The Iron Wall: Israel and the Arab World, 583.
} 
The Fundamental Differences Between Revisionist and Religious Zionist Views of the Territories and the Peace Process

While revisionist parties such as the Likud and religious Zionist parties such as the National Religious Party and later on the Jewish Home party are usually grouped as Israel's "right" by political pundits, in reality the ideology of these parties are vastly different. It is true that both the revisionist movement and the religious Zionist movement since 1967 have strongly advocated the annexation of the captured territories in the Six Day War, however the reasons behind such a position is vastly different between the two. As previous chapters have explained the ideological foundations of religious Zionism relies on a belief that the divine will of the Lord to redeem the people of Israel and subsequently the world, is being carried out through the State of Israel. As a result the State of Israel has to serve its "divine purpose" by helping settle the Jewish people on the Holy Land, which includes Judea and Samaria. As a result the religious Zionist movement has focused almost exclusively on settling the territories and making sure that the government does not "go astray" from its heavenly purpose, which will ultimately usher in the coming of "Messiah bin David."

The ideology of the revisionist Zionist movement on the other hand specifies that the Jewish people have the "right" to settle over all of Eretz Israel, which they argue has historically been their home for several millennia. This "right" however is not fundamentally due to religious reason or heavenly promises, in contrast to the religious Zionists, rather it's the result of a combination of perceived historical ties to the land as well the right of the Jewish 
Nation to "defend itself," which is assumed to be better achieved by holding on to the territories. Moreover in revisionist Zionism the Jewish people can only rely on their own military might, since they are an isolated and separate nation from a gentile world that has constantly worked to annihilate the Jewish people due to its "anti-Semitism." In this cynical view of international affairs, Israel has no real or permanent allies. Rather it has to rely on an "Iron Wall" of military supremacy in order to deter its enemies from creating "another Holocaust."

The above two ideational frameworks have been discussed in length in previous chapters and the point here is not to repeat it, but rather to show that while the political ideology and identity of both groups has been partly shaped in contrast and opposition to Labor, the two groups have fundamentally different ideational frameworks from which they see the world. As a result of this, the two groups saw eye to eye regarding Israel's territorial policy in the pre-Oslo period, while after Oslo and with the ideological tensions that emerged among revisionist Zionists, the two movements' views of the territories began to diverge and as a result religious Zionists, as junior coalition partners, have had to constantly threaten Likud led governments with a vote of no confidence in case of territorial withdrawal. Several reasons can be cited for the divergence of the two movements:

In Revisionist Zionist discourse holding on to the territories has important security benefits such as strategic military depth, advanced warning in case of military offensives by Israel's neighbors, and more leverage in "fighting terrorism." Moreover giving up land to Arab enemies would only be seen as a 
sign of weakness and understood as a hole in Israel's Iron Wall policy. While revisionist Zionists have emphasized the "right" of Jews to the land, their rationale behind the need for a Greater Israel has increasingly been one of "necessity" in which Israel needed to hold on to "both sides of the River Jordan," and later on to all the "lands west of the River Jordan" due to security concerns. The ideology of the revisionist movement as set out by Jabotinsky had an extreme Hobbesian perception of the international system and emphasized the need for the establishment of a militant Jewish state on both sides of the river Jordan so that it could ensure Jewish "self-defense" and "survival." In fact the charismatic revisionist leader, who was an atheist, never used biblical language such as the "Holy Land" or the "Promised Land." Throughout revisionist history opposition to the partition of Eretz Israel and withdrawal from the territories has partly been explained on pragmatic grounds, such as the security needs of the country and the necessity of having more land in order to facilitate the absorption of more immigrants. ${ }^{677}$ During the Yishuv period for example Jabotinsky attacked Labor's "appeasement" of the Arabs by partitioning the Land of Israel and "endangering Jewish security." 678

Such a view is a far cry from the religious Zionist view of the land as "holy" and the settlement of the territories as the "ushering of the messianic age." In religious Zionist ideology compromise on the territories is out of the question and

\footnotetext{
${ }^{677}$ See Shavit, Jabotinsky and the Revisionist Movement 1925-1948, 124.

${ }^{678}$ Ibid., 331.
} 
beyond mundane "earthly politics." Rabbi Kook clearly explains this when he states: "The Master of the Universe has His own political agenda, according to which politics here below are conducted. Part of this redemption is the conquest and settlement of the land. This is dictated by divine politics, and no earthly politics can supersede it." ${ }^{679}$

As a result of this discrepancy, while the revisionists, at least theoretically, see Israel's control of the West Bank and Gaza Strip as part of their security and power calculations in order to ensure the "survival" of Israel, which automatically opens it up for reevaluation and reassessment, the Religious Zionists see the territories as beyond an issue mortals can compromise on. In practice because of the revisionists' very negative view of international affairs and the "gravity" of Israel's security needs, they have been rather rigid regarding territorial compromises. Nevertheless it is important to point out that long before Oslo, the revisionist successfully gave up claims over Transjordan, as discussed in chapter four. In the post Oslo period, revisionist Zionism's increasingly instrumentalist approach to the territories has meant that some groups within the movement have been open to some sort of compromise as long as they see it to be beneficial to Israel's security and power needs. Thus for example when Ariel Sharon came to the conclusion that it was in Israel's benefit to withdraw from the overcrowded Gaza Strip, he dismantled the settlements even though the revisionist general had played the leading role in establishing settlements in the

\footnotetext{
${ }^{679}$ Quoted in Ravitzky, Messianism, Zionism, and Jewish Religious Radicalism, 131.
} 
occupied territories. Even revisionist leaders who were against any form of territorial withdrawal based their arguments on the security and immigration needs of Israel discussed above. For example when a reporter asked Yitzhak Shamir in 1998 whether Israel could exist even if it were a little smaller, now that it is so strong, he replied:

No. No...we won't be able to sustain ourselves, won't be able to bring more Jews here...the power of a nation is not just the army. It is also population. If there are more Jews there will be more in the army. I think that [the] 5 million Jews we have now is not enough...we need at least 10 million. We can't accept the immigration of millions of Jews if we give up parts of our territory. ${ }^{680}$

By comparing the ideologies of the two movements we are thus able to discern each camps motives for holding on to the territories and opposing the peace process. Such a comparison also allows us to understand why in the post Oslo era, the revisionist Zionist movement has witnessed an ideological challenge leading to a recalculation of the security worth of the territories among some segments of the group, while in the religious Zionist camp there has been no such change. The different ideologies of the two movements also allows us to explain how one movement can dismantle 24 settlements in the Gaza Strip and 4 settlements in the West Bank, and how a revisionist Prime Minister can accept, even if only in rhetoric, a conditional Palestinian state, while another movement spends enormous political capital and unparalleled self sacrifice in order to prevent the dismantling of even the most remote and smallest settlements. Even

${ }^{680}$ Quoted in Aronoff, The Political Psychology of Israeli Prime Ministers, 28. 
if one dismisses the changes in revisionist policies as tactics aimed at fending off growing international and domestic pressure, it still proves the point that the territories are up for political negotiation among important segments of the revisionist movement, though they have shown little flexibility in this regard. In contrast for the religious Zionists any form of withdrawal is an unforgivable act that can delay and hamper the divine redemptive process.

Another difference between the two movements worth mentioning is the revisionist need to govern the Israeli state, with all that this entails. This is why Likud leaders are much more ferocious in their rhetoric when they are sitting in opposition compared to when they are leading government coalitions. Since 1977 when the revisionists moved from opposition to governor in Israeli politics, they have been forced to become more pragmatic in their rhetoric and policies in order to keep the government functional. Thus for example while revisionist leaders despise American pressure and even describe it as "anti-Semitic," at the end of the day they are usually forced to make some sort of concession, even if it falls short of American demands. Thus for example Menachem Begin had to compromise in Camp David on issues that would have otherwise been off the negotiating table, such as Palestinian autonomy. American pressure also forced Yitzhak Shamir to attend the Madrid peace talks, much to his disliking. US policy regarding the peace process has also been instrumental in forcing the changes in revisionist rhetoric and behavior in the post-Oslo period discussed earlier. Thus the economic and political needs of the country force revisionist leaders to be more forthcoming in renegotiating their ideological positions. As one US 
diplomat said of Netanyahu, "You can be an ideologue in the opposition. But when you are a prime minister, you have to adjust your ideological underpinnings. The world is putting tremendous stock in these talks. You cannot ignore this reality without a paying price in Israel's standing." 681

In contrast the religious Zionists have always been junior partners in Israeli coalitions, as a result they have been able to focus on their own narrow ideological views without compromise. The revisionists have also been forced to negotiate and compromise with various parties in their often-fragile coalitions. This has made them more amendable to political cooperation and concession. The current Likud led Israeli government for example is the result of an odd variety of coalition partners with very diverse views on politics, economics and culture that Netanyahu has had to juggle with, a task which ultimately failed with the collapse of the coalition in December $2014{ }^{682}$

\section{Conclusion}

If the eighties saw the rise of the new liberal ideology of Labor in opposition to the religious messianic ideology of the settler movement, during the nineties the two camps clashed head on. The battle began with the 1992 elections, which were effectively a national referendum about the very definition of Zionism and the character of the Israeli nation-state. Was Israel a secular,

\footnotetext{
${ }^{681}$ Shelef, Evolving Nationalism: Homeland, Identity, and Religion in Israel, 1925-2005, 174.

${ }^{682}$ For an analysis of coalition's break up see Brent E. Sasley, "Israel's Tangled Democracy Why Governments Will Keep Falling," Foreign Affairs, December 3, 2014.
} 
modern, democratic and Western oriented country? Or, was it a religious, traditional, and "unique" country? The results of the election were not overwhelmingly in either direction, thus signifying the onset of "Israel's civil war."

This is why the Rabin government's plan to reach a deal with the Palestinians regarding the territories should be seen as a part of Labor's larger approach in the "normalization" and "civilianization" of Israeli politics and society in line with its new ideology discussed in the previous chapter. The new approach was not just limited to the peace process but also included many new initiatives such as the revamping of the religious, educational and legal affairs of the country in a new secular, inclusive and more tolerant direction. This is why it is important to understand Labor's decision to pursue peace with the Palestinians as a result of the emergence of a new liberal identity that in turn was the outcome of the movement's ideological transformation. Labor's new worldview allowed it to interpret the international developments of the late eighties and early nineties in a new positive light, which allowed it to reassess Israel's "security dilemma" and adopt a new foreign policy framework accordingly.

In contrast, the religious Zionists saw the new orientation of the Israeli government as a process of "de-Judification" or "Hellenization" of state and society. This is why shortly after the Rabin took office, Nekuda, the main settler publication declared that the government "is aiming to put the Zionist project and Zionist belief into retreat and to replace it with the golden calf and false peace. 
There is only one way for such a government: It must pass from the earth." The "golden calf" refers to the idol the Israelites started to worship during Moses' absence. According to the Torah, God's wrath because of "The Sin of the Calf" was so severe that it nearly destroyed the Israelites. ${ }^{684}$ Thus according to religious Zionist discourse, while the peace process looked pretty on the surface like the golden calf, it was in fact a grave deviation from God's path.

The Hebron massacre was the turning point in the clash of the two movements and in retrospect it can be seen as the beginning of the end of the peace process. Goldstein's attack effectively led to the suspension of the peace talks. Moreover Arafat and the PA were weakened in the Palestinian political landscape, while Hamas made the strategic decision to use suicide attacks against Israeli targets, a development that would have far reaching consequences. Yet all these consequences, while important, are not the primary reason why the Hebron massacre, which took place a mere five months after the signing of the Oslo Accords, severely undermined the peace process. Rather it was the month long showdown of the two camps within Israel in the aftermath of the attacks that changed the fate of the peace talks. Initially it seemed that the Rabin government would show a strong response to the settler movement by evacuating the settlers in Tel Rumeida and part or all of the settlers in Hebron.

\footnotetext{
${ }^{683}$ Zertal and Eldar, Lords of the Land: The War Over Israel's Settlements in the Occupied Territories, 1967-2007, 130.

${ }^{684}$ See Exodus 32.
} 
However after severe pressure and lobbying by the religious Zionist movement and the issuing of damning Halacha rulings against any settlement dismantling, Rabin finally backed down. Goldstein's attack and its aftermath strongly emboldened the settler movement which became more ferocious and determined in their aim of bringing down the Labor led government. In fact Yigal Amir would tell his interrogators after the assassination that it was at Goldstein's funeral that he decided to commit an "exemplary act," adding, "It began after Goldstein, That's when I had the idea that it's necessary to take Rabin down." 685

While it was the religious Zionist movement that played the leading role in bringing down the Rabin government and the peace process, the larger revisionist movement was a full partner in the enterprise. For the revisionists the changes in the balance of power in the Middle East had little to no meaning and as a result had little effect on the movement's approach to the "Arab problem." Yet as the 1996 elections approached, with polls indicating a Labor lead, the movement became divided as never before over how to approach the peace process. In the end Netanyahu and his allies within the revisionist movement, who intended to embrace the peace talks in rhetoric and torpedo it in practice, won the day. Netanyahu and the revisionist movement more generally soon found out however that rhetorical change ultimately leads to policy change and

${ }^{685}$ Quoted in Karpin and Friedman, Murder in the Name of God: The Plot to Kill Yitzhak Rabin, 16. 
eventually to ideological transformation. This finding has important theoretical implications, which will be discussed in the next chapter.

The change in Likud's approach to the territories and the peace talks with the Palestinians exposed the underlying differences in the ideology of the revisionist movement and its religious Zionist allies. The most important point of divergence between the two movements is that revisionist rejection of withdrawal from the territories is increasingly based on a security related ideational framework, not a moral or religious one. In contrast, religious Zionists have relied on the "Lord's divine plan" as explained in sacred text and as defined by Rabbi Kook, to form an ideology that is withdrawn from worldly politics, and is seen as superseding and overruling it. However the reason why there have been few actual revisionist policy changes in this regard is that the world is seen as eternally hostile and Jews as perpetual victims who have to rely on military might to ensure their own survival. Nevertheless this means that revisionist ideology has the capacity for change, even if there is great resistance to it.

As discussed earlier ideological change is defined as significant alterations to a movement's worldview that is accepted by a majority of its members, including party elites as well as supporters within the general public. Real ideological change can be difficult to differentiate from tactical policy changes that are regularly adopted by political parties due to political expediency. Nevertheless real ideological change manifests itself in the adoption of new policies and rhetoric that are accepted by a majority of the movement's members and are consistent over the long run. For example when the revisionist 
movement began to exclude Transjordan from the land of "Eretz Israel" in the 50 s and 60 s, claims to Transjordan began to dissipate both from the movement's rhetoric and from its policy proposals from then on, so that by the late sixties the movement had completely dropped Zionist claims to the area. As a result of this ideological change, the grand majority of the revisionist movement no longer called for the "liberation" of Transjordan, a development that has lasted until today. In contrast no such consensus has emerged regarding a withdrawal from the occupied territories, even after two decades. Therefore revisionist policy regarding the peace process should be seen as the result of a significant challenge to the movement's ideology, and not as a sign of a decisive ideological transformation.

In conclusion both the rise and the fall of the peace process should be seen as a result of the struggle between the Labor movement and the religious and revisionist Zionist movements, each of which sought to redefine Zionism and Israel in its own image and according to its own ideology. Rabbi Benjamin Zeev Kahane, the son of the late rabbi Meir Kahane, in an article that was part of an edited volume ${ }^{686}$ published in support of Baruch Goldstein that was not surprisingly avidly read by Yigal Amir, wrote:

The problem is not the Arabs - the problem is the Jews. The truth, the way we look at it, is that there has never been an Arab problem. We could have solved that problem in 48 hours, if only we wanted to. The real war is not with the Arabs but with the Hellenized Jews. All the blood shed by

\footnotetext{
${ }^{686}$ The 550-page book was titled 'Baruch, the Man: A Memorial Volume for Dr. Baruch Goldstein, the Saint, May God Avenge His Blood.'
} 
Arab terrorism is "as if" shed by the Arabs; the people really responsible for the bloodshed are Jews scared by the gentiles and attached to distorted Western ideas. ${ }^{687}$

${ }^{687}$ Quoted in Sprinzak, "Israel's Radical Right and the Countdown to the Rabin Assassination," 113. 


\section{Chapter 7: Conclusion}

When the Oslo Accords were signed in September 1993, Rabbi Bin Nun, a religious Zionist leader, declared to Labor: "Do not build your dream on the ruins of our dream." ${ }^{\text {" }} 8$ As this dissertation has demonstrated however, this was not possible as the political movements in Israel had very contrasting views of Zionism and the kind of Israel they envisioned. This is why both the rise of the peace process as well as its demise should be seen as part of a larger ideological struggle between Labor on the one hand and the religious and revisionist Zionist movements on the other, each of which sought to redefine Zionism and Israel in its own image and according to its own ideology. This is why we need to examine Israel's domestic political ideologies in order to understand the country's foreign policy toward the peace process during the nineteen nineties.

\section{Labor: From Militarism to Peace}

During the years of the Yishuv and the early days of the state, the Labor movement was able to achieve ideological hegemony and create an ideal Sabra identity that was accepted by a large majority of the public. The Sabra, which was constructed in opposition to the perceived negative characteristics of "exile" Jews, was a "Jewish warrior" who relied on inner strength and self-sacrifice in the defense of the Jewish community. This translated into a security oriented foreign policy approach that heavily relied on military power. Yet, Labor's political

\footnotetext{
${ }^{688}$ Ravitzky, “'Let Us Search Our Path': Religious Zionism After the Assassination," 143.
} 
ideology also had strong pragmatic elements that sought Zionist aims through practical cost-benefit calculations. This is why during the Yishuv period, Labor was willing to negotiate with the Palestinians and even partition the land in favor of establishing a Jewish majority state.

Labor's ideological hegemony however was undermined by its decline and the ascendance of the revisionist movement in the 1960s and 1970s, finally leading to the fateful 1977 "revolution." More significant for the peace process, in the wake of the Six Day War, the religious Zionist movement saw the rise of a messianic ideology that tied the settlement of the new captured territories with the "divine redemptive process" of the Jewish people and the human race. The rise of a militant settler identity within Israeli society under the full support of successive revisionist governments was a significant ideological threat to Labor.

The Labor movement, which had played the leading role in the Zionist cause and the establishment of the state, had reached the end of the list of its idealistic goals and as a result was entangled in an ideological crisis. This is because the movement had effectively reached the "end" of Zionism, in the sense that the secular Zionist enterprise had very little to strive for and was thus "dead," in contrast to the settlers who saw the Zionist enterprise as part of an ongoing and larger redemptive process. As a result of this, while Labor no longer had an ideological message that could mobilize and energize the masses, the settlers presented themselves as "new" and energetic Zionist pioneers who were tasked with restoring Zionism and taking it back to its "true" path. 
The settlers' drive to redefine Zionism was highly troubling for the Labor movement which believed that the fundamentals of Zionism were coming under threat by a racist, ethnocentric, illiberal, messianic movement that was camouflaging its activities with Sabra symbols and values. The rise of the religious settler movement and the events of nineteen eighties such as the Lebanon War, the exposure of the Jewish underground and the Palestinian Intifada, led to the rise of a liberal Zionist identity within Labor that was constructed in opposition to religious Zionists. The rise of the peace movement within Labor in effect revitalized it and gave it a new ideological message and a corresponding liberal Zionist identity that sought to bring Zionism back to its "original roots."

If in the first decades of Zionism, the Labor movement saw Jewish life in the diaspora as "diseased" and sought to "cure" it through the creation of the Sabra warrior, the Labor of the 80s now saw Israeli society, under the spell of the religious Zionists, as "diseased." Thus while Labor's ideology was constructed in opposition to the "exile Jew" initially, it now began to change out of rivalry with the religious Zionists. The "them" for Labor had thus moved from the diaspora to within Israeli society. The diagram below illustrates the changes in Labor's ideology: 
Figure 6: The Evolution of Labor Zionist Ideology

$1920 s$ 1970 s 1980 s Today Sabra Identity Period of Ideological Transition

Liberal Zionist Identity

The rise of the peace movement within Labor, which led to the construction of a liberal Zionist identity that saw Israel as part of the democratic, secular and modern West, allowed the movement to interpret the regional and global developments of the late eighties and nineties in a positive light, in contrast to the revisionists and the religious Zionists. In Labor's new worldview Israel was no longer a weak and isolated "David" fighting numerous Arab "Goliaths," and thus no longer did the Jews need to "live by the sword," rather they could rely on political negotiations and compromise to ensure their security. This new worldview was the result of both its new ideology as well as Israel's improved security status in the early nineties, in which the country's enemies no longer posed an "existential threat." Rabin explained that "the PLO and other terrorist organization are not an existential threat to the state of Israel and it would be an insult to the IDF were I to consider the Hamas and the Hizballah as a serious threat to Israel." ${ }^{\prime 689}$

${ }^{689}$ Quoted in Inbar, Rabin and Israel's National Security, 141-142. 
Therefore rather than associating Israel's drive for peace in the early nineties solely to a new liberal identity, as argued by constructivists, or the result of changes in the balance of power in the Middle East, as realists would argue, the important change in the foreign policy of the Jewish state should be seen as a result of the interaction between the new liberal Zionist identity of the Labor movement and the country's greatly improved security status. The combination of these two compelled Labor leaders that a political compromise with the Palestinians was now "affordable" and even desirable. It is important to point out that had the movement not experienced the ideological change it did in the eighties and in response to the rise of its messianic and xenophobic rival, it is difficult to imagine how Labor would have changed its decades long approach to the Palestinians and the territories. This is why the study of ideology is vital in understanding how a political movement views global developments and changes in the balance of power and reacts to them. This issue will be discussed in future sections of this chapter.

The study of political ideologies also allows us to understand the motivations behind a movement's behavior. For example while the behavior of Labor in the 30 s and 40 s was similar to Gush activities in the 70 s and 80 s, their motivation and belief systems were different. Also while Labor saw militarism as a "necessary evil" and only in a "defensive capacity" due to external circumstances, the revisionists believed that only by infusing a "psychology of shooting" could a new strong Jewish nation be born, while for the religious Zionists militarism was seen as a legitimate tool for the "soldiers of the Messiah." 
Thus while militarism is a component of all three ideologies, there are important differences between them. This is why without the study of these movements' ideologies we are not able to understand why they behave similarly during some circumstances and time periods, while acting completely different in others.

\section{Revisionist Zionism: From Ideological 'Purity' to Ideological Crisis}

Out of the three Israeli movements studied in this dissertation, the revisionist movement has arguably witnessed the most changes in its ideology. Revisionist Zionism was established out of an ideology that demanded the unconditional territorial integrity of Eretz Israel. Revisionist Zionism as laid down by Jabotinsky called for the immediate creation of a Jewish state using military means. The foundation of the movement's ideology was based on a very cynical view of international affairs in which the Jews were under constant threat of extermination under the hands of their enemies. Moreover revisionist Zionists believed that such conditions were eternal and non-changing and the only solution was an "Iron Wall" of military force, especially when dealing with the Arabs. Also in contrast to Labor's early militarism, the much more extreme revisionist militarism saw military power as the sole guarantor of Jewish survival and dismissed humanistic morality in favor of nationalism. As a result the movement had no qualms about targeting Arab, British and even Jewish civilians to achieve its aims.

During the nineteen fifties and sixties however in order to come out of a deep political crisis that was the result of the movement's unpopularity and the strength of Labor, the revisionists transformed themselves from a fringe 
underground militant movement to a legitimate political party in Israeli politics. In this process revisionist ideology experienced steady yet important changes which included increasing pragmatism, the shedding of the movement's anti-socialist philosophy, the exclusion of Transjordan from the "Land of Israel," and the acceptance of political alliances and compromises within Israeli politics. Studying these changes is necessary in order to understand the movement's behavior in regards to the peace process during the nineteen nineties.

Figure 7: The Evolution of Revisionist Zionist Ideology

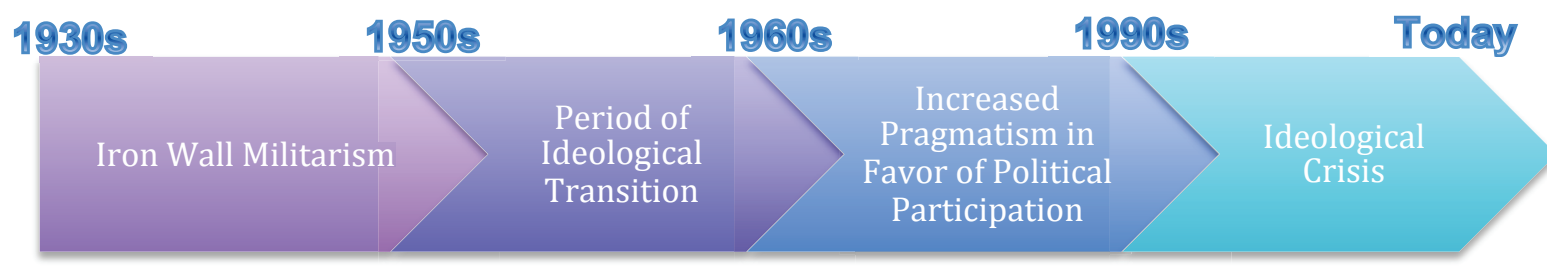

Although revisionist ideology witnessed increased changes towards moderation and pragmatism during the fifties and sixties, even going as far as shedding claim to parts of the "Jewish land," the extreme Hobbesian view of international affairs, which according to Jabotinsky was based on homo homini lupus (man is a wolf to [his fellow] man), ${ }^{690}$ of the movement was largely intact. This is why

${ }^{690}$ See Yonathan Shapiro, The Road to Power: Herut Party in Israel (Albany: State University of New York Press, 1991), 11-12. 
even though there were important developments in the Middle East during the eighties and nineties, which according to Labor had highly improved Israel's "security dilemma," the revisionists believed that essentially nothing had changed. As a result when a Labor government reached political agreements with the Palestinians, the revisionists saw this as the weakening of Israel's "Iron Wall" defense and the beginning of the end of the Jewish state. In response, the movement led by Benjamin Netanyahu decided to take the practical approach of accepting the peace process in rhetoric and torpedoing it in practice. As Benzion Netanyahu, the Prime Minister's staunchly revisionist father explained, "Bibi might aim for the same goals as mine, but he keeps to himself the ways to achieve them, because if he expressed them, he would expose his goals...l am talking about tactics regarding the revealing of theories that people with different ideology might not accept." 691

Yet the revisionist's tactical acceptance of the peace talks in rhetoric as well as the small but nonetheless significant territorial withdrawals it undertook, effectively legitimized the peace process, and established it as the sole way to resolve the Israeli-Palestinian conflict in the international community as well as to a large extent within Israeli society. At the same time however the revisionist tactic of delaying and subverting the peace talks in practice led to its collapse. Thus while negotiating with the Palestinians and withdrawing from "Jewish land" had become justified and accepted, the Oslo process had also "died."

\footnotetext{
${ }^{691}$ Quoted in Peter Beinart, The Crisis of Zionism (New York: Times Books, 2012), 113.
} 
While the revisionist approach to the peace talks was perhaps the most practical and efficient method in confronting it, this dissertation argues that the unintended consequence of the approach was the creation of a significant challenge to the movement's ideology. This is because when the rhetoric of a movement's leaders diverges from ideology frequently, it leads to policy change and eventually to ideological transformation. Narratives play an important role in shaping identities and norms and in legitimizing political action. Thus when the ideological discourse of the movement changed from a total rejection of withdrawal to how much to withdraw, it affected the ideological attitudes of its members. Two decades after the Oslo Accords however, the revisionist movement largely continues to resist an ideological change in favor of withdrawal. This even though the movement has struggled with numerous challenges as a result of its position, from increased international pressure, particularly from the Americans, to mass defections from the party in favor of a withdrawal and the formation of the rival Kadima party.

Such resoluteness against the peace process in defiance of pressures for change is because the idea of "Greater Israel" has been the rasion d'etre of the revisionist movement and its core ideological principle. It is true that the movement has accepted and implemented territorial withdrawals before, however the renunciation of claims to Transjordan, the withdrawal from Sinai and southern Lebanon and even from the Gaza Strip where all seen as secondary, and in some cases even strengthening, Israel's hold on "Judea and Samaria." If the 
revisionist movement were to in fact give in to demands to withdraw from the West Bank, it would effectively mean the end of revisionist ideology.

From its inception revisionist ideology has been able to offer very little in contrast to its Labor rivals aside from the concept of Greater Israel. Abandoning this core ideational principle would automatically leave the movement at an ideological dead-end, unless it is able to come up with a new ideological goal or struggle. Up until now the revisionists have had very little to offer in the realm of politics, economics and culture that is fundamentally different from their rivals. As a result, if they accept a withdrawal from the territories and the establishment of a Palestinian state, then they will be left with no ideological message to rally party members and the masses.

Another reason why the revisionist movement has been able to sustain its contradictory and ambiguous approach, where rhetoric does not match policy, for over two decades has been the political crisis of Labor, which has left Likud with no significant political opponents. In contrast during the 50 s and 60 s, when the movement was also witnessing an impetus for change, the revisionists sustained repeated defeats during elections. On the other hand in the past two decades the revisionists' two-pronged "Peace with Security" approach has actually rewarded them politically. Aside from the crisis of Labor, which will be discussed in future sections, the primary reason for Likud's success has been the onset of Palestinian violence against Israeli citizens. Attacks by Islamic militants since the mid nineties and particularly after the Second Palestinian Intifada have helped Likud portray itself as the only force capable of "dealing with Arab violence," in 
contrast to the left who are "soft on terrorism" and want "peace at any price." Thus, ironically hardline Palestinian groups such as Hamas and Islamic Jihad have played an important role in revisionist success. Arguably, groups that oppose the peace process on both the Israeli and Palestinian sides have been good for each other politically.

\section{Religious Zionism: The Persistence of a Messianic Ideology}

In the wake of the Six Day War the Religious Zionist movement dramatically changed from a movement largely concerned with the institutionalization of Halacha in society to a messianic movement as set out by Rabbi Abraham Kook. Thus the war fundamentally transformed the religious Zionist movement, which up until then was not an important ideological contestant in Israeli politics. The rise of messianic religious Zionism provided the revisionists with a powerful and determined ally, a development that would have far reaching consequences for Israel and the Middle East.

Kook saw Zionism and the settlement of the Holy Land as part of "God's plan" and the hastening of the "divine redemptive process." Rabbi Zvi Kook, the movement's leader after his father's death, declared after the war that "the footsteps of the Messiah" could be heard. According to sacred Jewish text when the footsteps of the Messiah were heard the world would be replete with moral decay, apostasy, brazenness and untruthfulness as well as physical destruction. According to the Mishnah, or Oral Torah, this age would be full of sin, where 
"government will turn to heresy...the wisdom of the Scribes will decay and those who fear sin will be utterly despised. Truth will be absent." ${ }^{692}$

According to Rabbi Kook during this age a young generation would rise who were "willing to die bravely for what, to its mind, are noble ideas, among them the sense of righteousness, justice, and knowledge that it feels within it, can't be lowly." ${ }^{\prime 93}$ This generation would play the leading role in taking the world from the previous "darkness" of the "footsteps of the Messiah" era into the "days of the Messiah" period. ${ }^{694}$ The founding of Gush Emunim was the first step of translating the rabbi's worldview into an organized political movement. According to the movement's new ideology the Israeli left was in the process of "Hellenizing" Jewish state and society. Moreover, in line with this "de-Judification" activity, the "corrupt" Labor was handing "holy territory" to "impure gentiles," a process that if left unabated would hamper the divine redemption and the coming of the Messiah. This ideological change of the movement, shown in figure 7, led to the rise of a religious settler identity that was willing to make great sacrifices in

${ }^{692}$ Mishnah Sotah 9:15.

${ }^{693}$ Quoted in Yehudah Mirsky, Rav Kook: Mystic in a Time of Revolution (New Haven: Yale University Press, 2014), 59.

694 For a discussion of the "footsteps of Messiah" concept in Rabbi Kook's thought see: Menachem Friedman, "Jewish Zealots: Conservative and," in Religious Radicalism and Politics in the Middle East, by Emmanuel Sivan and Menachem Friedman (New York: State University of New York Press, 1990), 139-141; Mirsky, Rav Kook: Mystic in a Time of Revolution, 59-62; Ravitzky, Messianism, Zionism, and Jewish Religious Radicalism, 107-109; For an overview of the Rabbi's messianic philosophy see Ben Zion Bokser, The Essential Writings of Abraham Isaac Kook (Teaneck: Ben Yehuda Press, 2006); Gellman, Essays on the Thought and Philosophy of Rabbi Kook. 
order to settle the territories and who showed extreme devotion in fighting its opponents.

Figure 8: The Evolution of Religious Zionist Ideology

\section{Working Toward a 'Torah State' \\ Messianic religious Zionism}

As apparent in the above graph, the religious Zionist movement has witnessed little ideological change. In fact even prior to the 1967 war, messianic religious Zionism existed, albeit among a small group of Kook's followers. The war only allowed this "young guard" to use the euphoria following the war to take over the religious Zionist movement. While it took Kook's students around a decade to fully grasp the leadership of the movement, the religious Zionist movement did not witness a period of ideological transition that is marked by inner movement resistance, confrontation and defection, as with the other two movements.

The religious Zionist movement has thus shown a surprising degree of ideological consistency and sustainability. While the movement has shown flexibility in its tactics and methods, its ideological goals have largely been constant and in line with Kook's ideas. Such persistence is extraordinary given the various challenges and pressures the movement has faced, from periods of 
political turmoil, organizational failures, such as the collapse of the Gush's organizational wings in the late $80 \mathrm{~s}$, to extreme pressure and scorn from inside Israeli society, particularly after the assassination of Rabin. Moreover since 1967 there have been major external events that contradict the movement's beliefs. This dissertation has demonstrated that when external events are inconsistent with the expectations of the ideological belief system of a movement, an opportunity for the rise of competing ideas and explanations is created. For example the Eichmann trials, which disaffirmed negative stereotypes of diaspora Jews, challenged and ultimately weakened Labor's Sabra ideology.

On the other hand the Religious Zionist movement has shown that it is largely immune from unwanted external developments. First and foremost, unlike Kook's assertion that the coming of the Messiah was very near after the Six Day War, nearly half a century later this has not taken place and the "Messiah" has not come. Instead Israel nearly lost the 1973 War, withdrew from the Sinai and the "biblical lands" of southern Lebanon, and most important of all gave back the Gaza Strip and parts of the West Bank to the Palestinians. In fact Religious Zionist leaders have explained these events as "brief delays" that are not able to halt the redemptive process, which would proceed with "utmost certainty." In fact the movement has very rarely seen any internal voicing of criticism and calls for ideological change, even after turbulent events such as the assassination of Rabin. Such ideological persistency presents a theoretical anomaly to some of this dissertation's findings presented in chapter two. This is discussed further in the next section. 


\section{The Merits of 'Bringing Back' Ideology Into Foreign Policy}

\section{Analysis}

Throughout this dissertation it has been demonstrated that domestic political ideologies act as a lens through which external events and global developments are understood and acted upon. As a result the realist assumption that ideologies act in contrast to national interests is incorrect. Realist scholars have argued that political ideologies interfere with cool-headed pursuit of national interests. Norman Graebner and Arthur Schlesinger for example analyze the mixing of ideology with real-politik in US foreign policy and argue that instead of ideology, foreign policy should be based on "practical" considerations. ${ }^{695}$

In contrast this dissertation has argued that ideology, rather than being in competition with national interests, provides a lens through which "national interests" are defined and provides a prescriptive action plan on how they should be pursued, in the process determining friend and foe, threat and opportunity. This is because "national interests" are not objectively given but are rather determined based on the interaction of a movement's ideology and international events and developments. This is why the three movements discussed in this dissertation understood and reacted to the new international environment of the nineties so differently. In fact a testament to the subjective nature of international relations is that each movement saw the other's definition of the national

\footnotetext{
${ }^{695}$ See Graebner, America As a World Power: A Realist Appraisal from Wilson to Reagan; Schlesinger, "Foreign Policy and the American Character."
} 
interests and understanding of the global environment as not based "in reality." For example Netanyahu, after becoming Prime Minister in 1996, in an interview with Ari Shavit of Haaretz, accused the previous Labor government of basing its policies on "some vision of a new Middle East that had no foundation in reality," explaining that "when people detach themselves from reality, floating around in the clouds and losing contact with the ground, they will eventually crash on the rocky realities of the true Middle East." ${ }^{\text {"966 }}$

Neoclassical realism attempts to correct the weaknesses of earlier realist approaches by accounting for domestic ideational variables and the perceptions of decision makers by stressing the role of "intervening variables" which act in between relative power capabilities and foreign policy making. Nevertheless, while this latest addition to realist theories of international relations improves upon the structural realism that it is based on, it reduces the role of ideas to "misperceptions" and "distortions" that prevent state leaders from seeing the balance of power objectively. As a result the theory emphasizes that such "misunderstandings" that are due to "incomplete information" of objective power relations and national interests are only temporary and in the long run states have no choice but to follow objective material power trends.

In contrast this dissertation has demonstrated that ideologies can show remarkable continuity in defiance of changes in the balance of power, such as the religious Zionist and the revisionist movements' disregard for the external

\footnotetext{
${ }^{696}$ Quoted in “Interview with Prime Minister Netanyahu in Ha'aretz."
} 
developments of the late 80 s and early 90 s. Even in cases when political ideologies have evolved, the impetus for change has rarely been external power relations. Therefore ideas, rather than being limited to misunderstanding and misinformation, form the very identity of the state and define its "interests" and how they should be pursued. Thus, neoclassical realism's view of ideas risks misrepresenting and oversimplifying a complicated topic.

The theoretical framework used in this dissertation also makes modifications to existing cultural and constructivist approaches to foreign policy analysis. Constructivists regularly assume that there is a single national identity that influences foreign policy. Moreover it is assumed that the national identity is constructed in relation to other states. On the other hand this dissertation has demonstrated that identity formation does not solely take place at the international level, rather domestic ideological divisions also shape it, therefore the "self" is not created only in relation to the international "other" but to the domestic "other" as well. Thus, the current framework attempts to shift constructivism's focus on the third image to the second image by "bringing back" the study of domestic political ideologies in shaping national identities and subsequently the state's foreign policy.

The proposed changes do not alter Constructivism as a meta-theory, which does not necessarily entail overemphasis on the third image or the assumption of unitary national identities, rather the new framework suggests a redirection of where and how the theory has been used. Such a redirection leads to a better understanding of a state's foreign policy. Moreover, by discarding the 
assumption that social identity formation exclusively takes place at the international level, states are no longer assumed to be unitary actors. Rather domestic political movements are in a continuous struggle to shape foreign policy according to their own ideologies.

In the context of the case under study in this dissertation, the assumption of a single national identity has led many constructivist scholars to argue that the rise of the Oslo process was the result of the creation of a new liberal or "postmaterialist" Israeli identity tied to the peace process. In contrast this dissertation has demonstrated that Israel's foreign policy was never driven by a sole national identity, rather it was an arena where different identities, each constructed based on a specific ideology, fought over the very definition of Zionism and what it meant to be an "Israeli." Seeking a political settlement with the Palestinians became a central component of this much larger struggle.

The weakness of a constructivist approach that assumes a unitary national identity becomes apparent when the fall of the peace process in the late nineties is explained as the result of the "crisis" of the peace seeking Israeli identity. Dov Waxman for example notes how "many observers, both inside and outside the country, claimed that Israelis were suffering from an identity crisis" after Oslo. In contrast this dissertation has argued that there never was a single hegemonic identity within Israeli society that sought peace to begin with, rather both the rise and the fall of the peace process should be seen as the result of an ideological battle between entrenched political movements and their corresponding identities. This argument was backed up by statistical evidence 
over a prolonged period of time that showed that the Israeli public has been highly polarized about the peace process from its onset. In fact the consistency of viewpoints regarding the peace process both among political elites and the Israeli public, despite the dramatic developments of the past two decades, points to the existence of highly reified ideological camps within the country. The acceptance of a multitude of Israeli identities thus allows us to study how different domestic political groups have fought each other over the character of the Israeli nation-state and subsequently its foreign policy towards the Palestinians.

The only noted work that departs from the previously discussed constructivist framework is Waxman's The Pursuit of Peace and The Crisis of Israeli Identity. Waxman argues that the disagreement in Israel over the Oslo peace process was the result of a conflict over Israeli national identity. Similar to this dissertation, Waxman attempts to debunk the assumption that a single unitary identity shapes a state's foreign policy. Also unlike how constructivism has been conventionally used, he attempts to identify the domestic sources of identity formation. As a result his approach addresses many of the weaknesses of past constructivist approaches and has some similarities with this dissertation, although as discussed below there are also important differences.

While Waxman's book successfully presents a modified constructivist approach to examine Israeli foreign policy, by completely disregarding the role of political ideologies in identity formation he does not take his improvement far enough as to completely address the weaknesses of past constructivist studies 
of the issue. The main factor driving the ideational clash within Israeli society in Waxman's approach is religion. He defines two Israeli identities that have emerged as a result of Oslo: 'Israelis' and 'Jews,' the former adhering to a civic conception of Israeli national identity and the latter to an ethno-religious conception." 697

While Judaism has definitely been an important element in the construction of the identity of a group of Israelis, as this dissertation has demonstrated the identity of each of the three groups discussed was primarily shaped as a result of their political ideologies in which religion was only one factor among many. Moreover this dissertation argues that the ideologies of the three movements were constructed and later on evolved in contrast and opposition to one another. This is why it is important to examine how these ideologies were shaped throughout the twentieth century and not only during the peace process. This is because the identity clash that Waxman discusses has been ongoing since the very early days of Zionism. The peace process was only the latest phase in a decades-long ideological clash. ${ }^{698}$

\footnotetext{
${ }^{697}$ Waxman, The Pursuit of Peace and the Crisis of Israeli Identity, 4.
}

${ }^{698}$ Contrary to conventional wisdom the 1990s might not even be the peak of this struggle. For example in the 1944-1945 the Labor movement in cooperation with British intelligence led a campaign to arrest and kill revisionist activists in Palestine, in what became known as "The Hunting Season" (See Shavit, Jabotinsky and the Revisionist Movement 1925-1948, 234-236). The point of the example is not to downplay the identity clash of the 1990s, but to show that from the very early days of the Zionist enterprise the different political movements were fighting each other over the power to define Zionism and subsequently Israeli identity. 
Waxman's exclusion of ideology in his theoretical framework has also resulted in only two Israeli identities, a secular civic identity in favor of the peace process and a religious identity opposed to it. The weakness of such an approach is that it oversimplifies opposition to the peace talks as based primarily in religious beliefs and lumps very different movements into a single broad category. As the previous chapter demonstrated the revisionist Zionist movement, the religious Zionist movement and the Haredim each adhere to their own distinct ideologies and as a result have very different reasons behind their opposition to the peace process. Without accounting for these ideological differences we cannot explain Israeli foreign policy behavior in the post-Oslo period. For example it would be very difficult to explain how a group of revisionist Zionists led the plan to evacuate the Gaza Strip in 2005 in defiance of their religious Zionist allies.

When compared to existing cultural approach to foreign policy, this dissertation's framework does not assume the existence of a hegemonic and homogeneous "political culture" that influences policy, rather it argues that rival ideologies differ and fight over government policy. As a result the framework is able to account for fluctuations in foreign policy behavior in addition to policy continuities, which has been the main focus of cultural approaches to international relations thus far. This is because culture is no longer assumed to be static and stable, rather it is affected by external events and developments. Ideologies are especially prone to change during times of political turmoil and consecutive election losses. Furthermore when political leaders adopt rhetoric 
that diverges from the movement's ideology for tactical short-term benefits, in the long run this will undermine the movement's narrative and as a result create pressure for ideological change.

The theoretical framework presented in this dissertation also stresses that the relationship between ideology and foreign policy is not a one-way street; rather a state's foreign policy as well as external material developments, such as changes in the balance of power, also affect domestic political ideologies. For example it was argued that the regional and global developments of the 1990s and Israel's subsequent pursuit of the peace process affected both the Labor movement as well the revisionist movement. As a result the study of a state's foreign policy should look at both ideational factors as well as material ones. The study of the two sets of factors should not be seen as an either/or decision since the elimination of any of the two would result in a very partial understanding of foreign policy behavior.

One theoretical research avenue suggested by this project is the development of theoretical frameworks that use both realist as well as constructivist insights. ${ }^{699}$ While realism and constructivism are usually assumed to be mutually exclusive ways of understanding state behavior, in reality they can

\footnotetext{
${ }^{699}$ There have been some rare attempts to achieve this very aim, however suggestions of such a framework have not been widely accepted in the IR community and as a result have not been used to understand state behavior. See Patrick Thaddeus Jackson and Daniel H. Nexon, "Constructivist Realism or Realist-Constructivism?," International Studies Review 6 (2004); Samuel Barkin, Realist Constructivism: Rethinking International Relations Theory (Cambridge: Cambridge University Press, 2010).
} 
be merged to create more comprehensive theories. Indeed the epistemology of the two theoretical frameworks is not necessarily incompatible with each other. As Samuel Barkin explains "constructivist research is as compatible with a realist worldview as with any other." ${ }^{700}$ This is because constructivism is nothing more than a meta-theory that examines the relationship between structures and agents and the role of ideas and norms in this relationship. As such, accurately speaking, constructivism has no specific claims and propositions regarding international politics (unlike liberalism and realism), rather it can be contrasted to other meta-theories like Rational Choice. Thus while most current constructivists working in the United States are liberal idealists, this does not mean that constructivism is inherently liberal or critical. Alexander Wendt distinguishes between idealism as a theory of social politics (that investigates the roles of ideas) and Idealism as a theory of IR. Wendt asserts that he is involved in doing the former, not the latter. ${ }^{701}$

At the same time while more recent variants of realism such as neorealism completely ignore unit level variables as well ideational variables, and neoclassical realism which reduces ideational factors to "intervening variables" that only cause "misunderstanding" of objective power relations, the founders of realist IR theory do in fact account for some ideational variables. For example 'Classical Realists' such as Hans Morgenthau and E. H. Carr take a more

\footnotetext{
${ }^{700}$ Samuel Barkin, "Realist Constructivism," International Studies Review 5, no. 3 (2003): 325-42.

${ }^{701}$ Wendt, Social Theory of International Politics., 33.
} 
complex and nuanced approach to IR compared to more contemporary scholars by not disregarding domestic variables and individual level variables. Carr for example, while strongly attacking the liberals of the interwar years for their "utopianism," nevertheless criticizes Realism for its lack of finite goal, emotional appeal, moral judgment and ground for political action, concluding that realism leads to the "sterilization" of thought. ${ }^{702}$ As a result he advocates for a mixture of "utopianism" and realism. On the other hand Morgenthau does not limit state power to only material factors, rather he places material elements such as geography, population, military preparedness and military capability, alongside non-material variables such as "national moral," "national character," "quality of government" and "quality of diplomacy."703

The results of this research suggest that by examining the interaction between global developments, including changes in the balance of power, and domestic ideologies, defined as political ideational frameworks that act as a lens in understanding the world, we can understand complex foreign policy behavior such as Israeli policy toward the peace process much more effectively. This is why theoretical frameworks that borrow from both constructivist as well as realist schools of thought can be productive.

\footnotetext{
${ }^{702}$ Edward Hallett Carr, The Twenty Years' Crisis, 1919-1939: An Introduction to the Study of International Relations (Harper Perennial, 1964), Chapters 6 and 14.

${ }^{703}$ Hans Morgenthau, Politics Among Nations: The Struggle for Power and Peace, 6th ed. (New York: McGraw Hill, 1948), Chapter 9.
} 
Another research avenue suggested by this dissertation is the study of religious political movements. As noted earlier the religious Zionist movement has shown very little ideological evolution when compared to the secular Labor and Revisionist movements. In fact the movement has been able to explain all unforeseen external events that run counter to the movement's ideology "as part of the redemptive process" and any obstacles as unimportant and temporary. This presents an anomaly to some of the theoretical arguments of this dissertation.

The persistence of religious Zionist ideology in defiance of domestic and international political circumstances suggests fundamental differences between religious and secular political ideologies. It would be fruitful to find out whether such ideological consistency also applies to religious political movements in other countries and how this affects the state's foreign policy. These questions also point to the importance of considering religious movements, even within "secular states," in the study of international relations. In fact the turbulent events of the past decade in the Middle East, including the eruption of the 'Arab Spring,' the rise and fall of the Muslim Brotherhood, and finally the surprising ascent of ISIS, suggest a rethinking of the role of religion in international affairs, an issue that is routinely overlooked in IR theoretical debates, which have largely focused on great power behavior and have relied on European enlightenment and Western secular traditions. 


\section{The End of the Peace Process?}

With the turn of the century the peace process also took a turn for the worst. Although the peace process had begun to falter well before Labor leader Ehud Barak took office in July 1999, with the collapse of the Camp David summit in July 2000 and the subsequent onset of the Second Palestinian Intifada in September 2000 , it completely collapsed. ${ }^{704}$ The Intifada, which erupted after Likud leader Ariel Sharon visited the Al-Aqsa mosque accompanied by a thousand Israeli security officers and declared, "The Temple Mount is in our hands, ${ }^{705}$ was more fundamentally the result of Palestinian frustration over the lack of progress in the peace talks and the deteriorating conditions in the occupied territories. The ensuing violence and the breakdown of the IsraeliPalestinian negotiations has been well documented by scholars. ${ }^{706}$ What is perhaps missing in such discussions is how the collapse of the peace process would inevitably lead to the political collapse of the Labor movement as well.

${ }^{704}$ There is widespread disagreement about exactly what transpired during the summit, see Clayton E. Swisher, The Truth About Camp David: The Untold Story About the Collapse of the Middle East peace process (New York: Nation Books, 2004).

705 Quoted in Jon Elmer, "Remembering the Second Intifada," Aljazeera, 2011, http://www.aljazeera.com/photo_galleries/middleeast/2010103132115872256.html.

${ }^{706}$ See for example: Shlaim, The Iron Wall: Israel and the Arab World (Updated and Expanded), Chapters 17-19; Howard M. Sachar, A History of Israel: From the Rise of Zionism to Our Time, 3rd ed. (Alfred A. Knopf, 2007), Chapters 37-40; Dennis J. Deeb, Israel, Palestine, \& the Quest for Middle East Peace (Lanham: University Press of America, 2013), Chapters 4-9; James Gelvin, The Israel-Palestine Conflict: One Hundred Years of War, Third Edition (Cambridge: Cambridge University Press, 2014), Chapter 10. 
To understand how the fate of the Labor movement got tied to the peace process we must go back to the movement's initial framing of the peace talks for the Israeli public. In order to make the peace process appealing to the Israeli public, Labor leaders such as Rabin portrayed political compromise with the Palestinians and withdrawal from the territories as in line with making Israel more secure. In fact before Netanyahu was to adopt the "Peace with Security" slogan, Rabin had already established such a relationship. This was arguably done to win more votes in the 1992 elections, especially from centrist voters. For example a Gallup poll conducted before the elections found that 39 percent of Israelis ranked security as the most important issue of the elections, while 22 percent considered peace talks to be the primary issue. Even among Labor voters the two issues were tied at 39 percent. ${ }^{707}$ Moreover Rabin's attack on the settlements was framed in regards to how they did not contribute to security. ${ }^{708}$ The framing of the peace process as in line with improving Israel's security had become well ingrained by the time of Oslo. A 1994 poll by Arian for example found that the number one reason cited for a withdrawal from the territories was "to lower the risk of war."

With the onset of the peace process, and the eruption of Jewish settler violence as well Palestinian suicide attacks, it became obvious however that the

\footnotetext{
${ }^{707}$ Steinberg, "A Nation That Dwells Alone? Foreign Policy in the 1992 Elections."

${ }^{708}$ lbid., 191.

${ }^{709}$ Arian, Security Threatened: Surveying Israeli Opinion on Peace and War, 31.
} 
agreements were not going to enhance Israeli security, at least not in the short term. This eroded public support for the peace process and even created doubts among Labor leaders. In October 1994 Rabin declared in a Knesset speech "security is the foremost of our concerns and that peace will not come to this country without security." ${ }^{710}$ The realization that the peace process was not improving Israeli security became more apparent as time went on. In February 1995 for example, eight months before his assassination. Rabin remarked, "I am torn between two problems. On the one hand implementing the agreement and, on the other hand, Israel's security."711

The violence of the 1990s however was not even comparable to that of the 2000s. According to the United Nations Office for the Coordination of Humanitarian Affairs, 4,228 Palestinians, including 855 children, and 1,024 Israelis, including 116 children, lost their lives from 2000 to $2007 .{ }^{712}$ As a result, with the fall of the peace process, Labor's discourse, in which peace talks would lead to increased security, also faltered, leading to the political downfall of the movement. Interestingly, the eruption of violence has not necessarily led to decrease support for the peace process in the long run, but rather to a

\footnotetext{
${ }^{710}$ See Yitzhak Rabin, Policy Statement by Prime Minister Yitzhak Rabin to the Knesset Oct 3, 94 (Israel Ministry of Foreign Affairs, October 3, 1994), http://mfa.gov.il/MFA/PressRoom/1994/Pages/POLICY\%20STATEMENT\%20BY\%20PRIME\%20 MINISTER\%20YITZHAK\%20RABIN\%20T.aspx.

${ }^{711}$ Quoted in Inbar, Rabin and Israel's National Security, 155-156.

${ }^{712}$ United Nations Office for the Coordination of Humanitarian Affairs, Israeli-Palestinian Fatalities Since 2000 - Key Trends (United Nations Office for the Coordination of Humanitarian Affairs, August 2007), http://unispal.un.org/UNISPAL.NSF/0/BE07C80CDA4579468525734800500272.
} 
preference to have Likud in power which would be "tough" on security, while supposedly simultaneously pursuing peace. This development coupled with other internal problems such as the lack of a charismatic leader has resulted in dismal election results, making the movement a very weak opposition to the revisionistreligious Zionist alliance. In the 2013 Knesset elections the Labor party won only fifteen seats and Meretz won just six. ${ }^{713}$

Thus Labor's security based framing of the peace process arguably led to its own political decline and the rise of the revisionist movement, which would subsequently lead to the derailment of the peace talks. This is why Yoram Peri, a senior advisor to Rabin, would write in 2000: "In the desire to sell the Oslo Accords to the Israeli public, he [Rabin] and Shimon Peres used the argument that the agreement would reduce Palestinian terrorism. This was not only an erroneous historical assessment but also a political mistake. The history of colonialism teaches that as the hour of agreement and separation draws near, violence increases." ${ }^{714}$ From another perspective however, Labor led by Rabin may have had little other choice, since as discussed earlier the pro-peace camp in Israel never included a majority of the public, including during its peak years in the 1991-1993 period. As a result, Labor was only able to win the 1992 elections and initiate the peace process after winning the support of the Israeli center by

\footnotetext{
713 The Knesset, Elections to the Nineteenth Knesset, January 22, 2013, http://knesset.gov.il/description/eng/eng_mimshal_res19.htm.

${ }^{714}$ Peri, “The Assassination: Causes, Meaning, Outcomes," 14.
} 
promising increased security and stability as a result of its new foreign policy approach.

The developments of the 2000s on the other hand were very advantageous for the revisionist movement. After the collapse of Camp David talks and the eruption of the Intifada, the primary Israeli narrative became "Barak gave them [the Palestinians] almost everything and Arafat responded with terror," as one Israeli negotiator in the Oslo process put it. ${ }^{715}$ Nevertheless while the revisionist movement has enjoyed political success in the past one and half decades, this has not eliminated the ideological dilemma, discussed earlier, it faces. The onset of the peace process and Likud's rhetorical adoption of it has made the "two-state solution" the only legitimate scenario for the resolution of the conflict.

Thus while the revisionists have been able to put off an ideological transformation due to their political success, at the same time they still are not able to openly declare the end of the two state solution and the possibility of annexing the territories, as the religious Zionists demand. ${ }^{716}$ Therefore while the revisionists have been able to successfully "wait out" Oslo thus far, the wait has not ended and does not seem to be ending in the short term. Indeed every US administration in the past two decades has drawn up plans for the resumption of

\footnotetext{
${ }^{715}$ See Kacowicz, "Rashomon in the Middle East: Clashing Narratives, Images, and Frames in the Israeli-Palestinian Conflict."

${ }^{716}$ Naftali Bennett, "For Israel, Two-State Is No Solution," New York Times, November 5, 2014.
} 
the peace process. Moreover the results of this dissertation's statistical analyses show that revisionist constituents have gradually but firmly moderated their opposition to Oslo. The figure below portrays opposition levels to the peace process for each movement from 1994 to $2013 .^{717}$

Figure 9: Opposition to the Peace Process ${ }^{718}$

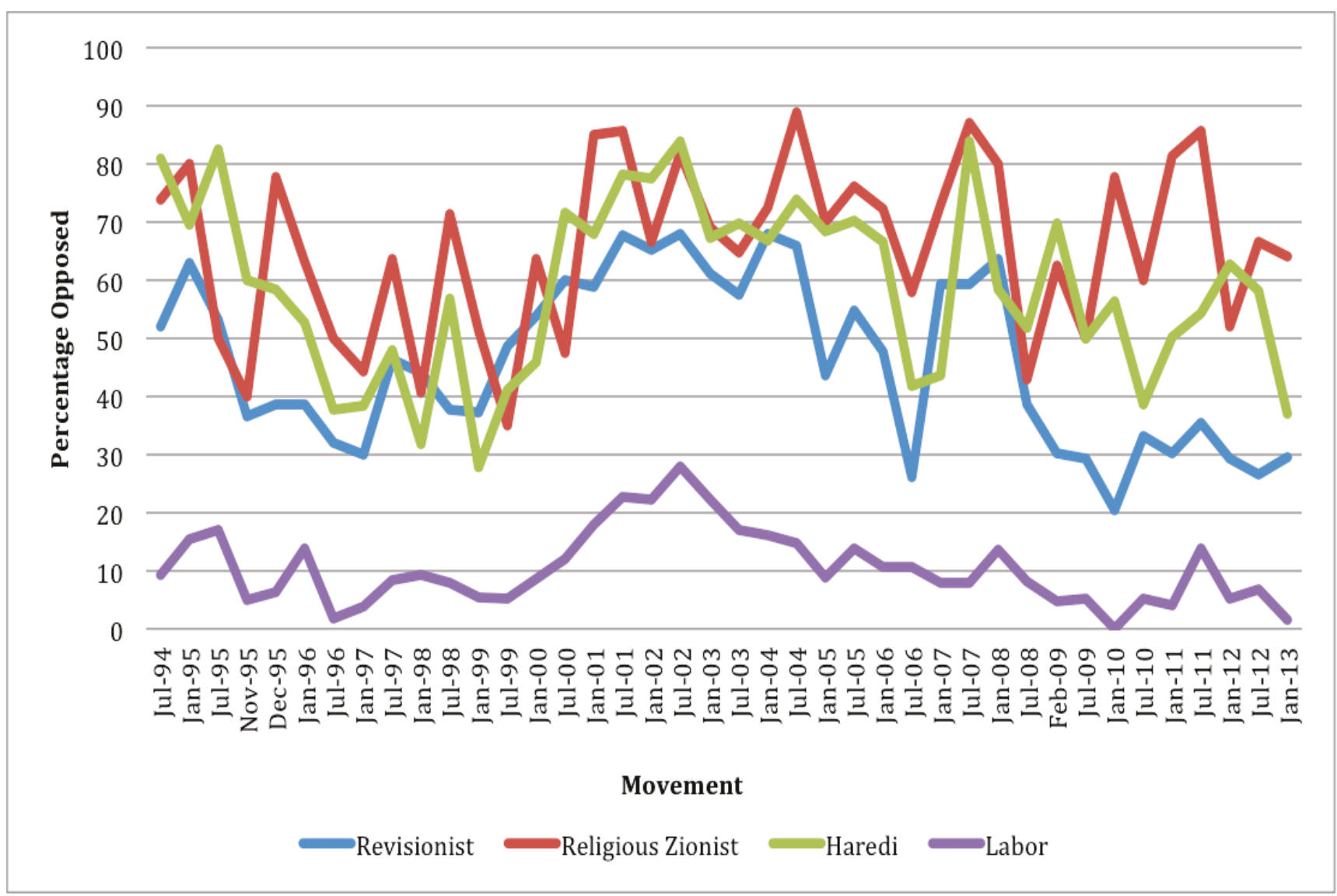

717 See the appendix for full results.

718 Method of Calculation: Each data point in the graph is the total percentage of each movement's voters who are either "very opposed" or "somewhat opposed" to the peace process. The percentage points are the result of cross tabulation statistical analysis of this dissertation for the 94-2013 period, presented in the appendix. 
Several important conclusions can be drawn from the above graph. First of all while the onset of the Palestinian Intifada hardened negative attitudes toward the peace process, starting from 2004 opposition levels among Labor and revisionist supporters began to decline. Thus while the Intifada increased negative opinions of the peace process for around four years, it had no long lasting effect on the constituents of the two movements. In contrast, opposition to the peace talks from religious Zionists witnessed no such decline. Secondly, as apparent in the graph, revisionist opposition to the peace process has been significantly dropping in recent years. Indeed from 2008 to 2013 only around 30 percent of revisionist voters were either "strongly opposed" or "somewhat opposed" to the peace process. This shows a significant decrease from opposition levels of the past. This provides evidence for this dissertation's argument that the revisionist movement's approach, in which the peace talks were adopted rhetorically but not implemented in practice, would ultimately lead to an impetus for ideological change. This is because the rhetoric of a movement's leaders plays an important role in setting the ideological discourse, which in turn shapes the norms and identities of the group. This is true even for "tactical" rhetoric, since the movement's constituents might not be able to differentiate between tactical rhetoric and ideological rhetoric. The change in the attitudes of revisionist voters towards the peace talks with the Palestinians will further pressure the movement to change its policies, especially if in the future the movement faces political turmoil in the form of election losses. As discussed 
in chapter two, the results of this research show that political movements are more likely to change their ideologies when they are in decline.

The core challenge revisionist leaders face is that they have not been able to provide a viable alternative to the two-state solution. The two Palestinian Intifadas as well as the peace negotiations have intensified Palestinian nationalism as never before. As a result going back to the arrangement of the 70 s and 80 s seems impossible. Indeed the Likud has itself played the leading role in separating the Palestinians and the territories from Israel. The building of the West Bank 'Wall' by the revisionists, despite its human rights implications, has meant that any form of annexation will be very difficult. Indeed in line with their ideology, the revisionists had always worked to blur the green line separating Israel proper from the West Bank, something the wall works against. In fact it was Rabin who first proposed the construction of a barrier enclosing the West Bank and separating it from Israel in January 1995, at which time it was strongly opposed by the Likud, which thought that separation fences would create fixed borders, something anathema to the Greater Israel idea. ${ }^{719}$ The point of the example is to show how the revisionists have been forced in a situation in which a return to the pre-Oslo period has become very difficult.

In the current circumstances it seems that the revisionists have correctly understood that their best bet would be to keep the current status quo, in which

\footnotetext{
${ }^{719}$ See Mendilow, "The Likud's Double Campaign: Between the Devil and the Deep Blue Sea," 193.
} 
they avoid a retreat from their ideological principles by not withdrawing from the territories, while simultaneously "negotiations for peace" indefinitely and without any meaningful results. Moreover the recent instabilities in the Middle East have made a withdrawal from the territories even more unlikely. Ari Harrow, Netanyahu's current chief of staff, for example wrote in a Jerusalem Post op-ed:

Netanyahu must use this opportunity [of addressing the US Congress] to snuff out the world's pipe dream of instantly establishing a Palestinian state...With northern Israel in the crosshairs of Hezbollah rockets, Egypt's future uncertain at best to our south, and Syria on the brink of chaos, we cannot possibly conduct talks over relinquishing land to another perilous unknown in the shape of a Palestinian state. The reality of the FatahHamas coalition and its current refusal to abandon violence or recognize the Jewish State of Israel makes principled inaction imperative. Any negotiations at this point would be an act of masochism at best, and simply suicidal at worst. ${ }^{720}$

While Likud's policy is to keep the current status quo, it seems that this approach is not sustainable in the long run. The continuation of the conflict and the lack of any progress in the peace talks will increase international pressure on Israel, including in new forms such as the BDS movement and the Palestinian bid for statehood at the UN, it will damage the country's alliance with the US and finally it will lead to increased Palestinian violence. Moreover the Middle East is changing in unforeseen directions, challenging Israeli power and security. More importantly, just as the onset of the peace process had unintended and irreversible consequence, the full collapse of the peace process can also open

\footnotetext{
${ }^{720}$ Ari Harrow, "The PM's Speech: History in the Making?," The Jerusalem Post, May 21, 2011.
} 
up a Pandora's box that might not be easily closed. As a result, the revisionist motto that "time is on Israel's side" seems misguided.

Success in the peace talks also depends on the willingness and capacity of the Israeli government in confronting the religious Zionist movement and the numerous settlements it has erected. By June 2014 there were 382,031 settlers living in the West Bank, plus around 200,000 living in East Jerusalem, bringing the total number of settlers in the occupied territories to over half a million. ${ }^{721}$ Moreover the religious Zionists have shown time and again that they are willing and able to do much more than create "facts on the ground." While the threat of violence and a "Jewish civil war" have largely remained a threat, they have been enough to deter all Israeli governments from confronting the settlers, even in the wake of events such as the assassination of Rabin. As David Newman explains "The option of using sheer physical force against Gush Emunim was, practically speaking, never available to the Prime Minister. Any exercise of that option would have resulted in a major government crisis." ${ }^{722}$

While the religious Zionists continue to be a small group within Israeli society, for example winning 9.2 percent of the vote in the 2013 elections, ${ }^{723}$ their

\footnotetext{
721 AFP, "West Bank Jewish Settler Population Soars: Settlers," September 16, 2014, http://news.yahoo.com/west-bank-jewish-settler-population-soars-settlers-180527269.html.

${ }^{722}$ Newman, Impact of Gush Emunim: Politics and Settlement in the West Bank, 40.

${ }^{723}$ For official Knesset election results see: The Central Elections Committee, Final Official Results of the Elections for the Nineteenth Knesset, 2013, http://www.bechirot.gov.il/elections19/eng/list/results_eng.aspx.
} 
unbending determination in bringing about "the divine redemption" and the extent they are willing to go in confronting their opponents, including the use of violence, has made them a strong force in Israeli politics. This coupled with the fact that successive Israeli governments have been dependent on them as junior coalition partners, has made the movement a serious impediment to any future agreement with the Palestinians. The situation is made worse when we consider the fact that the previously "non-Zionist" ultra-Orthodox parties in Israel have adopted hawkish positions regarding the peace talks and have moved closer to the religious Zionists in the past two decades. Nevertheless, while Haredi Israelis have been one of the most adamant opponents of the peace process, as displayed in the graphs presented in this dissertation, their prime political goal remains the securing of their "special needs" such as exemption from military service and funding for their institutions. Since the 2013 Knesset elections a gap has opened up between the Haredim and the revisionist-religious Zionist alliance, both of which have called for Haredi military enlistment. In response the Haredim have threatened that they might support an "aggressive peace agenda" with the Palestinians. In fact a senior Shas official told Haaretz "We are going to walk all over the settlements, we're not afraid. We'll vote to evacuate outposts, we'll vote to freeze construction, we'll support diplomatic initiatives, we'll vote to cut funding to the settlements. ${ }^{724}$

\footnotetext{
${ }^{724}$ See Yair Ettinger, "Shas Official Tells Haaretz: We're Ready to Evacuate Settlements, Back Mideast Talks," Haaretz, March 3, 2013; Also see Jeremy Sharon, "UTJ Weighs Backing Aggressive Peace Agenda," The Jerusalem Post, February 17, 2013.
} 
When we consider the fact that the birthrate for Haredi women is 6.5 compared to 3 for non-Orthodox Jewish Israeli women and 3.5 for Palestinian Arabs, ${ }^{725}$ it becomes clear that the ultra-Orthodox community will play an increasingly leading role in influencing any future peace initiative. According to Israel's Central Bureau for Statistics by 2019 more than half of new pupils in Israel will be either Haredi or Arab, due to higher population growth rates. ${ }^{726}$ Indeed the Haredi community has grown from a very small community at the time of Israel's founding, to a sizable population today.

As a result of this population increase as well as a surge in Haredi political participation, ultra-Orthodox parties have increased their share of the Knesset to 18 seats, up from ten seats two decades earlier. ${ }^{727}$ Moreover while traditionally ultra-Orthodox parties did not involve themselves with matters of the state, more recently they are increasingly becoming politicized. This provides an opportunity for the Labor movement to persuade the Haredim away from the religious Zionists and toward a pro-peace coalition, however such attempts will be difficult given the religious and ethnocentric positions of the ultra-Orthodox and the secular Western roots of the peace camp.

\footnotetext{
${ }^{725}$ Shmuel Rosner, “Children of Israel," The New York Times, August 28, 2013.

${ }^{726}$ Zeev Klein, "Report: More than Half of New Pupils Will Be Haredi or Arab by 2019," Israel Hayom, August 7, 2013.

${ }^{727}$ In the 1992 Knesset elections Shas won 6 seats while United Torah Judaism won 4 seats. These numbers increased to 11 and 7 respectively. For official election results see: The Knesset, Knesset Elections Results, 2013, http://knesset.gov.il/description/eng/eng_mimshal_res.htm.
} 
As stressed throughout this dissertation, the conflict over Israel's territorial policy should be seen as part of a much larger struggle over the very meaning of Zionism and the character and identity of the Israeli nation-state. The collapse of Netanyahu's governing coalition in December 2014 over a controversial bill that would define Israel as "the nation-state of the Jewish people," ${ }^{\prime 72}$ shows that the ideological struggle to define Israel is alive and well. Nevertheless the obstacles to the peace process discussed above have made the prospects of achieving a two-state solution any time soon very slim. With the lack of a viable alternative however, the Israeli-Palestinian conflict will continue unabated. The fate of any prospective peace initiatives will be highly dependent on the outcome of the crisis of revisionist Zionist ideology discussed earlier as well as the future path of the Haredim.

${ }^{728}$ See Bernard Avishai, "Netanyahu's Inflammatory New Bill," The New Yorker, December 2, 2014; Michael Bell, "Netanyahu's 'Jewish State' Bill Would Be a Crippling Blow to Israel," The Globe and Mail, December 5, 2014; Ilan Ben Zion, "Netanyahu Fires Lapid, Livni from Ministerial Posts," The Times of Israel, December 2, 2014; Sasley, "Israel's Tangled Democracy Why Governments Will Keep Falling." 


\section{Appendix}

\section{Methodology}

For the purposes of this research project statistical analysis of the Peace Index for the 1994-2013 period was conducted. The Peace Index is an ongoing monthly public opinion survey of a representative sample of Israel's adult population regarding the peace process. The survey which polls approximately 600 people each month is led by Ephraim Ya'ar of Tel Aviv University and Prof. Tamar Hermann of the Israel Democracy Institute. For the purposes of this dissertation the data sets for January and July of each year from 1994 to 2013 were obtained from the Democracy Institute. While this dissertation primarily focuses on Israeli policy toward the peace process in the 1990s, analysis of the peace index was conducted up to 2013 in order to substantiate the claim that opposition to the peace talks from Likud voters has been steadily dropping due to an ideological crisis, as discussed in chapter six. By analyzing the data for nearly two decades we are able to discern consistent and long-term ideological changes from short-term variations that can be due to temporary developments.

It should also be noted that the data set for January 2009 was replaced with the February 2009 data set due to unavailability. In addition to these sixmonth intervals, three opinion polls conducted several days after, several weeks after and a month after Yitzhak Rabin's assassination were also obtained. Each of the 41 data sets were then re-coded and analyzed using SPSS software. The variables used in the analysis are as follows: 
Dependent Variable: The dependent variable of this study is the level of support for the peace process. This is obtained through the results of the Peace Index's main question which is repeated in each monthly survey, although in July 2006 the question was slightly revised as follows:

* From July 1994 to June 2006 the question asks: "What is your opinion in regards to the agreement signed at Oslo between Israel and the PLO (Declaration of Principles)?" (1- Very for it, 2Somewhat for it, 3- So-so, in the middle, 4- Somewhat against it, 5Very against it)

* Starting from July 2006 the Democracy Institute changed the above question to: "What is your position in regards to conducting peace negotiations between Israel and the Palestinian Authority?" (1- Very for it, 2- Somewhat for it, 3- Somewhat against it, 4- Very against it, 5- Do not know/no opinion)

Independent Variable: Each monthly survey asks participants about the party they voted for in the last elections. While the question remains the same in each survey, the choice of answers offered depends on the parties that participated in the last elections. The example below presents the choices offered for the July 1996 survey.

* Question: "Which party did you vote for in the most recent elections to Knesset?" (1- Likud, 2- Labor, 3- Meretz, 4- Mafdal, 5- Yahaduth HaTorah, 6-Moledet, 7- The Third Way, 8- Shas, 9- Immigrant List , 10- Hadash, 11-16 - Do not read.) 
In order to examine the attitudes of each of the three ideological movements' constituents towards the peace process the independent variable was recoded from party preference to political movement preference. In addition to serving the purposes of this dissertation, recoding the variables was necessary in order to reach statistically significant results. Without recoding the independent variable, and using party preference as the independent variable, nearly all relationships of a multinomial regression show unusually high sig values, making the results unusable. This is due to the fact that many of the cells are either under populated or totally empty. This is because few of the participants indicated voting for small marginal political parties. Moreover each data set has several identical categories in which the participants refused to answer the question. The effect of this is that the results of the regression become unreliable.

By recoding the independent variable based on political ideologies, not only is the variable simplified and the categories reduced, but also and more importantly, under populated cells are merged or discarded, making the results statistically significant. Moreover while SPSS software automatically allows the user to chose the reference category of the dependent variable right before running the regression (for the purpose of this research the reference category of the dependent variable was always chosen as "strongly in favor" of the peace process), it automatically takes the last category of the independent variable as the reference category. Since the last category of the independent variable is "do not read," all the other categories will be automatically compared to this category, 
making the comparison less useful. By recoding the independent variable, we are able to reorder the categories. In this research project the last category of the independent variable was recoded to the Labor movement.

The details of how the independent variable was recoded are as follows:

> Data sets from July 1994 until January 1996 were recoded using the following method:

* Likud $\rightarrow$ Revisionist Movement

* Labor + Meretz $\rightarrow$ Labor Movement

* Mafdal + HaTehiya $\rightarrow$ Religious Zionist Movement

* Yahaduth HaTorah + Shas $\rightarrow$ Ultra-Orthodox

> Data sets from July 1996 until July 1998 were recoded into:

* Likud $\rightarrow$ Revisionist Movement

* Labor + Meretz $\rightarrow$ Labor Movement

* Mafdal $\rightarrow$ Religious Zionist Movement

* Yahaduth HaTorah + Shas $\rightarrow$ Ultra-Orthodox

> Jan 1999 was recoded into:

* Likud $\rightarrow$ Revisionist Movement

* Labor + Meretz $\rightarrow \quad$ Labor Movement

* Mafdal $\rightarrow$ Religious Zionist Movement

Agudath Israel and Degel HaTorah + Shas $\rightarrow$ Ultra-Orthodox

> Data sets from July 1999 to January 2006 were recoded into:

* Likud + Ichud LeUmi $\rightarrow$ Revisionist Movement

* One Israel + Meretz + One Nation + Shinui $\rightarrow$ Labor Movement 
* Mafdal $\rightarrow$ Religious Zionist Movement

* Agudath Israel and Degel HaTorah + Shas $\rightarrow$ Ultra-Orthodox

> Data sets from July 2006 to July 2008 were recoded into:

* Likud $\rightarrow$ Revisionist Movement

* Labor + Meretz $\rightarrow$ Labor Movement

* Mafdal $\rightarrow$ Religious Zionist Movement

* Yahaduth HaTorah + Shas $\rightarrow$ Ultra-Orthodox

Kadima $\rightarrow$ Kadima

> From Feb 2009 to Jan 2013 were recoded into:

* Likud $\rightarrow$ Revisionist Movement

* One Israel + Meretz $\rightarrow \quad$ Labor Movement

- HaBayit HaYehudi (new Mafdal) $\rightarrow$ Religious Zionist Movement

* Yahaduth HaTorah + Shas $\rightarrow$ Ultra-Orthodox

* Kadima $\rightarrow$ Kadima

Multinomial Logistic Regression was subsequently used to analyze the data. The confidence level for rejecting the null hypothesis was $5 \%(p<0.05)$. Multiple line charts and cross tabulation analysis were also used to better demonstrate and predict the relationship between the dependent and independent variables. The results of the analysis for each data set are presented in the following sections. 
July 1994

Crosstabs

Movement * What is your opinion in regards to the agreement signed at Oslo between Israel and the PLO (Declaration of Principles)? Crosstabulation

\begin{tabular}{|c|c|c|c|c|c|c|c|}
\hline & \multicolumn{5}{|c|}{$\begin{array}{c}\text { What is your opinion in regards to the agreement signed at } \\
\text { Oslo between Israel and the PLO (Declaration of } \\
\text { Principles)? }\end{array}$} \\
\hline & & & very for it & $\begin{array}{l}\text { somewhat } \\
\text { for it }\end{array}$ & $\begin{array}{c}\text { so-so, in } \\
\text { the middle }\end{array}$ & $\begin{array}{l}\text { somewhat } \\
\text { against it }\end{array}$ & $\begin{array}{c}\text { very } \\
\text { against it }\end{array}$ \\
\hline \multirow{4}{*}{$\begin{array}{c}\text { Moveme } \\
\mathrm{nt}\end{array}$} & Revisionist & $\begin{array}{c}\text { Count } \\
\% \text { within } \\
\text { Movement }\end{array}$ & $\begin{array}{c}3 \\
3.2 \%\end{array}$ & $\begin{array}{c}8 \\
8.5 \%\end{array}$ & $\begin{array}{c}34 \\
36.2 \%\end{array}$ & $\begin{array}{c}13 \\
13.8 \%\end{array}$ & $\begin{array}{c}36 \\
38.3 \%\end{array}$ \\
\hline & $\begin{array}{l}\text { Religious } \\
\text { Zionist }\end{array}$ & $\begin{array}{c}\text { Count } \\
\% \text { within } \\
\text { Movement }\end{array}$ & $\begin{array}{c}1 \\
4.3 \%\end{array}$ & $\begin{array}{c}1 \\
4.3 \%\end{array}$ & $\begin{array}{c}3 \\
13.0 \%\end{array}$ & $\begin{array}{c}6 \\
26.1 \%\end{array}$ & $\begin{array}{c}11 \\
47.8 \%\end{array}$ \\
\hline & $\begin{array}{l}\text { Haredi (Ultra- } \\
\text { Orthodox) }\end{array}$ & $\begin{array}{c}\text { Count } \\
\% \text { within } \\
\text { Movement }\end{array}$ & $\begin{array}{c}0 \\
0.0 \%\end{array}$ & $\begin{array}{c}0 \\
0.0 \%\end{array}$ & $\begin{array}{c}4 \\
19.0 \%\end{array}$ & $\begin{array}{c}5 \\
23.8 \%\end{array}$ & $\begin{array}{c}12 \\
57.1 \%\end{array}$ \\
\hline & Labor & $\begin{array}{c}\text { Count } \\
\% \text { within } \\
\text { Movement }\end{array}$ & $\begin{array}{c}97 \\
44.3 \%\end{array}$ & $\begin{array}{c}68 \\
31.1 \%\end{array}$ & $\begin{array}{c}31 \\
14.2 \%\end{array}$ & $\begin{array}{c}8 \\
3.7 \%\end{array}$ & $\begin{array}{c}12 \\
5.5 \%\end{array}$ \\
\hline \multicolumn{2}{|r|}{ Total } & $\begin{array}{c}\text { Count } \\
\% \text { within } \\
\text { Movement }\end{array}$ & $\begin{array}{c}101 \\
28.3 \%\end{array}$ & $\begin{array}{c}77 \\
21.6 \%\end{array}$ & $\begin{array}{c}72 \\
20.2 \%\end{array}$ & $\begin{array}{c}32 \\
9.0 \%\end{array}$ & $\begin{array}{c}71 \\
19.9 \%\end{array}$ \\
\hline
\end{tabular}




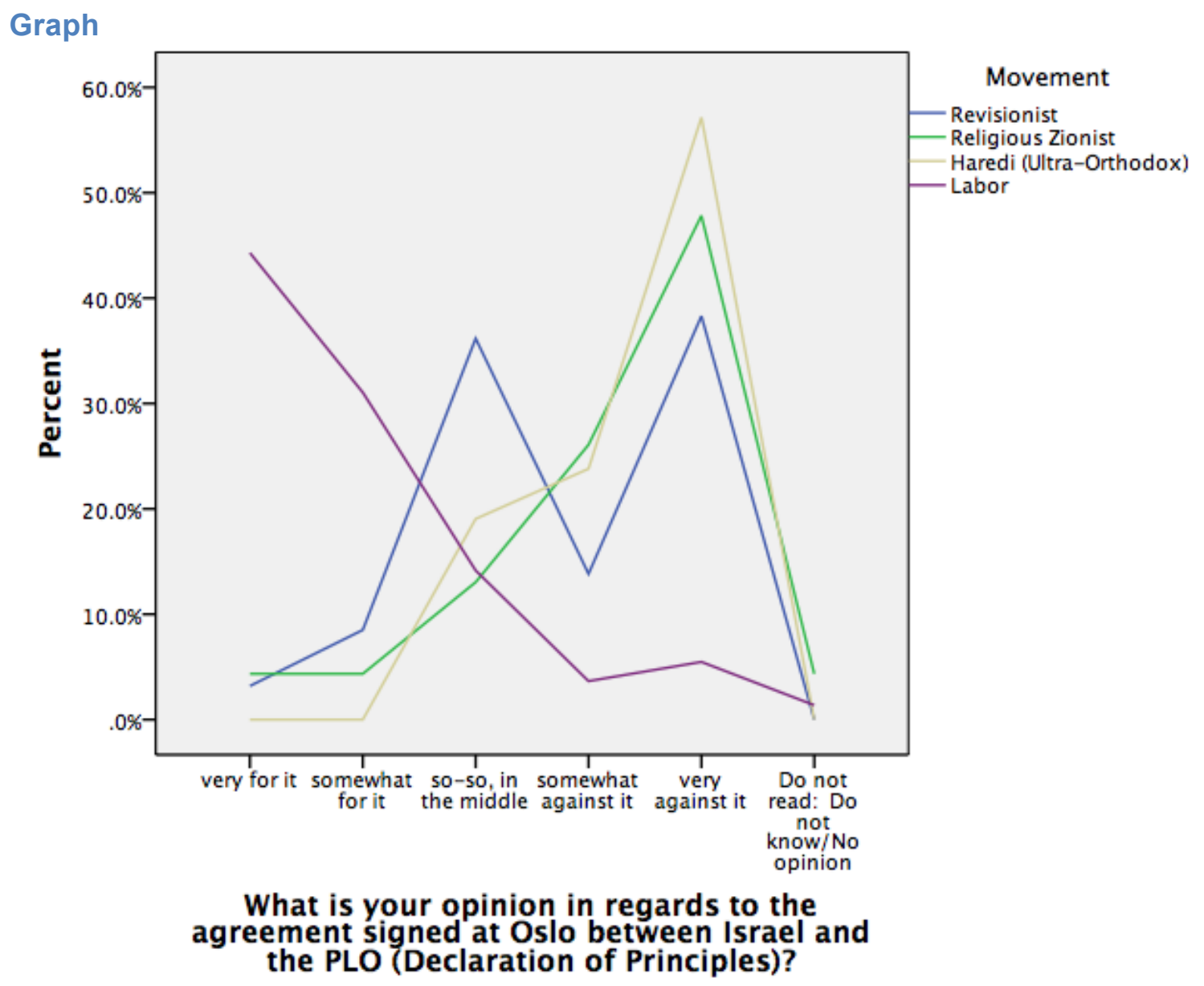

Nominal Regression

Model Fitting Information

\begin{tabular}{|l|r|r|r|r|}
\hline \multirow{2}{*}{ Model } & \multicolumn{1}{|c|}{$\begin{array}{l}\text { Model Fitting } \\
\text { Criteria }\end{array}$} & \multicolumn{3}{|c|}{ Likelihood Ratio Tests } \\
\cline { 2 - 5 } & $\begin{array}{c}\text {-2 Log } \\
\text { Likelihood }\end{array}$ & Chi-Square & df & \multicolumn{1}{c|}{ Sig. } \\
\hline Intercept Only & $\begin{array}{r}256.251 \\
55.660\end{array}$ & 200.590 & 15 & .000 \\
\hline
\end{tabular}

Goodness-of-Fit

\begin{tabular}{|l|r|r|r|}
\hline & Chi-Square & df & Sig. \\
\hline Pearson & .000 & 0 & \\
Deviance & .000 & 0 & \\
\hline
\end{tabular}

Likelihood Ratio Tests

\begin{tabular}{|l|r|r|r|r|}
\hline \multirow{2}{*}{} & \multicolumn{1}{|c|}{$\begin{array}{c}\text { Model Fitting } \\
\text { Criteria }\end{array}$} & \multicolumn{3}{|c|}{ Likelihood Ratio Tests } \\
\cline { 2 - 6 } & $\begin{array}{c}\text {-2 Log } \\
\text { Likelihood of } \\
\text { Redfect }\end{array}$ & & & \\
\hline Intercept & $55.660^{\text {a }}$ & df & \multicolumn{1}{c|}{ Sig. } \\
Movement & 256.251 & 200.590 & 0 & .000 \\
\hline
\end{tabular}


Parameter Estimates

\begin{tabular}{|c|c|c|c|c|c|c|c|c|c|}
\hline \multirow{2}{*}{\multicolumn{2}{|c|}{$\begin{array}{l}\text { What is your opinion in } \\
\text { regards to the agreement } \\
\text { signed at Oslo between } \\
\text { Israel and the PLO } \\
\text { (Declaration of Principles)? }{ }^{\mathrm{a}}\end{array}$}} & \multirow{2}{*}{ B } & \multirow{2}{*}{$\begin{array}{l}\text { Std. } \\
\text { Error }\end{array}$} & \multirow{2}{*}{ Wald } & \multirow{2}{*}{ df } & \multirow{2}{*}{ Sig. } & \multirow{2}{*}{$\operatorname{Exp}(B)$} & \multicolumn{2}{|c|}{$\begin{array}{l}95 \% \text { Confidence } \\
\text { Interval for } \operatorname{Exp}(B)\end{array}$} \\
\hline & & & & & & & & $\begin{array}{l}\text { Lower } \\
\text { Bound }\end{array}$ & $\begin{array}{l}\text { Upper } \\
\text { Bound }\end{array}$ \\
\hline \multirow{5}{*}{$\begin{array}{l}\text { somewhat } \\
\text { for it }\end{array}$} & Intercept & -.355 & .158 & 5.044 & 1 & .025 & & & \\
\hline & Revisionist & 1.336 & .695 & 3.693 & 1 & .055 & 3.804 & .974 & 14.860 \\
\hline & $\begin{array}{l}\text { Religious } \\
\text { Zionist }\end{array}$ & .355 & 1.423 & .062 & 1 & .803 & 1.426 & .088 & 23.203 \\
\hline & $\begin{array}{l}\text { Haredi (ultra- } \\
\text { Orthodox) }\end{array}$ & .084 & $\begin{array}{c}4779.53 \\
3\end{array}$ & .000 & 1 & 1.000 & 1.088 & .000 & b \\
\hline & Labor & $0^{c}$ & & & 0 & $\dot{0}$ & & . & . \\
\hline \multirow{4}{*}{$\begin{array}{l}\text { so-so, in the } \\
\text { middle }\end{array}$} & Intercept & $\begin{array}{c}- \\
1.141\end{array}$ & .206 & 30.569 & 1 & .000 & & & \\
\hline & Revisionist & 3.568 & .637 & 31.418 & 1 & .000 & 35.462 & 10.183 & 123.503 \\
\hline & $\begin{array}{c}\text { Religious } \\
\text { Zionist }\end{array}$ & 2.239 & 1.173 & 3.645 & 1 & .056 & 9.387 & .942 & 93.536 \\
\hline & $\begin{array}{l}\text { Haredi (ultra- } \\
\text { Orthodox) } \\
\text { Labor }\end{array}$ & $\begin{array}{c}18.65 \\
0 \\
0^{c} \\
\end{array}$ & $\begin{array}{c}3108.81 \\
7\end{array}$ & .000 & $\begin{array}{l}1 \\
0\end{array}$ & .995 & $\begin{array}{c}12575583 \\
4.816\end{array}$ & .000 & b \\
\hline \multirow{4}{*}{$\begin{array}{l}\text { somewhat } \\
\text { against it }\end{array}$} & Intercept & 2.495 & .368 & 46.016 & 1 & .000 & & & \\
\hline & Revisionist & 3.962 & .739 & 28.767 & 1 & .000 & 52.542 & 12.353 & 223.471 \\
\hline & $\begin{array}{c}\text { Religious } \\
\text { Zionist }\end{array}$ & 4.287 & 1.141 & 14.116 & 1 & .000 & 72.750 & 7.773 & 680.909 \\
\hline & $\begin{array}{c}\text { Haredi (ultra- } \\
\text { Orthodox) } \\
\text { Labor }\end{array}$ & $\begin{array}{c}20.22 \\
8 \\
0^{c} \\
\end{array}$ & $\begin{array}{c}3108.81 \\
7\end{array}$ & .000 & $\begin{array}{l}1 \\
0 \\
\end{array}$ & .995 & $\begin{array}{c}60912982 \\
4.890\end{array}$ & .000 & b \\
\hline \multirow{4}{*}{$\begin{array}{l}\text { very against } \\
\text { it }\end{array}$} & Intercept & 2.090 & .306 & 46.638 & 1 & .000 & & & \\
\hline & Revisionist & 4.575 & .674 & 46.020 & 1 & .000 & 97.000 & 25.868 & 363.733 \\
\hline & $\begin{array}{c}\text { Religious } \\
\text { Zionist }\end{array}$ & 4.488 & 1.088 & 17.002 & 1 & .000 & 88.917 & 10.533 & 750.596 \\
\hline & $\begin{array}{c}\text { Haredi (ultra- } \\
\text { Orthodox) } \\
\text { Labor }\end{array}$ & \begin{tabular}{|c}
20.69 \\
8 \\
$0^{c}$ \\
\end{tabular} & $\begin{array}{c}3108.81 \\
7\end{array}$ & .000 & $\begin{array}{l}1 \\
0 \\
\end{array}$ & .995 & $\begin{array}{c}97460771 \\
9.819\end{array}$ & .000 & ${ }^{b}$ \\
\hline \multirow{5}{*}{$\begin{array}{c}\text { Do not read: } \\
\text { Do not } \\
\text { know/No } \\
\text { opinion }\end{array}$} & Intercept & $3 . \overline{-}$ & .586 & 35.162 & 1 & .000 & & & \\
\hline & Revisionist & $\begin{array}{c}- \\
14.88 \\
5\end{array}$ & $\begin{array}{c}5605.16 \\
5\end{array}$ & .000 & 1 & .998 & 3.430E-7 & .000 & b \\
\hline & $\begin{array}{l}\text { Religious } \\
\text { Zionist }\end{array}$ & 3.476 & 1.531 & 5.156 & 1 & .023 & 32.333 & 1.609 & 649.758 \\
\hline & $\begin{array}{l}\text { Haredi (ultra- } \\
\text { Orthodox) }\end{array}$ & .247 & .000 & & 1 & . & 1.281 & 1.281 & 1.281 \\
\hline & Labor & $0^{c}$ & & & 0 & & & & 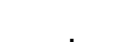 \\
\hline
\end{tabular}


January 1995

Crosstabs

Movement * What is your opinion in regards to the agreement signed at Oslo between Israel and the PLO (Declaration of Principles)? Crosstabulation

\begin{tabular}{|c|c|c|c|c|c|c|c|}
\hline & \multicolumn{5}{|c|}{$\begin{array}{l}\text { What is your opinion in regards to the agreement signed at } \\
\text { Oslo between Israel and the PLO (Declaration of Principles)? }\end{array}$} \\
\hline & & & very for it & $\begin{array}{l}\text { somewhat } \\
\text { for it }\end{array}$ & $\begin{array}{l}\text { so-so, in } \\
\text { the middle }\end{array}$ & $\begin{array}{l}\text { somewhat } \\
\text { against it }\end{array}$ & $\begin{array}{c}\text { very } \\
\text { against it }\end{array}$ \\
\hline \multirow{4}{*}{$\begin{array}{c}\text { Moveme } \\
\mathrm{nt}\end{array}$} & Revisionist & $\begin{array}{c}\text { Count } \\
\% \text { within } \\
\text { Movement }\end{array}$ & $\begin{array}{c}0 \\
0.0 \%\end{array}$ & $\begin{array}{c}9 \\
9.0 \%\end{array}$ & $\begin{array}{c}20 \\
20.0 \%\end{array}$ & $\begin{array}{c}22 \\
22.0 \%\end{array}$ & $\begin{array}{c}41 \\
41.0 \%\end{array}$ \\
\hline & $\begin{array}{l}\text { Religious } \\
\text { Zionist }\end{array}$ & $\begin{array}{c}\text { Count } \\
\% \text { within } \\
\text { Movement }\end{array}$ & $\begin{array}{c}2 \\
10.0 \%\end{array}$ & $\begin{array}{c}1 \\
5.0 \%\end{array}$ & $\begin{array}{c}1 \\
5.0 \%\end{array}$ & $\begin{array}{c}2 \\
10.0 \%\end{array}$ & $\begin{array}{c}14 \\
70.0 \%\end{array}$ \\
\hline & $\begin{array}{l}\text { Haredi (Ultra- } \\
\text { Orthodox) }\end{array}$ & $\begin{array}{c}\text { Count } \\
\% \text { within } \\
\text { Movement }\end{array}$ & $\begin{array}{c}0 \\
0.0 \%\end{array}$ & $\begin{array}{c}1 \\
4.3 \%\end{array}$ & $\begin{array}{c}4 \\
17.4 \%\end{array}$ & $\begin{array}{c}7 \\
30.4 \%\end{array}$ & $\begin{array}{c}9 \\
39.1 \%\end{array}$ \\
\hline & Labor & $\begin{array}{c}\text { Count } \\
\% \text { within } \\
\text { Movement }\end{array}$ & $\begin{array}{c}30 \\
14.9 \%\end{array}$ & $\begin{array}{c}80 \\
39.6 \%\end{array}$ & $\begin{array}{c}54 \\
26.7 \%\end{array}$ & $\begin{array}{c}18 \\
8.9 \%\end{array}$ & $\begin{array}{c}13 \\
6.4 \%\end{array}$ \\
\hline \multicolumn{2}{|r|}{ Total } & $\begin{array}{c}\text { Count } \\
\% \text { within } \\
\text { Movement }\end{array}$ & $\begin{array}{c}32 \\
9.3 \%\end{array}$ & $\begin{array}{c}91 \\
26.4 \%\end{array}$ & $\begin{array}{c}79 \\
22.9 \%\end{array}$ & $\begin{array}{c}49 \\
14.2 \%\end{array}$ & $\begin{array}{c}77 \\
22.3 \%\end{array}$ \\
\hline
\end{tabular}




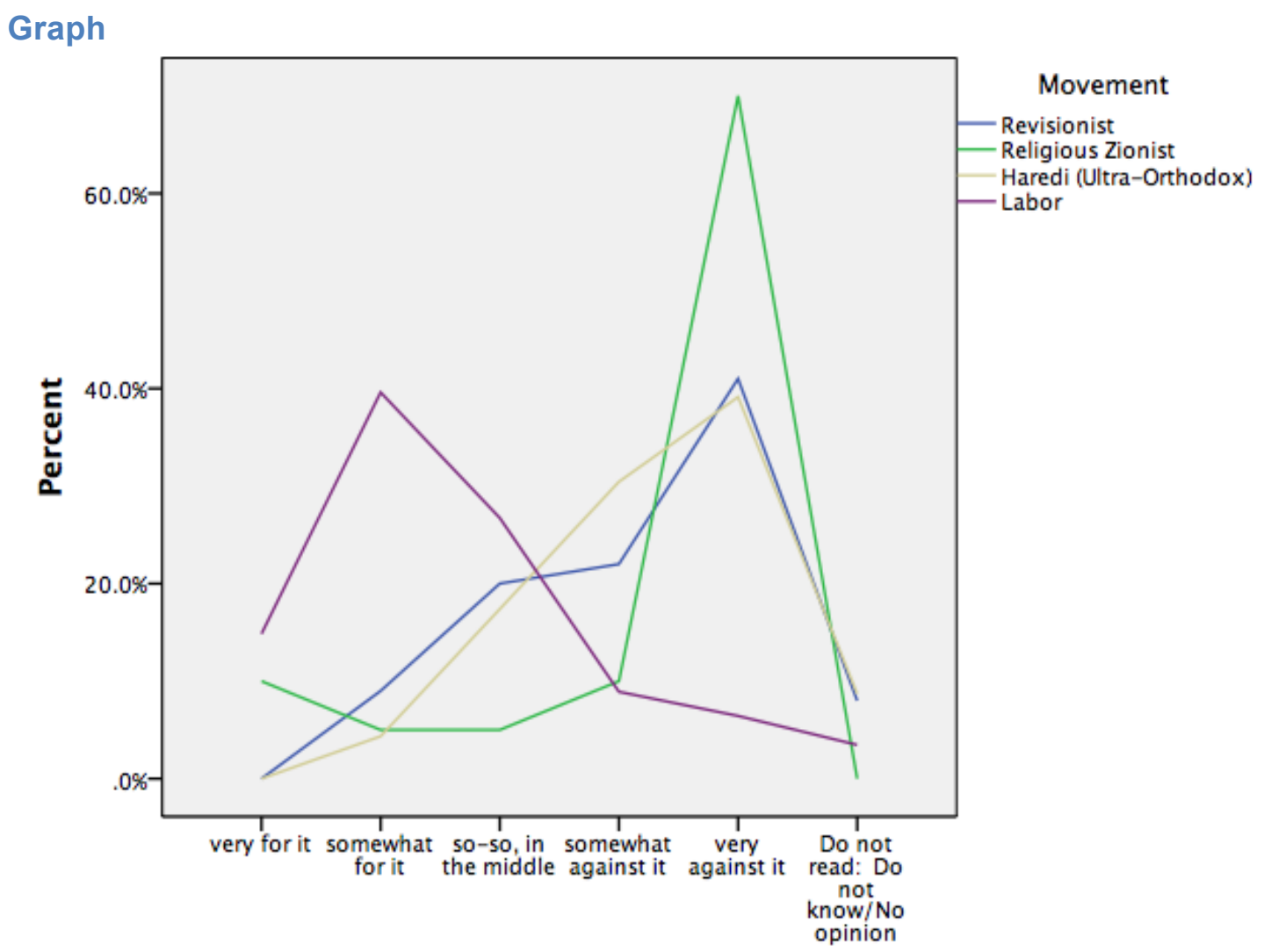

What is your opinion in regards to the agreement signed at Oslo between Israel and the PLO (Declaration of Principles)?

Nominal Regression

Model Fitting Information

\begin{tabular}{|c|c|c|c|c|}
\hline \multirow[b]{2}{*}{ Model } & $\begin{array}{c}\text { Model Fitting } \\
\text { Criteria }\end{array}$ & \multicolumn{3}{|c|}{ Likelihood Ratio Tests } \\
\hline & $\begin{array}{c}-2 \text { Log } \\
\text { Likelihood }\end{array}$ & Chi-Square & df & Sig. \\
\hline $\begin{array}{l}\text { Intercept Only } \\
\text { Final }\end{array}$ & $\begin{array}{r}209.460 \\
59.626\end{array}$ & 149.834 & 15 & .000 \\
\hline
\end{tabular}

Goodness-of-Fit

\begin{tabular}{|c|c|c|c|}
\hline & Chi-Square & $\mathrm{df}$ & Sig. \\
\hline Pearson & .000 & 0 & \\
\hline Deviance & .000 & 0 & \\
\hline
\end{tabular}

\section{Likelihood Ratio Tests}

\begin{tabular}{|l|r|r|r|r|}
\hline \multirow{2}{*}{} & \multicolumn{1}{|c|}{$\begin{array}{c}\text { Model Fitting } \\
\text { Criteria }\end{array}$} & \multicolumn{3}{|c|}{ Likelihood Ratio Tests } \\
\cline { 2 - 6 } & $\begin{array}{c}-2 \text { Log } \\
\text { Likelihood of } \\
\text { Reduced Model }\end{array}$ & Chi-Square & df & \multicolumn{1}{c|}{ Sig. } \\
\hline Intercept & $59.626^{\mathrm{a}}$ & .000 & 0 & \\
Movement & 209.460 & 149.834 & 15 & .000 \\
\hline
\end{tabular}


Parameter Estimates

\begin{tabular}{|c|c|c|c|c|c|c|c|c|c|}
\hline \multirow{2}{*}{\multicolumn{2}{|c|}{$\begin{array}{l}\text { What is your opinion in } \\
\text { regards to the agreement } \\
\text { signed at Oslo between } \\
\text { Israel and the PLO } \\
\text { (Declaration of } \\
\text { Principles)? }\end{array}$}} & \multirow[b]{2}{*}{ B } & \multirow[b]{2}{*}{$\begin{array}{l}\text { Std. } \\
\text { Error }\end{array}$} & \multirow[b]{2}{*}{ Wald } & \multirow[b]{2}{*}{ df } & \multirow[b]{2}{*}{ Sig. } & \multirow[b]{2}{*}{$\operatorname{Exp}(B)$} & \multicolumn{2}{|c|}{$\begin{array}{l}95 \% \text { Confidence } \\
\text { Interval for } \operatorname{Exp}(\mathrm{B})\end{array}$} \\
\hline & & & & & & & & $\begin{array}{l}\text { Lower } \\
\text { Bound }\end{array}$ & $\begin{array}{l}\text { Upper } \\
\text { Bound }\end{array}$ \\
\hline \multirow{4}{*}{$\begin{array}{l}\text { somewhat } \\
\text { for it }\end{array}$} & $\begin{array}{c}\text { Intercept } \\
\text { Revisionist }\end{array}$ & $\begin{array}{c}.981 \\
17.216\end{array}$ & $\begin{array}{c}.214 \\
2980.10 \\
8 \\
\end{array}$ & $\begin{array}{c}20.990 \\
.000\end{array}$ & $\begin{array}{l}1 \\
1\end{array}$ & $\begin{array}{l}.000 \\
.995\end{array}$ & \begin{tabular}{|c|}
29973540 \\
.786 \\
\end{tabular} & .000 & b \\
\hline & $\begin{array}{l}\text { Religious } \\
\text { Zionist }\end{array}$ & -1.674 & 1.243 & 1.813 & 1 & .178 & & .016 & 2.144 \\
\hline & $\begin{array}{l}\text { Haredi (ultra- } \\
\text { Orthodox) } \\
\end{array}$ & 16.599 & $\begin{array}{c}6566.61 \\
7 \\
\end{array}$ & .000 & 1 & .998 & $\begin{array}{c}16170196 \\
.167 \\
\end{array}$ & .000 & b \\
\hline & Labor & $0^{c}$ & & & 0 & & & . &. \\
\hline \multirow{4}{*}{$\begin{array}{l}\text { so-so, in the } \\
\text { middle }\end{array}$} & Intercept & .588 & .228 & 6.663 & 1 & .010 & & & \\
\hline & Revisionist & 18.407 & $\begin{array}{c}2980.10 \\
8\end{array}$ & .000 & 1 & .995 & \begin{tabular}{|l}
98678323 \\
.576
\end{tabular} & .000 & b \\
\hline & $\begin{array}{l}\text { Religious } \\
\text { Zionist }\end{array}$ & -1.281 & 1.246 & 1.057 & 1 & .304 & .278 & .024 & 3.192 \\
\hline & $\begin{array}{l}\text { Haredi (ultra- } \\
\text { Orthodox) } \\
\text { Labor }\end{array}$ & $\begin{array}{c}18.378 \\
0^{c}\end{array}$ & $\begin{array}{c}6566.61 \\
7\end{array}$ & .000 & $\begin{array}{l}1 \\
0\end{array}$ & .998 & $\begin{array}{c}95823384 \\
.693\end{array}$ & .000 & ${ }^{b}$ \\
\hline \multirow{4}{*}{$\begin{array}{l}\text { somewhat } \\
\text { against it }\end{array}$} & $\begin{array}{c}\text { Intercept } \\
\text { Revisionist } \\
\end{array}$ & $\begin{array}{c}-.511 \\
19.601\end{array}$ & $\begin{array}{c}.298 \\
2980.10 \\
8 \\
\end{array}$ & $\begin{array}{l}2.936 \\
.000\end{array}$ & $\begin{array}{l}1 \\
1\end{array}$ & $\begin{array}{l}.087 \\
.995\end{array}$ & \begin{tabular}{|c|}
32563846 \\
7.800 \\
\end{tabular} & .000 & b \\
\hline & $\begin{array}{l}\text { Religious } \\
\text { Zionist }\end{array}$ & .511 & 1.043 & .240 & 1 & .624 & & .216 & 12.885 \\
\hline & $\begin{array}{c}\text { Haredi (ultra- } \\
\text { Orthodox) } \\
\end{array}$ & 20.036 & \begin{tabular}{|c|}
6566.61 \\
7 \\
\end{tabular} & .000 & 1 & .998 & \begin{tabular}{|c|}
50307276 \\
9.639 \\
\end{tabular} & .000 & b \\
\hline & Labor & $0^{\mathrm{C}}$ & & & 0 & . & . & . & . \\
\hline \multirow{4}{*}{$\begin{array}{c}\text { very against } \\
\text { it }\end{array}$} & Intercept & -.836 & .332 & 6.343 & 1 & .012 & & & \\
\hline & Revisionist & 20.549 & $\begin{array}{c}2980.10 \\
8\end{array}$ & .000 & 1 & .994 & $\begin{array}{c}84028387 \\
8.447\end{array}$ & .000 & b \\
\hline & $\begin{array}{l}\text { Religious } \\
\text { Zionist }\end{array}$ & 2.782 & .826 & 11.355 & 1 & .001 & 16.154 & 3.202 & 81.482 \\
\hline & $\begin{array}{l}\text { Haredi (ultra- } \\
\text { Orthodox) } \\
\text { Labor }\end{array}$ & $\begin{array}{c}20.613 \\
0^{c}\end{array}$ & $\begin{array}{c}6566.61 \\
7\end{array}$ & .000 & $\begin{array}{l}1 \\
0\end{array}$ & .997 & $\begin{array}{c}89558009 \\
5.399\end{array}$ & .000 & b \\
\hline \multirow{4}{*}{$\begin{array}{l}\text { Do not read: } \\
\text { Do not } \\
\text { know/No } \\
\text { opinion }\end{array}$} & $\begin{array}{c}\text { Intercept } \\
\text { Revisionist }\end{array}$ & $\begin{array}{l}-1.455 \\
19.534\end{array}$ & $\begin{array}{c}420 \\
2980.10 \\
8 \\
\end{array}$ & $\begin{array}{c}12.020 \\
.000\end{array}$ & $\begin{array}{l}1 \\
1\end{array}$ & $\begin{array}{l}.001 \\
.995\end{array}$ & \begin{tabular}{|c|}
30449311 \\
2.748 \\
\end{tabular} & .000 & b \\
\hline & $\begin{array}{l}\text { Religious } \\
\text { Zionist }\end{array}$ & $18 \overline{235}$ & .000 & & 1 & . & 1.204E-8 & $1.204 \mathrm{E}-8$ & 1.204E-8 \\
\hline & $\begin{array}{l}\text { Haredi (ultra- } \\
\text { Orthodox) } \\
\end{array}$ & 19.728 & \begin{tabular}{|c}
6566.61 \\
7 \\
\end{tabular} & .000 & 1 & .998 & \begin{tabular}{|c|}
36960448 \\
3.817 \\
\end{tabular} & .000 & b \\
\hline & Labor & $0^{C}$ & & & 0 & & & & \\
\hline
\end{tabular}


July 1995

Crosstabs

Movement * What is your opinion in regards to the agreement signed at Oslo between Israel and the PLO (Declaration of Principles)? Crosstabulation

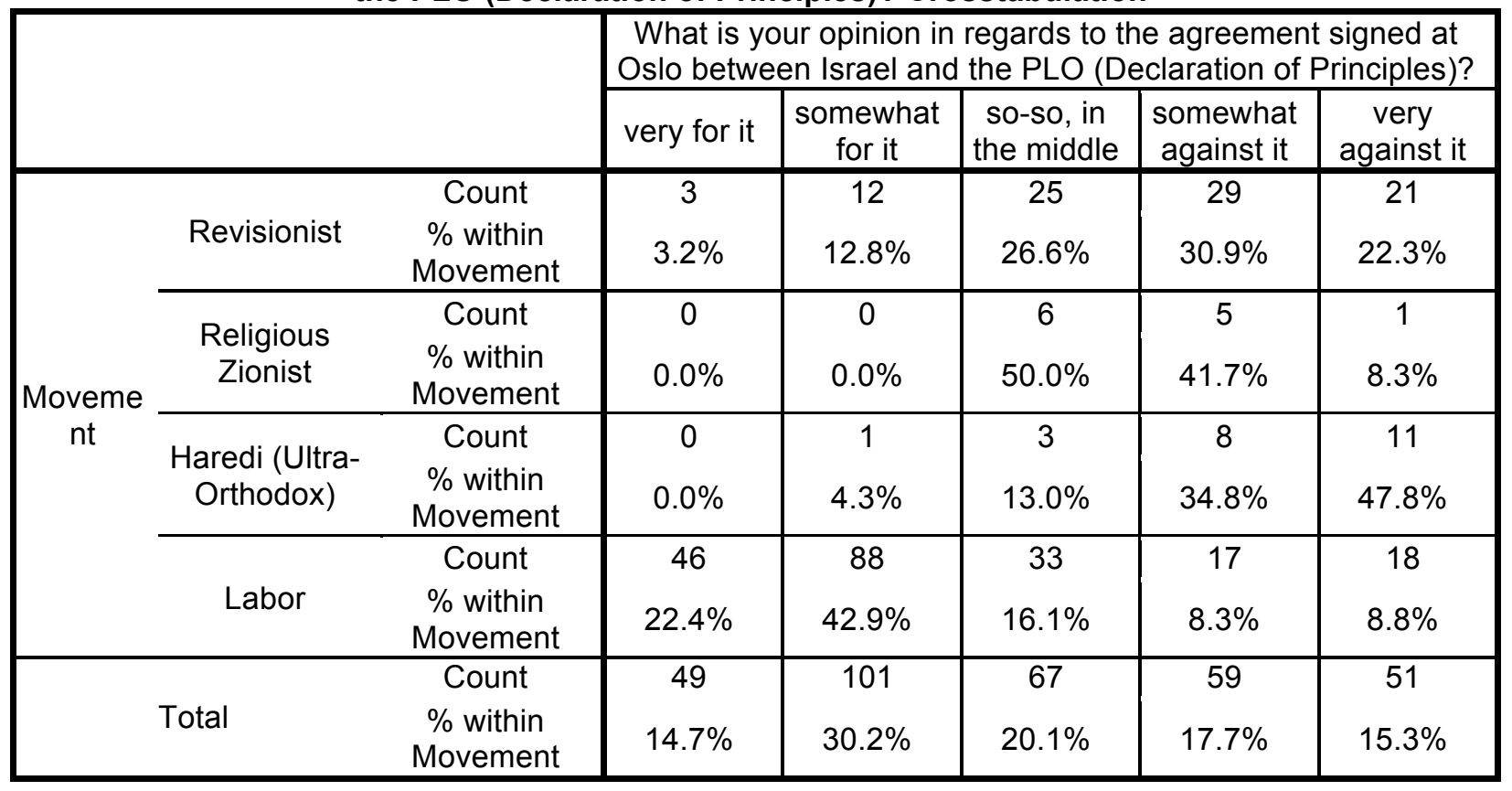




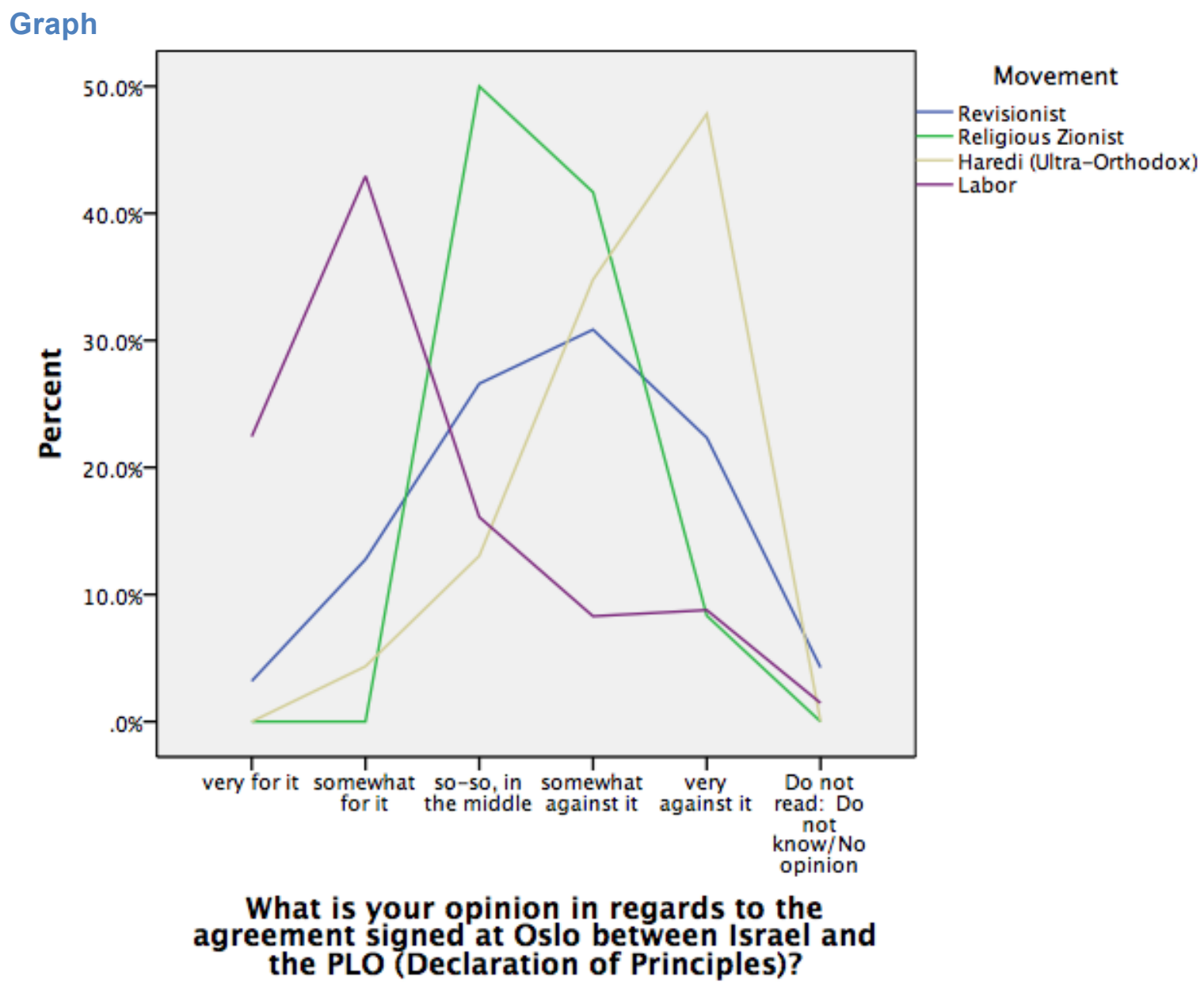

Nominal Regression

Model Fitting Information

\begin{tabular}{|l|r|r|r|r|}
\hline \multirow{2}{*}{ Model } & \multicolumn{1}{|c|}{$\begin{array}{c}\text { Model Fitting } \\
\text { Criteria }\end{array}$} & \multicolumn{3}{|c|}{ Likelihood Ratio Tests } \\
\cline { 2 - 5 } & $\begin{array}{c}-2 \text { Log } \\
\text { Likelihood }\end{array}$ & Chi-Square & df & Sig. \\
\hline Intercept Only & $\begin{array}{r}179.470 \\
54.953\end{array}$ & 124.517 & 15 & .000 \\
\hline
\end{tabular}

Goodness-of-Fit

\begin{tabular}{|c|c|c|c|}
\hline & Chi-Square & $\mathrm{df}$ & Sig. \\
\hline Pearson & .000 & 0 & \\
\hline Deviance & .000 & 0 & \\
\hline
\end{tabular}

Likelihood Ratio Tests

\begin{tabular}{|c|c|c|c|c|}
\hline \multirow[b]{2}{*}{ Effect } & $\begin{array}{l}\text { Model Fitting } \\
\text { Criteria }\end{array}$ & \multicolumn{3}{|c|}{ Likelihood Ratio Tests } \\
\hline & $\begin{array}{c}-2 \text { Log } \\
\text { Likelihood of } \\
\text { Reduced Model }\end{array}$ & Chi-Square & df & Sig. \\
\hline $\begin{array}{l}\text { Intercept } \\
\text { Movement }\end{array}$ & $\begin{array}{l}54.953^{a} \\
179.470\end{array}$ & $\begin{array}{r}.000 \\
124.517\end{array}$ & $\begin{array}{r}0 \\
15\end{array}$ & .000 \\
\hline
\end{tabular}


Parameter Estimates

\begin{tabular}{|c|c|c|c|c|c|c|c|c|c|}
\hline \multirow{2}{*}{\multicolumn{2}{|c|}{$\begin{array}{l}\text { What is your opinion in } \\
\text { regards to the agreement } \\
\text { signed at Oslo between } \\
\text { Israel and the PLO } \\
\text { (Declaration of } \\
\text { Principles)? }\end{array}$}} & \multirow[b]{2}{*}{ B } & \multirow[b]{2}{*}{$\begin{array}{l}\text { Std. } \\
\text { Error }\end{array}$} & \multirow[b]{2}{*}{ Wald } & \multirow[b]{2}{*}{$d f$} & \multirow[b]{2}{*}{ Sig. } & \multirow[b]{2}{*}{$\operatorname{Exp}(B)$} & \multicolumn{2}{|c|}{$\begin{array}{l}\text { 95\% Confidence } \\
\text { Interval for } \operatorname{Exp}(B)\end{array}$} \\
\hline & & & & & & & & $\begin{array}{l}\text { Lower } \\
\text { Bound }\end{array}$ & $\begin{array}{l}\text { Upper } \\
\text { Bound }\end{array}$ \\
\hline \multirow{5}{*}{$\begin{array}{l}\text { somewhat } \\
\text { for it }\end{array}$} & Intercept & 649 & .182 & 12.712 & 1 & .000 & & & \\
\hline & Revisionist & .738 & 671 & 1.210 & 1 & .271 & 2.091 & .562 & 7.784 \\
\hline & $\begin{array}{l}\text { Religious } \\
\text { Zionist }\end{array}$ & .075 & $\begin{array}{c}6077.59 \\
0\end{array}$ & .000 & 1 & 1.000 & & .000 & \\
\hline & $\begin{array}{l}\text { Haredi (ultra- } \\
\text { Orthodox) }\end{array}$ & 15.983 & $\begin{array}{c}3824.64 \\
6 \\
\end{array}$ & .000 & 1 & .997 & $\begin{array}{c}8738754 \\
655 \\
\end{array}$ & .000 & b \\
\hline & Labor & $0^{c}$ & & & 0 & & & & . \\
\hline \multirow{4}{*}{$\begin{array}{l}\text { so-so, in the } \\
\text { middle }\end{array}$} & Intercept & -.332 & 228 & 2.120 & 1 & .145 & & & \\
\hline & Revisionist & 2.452 & .652 & 14.139 & 1 & .000 & 11.616 & 3.235 & 41.708 \\
\hline & $\begin{array}{l}\text { Religious } \\
\text { Zionist }\end{array}$ & 19.241 & $\begin{array}{c}4874.63 \\
7\end{array}$ & .000 & 1 & .997 & $\begin{array}{c}22712848 \\
0.038\end{array}$ & .000 & b \\
\hline & $\begin{array}{c}\text { Haredi (ultra- } \\
\text { Orthodox) } \\
\text { Labor }\end{array}$ & $\begin{array}{c}18.063 \\
0^{c}\end{array}$ & $\begin{array}{c}3824.64 \\
6\end{array}$ & .000 & 1 & .996 & $\begin{array}{c}69910037 \\
.242\end{array}$ & .000 & b \\
\hline \multirow{5}{*}{$\begin{array}{l}\text { somewhat } \\
\text { against it }\end{array}$} & Intercept & -.995 & .284 & 12.299 & 1 & .000 & & & \\
\hline & Revisionist & 3.264 & .670 & 23.762 & 1 & .000 & 26.157 & 7.041 & 97.176 \\
\hline & $\begin{array}{l}\text { Religious } \\
\text { Zionist }\end{array}$ & 19.722 & $\begin{array}{c}4874.63 \\
7\end{array}$ & .000 & 1 & .997 & $\begin{array}{c}36741371 \\
7.708\end{array}$ & .000 & b \\
\hline & Haredi (ultra- & 190707 & 3824.64 & 000 & 1 & & 36188725 & & b \\
\hline & $\begin{array}{l}\text { Orthodox) } \\
\text { Labor }\end{array}$ & $\begin{array}{c}19.707 \\
0^{c}\end{array}$ & 6 & .000 & $\begin{array}{l}1 \\
0\end{array}$ & .996 & 1.606 & .000 & \\
\hline \multirow{6}{*}{$\begin{array}{c}\text { very against } \\
\text { it }\end{array}$} & Intercept & -.938 & .278 & 11.390 & 1 & .001 & & & \\
\hline & Revisionist & 2.884 & .677 & 18.153 & 1 & .000 & 17.889 & 4.746 & 67.421 \\
\hline & Religious & 18.055 & $\begin{array}{c}4874.63 \\
7\end{array}$ & .000 & 1 & .997 & 69400368 & .000 & $\mathrm{~b}$ \\
\hline & Haredi (ultra- & 110068 & 3824.64 & & 1 & & 46995080 & & $\mathrm{~b}$ \\
\hline & Orthodox) & 19.968 & 6 & .000 & 1 & .996 & 5.905 & .000 & \\
\hline & Labor & $0^{c}$ & & & 0 & & & & \\
\hline \multirow{5}{*}{$\begin{array}{l}\text { Do not read: } \\
\text { Do not } \\
\text { know/No } \\
\text { opinion }\end{array}$} & Intercept & -2.730 & .596 & 20.990 & 1 & .000 & & & \\
\hline & Revisionist & 3.018 & .969 & 9.704 & 1 & .002 & 20.444 & 3.062 & 136.504 \\
\hline & $\begin{array}{l}\text { Religious } \\
\text { Zionist }\end{array}$ & .784 & .000 & . & 1 & & 2.190 & 2.190 & 2.190 \\
\hline & Haredi (ultra- & .784 & .000 & . & 1 & & 2.190 & 2.190 & 2.190 \\
\hline & Labor & $0^{c}$ & & & 0 & & & & \\
\hline
\end{tabular}


November 8, 1995

Crosstabs

Movement * What is your opinion in regards to the agreement signed at Oslo between Israel and the PLO (Declaration of Principles)? Crosstabulation

\begin{tabular}{|c|c|c|c|c|c|c|c|}
\hline & \multicolumn{5}{|c|}{$\begin{array}{l}\text { What is your opinion in regards to the agreement signed at } \\
\text { Oslo between Israel and the PLO (Declaration of Principles)? }\end{array}$} \\
\hline & & & very for it & $\begin{array}{l}\text { somewhat } \\
\text { for it }\end{array}$ & $\begin{array}{l}\text { so-so, in } \\
\text { the middle }\end{array}$ & $\begin{array}{l}\text { somewhat } \\
\text { against it }\end{array}$ & $\begin{array}{l}\text { very } \\
\text { against it }\end{array}$ \\
\hline \multirow{4}{*}{$\begin{array}{l}\text { Moveme } \\
\text { nt }\end{array}$} & Revisionist & $\begin{array}{c}\text { Count } \\
\% \text { within } \\
\text { Movement }\end{array}$ & $\begin{array}{c}8 \\
8.3 \%\end{array}$ & $\begin{array}{c}19 \\
19.8 \%\end{array}$ & $\begin{array}{c}32 \\
33.3 \%\end{array}$ & $\begin{array}{c}12 \\
12.5 \%\end{array}$ & $\begin{array}{c}23 \\
24.0 \%\end{array}$ \\
\hline & $\begin{array}{l}\text { Religious } \\
\text { Zionist }\end{array}$ & $\begin{array}{c}\text { Count } \\
\% \text { within } \\
\text { Movement }\end{array}$ & $\begin{array}{c}1 \\
5.0 \%\end{array}$ & $\begin{array}{c}5 \\
25.0 \%\end{array}$ & $\begin{array}{c}5 \\
25.0 \%\end{array}$ & $\begin{array}{c}3 \\
15.0 \%\end{array}$ & $\begin{array}{c}5 \\
25.0 \%\end{array}$ \\
\hline & $\begin{array}{l}\text { Haredi (Ultra } \\
\text { Orthodox) }\end{array}$ & $\begin{array}{c}\text { Count } \\
\% \text { within } \\
\text { Movement }\end{array}$ & $\begin{array}{c}2 \\
8.0 \%\end{array}$ & $\begin{array}{c}2 \\
8.0 \%\end{array}$ & $\begin{array}{c}4 \\
16.0 \%\end{array}$ & $\begin{array}{c}4 \\
16.0 \%\end{array}$ & $\begin{array}{c}11 \\
44.0 \%\end{array}$ \\
\hline & Labor & $\begin{array}{c}\text { Count } \\
\% \text { within } \\
\text { Movement }\end{array}$ & $\begin{array}{c}79 \\
35.0 \%\end{array}$ & $\begin{array}{c}90 \\
39.8 \%\end{array}$ & $\begin{array}{c}40 \\
17.7 \%\end{array}$ & $\begin{array}{c}6 \\
2.7 \%\end{array}$ & $\begin{array}{c}5 \\
2.2 \%\end{array}$ \\
\hline \multicolumn{2}{|r|}{ Total } & $\begin{array}{c}\text { Count } \\
\% \text { within } \\
\text { Movement }\end{array}$ & $\begin{array}{c}90 \\
24.5 \%\end{array}$ & $\begin{array}{c}116 \\
31.6 \%\end{array}$ & $\begin{array}{c}81 \\
22.1 \%\end{array}$ & $\begin{array}{c}25 \\
6.8 \%\end{array}$ & $\begin{array}{c}44 \\
12.0 \%\end{array}$ \\
\hline
\end{tabular}




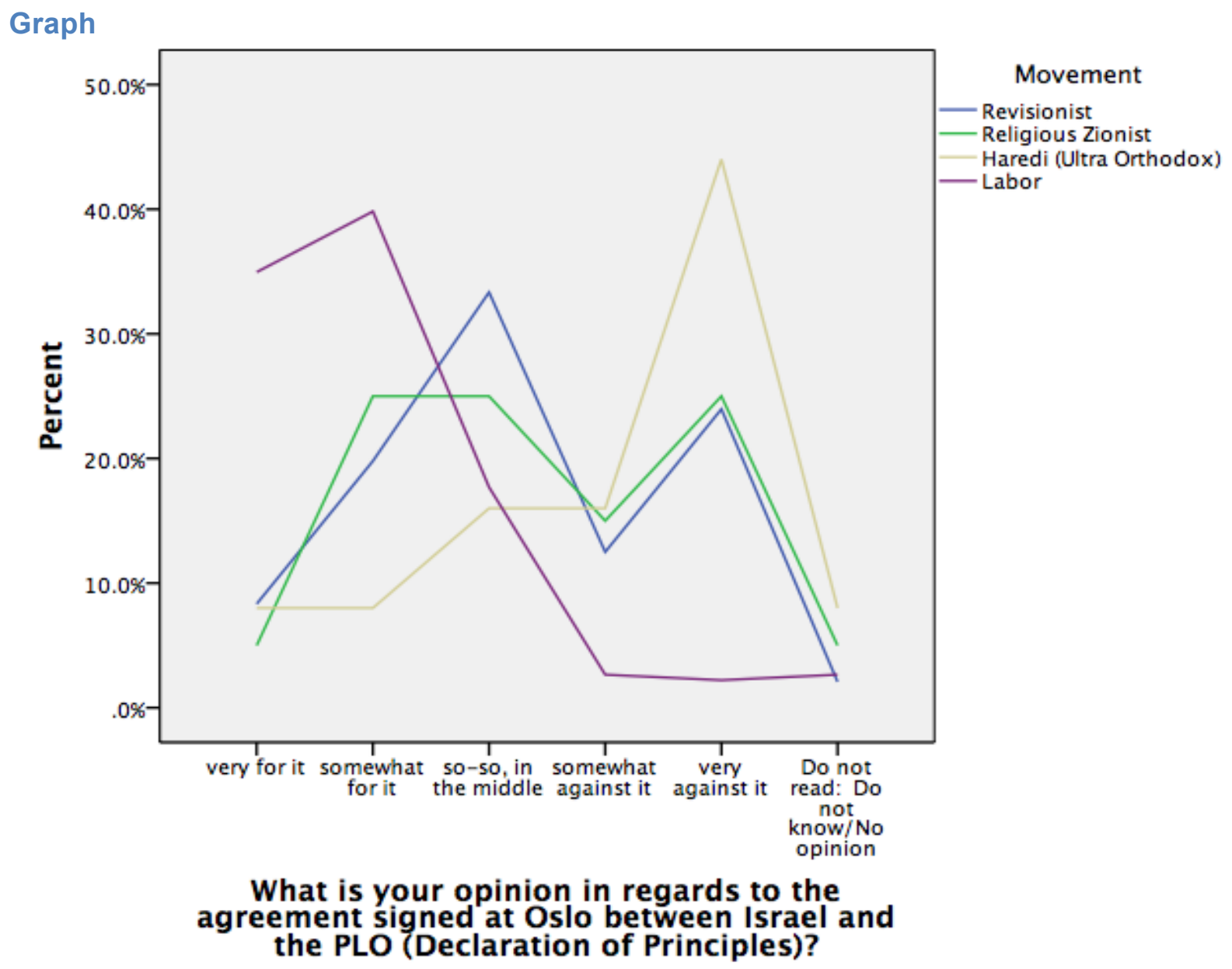

Nominal Regression

Model Fitting Information

\begin{tabular}{|c|c|c|c|c|}
\hline \multirow[b]{2}{*}{ Model } & $\begin{array}{l}\text { Model Fitting } \\
\text { Criteria }\end{array}$ & \multicolumn{3}{|c|}{ Likelihood Ratio Tests } \\
\hline & $\begin{array}{c}-2 \text { Log } \\
\text { Likelihood }\end{array}$ & Chi-Square & $\mathrm{df}$ & Sig. \\
\hline $\begin{array}{l}\text { Intercept Only } \\
\text { Final }\end{array}$ & $\begin{array}{r}189.536 \\
67.333\end{array}$ & 122.203 & 15 & .000 \\
\hline
\end{tabular}

Goodness-of-Fit

\begin{tabular}{|c|c|c|c|}
\hline & Chi-Square & $\mathrm{df}$ & Sig. \\
\hline $\begin{array}{l}\text { Pearson } \\
\text { Deviance }\end{array}$ & $\begin{array}{l}.000 \\
.000\end{array}$ & $\begin{array}{l}0 \\
0\end{array}$ & \\
\hline
\end{tabular}

Likelihood Ratio Tests

\begin{tabular}{|l|r|r|r|r|}
\hline \multirow{2}{*}{} & \multicolumn{1}{|c|}{$\begin{array}{c}\text { Model Fitting } \\
\text { Criteria }\end{array}$} & \multicolumn{3}{|c|}{ Likelihood Ratio Tests } \\
\cline { 2 - 5 } & $\begin{array}{c}-2 \text { Log } \\
\text { Likelihood of } \\
\text { Eeffect }\end{array}$ & & & \\
\hline Reduced Model & Chi-Square & df & \multicolumn{1}{c|}{ Sig. } \\
\hline Movement & $67.333^{\mathrm{a}}$ & .000 & 0 & \\
\hline
\end{tabular}


Parameter Estimates

\begin{tabular}{|c|c|c|c|c|c|c|c|c|c|}
\hline \multirow{2}{*}{\multicolumn{2}{|c|}{$\begin{array}{l}\text { What is your opinion in } \\
\text { regards to the agreement } \\
\text { signed at Oslo between } \\
\text { Israel and the PLO } \\
\text { (Declaration of Principles)? }\end{array}$}} & \multirow[b]{2}{*}{ B } & \multirow{2}{*}{$\begin{array}{l}\text { Std. } \\
\text { Error }\end{array}$} & \multirow{2}{*}{ Wald } & \multirow[b]{2}{*}{ df } & \multirow{2}{*}{ Sig. } & \multirow{2}{*}{$\operatorname{Exp}(B)$} & \multicolumn{2}{|c|}{$\begin{array}{l}\text { 95\% Confidence } \\
\text { Interval for } \operatorname{Exp}(\mathrm{B})\end{array}$} \\
\hline & & & & & & & & $\begin{array}{l}\text { Lower } \\
\text { Bound }\end{array}$ & $\begin{array}{l}\text { Upper } \\
\text { Bound }\end{array}$ \\
\hline \multirow{5}{*}{$\begin{array}{c}\text { somewhat for } \\
\text { it }\end{array}$} & Intercept & .130 & .154 & .715 & 1 & .398 & & & \\
\hline & Revisionist & .735 & .449 & 2.680 & 1 & .102 & 2.085 & .865 & 5.024 \\
\hline & $\begin{array}{l}\text { Religious } \\
\text { Zionist }\end{array}$ & 1.479 & 1.106 & 1.788 & 1 & .181 & 4.389 & .502 & 38.370 \\
\hline & $\begin{array}{l}\text { Haredi (ultra- } \\
\text { Orthodox) }\end{array}$ & -.130 & 1.012 & .017 & 1 & .897 & .878 & .121 & 6.377 \\
\hline & Labor & $0^{\mathrm{b}}$ & & & 0 & & & & \\
\hline \multirow{4}{*}{$\begin{array}{l}\text { so-so, in the } \\
\text { middle }\end{array}$} & Intercept & -.681 & .194 & 12.299 & 1 & .000 & & & \\
\hline & Revisionist & 2.067 & .440 & 22.031 & 1 & .000 & 7.900 & 3.333 & 18.726 \\
\hline & $\begin{array}{l}\text { Religious } \\
\text { Zionist }\end{array}$ & 2.290 & 1.113 & 4.237 & 1 & .040 & 9.875 & 1.116 & 87.398 \\
\hline & $\begin{array}{l}\text { Haredi (ultra- } \\
\text { Orthodox) } \\
\text { Labor }\end{array}$ & $\begin{array}{c}1.374 \\
0^{\mathrm{b}}\end{array}$ & .888 & 2.396 & $\begin{array}{l}1 \\
0\end{array}$ & .122 & 3.950 & .694 & 22.493 \\
\hline \multirow{5}{*}{$\begin{array}{l}\text { somewhat } \\
\text { against it }\end{array}$} & Intercept & -2.578 & .423 & 37.053 & 1 & .000 & & & \\
\hline & Revisionist & 2.983 & .623 & 22.956 & 1 & .000 & 19.750 & 5.829 & 66.918 \\
\hline & $\begin{array}{l}\text { Religious } \\
\text { Zionist }\end{array}$ & 3.676 & 1.230 & 8.935 & 1 & .003 & 39.500 & 3.546 & 440.039 \\
\hline & Haredi (ultra- & 3.271 & .964 & 11.512 & 1 & & 26.333 & 3.980 & 174.212 \\
\hline & Labor & $0^{\mathrm{D}}$ & & & 0 & & & & \\
\hline \multirow{5}{*}{ very against it } & Intercept & -2.760 & .461 & 35.821 & 1 & .000 & & & \\
\hline & Revisionist & 3.816 & .617 & 38.208 & 1 & .000 & 45.425 & 13.545 & 152.333 \\
\hline & $\begin{array}{l}\text { Religious } \\
\text { Zionist }\end{array}$ & 4.369 & 1.189 & 13.515 & 1 & .000 & 79.000 & 7.690 & 811.569 \\
\hline & Haredi (ultra- & 4.465 & .896 & 24.807 & 1 & .000 & 86.900 & 14.996 & 503.562 \\
\hline & Labor & & & & 0 & & & & \\
\hline \multirow{5}{*}{$\begin{array}{l}\text { Do not read: } \\
\text { Do not } \\
\text { know/No } \\
\text { opinion }\end{array}$} & Intercept & -2.578 & .423 & 37.053 & 1 & .000 & & & \\
\hline & Revisionist & 1.191 & .897 & 1.765 & 1 & .184 & 3.292 & .568 & 19.090 \\
\hline & $\begin{array}{l}\text { Religious } \\
\text { Zionist }\end{array}$ & 2.578 & 1.476 & 3.049 & 1 & .081 & 13.167 & .729 & 237.720 \\
\hline & $\begin{array}{l}\text { Haredi (ultra- } \\
\text { Orthodox) }\end{array}$ & 2.578 & 1.086 & 5.634 & 1 & .018 & 13.167 & 1.567 & 110.625 \\
\hline & Labor & $0^{\mathrm{b}}$ & & & 0 & & & & \\
\hline
\end{tabular}


November 29, 1995

\section{Crosstabs}

Movement * a13 Crosstabulation

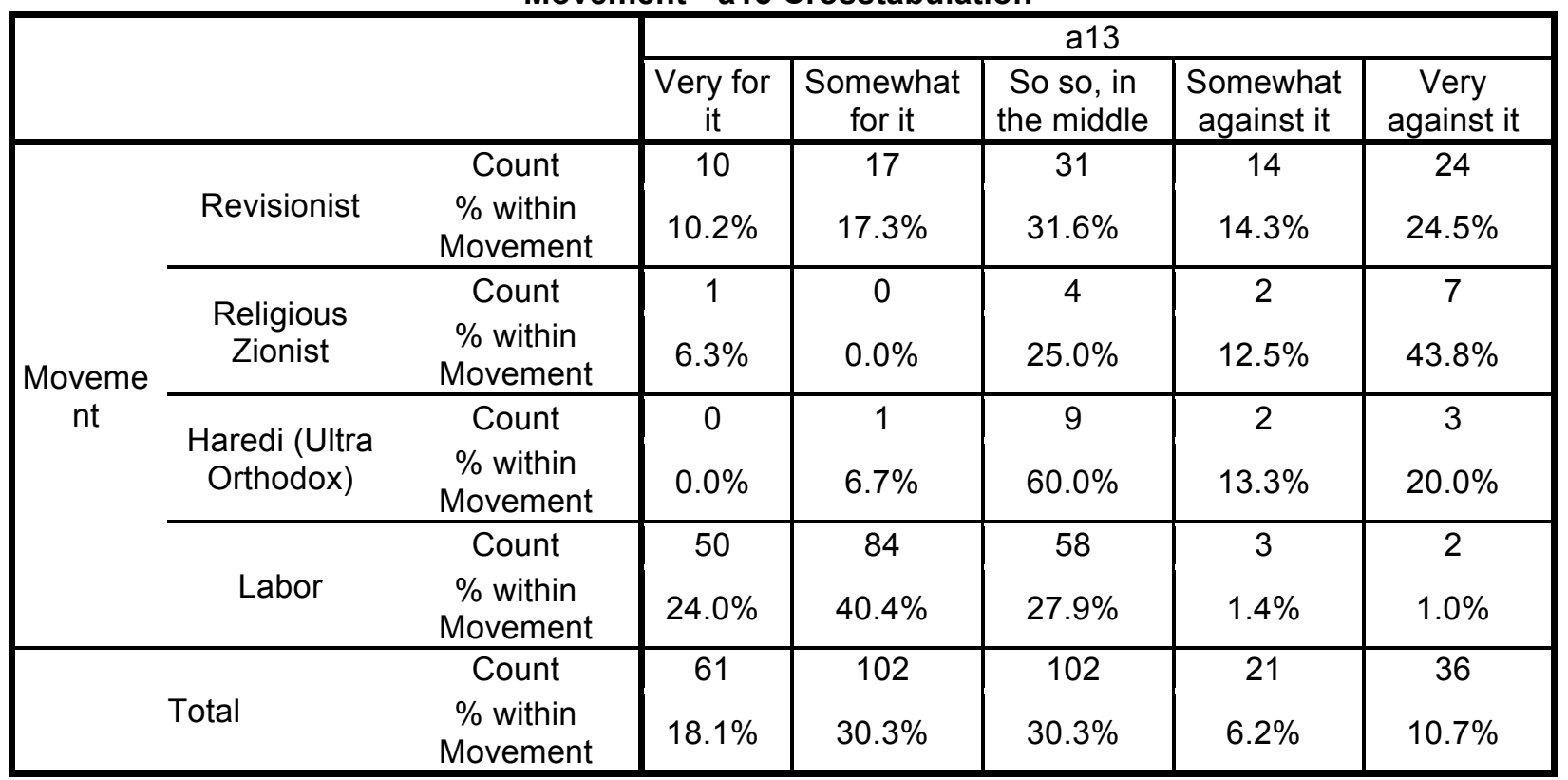




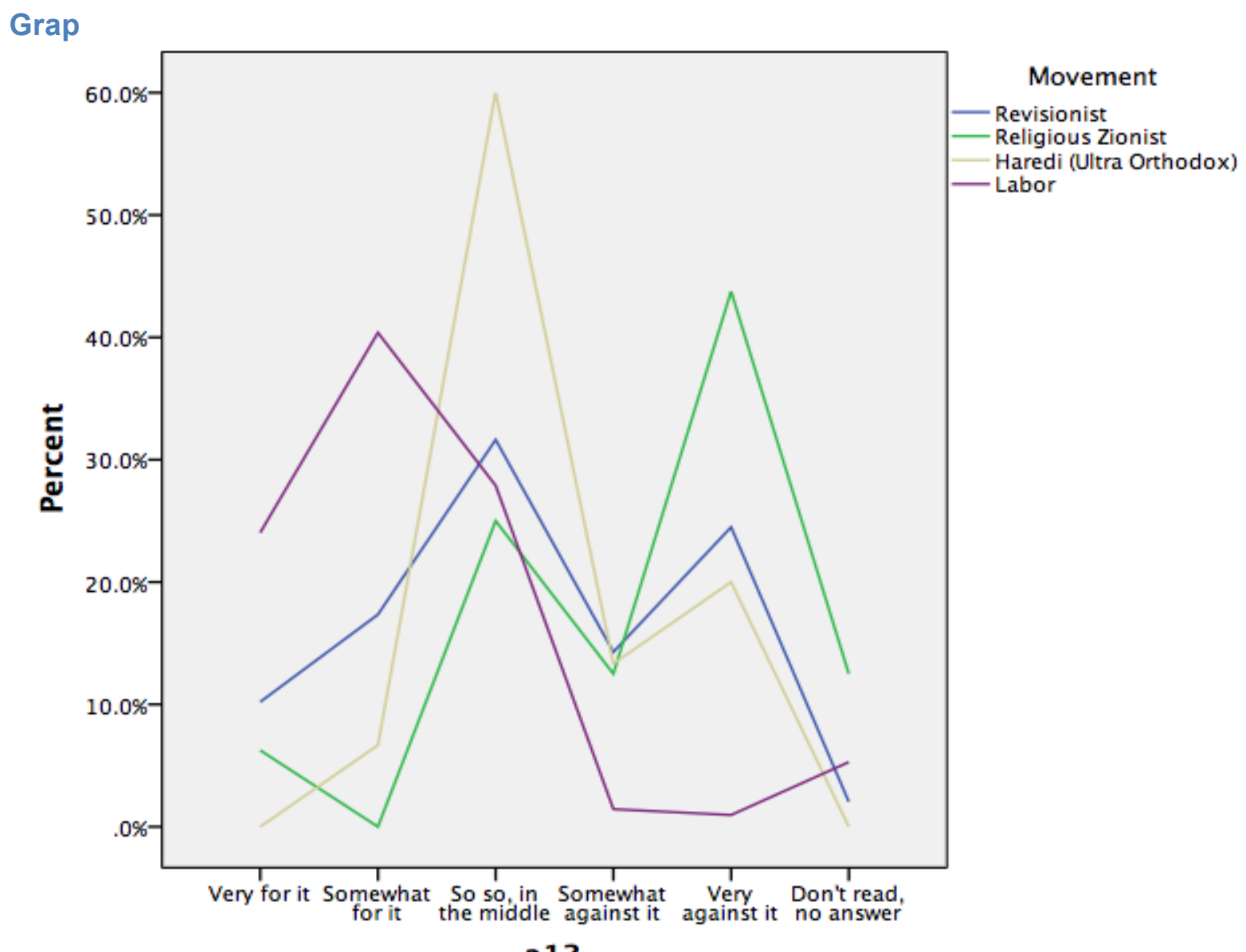

a13

Nominal Regression

Model Fitting Information

\begin{tabular}{|c|c|c|c|c|}
\hline \multirow[b]{2}{*}{ Model } & $\begin{array}{c}\text { Model Fitting } \\
\text { Criteria }\end{array}$ & \multicolumn{3}{|c|}{ Likelihood Ratio Tests } \\
\hline & $\begin{array}{c}-2 \text { Log } \\
\text { Likelihood }\end{array}$ & Chi-Square & $d f$ & Sig. \\
\hline $\begin{array}{l}\text { Intercept Only } \\
\text { Final }\end{array}$ & $\begin{array}{r}181.268 \\
57.203\end{array}$ & 124.064 & 15 & .000 \\
\hline
\end{tabular}

Goodness-of-Fit

\begin{tabular}{|l|r|r|r|}
\hline & Chi-Square & df & Sig. \\
\hline Pearson & .000 & 0 & \\
Deviance & .000 & 0 & \\
\hline
\end{tabular}

\section{Likelihood Ratio Tests}

\begin{tabular}{|l|r|r|r|r|}
\hline \multirow{2}{*}{} & \multicolumn{1}{|c|}{$\begin{array}{c}\text { Model Fitting } \\
\text { Criteria }\end{array}$} & \multicolumn{3}{|c|}{ Likelihood Ratio Tests } \\
\cline { 2 - 6 } & $\begin{array}{c}-2 \text { Log } \\
\text { Likelihood of } \\
\text { Eeduced Model }\end{array}$ & Chi-Square & df & \multicolumn{1}{c|}{ Sig. } \\
\hline Intercept & $57.203^{\mathrm{a}}$ & .000 & 0 & .000 \\
Movement & 181.268 & 124.064 & 15 & .000 \\
\hline
\end{tabular}


Parameter Estimates

\begin{tabular}{|c|c|c|c|c|c|c|c|c|c|}
\hline \multirow{2}{*}{\multicolumn{2}{|c|}{$a 13^{a}$}} & \multirow{2}{*}{ B } & \multirow{2}{*}{$\begin{array}{l}\text { Std. } \\
\text { Error }\end{array}$} & \multirow{2}{*}{ Wald } & \multirow{2}{*}{ df } & \multirow{2}{*}{ Sig. } & \multirow{2}{*}{$\operatorname{Exp}(B)$} & \multicolumn{2}{|c|}{$\begin{array}{l}\text { 95\% Confidence } \\
\text { Interval for } \operatorname{Exp}(B)\end{array}$} \\
\hline & & & & & & & & $\begin{array}{l}\text { Lower } \\
\text { Bound }\end{array}$ & $\begin{array}{l}\text { Upper } \\
\text { Bound }\end{array}$ \\
\hline \multirow{5}{*}{$\begin{array}{l}\text { Somewhat } \\
\text { for it }\end{array}$} & Intercept & .519 & .179 & 8.436 & 1 & .004 & & & \\
\hline & Revisionist & .012 & .437 & .001 & 1 & .978 & 1.012 & .430 & 2.382 \\
\hline & $\begin{array}{l}\text { Religious } \\
\text { Zionist }\end{array}$ & $\begin{array}{c}- \\
18.711\end{array}$ & $\begin{array}{c}8920.56 \\
1\end{array}$ & .000 & 1 & .998 & 7.480E-9 & .000 & b \\
\hline & $\begin{array}{l}\text { Haredi } \\
\text { (ultra- } \\
\text { Orthodox) }\end{array}$ & 16.915 & $\begin{array}{c}5470.76 \\
5\end{array}$ & .000 & 1 & .998 & $\begin{array}{c}22195800 . \\
224\end{array}$ & .000 & ${ }^{b}$ \\
\hline & Labor & $0^{c}$ & & & 0 & 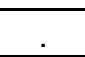 & & . & . \\
\hline \multirow{4}{*}{$\begin{array}{l}\text { So so, in the } \\
\text { middle }\end{array}$} & Intercept & .148 & .193 & .592 & 1 & .442 & & & \\
\hline & Revisionist & .983 & .412 & 5.701 & 1 & .017 & 2.672 & 1.193 & 5.989 \\
\hline & $\begin{array}{l}\text { Religious } \\
\text { Zionist }\end{array}$ & 1.238 & 1.135 & 1.190 & 1 & .275 & 3.448 & .373 & 31.867 \\
\hline & $\begin{array}{c}\text { Haredi } \\
\text { (ultra- } \\
\text { Orthodox) } \\
\text { Labor }\end{array}$ & $\begin{array}{c}19.483 \\
0^{c} \\
\end{array}$ & $\begin{array}{c}5470.76 \\
5\end{array}$ & .000 & 1 & .997 & $\begin{array}{c}28931077 \\
5.334\end{array}$ & .000 & $b^{b}$ \\
\hline \multirow{5}{*}{$\begin{array}{l}\text { Somewhat } \\
\text { against it }\end{array}$} & Intercept & -2.813 & .594 & 22.402 & 1 & .000 & & & \\
\hline & Revisionist & 3.150 & .724 & 18.907 & 1 & .000 & 23.333 & 5.641 & 96.514 \\
\hline & $\begin{array}{l}\text { Religious } \\
\text { Zionist }\end{array}$ & 3.507 & 1.361 & 6.635 & 1 & .010 & 33.333 & 2.312 & 480.486 \\
\hline & $\begin{array}{l}\text { Haredi } \\
\text { (ultra- }\end{array}$ & 20.941 & 5470.76 & .000 & 1 & .997 & 12429648 & .000 & b \\
\hline & $\begin{array}{l}\text { Orthodox) } \\
\text { Labor }\end{array}$ & $0^{c}$ & & & 0 & & & & \\
\hline \multirow{6}{*}{$\begin{array}{l}\text { Very against } \\
\text { it }\end{array}$} & Intercept & -3.219 & .721 & 19.925 & 1 & .000 & & & \\
\hline & Revisionist & 4.094 & .813 & 25.336 & 1 & .000 & 60.000 & 12.183 & 295.490 \\
\hline & $\begin{array}{c}\text { Religious } \\
\text { Zionist }\end{array}$ & 5.165 & 1.290 & 16.042 & 1 & .000 & 175.000 & 13.976 & 2191.179 \\
\hline & Haredi & 21752 & 5470.76 & 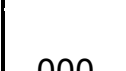 & 1 & 007 & 27966708 & 000 & b \\
\hline & $\begin{array}{l}\text { (ultra- } \\
\text { Orthodox) }\end{array}$ & 21.152 & 5 & .000 & 1 & .991 & 28.228 & .000 & \\
\hline & Labor & $0^{c}$ & & & 0 & & & 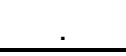 & \\
\hline \multirow{6}{*}{$\begin{array}{l}\text { Don't read, } \\
\text { no answer }\end{array}$} & Intercept & -1.514 & .333 & 20.671 & 1 & .000 & & & \\
\hline & Revisionist & -.095 & .843 & .013 & 1 & .910 & .909 & .174 & 4.746 \\
\hline & Religious & 2.207 & 1.269 & 3.024 & 1 & .082 & 9.091 & .756 & 109.387 \\
\hline & $\begin{array}{l}\text { Zlonist } \\
\text { Haredi }\end{array}$ & & & & & & & & \\
\hline & $\begin{array}{l}\text { (ultra- } \\
\text { Orthodox) }\end{array}$ & .111 & .000 & . & 1 & . & 1.118 & 1.118 & 1.118 \\
\hline & Labor & $0^{c}$ & & & 0 & & & & \\
\hline
\end{tabular}




\section{December 1995}

\section{Crosstabs}

Movement * What is your opinion in regards to the agreement signed at Oslo between Israel and the PLO (Declaration of Principles)? Crosstabulation

\begin{tabular}{|ccc|c|c|c|c|}
\hline & & & \multicolumn{2}{c}{ What is your opinion in regards to the agreement signed at } \\
Oslo between Israel and the PLO (Declaration of Principles)?
\end{tabular}




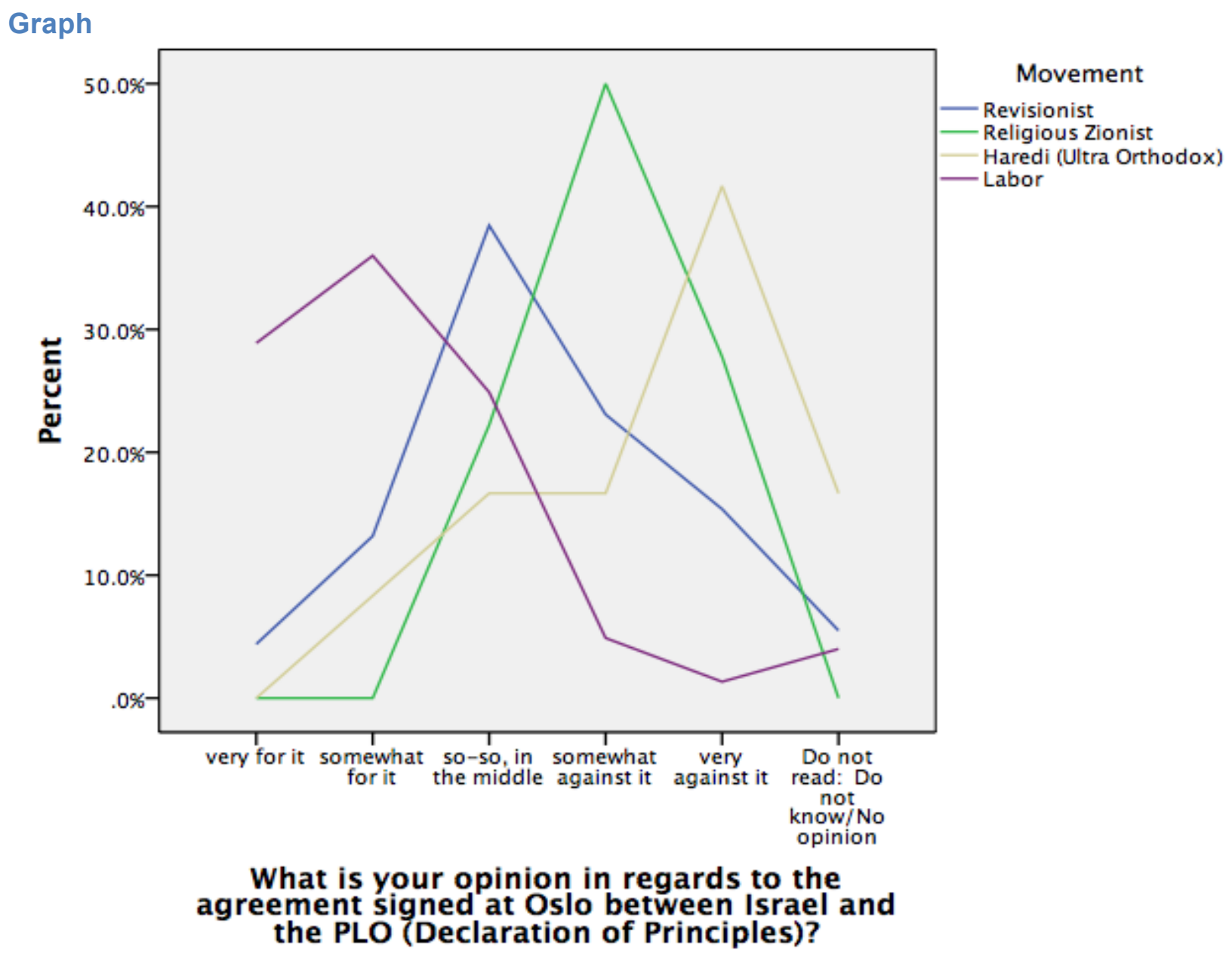

Nominal Regression

Model Fitting Information

\begin{tabular}{|l|r|r|r|r|}
\hline \multirow{2}{*}{ Model } & \multicolumn{1}{|c|}{$\begin{array}{c}\text { Model Fitting } \\
\text { Criteria }\end{array}$} & \multicolumn{3}{|c|}{ Likelihood Ratio Tests } \\
\cline { 2 - 5 } & $\begin{array}{c}-2 \text { Log } \\
\text { Likelihood }\end{array}$ & Chi-Square & df & \multicolumn{1}{c|}{ Sig. } \\
\hline Intercept Only & $\begin{array}{r}197.349 \\
56.714\end{array}$ & 140.635 & 15 & .000 \\
\hline
\end{tabular}

\section{Pseudo R-Square}

\begin{tabular}{|l|l|}
\hline Cox and Snell & .334 \\
Nagelkerke & .347 \\
McFadden & .124 \\
\hline
\end{tabular}

\section{Likelihood Ratio Tests}

\begin{tabular}{|l|r|r|r|r|}
\hline \multirow{2}{*}{} & \multicolumn{1}{|c|}{$\begin{array}{c}\text { Model Fitting } \\
\text { Criteria }\end{array}$} & \multicolumn{3}{|c|}{ Likelihood Ratio Tests } \\
\cline { 2 - 6 } & $\begin{array}{c}-2 \text { Log } \\
\text { Likelihood of } \\
\text { Reduced Model }\end{array}$ & Chi-Square & df & \multicolumn{1}{c|}{ Sig. } \\
\hline Intercept & $56.714^{\mathrm{a}}$ & .000 & 0 & \\
Movement & 197.349 & 140.635 & 15 & .000 \\
\hline
\end{tabular}


Parameter Estimates

\begin{tabular}{|c|c|c|c|c|c|c|c|c|c|}
\hline \multirow{2}{*}{\multicolumn{2}{|c|}{$\begin{array}{l}\text { What is your opinion in } \\
\text { regards to the agreement } \\
\text { signed at Oslo between } \\
\text { Israel and the PLO } \\
\text { (Declaration of } \\
\text { Principles)? }\end{array}$}} & \multirow[b]{2}{*}{ B } & \multirow[b]{2}{*}{$\begin{array}{l}\text { Std. } \\
\text { Error }\end{array}$} & \multirow[b]{2}{*}{ Wald } & \multirow[b]{2}{*}{ df } & \multirow[b]{2}{*}{ Sig. } & \multirow[b]{2}{*}{$\operatorname{Exp}(B)$} & \multicolumn{2}{|c|}{$\begin{array}{l}\text { 95\% Confidence } \\
\text { Interval for } \operatorname{Exp}(B)\end{array}$} \\
\hline & & & & & & & & $\begin{array}{l}\text { Lower } \\
\text { Bound }\end{array}$ & $\begin{array}{l}\text { Upper } \\
\text { Bound }\end{array}$ \\
\hline \multirow{5}{*}{$\begin{array}{l}\text { somewhat } \\
\text { for it }\end{array}$} & Intercept & 220 & .167 & 1.746 & 1 & .186 & & & \\
\hline & Revisionist & .879 & 601 & 2.138 & 1 & .144 & 2.407 & .741 & 7.817 \\
\hline & $\begin{array}{l}\text { Religious } \\
\text { Zionist }\end{array}$ & .089 & $\begin{array}{c}5649.18 \\
4\end{array}$ & .000 & 1 & 1.000 & 1.093 & .000 & b \\
\hline & $\begin{array}{l}\text { Haredi (ultra- } \\
\text { Orthodox) } \\
\end{array}$ & 18.037 & 1.274 & $\begin{array}{c}200.40 \\
0\end{array}$ & 1 & .000 & $\begin{array}{c}68147416 \\
.910 \\
\end{array}$ & $\begin{array}{c}5609077 \\
387\end{array}$ & $\begin{array}{c}82795620 \\
5.754 \\
\end{array}$ \\
\hline & Labor & $0^{c}$ & & & 0 & & & & \\
\hline \multirow{4}{*}{$\begin{array}{l}\text { so-so, in the } \\
\text { middle }\end{array}$} & Intercept & -.149 & 182 & .668 & 1 & .414 & & & \\
\hline & Revisionist & 2.318 & .558 & 17.233 & 1 & .000 & 10.156 & 3.400 & 30.342 \\
\hline & $\begin{array}{l}\text { Religious } \\
\text { Zionist }\end{array}$ & 18.263 & $\begin{array}{c}4289.98 \\
6\end{array}$ & .000 & 1 & .997 & $\begin{array}{c}85447029 \\
.734\end{array}$ & .000 & $\mathrm{~b}$ \\
\hline & $\begin{array}{l}\text { Haredi (ultra- } \\
\text { Orthodox) } \\
\text { Labor }\end{array}$ & $\begin{array}{c}19.099 \\
0^{c}\end{array}$ & 1.063 & $\begin{array}{c}323.11 \\
6\end{array}$ & $\begin{array}{l}1 \\
0\end{array}$ & .000 & $\begin{array}{c}19714074 \\
1.776\end{array}$ & $\begin{array}{c}24566874 \\
.754\end{array}$ & $\begin{array}{c}15819868 \\
19.968\end{array}$ \\
\hline \multirow{5}{*}{$\begin{array}{l}\text { somewhat } \\
\text { against it }\end{array}$} & Intercept & -1.776 & .326 & 29.691 & 1 & .000 & & & \\
\hline & Revisionist & 3.435 & .636 & 29.208 & 1 & .000 & 31.023 & 8.927 & 107.809 \\
\hline & $\begin{array}{l}\text { Religious } \\
\text { Zionist }\end{array}$ & 20.702 & $\begin{array}{c}4289.98 \\
6\end{array}$ & .000 & 1 & .996 & $\begin{array}{c}97875688 \\
6.038\end{array}$ & .000 & \\
\hline & Haredi (ultra- & 20.727 & 1.096 & 357.40 & 1 & .000 & $\begin{array}{c}10036255 \\
94496\end{array}$ & $\begin{array}{c}11704223 \\
3603\end{array}$ & $\begin{array}{c}86059903 \\
58531\end{array}$ \\
\hline & $\begin{array}{l}\text { Orthodox) } \\
\text { Labor }\end{array}$ & $0^{\mathrm{c}}$ & & & 0 & & & & \\
\hline \multirow{5}{*}{$\begin{array}{l}\text { very against } \\
\text { it }\end{array}$} & Intercept & -3.076 & .591 & 27.129 & 1 & .000 & & & \\
\hline & Revisionist & 4.329 & .819 & 27.958 & 1 & .000 & 75.833 & 15.242 & 377.290 \\
\hline & $\begin{array}{l}\text { Religious } \\
\text { Zionist }\end{array}$ & 21.413 & $\begin{array}{c}4289.98 \\
6\end{array}$ & .000 & 1 & .996 & $\begin{array}{c}19937640 \\
27.100\end{array}$ & .000 & $\mathrm{~b}$ \\
\hline & Haredi (ultra- & 122 942 & & 459.92 & 1 & & 91999012 & 11302609 & 74883752 \\
\hline & $\begin{array}{l}\text { Orthodox) } \\
\text { Labor }\end{array}$ & $\left.\right|^{22.942} 0^{c}$ & 1.070 & 3 & 1 & .000 & 82.805 & 84.116 & 339.331 \\
\hline \multirow{5}{*}{$\begin{array}{l}\text { Do not read: } \\
\text { Do not } \\
\text { know/No } \\
\text { opinion }\end{array}$} & Intercept & -1.977 & .356 & 30.904 & 1 & .000 & & & \\
\hline & Revisionist & 2.200 & .759 & 8.398 & 1 & .004 & 9.028 & 2.038 & 39.983 \\
\hline & $\begin{array}{l}\text { Religious } \\
\text { Zionist }\end{array}$ & .516 & $\begin{array}{c}9887.92 \\
8\end{array}$ & .000 & 1 & 1.000 & 1.675 & .000 & b \\
\hline & Haredi (ultra- & 20.928 & .000 & & 1 & & 12266535 & 12266535 & 12266535 \\
\hline & Labor & $0^{c}$ & & & 0 & & & & \\
\hline
\end{tabular}


January 1996

Crosstabs

Movement * What is your opinion in regards to the agreement signed at Oslo between Israel and the PLO (Declaration of Principles)? Crosstabulation

\begin{tabular}{|c|c|c|c|c|c|c|c|}
\hline & \multicolumn{5}{|c|}{$\begin{array}{l}\text { What is your opinion in regards to the agreement signed at } \\
\text { Oslo between Israel and the PLO (Declaration of Principles)? }\end{array}$} \\
\hline & & & very for it & $\begin{array}{l}\text { somewhat } \\
\text { for it }\end{array}$ & $\begin{array}{l}\text { so-so, in } \\
\text { the middle }\end{array}$ & $\begin{array}{l}\text { somewhat } \\
\text { against it }\end{array}$ & $\begin{array}{l}\text { very } \\
\text { against it }\end{array}$ \\
\hline \multirow{4}{*}{$\begin{array}{l}\text { Moveme } \\
\text { nt }\end{array}$} & Revisionist & $\begin{array}{c}\text { Count } \\
\% \text { within } \\
\text { Movement }\end{array}$ & $\begin{array}{c}4 \\
3.6 \%\end{array}$ & $\begin{array}{c}15 \\
13.5 \%\end{array}$ & $\begin{array}{c}38 \\
34.2 \%\end{array}$ & $\begin{array}{c}24 \\
21.6 \%\end{array}$ & $\begin{array}{c}19 \\
17.1 \%\end{array}$ \\
\hline & $\begin{array}{l}\text { Religious } \\
\text { Zionist }\end{array}$ & $\begin{array}{c}\text { Count } \\
\% \text { within } \\
\text { Movement }\end{array}$ & $\begin{array}{c}0 \\
0.0 \%\end{array}$ & $\begin{array}{c}0 \\
0.0 \%\end{array}$ & $\begin{array}{c}5 \\
26.3 \%\end{array}$ & $\begin{array}{c}5 \\
26.3 \%\end{array}$ & $\begin{array}{c}7 \\
36.8 \%\end{array}$ \\
\hline & $\begin{array}{l}\text { Haredi (Ultra } \\
\text { Orthodox) }\end{array}$ & $\begin{array}{c}\text { Count } \\
\% \text { within } \\
\text { Movement }\end{array}$ & $\begin{array}{c}0 \\
0.0 \%\end{array}$ & $\begin{array}{c}1 \\
5.3 \%\end{array}$ & $\begin{array}{c}5 \\
26.3 \%\end{array}$ & $\begin{array}{c}5 \\
26.3 \%\end{array}$ & $\begin{array}{c}5 \\
26.3 \%\end{array}$ \\
\hline & Labor & $\begin{array}{c}\text { Count } \\
\% \text { within } \\
\text { Movement }\end{array}$ & $\begin{array}{c}58 \\
26.7 \%\end{array}$ & $\begin{array}{c}66 \\
30.4 \%\end{array}$ & $\begin{array}{c}55 \\
25.3 \%\end{array}$ & $\begin{array}{c}19 \\
8.8 \%\end{array}$ & $\begin{array}{c}11 \\
5.1 \%\end{array}$ \\
\hline \multicolumn{2}{|r|}{ Total } & $\begin{array}{c}\text { Count } \\
\% \text { within } \\
\text { Movement }\end{array}$ & $\begin{array}{c}62 \\
16.9 \%\end{array}$ & $\begin{array}{c}82 \\
22.4 \%\end{array}$ & $\begin{array}{c}103 \\
28.1 \%\end{array}$ & $\begin{array}{c}53 \\
14.5 \%\end{array}$ & $\begin{array}{c}42 \\
11.5 \%\end{array}$ \\
\hline
\end{tabular}




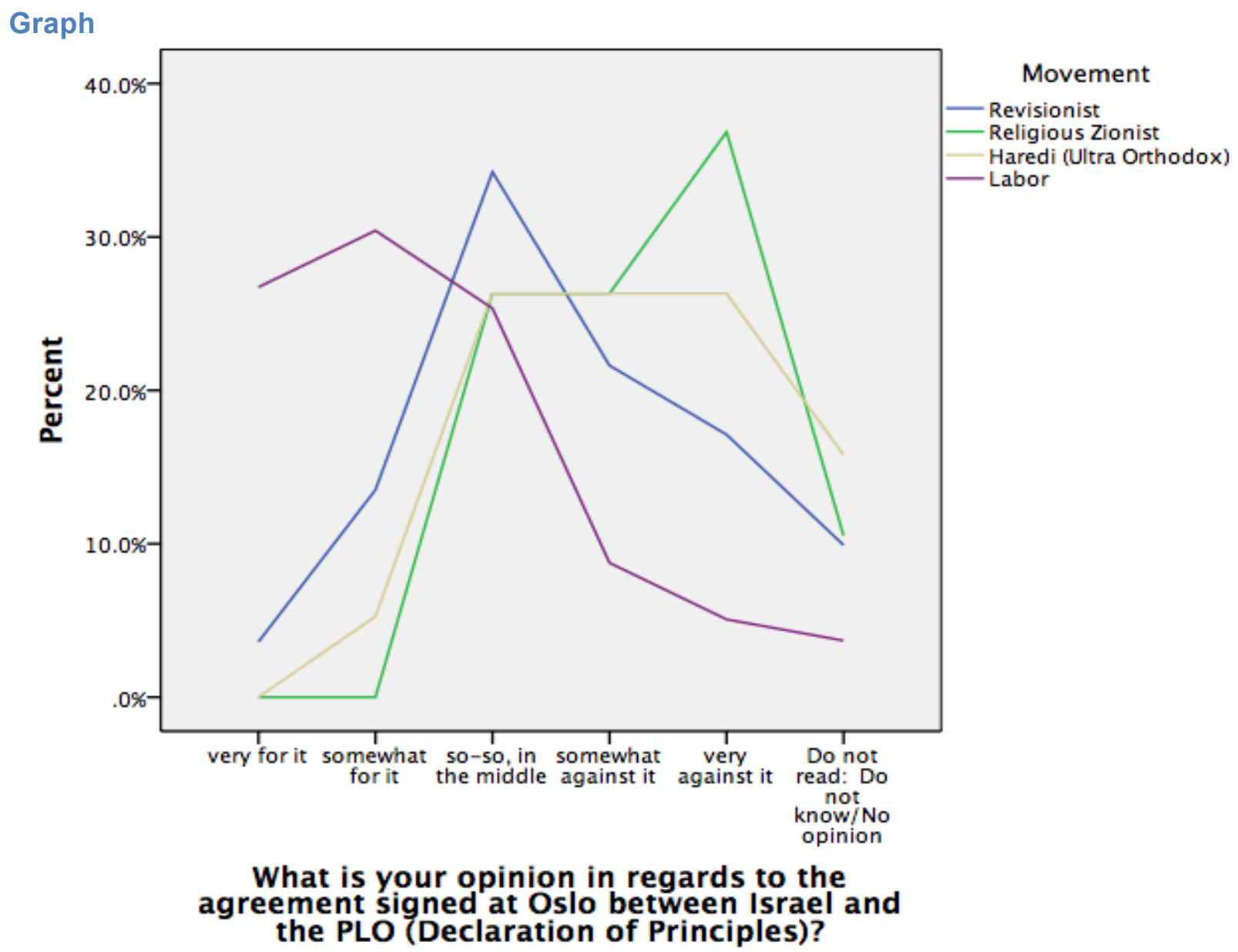

Nominal Regression

Model Fitting Information

\begin{tabular}{|c|c|c|c|c|}
\hline \multirow[b]{2}{*}{ Model } & \multirow{2}{*}{$\begin{array}{c}\text { Model Fitting } \\
\text { Criteria } \\
-2 \text { Log } \\
\text { Likelihood }\end{array}$} & \multicolumn{3}{|c|}{ Likelihood Ratio Tests } \\
\hline & & Chi-Square & $\mathrm{df}$ & Sig. \\
\hline $\begin{array}{l}\text { Intercept Only } \\
\text { Final }\end{array}$ & $\begin{array}{r}169.392 \\
63.594\end{array}$ & 105.799 & 15 & .000 \\
\hline
\end{tabular}

Goodness-of-Fit

\begin{tabular}{|l|r|r|r|}
\hline & Chi-Square & df & Sig. \\
\hline Pearson & .000 & 0 & \\
Deviance & .000 & 0 &. \\
\hline
\end{tabular}

\section{Likelihood Ratio Tests}

\begin{tabular}{|l|r|r|r|r|}
\hline \multirow{2}{*}{} & \multicolumn{1}{|c|}{$\begin{array}{c}\text { Model Fitting } \\
\text { Criteria }\end{array}$} & \multicolumn{3}{|c|}{ Likelihood Ratio Tests } \\
\cline { 2 - 6 } & $\begin{array}{c}-2 \text { Log } \\
\text { Likelihood of } \\
\text { Reduced Model }\end{array}$ & Chi-Square & df & \multicolumn{1}{c|}{ Sig. } \\
\hline Intercept & $63.594^{\mathrm{a}}$ & .000 & 0 & .000 \\
\hline
\end{tabular}


Parameter Estimates

\begin{tabular}{|c|c|c|c|c|c|c|c|c|c|}
\hline \multirow{2}{*}{\multicolumn{2}{|c|}{$\begin{array}{l}\text { What is your opinion in } \\
\text { regards to the agreement } \\
\text { signed at Oslo between } \\
\text { Israel and the PLO } \\
\text { (Declaration of } \\
\text { Principles)? }{ }^{\mathrm{a}}\end{array}$}} & \multirow[b]{2}{*}{ B } & \multirow[b]{2}{*}{$\begin{array}{l}\text { Std. } \\
\text { Error }\end{array}$} & \multirow[b]{2}{*}{ Wald } & \multirow[b]{2}{*}{$\mathrm{df}$} & \multirow[b]{2}{*}{ Sig. } & \multirow[b]{2}{*}{$\operatorname{Exp}(B)$} & \multicolumn{2}{|c|}{$\begin{array}{l}\text { 95\% Confidence } \\
\text { Interval for } \operatorname{Exp}(\mathrm{B})\end{array}$} \\
\hline & & & & & & & & $\begin{array}{l}\text { Lower } \\
\text { Bound }\end{array}$ & $\begin{array}{l}\text { Upper } \\
\text { Bound }\end{array}$ \\
\hline \multirow{5}{*}{$\begin{array}{l}\text { somewhat } \\
\text { for it }\end{array}$} & Intercept & .129 & .180 & .515 & 1 & .473 & & & \\
\hline & Revisionist & 1.193 & .591 & 4.074 & 1 & .044 & 3.295 & 1.035 & 10.491 \\
\hline & $\begin{array}{l}\text { Religious } \\
\text { Zionist }\end{array}$ & 150 & $\begin{array}{c}9781.44 \\
9\end{array}$ & .000 & 1 & 1.000 & 1.162 & .000 & \\
\hline & $\begin{array}{l}\text { Haredi (ultra- } \\
\text { Orthodox) } \\
\end{array}$ & 18.123 & 1.214 & $\begin{array}{c}222.90 \\
5\end{array}$ & 1 & .000 & $\begin{array}{c}74263312 \\
.082 \\
\end{array}$ & $\begin{array}{c}6878990 \\
823\end{array}$ & $\begin{array}{c}80172218 \\
0.407\end{array}$ \\
\hline & Labor & $0^{c}$ & & & 0 & & & & \\
\hline \multirow{3}{*}{$\begin{array}{l}\text { so-so, in the } \\
\text { middle }\end{array}$} & Intercept & -.053 & .188 & .080 & 1 & .778 & & & \\
\hline & $\begin{array}{c}\text { Revisionist } \\
\text { Religious } \\
\text { Zionist }\end{array}$ & $\begin{array}{l}2.304 \\
20.319\end{array}$ & $\begin{array}{l}.558 \\
.918\end{array}$ & $\begin{array}{c}17.034 \\
489.62 \\
9\end{array}$ & $\begin{array}{l}1 \\
1\end{array}$ & $\begin{array}{l}.000 \\
.000\end{array}$ & $\begin{array}{c}10.018 \\
66721198 \\
9.321\end{array}$ & $\begin{array}{c}3.354 \\
11031856 \\
4.629\end{array}$ & $\begin{array}{c}29.926 \\
40353302 \\
29.224\end{array}$ \\
\hline & $\begin{array}{c}\text { Haredi (ultra- } \\
\text { Orthodox) } \\
\text { Labor }\end{array}$ & $\begin{array}{c}19.915 \\
0^{c}\end{array}$ & .823 & $\begin{array}{c}586.24 \\
4\end{array}$ & $\begin{array}{l}1 \\
0\end{array}$ & .000 & $\begin{array}{c}44557987 \\
2.489\end{array}$ & $\begin{array}{c}88880745 \\
.920\end{array}$ & $\begin{array}{c}22337956 \\
40.586\end{array}$ \\
\hline \multirow{5}{*}{$\begin{array}{l}\text { somewhat } \\
\text { against it }\end{array}$} & Intercept & -1.116 & .264 & 17.825 & 1 & .000 & & & \\
\hline & Revisionist & 2.908 & .601 & 23.386 & 1 & .000 & 18.316 & 5.637 & 59.517 \\
\hline & $\begin{array}{c}\text { Religious } \\
\text { Zionist }\end{array}$ & 21.382 & .937 & $\begin{array}{c}520.91 \\
2\end{array}$ & 1 & .000 & $\begin{array}{c}19314031 \\
26.981\end{array}$ & $\begin{array}{c}30792883 \\
7.400\end{array}$ & $\begin{array}{c}12114221 \\
163.613\end{array}$ \\
\hline & Haredi (ultra- & 20978 & 843 & 618.97 & 1 & 000 & 12898364 & 24706559 & 67337506 \\
\hline & $\begin{array}{l}\text { Orthodox) } \\
\text { Labor }\end{array}$ & $0^{20.910}$ & .043 & 2 & $\begin{array}{l}1 \\
0\end{array}$ & .000 & 72.995 & 8.595 & 17.375 \\
\hline \multirow{5}{*}{$\begin{array}{c}\text { very against } \\
\text { it }\end{array}$} & Intercept & -1.663 & .329 & 25.558 & 1 & .000 & & & \\
\hline & Revisionist & 3.221 & .641 & 25.251 & 1 & .000 & 25.045 & 7.131 & 87.960 \\
\hline & $\begin{array}{l}\text { Religious } \\
\text { Zionist }\end{array}$ & 22.265 & .927 & $\begin{array}{c}577.23 \\
4\end{array}$ & 1 & .000 & $\begin{array}{c}46704839 \\
25.246\end{array}$ & $\begin{array}{c}75955017 \\
7.870\end{array}$ & $\begin{array}{c}28718866 \\
417.962\end{array}$ \\
\hline & Haredi (ultra- & & 86 & 618.35 & 1 & & 22278993 & 40841887 & 12153051 \\
\hline & $\begin{array}{l}\text { Orthodox) } \\
\text { Labor }\end{array}$ & $\begin{array}{c}21.024 \\
0^{c}\end{array}$ & .000 & 3 & 0 & .000 & 62.446 & 8.420 & 270.265 \\
\hline \multirow{5}{*}{$\begin{array}{l}\text { Do not read: } \\
\text { Do not } \\
\text { know/No } \\
\text { opinion }\end{array}$} & Intercept & -1.981 & .377 & 27.589 & 1 & .000 & & & \\
\hline & Revisionist & 2.993 & .695 & 18.536 & 1 & .000 & 19.937 & 5.105 & 77.863 \\
\hline & $\begin{array}{l}\text { Religious } \\
\text { Zionist }\end{array}$ & 21.330 & .000 & & 1 & . & $\begin{array}{c}18348329 \\
70.632\end{array}$ & $\begin{array}{c}18348329 \\
70.632\end{array}$ & $\begin{array}{c}18348329 \\
70.632\end{array}$ \\
\hline & Haredi (ultra- & 21.332 & .000 & & 1 & & 18380169 & 18380169 & 18380169 \\
\hline & $\begin{array}{c}\text { Orthodox) } \\
\text { Labor }\end{array}$ & $0^{c}$ & .000 & & 0 & & 74 & 74.018 & 74.018 \\
\hline
\end{tabular}


July 1996

Crosstabs

Movement * What is your opinion in regards to the agreement signed at Oslo between Israel and the PLO (Declaration of Principles)? Crosstabulation

\begin{tabular}{|c|c|c|c|c|c|c|c|}
\hline & \multicolumn{5}{|c|}{$\begin{array}{l}\text { What is your opinion in regards to the agreement signed at } \\
\text { Oslo between Israel and the PLO (Declaration of Principles)? }\end{array}$} \\
\hline & & & very for it & $\begin{array}{l}\text { somewhat } \\
\text { for it }\end{array}$ & $\begin{array}{l}\text { so-so, in } \\
\text { the middle }\end{array}$ & $\begin{array}{l}\text { somewhat } \\
\text { against it }\end{array}$ & $\begin{array}{l}\text { very } \\
\text { against it }\end{array}$ \\
\hline \multirow{4}{*}{$\begin{array}{l}\text { Moveme } \\
\text { nt }\end{array}$} & Revisionist & $\begin{array}{c}\text { Count } \\
\% \text { within } \\
\text { Movement }\end{array}$ & $\begin{array}{c}8 \\
6.1 \%\end{array}$ & $\begin{array}{c}20 \\
15.3 \%\end{array}$ & $\begin{array}{c}48 \\
36.6 \%\end{array}$ & $\begin{array}{c}14 \\
10.7 \%\end{array}$ & $\begin{array}{c}28 \\
21.4 \%\end{array}$ \\
\hline & $\begin{array}{l}\text { Religious } \\
\text { Zionist }\end{array}$ & $\begin{array}{c}\text { Count } \\
\% \text { within } \\
\text { Movement }\end{array}$ & $\begin{array}{c}3 \\
6.0 \%\end{array}$ & $\begin{array}{c}6 \\
12.0 \%\end{array}$ & $\begin{array}{c}11 \\
22.0 \%\end{array}$ & $\begin{array}{c}10 \\
20.0 \%\end{array}$ & $\begin{array}{c}15 \\
30.0 \%\end{array}$ \\
\hline & $\begin{array}{l}\text { Haredi (Ultra } \\
\text { Orthodox) }\end{array}$ & $\begin{array}{c}\text { Count } \\
\% \text { within } \\
\text { Movement }\end{array}$ & $\begin{array}{c}0 \\
0.0 \%\end{array}$ & $\begin{array}{c}4 \\
8.9 \%\end{array}$ & $\begin{array}{c}18 \\
40.0 \%\end{array}$ & $\begin{array}{c}5 \\
11.1 \%\end{array}$ & $\begin{array}{c}12 \\
26.7 \%\end{array}$ \\
\hline & Labor & $\begin{array}{c}\text { Count } \\
\% \text { within } \\
\text { Movement }\end{array}$ & $\begin{array}{c}40 \\
24.8 \%\end{array}$ & $\begin{array}{c}84 \\
52.2 \%\end{array}$ & $\begin{array}{c}29 \\
18.0 \%\end{array}$ & $\begin{array}{c}2 \\
1.2 \%\end{array}$ & $\begin{array}{c}1 \\
0.6 \%\end{array}$ \\
\hline \multicolumn{2}{|r|}{ Total } & $\begin{array}{c}\text { Count } \\
\% \text { within } \\
\text { Movement }\end{array}$ & $\begin{array}{c}51 \\
13.2 \%\end{array}$ & $\begin{array}{c}114 \\
29.5 \%\end{array}$ & $\begin{array}{c}106 \\
27.4 \%\end{array}$ & $\begin{array}{c}31 \\
8.0 \%\end{array}$ & $\begin{array}{c}56 \\
14.5 \%\end{array}$ \\
\hline
\end{tabular}




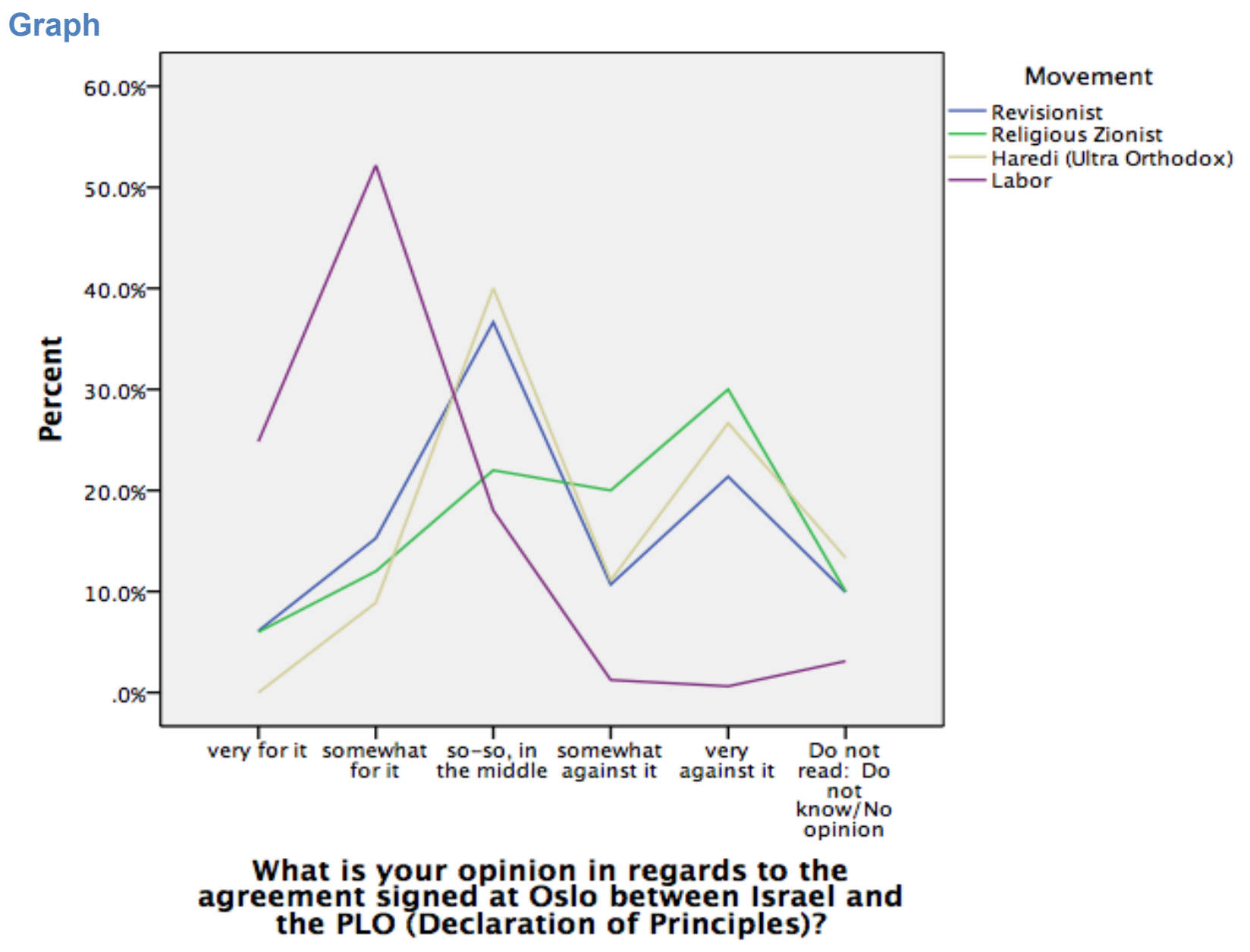

Nominal Regression

Model Fitting Information

\begin{tabular}{|l|r|r|r|r|}
\hline \multirow{2}{*}{ Model } & \multicolumn{1}{|c|}{$\begin{array}{c}\text { Model Fitting } \\
\text { Criteria }\end{array}$} & \multicolumn{3}{|c|}{ Likelihood Ratio Tests } \\
\cline { 2 - 5 } & $\begin{array}{c}-2 \text { Log } \\
\text { Likelihood }\end{array}$ & Chi-Square & df & \multicolumn{1}{c|}{ Sig. } \\
\hline Intercept Only & $\begin{array}{r}249.313 \\
71.217\end{array}$ & 178.097 & 15 & .000 \\
\hline
\end{tabular}

Goodness-of-Fit

\begin{tabular}{|l|r|r|r|}
\hline & Chi-Square & df & Sig. \\
\hline Pearson & .000 & 0 & \\
Deviance & .000 & 0 & \\
\hline
\end{tabular}

Likelihood Ratio Tests

\begin{tabular}{|l|r|r|r|r|}
\hline \multirow{2}{*}{} & \multicolumn{1}{|c|}{$\begin{array}{c}\text { Model Fitting } \\
\text { Criteria }\end{array}$} & \multicolumn{3}{|c|}{ Likelihood Ratio Tests } \\
\cline { 2 - 6 } & $\begin{array}{c}\text {-2 Log } \\
\text { Likelihood of } \\
\text { Reduced Model }\end{array}$ & Chi-Square & df & \multicolumn{1}{c|}{ Sig. } \\
\hline Intercept & $71.217^{\text {a }}$ & .000 & 0 & .000 \\
Movement & 249.313 & 178.097 & 15 & .000 \\
\hline
\end{tabular}


Parameter Estimates

\begin{tabular}{|c|c|c|c|c|c|c|c|c|c|}
\hline \multirow{2}{*}{\multicolumn{2}{|c|}{$\begin{array}{l}\text { What is your opinion in } \\
\text { regards to the agreement } \\
\text { signed at Oslo between } \\
\text { Israel and the PLO } \\
\text { (Declaration of } \\
\text { Principles)? }^{\mathrm{a}}\end{array}$}} & \multirow[b]{2}{*}{ B } & \multirow[b]{2}{*}{$\begin{array}{l}\text { Std. } \\
\text { Error }\end{array}$} & \multirow[b]{2}{*}{ Wald } & \multirow[b]{2}{*}{$d f$} & \multirow[b]{2}{*}{ Sig. } & \multirow[b]{2}{*}{$\operatorname{Exp}(B)$} & \multicolumn{2}{|c|}{$\begin{array}{c}95 \% \text { Confidence } \\
\text { Interval for } \operatorname{Exp}(B)\end{array}$} \\
\hline & & & & & & & & $\begin{array}{l}\text { Lower } \\
\text { Bound }\end{array}$ & $\begin{array}{l}\text { Upper } \\
\text { Bound }\end{array}$ \\
\hline \multirow{4}{*}{$\begin{array}{l}\text { somewhat } \\
\text { for it }\end{array}$} & $\begin{array}{c}\text { Intercept } \\
\text { Revisionist }\end{array}$ & $\begin{array}{l}.742 \\
.174 \\
\end{array}$ & $\begin{array}{l}.192 \\
.460 \\
\end{array}$ & $\begin{array}{c}14.916 \\
.143 \\
\end{array}$ & $\begin{array}{l}1 \\
1 \\
\end{array}$ & $\begin{array}{l}.000 \\
.705 \\
\end{array}$ & 1.190 & .483 & 2.935 \\
\hline & $\begin{array}{l}\text { Religious } \\
\text { Zionist }\end{array}$ & -.049 & .733 & .004 & 1 & .947 & .952 & .227 & 4.004 \\
\hline & $\begin{array}{l}\text { Haredi (ultra- } \\
\text { Orthodox) }\end{array}$ & 18.116 & .793 & $\begin{array}{c}522.10 \\
9\end{array}$ & 1 & .000 & $\begin{array}{c}73721688 . \\
095\end{array}$ & $\begin{array}{c}15586242 . \\
803\end{array}$ & $\begin{array}{c}34869771 \\
7.870\end{array}$ \\
\hline & Labor & $0^{\mathrm{b}}$ & & & 0 & & & & \\
\hline \multirow{4}{*}{$\begin{array}{l}\text { so-so, in the } \\
\text { middle }\end{array}$} & Intercept & -.322 & .244 & 1.739 & 1 & .187 & & & \\
\hline & Revisionist & 2.113 & .453 & 21.753 & 1 & .000 & 8.276 & 3.405 & 20.114 \\
\hline & $\begin{array}{l}\text { Religious } \\
\text { Zionist } \\
\end{array}$ & 1.621 & .696 & 5.431 & 1 & .020 & 5.057 & 1.294 & 19.767 \\
\hline & $\begin{array}{l}\text { Haredi (ultra- } \\
\text { Orthodox) } \\
\text { Labor }\end{array}$ & $\begin{array}{c}20.683 \\
0^{\mathrm{b}}\end{array}$ & .676 & $\begin{array}{c}936.71 \\
7\end{array}$ & $\begin{array}{l}1 \\
0 \\
\end{array}$ & .000 & $\begin{array}{c}96092407 \\
2.411\end{array}$ & $\begin{array}{c}25553329 \\
0.552\end{array}$ & $\begin{array}{c}36135216 \\
31.341\end{array}$ \\
\hline \multirow{5}{*}{$\begin{array}{l}\text { somewhat } \\
\text { against it }\end{array}$} & Intercept & -2.996 & .725 & 17.094 & 1 & .000 & & & \\
\hline & Revisionist & 3.555 & .849 & 17.521 & 1 & .000 & 35.000 & 6.623 & 184.949 \\
\hline & $\begin{array}{l}\text { Religious } \\
\text { Zionist }\end{array}$ & 4.200 & .979 & 18.404 & 1 & .000 & 66.667 & 9.787 & 454.138 \\
\hline & $\begin{array}{l}\text { Haredi (ultra- } \\
\text { Orthodox) }\end{array}$ & 22.077 & 1.033 & $\begin{array}{c}456.91 \\
6\end{array}$ & 1 & .000 & $\begin{array}{c}38703886 \\
24.987\end{array}$ & $\begin{array}{c}51125480 \\
4.548\end{array}$ & $\begin{array}{c}29300278 \\
403.610\end{array}$ \\
\hline & Labor & $0^{\mathrm{b}}$ & & & 0 & & & & \\
\hline \multirow{5}{*}{$\begin{array}{l}\text { very against } \\
\text { it }\end{array}$} & Intercept & -3.689 & 1.012 & 13.276 & 1 & .000 & & & \\
\hline & Revisionist & 4.942 & 1.089 & 20.595 & 1 & .000 & 140.000 & 16.567 & 1183.057 \\
\hline & $\begin{array}{l}\text { Religious } \\
\text { Zionist }\end{array}$ & 5.298 & 1.194 & 19.700 & 1 & .000 & 200.000 & 19.272 & 2075.573 \\
\hline & Haredi (ultra- & 23.645 & 1.204 & 385.58 & 1 & 000 & 18577865 & 17539347 & 19677875 \\
\hline & $\begin{array}{l}\text { Orthodox) } \\
\text { Labor }\end{array}$ & $\begin{array}{c}20.040 \\
0^{\mathrm{b}}\end{array}$ & & 4 & 0 & & 399.842 & 16.422 & 0989.466 \\
\hline \multirow{5}{*}{$\begin{array}{l}\text { Do not read: } \\
\text { Do not } \\
\text { know/No } \\
\text { opinion }\end{array}$} & Intercept & -2.079 & .474 & 19.218 & 1 & .000 & & & \\
\hline & Revisionist & 2.565 & .653 & 15.410 & 1 & .000 & 13.000 & 3.612 & 46.786 \\
\hline & $\begin{array}{l}\text { Religious } \\
\text { Zionist }\end{array}$ & 2.590 & .871 & 8.848 & 1 & .003 & 13.333 & 2.419 & 73.483 \\
\hline & $\begin{array}{c}\text { Haredi (ultra- } \\
\text { Orthodox) }\end{array}$ & 21.343 & .000 & . & 1 & & $\begin{array}{c}18577865 \\
39994\end{array}$ & $\begin{array}{c}18577865 \\
39994\end{array}$ & $\begin{array}{c}18577865 \\
39994\end{array}$ \\
\hline & Labor & & & & 0 & & & & \\
\hline
\end{tabular}




\section{PM Elections Crosstabs}

Who did you vote for, for PM two months ago? * What is your opinion in regards to the agreement signed at Oslo between Israel and the PLO (Declaration of Principles)? Crosstabulation

\begin{tabular}{|c|c|c|c|c|c|c|c|c|c|}
\hline & \multicolumn{6}{|c|}{$\begin{array}{c}\text { What is your opinion in regards to the agreement signed at } \\
\text { Oslo between Israel and the PLO (Declaration of } \\
\text { Principles)? }\end{array}$} & \multirow[b]{2}{*}{ Total } \\
\hline & & & $\begin{array}{c}\text { very for } \\
\text { it }\end{array}$ & $\begin{array}{l}\text { somewh } \\
\text { at for it }\end{array}$ & $\begin{array}{l}\text { so-so, in } \\
\text { the } \\
\text { middle }\end{array}$ & $\begin{array}{l}\text { somewh } \\
\text { at } \\
\text { against it }\end{array}$ & $\begin{array}{c}\text { very } \\
\text { against it }\end{array}$ & $\begin{array}{l}\text { Do not } \\
\text { read: } \\
\text { Do not } \\
\text { know/No } \\
\text { opinion }\end{array}$ & \\
\hline \multirow{6}{*}{$\begin{array}{l}\text { Who did } \\
\text { you vote } \\
\text { for, for PM } \\
\text { two months } \\
\text { ago? }\end{array}$} & $\begin{array}{c}\text { Bibi } \\
\text { Netanyahu }\end{array}$ & $\begin{array}{c}\text { Count } \\
\% \text { within } \\
\text { Who did } \\
\text { you vote } \\
\text { for, for PM } \\
\text { two months } \\
\text { ago? }\end{array}$ & $5.3 \%$ & $14.2 \%$ & $32.4 \%$ & $13.8 \%$ & $23.9 \%$ & $10.5 \%$ & $\begin{array}{c}247 \\
100.0 \\
\%\end{array}$ \\
\hline & $\begin{array}{l}\text { Shimon } \\
\text { Peres }\end{array}$ & $\begin{array}{c}\text { Count } \\
\% \text { within } \\
\text { Who did } \\
\text { you vote } \\
\text { for, for PM } \\
\text { two months } \\
\text { ago? }\end{array}$ & $22.9 \%$ & $52.0 \%$ & $18.3 \%$ & $1.1 \%$ & $1.7 \%$ & $4.0 \%$ & $\begin{array}{c}175 \\
\\
100.0 \\
\%\end{array}$ \\
\hline & & Count & 0 & 0 & 0 & 1 & 0 & 0 & 1 \\
\hline & $\begin{array}{l}\text { Do not } \\
\text { read: } \\
\text { neither/l } \\
\text { would not } \\
\text { vote }\end{array}$ & $\begin{array}{l}\text { \% within } \\
\text { Who did } \\
\text { you vote } \\
\text { for, for PM } \\
\text { two months } \\
\text { ago? }\end{array}$ & $0.0 \%$ & $0.0 \%$ & $0.0 \%$ & $100.0 \%$ & $0.0 \%$ & $0.0 \%$ & $\begin{array}{c}100.0 \\
\%\end{array}$ \\
\hline & $\begin{array}{c}\text { Do not } \\
\text { read:have } \\
\text { not yet } \\
\text { decided }\end{array}$ & $\begin{array}{c}\text { Count } \\
\% \text { within } \\
\text { Who did } \\
\text { you vote } \\
\text { for, for PM } \\
\text { two months } \\
\text { ago? }\end{array}$ & $10.3 \%$ & $31.0 \%$ & $41.4 \%$ & $3.4 \%$ & $6.9 \%$ & $6.9 \%$ & $\begin{array}{c}29 \\
\\
100.0 \\
\%\end{array}$ \\
\hline & $\begin{array}{l}\text { Do not } \\
\text { read: } \\
\text { refuses to } \\
\text { answer }\end{array}$ & $\begin{array}{c}\text { Count } \\
\% \text { within } \\
\text { Who did } \\
\text { you vote } \\
\text { for, for PM } \\
\text { two months } \\
\text { ago? }\end{array}$ & $8.3 \%$ & $29.2 \%$ & $29.2 \%$ & $12.5 \%$ & $12.5 \%$ & $8.3 \%$ & $\begin{array}{c}48 \\
\\
100.0 \\
\%\end{array}$ \\
\hline Tot & tal & $\begin{array}{c}\text { Count } \\
\% \text { within } \\
\text { Who did } \\
\text { you vote } \\
\text { for, for PM } \\
\text { two months } \\
\text { ago? }\end{array}$ & $12.0 \%$ & $29.8 \%$ & $27.6 \%$ & $8.8 \%$ & $14.0 \%$ & $7.8 \%$ & $\begin{array}{c}100.0 \\
\%\end{array}$ \\
\hline
\end{tabular}




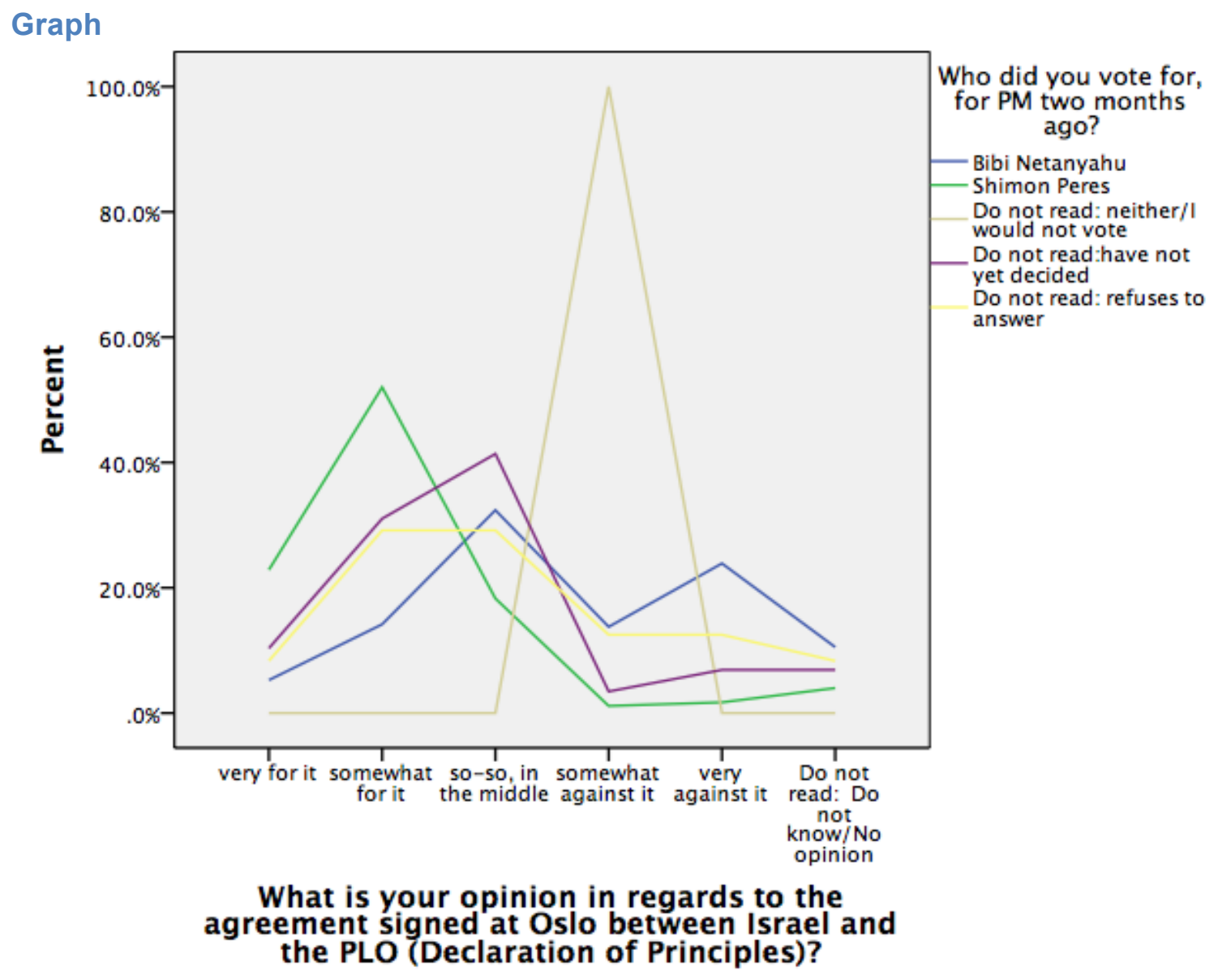




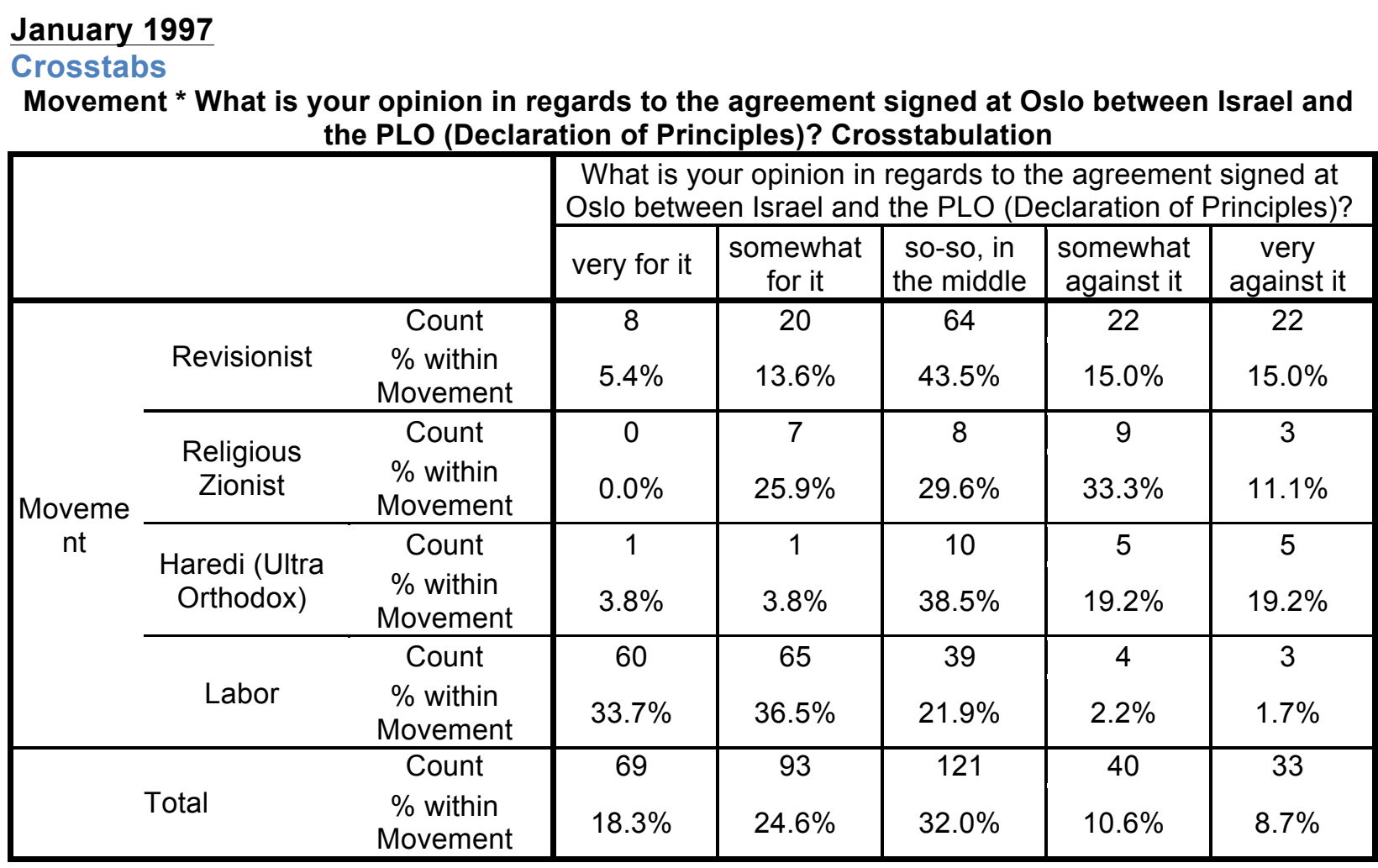




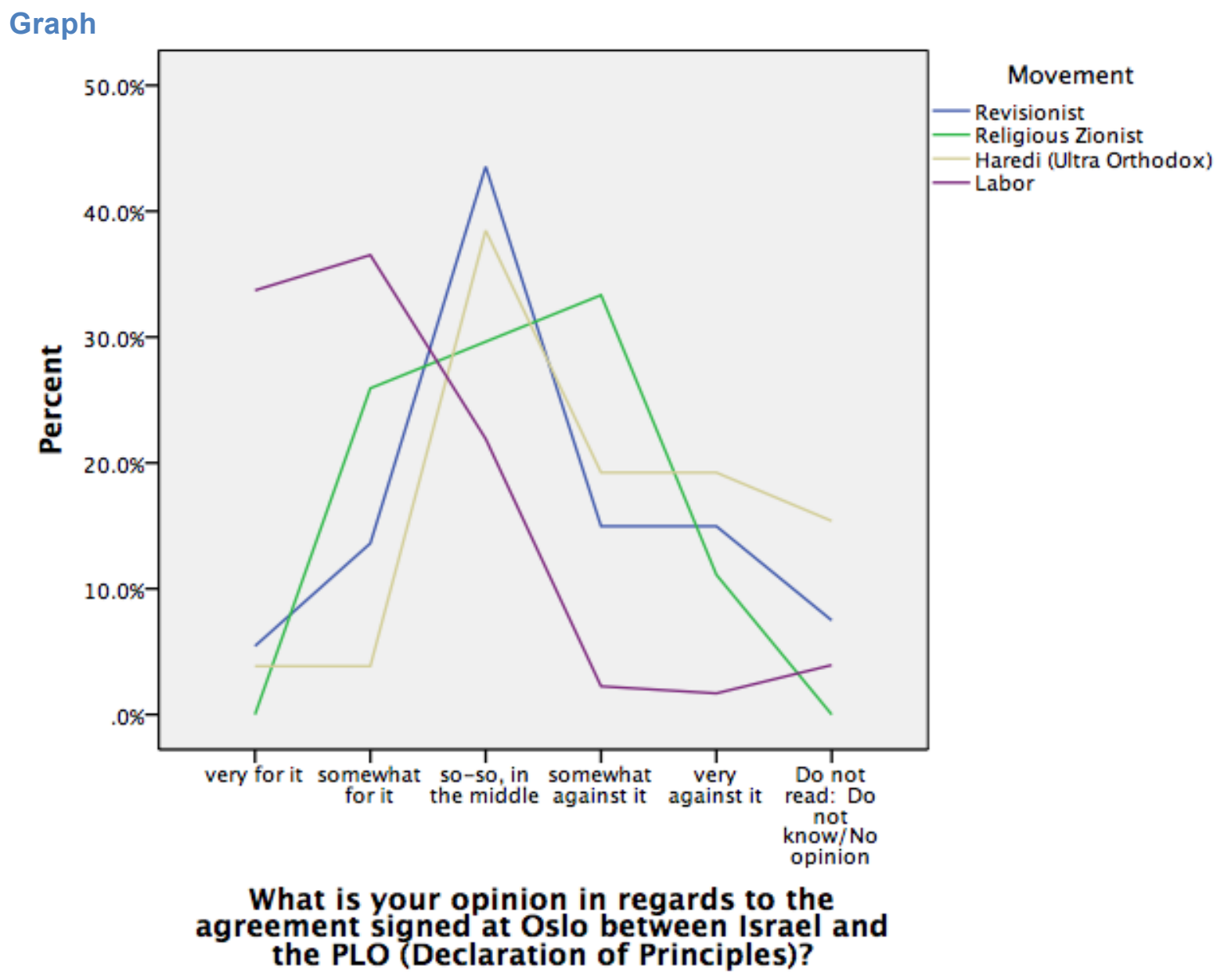

Nominal Regression

Model Fitting Information

\begin{tabular}{|l|r|r|r|r|}
\hline \multirow{2}{*}{} & \multicolumn{1}{|c|}{$\begin{array}{c}\text { Model Fitting } \\
\text { Criteria }\end{array}$} & \multicolumn{3}{|c|}{ Likelihood Ratio Tests } \\
\cline { 2 - 5 } & $\begin{array}{r}-2 \text { Log } \\
\text { Likelihood }\end{array}$ & Chi-Square & \multicolumn{1}{c|}{ df } & Sig. \\
\hline Model & $\begin{array}{r}214.015 \\
65.507\end{array}$ & 148.508 & 15 & .000 \\
\hline
\end{tabular}

Goodness-of-Fit

\begin{tabular}{|l|r|r|r|}
\hline & Chi-Square & \multicolumn{1}{|c|}{ df } & Sig. \\
\hline Pearson & .000 & 0 & \\
Deviance & .000 & 0 & \\
\hline
\end{tabular}

\section{Likelihood Ratio Tests}

\begin{tabular}{|l|r|r|r|r|}
\hline \multirow{2}{*}{} & \multicolumn{1}{|c|}{$\begin{array}{c}\text { Model Fitting } \\
\text { Criteria }\end{array}$} & \multicolumn{3}{|c|}{ Likelihood Ratio Tests } \\
\cline { 2 - 6 } & $\begin{array}{c}-2 \text { Log } \\
\text { Likelihood of } \\
\text { Reduced Model }\end{array}$ & Chi-Square & \multicolumn{1}{c|}{ df } & \multicolumn{1}{c|}{ Sig. } \\
\hline Intercept & $65.507^{2}$ & .000 & 0 & \\
Movement & 214.015 & 148.508 & 15 & .000 \\
\hline
\end{tabular}


Parameter Estimates

\begin{tabular}{|c|c|c|c|c|c|c|c|c|c|}
\hline \multirow{2}{*}{\multicolumn{2}{|c|}{$\begin{array}{l}\text { What is your opinion in } \\
\text { regards to the agreement } \\
\text { signed at Oslo between } \\
\text { Israel and the PLO } \\
\text { (Declaration of } \\
\text { Principles)? }\end{array}$}} & \multirow[b]{2}{*}{ B } & \multirow[b]{2}{*}{$\begin{array}{l}\text { Std. } \\
\text { Error }\end{array}$} & \multirow[b]{2}{*}{ Wald } & \multirow[b]{2}{*}{ df } & \multirow[b]{2}{*}{ Sig. } & \multirow[b]{2}{*}{$\operatorname{Exp}(B)$} & \multicolumn{2}{|c|}{$\begin{array}{l}\text { 95\% Confidence } \\
\text { Interval for } \operatorname{Exp}(B)\end{array}$} \\
\hline & & & & & & & & $\begin{array}{l}\text { Lower } \\
\text { Bound }\end{array}$ & $\begin{array}{l}\text { Upper } \\
\text { Bound }\end{array}$ \\
\hline \multirow{5}{*}{$\begin{array}{l}\text { somewhat } \\
\text { for it }\end{array}$} & Intercept & .080 & .179 & .200 & 1 & .655 & & & \\
\hline & Revisionist & .836 & .455 & 3.377 & 1 & .066 & 2.308 & .946 & 5.630 \\
\hline & $\begin{array}{c}\text { Religious } \\
\text { Zionist }\end{array}$ & 19.946 & .908 & $\begin{array}{c}482.27 \\
2\end{array}$ & 1 & .000 & $\begin{array}{l}45951319 \\
2.285\end{array}$ & $\begin{array}{c}77481621 . \\
774\end{array}$ & $\begin{array}{c}27251930 \\
07.710\end{array}$ \\
\hline & $\begin{array}{l}\text { Haredi (ultra- } \\
\text { Orthodox) }\end{array}$ & -.080 & 1.426 & .003 & 1 & .955 & .923 & .056 & 15.088 \\
\hline & Labor & $0^{\mathrm{b}}$ & & & 0 & & & & \\
\hline \multirow{3}{*}{$\begin{array}{l}\text { so-so, in the } \\
\text { middle }\end{array}$} & Intercept & -.431 & .206 & 4.386 & 1 & .036 & & & \\
\hline & $\begin{array}{c}\text { Revisionist } \\
\text { Religious } \\
\text { Zionist }\end{array}$ & \begin{tabular}{|l|}
2.510 \\
20.590
\end{tabular} & $\begin{array}{l}.428 \\
.904\end{array}$ & $\begin{array}{c}34.446 \\
518.71 \\
5\end{array}$ & $\begin{array}{l}1 \\
1\end{array}$ & $\begin{array}{l}.000 \\
.000\end{array}$ & $\begin{array}{c}12.308 \\
87526322 \\
3.400\end{array}$ & $\begin{array}{c}5.322 \\
14880218 \\
9.711\end{array}$ & $\begin{array}{c}28.460 \\
51483497 \\
09.929\end{array}$ \\
\hline & $\begin{array}{l}\text { Haredi (ultra- } \\
\text { Orthodox) } \\
\text { Labor }\end{array}$ & $\begin{array}{c}2.733 \\
0^{\mathrm{b}}\end{array}$ & 1.069 & 6.541 & 1 & .011 & 15.385 & 1.894 & 124.980 \\
\hline \multirow{5}{*}{$\begin{array}{l}\text { somewhat } \\
\text { against it }\end{array}$} & Intercept & -2.708 & .516 & 27.501 & 1 & .000 & & & \\
\hline & Revisionist & 3.720 & .661 & 31.652 & 1 & .000 & 41.250 & 11.289 & 150.729 \\
\hline & $\begin{array}{c}\text { Religious } \\
\text { Zionist }\end{array}$ & 22.985 & 1.014 & $\begin{array}{c}514.03 \\
5\end{array}$ & 1 & .000 & $\begin{array}{c}96005434 \\
81.668\end{array}$ & $\begin{array}{c}13162943 \\
38.763\end{array}$ & $\begin{array}{c}70022663 \\
190.998\end{array}$ \\
\hline & Haredi (ultra- & 4317 & & & 1 & & & & \\
\hline & Orthodox) & $\begin{array}{c}4.311 \\
0^{\mathrm{D}}\end{array}$ & & & 1 & .000 & 15.000 & 6.986 & 805.226 \\
\hline \multirow{6}{*}{$\begin{array}{l}\text { very against } \\
\text { it }\end{array}$} & Intercept & \begin{tabular}{|c|} 
\\
-2.996 \\
\end{tabular} & .592 & 25.641 & 1 & .000 & & & \\
\hline & Revisionist & 4.007 & .721 & 30.855 & 1 & .000 & 55.000 & 13.375 & 226.173 \\
\hline & $\begin{array}{l}\text { Religious } \\
\text { Zionist }\end{array}$ & 22.174 & .000 & & 1 & & $\begin{array}{c}42669082 \\
14.075\end{array}$ & $\begin{array}{c}42669082 \\
14.075\end{array}$ & $\begin{array}{c}42669082 \\
14.075\end{array}$ \\
\hline & Haredi (ultra- & 4605 & & & & & & & \\
\hline & Orthodox) & 4.605 & 1.245 & 13.682 & 1 & .000 & 100.000 & 8.715 & 1147.460 \\
\hline & Labor & $0^{\mathrm{b}}$ & & & 0 & & & & \\
\hline \multirow{5}{*}{$\begin{array}{l}\text { Do not read: } \\
\text { Do not } \\
\text { know/No } \\
\text { opinion }\end{array}$} & Intercept & \begin{tabular}{|l|}
-2.148 \\
\end{tabular} & .399 & 28.935 & 1 & .000 & & & \\
\hline & Revisionist & 2.467 & .613 & 16.209 & 1 & .000 & 11.786 & 3.547 & 39.166 \\
\hline & $\begin{array}{l}\text { Religious } \\
\text { Zionist }\end{array}$ & 1.005 & .000 & & 1 & & 2.733 & 2.733 & 2.733 \\
\hline & $\begin{array}{c}\text { Haredi (ultra- } \\
\text { Orthodox) }\end{array}$ & 3.535 & 1.187 & 8.864 & 1 & .003 & 34.286 & 3.346 & 351.308 \\
\hline & Labor & $0^{\mathrm{b}}$ & & & 0 & & & & \\
\hline
\end{tabular}


July 1997

Crosstabs

Movement * What is your opinion in regards to the agreement signed at Oslo between Israel and the PLO (Declaration of Principles)? Crosstabulation

\begin{tabular}{|c|c|c|c|c|c|c|c|}
\hline & \multicolumn{5}{|c|}{$\begin{array}{l}\text { What is your opinion in regards to the agreement signed at } \\
\text { Oslo between Israel and the PLO (Declaration of Principles)? }\end{array}$} \\
\hline & & & very for it & $\begin{array}{l}\text { somewhat } \\
\text { for it }\end{array}$ & $\begin{array}{l}\text { so-so, in } \\
\text { the middle }\end{array}$ & $\begin{array}{l}\text { somewhat } \\
\text { against it }\end{array}$ & $\begin{array}{l}\text { very } \\
\text { against it }\end{array}$ \\
\hline \multirow{4}{*}{$\begin{array}{l}\text { Moveme } \\
\text { nt }\end{array}$} & Revisionist & $\begin{array}{c}\text { Count } \\
\% \text { within } \\
\text { Movement }\end{array}$ & $\begin{array}{c}8 \\
4.5 \%\end{array}$ & $\begin{array}{c}28 \\
15.8 \%\end{array}$ & $\begin{array}{c}46 \\
26.0 \%\end{array}$ & $\begin{array}{c}38 \\
21.5 \%\end{array}$ & $\begin{array}{c}44 \\
24.9 \%\end{array}$ \\
\hline & $\begin{array}{l}\text { Religious } \\
\text { Zionist }\end{array}$ & $\begin{array}{c}\text { Count } \\
\% \text { within } \\
\text { Movement }\end{array}$ & $\begin{array}{c}1 \\
3.0 \%\end{array}$ & $\begin{array}{c}3 \\
9.1 \%\end{array}$ & $\begin{array}{c}6 \\
18.2 \%\end{array}$ & $\begin{array}{c}8 \\
24.2 \%\end{array}$ & $\begin{array}{c}13 \\
39.4 \%\end{array}$ \\
\hline & $\begin{array}{l}\text { Haredi (Ultra- } \\
\text { Orthodox) }\end{array}$ & $\begin{array}{c}\text { Count } \\
\% \text { within } \\
\text { Movement }\end{array}$ & $\begin{array}{c}0 \\
0.0 \%\end{array}$ & $\begin{array}{c}2 \\
8.0 \%\end{array}$ & $\begin{array}{c}7 \\
28.0 \%\end{array}$ & $\begin{array}{c}7 \\
28.0 \%\end{array}$ & $\begin{array}{c}5 \\
20.0 \%\end{array}$ \\
\hline & Labor & $\begin{array}{c}\text { Count } \\
\% \text { within } \\
\text { Movement }\end{array}$ & $\begin{array}{c}34 \\
20.2 \%\end{array}$ & $\begin{array}{c}84 \\
50.0 \%\end{array}$ & $\begin{array}{c}33 \\
19.6 \%\end{array}$ & $\begin{array}{c}6 \\
3.6 \%\end{array}$ & $\begin{array}{c}8 \\
4.8 \%\end{array}$ \\
\hline \multicolumn{2}{|r|}{ Total } & $\begin{array}{c}\text { Count } \\
\% \text { within } \\
\text { Movement }\end{array}$ & $\begin{array}{c}43 \\
10.7 \%\end{array}$ & $\begin{array}{c}117 \\
29.0 \%\end{array}$ & $\begin{array}{c}92 \\
22.8 \%\end{array}$ & $\begin{array}{c}59 \\
14.6 \%\end{array}$ & $\begin{array}{c}70 \\
17.4 \%\end{array}$ \\
\hline
\end{tabular}




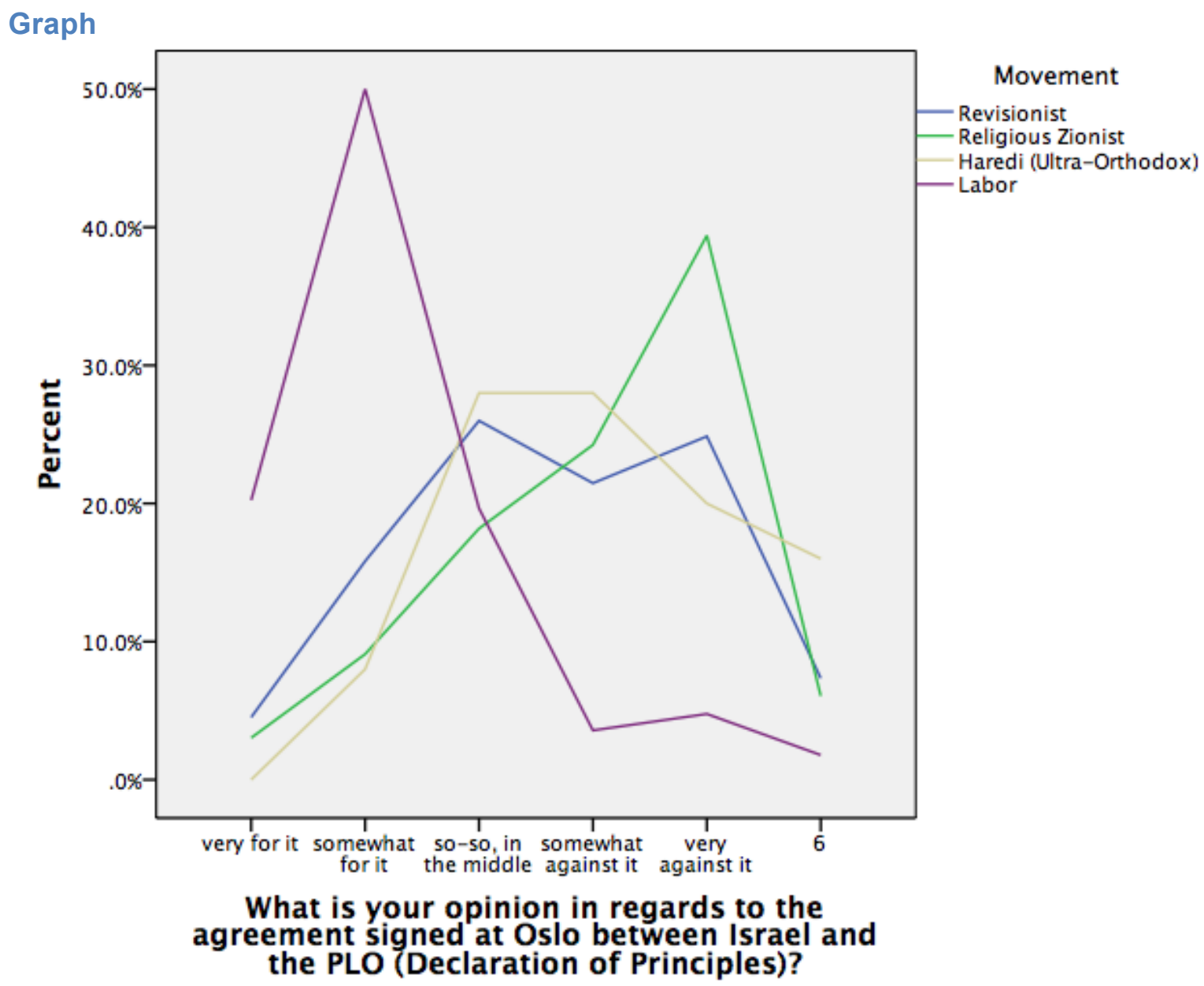

Nominal Regression

Model Fitting Information

\begin{tabular}{|l|r|r|r|r|}
\hline \multirow{2}{*}{ Model } & \multicolumn{1}{|c|}{$\begin{array}{c}\text { Model Fitting } \\
\text { Criteria }\end{array}$} & \multicolumn{3}{|c|}{ Likelihood Ratio Tests } \\
\cline { 2 - 5 } & $\begin{array}{c}-2 \text { Log } \\
\text { Likelihood }\end{array}$ & Chi-Square & \multicolumn{1}{c|}{ df } & \multicolumn{1}{|c|}{ Sig. } \\
\hline Intercept Only & $\begin{array}{r}217.573 \\
70.084\end{array}$ & 147.490 & 15 & .000 \\
\hline Final & &
\end{tabular}

Goodness-of-Fit

\begin{tabular}{|l|r|r|r|}
\hline & Chi-Square & df & Sig. \\
\hline Pearson & .000 & 0 & \\
Deviance & .000 & 0 & \\
\hline
\end{tabular}

\section{Likelihood Ratio Tests}

\begin{tabular}{|l|r|r|r|r|}
\hline \multirow{2}{*}{ Effect } & \multicolumn{1}{|c|}{$\begin{array}{c}\text { Model Fitting } \\
\text { Criteria }\end{array}$} & \multicolumn{3}{|c|}{ Likelihood Ratio Tests } \\
\cline { 2 - 6 } & $\begin{array}{c}\text {-2 Log } \\
\text { Likelihood of } \\
\text { Reduced Model }\end{array}$ & Chi-Square & df & \multicolumn{1}{c|}{ Sig. } \\
\hline Intercept & $70.084^{2}$ & .000 & 0 & \\
Movement & 217.573 & 147.490 & 15 & .000 \\
\hline
\end{tabular}


Parameter Estimates

\begin{tabular}{|c|c|c|c|c|c|c|c|c|c|}
\hline \multirow{2}{*}{\multicolumn{2}{|c|}{$\begin{array}{l}\text { What is your opinion in } \\
\text { regards to the agreement } \\
\text { signed at Oslo between } \\
\text { Israel and the PLO } \\
\text { (Declaration of } \\
\text { Principles)? }^{\mathrm{a}}\end{array}$}} & \multirow[b]{2}{*}{ B } & \multirow[b]{2}{*}{$\begin{array}{l}\text { Std. } \\
\text { Error }\end{array}$} & \multirow[b]{2}{*}{ Wald } & \multirow[b]{2}{*}{$d f$} & \multirow[b]{2}{*}{ Sig. } & \multirow[b]{2}{*}{$\operatorname{Exp}(B)$} & \multicolumn{2}{|c|}{$\begin{array}{c}95 \% \text { Confidence } \\
\text { Interval for } \operatorname{Exp}(\mathrm{B}) \\
\end{array}$} \\
\hline & & & & & & & & $\begin{array}{l}\text { Lower } \\
\text { Bound }\end{array}$ & $\begin{array}{l}\text { Upper } \\
\text { Bound }\end{array}$ \\
\hline \multirow{4}{*}{$\begin{array}{l}\text { somewhat } \\
\text { for it }\end{array}$} & $\begin{array}{c}\text { Intercept } \\
\text { Revisionist }\end{array}$ & $\begin{array}{l}.904 \\
.348 \\
\end{array}$ & $\begin{array}{l}.203 \\
.449 \\
\end{array}$ & $\begin{array}{c}19.799 \\
.600 \\
\end{array}$ & $\begin{array}{l}1 \\
1 \\
\end{array}$ & $\begin{array}{l}.000 \\
.438 \\
\end{array}$ & 1.417 & .587 & 3.419 \\
\hline & $\begin{array}{l}\text { Religious } \\
\text { Zionist }\end{array}$ & 194 & 1.172 & .027 & 1 & .868 & 1.214 & .122 & 12.087 \\
\hline & $\begin{array}{l}\text { Haredi (ultra- } \\
\text { Orthodox) }\end{array}$ & 17.216 & 1.047 & $\begin{array}{c}270.63 \\
3\end{array}$ & 1 & .000 & $\begin{array}{c}29993373 . \\
400\end{array}$ & $\begin{array}{c}3856666.2 \\
54\end{array}$ & $\begin{array}{c}23325908 \\
6.656\end{array}$ \\
\hline & Labor & $0^{\mathrm{b}}$ & & & 0 & & & & \\
\hline \multirow{4}{*}{$\begin{array}{l}\text { so-so, in the } \\
\text { middle }\end{array}$} & Intercept & -.030 & .244 & .015 & 1 & .903 & & & \\
\hline & Revisionist & 1.779 & .454 & 15.330 & 1 & .000 & 5.924 & 2.431 & 14.434 \\
\hline & $\begin{array}{l}\text { Religious } \\
\text { Zionist } \\
\end{array}$ & 1.822 & 1.107 & 2.706 & 1 & .100 & 6.182 & .705 & 54.169 \\
\hline & $\begin{array}{l}\text { Haredi (ultra- } \\
\text { Orthodox) } \\
\text { Labor }\end{array}$ & \begin{tabular}{|c|}
19.404 \\
$0^{\mathrm{b}}$ \\
\end{tabular} & .870 & $\begin{array}{c}497.68 \\
8\end{array}$ & $\begin{array}{l}1 \\
0 \\
\end{array}$ & .000 & $\begin{array}{c}26721369 \\
0.294\end{array}$ & $\begin{array}{c}48586123 . \\
338\end{array}$ & $\begin{array}{c}14696203 \\
64.305\end{array}$ \\
\hline \multirow{5}{*}{$\begin{array}{l}\text { somewhat } \\
\text { against it }\end{array}$} & Intercept & -1.735 & .443 & 15.345 & 1 & .000 & & & \\
\hline & Revisionist & 3.293 & .589 & 31.210 & 1 & .000 & 26.917 & 8.479 & 85.452 \\
\hline & $\begin{array}{l}\text { Religious } \\
\text { Zionist }\end{array}$ & 3.814 & 1.149 & 11.011 & 1 & .001 & 45.333 & 4.765 & 431.294 \\
\hline & $\begin{array}{l}\text { Haredi (ultra- } \\
\text { Orthodox) }\end{array}$ & 21.108 & .945 & $\begin{array}{c}499.02 \\
8\end{array}$ & 1 & .000 & $\begin{array}{c}14696752 \\
96.612\end{array}$ & $\begin{array}{c}23062773 \\
9.074\end{array}$ & $\begin{array}{c}93655060 \\
14.785\end{array}$ \\
\hline & Labor & $0^{\mathrm{b}}$ & & & 0 & & & & \\
\hline \multirow{5}{*}{$\begin{array}{l}\text { very against } \\
\text { it }\end{array}$} & Intercept & -1.447 & .393 & 13.558 & 1 & .000 & & & \\
\hline & Revisionist & 3.152 & .550 & 32.876 & 1 & .000 & 23.375 & 7.959 & 68.649 \\
\hline & $\begin{array}{l}\text { Religious } \\
\text { Zionist }\end{array}$ & 4.012 & 1.110 & 13.071 & 1 & .000 & 55.250 & 6.278 & 486.265 \\
\hline & Haredi (ultra- & 20.484 & .953 & 461.94 & 1 & .000 & $\begin{array}{c}78732605 \\
1759\end{array}$ & $\begin{array}{c}12159172 \\
8152\end{array}$ & $\begin{array}{c}50980631 \\
75834\end{array}$ \\
\hline & Labor & $0^{\mathrm{b}}$ & & & 0 & & & & \\
\hline \multirow{5}{*}{6} & Intercept & -2.428 & .602 & 16.248 & 1 & .000 & & & \\
\hline & Revisionist & 2.913 & .751 & 15.030 & 1 & .000 & 18.417 & 4.223 & 80.323 \\
\hline & $\begin{array}{l}\text { Religious } \\
\text { Zionist }\end{array}$ & 3.121 & 1.365 & 5.229 & 1 & .022 & 22.667 & 1.562 & 328.949 \\
\hline & $\begin{array}{l}\text { Haredi (ultra- } \\
\text { Orthodox) }\end{array}$ & 21.242 & .000 & . & 1 & & $\begin{array}{c}16796289 \\
10.420\end{array}$ & $\begin{array}{c}16796289 \\
10.420\end{array}$ & $\begin{array}{c}16796289 \\
10.420\end{array}$ \\
\hline & Labor & $0^{\mathrm{b}}$ & & & 0 & & & & \\
\hline
\end{tabular}


January 1998

Crosstabs

Movement * What is your opinion in regards to the agreement signed at Oslo between Israel and the PLO (Declaration of Principles)? Crosstabulation

\begin{tabular}{|c|c|c|c|c|c|c|c|}
\hline & \multicolumn{5}{|c|}{$\begin{array}{l}\text { What is your opinion in regards to the agreement signed at } \\
\text { Oslo between Israel and the PLO (Declaration of Principles)? }\end{array}$} \\
\hline & & & very for it & $\begin{array}{l}\text { somewhat } \\
\text { for it }\end{array}$ & $\begin{array}{l}\text { so-so, in } \\
\text { the middle }\end{array}$ & $\begin{array}{l}\text { somewhat } \\
\text { against it }\end{array}$ & $\begin{array}{l}\text { very } \\
\text { against it }\end{array}$ \\
\hline \multirow{4}{*}{$\begin{array}{l}\text { Moveme } \\
\text { nt }\end{array}$} & Revisionist & $\begin{array}{c}\text { Count } \\
\% \text { within } \\
\text { Movement }\end{array}$ & $\begin{array}{c}3 \\
1.7 \%\end{array}$ & $\begin{array}{c}31 \\
17.5 \%\end{array}$ & $\begin{array}{c}51 \\
28.8 \%\end{array}$ & $\begin{array}{c}29 \\
16.4 \%\end{array}$ & $\begin{array}{c}49 \\
27.7 \%\end{array}$ \\
\hline & $\begin{array}{l}\text { Religious } \\
\text { Zionist }\end{array}$ & $\begin{array}{c}\text { Count } \\
\% \text { within } \\
\text { Movement }\end{array}$ & $\begin{array}{c}0 \\
0.0 \%\end{array}$ & $\begin{array}{c}5 \\
18.5 \%\end{array}$ & $\begin{array}{c}9 \\
33.3 \%\end{array}$ & $\begin{array}{c}7 \\
25.9 \%\end{array}$ & $\begin{array}{c}4 \\
14.8 \%\end{array}$ \\
\hline & $\begin{array}{l}\text { Haredi (Ultra- } \\
\text { Orthodox) }\end{array}$ & $\begin{array}{c}\text { Count } \\
\% \text { within } \\
\text { Movement }\end{array}$ & $\begin{array}{c}0 \\
0.0 \%\end{array}$ & $\begin{array}{c}1 \\
4.5 \%\end{array}$ & $\begin{array}{c}9 \\
40.9 \%\end{array}$ & $\begin{array}{c}4 \\
18.2 \%\end{array}$ & $\begin{array}{c}3 \\
13.6 \%\end{array}$ \\
\hline & Labor & $\begin{array}{c}\text { Count } \\
\% \text { within } \\
\text { Movement }\end{array}$ & $\begin{array}{c}64 \\
37.0 \%\end{array}$ & $\begin{array}{c}49 \\
28.3 \%\end{array}$ & $\begin{array}{c}36 \\
20.8 \%\end{array}$ & $\begin{array}{c}8 \\
4.6 \%\end{array}$ & $\begin{array}{c}8 \\
4.6 \%\end{array}$ \\
\hline \multicolumn{2}{|r|}{ Total } & $\begin{array}{c}\text { Count } \\
\% \text { within } \\
\text { Movement }\end{array}$ & $\begin{array}{c}67 \\
16.8 \%\end{array}$ & $\begin{array}{c}86 \\
21.6 \%\end{array}$ & $\begin{array}{c}105 \\
26.3 \%\end{array}$ & $\begin{array}{c}48 \\
12.0 \%\end{array}$ & $\begin{array}{c}64 \\
16.0 \%\end{array}$ \\
\hline
\end{tabular}




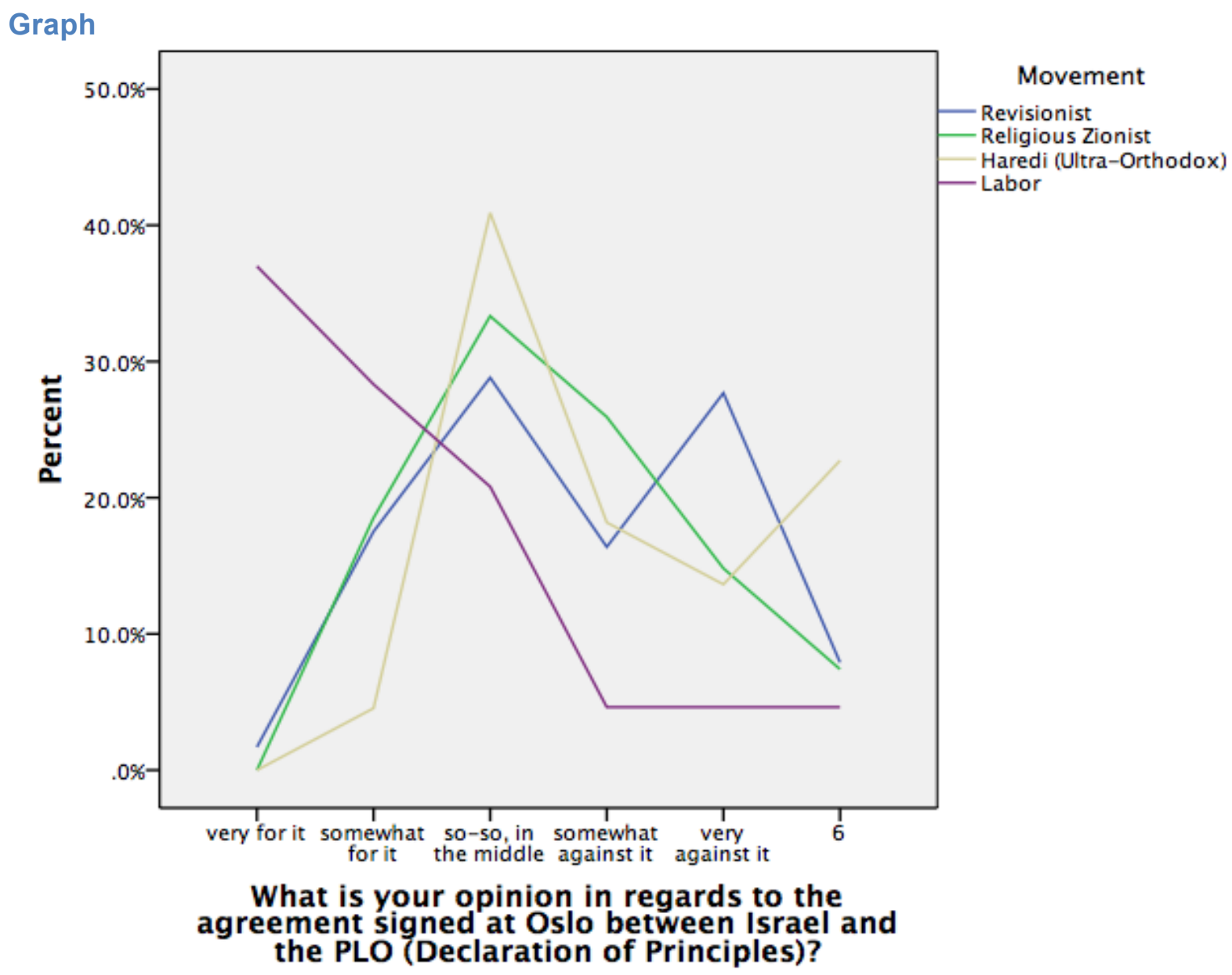

Nominal Regression

Model Fitting Information

\begin{tabular}{|l|r|r|r|r|}
\hline \multirow{2}{*}{} & \multicolumn{1}{|c|}{$\begin{array}{l}\text { Model Fitting } \\
\text { Criteria }\end{array}$} & \multicolumn{3}{|c|}{ Likelihood Ratio Tests } \\
\cline { 2 - 5 } & $\begin{array}{c}-2 \text { Log } \\
\text { Likelihood }\end{array}$ & Chi-Square & df & \multicolumn{1}{c|}{ Sig. } \\
\hline Intercept Only & $\begin{array}{r}223.787 \\
67.377\end{array}$ & 156.409 & 15 & .000 \\
\hline
\end{tabular}

Goodness-of-Fit

\begin{tabular}{|l|r|r|r|}
\hline & Chi-Square & df & Sig. \\
\hline Pearson & .000 & 0 & \\
Deviance & .000 & 0 &. \\
\hline
\end{tabular}

Likelihood Ratio Tests

\begin{tabular}{|l|r|r|r|r|}
\hline \multirow{2}{*}{} & \multicolumn{1}{|c|}{$\begin{array}{c}\text { Model Fitting } \\
\text { Criteria }\end{array}$} & \multicolumn{3}{|c|}{ Likelihood Ratio Tests } \\
\cline { 2 - 6 } & $\begin{array}{c}-2 \text { Log } \\
\text { Likelihood of } \\
\text { Reduced Model }\end{array}$ & Chi-Square & df & \multicolumn{1}{c|}{ Sig. } \\
\hline Effect & $67.377^{\text {a }}$ & .000 & 0 & .000 \\
\hline Movement & 223.787 & 156.409 & 15 & .000 \\
\hline
\end{tabular}


Parameter Estimates

\begin{tabular}{|c|c|c|c|c|c|c|c|c|c|}
\hline \multirow{2}{*}{\multicolumn{2}{|c|}{$\begin{array}{l}\text { What is your opinion in } \\
\text { regards to the agreement } \\
\text { signed at Oslo between } \\
\text { Israel and the PLO } \\
\text { (Declaration of } \\
\text { Principles)? }\end{array}$}} & \multirow[b]{2}{*}{ B } & \multirow[b]{2}{*}{$\begin{array}{l}\text { Std. } \\
\text { Error }\end{array}$} & \multirow[b]{2}{*}{ Wald } & \multirow[b]{2}{*}{ df } & \multirow[b]{2}{*}{ Sig. } & \multirow[b]{2}{*}{$\operatorname{Exp}(B)$} & \multicolumn{2}{|c|}{$\begin{array}{c}95 \% \text { Confidence } \\
\text { Interval for } \operatorname{Exp}(B)\end{array}$} \\
\hline & & & & & & & & $\begin{array}{l}\text { Lower } \\
\text { Bound }\end{array}$ & $\begin{array}{l}\text { Upper } \\
\text { Bound }\end{array}$ \\
\hline \multirow{5}{*}{$\begin{array}{l}\text { somewhat } \\
\text { for it }\end{array}$} & Intercept & -.267 & .190 & 1.979 & 1 & .159 & & & \\
\hline & Revisionist & 2.602 & 634 & 16.863 & 1 & .000 & 13.497 & 3.897 & 46.737 \\
\hline & $\begin{array}{l}\text { Religious } \\
\text { Zionist }\end{array}$ & 18.590 & $\begin{array}{c}4258.56 \\
9\end{array}$ & .000 & 1 & .997 & $\begin{array}{c}11843539 \\
0.613\end{array}$ & & \\
\hline & $\begin{array}{l}\text { Haredi (ultra- } \\
\text { Orthodox) }\end{array}$ & 17.514 & 1.160 & $\begin{array}{c}227.99 \\
1\end{array}$ & 1 & .000 & $\begin{array}{l}40386639 \\
.102\end{array}$ & $\begin{array}{c}4158285 . \\
567\end{array}$ & $\begin{array}{c}39224834 \\
1.673\end{array}$ \\
\hline & Labor & $0^{c}$ & & & 0 & & & & \\
\hline \multirow{4}{*}{$\begin{array}{l}\text { so-so, in the } \\
\text { middle }\end{array}$} & Intercept & -.575 & 208 & 7.627 & 1 & .006 & & & \\
\hline & Revisionist & 3.409 & .630 & 29.314 & 1 & .000 & 30.222 & 8.799 & 103.802 \\
\hline & $\begin{array}{c}\text { Religious } \\
\text { Zionist }\end{array}$ & 19.486 & $\begin{array}{c}4258.56 \\
9\end{array}$ & .000 & 1 & .996 & $\begin{array}{c}29016670 \\
7.001\end{array}$ & .000 & b \\
\hline & $\begin{array}{l}\text { Haredi (ultra- } \\
\text { Orthodox) } \\
\text { Labor }\end{array}$ & $\begin{array}{c}20.020 \\
0^{c}\end{array}$ & .681 & $\begin{array}{c}863.96 \\
1\end{array}$ & 1 & .000 & $\begin{array}{c}49473632 \\
8.998\end{array}$ & $\begin{array}{c}13020439 \\
1.619\end{array}$ & $\begin{array}{c}18798446 \\
97.909\end{array}$ \\
\hline \multirow{5}{*}{$\begin{array}{l}\text { somewhat } \\
\text { against it }\end{array}$} & Intercept & -2.079 & .375 & 30.749 & 1 & .000 & & & \\
\hline & Revisionist & 4.348 & .713 & 37.185 & 1 & .000 & 77.333 & 19.117 & 312.836 \\
\hline & $\begin{array}{l}\text { Religious } \\
\text { Zionist }\end{array}$ & 20.739 & $\begin{array}{c}4258.56 \\
9\end{array}$ & .000 & 1 & .996 & $\begin{array}{c}10155834 \\
74.504\end{array}$ & .000 & \\
\hline & Haredi (ultra- & 713 م2 & & 612.87 & 1 & & 98947265 & 19197182 & 50999991 \\
\hline & $\begin{array}{l}\text { Orthodox) } \\
\text { Labor }\end{array}$ & $\begin{array}{c}20.173 \\
0^{c}\end{array}$ & .831 & 9 & 0 & .000 & 7.996 & 4.993 & 32.446 \\
\hline \multirow{5}{*}{$\begin{array}{c}\text { very against } \\
\text { it }\end{array}$} & Intercept & -2.079 & .375 & 30.749 & 1 & .000 & & & \\
\hline & Revisionist & 4.873 & .703 & 48.027 & 1 & .000 & 130.667 & 32.936 & 518.388 \\
\hline & Religious & 20.179 & 4258.56 & .000 & 1 & .996 & $\begin{array}{c}58033341 \\
4002\end{array}$ & .000 & \\
\hline & Haredi (ultra- & & & 532.57 & & & 74210449 & 13094822 & 42056247 \\
\hline & $\begin{array}{l}\text { Orthodox) } \\
\text { Labor }\end{array}$ & $\begin{array}{c}20.425 \\
0^{c}\end{array}$ & .885 & . & 1 & .000 & 3.497 & 0.366 & 70.841 \\
\hline \multirow{5}{*}{6} & Intercept & -2.079 & .375 & 30.749 & 1 & .000 & & & \\
\hline & Revisionist & 3.620 & .739 & 24.026 & 1 & .000 & 37.333 & 8.780 & 158.749 \\
\hline & $\begin{array}{l}\text { Religious } \\
\text { Zionist }\end{array}$ & 19.486 & $\begin{array}{c}4258.56 \\
9\end{array}$ & .000 & 1 & .996 & $\begin{array}{l}29016670 \\
7.001\end{array}$ & .000 & b \\
\hline & $\begin{array}{l}\text { Haredi (ultra- } \\
\text { Orthodox) }\end{array}$ & 20.936 & .000 & . & 1 & & $\begin{array}{c}12368408 \\
22.494\end{array}$ & $\begin{array}{c}12368408 \\
22.494\end{array}$ & $\begin{array}{c}12368408 \\
22.494\end{array}$ \\
\hline & Labor & $0^{c}$ & & & 0 & & & & \\
\hline
\end{tabular}


July 1998

Crosstabs

Movement * What is your opinion in regards to the agreement signed at Oslo between Israel and the PLO (Declaration of Principles)? Crosstabulation

\begin{tabular}{|c|c|c|c|c|c|c|c|}
\hline & \multicolumn{5}{|c|}{$\begin{array}{l}\text { What is your opinion in regards to the agreement signed at } \\
\text { Oslo between Israel and the PLO (Declaration of Principles)? }\end{array}$} \\
\hline & & & very for it & $\begin{array}{l}\text { somewhat } \\
\text { for it }\end{array}$ & $\begin{array}{l}\text { so-so, in } \\
\text { the middle }\end{array}$ & $\begin{array}{l}\text { somewhat } \\
\text { against it }\end{array}$ & $\begin{array}{l}\text { very } \\
\text { against it }\end{array}$ \\
\hline \multirow{4}{*}{$\begin{array}{l}\text { Moveme } \\
\text { nt }\end{array}$} & Revisionist & $\begin{array}{c}\text { Count } \\
\% \text { within } \\
\text { Movement }\end{array}$ & $\begin{array}{c}15 \\
10.6 \%\end{array}$ & $\begin{array}{c}22 \\
15.6 \%\end{array}$ & $\begin{array}{c}46 \\
32.6 \%\end{array}$ & $\begin{array}{c}21 \\
14.9 \%\end{array}$ & $\begin{array}{c}32 \\
22.7 \%\end{array}$ \\
\hline & $\begin{array}{l}\text { Religious } \\
\text { Zionist }\end{array}$ & $\begin{array}{c}\text { Count } \\
\% \text { within } \\
\text { Movement }\end{array}$ & $\begin{array}{c}1 \\
4.8 \%\end{array}$ & $\begin{array}{c}0 \\
0.0 \%\end{array}$ & $\begin{array}{c}2 \\
9.5 \%\end{array}$ & $\begin{array}{c}2 \\
9.5 \%\end{array}$ & $\begin{array}{c}13 \\
61.9 \%\end{array}$ \\
\hline & $\begin{array}{l}\text { Haredi (Ultra- } \\
\text { Orthodox) }\end{array}$ & $\begin{array}{c}\text { Count } \\
\% \text { within } \\
\text { Movement }\end{array}$ & $\begin{array}{c}1 \\
3.3 \%\end{array}$ & $\begin{array}{c}3 \\
10.0 \%\end{array}$ & $\begin{array}{c}7 \\
23.3 \%\end{array}$ & $\begin{array}{c}6 \\
20.0 \%\end{array}$ & $\begin{array}{c}11 \\
36.7 \%\end{array}$ \\
\hline & Labor & $\begin{array}{c}\text { Count } \\
\% \text { within } \\
\text { Movement }\end{array}$ & $\begin{array}{c}70 \\
39.8 \%\end{array}$ & $\begin{array}{c}60 \\
34.1 \%\end{array}$ & $\begin{array}{c}26 \\
14.8 \%\end{array}$ & $\begin{array}{c}5 \\
2.8 \%\end{array}$ & $\begin{array}{c}9 \\
5.1 \%\end{array}$ \\
\hline \multicolumn{2}{|r|}{ Total } & $\begin{array}{c}\text { Count } \\
\% \text { within } \\
\text { Movement }\end{array}$ & $\begin{array}{c}87 \\
23.6 \%\end{array}$ & $\begin{array}{c}85 \\
23.1 \%\end{array}$ & $\begin{array}{c}81 \\
22.0 \%\end{array}$ & $\begin{array}{c}34 \\
9.2 \%\end{array}$ & $\begin{array}{c}65 \\
17.7 \%\end{array}$ \\
\hline
\end{tabular}




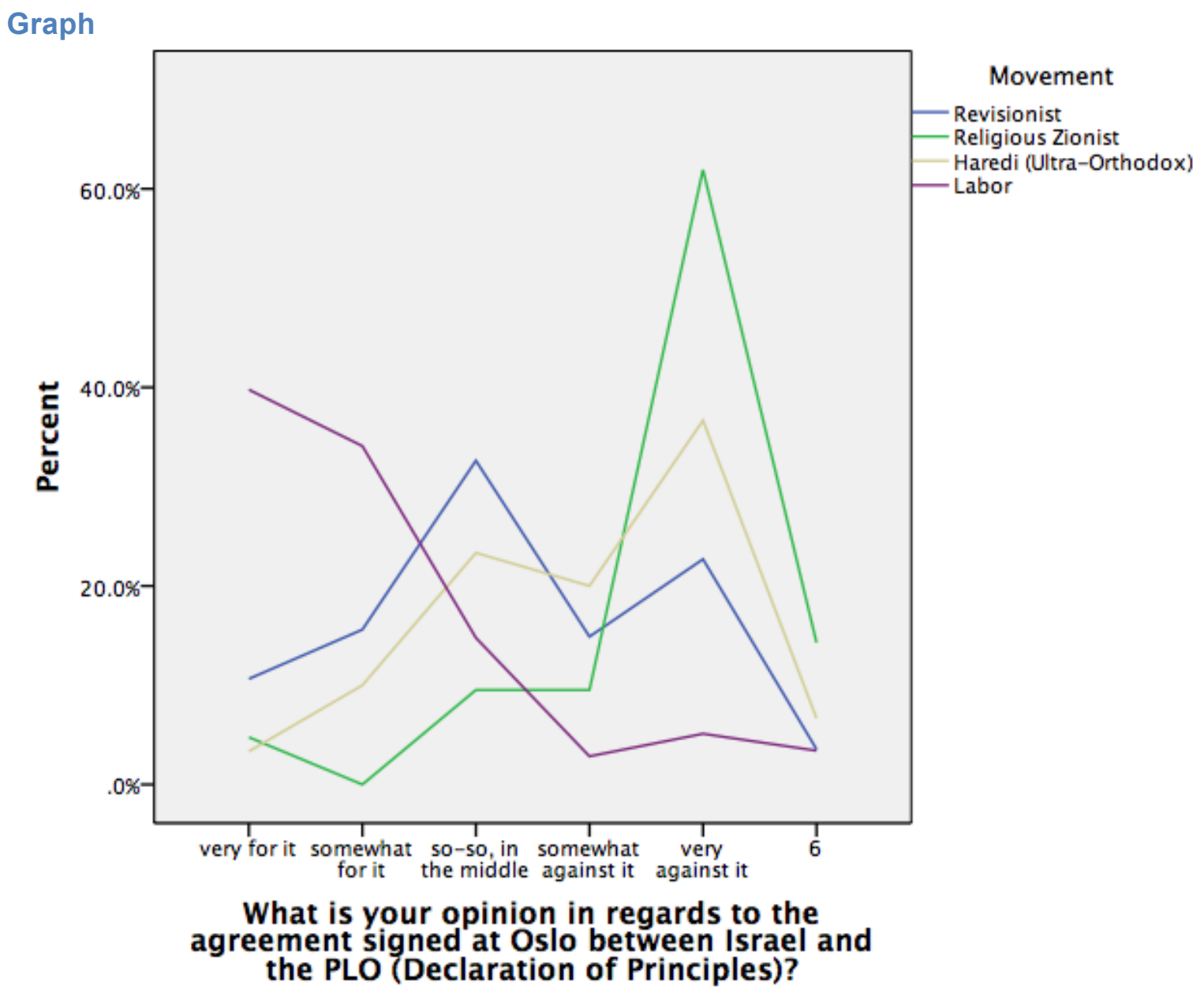

Nominal Regression

Model Fitting Information

\begin{tabular}{|l|r|r|r|r|}
\hline \multirow{2}{*}{} & \multicolumn{1}{|c|}{$\begin{array}{c}\text { Model Fitting } \\
\text { Criteria }\end{array}$} & \multicolumn{3}{|c|}{ Likelihood Ratio Tests } \\
\cline { 2 - 5 } & $\begin{array}{r}-2 \text { Log } \\
\text { Likelihood }\end{array}$ & Chi-Square & \multicolumn{1}{c|}{$\mathrm{df}$} & \multicolumn{1}{|c|}{ Sig. } \\
\hline Model & $\begin{array}{r}210.245 \\
67.185\end{array}$ & 143.060 & 15 & .000 \\
\hline
\end{tabular}

Goodness-of-Fit

\begin{tabular}{|l|r|r|r|}
\hline & Chi-Square & \multicolumn{1}{|c|}{ df } & Sig. \\
\hline Pearson & .000 & 0 & \\
Deviance & .000 & 0 &. \\
\hline
\end{tabular}

Likelihood Ratio Tests

\begin{tabular}{|l|r|r|r|r|}
\hline \multirow{2}{*}{} & \multicolumn{1}{|c|}{$\begin{array}{c}\text { Model Fitting } \\
\text { Criteria }\end{array}$} & \multicolumn{3}{|c|}{ Likelihood Ratio Tests } \\
\cline { 2 - 6 } & $\begin{array}{c}-2 \text { Log } \\
\text { Likelihood of } \\
\text { Eeduced Model }\end{array}$ & Chi-Square & \multicolumn{1}{c|}{ df } & \multicolumn{1}{c|}{ Sig. } \\
\hline Intercept & $67.185^{\text {a }}$ & .000 & 0 & .000 \\
\hline Movement & 210.245 & 143.060 & 15 & .000 \\
\hline
\end{tabular}


Parameter Estimates

\begin{tabular}{|c|c|c|c|c|c|c|c|c|c|}
\hline \multirow{2}{*}{\multicolumn{2}{|c|}{$\begin{array}{l}\text { What is your opinion in } \\
\text { regards to the agreement } \\
\text { signed at Oslo between } \\
\text { Israel and the PLO } \\
\text { (Declaration of Principles)? }\end{array}$}} & \multirow{2}{*}{ B } & \multirow{2}{*}{$\begin{array}{l}\text { Std. } \\
\text { Error }\end{array}$} & \multirow{2}{*}{ Wald } & \multirow{2}{*}{$d f$} & \multirow{2}{*}{ Sig. } & \multirow{2}{*}{$\operatorname{Exp}(B)$} & \multicolumn{2}{|c|}{$\begin{array}{l}95 \% \text { Confidence } \\
\text { Interval for Exp(B) }\end{array}$} \\
\hline & & & & & & & & $\begin{array}{l}\text { Lower } \\
\text { Bound }\end{array}$ & $\begin{array}{l}\text { Upper } \\
\text { Bound }\end{array}$ \\
\hline \multirow{4}{*}{$\begin{array}{l}\text { somewhat for } \\
\text { it }\end{array}$} & $\begin{array}{c}\text { Intercept } \\
\text { Revisionist }\end{array}$ & $\begin{array}{l}-.154 \\
537\end{array}$ & $\begin{array}{l}.176 \\
378\end{array}$ & $\begin{array}{l}.768 \\
2017\end{array}$ & $\begin{array}{l}1 \\
1\end{array}$ & $\begin{array}{r}.381 \\
156\end{array}$ & 1711 & 815 & 3501 \\
\hline & Religious & -18.605 & .000 & 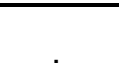 & 1 & & $8.321 \mathrm{E}-$ & $8.321 \mathrm{E}-9$ & $8.321 \mathrm{E}-9$ \\
\hline & $\begin{array}{l}\text { Haredi (ultra- } \\
\text { Orthodox) }\end{array}$ & 1.253 & 1.168 & 1.150 & 1 & .283 & 3.500 & .355 & \\
\hline & Labor & $0^{\mathrm{b}}$ & & & 0 & & & & \\
\hline \multirow{4}{*}{$\begin{array}{l}\text { so-so, in the } \\
\text { middle }\end{array}$} & Intercept & -.990 & .230 & 18.596 & 1 & .000 & & & \\
\hline & Revisionist & 2.111 & .376 & 31.571 & 1 & .000 & 8.256 & 3.954 & 17.242 \\
\hline & $\begin{array}{l}\text { Religious } \\
\text { Zionist }\end{array}$ & 1.684 & 1.246 & 1.825 & 1 & .177 & 5.385 & .468 & 61.920 \\
\hline & $\begin{array}{l}\text { Haredi (ultra- } \\
\text { Orthodox) } \\
\text { Labor }\end{array}$ & $\begin{array}{c}2.936 \\
0^{\mathrm{b}}\end{array}$ & 1.093 & 7.211 & $\begin{array}{l}1 \\
0\end{array}$ & .007 & 18.846 & 2.210 & 160.679 \\
\hline \multirow{5}{*}{$\begin{array}{l}\text { somewhat } \\
\text { against it }\end{array}$} & Intercept & -2.639 & .463 & 32.502 & 1 & .000 & & & \\
\hline & Revisionist & 2.976 & .573 & 26.946 & 1 & .000 & 19.600 & 6.373 & 60.280 \\
\hline & $\begin{array}{l}\text { Religious } \\
\text { Zionist }\end{array}$ & 3.332 & 1.309 & 6.477 & 1 & .011 & 28.000 & 2.151 & 364.454 \\
\hline & Haredi (ultra- & 4.431 & 1.175 & 14.216 & 1 & .000 & 84.000 & 8.395 & 840.542 \\
\hline & $\begin{array}{l}\text { Orthodox) } \\
\text { Labor }\end{array}$ & $0^{\mathrm{D}}$ & & & 0 & & & & \\
\hline \multirow{5}{*}{$\begin{array}{l}\text { very against } \\
\text { it }\end{array}$} & Intercept & -2.051 & .354 & 33.555 & 1 & .000 & & & \\
\hline & Revisionist & 2.809 & .473 & 35.333 & 1 & .000 & 16.593 & 6.572 & 41.895 \\
\hline & $\begin{array}{l}\text { Religious } \\
\text { Zionist }\end{array}$ & 4.616 & 1.097 & 17.724 & 1 & .000 & 101.111 & 11.788 & 867.250 \\
\hline & Haredi (ultra- & 4.449 & 1.103 & 16.275 & 1 & .000 & & 9.851 & 743.030 \\
\hline & Labor & $0^{\mathrm{b}}$ & & & 0 & & & & \\
\hline \multirow{5}{*}{6} & Intercept & -2.457 & .425 & 33.354 & 1 & .000 & & & \\
\hline & Revisionist & 1.358 & .669 & 4.121 & 1 & .042 & 3.889 & 1.048 & 14.432 \\
\hline & $\begin{array}{l}\text { Religious } \\
\text { Zionist }\end{array}$ & 3.555 & 1.231 & 8.347 & 1 & .004 & 35.000 & 3.138 & 390.414 \\
\hline & $\begin{array}{l}\text { Haredi (ultra- } \\
\text { Orthodox) }\end{array}$ & 3.150 & 1.297 & 5.902 & 1 & .015 & 23.333 & 1.838 & 296.192 \\
\hline & Labor & $0^{\mathrm{b}}$ & & & 0 & & & & \\
\hline
\end{tabular}


January 1999

Crosstabs

Movement * What is your opinion in regards to the agreement signed at Oslo between Israel and the PLO (Declaration of Principles)? Crosstabulation

\begin{tabular}{|c|c|c|c|c|c|c|c|}
\hline & \multicolumn{5}{|c|}{$\begin{array}{l}\text { What is your opinion in regards to the agreement signed at } \\
\text { Oslo between Israel and the PLO (Declaration of Principles)? }\end{array}$} \\
\hline & & & very for it & $\begin{array}{l}\text { somewhat } \\
\text { for it }\end{array}$ & $\begin{array}{l}\text { so-so, in } \\
\text { the middle }\end{array}$ & $\begin{array}{l}\text { somewhat } \\
\text { against it }\end{array}$ & $\begin{array}{l}\text { very } \\
\text { against it }\end{array}$ \\
\hline \multirow{4}{*}{$\begin{array}{l}\text { Moveme } \\
\text { nt }\end{array}$} & Revisionist & $\begin{array}{c}\text { Count } \\
\% \text { within } \\
\text { Movement }\end{array}$ & $\begin{array}{c}12 \\
7.7 \%\end{array}$ & $\begin{array}{c}29 \\
18.6 \%\end{array}$ & $\begin{array}{c}45 \\
28.8 \%\end{array}$ & $\begin{array}{c}24 \\
15.4 \%\end{array}$ & $\begin{array}{c}34 \\
21.8 \%\end{array}$ \\
\hline & $\begin{array}{l}\text { Religious } \\
\text { Zionist }\end{array}$ & $\begin{array}{c}\text { Count } \\
\% \text { within } \\
\text { Movement }\end{array}$ & $\begin{array}{c}1 \\
2.7 \%\end{array}$ & $\begin{array}{c}3 \\
8.1 \%\end{array}$ & $\begin{array}{c}13 \\
35.1 \%\end{array}$ & $\begin{array}{c}11 \\
29.7 \%\end{array}$ & $\begin{array}{c}8 \\
21.6 \%\end{array}$ \\
\hline & $\begin{array}{l}\text { Haredi (Ultra- } \\
\text { Orthodox) }\end{array}$ & $\begin{array}{c}\text { Count } \\
\% \text { within } \\
\text { Movement }\end{array}$ & $\begin{array}{c}1 \\
5.6 \%\end{array}$ & $\begin{array}{c}3 \\
16.7 \%\end{array}$ & $\begin{array}{c}6 \\
33.3 \%\end{array}$ & $\begin{array}{c}4 \\
22.2 \%\end{array}$ & $\begin{array}{c}1 \\
5.6 \%\end{array}$ \\
\hline & Labor & $\begin{array}{c}\text { Count } \\
\% \text { within } \\
\text { Movement }\end{array}$ & $\begin{array}{c}86 \\
45.5 \%\end{array}$ & $\begin{array}{c}52 \\
27.5 \%\end{array}$ & $\begin{array}{c}36 \\
19.0 \%\end{array}$ & $\begin{array}{c}3 \\
1.6 \%\end{array}$ & $\begin{array}{c}7 \\
3.7 \%\end{array}$ \\
\hline \multicolumn{2}{|r|}{ Total } & $\begin{array}{c}\text { Count } \\
\% \text { within } \\
\text { Movement }\end{array}$ & $\begin{array}{c}100 \\
25.0 \%\end{array}$ & $\begin{array}{c}87 \\
21.8 \%\end{array}$ & $\begin{array}{c}100 \\
25.0 \%\end{array}$ & $\begin{array}{c}42 \\
10.5 \%\end{array}$ & $\begin{array}{c}50 \\
12.5 \%\end{array}$ \\
\hline
\end{tabular}






Nominal Regression

Model Fitting Information

\begin{tabular}{|l|r|r|r|r|}
\hline \multirow{2}{*}{} & \multicolumn{1}{|c|}{$\begin{array}{c}\text { Model Fitting } \\
\text { Criteria }\end{array}$} & \multicolumn{3}{|c|}{ Likelihood Ratio Tests } \\
\cline { 2 - 5 } & $\begin{array}{r}\text {-2 Log } \\
\text { Likelihood }\end{array}$ & Chi-Square & df & \multicolumn{1}{|c|}{ Sig. } \\
\hline $\begin{array}{l}\text { Intercept Only } \\
\text { Final }\end{array}$ & $\begin{array}{r}222.479 \\
70.060\end{array}$ & 152.419 & 15 & .000 \\
\hline
\end{tabular}

Goodness-of-Fit

\begin{tabular}{|l|r|r|r|}
\hline & Chi-Square & \multicolumn{1}{c|}{ df } & Sig. \\
\hline Pearson & .000 & 0 & \\
Deviance & .000 & 0 & \\
\hline
\end{tabular}

Likelihood Ratio Tests

\begin{tabular}{|l|r|r|r|r|}
\hline \multirow{2}{*}{} & \multicolumn{1}{|c|}{$\begin{array}{c}\text { Model Fitting } \\
\text { Criteria }\end{array}$} & \multicolumn{3}{|c|}{ Likelihood Ratio Tests } \\
\cline { 2 - 5 } & $\begin{array}{c}-2 \text { Log } \\
\text { Likelihood of } \\
\text { Reduced Model }\end{array}$ & Chi-Square & df & \multicolumn{1}{c|}{ Sig. } \\
\hline Intercept & $70.060^{\text {a }}$ & .000 & 0 & .000 \\
Movement & 222.479 & 152.419 & 15 & .000 \\
\hline
\end{tabular}


Parameter Estimates

\begin{tabular}{|c|c|c|c|c|c|c|c|c|c|}
\hline \multirow{2}{*}{\multicolumn{2}{|c|}{$\begin{array}{l}\text { What is your opinion in } \\
\text { regards to the agreement } \\
\text { signed at Oslo between } \\
\text { Israel and the PLO } \\
\text { (Declaration of Principles)? }\end{array}$}} & \multirow[b]{2}{*}{ B } & \multirow{2}{*}{$\begin{array}{l}\text { Std. } \\
\text { Error }\end{array}$} & \multirow[b]{2}{*}{ Wald } & \multirow[b]{2}{*}{ df } & \multirow[b]{2}{*}{ Sig. } & \multirow[b]{2}{*}{$\operatorname{Exp}(B)$} & \multicolumn{2}{|c|}{$\begin{array}{c}95 \% \text { Confidence } \\
\text { Interval for } \operatorname{Exp}(B)\end{array}$} \\
\hline & & & & & & & & $\begin{array}{l}\text { Lower } \\
\text { Bound }\end{array}$ & $\begin{array}{l}\text { Upper } \\
\text { Bound }\end{array}$ \\
\hline \multirow{5}{*}{$\begin{array}{c}\text { somewhat for } \\
\text { it }\end{array}$} & Intercept & $\begin{array}{l}-.503 \\
1385\end{array}$ & .176 & 8.202 & 1 & .004 & 3007 & 1077 & 510 \\
\hline & Religious & & & & & & 0.008 & 1.017 & 8.510 \\
\hline & Zionist & 1.602 & 1.168 & $\mid 1.881$ & 1 & .170 & 4.962 & .503 & 48.956 \\
\hline & $\begin{array}{l}\text { Haredi (ultra- } \\
\text { Orthodox) }\end{array}$ & 1.602 & 1.168 & 1.881 & 1 & .170 & 4.962 & .503 & 48.956 \\
\hline & Labor & $0^{\mathrm{b}}$ & & & 0 & & & & \\
\hline \multirow{4}{*}{$\begin{array}{l}\text { so-so, in the } \\
\text { middle }\end{array}$} & Intercept & -.871 & .199 & 19.244 & 1 & .000 & & & \\
\hline & Revisionist & 2.193 & .381 & 33.164 & 1 & .000 & 8.958 & 4.248 & 18.893 \\
\hline & $\begin{array}{l}\text { Religious } \\
\text { Zionist }\end{array}$ & 3.436 & 1.057 & 10.574 & 1 & .001 & 31.056 & 3.916 & 246.314 \\
\hline & $\begin{array}{l}\text { Haredi (ultra- } \\
\text { Orthodox) } \\
\text { Labor }\end{array}$ & $\begin{array}{c}2.663 \\
0^{\mathrm{b}}\end{array}$ & 1.098 & 5.878 & $\begin{array}{l}1 \\
0\end{array}$ & .015 & 14.333 & 1.666 & 123.353 \\
\hline \multirow{5}{*}{$\begin{array}{l}\text { somewhat } \\
\text { against it }\end{array}$} & Intercept & -3.356 & .587 & 32.644 & 1 & .000 & & & \\
\hline & Revisionist & 4.049 & .686 & 34.883 & 1 & .000 & 57.333 & 14.958 & 219.754 \\
\hline & $\begin{array}{l}\text { Religious } \\
\text { Zionist }\end{array}$ & 5.754 & 1.198 & 23.055 & 1 & .000 & $\begin{array}{c}315.33 \\
3\end{array}$ & 30.116 & 3301.764 \\
\hline & Haredi (ultra- & 4.742 & & & 1 & & 114.66 & & 1362.808 \\
\hline & $\begin{array}{l}\text { Orthodox) } \\
\text { Labor }\end{array}$ & $0^{\mathrm{b}}$ & & & 0 & & & & \\
\hline \multirow{5}{*}{ very against it } & Intercept & -2.508 & .393 & 40.731 & 1 & .000 & & & \\
\hline & Revisionist & 3.550 & .517 & 47.157 & 1 & .000 & 34.810 & 12.638 & 95.878 \\
\hline & $\begin{array}{l}\text { Religious } \\
\text { Zionist }\end{array}$ & 4.588 & 1.131 & 16.451 & 1 & .000 & 98.286 & 10.707 & 902.238 \\
\hline & $\begin{array}{c}\text { Haredi (ultra- } \\
\text { Orthodox) }\end{array}$ & 2.508 & 1.468 & 2.921 & 1 & .087 & 12.286 & & 218.177 \\
\hline & Labor & $0^{\mathrm{b}}$ & & & 0 & & & & \\
\hline \multirow{5}{*}{6} & Intercept & -2.845 & .460 & 38.244 & 1 & .000 & & & \\
\hline & Revisionist & 2.845 & .615 & 21.395 & 1 & .000 & 17.200 & 5.152 & 57.420 \\
\hline & $\begin{array}{l}\text { Religious } \\
\text { Zionist }\end{array}$ & 2.845 & 1.487 & 3.660 & 1 & .056 & 17.200 & .933 & 317.246 \\
\hline & $\begin{array}{c}\text { Haredi (ultra- } \\
\text { Orthodox) }\end{array}$ & 3.944 & 1.243 & 10.066 & 1 & .002 & 51.600 & 4.515 & 589.744 \\
\hline & Labor & $0^{\mathrm{b}}$ & & & 0 & & & & \\
\hline
\end{tabular}


July 1999

Crosstabs

Movement * What is your opinion in regards to the agreement signed at Oslo between Israel and the PLO (Declaration of Principles)? Crosstabulation

\begin{tabular}{|c|c|c|c|c|c|c|c|}
\hline & \multicolumn{5}{|c|}{$\begin{array}{l}\text { What is your opinion in regards to the agreement signed at } \\
\text { Oslo between Israel and the PLO (Declaration of Principles)? }\end{array}$} \\
\hline & & & very for it & $\begin{array}{l}\text { somewhat } \\
\text { for it }\end{array}$ & $\begin{array}{l}\text { so-so, in } \\
\text { the middle }\end{array}$ & $\begin{array}{l}\text { somewhat } \\
\text { against it }\end{array}$ & $\begin{array}{l}\text { very } \\
\text { against it }\end{array}$ \\
\hline \multirow{4}{*}{$\begin{array}{l}\text { Moveme } \\
\text { nt }\end{array}$} & Revisionist & $\begin{array}{c}\text { Count } \\
\% \text { within } \\
\text { Movement }\end{array}$ & $\begin{array}{c}3 \\
4.3 \%\end{array}$ & $\begin{array}{c}11 \\
15.7 \%\end{array}$ & $\begin{array}{c}20 \\
28.6 \%\end{array}$ & $\begin{array}{c}11 \\
15.7 \%\end{array}$ & $\begin{array}{c}23 \\
32.9 \%\end{array}$ \\
\hline & $\begin{array}{l}\text { Religious } \\
\text { Zionist }\end{array}$ & $\begin{array}{c}\text { Count } \\
\% \text { within } \\
\text { Movement }\end{array}$ & $\begin{array}{c}0 \\
0.0 \%\end{array}$ & $\begin{array}{c}3 \\
15.0 \%\end{array}$ & $\begin{array}{c}8 \\
40.0 \%\end{array}$ & $\begin{array}{c}4 \\
20.0 \%\end{array}$ & $\begin{array}{c}3 \\
15.0 \%\end{array}$ \\
\hline & $\begin{array}{l}\text { Haredi (Ultra- } \\
\text { Orthodox) }\end{array}$ & $\begin{array}{c}\text { Count } \\
\% \text { within } \\
\text { Movement }\end{array}$ & $\begin{array}{c}2 \\
5.1 \%\end{array}$ & $\begin{array}{c}7 \\
17.9 \%\end{array}$ & $\begin{array}{c}9 \\
23.1 \%\end{array}$ & $\begin{array}{c}7 \\
17.9 \%\end{array}$ & $\begin{array}{c}9 \\
23.1 \%\end{array}$ \\
\hline & Labor & $\begin{array}{c}\text { Count } \\
\% \text { within } \\
\text { Movement }\end{array}$ & $\begin{array}{c}71 \\
30.6 \%\end{array}$ & $\begin{array}{c}85 \\
36.6 \%\end{array}$ & $\begin{array}{c}54 \\
23.3 \%\end{array}$ & $\begin{array}{c}6 \\
2.6 \%\end{array}$ & $\begin{array}{c}6 \\
2.6 \%\end{array}$ \\
\hline \multicolumn{2}{|r|}{ Total } & $\begin{array}{c}\text { Count } \\
\% \text { within } \\
\text { Movement }\end{array}$ & $\begin{array}{c}76 \\
21.1 \%\end{array}$ & $\begin{array}{c}106 \\
29.4 \%\end{array}$ & $\begin{array}{c}91 \\
25.2 \%\end{array}$ & $\begin{array}{c}28 \\
7.8 \%\end{array}$ & $\begin{array}{c}41 \\
11.4 \%\end{array}$ \\
\hline
\end{tabular}




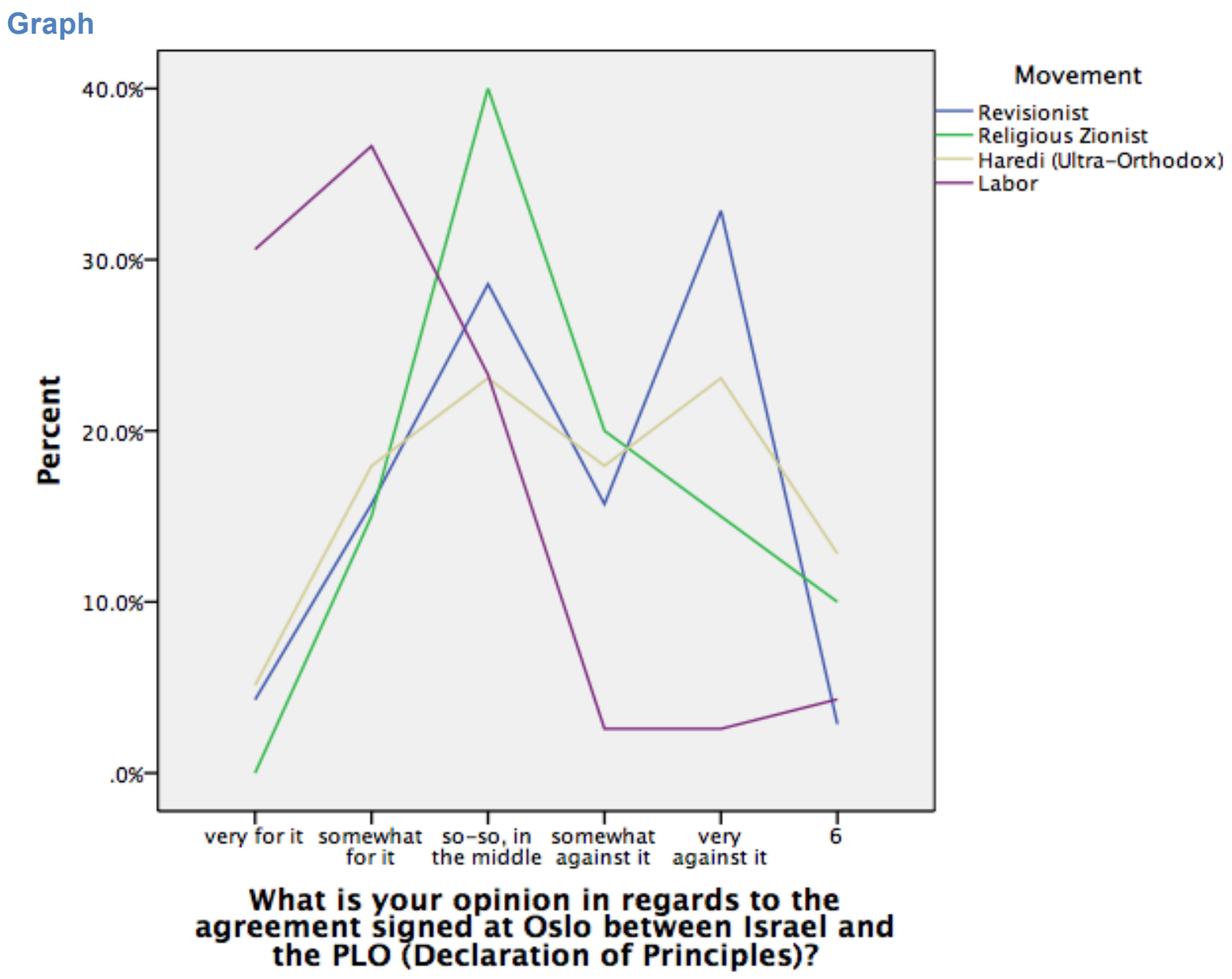

Nominal Regression

Model Fitting Information

\begin{tabular}{|l|r|r|r|r|}
\hline \multirow{2}{*}{ Model } & \multicolumn{1}{|c|}{$\begin{array}{c}\text { Model Fitting } \\
\text { Criteria }\end{array}$} & \multicolumn{3}{|c|}{ Likelihood Ratio Tests } \\
\cline { 2 - 5 } & $\begin{array}{r}-2 \text { Log } \\
\text { Likelihood }\end{array}$ & Chi-Square & df & \multicolumn{1}{c|}{ Sig. } \\
\hline Intercept Only & $\begin{array}{r}192.838 \\
67.513\end{array}$ & 125.324 & 15 & .000 \\
\hline
\end{tabular}

Goodness-of-Fit

\begin{tabular}{|c|c|c|c|}
\hline & Chi-Square & $\mathrm{df}$ & Sig. \\
\hline Pearson & .000 & 0 & \\
\hline Deviance & .000 & 0 & \\
\hline
\end{tabular}

Likelihood Ratio Tests

\begin{tabular}{|c|c|c|c|c|}
\hline \multirow[b]{2}{*}{ Effect } & $\begin{array}{l}\text { Model Fitting } \\
\text { Criteria }\end{array}$ & \multicolumn{3}{|c|}{ Likelihood Ratio Tests } \\
\hline & $\begin{array}{c}-2 \text { Log } \\
\text { Likelihood of } \\
\text { Reduced Model }\end{array}$ & Chi-Square & df & Sig. \\
\hline $\begin{array}{l}\text { Intercept } \\
\text { Movement }\end{array}$ & $\begin{array}{c}67.513^{a} \\
192.838\end{array}$ & $\begin{array}{r}.000 \\
125.324\end{array}$ & $\begin{array}{r}0 \\
15 \\
\end{array}$ & .000 \\
\hline
\end{tabular}


Parameter Estimates

\begin{tabular}{|c|c|c|c|c|c|c|c|c|c|}
\hline \multirow{2}{*}{\multicolumn{2}{|c|}{$\begin{array}{l}\text { What is your opinion in } \\
\text { regards to the agreement } \\
\text { signed at Oslo between } \\
\text { Israel and the PLO } \\
\text { (Declaration of } \\
\text { Principles)? }\end{array}$}} & \multirow[b]{2}{*}{ B } & \multirow[b]{2}{*}{$\begin{array}{l}\text { Std. } \\
\text { Error }\end{array}$} & \multirow[b]{2}{*}{ Wald } & \multirow[b]{2}{*}{ df } & \multirow[b]{2}{*}{ Sig. } & \multirow[b]{2}{*}{$\operatorname{Exp}(B)$} & \multicolumn{2}{|c|}{$\begin{array}{l}95 \% \text { Confidence } \\
\text { Interval for } \operatorname{Exp}(B)\end{array}$} \\
\hline & & & & & & & & $\begin{array}{l}\text { Lower } \\
\text { Bound }\end{array}$ & $\begin{array}{l}\text { Upper } \\
\text { Bound }\end{array}$ \\
\hline \multirow{5}{*}{$\begin{array}{l}\text { somewhat } \\
\text { for it }\end{array}$} & Intercept & .180 & .161 & 1.253 & 1 & .263 & & & \\
\hline & Revisionist & 1.119 & .671 & 2.784 & 1 & .095 & 3.063 & .822 & 11.407 \\
\hline & $\begin{array}{c}\text { Religious } \\
\text { Zionist }\end{array}$ & 18.854 & .972 & $\begin{array}{c}376.14 \\
1\end{array}$ & 1 & .000 & $\begin{array}{c}15430476 \\
0.271\end{array}$ & $\begin{array}{c}22954822 . \\
154\end{array}$ & $\begin{array}{c}10372530 \\
39.119\end{array}$ \\
\hline & $\begin{array}{l}\text { Haredi (ultra- } \\
\text { Orthodox) }\end{array}$ & 1.073 & .818 & 1.721 & 1 & .190 & 2.924 & .589 & 14.520 \\
\hline & Labor & $0^{\mathrm{b}}$ & & & 0 & & & & \\
\hline \multirow{3}{*}{$\begin{array}{l}\text { so-so, in the } \\
\text { middle }\end{array}$} & Intercept & -.274 & .181 & 2.298 & 1 & .130 & & & \\
\hline & $\begin{array}{c}\text { Revisionist } \\
\text { Religious } \\
\text { Zionist }\end{array}$ & \begin{tabular}{|l|}
2.171 \\
20.289
\end{tabular} & $\begin{array}{l}.645 \\
.862\end{array}$ & $\begin{array}{c}11.330 \\
553.63 \\
9\end{array}$ & $\begin{array}{l}1 \\
1\end{array}$ & $\begin{array}{l}.001 \\
.000\end{array}$ & $\begin{array}{c}8.765 \\
64769899 \\
3.729\end{array}$ & $\begin{array}{c}2.476 \\
11950972 \\
4.445\end{array}$ & $\begin{array}{c}31.027 \\
35102916 \\
38.811\end{array}$ \\
\hline & $\begin{array}{l}\text { Haredi (ultra- } \\
\text { Orthodox) } \\
\text { Labor }\end{array}$ & $\begin{array}{c}1.778 \\
0^{\mathrm{b}}\end{array}$ & .802 & 4.910 & 1 & .027 & 5.917 & 1.228 & 28.511 \\
\hline \multirow{5}{*}{$\begin{array}{l}\text { somewhat } \\
\text { against it }\end{array}$} & Intercept & -2.471 & .425 & 33.778 & 1 & .000 & & & \\
\hline & Revisionist & 3.770 & .778 & 23.495 & 1 & .000 & 43.389 & 9.447 & 199.276 \\
\hline & $\begin{array}{l}\text { Religious } \\
\text { Zionist }\end{array}$ & 21.793 & 1.008 & $\begin{array}{c}467.15 \\
0\end{array}$ & 1 & .000 & $\begin{array}{c}29146454 \\
71.925\end{array}$ & $\begin{array}{c}40394306 \\
9.020\end{array}$ & $\begin{array}{c}21030582 \\
967.087\end{array}$ \\
\hline & Haredi (ultra- & 3724 & & & 1 & & & & \\
\hline & Orthodox) & $\begin{array}{l}3.1 \angle 4 \\
0^{0}\end{array}$ & .900 & 10.835 & 1 & .000 & 41.411 & 0.993 & 245.202 \\
\hline \multirow{6}{*}{$\begin{array}{l}\text { very against } \\
\text { it }\end{array}$} & Intercept & -2.471 & .425 & 33.778 & 1 & .000 & & & \\
\hline & Revisionist & 4.508 & .747 & 36.445 & 1 & .000 & 90.722 & 20.995 & 392.019 \\
\hline & Religious & 21.505 & 1.049 & 420.43 & 1 & .000 & 21859841 & 27983323 & 17076336 \\
\hline & Zlonist & & & 6 & & & 03.834 & 3.937 & 627.316 \\
\hline & Orthodox) & 3.975 & .890 & 19.954 & 1 & .000 & 53.250 & 9.308 & 304.632 \\
\hline & Labor & $0^{\mathrm{b}}$ & & & 0 & & & & \\
\hline \multirow{5}{*}{6} & Intercept & -1.960 & .338 & 33.677 & 1 & .000 & & & \\
\hline & Revisionist & 1.555 & .973 & 2.551 & 1 & .110 & 4.733 & .703 & 31.892 \\
\hline & $\begin{array}{l}\text { Religious } \\
\text { Zionist }\end{array}$ & 20.589 & .000 & & 1 & & $\begin{array}{c}87439364 \\
1.577\end{array}$ & $\begin{array}{c}87439364 \\
1.577\end{array}$ & $\begin{array}{c}87439364 \\
1.577\end{array}$ \\
\hline & $\begin{array}{l}\text { Haredi (ultra- } \\
\text { Orthodox) }\end{array}$ & 2.876 & .902 & 10.163 & 1 & .001 & 17.750 & 3.028 & 104.042 \\
\hline & Labor & $0^{\mathrm{b}}$ & & & 0 & & & & \\
\hline
\end{tabular}


January 2000

Crosstabs

Movement * What is your opinion in regards to the agreement signed at Oslo between Israel and the PLO (Declaration of Principles)? Crosstabulation

\begin{tabular}{|c|c|c|c|c|c|c|c|}
\hline & \multicolumn{5}{|c|}{$\begin{array}{l}\text { What is your opinion in regards to the agreement signed at } \\
\text { Oslo between Israel and the PLO (Declaration of Principles)? }\end{array}$} \\
\hline & & & very for it & $\begin{array}{l}\text { somewhat } \\
\text { for it }\end{array}$ & $\begin{array}{l}\text { so-so, in } \\
\text { the middle }\end{array}$ & $\begin{array}{l}\text { somewhat } \\
\text { against it }\end{array}$ & $\begin{array}{l}\text { very } \\
\text { against it }\end{array}$ \\
\hline \multirow{4}{*}{$\begin{array}{l}\text { Moveme } \\
\text { nt }\end{array}$} & Revisionist & $\begin{array}{c}\text { Count } \\
\% \text { within } \\
\text { Movement }\end{array}$ & $\begin{array}{c}7 \\
7.5 \%\end{array}$ & $\begin{array}{c}13 \\
14.0 \%\end{array}$ & $\begin{array}{c}17 \\
18.3 \%\end{array}$ & $\begin{array}{c}13 \\
14.0 \%\end{array}$ & $\begin{array}{c}37 \\
39.8 \%\end{array}$ \\
\hline & $\begin{array}{l}\text { Religious } \\
\text { Zionist }\end{array}$ & $\begin{array}{c}\text { Count } \\
\% \text { within } \\
\text { Movement }\end{array}$ & $\begin{array}{c}0 \\
0.0 \%\end{array}$ & $\begin{array}{c}3 \\
27.3 \%\end{array}$ & $\begin{array}{c}1 \\
9.1 \%\end{array}$ & $\begin{array}{c}2 \\
18.2 \%\end{array}$ & $\begin{array}{c}5 \\
45.5 \%\end{array}$ \\
\hline & $\begin{array}{l}\text { Haredi (Ultra- } \\
\text { Orthodox) }\end{array}$ & $\begin{array}{c}\text { Count } \\
\% \text { within } \\
\text { Movement }\end{array}$ & $\begin{array}{c}3 \\
6.3 \%\end{array}$ & $\begin{array}{c}6 \\
12.5 \%\end{array}$ & $\begin{array}{c}10 \\
20.8 \%\end{array}$ & $\begin{array}{c}10 \\
20.8 \%\end{array}$ & $\begin{array}{c}12 \\
25.0 \%\end{array}$ \\
\hline & Labor & $\begin{array}{c}\text { Count } \\
\% \text { within } \\
\text { Movement }\end{array}$ & $\begin{array}{c}59 \\
33.1 \%\end{array}$ & $\begin{array}{c}59 \\
33.1 \%\end{array}$ & $\begin{array}{c}23 \\
12.9 \%\end{array}$ & $\begin{array}{c}6 \\
3.4 \%\end{array}$ & $\begin{array}{c}9 \\
5.1 \%\end{array}$ \\
\hline \multicolumn{2}{|r|}{ Total } & $\begin{array}{c}\text { Count } \\
\% \text { within } \\
\text { Movement }\end{array}$ & $\begin{array}{c}69 \\
20.9 \%\end{array}$ & $\begin{array}{c}81 \\
24.5 \%\end{array}$ & $\begin{array}{c}51 \\
15.5 \%\end{array}$ & $\begin{array}{c}31 \\
9.4 \%\end{array}$ & $\begin{array}{c}63 \\
19.1 \%\end{array}$ \\
\hline
\end{tabular}




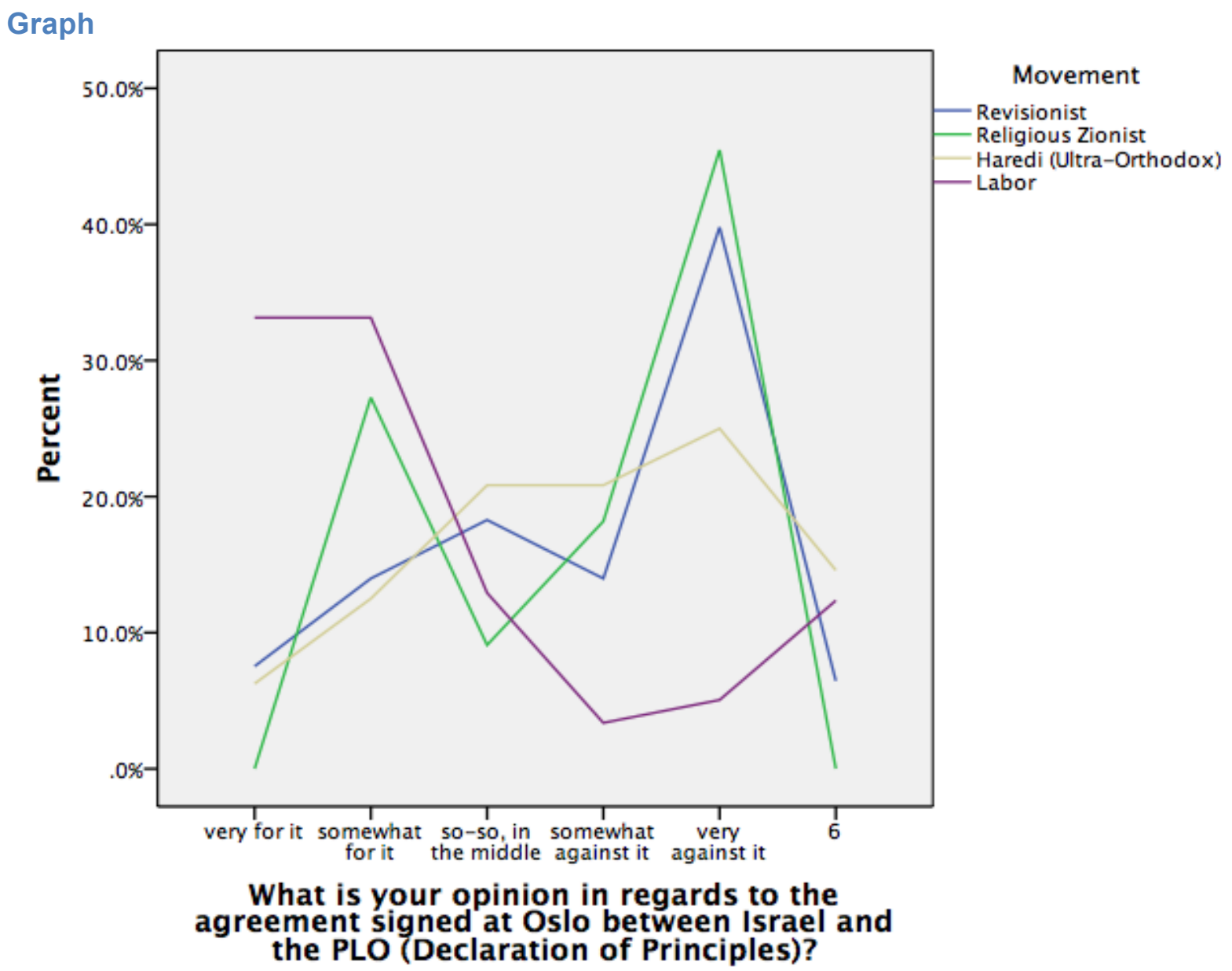

Nominal Regression

Model Fitting Information

\begin{tabular}{|l|r|r|r|r|}
\hline \multirow{2}{*}{ Model } & \multicolumn{1}{|c|}{$\begin{array}{c}\text { Model Fitting } \\
\text { Criteria }\end{array}$} & \multicolumn{3}{|c|}{ Likelihood Ratio Tests } \\
\cline { 2 - 5 } & $\begin{array}{c}-2 \text { Log } \\
\text { Likelihood }\end{array}$ & Chi-Square & df & \multicolumn{1}{c|}{ Sig. } \\
\hline Intercept Only & $\begin{array}{r}182.678 \\
66.733\end{array}$ & 115.946 & 15 & .000 \\
\hline
\end{tabular}

Goodness-of-Fit

\begin{tabular}{|l|r|r|r|}
\hline & Chi-Square & df & Sig. \\
\hline Pearson & .000 & 0 & \\
Deviance & .000 & 0 & \\
\hline
\end{tabular}

Likelihood Ratio Tests

\begin{tabular}{|l|r|r|r|r|}
\hline \multirow{2}{*}{} & \multicolumn{1}{|c|}{$\begin{array}{c}\text { Model Fitting } \\
\text { Criteria }\end{array}$} & \multicolumn{3}{|c|}{ Likelihood Ratio Tests } \\
\cline { 2 - 6 } & $\begin{array}{c}\text {-2 Log } \\
\text { Likelihood of } \\
\text { Reduced Model }\end{array}$ & Chi-Square & \multicolumn{1}{c|}{ df } & \multicolumn{1}{c|}{ Sig. } \\
\hline Intercept & $66.733^{\mathrm{a}}$ & .000 & 0 & \\
Movement & 182.678 & 115.946 & 15 & .000 \\
\hline
\end{tabular}


Parameter Estimates

\begin{tabular}{|c|c|c|c|c|c|c|c|c|c|}
\hline \multirow{2}{*}{\multicolumn{2}{|c|}{$\begin{array}{l}\text { What is your opinion in } \\
\text { regards to the agreement } \\
\text { signed at Oslo between } \\
\text { Israel and the PLO } \\
\text { (Declaration of } \\
\text { Principles)? }{ }^{\mathrm{a}}\end{array}$}} & \multirow[b]{2}{*}{ B } & \multirow[b]{2}{*}{$\begin{array}{l}\text { Std. } \\
\text { Error }\end{array}$} & \multirow[b]{2}{*}{ Wald } & \multirow[b]{2}{*}{$d f$} & \multirow[b]{2}{*}{ Sig. } & \multirow[b]{2}{*}{$\operatorname{Exp}(B)$} & \multicolumn{2}{|c|}{$\begin{array}{c}95 \% \text { Confidence } \\
\text { Interval for } \operatorname{Exp}(B)\end{array}$} \\
\hline & & & & & & & & $\begin{array}{l}\text { Lower } \\
\text { Bound }\end{array}$ & $\begin{array}{l}\text { Upper } \\
\text { Bound }\end{array}$ \\
\hline \multirow{5}{*}{$\begin{array}{l}\text { somewhat } \\
\text { for it }\end{array}$} & Intercept & .000 & .184 & .000 & 1 & 1.000 & & & \\
\hline & Revisionist & 619 & .504 & 1.511 & 1 & .219 & 1.857 & .692 & 4.984 \\
\hline & $\begin{array}{l}\text { Religious } \\
\text { Zionist }\end{array}$ & 19.743 & .813 & $\begin{array}{c}589.31 \\
9\end{array}$ & 1 & .000 & $\begin{array}{c}37507482 \\
6.535\end{array}$ & $\begin{array}{c}76184886 . \\
415\end{array}$ & $\begin{array}{c}18465752 \\
47.662\end{array}$ \\
\hline & $\begin{array}{l}\text { Haredi (ultra- } \\
\text { Orthodox) } \\
\end{array}$ & 693 & .731 & .900 & 1 & .343 & 2.000 & .478 & 8.375 \\
\hline & Labor & $0^{\mathrm{b}}$ & & & 0 & & & & \\
\hline \multirow{3}{*}{$\begin{array}{l}\text { so-so, in the } \\
\text { middle }\end{array}$} & Intercept & -.942 & .246 & 14.686 & 1 & .000 & & & \\
\hline & $\begin{array}{l}\text { Revisionist } \\
\text { Religious } \\
\text { Zionist }\end{array}$ & \begin{tabular}{|l|}
1.829 \\
19.586
\end{tabular} & $\begin{array}{l}.512 \\
1.164\end{array}$ & $\begin{array}{c}12.768 \\
283.19 \\
6\end{array}$ & $\begin{array}{l}1 \\
1\end{array}$ & $\begin{array}{l}.000 \\
.000\end{array}$ & $\begin{array}{c}6.230 \\
32071615 \\
6.022\end{array}$ & $\begin{array}{c}2.284 \\
32766825 . \\
050\end{array}$ & $\begin{array}{c}16.993 \\
31391156 \\
32.252\end{array}$ \\
\hline & $\begin{array}{l}\text { Haredi (ultra- } \\
\text { Orthodox) } \\
\text { Labor }\end{array}$ & $\begin{array}{c}2.146 \\
0^{\mathrm{b}}\end{array}$ & .703 & 9.327 & 1 & .002 & 8.551 & 2.157 & 33.894 \\
\hline \multirow{6}{*}{$\begin{array}{l}\text { somewhat } \\
\text { against it }\end{array}$} & Intercept & -2.286 & .429 & 28.455 & 1 & .000 & & & \\
\hline & Revisionist & 2.905 & .635 & 20.917 & 1 & .000 & 18.262 & 5.259 & 63.412 \\
\hline & $\begin{array}{l}\text { Religious } \\
\text { Zionist }\end{array}$ & 21.623 & .989 & $\begin{array}{c}478.17 \\
8\end{array}$ & 1 & .000 & $\begin{array}{c}24588238 \\
62.838\end{array}$ & $\begin{array}{c}35402734 \\
3.687\end{array}$ & $\begin{array}{c}17077253 \\
766.615\end{array}$ \\
\hline & Haredi (ultra- & 3490 & & & & & & & \\
\hline & Orthodox) & 3.490 & .185 & 19.140 & 1 & .000 & 32.118 & 1.031 & 152.815 \\
\hline & Labor & $0^{\mathrm{b}}$ & & & 0 & & & & \\
\hline \multirow{6}{*}{$\begin{array}{c}\text { very against } \\
\text { it }\end{array}$} & Intercept & -1.880 & .358 & 27.609 & 1 & .000 & & & \\
\hline & Revisionist & 3.545 & .546 & 42.187 & 1 & .000 & 34.651 & 11.888 & 101.003 \\
\hline & $\begin{array}{c}\text { Religious } \\
\text { Zionist }\end{array}$ & 22.134 & .000 & & 1 & & $\begin{array}{c}40980397 \\
71.311\end{array}$ & $\begin{array}{c}40980397 \\
71.311\end{array}$ & $\begin{array}{c}40980397 \\
71.311\end{array}$ \\
\hline & Haredi (ultra- & 2267 & & & & & & & \\
\hline & Orthodox) & 3.267 & .738 & 19.589 & 1 & .000 & 26.222 & 6.172 & 111.405 \\
\hline & Labor & $0^{\mathrm{b}}$ & & & 0 & & & & \\
\hline \multirow{5}{*}{6} & Intercept & -.986 & .250 & 15.595 & 1 & .000 & & & \\
\hline & Revisionist & .832 & .610 & 1.863 & 1 & .172 & 2.299 & .696 & 7.596 \\
\hline & $\begin{array}{l}\text { Religious } \\
\text { Zionist }\end{array}$ & 308 & .000 & & 1 & & 1.360 & 1.360 & 1.360 \\
\hline & $\begin{array}{l}\text { Haredi (ultra- } \\
\text { Orthodox) }\end{array}$ & 1.834 & .734 & 6.244 & 1 & .012 & 6.258 & 1.485 & 26.369 \\
\hline & Labor & $0^{\mathrm{b}}$ & & & 0 & & & & \\
\hline
\end{tabular}


July 2000

Crosstabs

Movement * What is your opinion in regards to the agreement signed at Oslo between Israel and the PLO (Declaration of Principles)? Crosstabulation

\begin{tabular}{|c|c|c|c|c|c|c|c|}
\hline & \multicolumn{5}{|c|}{$\begin{array}{l}\text { What is your opinion in regards to the agreement signed at } \\
\text { Oslo between Israel and the PLO (Declaration of Principles)? }\end{array}$} \\
\hline & & & very for it & $\begin{array}{l}\text { somewhat } \\
\text { for it }\end{array}$ & $\begin{array}{l}\text { so-so, in } \\
\text { the middle }\end{array}$ & $\begin{array}{l}\text { somewhat } \\
\text { against it }\end{array}$ & $\begin{array}{l}\text { very } \\
\text { against it }\end{array}$ \\
\hline \multirow{4}{*}{$\begin{array}{l}\text { Moveme } \\
\text { nt }\end{array}$} & Revisionist & $\begin{array}{c}\text { Count } \\
\% \text { within } \\
\text { Movement }\end{array}$ & $\begin{array}{c}4 \\
3.6 \%\end{array}$ & $\begin{array}{c}9 \\
8.2 \%\end{array}$ & $\begin{array}{c}20 \\
18.2 \%\end{array}$ & $\begin{array}{c}35 \\
31.8 \%\end{array}$ & $\begin{array}{c}31 \\
28.2 \%\end{array}$ \\
\hline & $\begin{array}{l}\text { Religious } \\
\text { Zionist }\end{array}$ & $\begin{array}{c}\text { Count } \\
\% \text { within } \\
\text { Movement }\end{array}$ & $\begin{array}{c}0 \\
0.0 \%\end{array}$ & $\begin{array}{c}5 \\
26.3 \%\end{array}$ & $\begin{array}{c}5 \\
26.3 \%\end{array}$ & $\begin{array}{c}3 \\
15.8 \%\end{array}$ & $\begin{array}{c}6 \\
31.6 \%\end{array}$ \\
\hline & $\begin{array}{l}\text { Haredi (Ultra- } \\
\text { Orthodox) }\end{array}$ & $\begin{array}{c}\text { Count } \\
\% \text { within } \\
\text { Movement }\end{array}$ & $\begin{array}{c}1 \\
2.4 \%\end{array}$ & $\begin{array}{c}5 \\
11.9 \%\end{array}$ & $\begin{array}{c}6 \\
14.3 \%\end{array}$ & $\begin{array}{c}12 \\
28.6 \%\end{array}$ & $\begin{array}{c}18 \\
42.9 \%\end{array}$ \\
\hline & Labor & $\begin{array}{c}\text { Count } \\
\% \text { within } \\
\text { Movement }\end{array}$ & $\begin{array}{c}53 \\
26.4 \%\end{array}$ & $\begin{array}{c}76 \\
37.8 \%\end{array}$ & $\begin{array}{c}32 \\
15.9 \%\end{array}$ & $\begin{array}{c}14 \\
7.0 \%\end{array}$ & $\begin{array}{c}10 \\
5.0 \%\end{array}$ \\
\hline \multicolumn{2}{|r|}{ Total } & $\begin{array}{c}\text { Count } \\
\% \text { within } \\
\text { Movement }\end{array}$ & $\begin{array}{c}58 \\
15.6 \%\end{array}$ & $\begin{array}{c}95 \\
25.5 \%\end{array}$ & $\begin{array}{c}63 \\
16.9 \%\end{array}$ & $\begin{array}{c}64 \\
17.2 \%\end{array}$ & $\begin{array}{c}65 \\
17.5 \%\end{array}$ \\
\hline
\end{tabular}




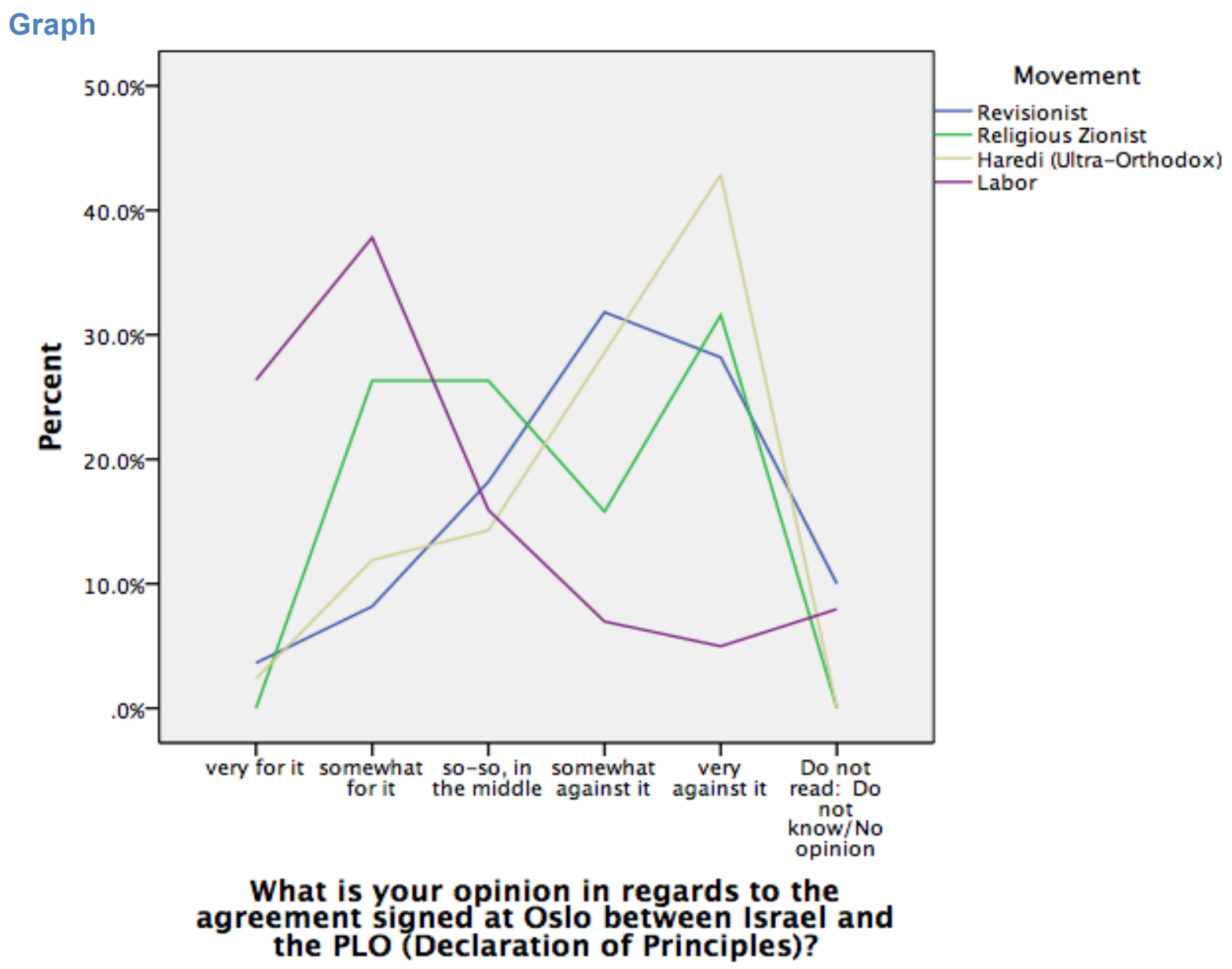

Nominal Regression

Model Fitting Information

\begin{tabular}{|l|r|r|r|r|}
\hline \multirow{2}{*}{ Model } & \multicolumn{1}{|c|}{$\begin{array}{c}\text { Model Fitting } \\
\text { Criteria }\end{array}$} & \multicolumn{3}{|c|}{ Likelihood Ratio Tests } \\
\cline { 2 - 5 } & $\begin{array}{r}\text {-2 Log } \\
\text { Likelihood }\end{array}$ & Chi-Square & df & \multicolumn{1}{c|}{ Sig. } \\
\hline $\begin{array}{l}\text { Intercept Only } \\
\text { Final }\end{array}$ & $\begin{array}{r}222.090 \\
65.415\end{array}$ & 156.675 & 15 & .000 \\
\hline
\end{tabular}

Goodness-of-Fit

\begin{tabular}{|c|c|c|c|}
\hline & Chi-Square & $\mathrm{df}$ & Sig. \\
\hline Pearson & .000 & $\begin{array}{l}0 \\
0\end{array}$ & \\
\hline
\end{tabular}

\section{Likelihood Ratio Tests}

\begin{tabular}{|l|r|r|r|r|}
\hline \multirow{2}{*}{} & \multicolumn{1}{|c|}{$\begin{array}{c}\text { Model Fitting } \\
\text { Criteria }\end{array}$} & \multicolumn{3}{|c|}{ Likelihood Ratio Tests } \\
\cline { 2 - 6 } & $\begin{array}{c}\text {-2 Log } \\
\text { Likelihood of } \\
\text { Redfect }\end{array}$ & & & \\
\hline Intercept & $65.415^{a}$ & Chi-Square & df & \multicolumn{1}{c|}{ Sig. } \\
Movement & 222.090 & 156.675 & 0 & .000 \\
\hline
\end{tabular}


Parameter Estimates

\begin{tabular}{|c|c|c|c|c|c|c|c|c|c|}
\hline \multirow{2}{*}{\multicolumn{2}{|c|}{$\begin{array}{l}\text { What is your opinion in } \\
\text { regards to the agreement } \\
\text { signed at Oslo between } \\
\text { Israel and the PLO } \\
\text { (Declaration of } \\
\text { Principles)? }\end{array}$}} & \multirow[b]{2}{*}{ B } & \multirow[b]{2}{*}{$\begin{array}{l}\text { Std. } \\
\text { Error }\end{array}$} & \multirow[b]{2}{*}{ Wald } & \multirow[b]{2}{*}{$d f$} & \multirow[b]{2}{*}{ Sig. } & \multirow[b]{2}{*}{$\operatorname{Exp}(B)$} & \multicolumn{2}{|c|}{$\begin{array}{l}\text { 95\% Confidence } \\
\text { Interval for } \operatorname{Exp}(B)\end{array}$} \\
\hline & & & & & & & & $\begin{array}{l}\text { Lower } \\
\text { Bound }\end{array}$ & $\begin{array}{l}\text { Upper } \\
\text { Bound }\end{array}$ \\
\hline \multirow{5}{*}{$\begin{array}{l}\text { somewhat } \\
\text { for it }\end{array}$} & Intercept & 360 & 179 & 4.057 & 1 & .044 & & & \\
\hline & Revisionist & .450 & 627 & .516 & 1 & .472 & 1.569 & .459 & 5.362 \\
\hline & $\begin{array}{c}\text { Religious } \\
\text { Zionist }\end{array}$ & 19.387 & .693 & $\begin{array}{c}783.29 \\
4\end{array}$ & 1 & .000 & $\begin{array}{l}26274325 \\
5.794\end{array}$ & $\begin{array}{c}67594231 \\
.032\end{array}$ & $\begin{array}{c}10213004 \\
48.451\end{array}$ \\
\hline & $\begin{array}{l}\text { Haredi (ultra- } \\
\text { Orthodox) }\end{array}$ & 1.249 & 1.110 & 1.266 & 1 & .260 & 3.487 & .396 & 30.707 \\
\hline & Labor & $0^{\mathrm{b}}$ & & & 0 & & & . & \\
\hline \multirow{4}{*}{$\begin{array}{l}\text { so-so, in the } \\
\text { middle }\end{array}$} & Intercept & -.505 & .224 & 5.080 & 1 & .024 & & & \\
\hline & Revisionist & 2.114 & .592 & 12.764 & 1 & .000 & 8.281 & 2.597 & 26.409 \\
\hline & $\begin{array}{l}\text { Religious } \\
\text { Zionist } \\
\end{array}$ & 20.252 & .706 & $\begin{array}{c}823.69 \\
4 \\
\end{array}$ & 1 & .000 & $\begin{array}{c}62401523 \\
2.512 \\
\end{array}$ & $\begin{array}{c}15651647 \\
4.016\end{array}$ & $\begin{array}{c}24878851 \\
43.432\end{array}$ \\
\hline & $\begin{array}{l}\text { Haredi (ultra- } \\
\text { Orthodox) } \\
\text { Labor }\end{array}$ & $\begin{array}{c}2.296 \\
0^{\mathrm{b}}\end{array}$ & 1.103 & 4.334 & $\begin{array}{l}1 \\
0\end{array}$ & .037 & 9.937 & 1.144 & 86.342 \\
\hline \multirow{5}{*}{$\begin{array}{l}\text { somewhat } \\
\text { against it }\end{array}$} & Intercept & -1.331 & 300 & 19.626 & 1 & .000 & & & \\
\hline & Revisionist & 3.500 & 607 & 33.215 & 1 & .000 & 33.125 & 10.074 & 108.925 \\
\hline & $\begin{array}{l}\text { Religious } \\
\text { Zionist }\end{array}$ & 20.568 & .819 & $\begin{array}{c}630.03 \\
5\end{array}$ & 1 & .000 & $\begin{array}{c}85579231 \\
8.873\end{array}$ & $\begin{array}{c}17174634 \\
2.636\end{array}$ & $\begin{array}{c}42643149 \\
29.815\end{array}$ \\
\hline & $\begin{array}{l}\text { Haredi (ultra- } \\
\text { Orthodox) }\end{array}$ & 3.816 & 1.083 & 12.408 & 1 & & & & \\
\hline & Labor & $0^{\mathrm{D}}$ & & & 0 & & & & \\
\hline \multirow{5}{*}{$\begin{array}{c}\text { very against } \\
\text { it }\end{array}$} & Intercept & \begin{tabular}{|l|}
-1.668 \\
\end{tabular} & .345 & 23.398 & 1 & .000 & & & \\
\hline & Revisionist & 3.715 & .633 & 34.414 & 1 & .000 & 41.075 & 11.871 & 142.129 \\
\hline & $\begin{array}{l}\text { Religious } \\
\text { Zionist }\end{array}$ & 21.597 & .000 & . & 1 & . & $\begin{array}{c}23962184 \\
92.842\end{array}$ & $\begin{array}{c}23962184 \\
92.842\end{array}$ & $\begin{array}{c}23962184 \\
92.842\end{array}$ \\
\hline & Haredi (ultra- & 4558 & & & & & & & \\
\hline & $\begin{array}{l}\text { Orthodox) } \\
\text { Labor }\end{array}$ & $\begin{array}{c}4.558 \\
0^{\mathrm{b}}\end{array}$ & 1.084 & 17.690 & $\begin{array}{l}1 \\
0\end{array}$ & .000 & 95.400 & 11.405 & 797.999 \\
\hline \multirow{5}{*}{$\begin{array}{c}\text { Do not read: } \\
\text { Do not } \\
\text { know/No } \\
\text { opinion }\end{array}$} & Intercept & -1.198 & 285 & 17.630 & 1 & .000 & & & \\
\hline & Revisionist & 2.209 & 650 & 11.559 & 1 & .001 & 9.109 & 2.549 & 32.555 \\
\hline & $\begin{array}{l}\text { Religious } \\
\text { Zionist }\end{array}$ & .433 & .000 & & 1 & . & 1.542 & 1.542 & 1.542 \\
\hline & Haredi (ultra- & $17 \overline{114}$ & 9468.43 & .000 & 1 & .999 & 3.695E-8 & .000 &.$^{c}$ \\
\hline & Labor & $0^{\mathrm{b}}$ & & & 0 & & & & \\
\hline
\end{tabular}


January 2001

Crosstabs

Movement * What is your opinion in regards to the agreement signed at Oslo between Israel and the PLO (Declaration of Principles)? Crosstabulation

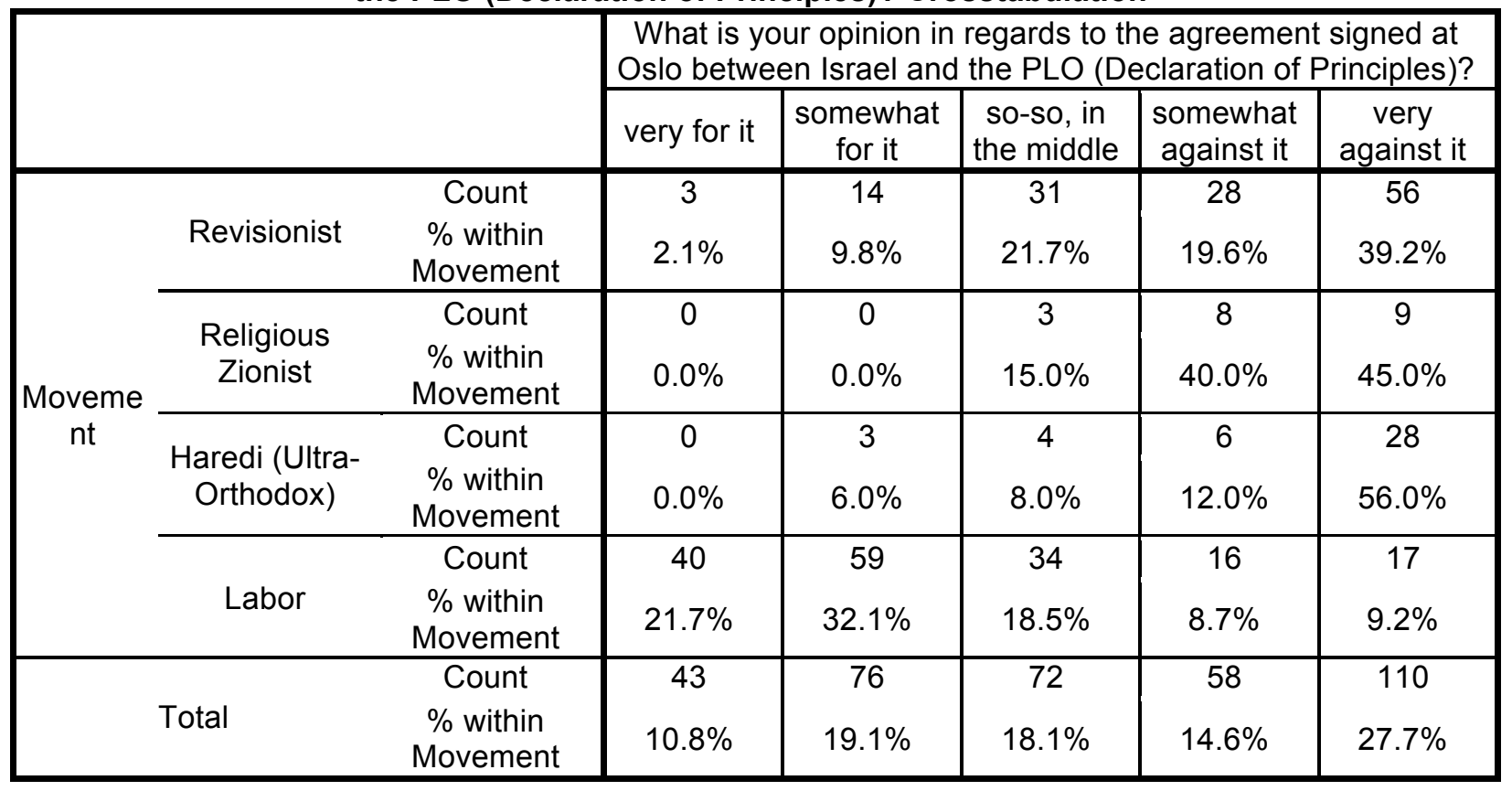




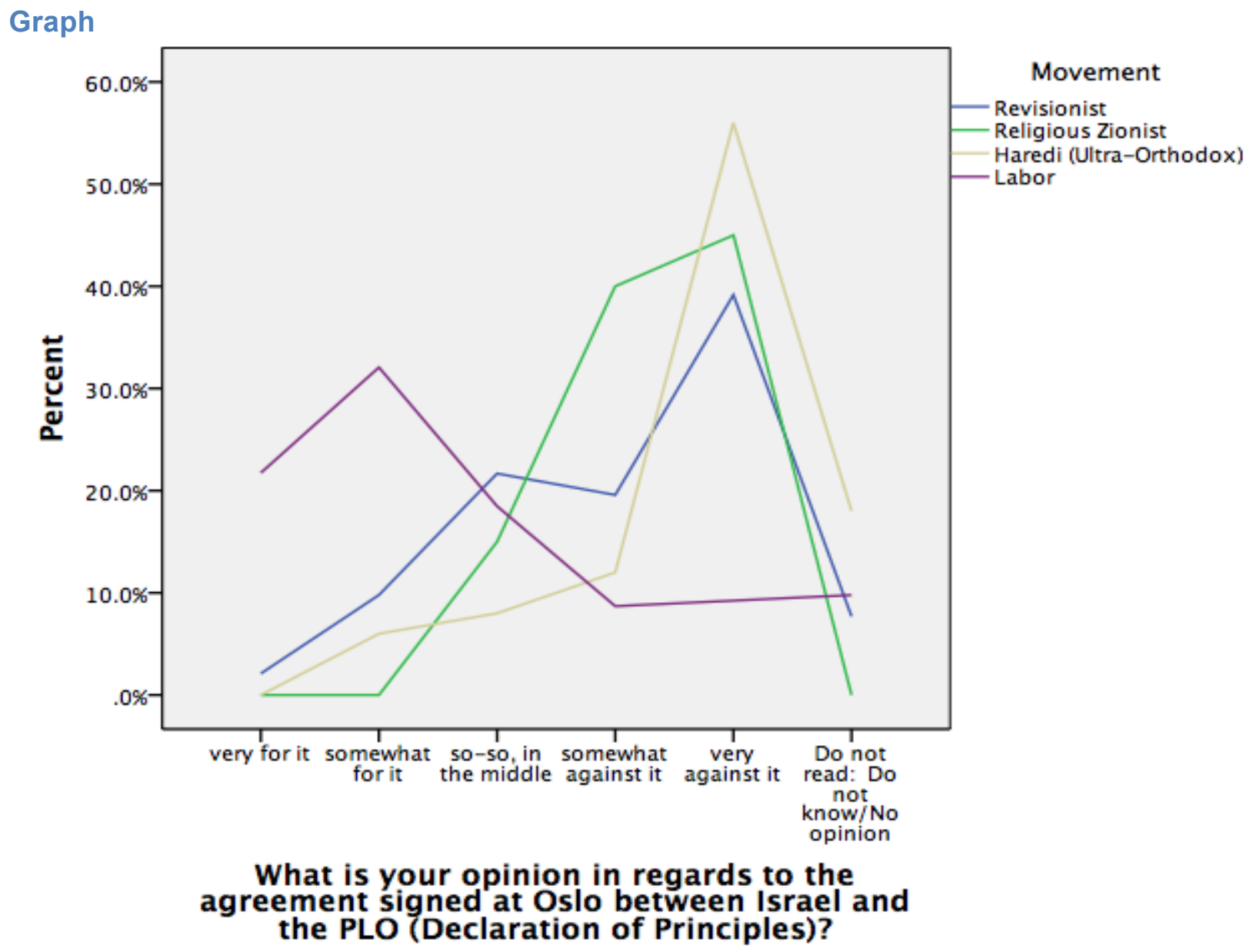

Nominal Regression

Model Fitting Information

\begin{tabular}{|c|c|c|c|c|}
\hline \multirow[b]{2}{*}{ Model } & \multirow{2}{*}{$\begin{array}{c}\text { Model Fitting } \\
\text { Criteria } \\
-2 \text { Log } \\
\text { Likelihood }\end{array}$} & \multicolumn{3}{|c|}{ Likelihood Ratio Tests } \\
\hline & & Chi-Square & $d f$ & Sig. \\
\hline $\begin{array}{l}\text { Intercept Only } \\
\text { Final }\end{array}$ & $\begin{array}{r}220.678 \\
64.586\end{array}$ & 156.092 & 15 & .000 \\
\hline
\end{tabular}

Goodness-of-Fit

\begin{tabular}{|l|r|r|r|}
\hline & Chi-Square & df & Sig. \\
\hline Pearson & .000 & 0 & \\
Deviance & .000 & 0 &. \\
\hline
\end{tabular}

\section{Likelihood Ratio Tests}

\begin{tabular}{|l|r|r|r|r|}
\hline \multirow{2}{*}{} & \multicolumn{1}{|c|}{$\begin{array}{c}\text { Model Fitting } \\
\text { Criteria }\end{array}$} & \multicolumn{3}{|c|}{ Likelihood Ratio Tests } \\
\cline { 2 - 5 } & $\begin{array}{c}-2 \text { Log } \\
\text { Likelihood of } \\
\text { Reduced Model }\end{array}$ & & & \\
Chi-Square & df & \multicolumn{1}{c|}{ Sig. } \\
\hline Intercept & $64.586^{\mathrm{a}}$ & .000 & 0 & \\
Movement & 220.678 & 156.092 & 15 & .000 \\
\hline
\end{tabular}


Parameter Estimates

\begin{tabular}{|c|c|c|c|c|c|c|c|c|c|}
\hline \multirow{2}{*}{\multicolumn{2}{|c|}{$\begin{array}{l}\text { What is your opinion in } \\
\text { regards to the agreement } \\
\text { signed at Oslo between } \\
\text { Israel and the PLO } \\
\text { (Declaration of } \\
\text { Principles)? }\end{array}$}} & \multirow[b]{2}{*}{ B } & \multirow[b]{2}{*}{$\begin{array}{l}\text { Std. } \\
\text { Error }\end{array}$} & \multirow[b]{2}{*}{ Wald } & \multirow[b]{2}{*}{ df } & \multirow[b]{2}{*}{ Sig. } & \multirow[b]{2}{*}{$\operatorname{Exp}(B)$} & \multicolumn{2}{|c|}{$\begin{array}{l}95 \% \text { Confidence } \\
\text { Interval for } \operatorname{Exp}(B)\end{array}$} \\
\hline & & & & & & & & $\begin{array}{l}\text { Lower } \\
\text { Bound }\end{array}$ & $\begin{array}{l}\text { Upper } \\
\text { Bound }\end{array}$ \\
\hline \multirow{5}{*}{$\begin{array}{l}\text { somewhat } \\
\text { for it }\end{array}$} & Intercept & .389 & .205 & 3.601 & 1 & .058 & & & \\
\hline & Revisionist & 1.152 & 668 & 2.970 & 1 & .085 & 3.164 & .854 & 11.725 \\
\hline & $\begin{array}{c}\text { Religious } \\
\text { Zionist }\end{array}$ & 181 & $\begin{array}{c}5620.13 \\
8\end{array}$ & .000 & 1 & 1.000 & 1.198 & .000 & \\
\hline & $\begin{array}{l}\text { Haredi (ultra- } \\
\text { Orthodox) }\end{array}$ & 17.354 & .719 & 582.552 & 1 & .000 & $\begin{array}{c}34403585 \\
.380\end{array}$ & $\begin{array}{c}8406143 . \\
686\end{array}$ & $\begin{array}{c}14080257 \\
6.217\end{array}$ \\
\hline & Labor & $0^{c}$ & & & 0 & & & & \\
\hline \multirow{5}{*}{$\begin{array}{l}\text { so-so, in the } \\
\text { middle }\end{array}$} & Intercept & -.163 & .233 & 485 & 1 & .486 & & & \\
\hline & Revisionist & 2.498 & .648 & 14.856 & 1 & .000 & 12.157 & 3.413 & 43.298 \\
\hline & $\begin{array}{l}\text { Religious } \\
\text { Zionist }\end{array}$ & 19.099 & .730 & 684.778 & 1 & .000 & $\begin{array}{c}19703410 \\
3.330\end{array}$ & $\begin{array}{c}47129486 \\
.039\end{array}$ & $\begin{array}{c}82373989 \\
4.871\end{array}$ \\
\hline & $\begin{array}{l}\text { Haredi (ultra- } \\
\text { Orthodox) }\end{array}$ & 18.193 & .668 & 741.951 & 1 & .000 & $\begin{array}{c}79600452 \\
.448\end{array}$ & $\begin{array}{c}21498376 \\
.254\end{array}$ & $\begin{array}{c}29473072 \\
5.475\end{array}$ \\
\hline & Labor & $0^{c}$ & & & 0 & & & & \\
\hline \multirow{6}{*}{$\begin{array}{l}\text { somewhat } \\
\text { against it }\end{array}$} & Intercept & -.916 & .296 & 9.595 & 1 & .002 & & & \\
\hline & Revisionist & 3.150 & .676 & 21.732 & 1 & .000 & 23.333 & 6.206 & 87.724 \\
\hline & $\begin{array}{l}\text { Religious } \\
\text { Zionist }\end{array}$ & 20.833 & .598 & $\begin{array}{c}1214.30 \\
4\end{array}$ & 1 & .000 & $\begin{array}{c}11165265 \\
85.537\end{array}$ & $\begin{array}{c}34591635 \\
3.424\end{array}$ & $\begin{array}{c}36038527 \\
92.362\end{array}$ \\
\hline & Haredi (ultra- & 19352 & & & 1 & & 25372644 & 73931554 & 87076631 \\
\hline & Orthodox) & |19.352 & .029 & 946.082 & 1 & .000 & 2.179 & .367 & 9.096 \\
\hline & Labor & $0^{c}$ & & & 0 & & & & \\
\hline \multirow{6}{*}{$\begin{array}{c}\text { very against } \\
\text { it }\end{array}$} & Intercept & -.856 & .290 & 8.735 & 1 & .003 & & & \\
\hline & Revisionist & 3.782 & .660 & 32.888 & 1 & .000 & 43.922 & 12.058 & 159.990 \\
\hline & $\begin{array}{l}\text { Religious } \\
\text { Zionist }\end{array}$ & 20.891 & .000 & 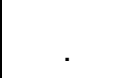 & 1 & . & $\begin{array}{c}11822046 \\
19981\end{array}$ & $\begin{array}{c}11822046 \\
19981\end{array}$ & $\begin{array}{c}11822046 \\
19981\end{array}$ \\
\hline & Haredi (ultra- & (20 & & 1661.36 & & & 11144063 & 40927013 & 30344297 \\
\hline & Orthodox) & 20.832 & .511 & 1 & 1 & .000 & 34.278 & 9.985 & 23.908 \\
\hline & Labor & $0^{c}$ & & & 0 & & & & \\
\hline \multirow{5}{*}{$\begin{array}{l}\text { Do not read: } \\
\text { Do not } \\
\text { know/No } \\
\text { opinion }\end{array}$} & Intercept & -.799 & .284 & 7.915 & 1 & .005 & & & \\
\hline & Revisionist & 2.098 & .710 & 8.718 & 1 & .003 & 8.148 & 2.024 & 32.797 \\
\hline & $\begin{array}{l}\text { Religious } \\
\text { Zionist }\end{array}$ & .675 & $\begin{array}{c}7948.07 \\
5\end{array}$ & .000 & 1 & 1.000 & 1.964 & .000 & b \\
\hline & Haredi (ultra- & 19.639 & 000 & & 1 & & 33830192 & 33830192 & 33830192 \\
\hline & $\begin{array}{c}\text { Orthodox) } \\
\text { Labor }\end{array}$ & $0^{c}$ & & & 0 & & 20 & 2.906 & 2.906 \\
\hline
\end{tabular}


July 2001

Crosstabs

Movement * What is your opinion in regards to the agreement signed at Oslo between Israel and the PLO (Declaration of Principles)? Crosstabulation

\begin{tabular}{|c|c|c|c|c|c|c|c|}
\hline & \multicolumn{5}{|c|}{$\begin{array}{l}\text { What is your opinion in regards to the agreement signed at } \\
\text { Oslo between Israel and the PLO (Declaration of Principles)? }\end{array}$} \\
\hline & & & very for it & $\begin{array}{l}\text { somewhat } \\
\text { for it }\end{array}$ & $\begin{array}{l}\text { so-so, in } \\
\text { the middle }\end{array}$ & $\begin{array}{l}\text { somewhat } \\
\text { against it }\end{array}$ & $\begin{array}{l}\text { very } \\
\text { against it }\end{array}$ \\
\hline \multirow{4}{*}{$\begin{array}{l}\text { Moveme } \\
\text { nt }\end{array}$} & Revisionist & $\begin{array}{c}\text { Count } \\
\% \text { within } \\
\text { Movement }\end{array}$ & $\begin{array}{c}5 \\
3.0 \%\end{array}$ & $\begin{array}{c}18 \\
11.0 \%\end{array}$ & $\begin{array}{c}16 \\
9.8 \%\end{array}$ & $\begin{array}{c}21 \\
12.8 \%\end{array}$ & $\begin{array}{c}90 \\
54.9 \%\end{array}$ \\
\hline & $\begin{array}{l}\text { Religious } \\
\text { Zionist }\end{array}$ & $\begin{array}{c}\text { Count } \\
\% \text { within } \\
\text { Movement }\end{array}$ & $\begin{array}{c}0 \\
0.0 \%\end{array}$ & $\begin{array}{c}0 \\
0.0 \%\end{array}$ & $\begin{array}{c}1 \\
7.1 \%\end{array}$ & $\begin{array}{c}1 \\
7.1 \%\end{array}$ & $\begin{array}{c}11 \\
78.6 \%\end{array}$ \\
\hline & $\begin{array}{l}\text { Haredi (Ultra- } \\
\text { Orthodox) }\end{array}$ & $\begin{array}{c}\text { Count } \\
\% \text { within } \\
\text { Movement }\end{array}$ & $\begin{array}{c}0 \\
0.0 \%\end{array}$ & $\begin{array}{c}0 \\
0.0 \%\end{array}$ & $\begin{array}{c}3 \\
13.0 \%\end{array}$ & $\begin{array}{c}1 \\
4.3 \%\end{array}$ & $\begin{array}{c}17 \\
73.9 \%\end{array}$ \\
\hline & Labor & $\begin{array}{c}\text { Count } \\
\% \text { within } \\
\text { Movement }\end{array}$ & $\begin{array}{c}29 \\
17.8 \%\end{array}$ & $\begin{array}{c}55 \\
33.7 \%\end{array}$ & $\begin{array}{c}26 \\
16.0 \%\end{array}$ & $\begin{array}{c}15 \\
9.2 \%\end{array}$ & $\begin{array}{c}22 \\
13.5 \%\end{array}$ \\
\hline \multicolumn{2}{|r|}{ Total } & $\begin{array}{c}\text { Count } \\
\% \text { within } \\
\text { Movement }\end{array}$ & $\begin{array}{c}34 \\
9.3 \%\end{array}$ & $\begin{array}{c}73 \\
20.1 \%\end{array}$ & $\begin{array}{c}46 \\
12.6 \%\end{array}$ & $\begin{array}{c}38 \\
10.4 \%\end{array}$ & $\begin{array}{c}140 \\
38.5 \%\end{array}$ \\
\hline
\end{tabular}




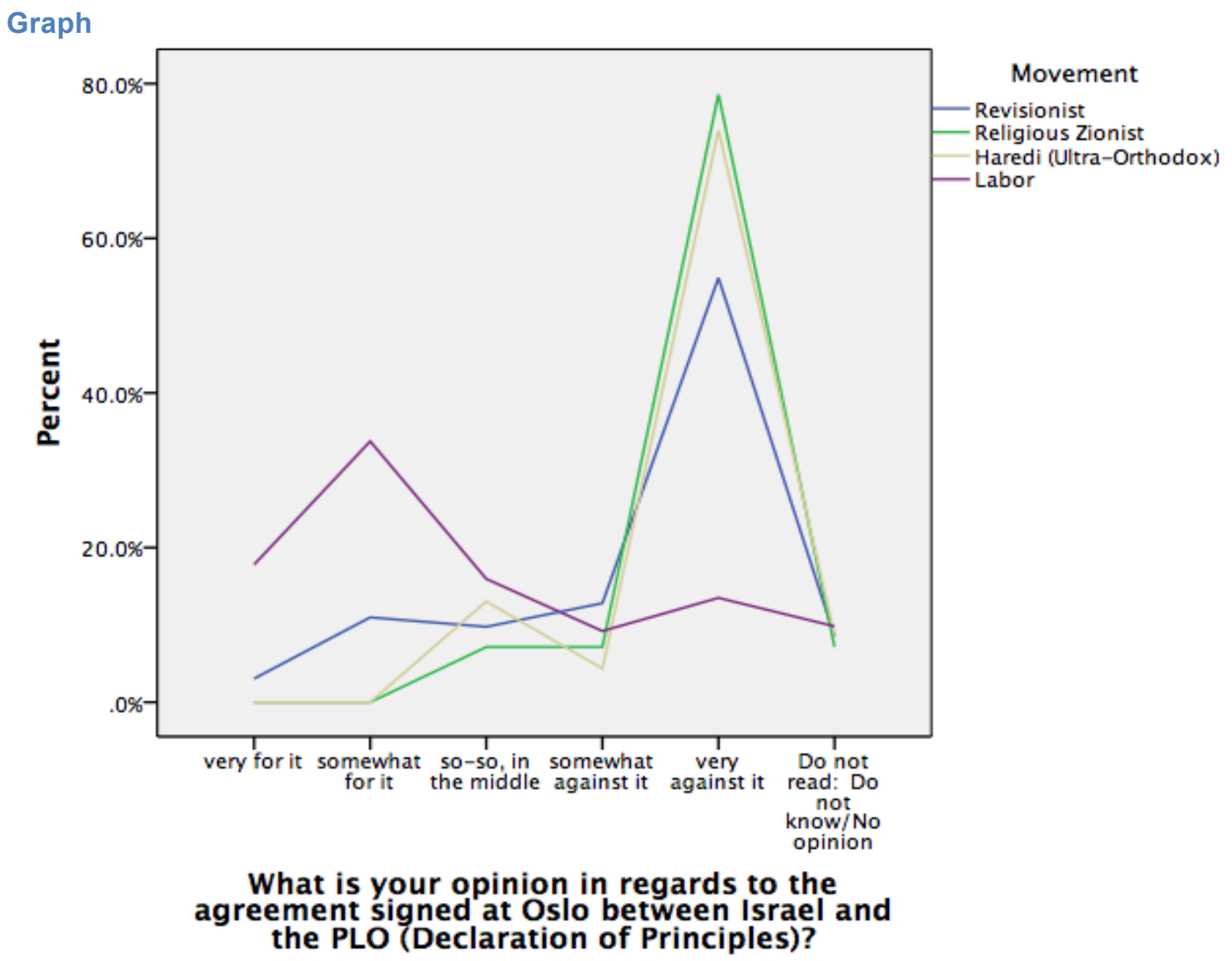

Nominal Regression

Model Fitting Information

\begin{tabular}{|l|r|r|r|r|}
\hline \multirow{2}{*}{ Model } & \multicolumn{1}{|c|}{$\begin{array}{c}\text { Model Fitting } \\
\text { Criteria }\end{array}$} & \multicolumn{3}{|c|}{ Likelihood Ratio Tests } \\
\cline { 2 - 5 } & $\begin{array}{c}-2 \text { Log } \\
\text { Likelihood }\end{array}$ & Chi-Square & df & \multicolumn{1}{c|}{ Sig. } \\
\hline Intercept Only & $\begin{array}{r}180.941 \\
\text { Final }\end{array}$ & 122.911 & 15 & .000 \\
\hline
\end{tabular}

Goodness-of-Fit

\begin{tabular}{|l|r|r|r|}
\hline & Chi-Square & \multicolumn{1}{c|}{ df } & Sig. \\
\hline Pearson & .000 & 0 & \\
Deviance & .000 & 0 &. \\
\hline
\end{tabular}

\section{Likelihood Ratio Tests}

\begin{tabular}{|l|r|r|r|r|}
\hline \multirow{2}{*}{} & \multicolumn{1}{|c|}{$\begin{array}{c}\text { Model Fitting } \\
\text { Criteria }\end{array}$} & \multicolumn{3}{|c|}{ Likelihood Ratio Tests } \\
\cline { 2 - 6 } & $\begin{array}{c}-2 \text { Log } \\
\text { Likelihood of } \\
\text { Reduced Model }\end{array}$ & Chi-Square & df & \multicolumn{1}{c|}{ Sig. } \\
\hline Intercept & $58.030^{\circ}$ & .000 & 0 & \\
Movement & 180.941 & 122.911 & 15 & .000 \\
\hline
\end{tabular}


Parameter Estimates

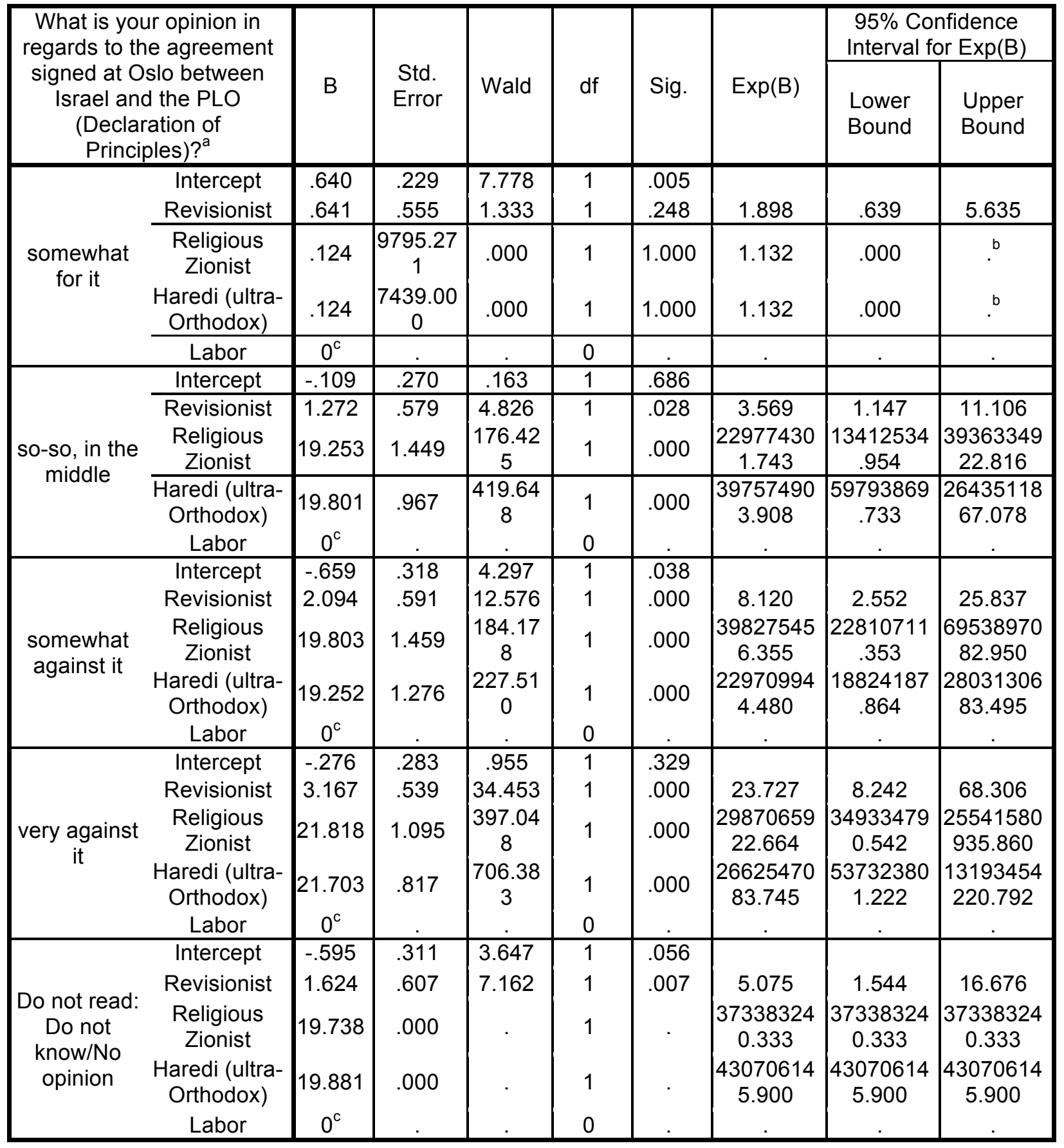


January 2002

Crosstabs

Movement * What is your opinion in regards to the agreement signed at Oslo between Israel and the PLO (Declaration of Principles)? Crosstabulation

\begin{tabular}{|c|c|c|c|c|c|c|c|}
\hline & \multicolumn{5}{|c|}{$\begin{array}{l}\text { What is your opinion in regards to the agreement signed at } \\
\text { Oslo between Israel and the PLO (Declaration of Principles)? }\end{array}$} \\
\hline & & & very for it & $\begin{array}{l}\text { somewhat } \\
\text { for it }\end{array}$ & $\begin{array}{l}\text { so-so, in } \\
\text { the middle }\end{array}$ & $\begin{array}{l}\text { somewhat } \\
\text { against it }\end{array}$ & $\begin{array}{l}\text { very } \\
\text { against it }\end{array}$ \\
\hline \multirow{4}{*}{$\begin{array}{l}\text { Moveme } \\
\text { nt }\end{array}$} & Revisionist & $\begin{array}{c}\text { Count } \\
\% \text { within } \\
\text { Movement }\end{array}$ & $\begin{array}{c}2 \\
1.5 \%\end{array}$ & $\begin{array}{c}13 \\
9.6 \%\end{array}$ & $\begin{array}{c}24 \\
17.8 \%\end{array}$ & $\begin{array}{c}19 \\
14.1 \%\end{array}$ & $\begin{array}{c}69 \\
51.1 \%\end{array}$ \\
\hline & $\begin{array}{l}\text { Religious } \\
\text { Zionist }\end{array}$ & $\begin{array}{c}\text { Count } \\
\% \text { within } \\
\text { Movement }\end{array}$ & $\begin{array}{c}0 \\
0.0 \%\end{array}$ & $\begin{array}{c}0 \\
0.0 \%\end{array}$ & $\begin{array}{c}3 \\
33.3 \%\end{array}$ & $\begin{array}{c}3 \\
33.3 \%\end{array}$ & $\begin{array}{c}3 \\
33.3 \%\end{array}$ \\
\hline & $\begin{array}{l}\text { Haredi (Ultra- } \\
\text { Orthodox) }\end{array}$ & $\begin{array}{c}\text { Count } \\
\% \text { within } \\
\text { Movement }\end{array}$ & $\begin{array}{c}0 \\
0.0 \%\end{array}$ & $\begin{array}{c}2 \\
5.0 \%\end{array}$ & $\begin{array}{c}1 \\
2.5 \%\end{array}$ & $\begin{array}{c}6 \\
15.0 \%\end{array}$ & $\begin{array}{c}25 \\
62.5 \%\end{array}$ \\
\hline & Labor & $\begin{array}{c}\text { Count } \\
\% \text { within } \\
\text { Movement }\end{array}$ & $\begin{array}{c}44 \\
23.3 \%\end{array}$ & $\begin{array}{c}51 \\
27.0 \%\end{array}$ & $\begin{array}{c}40 \\
21.2 \%\end{array}$ & $\begin{array}{c}25 \\
13.2 \%\end{array}$ & $\begin{array}{c}17 \\
9.0 \%\end{array}$ \\
\hline \multicolumn{2}{|r|}{ Total } & $\begin{array}{c}\text { Count } \\
\% \text { within } \\
\text { Movement }\end{array}$ & $\begin{array}{c}46 \\
12.3 \%\end{array}$ & $\begin{array}{c}66 \\
17.7 \%\end{array}$ & $\begin{array}{c}68 \\
18.2 \%\end{array}$ & $\begin{array}{c}53 \\
14.2 \%\end{array}$ & $\begin{array}{c}114 \\
30.6 \%\end{array}$ \\
\hline
\end{tabular}




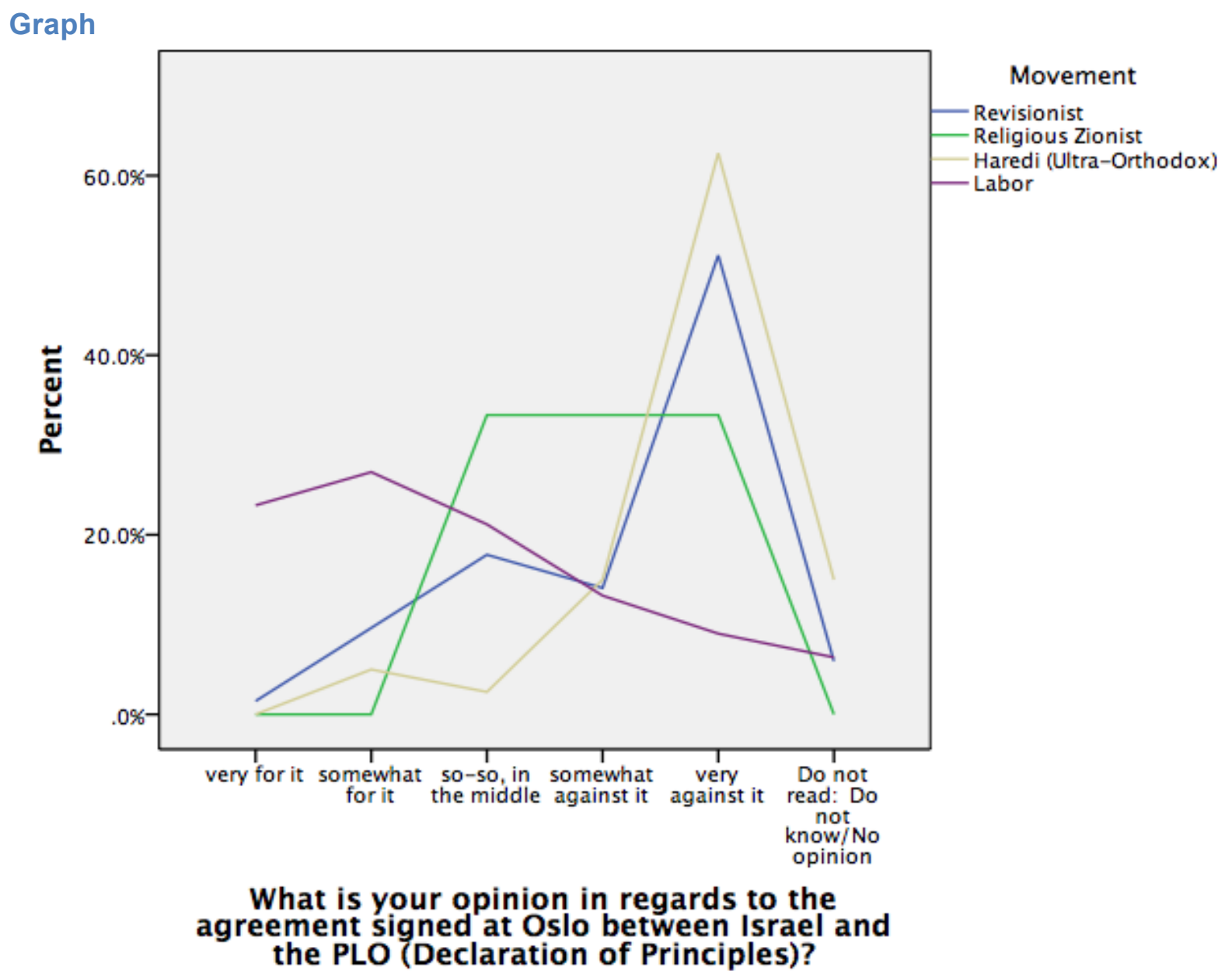

Nominal Regression

Model Fitting Information

\begin{tabular}{|c|c|c|c|c|}
\hline \multirow[b]{2}{*}{ Model } & \multirow{2}{*}{$\begin{array}{c}\text { Model Fitting } \\
\text { Criteria }\end{array}$} & \multicolumn{3}{|c|}{ Likelihood Ratio Tests } \\
\hline & & Chi-Square & $\mathrm{df}$ & Sig. \\
\hline $\begin{array}{l}\text { Intercept Only } \\
\text { Final }\end{array}$ & $\begin{array}{r}212.253 \\
60.425\end{array}$ & 151.829 & 15 & .000 \\
\hline
\end{tabular}

Goodness-of-Fit

\begin{tabular}{|l|r|r|r|}
\hline & Chi-Square & \multicolumn{1}{|c|}{ df } & Sig. \\
\hline Pearson & .000 & 0 & \\
Deviance & .000 & 0 &. \\
\hline
\end{tabular}

Likelihood Ratio Tests

\begin{tabular}{|l|r|r|r|r|}
\hline \multirow{4}{*}{} & \multicolumn{1}{|c|}{$\begin{array}{c}\text { Model Fitting } \\
\text { Criteria }\end{array}$} & \multicolumn{3}{|c|}{ Likelihood Ratio Tests } \\
\cline { 2 - 6 } & $\begin{array}{c}-2 \text { Log } \\
\text { Likelihood of } \\
\text { Reduced Model }\end{array}$ & Chi-Square & \multicolumn{1}{c|}{ df } & \multicolumn{1}{c|}{ Sig. } \\
\hline Intercept & $60.425^{\mathrm{a}}$ & .000 & 0 & \\
Movement & 212.253 & 151.829 & 15 & .000 \\
\hline
\end{tabular}


Parameter Estimates

\begin{tabular}{|c|c|c|c|c|c|c|c|c|c|}
\hline \multirow{2}{*}{\multicolumn{2}{|c|}{$\begin{array}{l}\text { What is your opinion in } \\
\text { regards to the agreement } \\
\text { signed at Oslo between } \\
\text { Israel and the PLO } \\
\text { (Declaration of } \\
\text { Principles)? }\end{array}$}} & \multirow[b]{2}{*}{ B } & \multirow[b]{2}{*}{$\begin{array}{l}\text { Std. } \\
\text { Error }\end{array}$} & \multirow[b]{2}{*}{ Wald } & \multirow[b]{2}{*}{ df } & \multirow[b]{2}{*}{ Sig. } & \multirow[b]{2}{*}{$\operatorname{Exp}(B)$} & \multicolumn{2}{|c|}{$\begin{array}{l}95 \% \text { Confidence } \\
\text { Interval for } \operatorname{Exp}(B)\end{array}$} \\
\hline & & & & & & & & $\begin{array}{l}\text { Lower } \\
\text { Bound }\end{array}$ & $\begin{array}{l}\text { Upper } \\
\text { Bound }\end{array}$ \\
\hline \multirow{5}{*}{$\begin{array}{l}\text { somewhat } \\
\text { for it }\end{array}$} & Intercept & .148 & .206 & .515 & 1 & .473 & & & \\
\hline & Revisionist & 1.724 & .787 & 4.801 & 1 & .028 & 5.608 & 1.199 & 26.220 \\
\hline & $\begin{array}{l}\text { Religious } \\
\text { Zionist }\end{array}$ & 213 & $\begin{array}{c}8018.00 \\
4\end{array}$ & .000 & 1 & 1.000 & 1.238 & .000 & \\
\hline & $\begin{array}{l}\text { Haredi (ultra- } \\
\text { Orthodox) }\end{array}$ & 17.358 & .877 & 391.506 & 1 & .000 & $\begin{array}{c}34558342 \\
.736\end{array}$ & $\begin{array}{c}6191798 . \\
474\end{array}$ & $\begin{array}{c}19288080 \\
1.549\end{array}$ \\
\hline & Labor & $0^{c}$ & & & 0 & & & & \\
\hline \multirow{5}{*}{$\begin{array}{l}\text { so-so, in the } \\
\text { middle }\end{array}$} & Intercept & -.095 & .218 & 190 & 1 & .663 & & & \\
\hline & Revisionist & 2.580 & .768 & \begin{tabular}{|l|}
11.296 \\
\end{tabular} & 1 & .001 & 13.200 & 2.931 & 59.437 \\
\hline & $\begin{array}{l}\text { Religious } \\
\text { Zionist }\end{array}$ & 19.534 & .866 & 508.428 & 1 & .000 & $\begin{array}{c}30439154 \\
5.389\end{array}$ & $\begin{array}{c}55722367 \\
.752\end{array}$ & $\begin{array}{c}16627831 \\
27.185\end{array}$ \\
\hline & $\begin{array}{c}\text { Haredi (ultra- } \\
\text { Orthodox) }\end{array}$ & 16.908 & 1.129 & 224.219 & 1 & .000 & $\begin{array}{c}22030943 \\
.494\end{array}$ & $\begin{array}{c}2409301 . \\
948\end{array}$ & $\begin{array}{c}20145356 \\
6.955\end{array}$ \\
\hline & Labor & $0^{c}$ & & & 0 & & & & \\
\hline \multirow{6}{*}{$\begin{array}{l}\text { somewhat } \\
\text { against it }\end{array}$} & Intercept & -.565 & .250 & 5.095 & 1 & .024 & & & \\
\hline & Revisionist & 2.817 & .784 & 12.892 & 1 & .000 & 16.720 & 3.593 & 77.796 \\
\hline & $\begin{array}{l}\text { Religious } \\
\text { Zionist }\end{array}$ & 20.004 & .875 & 522.741 & 1 & .000 & $\begin{array}{c}48702647 \\
2.622\end{array}$ & $\begin{array}{c}87663092 \\
.980\end{array}$ & $\begin{array}{c}27057542 \\
34.452\end{array}$ \\
\hline & Haredi (ultra- & 19170 & 676 & 804697 & 1 & & 21149705 & 56245382 & 79528315 \\
\hline & Orthodox) & $19.1 / 0$ & $.6 / 6$ & | 804.69 & 1 & (.000 & 7.541 & .340 & 9.041 \\
\hline & Labor & $0^{c}$ & & & 0 & & & & \\
\hline \multirow{6}{*}{$\begin{array}{c}\text { very against } \\
\text { it }\end{array}$} & Intercept & -.951 & .286 & \begin{tabular}{|l|}
11.089 \\
\end{tabular} & 1 & .001 & & & \\
\hline & Revisionist & 4.492 & .772 & 33.852 & 1 & .000 & 89.294 & 19.664 & 405.493 \\
\hline & $\begin{array}{l}\text { Religious } \\
\text { Zionist }\end{array}$ & 20.389 & .000 & 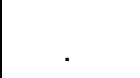 & 1 & . & $\begin{array}{c}71621540 \\
0915\end{array}$ & $\begin{array}{c}71621540 \\
0.915\end{array}$ & $\begin{array}{c}71621540 \\
0.915\end{array}$ \\
\hline & Haredi (ultra- & (20 & & 1262.14 & & & 12959378 & 40724298 & 41239627 \\
\hline & Orthodox) & 20.983 & .591 & 3 & 1 & .000 & 52.581 & 7.402 & 68.442 \\
\hline & Labor & $0^{c}$ & & & 0 & & & & \\
\hline \multirow{5}{*}{$\begin{array}{l}\text { Do not read: } \\
\text { Do not } \\
\text { know/No } \\
\text { opinion }\end{array}$} & Intercept & -1.299 & .326 & 15.917 & 1 & .000 & & & \\
\hline & Revisionist & 2.686 & .855 & 9.866 & 1 & .002 & 14.667 & 2.745 & 78.366 \\
\hline & $\begin{array}{l}\text { Religious } \\
\text { Zionist }\end{array}$ & .729 & .000 & & 1 & . & 2.072 & 2.072 & 2.072 \\
\hline & Haredi (ultra- & 19.904 & .000 & & 1 & . & 44061886 & 44061886 & 44061886 \\
\hline & $\begin{array}{l}\text { Orthodox) } \\
\text { Labor }\end{array}$ & $\begin{array}{c}10.004 \\
0^{c}\end{array}$ & .000 & & 0 & & 9878 & 9.878 & 9.878 \\
\hline
\end{tabular}


July 2002

Crosstabs

Movement * What is your opinion in regards to the agreement signed at Oslo between Israel and the PLO (Declaration of Principles)? Crosstabulation

\begin{tabular}{|c|c|c|c|c|c|c|c|}
\hline & \multicolumn{5}{|c|}{$\begin{array}{c}\text { What is your opinion in regards to the agreement signed at Oslo } \\
\text { between Israel and the PLO (Declaration of Principles)? }\end{array}$} \\
\hline & & & very for it & $\begin{array}{l}\text { somewhat } \\
\text { for it }\end{array}$ & $\begin{array}{l}\text { so-so, in } \\
\text { the middle }\end{array}$ & $\begin{array}{l}\text { somewhat } \\
\text { against it }\end{array}$ & $\begin{array}{c}\text { very against } \\
\text { it }\end{array}$ \\
\hline \multirow{4}{*}{ Movement } & Revisionist & $\begin{array}{c}\text { Count } \\
\% \text { within } \\
\text { Movement }\end{array}$ & $\begin{array}{c}2 \\
1.4 \%\end{array}$ & $\begin{array}{c}8 \\
5.4 \%\end{array}$ & $\begin{array}{c}21 \\
14.3 \%\end{array}$ & $\begin{array}{c}31 \\
21.1 \%\end{array}$ & $\begin{array}{c}69 \\
46.9 \%\end{array}$ \\
\hline & $\begin{array}{l}\text { Religious } \\
\text { Zionist }\end{array}$ & $\begin{array}{c}\text { Count } \\
\% \text { within } \\
\text { Movement }\end{array}$ & $\begin{array}{c}0 \\
0.0 \%\end{array}$ & $\begin{array}{c}1 \\
9.1 \%\end{array}$ & $\begin{array}{c}0 \\
0.0 \%\end{array}$ & $\begin{array}{c}0 \\
0.0 \%\end{array}$ & $\begin{array}{c}9 \\
81.8 \%\end{array}$ \\
\hline & $\begin{array}{c}\text { Haredi } \\
\text { (Ultra- } \\
\text { Orthodox) } \\
\end{array}$ & $\begin{array}{c}\text { Count } \\
\text { \% within } \\
\text { Movement }\end{array}$ & $\begin{array}{c}2 \\
5.4 \%\end{array}$ & $\begin{array}{c}0 \\
0.0 \%\end{array}$ & $\begin{array}{c}1 \\
2.7 \%\end{array}$ & $\begin{array}{c}4 \\
10.8 \%\end{array}$ & $\begin{array}{c}27 \\
73.0 \%\end{array}$ \\
\hline & Labor & $\begin{array}{c}\text { Count } \\
\% \text { within } \\
\text { Movement }\end{array}$ & $\begin{array}{c}24 \\
18.2 \%\end{array}$ & $\begin{array}{c}39 \\
29.5 \%\end{array}$ & $\begin{array}{c}19 \\
14.4 \%\end{array}$ & $\begin{array}{c}18 \\
13.6 \%\end{array}$ & $\begin{array}{c}19 \\
14.4 \%\end{array}$ \\
\hline \multicolumn{2}{|c|}{ Total } & $\begin{array}{c}\text { Count } \\
\text { \% within } \\
\text { Movement }\end{array}$ & $\begin{array}{c}28 \\
8.6 \%\end{array}$ & $\begin{array}{c}48 \\
14.7 \%\end{array}$ & $\begin{array}{c}41 \\
12.5 \%\end{array}$ & $\begin{array}{c}53 \\
16.2 \%\end{array}$ & $\begin{array}{c}124 \\
37.9 \%\end{array}$ \\
\hline
\end{tabular}




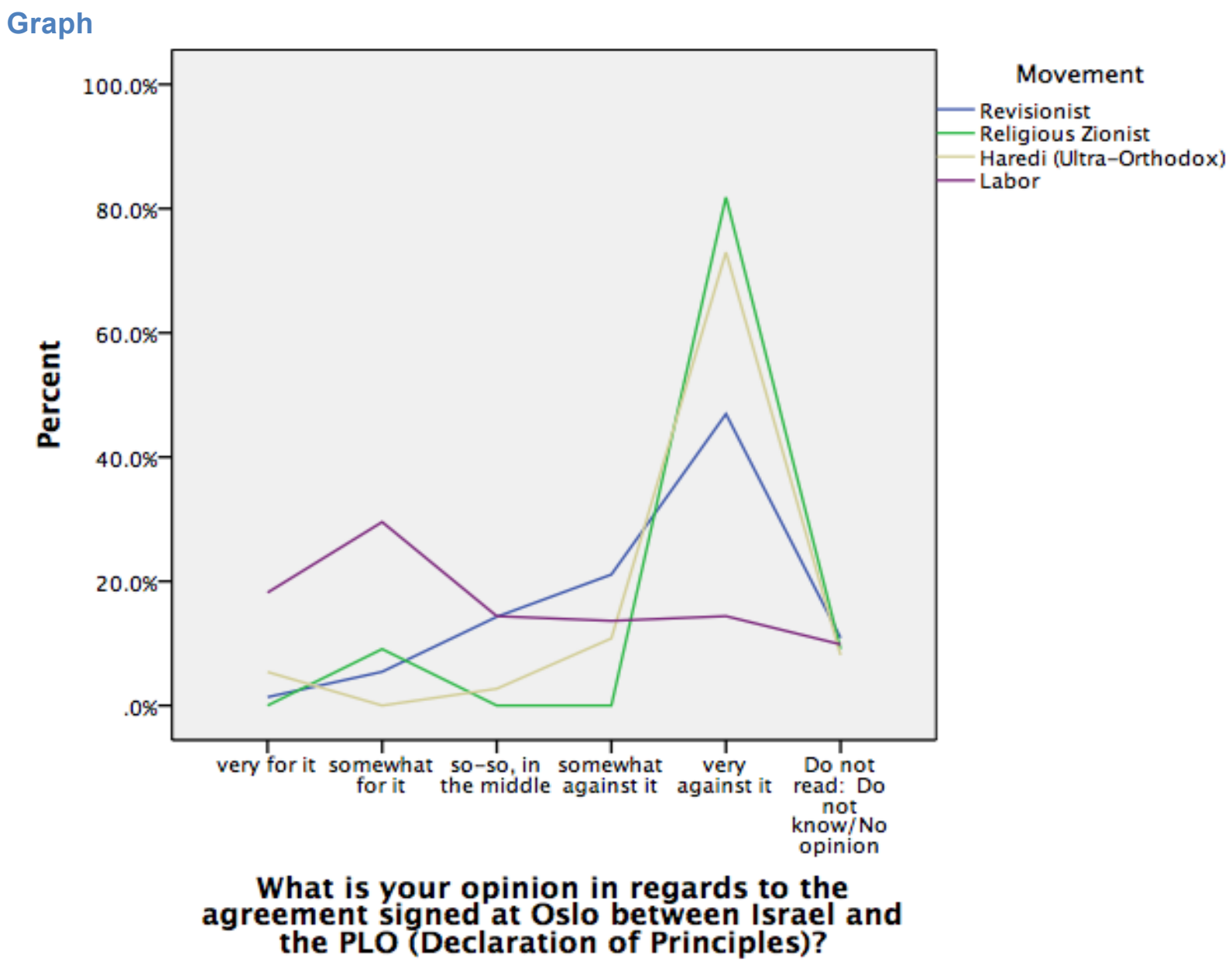

Nominal Regression

Model Fitting Information

\begin{tabular}{|l|r|r|r|r|}
\hline \multirow{2}{*}{} & $\begin{array}{c}\text { Model Fitting } \\
\text { Criteria }\end{array}$ & \multicolumn{3}{|c|}{ Likelihood Ratio Tests } \\
\cline { 2 - 6 } & $\begin{array}{c}-2 \text { Log } \\
\text { Likelihood }\end{array}$ & Chi-Square & df & Sig. \\
\hline Model & $\begin{array}{r}178.765 \\
57.488\end{array}$ & 121.278 & 15 & .000 \\
\hline
\end{tabular}

Goodness-of-Fit

\begin{tabular}{|l|r|r|r|}
\hline & Chi-Square & df & Sig. \\
\hline Pearson & .000 & 0 & \\
Deviance & .000 & 0 & \\
\hline
\end{tabular}

Likelihood Ratio Tests

\begin{tabular}{|l|r|r|r|r|}
\hline & \multicolumn{1}{|c|}{$\begin{array}{c}\text { Model Fitting } \\
\text { Criteria }\end{array}$} & \multicolumn{3}{|c|}{ Likelihood Ratio Tests } \\
\cline { 2 - 5 } & $\begin{array}{c}-2 \text { Log } \\
\text { Likelihood of } \\
\text { Reduced Model }\end{array}$ & Chi-Square & df & \multicolumn{1}{c|}{ Sig. } \\
\hline Effect & $57.488^{\mathrm{a}}$ & .000 & 0 & .000 \\
\hline Intercept & 178.765 & 121.278 & 15 & .000 \\
Movement & & & & \\
\hline
\end{tabular}


Parameter Estimates

\begin{tabular}{|c|c|c|c|c|c|c|c|c|c|}
\hline \multirow{2}{*}{\multicolumn{2}{|c|}{$\begin{array}{l}\text { What is your opinion in } \\
\text { regards to the agreement } \\
\text { signed at Oslo between } \\
\text { Israel and the PLO } \\
\text { (Declaration of } \\
\text { Principles)? }\end{array}$}} & \multirow[b]{2}{*}{ B } & \multirow[b]{2}{*}{$\begin{array}{l}\text { Std. } \\
\text { Error }\end{array}$} & \multirow[b]{2}{*}{ Wald } & \multirow[b]{2}{*}{$d f$} & \multirow[b]{2}{*}{ Sig. } & \multirow[b]{2}{*}{$\operatorname{Exp}(B)$} & \multicolumn{2}{|c|}{$\begin{array}{l}\text { 95\% Confidence } \\
\text { Interval for } \operatorname{Exp}(B)\end{array}$} \\
\hline & & & & & & & & $\begin{array}{l}\text { Lower } \\
\text { Bound }\end{array}$ & $\begin{array}{l}\text { Upper } \\
\text { Bound }\end{array}$ \\
\hline \multirow{5}{*}{$\begin{array}{l}\text { somewhat } \\
\text { for it }\end{array}$} & Intercept & .486 & 259 & 3.502 & 1 & .061 & & & \\
\hline & Revisionist & .901 & .832 & 1.172 & 1 & 279 & 2.462 & .482 & 12.573 \\
\hline & $\begin{array}{l}\text { Religious } \\
\text { Zionist }\end{array}$ & 18.071 & 1.450 & $\begin{array}{c}155.30 \\
9\end{array}$ & 1 & .000 & $\begin{array}{c}70465223 \\
.220\end{array}$ & $\begin{array}{c}4108788 . \\
440\end{array}$ & $\begin{array}{c}12084700 \\
28.472\end{array}$ \\
\hline & $\begin{array}{l}\text { Haredi (ultra- } \\
\text { Orthodox) }\end{array}$ & $\begin{array}{c}- \\
17.801 \\
\end{array}$ & $\begin{array}{c}4068.98 \\
4\end{array}$ & .000 & 1 & .997 & $1.858 \mathrm{E}-8$ & .000 & b \\
\hline & Labor & $0^{c}$ & & & 0 & & & . & \\
\hline \multirow{4}{*}{$\begin{array}{l}\text { so-so, in the } \\
\text { middle }\end{array}$} & Intercept & -.234 & .307 & .579 & 1 & .447 & & & \\
\hline & Revisionist & 2.585 & .801 & 10.410 & 1 & .001 & 13.263 & 2.758 & 63.772 \\
\hline & $\begin{array}{c}\text { Religious } \\
\text { Zionist }\end{array}$ & .615 & $\begin{array}{c}8843.03 \\
2\end{array}$ & .000 & 1 & 1.000 & 1.850 & .000 & b \\
\hline & $\begin{array}{l}\text { Haredi (ultra- } \\
\text { Orthodox) } \\
\text { Labor }\end{array}$ & $\begin{array}{c}-.460 \\
0^{c}\end{array}$ & 1.263 & .132 & $\begin{array}{l}1 \\
0\end{array}$ & .716 & 632 & .053 & 7.502 \\
\hline \multirow{5}{*}{$\begin{array}{l}\text { somewhat } \\
\text { against it }\end{array}$} & Intercept & -.288 & 312 & 851 & 1 & .356 & & & \\
\hline & Revisionist & 3.029 & .793 & 14.571 & 1 & .000 & 20.667 & 4.364 & 97.862 \\
\hline & $\begin{array}{l}\text { Religious } \\
\text { Zionist }\end{array}$ & .926 & $\begin{array}{c}7777.77 \\
2\end{array}$ & .000 & 1 & 1.000 & 2.524 & .000 & \\
\hline & Haredi (ultra- & .981 & & 1.136 & 1 & & 2.667 & .439 & 16.198 \\
\hline & $\begin{array}{l}\text { Orthodox) } \\
\text { Labor }\end{array}$ & $0^{c}$ & & & 0 & & & & \\
\hline \multirow{6}{*}{$\begin{array}{c}\text { very against } \\
\text { it }\end{array}$} & Intercept & -.234 & .307 & .579 & 1 & .447 & & & \\
\hline & Revisionist & 3.775 & .780 & 23.403 & 1 & .000 & 43.579 & 9.443 & 201.107 \\
\hline & $\begin{array}{l}\text { Religious } \\
\text { Zionist }\end{array}$ & 20.987 & 1.114 & $\begin{array}{c}355.01 \\
4\end{array}$ & 1 & .000 & $\begin{array}{c}13017522 \\
81.593\end{array}$ & $\begin{array}{c}14669523 \\
3.874\end{array}$ & $\begin{array}{c}11551561 \\
409883\end{array}$ \\
\hline & Haredi (ultra- & 2836 & & & & & & & \\
\hline & Orthodox) & 2.836 & .795 & 12.742 & 1 & .000 & 17.053 & 3.593 & 80.933 \\
\hline & Labor & $0^{c}$ & & & 0 & & & & \\
\hline \multirow{5}{*}{$\begin{array}{l}\text { Do not read: } \\
\text { Do not } \\
\text { know/No } \\
\text { opinion }\end{array}$} & Intercept & -.613 & .344 & 3.170 & 1 & .075 & & & \\
\hline & Revisionist & 2.693 & .825 & 10.644 & 1 & .001 & 14.769 & 2.930 & 74.446 \\
\hline & $\begin{array}{l}\text { Religious } \\
\text { Zionist }\end{array}$ & 19.169 & .000 & & 1 & & $\begin{array}{c}21139566 \\
9.660\end{array}$ & $\begin{array}{c}21139566 \\
9.660\end{array}$ & $\begin{array}{c}21139566 \\
9.660\end{array}$ \\
\hline & Haredi (ultra- & 1.019 & .976 & 1.090 & 1 & .296 & 2.769 & .409 & 18.743 \\
\hline & Labor & $0^{\mathrm{C}}$ & & & 0 & & & & \\
\hline
\end{tabular}


January 2003

Crosstabs

Movement * What is your opinion in regards to the agreement signed at Oslo between Israel and the PLO (Declaration of Principles)? Crosstabulation

\begin{tabular}{|c|c|c|c|c|c|c|c|}
\hline & \multicolumn{5}{|c|}{$\begin{array}{l}\text { What is your opinion in regards to the agreement signed at } \\
\text { Oslo between Israel and the PLO (Declaration of Principles)? }\end{array}$} \\
\hline & & & very for it & $\begin{array}{l}\text { somewhat } \\
\text { for it }\end{array}$ & $\begin{array}{l}\text { so-so, in } \\
\text { the middle }\end{array}$ & $\begin{array}{l}\text { somewhat } \\
\text { against it }\end{array}$ & $\begin{array}{l}\text { very } \\
\text { against it }\end{array}$ \\
\hline \multirow{4}{*}{$\begin{array}{l}\text { Moveme } \\
\text { nt }\end{array}$} & Revisionist & $\begin{array}{c}\text { Count } \\
\% \text { within } \\
\text { Movement }\end{array}$ & $\begin{array}{c}6 \\
3.5 \%\end{array}$ & $\begin{array}{c}16 \\
9.4 \%\end{array}$ & $\begin{array}{c}28 \\
16.5 \%\end{array}$ & $\begin{array}{c}25 \\
14.7 \%\end{array}$ & $\begin{array}{c}79 \\
46.5 \%\end{array}$ \\
\hline & $\begin{array}{l}\text { Religious } \\
\text { Zionist }\end{array}$ & $\begin{array}{c}\text { Count } \\
\% \text { within } \\
\text { Movement }\end{array}$ & $\begin{array}{c}0 \\
0.0 \%\end{array}$ & $\begin{array}{c}2 \\
15.4 \%\end{array}$ & $\begin{array}{c}1 \\
7.7 \%\end{array}$ & $\begin{array}{c}0 \\
0.0 \%\end{array}$ & $\begin{array}{c}9 \\
69.2 \%\end{array}$ \\
\hline & $\begin{array}{l}\text { Haredi (Ultra- } \\
\text { Orthodox) }\end{array}$ & $\begin{array}{c}\text { Count } \\
\% \text { within } \\
\text { Movement }\end{array}$ & $\begin{array}{c}0 \\
0.0 \%\end{array}$ & $\begin{array}{c}1 \\
2.0 \%\end{array}$ & $\begin{array}{c}5 \\
10.2 \%\end{array}$ & $\begin{array}{c}6 \\
12.2 \%\end{array}$ & $\begin{array}{c}27 \\
55.1 \%\end{array}$ \\
\hline & Labor & $\begin{array}{c}\text { Count } \\
\% \text { within } \\
\text { Movement }\end{array}$ & $\begin{array}{c}20 \\
13.1 \%\end{array}$ & $\begin{array}{c}45 \\
29.4 \%\end{array}$ & $\begin{array}{c}46 \\
30.1 \%\end{array}$ & $\begin{array}{c}18 \\
11.8 \%\end{array}$ & $\begin{array}{c}16 \\
10.5 \%\end{array}$ \\
\hline \multicolumn{2}{|r|}{ Total } & $\begin{array}{c}\text { Count } \\
\% \text { within } \\
\text { Movement }\end{array}$ & $\begin{array}{c}26 \\
6.8 \%\end{array}$ & $\begin{array}{c}64 \\
16.6 \%\end{array}$ & $\begin{array}{c}80 \\
20.8 \%\end{array}$ & $\begin{array}{c}49 \\
12.7 \%\end{array}$ & $\begin{array}{c}131 \\
34.0 \%\end{array}$ \\
\hline
\end{tabular}




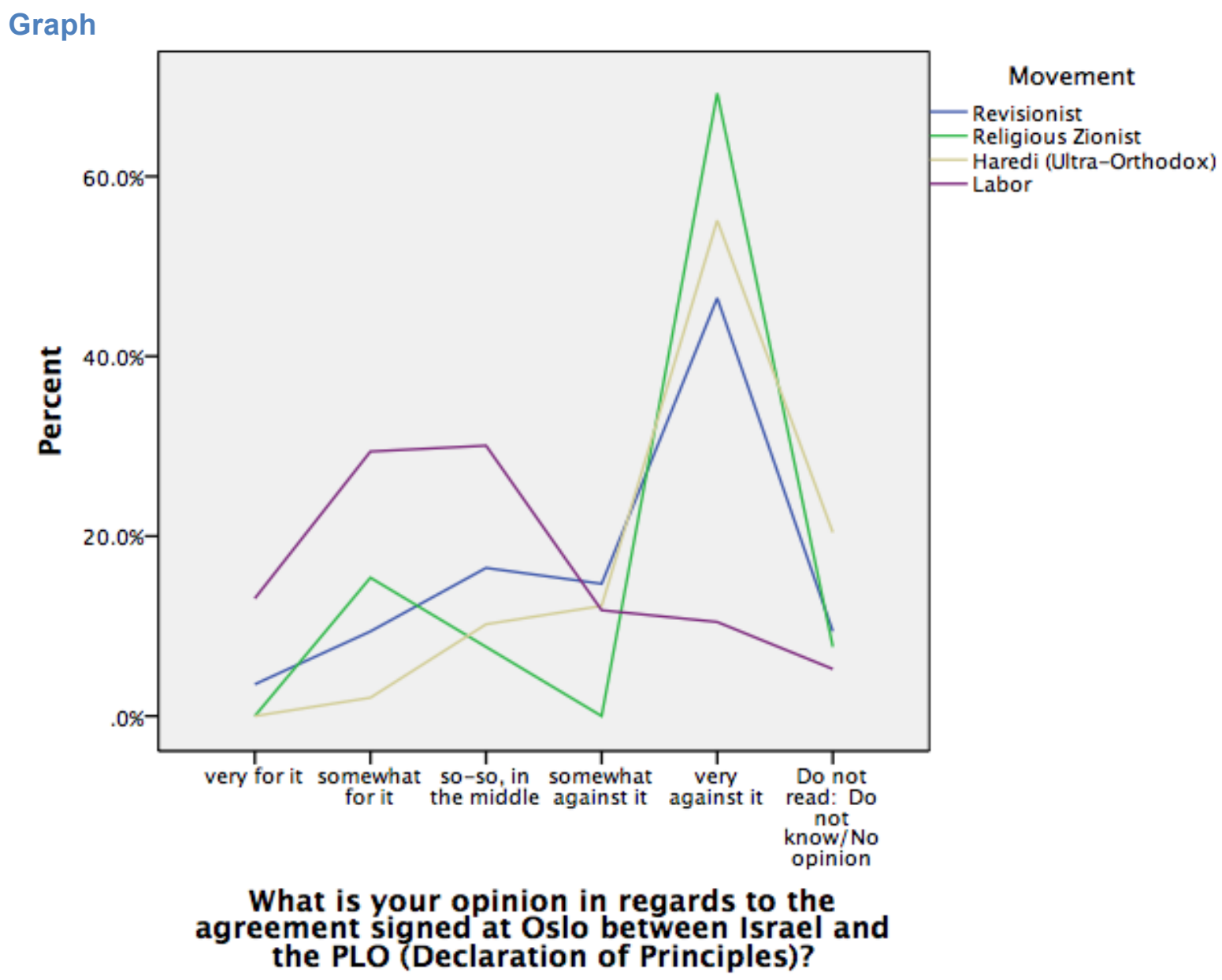

Nominal Regression

Model Fitting Information

\begin{tabular}{|l|r|r|r|r|}
\hline \multirow{4}{*}{ Model } & \multicolumn{2}{|c|}{$\begin{array}{l}\text { Model Fitting } \\
\text { Criteria }\end{array}$} & \multicolumn{3}{|c|}{ Likelihood Ratio Tests } \\
\cline { 2 - 5 } & $\begin{array}{c}-2 \text { Log } \\
\text { Likelihood }\end{array}$ & Chi-Square & \multicolumn{1}{c|}{ df } & \multicolumn{1}{c|}{ Sig. } \\
\hline Intercept Only & $\begin{array}{r}185.405 \\
63.914\end{array}$ & 121.491 & 15 & .000 \\
\hline Final & \multicolumn{4}{|c|}{} \\
\hline
\end{tabular}

Goodness-of-Fit

\begin{tabular}{|c|c|c|c|}
\hline & Chi-Square & $\mathrm{df}$ & Sig. \\
\hline Pearson & $\begin{array}{l}.000 \\
000\end{array}$ & $\begin{array}{l}0 \\
0\end{array}$ & \\
\hline
\end{tabular}

Likelihood Ratio Tests

\begin{tabular}{|l|r|r|r|r|}
\hline \multirow{2}{*}{} & \multicolumn{1}{|c|}{$\begin{array}{c}\text { Model Fitting } \\
\text { Criteria }\end{array}$} & \multicolumn{3}{|c|}{ Likelihood Ratio Tests } \\
\cline { 2 - 6 } & $\begin{array}{c}-2 \text { Log } \\
\text { Likelihood of } \\
\text { Reduced Model }\end{array}$ & Chi-Square & df & \multicolumn{1}{c|}{ Sig. } \\
\hline Effect & $63.914^{\text {a }}$ & .000 & 0 & .000 \\
\hline Movement & 185.405 & 121.491 & 15 & .000 \\
\hline
\end{tabular}


Parameter Estimates

\begin{tabular}{|c|c|c|c|c|c|c|c|c|c|}
\hline \multirow{2}{*}{\multicolumn{2}{|c|}{$\begin{array}{l}\text { What is your opinion in } \\
\text { regards to the agreement } \\
\text { signed at Oslo between } \\
\text { Israel and the PLO } \\
\text { (Declaration of } \\
\text { Principles)? }\end{array}$}} & \multirow[b]{2}{*}{ B } & \multirow[b]{2}{*}{$\begin{array}{l}\text { Std. } \\
\text { Error }\end{array}$} & \multirow[b]{2}{*}{ Wald } & \multirow[b]{2}{*}{ df } & \multirow[b]{2}{*}{ Sig. } & \multirow[b]{2}{*}{$\operatorname{Exp}(B)$} & \multicolumn{2}{|c|}{$\begin{array}{l}95 \% \text { Confidence } \\
\text { Interval for } \operatorname{Exp}(\mathrm{B})\end{array}$} \\
\hline & & & & & & & & $\begin{array}{l}\text { Lower } \\
\text { Bound }\end{array}$ & $\begin{array}{l}\text { Upper } \\
\text { Bound }\end{array}$ \\
\hline \multirow{5}{*}{$\begin{array}{l}\text { somewhat } \\
\text { for it }\end{array}$} & Intercept & .811 & 269 & 9.105 & 1 & .003 & & & \\
\hline & Revisionist & 170 & .549 & .096 & 1 & .757 & 1.185 & .404 & 3.476 \\
\hline & $\begin{array}{l}\text { Religious } \\
\text { Zionist }\end{array}$ & 18.372 & $\begin{array}{c}10348.9 \\
80\end{array}$ & .000 & 1 & .999 & $\begin{array}{l}95200991 \\
.783\end{array}$ & .000 & \\
\hline & $\begin{array}{l}\text { Haredi (ultra- } \\
\text { Orthodox) }\end{array}$ & 16.278 & 1.117 & 212.462 & 1 & .000 & $\begin{array}{c}11739127 \\
.621\end{array}$ & $\begin{array}{c}1315290 . \\
155\end{array}$ & $\begin{array}{c}10477316 \\
8.660\end{array}$ \\
\hline & Labor & $0^{c}$ & & & 0 & & & & (n) \\
\hline \multirow{4}{*}{$\begin{array}{l}\text { so-so, in the } \\
\text { middle }\end{array}$} & Intercept & 833 & 268 & 9.670 & 1 & .002 & & & \\
\hline & Revisionist & .708 & .524 & 1.826 & 1 & .177 & 2.029 & .727 & 5.662 \\
\hline & $\begin{array}{l}\text { Religious } \\
\text { Zionist }\end{array}$ & 17.656 & $\begin{array}{c}10348.9 \\
80\end{array}$ & .000 & 1 & .999 & $\begin{array}{c}46565702 \\
.502\end{array}$ & .000 & b \\
\hline & $\begin{array}{l}\text { Haredi (ultra- } \\
\text { Orthodox) } \\
\text { Labor }\end{array}$ & $\begin{array}{c}17.866 \\
0^{c}\end{array}$ & 668 & 714.489 & 1 & .000 & $\begin{array}{c}57419645 \\
.971\end{array}$ & $\begin{array}{c}15492794 \\
.912\end{array}$ & $\begin{array}{c}21280961 \\
6.485\end{array}$ \\
\hline \multirow{5}{*}{$\begin{array}{l}\text { somewhat } \\
\text { against it }\end{array}$} & Intercept & -.105 & .325 & .105 & 1 & .746 & & & \\
\hline & Revisionist & 1.532 & 559 & 7.522 & 1 & .006 & 4.630 & 1.549 & 13.841 \\
\hline & $\begin{array}{l}\text { Religious } \\
\text { Zionist }\end{array}$ & .739 & $\begin{array}{c}12803.5 \\
37\end{array}$ & .000 & 1 & 1.000 & 2.094 & .000 & \\
\hline & Haredi (ultra- & 18986 & & 806057 & 1 & 000 & 17608691 & 47477606 & 65307844 \\
\hline & $\begin{array}{l}\text { Orthodox) } \\
\text { Labor }\end{array}$ & $0^{c}$ & & & 0 & & 4.313 & .252 & 7.716 \\
\hline \multirow{6}{*}{$\begin{array}{l}\text { very against } \\
\text { it }\end{array}$} & Intercept & -.223 & .335 & 443 & 1 & .506 & & & \\
\hline & Revisionist & 2.801 & .540 & 26.881 & 1 & .000 & 16.458 & 5.709 & 47.447 \\
\hline & $\begin{array}{l}\text { Religious } \\
\text { Zionist }\end{array}$ & 20.910 & $\begin{array}{c}10348.9 \\
80\end{array}$ & .000 & 1 & .998 & $\begin{array}{c}12048875 \\
52.251\end{array}$ & .000 & $b^{b}$ \\
\hline & Haredi (ultra- & 20608 & & 1308.64 & 1 & & 89144000 & 29186252 & 27227383 \\
\hline & Orthodox) & 20.608 & $.5 / 0$ & 6 & 1 & .000 & 3.707 & 1.122 & 53.501 \\
\hline & Labor & $0^{\mathrm{C}}$ & & & 0 & & & & \\
\hline \multirow{5}{*}{$\begin{array}{l}\text { Do not read: } \\
\text { Do not } \\
\text { know/No } \\
\text { opinion }\end{array}$} & Intercept & -.916 & .418 & 4.798 & 1 & .028 & & & \\
\hline & Revisionist & 1.897 & .636 & 8.905 & 1 & .003 & 6.667 & 1.918 & 23.177 \\
\hline & $\begin{array}{l}\text { Religious } \\
\text { Zionist }\end{array}$ & 19.406 & $\begin{array}{c}10348.9 \\
80\end{array}$ & .000 & 1 & .999 & $\begin{array}{c}26775278 \\
9.389\end{array}$ & .000 & b \\
\hline & Haredi (ultra- & 20.308 & .000 & & 1 & & 66032592 & 66032592 & 66032592 \\
\hline & $\begin{array}{l}\text { Orthodox) } \\
\text { Labor }\end{array}$ & & & & 0 & & 8.672 & 8.672 & 8.672 \\
\hline
\end{tabular}


July 2003

Crosstabs

Movement * What is your opinion in regards to the agreement signed at Oslo between Israel and the PLO (Declaration of Principles)? Crosstabulation

\begin{tabular}{|c|c|c|c|c|c|c|c|}
\hline & \multicolumn{5}{|c|}{$\begin{array}{l}\text { What is your opinion in regards to the agreement signed at } \\
\text { Oslo between Israel and the PLO (Declaration of Principles)? }\end{array}$} \\
\hline & & & very for it & $\begin{array}{l}\text { somewhat } \\
\text { for it }\end{array}$ & $\begin{array}{l}\text { so-so, in } \\
\text { the middle }\end{array}$ & $\begin{array}{l}\text { somewhat } \\
\text { against it }\end{array}$ & $\begin{array}{l}\text { very } \\
\text { against it }\end{array}$ \\
\hline \multirow{4}{*}{$\begin{array}{l}\text { Moveme } \\
\text { nt }\end{array}$} & Revisionist & $\begin{array}{c}\text { Count } \\
\% \text { within } \\
\text { Movement }\end{array}$ & $\begin{array}{c}4 \\
2.3 \%\end{array}$ & $\begin{array}{c}20 \\
11.6 \%\end{array}$ & $\begin{array}{c}28 \\
16.3 \%\end{array}$ & $\begin{array}{c}28 \\
16.3 \%\end{array}$ & $\begin{array}{c}71 \\
41.3 \%\end{array}$ \\
\hline & $\begin{array}{l}\text { Religious } \\
\text { Zionist }\end{array}$ & $\begin{array}{c}\text { Count } \\
\% \text { within } \\
\text { Movement }\end{array}$ & $\begin{array}{c}1 \\
5.9 \%\end{array}$ & $\begin{array}{c}0 \\
0.0 \%\end{array}$ & $\begin{array}{c}4 \\
23.5 \%\end{array}$ & $\begin{array}{c}5 \\
29.4 \%\end{array}$ & $\begin{array}{c}6 \\
35.3 \%\end{array}$ \\
\hline & $\begin{array}{l}\text { Haredi (Ultra- } \\
\text { Orthodox) }\end{array}$ & $\begin{array}{c}\text { Count } \\
\% \text { within } \\
\text { Movement }\end{array}$ & $\begin{array}{c}0 \\
0.0 \%\end{array}$ & $\begin{array}{c}0 \\
0.0 \%\end{array}$ & $\begin{array}{c}7 \\
16.3 \%\end{array}$ & $\begin{array}{c}11 \\
25.6 \%\end{array}$ & $\begin{array}{c}19 \\
44.2 \%\end{array}$ \\
\hline & Labor & $\begin{array}{c}\text { Count } \\
\% \text { within } \\
\text { Movement }\end{array}$ & $\begin{array}{c}36 \\
23.4 \%\end{array}$ & $\begin{array}{c}43 \\
27.9 \%\end{array}$ & $\begin{array}{c}36 \\
23.4 \%\end{array}$ & $\begin{array}{c}10 \\
6.5 \%\end{array}$ & $\begin{array}{c}16 \\
10.4 \%\end{array}$ \\
\hline \multicolumn{2}{|r|}{ Total } & $\begin{array}{c}\text { Count } \\
\% \text { within } \\
\text { Movement }\end{array}$ & $\begin{array}{c}41 \\
10.6 \%\end{array}$ & $\begin{array}{c}63 \\
16.3 \%\end{array}$ & $\begin{array}{c}75 \\
19.4 \%\end{array}$ & $\begin{array}{c}54 \\
14.0 \%\end{array}$ & $\begin{array}{c}112 \\
29.0 \%\end{array}$ \\
\hline
\end{tabular}




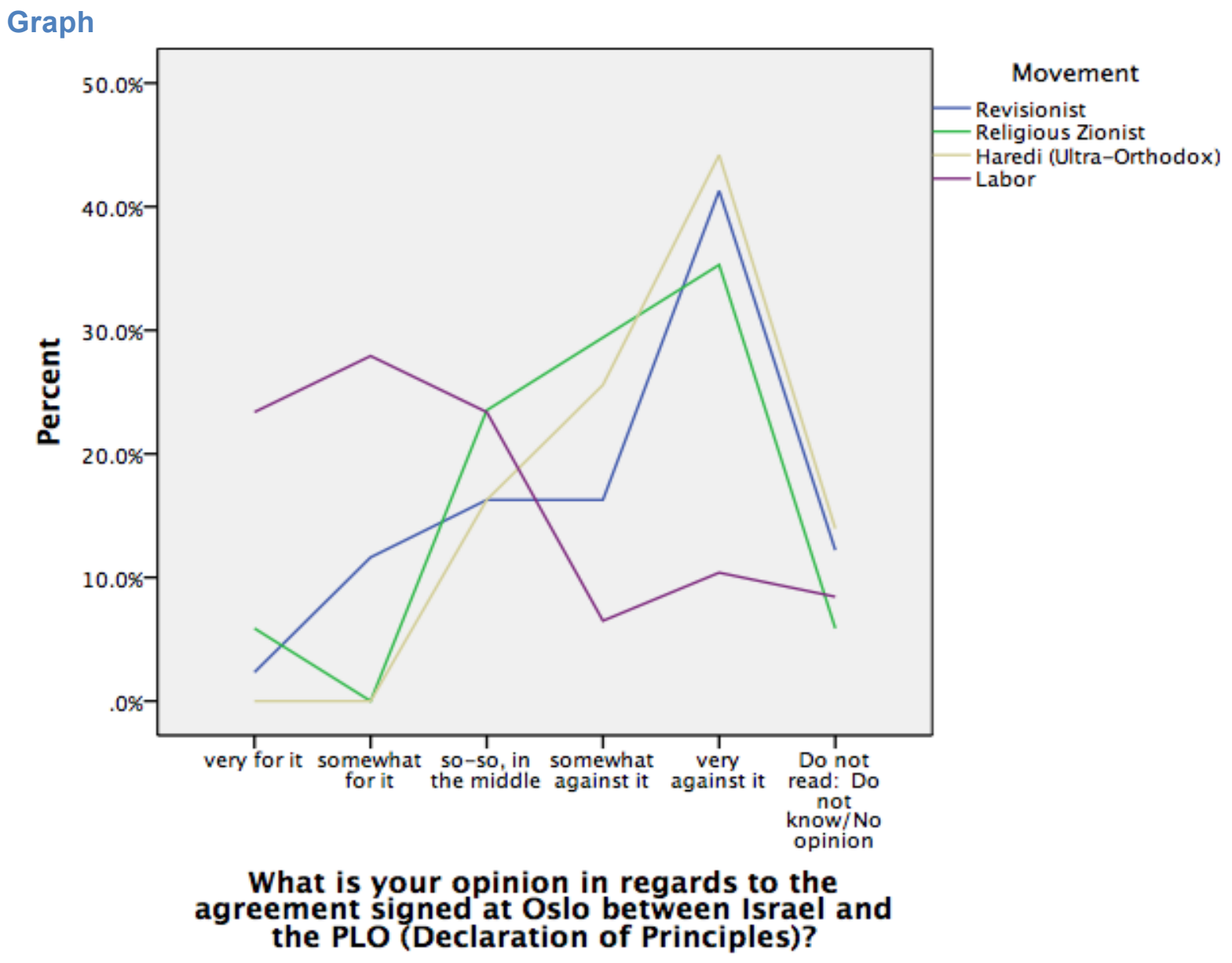

Nominal Regression

Model Fitting Information

\begin{tabular}{|l|r|r|r|r|}
\hline \multirow{2}{*}{} & \multicolumn{1}{|c|}{$\begin{array}{c}\text { Model Fitting } \\
\text { Criteria }\end{array}$} & \multicolumn{3}{|c|}{ Likelihood Ratio Tests } \\
\cline { 2 - 5 } & $\begin{array}{r}\text {-2 Log } \\
\text { Likelihood }\end{array}$ & Chi-Square & df & \multicolumn{1}{c|}{ Sig. } \\
\hline Intercept Only & $\begin{array}{r}195.745 \\
65.866\end{array}$ & 129.879 & 15 & .000 \\
\hline
\end{tabular}

Goodness-of-Fit

\begin{tabular}{|l|r|r|r|}
\hline & Chi-Square & df & Sig. \\
\hline Pearson & .000 & 0 & \\
Deviance & .000 & 0 &. \\
\hline
\end{tabular}

Likelihood Ratio Tests

\begin{tabular}{|l|r|r|r|r|}
\hline \multirow{2}{*}{} & \multicolumn{1}{|c|}{$\begin{array}{c}\text { Model Fitting } \\
\text { Criteria }\end{array}$} & \multicolumn{3}{|c|}{ Likelihood Ratio Tests } \\
\cline { 2 - 6 } & $\begin{array}{c}\text {-2 Log } \\
\text { Likelihood of } \\
\text { Reduced Model }\end{array}$ & Chi-Square & df & \multicolumn{1}{c|}{ Sig. } \\
\hline Effect & $65.866^{\mathrm{a}}$ & .000 & 0 & \\
Movement & 195.745 & 129.879 & 15 & .000 \\
\hline
\end{tabular}


Parameter Estimates

\begin{tabular}{|c|c|c|c|c|c|c|c|c|c|}
\hline \multirow{2}{*}{\multicolumn{2}{|c|}{$\begin{array}{l}\text { What is your opinion in } \\
\text { regards to the agreement } \\
\text { signed at Oslo between } \\
\text { Israel and the PLO } \\
\text { (Declaration of } \\
\text { Principles)? }{ }^{\mathrm{a}} \\
\end{array}$}} & \multirow[b]{2}{*}{ B } & \multirow[b]{2}{*}{$\begin{array}{l}\text { Std. } \\
\text { Error }\end{array}$} & \multirow[b]{2}{*}{ Wald } & \multirow[b]{2}{*}{$\mathrm{df}$} & \multirow[b]{2}{*}{ Sig. } & \multirow[b]{2}{*}{$\operatorname{Exp}(B)$} & \multicolumn{2}{|c|}{$\begin{array}{l}95 \% \text { Confidence } \\
\text { Interval for } \operatorname{Exp}(\mathrm{B})\end{array}$} \\
\hline & & & & & & & & $\begin{array}{l}\text { Lower } \\
\text { Bound }\end{array}$ & $\begin{array}{l}\text { Upper } \\
\text { Bound }\end{array}$ \\
\hline \multirow{5}{*}{$\begin{array}{l}\text { somewhat } \\
\text { for it }\end{array}$} & Intercept & .178 & .226 & .619 & 1 & .432 & & & \\
\hline & Revisionist & 1.432 & .592 & 5.840 & 1 & .016 & 4.186 & 1.311 & 13.370 \\
\hline & $\begin{array}{l}\text { Religious } \\
\text { Zionist }\end{array}$ & 18.396 & $\begin{array}{c}9036.21 \\
0\end{array}$ & .000 & 1 & .998 & $1.025 \mathrm{E}-8$ & .000 & b \\
\hline & $\begin{array}{l}\text { Haredi (ultra- } \\
\text { Orthodox) } \\
\end{array}$ & .252 & \begin{tabular}{|c}
5719.64 \\
2 \\
\end{tabular} & .000 & 1 & 1.000 & 1.286 & .000 & ${ }^{b}$ \\
\hline & Labor & $0^{c}$ & & & 0 & & & & . \\
\hline \multirow{4}{*}{$\begin{array}{l}\text { so-so, in the } \\
\text { middle }\end{array}$} & Intercept & .000 & 236 & .000 & 1 & 1.000 & & & \\
\hline & Revisionist & 1.946 & .584 & 11.096 & 1 & .001 & 7.000 & 2.228 & 21.997 \\
\hline & $\begin{array}{l}\text { Religious } \\
\text { Zionist }\end{array}$ & 1.386 & 1.143 & 1.472 & 1 & .225 & 4.000 & .426 & 37.554 \\
\hline & $\begin{array}{l}\text { Haredi (ultra- } \\
\text { Orthodox) } \\
\text { Labor }\end{array}$ & $\begin{array}{c}19.679 \\
0^{c}\end{array}$ & .644 & 934.891 & $\begin{array}{l}1 \\
0\end{array}$ & .000 & $\begin{array}{c}35187822 \\
2.922\end{array}$ & $\begin{array}{c}99668202 \\
.936\end{array}$ & $\begin{array}{c}12423047 \\
68.418\end{array}$ \\
\hline \multirow{5}{*}{$\begin{array}{l}\text { somewhat } \\
\text { against it }\end{array}$} & Intercept & -1.281 & .357 & 12.841 & 1 & .000 & & & \\
\hline & Revisionist & 3.227 & .643 & 25.182 & 1 & .000 & 25.200 & 7.146 & 88.869 \\
\hline & $\begin{array}{l}\text { Religious } \\
\text { Zionist }\end{array}$ & 2.890 & 1.152 & 6.292 & 1 & .012 & 18.000 & 1.881 & 172.229 \\
\hline & Haredi (ultra- & 21.412 & .659 & 1055.15 & 1 & .000 & 19906253 & 54689890 & 72455610 \\
\hline & $\begin{array}{l}\text { Urthodox) } \\
\text { Labor }\end{array}$ & $0^{c}$ & & & 0 & & & & \\
\hline \multirow{5}{*}{$\begin{array}{c}\text { very against } \\
\text { it }\end{array}$} & Intercept & -.811 & .300 & 7.284 & 1 & .007 & & & \\
\hline & Revisionist & 3.687 & .595 & 38.368 & 1 & .000 & 39.938 & 12.436 & 128.259 \\
\hline & $\begin{array}{l}\text { Religious } \\
\text { Zionist }\end{array}$ & 2.603 & 1.121 & 5.389 & 1 & .020 & 13.500 & 1.500 & 121.519 \\
\hline & Haredi (ultra- & 88 & & 1287.19 & 1 & & 21489705 & 66438123 & 69509406 \\
\hline & $\begin{array}{l}\text { Orthodox) } \\
\text { Labor }\end{array}$ & $\begin{array}{c}21.480 \\
0^{c}\end{array}$ & .599 & 7 & $\begin{array}{l}1 \\
0\end{array}$ & .000 & 75.705 & 9.904 & 01.389 \\
\hline \multirow{5}{*}{$\begin{array}{l}\text { Do not read: } \\
\text { Do not } \\
\text { know/No } \\
\text { opinion }\end{array}$} & Intercept & -1.019 & .324 & 9.909 & 1 & .002 & & & \\
\hline & Revisionist & 2.677 & .634 & 17.810 & 1 & .000 & 14.538 & 4.194 & 50.399 \\
\hline & $\begin{array}{l}\text { Religious } \\
\text { Zionist }\end{array}$ & 1.019 & 1.451 & .493 & 1 & .483 & 2.769 & 161 & 47.561 \\
\hline & Haredi (ultra- & 20.543 & .000 & & 1 & & 83522743 & 83522743 & 83522743 \\
\hline & $\begin{array}{l}\text { Orthodox) } \\
\text { Labor }\end{array}$ & $0^{c}$ & & & 0 & & & 0.234 & 0.234 \\
\hline
\end{tabular}


January 2004

Crosstabs

Movement * What is your opinion in regards to the agreement signed at Oslo between Israel and the PLO (Declaration of Principles)? Crosstabulation

\begin{tabular}{|c|c|c|c|c|c|c|c|}
\hline & \multicolumn{5}{|c|}{$\begin{array}{l}\text { What is your opinion in regards to the agreement signed at } \\
\text { Oslo between Israel and the PLO (Declaration of Principles)? }\end{array}$} \\
\hline & & & very for it & $\begin{array}{l}\text { somewhat } \\
\text { for it }\end{array}$ & $\begin{array}{l}\text { so-so, in } \\
\text { the middle }\end{array}$ & $\begin{array}{l}\text { somewhat } \\
\text { against it }\end{array}$ & $\begin{array}{l}\text { very } \\
\text { against it }\end{array}$ \\
\hline \multirow{4}{*}{$\begin{array}{l}\text { Moveme } \\
\text { nt }\end{array}$} & Revisionist & $\begin{array}{c}\text { Count } \\
\% \text { within } \\
\text { Movement }\end{array}$ & $\begin{array}{c}3 \\
2.0 \%\end{array}$ & $\begin{array}{c}11 \\
7.5 \%\end{array}$ & $\begin{array}{c}20 \\
13.6 \%\end{array}$ & $\begin{array}{c}28 \\
19.0 \%\end{array}$ & $\begin{array}{c}72 \\
49.0 \%\end{array}$ \\
\hline & $\begin{array}{l}\text { Religious } \\
\text { Zionist }\end{array}$ & $\begin{array}{c}\text { Count } \\
\% \text { within } \\
\text { Movement }\end{array}$ & $\begin{array}{c}0 \\
0.0 \%\end{array}$ & $\begin{array}{c}0 \\
0.0 \%\end{array}$ & $\begin{array}{c}2 \\
18.2 \%\end{array}$ & $\begin{array}{c}2 \\
18.2 \%\end{array}$ & $\begin{array}{c}6 \\
54.5 \%\end{array}$ \\
\hline & $\begin{array}{l}\text { Haredi (Ultra- } \\
\text { Orthodox) }\end{array}$ & $\begin{array}{c}\text { Count } \\
\% \text { within } \\
\text { Movement }\end{array}$ & $\begin{array}{c}0 \\
0.0 \%\end{array}$ & $\begin{array}{c}1 \\
3.0 \%\end{array}$ & $\begin{array}{c}4 \\
12.1 \%\end{array}$ & $\begin{array}{c}6 \\
18.2 \%\end{array}$ & $\begin{array}{c}16 \\
48.5 \%\end{array}$ \\
\hline & Labor & $\begin{array}{c}\text { Count } \\
\% \text { within } \\
\text { Movement }\end{array}$ & $\begin{array}{c}31 \\
19.9 \%\end{array}$ & $\begin{array}{c}40 \\
25.6 \%\end{array}$ & $\begin{array}{c}38 \\
24.4 \%\end{array}$ & $\begin{array}{c}11 \\
7.1 \%\end{array}$ & $\begin{array}{c}14 \\
9.0 \%\end{array}$ \\
\hline \multicolumn{2}{|r|}{ Total } & $\begin{array}{c}\text { Count } \\
\% \text { within } \\
\text { Movement }\end{array}$ & $\begin{array}{c}34 \\
9.8 \%\end{array}$ & $\begin{array}{c}52 \\
15.0 \%\end{array}$ & $\begin{array}{c}64 \\
18.4 \%\end{array}$ & $\begin{array}{c}47 \\
13.5 \%\end{array}$ & $\begin{array}{c}108 \\
31.1 \%\end{array}$ \\
\hline
\end{tabular}




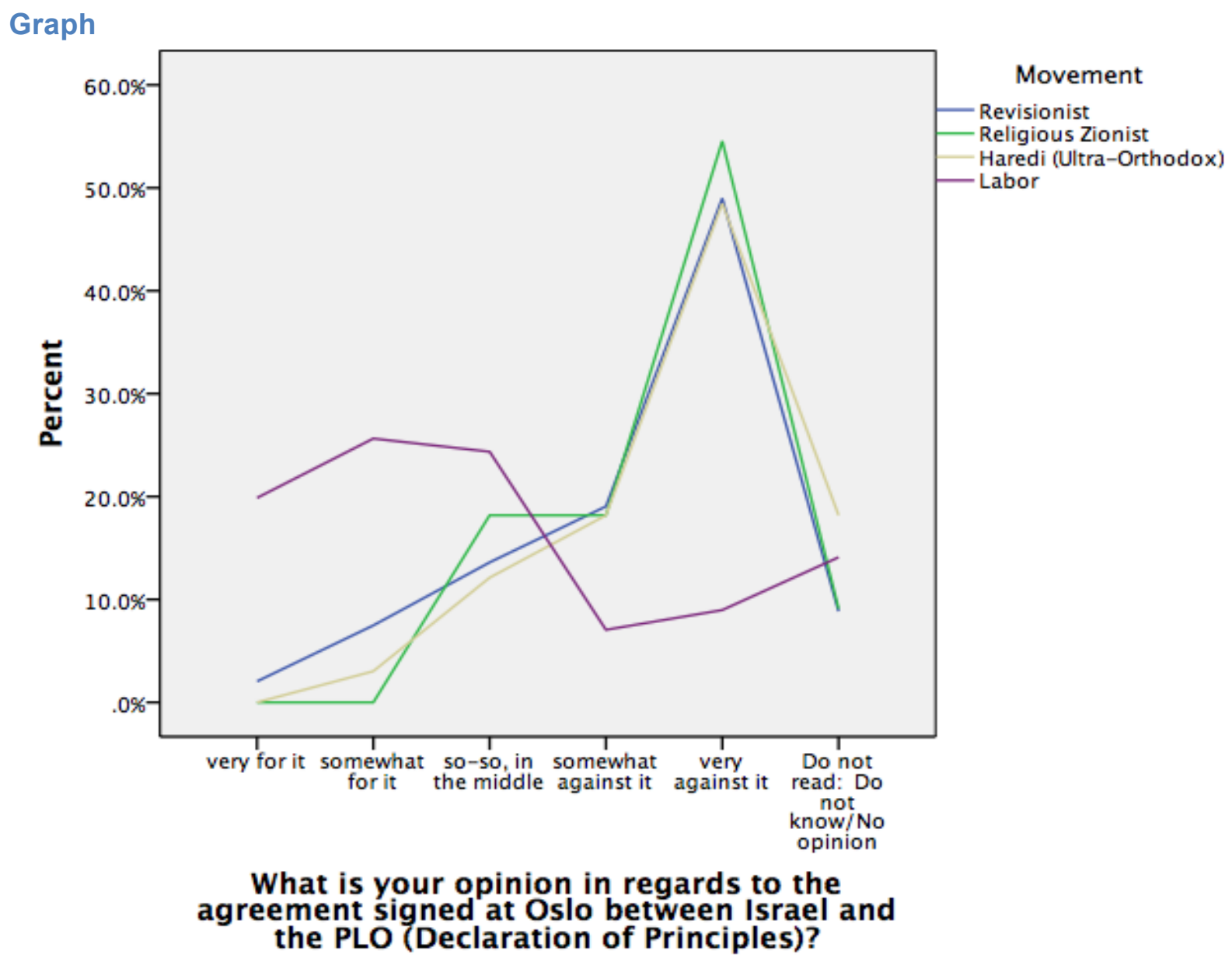

Nominal Regression

Model Fitting Information

\begin{tabular}{|l|r|r|r|r|}
\hline \multirow{2}{*}{ Model } & \multicolumn{1}{|c|}{$\begin{array}{c}\text { Model Fitting } \\
\text { Criteria }\end{array}$} & \multicolumn{3}{|c|}{ Likelihood Ratio Tests } \\
\cline { 2 - 5 } & $\begin{array}{c}-2 \text { Log } \\
\text { Likelihood }\end{array}$ & Chi-Square & \multicolumn{1}{c|}{ df } & \multicolumn{1}{|c|}{ Sig. } \\
\hline Intercept Only & $\begin{array}{r}190.719 \\
62.535\end{array}$ & 128.184 & 15 & .000 \\
\hline Final & 62.53 &
\end{tabular}

Goodness-of-Fit

\begin{tabular}{|l|r|r|r|}
\hline & Chi-Square & df & Sig. \\
\hline Pearson & .000 & 0 & \\
Deviance & .000 & 0 &. \\
\hline
\end{tabular}

Likelihood Ratio Tests

\begin{tabular}{|l|r|r|r|r|}
\hline \multirow{2}{*}{} & \multicolumn{1}{|c|}{$\begin{array}{c}\text { Model Fitting } \\
\text { Criteria }\end{array}$} & \multicolumn{3}{|c|}{ Likelihood Ratio Tests } \\
\cline { 2 - 6 } & $\begin{array}{c}\text {-2 Log } \\
\text { Likelihood of } \\
\text { Reduced Model }\end{array}$ & Chi-Square & df & \multicolumn{1}{c|}{ Sig. } \\
\hline Intercept & $62.535^{\mathrm{a}}$ & .000 & 0 & \\
Movement & 190.719 & 128.184 & 15 & .000 \\
\hline
\end{tabular}


Parameter Estimates

\begin{tabular}{|c|c|c|c|c|c|c|c|c|c|}
\hline \multirow{2}{*}{\multicolumn{2}{|c|}{$\begin{array}{l}\text { What is your opinion in } \\
\text { regards to the agreement } \\
\text { signed at Oslo between } \\
\text { Israel and the PLO } \\
\text { (Declaration of } \\
\text { Principles)? }^{\mathrm{a}}\end{array}$}} & \multirow[b]{2}{*}{ B } & \multirow[b]{2}{*}{$\begin{array}{l}\text { Std. } \\
\text { Error }\end{array}$} & \multirow[b]{2}{*}{ Wald } & \multirow[b]{2}{*}{ df } & \multirow[b]{2}{*}{ Sig. } & \multirow[b]{2}{*}{$\operatorname{Exp}(B)$} & \multicolumn{2}{|c|}{$\begin{array}{l}\text { 95\% Confidence } \\
\text { Interval for } \operatorname{Exp}(B)\end{array}$} \\
\hline & & & & & & & & $\begin{array}{l}\text { Lower } \\
\text { Bound }\end{array}$ & $\begin{array}{l}\text { Upper } \\
\text { Bound }\end{array}$ \\
\hline \multirow{5}{*}{$\begin{array}{l}\text { somewhat } \\
\text { for it }\end{array}$} & Intercept & .255 & .239 & 1.135 & 1 & .287 & & & \\
\hline & Revisionist & 1.044 & .694 & 2.265 & 1 & 132 & 2.842 & .729 & 11.072 \\
\hline & $\begin{array}{l}\text { Religious } \\
\text { Zionist }\end{array}$ & .170 & $\begin{array}{c}11361.3 \\
11\end{array}$ & .000 & 1 & 1.000 & & & b \\
\hline & $\begin{array}{l}\text { Haredi (ultra- } \\
\text { Orthodox) } \\
\end{array}$ & 16.754 & 1.112 & 226.882 & 1 & .000 & $\begin{array}{c}18878621 \\
.052 \\
\end{array}$ & $\begin{array}{c}2134092 . \\
600\end{array}$ & $\begin{array}{c}16700415 \\
5.688 \\
\end{array}$ \\
\hline & Labor & $0^{c}$ & & & 0 & & & & \\
\hline \multirow{3}{*}{$\begin{array}{l}\text { so-so, in the } \\
\text { middle }\end{array}$} & Intercept & .204 & .242 & .708 & 1 & .400 & & & \\
\hline & $\begin{array}{c}\text { Revisionist } \\
\text { Religious } \\
\text { Zionist }\end{array}$ & $\begin{array}{c}1.694 \\
18.662 \\
\end{array}$ & $\begin{array}{c}.665 \\
8834.47 \\
5\end{array}$ & $\begin{array}{l}6.490 \\
.000\end{array}$ & $\begin{array}{l}1 \\
1\end{array}$ & $\begin{array}{l}.011 \\
.998\end{array}$ & $\begin{array}{c}5.439 \\
12734158 \\
0.701\end{array}$ & $\begin{array}{l}1.478 \\
.000\end{array}$ & $\begin{array}{c}20.014 \\
b\end{array}$ \\
\hline & $\begin{array}{l}\text { Haredi (ultra- } \\
\text { Orthodox) } \\
\text { Labor }\end{array}$ & $\begin{array}{c}18.191 \\
0^{c}\end{array}$ & .699 & 677.502 & 1 & .000 & $\begin{array}{c}79488930 \\
.747\end{array}$ & $\begin{array}{c}20203036 \\
.079\end{array}$ & $\begin{array}{c}31274953 \\
3.613\end{array}$ \\
\hline \multirow{5}{*}{$\begin{array}{l}\text { somewhat } \\
\text { against it }\end{array}$} & Intercept & -1.036 & .351 & 8.716 & 1 & .003 & & & \\
\hline & Revisionist & 3.270 & .702 & 21.720 & 1 & .000 & 26.303 & 6.650 & 104.038 \\
\hline & $\begin{array}{l}\text { Religious } \\
\text { Zionist }\end{array}$ & 19.902 & $\begin{array}{c}8834.47 \\
5\end{array}$ & .000 & 1 & .998 & $\begin{array}{c}43990727 \\
8.786\end{array}$ & .000 & \\
\hline & Haredi (ultra- & $\mid 19.836$ & & 837.728 & 1 & .000 & 41189718 & 10750349 & 15781746 \\
\hline & $\begin{array}{l}\text { Orthodox) } \\
\text { Labor }\end{array}$ & $0^{c}$ & & & 0 & & 6.597 & 9.351 & 02.222 \\
\hline \multirow{5}{*}{$\begin{array}{c}\text { very against } \\
\text { it }\end{array}$} & Intercept & -.795 & .322 & 6.094 & 1 & .014 & & & \\
\hline & Revisionist & 3.973 & .671 & 35.006 & 1 & .000 & 53.143 & 14.252 & 198.164 \\
\hline & $\begin{array}{l}\text { Religious } \\
\text { Zionist }\end{array}$ & 20.760 & $\begin{array}{c}8834.47 \\
5\end{array}$ & .000 & 1 & .998 & $\begin{array}{c}10369242 \\
99.996\end{array}$ & .000 & b \\
\hline & Haredi (ultra- & & 588 & 1223.43 & 1 & 000 & 86302267 & 27245477 & 27336945 \\
\hline & $\begin{array}{l}\text { Orthodox) } \\
\text { Labor }\end{array}$ & $\begin{array}{c}20.0 / 0 \\
0^{c}\end{array}$ & & 6 & 0 & .000 & 6.679 & 3.017 & 95.312 \\
\hline \multirow{5}{*}{$\begin{array}{l}\text { Do not read: } \\
\text { Do not } \\
\text { know/No } \\
\text { opinion }\end{array}$} & Intercept & -.343 & .279 & 1.513 & 1 & .219 & & & \\
\hline & Revisionist & 1.809 & .699 & 6.708 & 1 & .010 & 6.106 & 1.553 & 24.009 \\
\hline & $\begin{array}{l}\text { Religious } \\
\text { Zionist }\end{array}$ & 18.516 & $\begin{array}{c}8834.47 \\
5\end{array}$ & .000 & 1 & .998 & $\begin{array}{c}10997681 \\
9.697\end{array}$ & .000 & b \\
\hline & Haredi (ultra- & 1914 & 000 & & 1 & & 20594859 & 20594859 & 20594859 \\
\hline & $\begin{array}{l}\text { Orthodox) } \\
\text { Labor }\end{array}$ & $\begin{array}{c}19.143 \\
0^{c}\end{array}$ & .000 & & 0 & - & 3.298 & 3.298 & 3.298 \\
\hline
\end{tabular}


July 2004

Crosstabs

Movement * What is your opinion in regards to the agreement signed at Oslo between Israel and the PLO (Declaration of Principles)? Crosstabulation

\begin{tabular}{|c|c|c|c|c|c|c|c|}
\hline & \multicolumn{5}{|c|}{$\begin{array}{l}\text { What is your opinion in regards to the agreement signed at } \\
\text { Oslo between Israel and the PLO (Declaration of Principles)? }\end{array}$} \\
\hline & & & very for it & $\begin{array}{l}\text { somewhat } \\
\text { for it }\end{array}$ & $\begin{array}{l}\text { so-so, in } \\
\text { the middle }\end{array}$ & $\begin{array}{l}\text { somewhat } \\
\text { against it }\end{array}$ & $\begin{array}{l}\text { very } \\
\text { against it }\end{array}$ \\
\hline \multirow{4}{*}{$\begin{array}{l}\text { Moveme } \\
\text { nt }\end{array}$} & Revisionist & $\begin{array}{c}\text { Count } \\
\% \text { within } \\
\text { Movement }\end{array}$ & $\begin{array}{c}9 \\
5.4 \%\end{array}$ & $\begin{array}{c}8 \\
4.8 \%\end{array}$ & $\begin{array}{c}24 \\
14.3 \%\end{array}$ & $\begin{array}{c}37 \\
22.0 \%\end{array}$ & $\begin{array}{c}74 \\
44.0 \%\end{array}$ \\
\hline & $\begin{array}{l}\text { Religious } \\
\text { Zionist }\end{array}$ & $\begin{array}{c}\text { Count } \\
\% \text { within } \\
\text { Movement }\end{array}$ & $\begin{array}{c}0 \\
0.0 \%\end{array}$ & $\begin{array}{c}0 \\
0.0 \%\end{array}$ & $\begin{array}{c}0 \\
0.0 \%\end{array}$ & $\begin{array}{c}4 \\
14.8 \%\end{array}$ & $\begin{array}{c}20 \\
74.1 \%\end{array}$ \\
\hline & $\begin{array}{l}\text { Haredi (Ultra- } \\
\text { Orthodox) }\end{array}$ & $\begin{array}{c}\text { Count } \\
\% \text { within } \\
\text { Movement }\end{array}$ & $\begin{array}{c}2 \\
8.7 \%\end{array}$ & $\begin{array}{c}1 \\
4.3 \%\end{array}$ & $\begin{array}{c}2 \\
8.7 \%\end{array}$ & $\begin{array}{c}6 \\
26.1 \%\end{array}$ & $\begin{array}{c}11 \\
47.8 \%\end{array}$ \\
\hline & Labor & $\begin{array}{c}\text { Count } \\
\% \text { within } \\
\text { Movement }\end{array}$ & $\begin{array}{c}43 \\
28.9 \%\end{array}$ & $\begin{array}{c}42 \\
28.2 \%\end{array}$ & $\begin{array}{c}34 \\
22.8 \%\end{array}$ & $\begin{array}{c}6 \\
4.0 \%\end{array}$ & $\begin{array}{c}16 \\
10.7 \%\end{array}$ \\
\hline \multicolumn{2}{|r|}{ Total } & $\begin{array}{c}\text { Count } \\
\% \text { within } \\
\text { Movement }\end{array}$ & $\begin{array}{c}54 \\
14.7 \%\end{array}$ & $\begin{array}{c}51 \\
13.9 \%\end{array}$ & $\begin{array}{c}60 \\
16.3 \%\end{array}$ & $\begin{array}{c}53 \\
14.4 \%\end{array}$ & $\begin{array}{c}121 \\
33.0 \%\end{array}$ \\
\hline
\end{tabular}




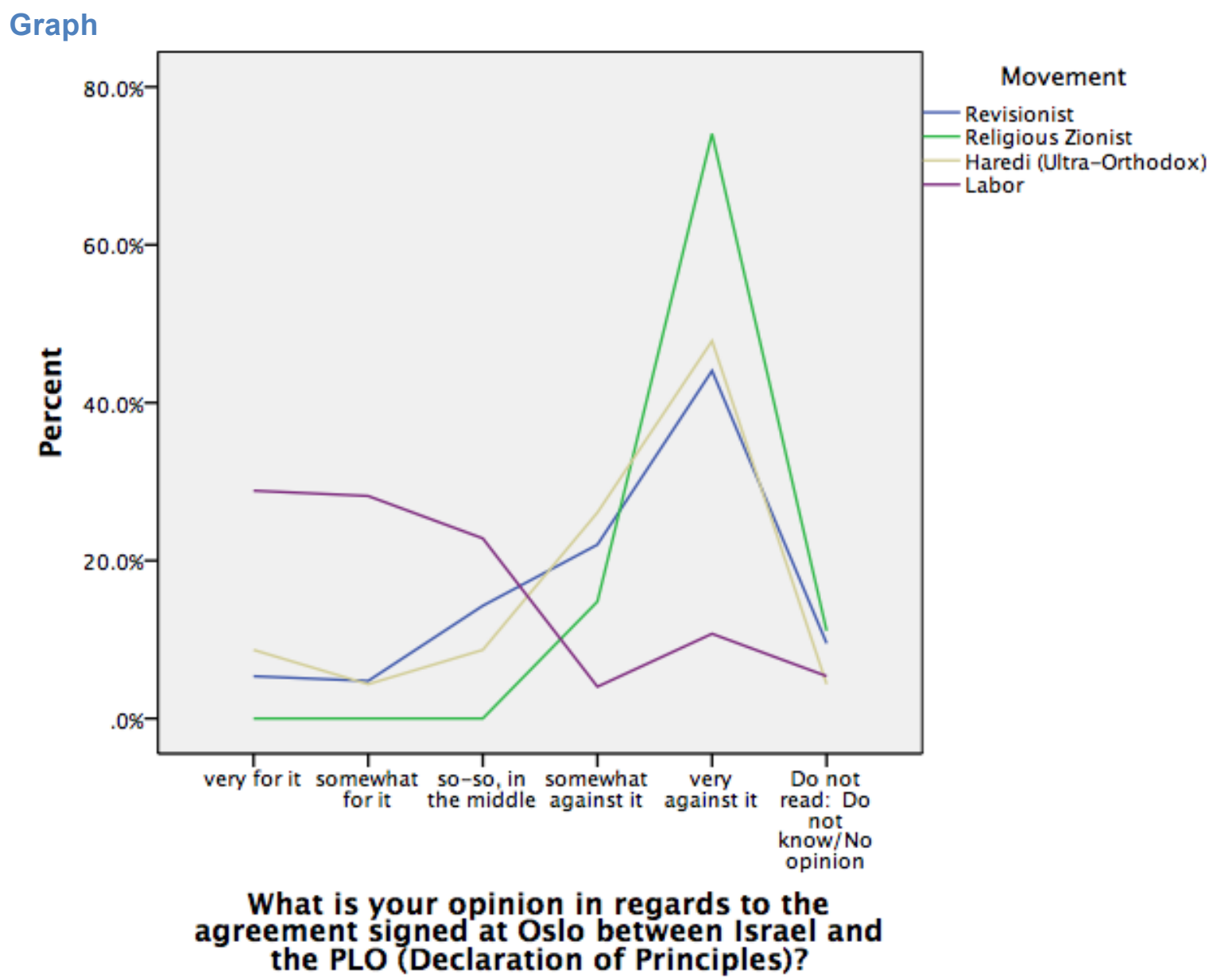

Nominal Regression

Model Fitting Information

\begin{tabular}{|l|r|r|r|r|}
\hline \multirow{2}{*}{} & \multicolumn{1}{|c|}{$\begin{array}{c}\text { Model Fitting } \\
\text { Criteria }\end{array}$} & \multicolumn{3}{|c|}{ Likelihood Ratio Tests } \\
\cline { 2 - 5 } & $\begin{array}{c}-2 \text { Log } \\
\text { Likelihood }\end{array}$ & Chi-Square & df & \multicolumn{1}{c|}{ Sig. } \\
\hline Intercept Only & $\begin{array}{r}226.923 \\
62.310\end{array}$ & 164.613 & 15 & .000 \\
\hline
\end{tabular}

Goodness-of-Fit

\begin{tabular}{|l|r|r|r|}
\hline & Chi-Square & df & Sig. \\
\hline Pearson & .000 & 0 &. \\
Deviance & .000 & 0 &. \\
\hline
\end{tabular}

Likelihood Ratio Tests

\begin{tabular}{|l|r|r|r|r|}
\hline \multirow{2}{*}{} & \multicolumn{1}{|c|}{$\begin{array}{c}\text { Model Fitting } \\
\text { Criteria }\end{array}$} & \multicolumn{3}{|c|}{ Likelihood Ratio Tests } \\
\cline { 2 - 6 } & $\begin{array}{c}\text {-2 Log } \\
\text { Likelihood of } \\
\text { Reduced Model }\end{array}$ & Chi-Square & df & \multicolumn{1}{c|}{ Sig. } \\
\hline Intercept & $62.310^{2}$ & .000 & 0 & \\
Movement & 226.923 & 164.613 & 15 & .000 \\
\hline
\end{tabular}


Parameter Estimates

\begin{tabular}{|c|c|c|c|c|c|c|c|c|c|}
\hline \multirow{2}{*}{\multicolumn{2}{|c|}{$\begin{array}{l}\text { What is your opinion in } \\
\text { regards to the agreement } \\
\text { signed at Oslo between } \\
\text { Israel and the PLO } \\
\text { (Declaration of } \\
\text { Principles)? }\end{array}$}} & \multirow[b]{2}{*}{ B } & \multirow[b]{2}{*}{$\begin{array}{l}\text { Std. } \\
\text { Error }\end{array}$} & \multirow[b]{2}{*}{ Wald } & \multirow[b]{2}{*}{ df } & \multirow[b]{2}{*}{ Sig. } & \multirow[b]{2}{*}{$\operatorname{Exp}(B)$} & \multicolumn{2}{|c|}{$\begin{array}{l}95 \% \text { Confidence } \\
\text { Interval for } \operatorname{Exp}(B)\end{array}$} \\
\hline & & & & & & & & $\begin{array}{l}\text { Lower } \\
\text { Bound }\end{array}$ & $\begin{array}{l}\text { Upper } \\
\text { Bound }\end{array}$ \\
\hline \multirow{5}{*}{$\begin{array}{l}\text { somewhat } \\
\text { for it }\end{array}$} & Intercept & -.024 & .217 & .012 & 1 & .914 & & & \\
\hline & Revisionist & -.094 & 532 & .031 & 1 & .859 & .910 & 321 & 2.582 \\
\hline & $\begin{array}{c}\text { Religious } \\
\text { Zionist }\end{array}$ & -.034 & $\begin{array}{c}9061.84 \\
2\end{array}$ & .000 & 1 & 1.000 & .967 & .000 & $\mathrm{~b}$ \\
\hline & $\begin{array}{l}\text { Haredi (ultra- } \\
\text { Orthodox) }\end{array}$ & -.670 & 1.244 & .290 & 1 & .590 & .512 & .045 & 5.860 \\
\hline & Labor & $0^{c}$ & & & 0 & & & & \\
\hline \multirow{4}{*}{$\begin{array}{l}\text { so-so, in the } \\
\text { middle }\end{array}$} & Intercept & -.235 & 229 & 1.047 & 1 & .306 & & & \\
\hline & Revisionist & 1.216 & .453 & 7.193 & 1 & .007 & 3.373 & 1.387 & 8.199 \\
\hline & $\begin{array}{l}\text { Religious } \\
\text { Zionist }\end{array}$ & .340 & $\begin{array}{c}8354.60 \\
6\end{array}$ & .000 & 1 & 1.000 & 1.405 & .000 & b \\
\hline & $\begin{array}{l}\text { Haredi (ultra- } \\
\text { Orthodox) } \\
\text { Labor }\end{array}$ & $\begin{array}{c}.235 \\
0^{c}\end{array}$ & 1.026 & .052 & 1 & .819 & 1.265 & 169 & 9.448 \\
\hline \multirow{5}{*}{$\begin{array}{l}\text { somewhat } \\
\text { against it }\end{array}$} & Intercept & -1.969 & .436 & 20.423 & 1 & .000 & & & \\
\hline & Revisionist & 3.383 & .573 & 34.889 & 1 & .000 & 29.463 & 9.588 & 90.535 \\
\hline & $\begin{array}{l}\text { Religious } \\
\text { Zionist }\end{array}$ & 21.522 & 935 & $\begin{array}{c}529.37 \\
9\end{array}$ & 1 & .000 & $\begin{array}{c}22232412 \\
71.384\end{array}$ & $\begin{array}{c}35543522 \\
1.279\end{array}$ & $\begin{array}{c}13906336 \\
386.692\end{array}$ \\
\hline & Haredi (ultra- & 3068 & 926 & & 1 & & & & \\
\hline & Orthodox) & $\begin{array}{c}3.068 \\
0\end{array}$ & $9<6$ & 10.989 & 1 & .001 & $\angle 1.500$ & 3.505 & 131.900 \\
\hline \multirow{6}{*}{$\begin{array}{c}\text { very against } \\
\text { it }\end{array}$} & Intercept & -.989 & 293 & 11.397 & 1 & .001 & & & \\
\hline & Revisionist & 3.095 & .459 & 45.545 & 1 & .000 & 22.097 & 8.993 & 54.295 \\
\hline & $\begin{array}{l}\text { Religious } \\
\text { Zionist }\end{array}$ & 22.151 & .756 & $\begin{array}{c}859.55 \\
0\end{array}$ & 1 & .000 & $\begin{array}{c}41685773 \\
83845\end{array}$ & $\begin{array}{c}94814596 \\
2892\end{array}$ & $\begin{array}{c}18327386 \\
378474\end{array}$ \\
\hline & Haredi (ultra- & $060 ?$ & & & & & & & \\
\hline & Orthodox) & 2.693 & .823 & 10.720 & 1 & .001 & 14.781 & 2.948 & 74.115 \\
\hline & Labor & $0^{c}$ & & & 0 & & & & \\
\hline \multirow{5}{*}{$\begin{array}{l}\text { Do not read: } \\
\text { Do not } \\
\text { know/No } \\
\text { opinion }\end{array}$} & Intercept & -1.682 & .385 & 19.077 & 1 & .000 & & & \\
\hline & Revisionist & 2.257 & .567 & 15.828 & 1 & .000 & 9.556 & 3.143 & 29.052 \\
\hline & $\begin{array}{l}\text { Religious } \\
\text { Zionist }\end{array}$ & 20.947 & .000 & & 1 & & $\begin{array}{c}12505732 \\
15.154\end{array}$ & $\begin{array}{c}12505732 \\
15.154\end{array}$ & $\begin{array}{c}12505732 \\
15.154\end{array}$ \\
\hline & Haredi (ultra- & .989 & 1.284 & .593 & 1 & .441 & 2.688 & .217 & 33.278 \\
\hline & Labor & $0^{c}$ & & & 0 & & & & \\
\hline
\end{tabular}


January 2005

Crosstabs

Movement * What is your opinion in regards to the agreement signed at Oslo between Israel and the PLO (Declaration of Principles)? Crosstabulation

\begin{tabular}{|c|c|c|c|c|c|c|c|}
\hline & \multicolumn{5}{|c|}{$\begin{array}{l}\text { What is your opinion in regards to the agreement signed at } \\
\text { Oslo between Israel and the PLO (Declaration of Principles)? }\end{array}$} \\
\hline & & & very for it & $\begin{array}{l}\text { somewhat } \\
\text { for it }\end{array}$ & $\begin{array}{l}\text { so-so, in } \\
\text { the middle }\end{array}$ & $\begin{array}{l}\text { somewhat } \\
\text { against it }\end{array}$ & $\begin{array}{l}\text { very } \\
\text { against it }\end{array}$ \\
\hline \multirow{4}{*}{$\begin{array}{l}\text { Moveme } \\
\text { nt }\end{array}$} & Revisionist & $\begin{array}{c}\text { Count } \\
\% \text { within } \\
\text { Movement }\end{array}$ & $\begin{array}{c}13 \\
6.8 \%\end{array}$ & $\begin{array}{c}24 \\
12.5 \%\end{array}$ & $\begin{array}{c}50 \\
26.0 \%\end{array}$ & $\begin{array}{c}29 \\
15.1 \%\end{array}$ & $\begin{array}{c}55 \\
28.6 \%\end{array}$ \\
\hline & $\begin{array}{l}\text { Religious } \\
\text { Zionist }\end{array}$ & $\begin{array}{c}\text { Count } \\
\% \text { within } \\
\text { Movement }\end{array}$ & $\begin{array}{c}0 \\
0.0 \%\end{array}$ & $\begin{array}{c}1 \\
10.0 \%\end{array}$ & $\begin{array}{c}2 \\
20.0 \%\end{array}$ & $\begin{array}{c}0 \\
0.0 \%\end{array}$ & $\begin{array}{c}7 \\
70.0 \%\end{array}$ \\
\hline & $\begin{array}{l}\text { Haredi (Ultra- } \\
\text { Orthodox) }\end{array}$ & $\begin{array}{c}\text { Count } \\
\% \text { within } \\
\text { Movement }\end{array}$ & $\begin{array}{c}0 \\
0.0 \%\end{array}$ & $\begin{array}{c}1 \\
2.6 \%\end{array}$ & $\begin{array}{c}3 \\
7.9 \%\end{array}$ & $\begin{array}{c}9 \\
23.7 \%\end{array}$ & $\begin{array}{c}17 \\
44.7 \%\end{array}$ \\
\hline & Labor & $\begin{array}{c}\text { Count } \\
\% \text { within } \\
\text { Movement }\end{array}$ & $\begin{array}{c}30 \\
20.5 \%\end{array}$ & $\begin{array}{c}49 \\
33.6 \%\end{array}$ & $\begin{array}{c}39 \\
26.7 \%\end{array}$ & $\begin{array}{c}9 \\
6.2 \%\end{array}$ & $\begin{array}{c}4 \\
2.7 \%\end{array}$ \\
\hline \multicolumn{2}{|r|}{ Total } & $\begin{array}{c}\text { Count } \\
\% \text { within } \\
\text { Movement }\end{array}$ & $\begin{array}{c}43 \\
11.1 \%\end{array}$ & $\begin{array}{c}75 \\
19.4 \%\end{array}$ & $\begin{array}{c}94 \\
24.4 \%\end{array}$ & $\begin{array}{c}47 \\
12.2 \%\end{array}$ & $\begin{array}{c}83 \\
21.5 \%\end{array}$ \\
\hline
\end{tabular}




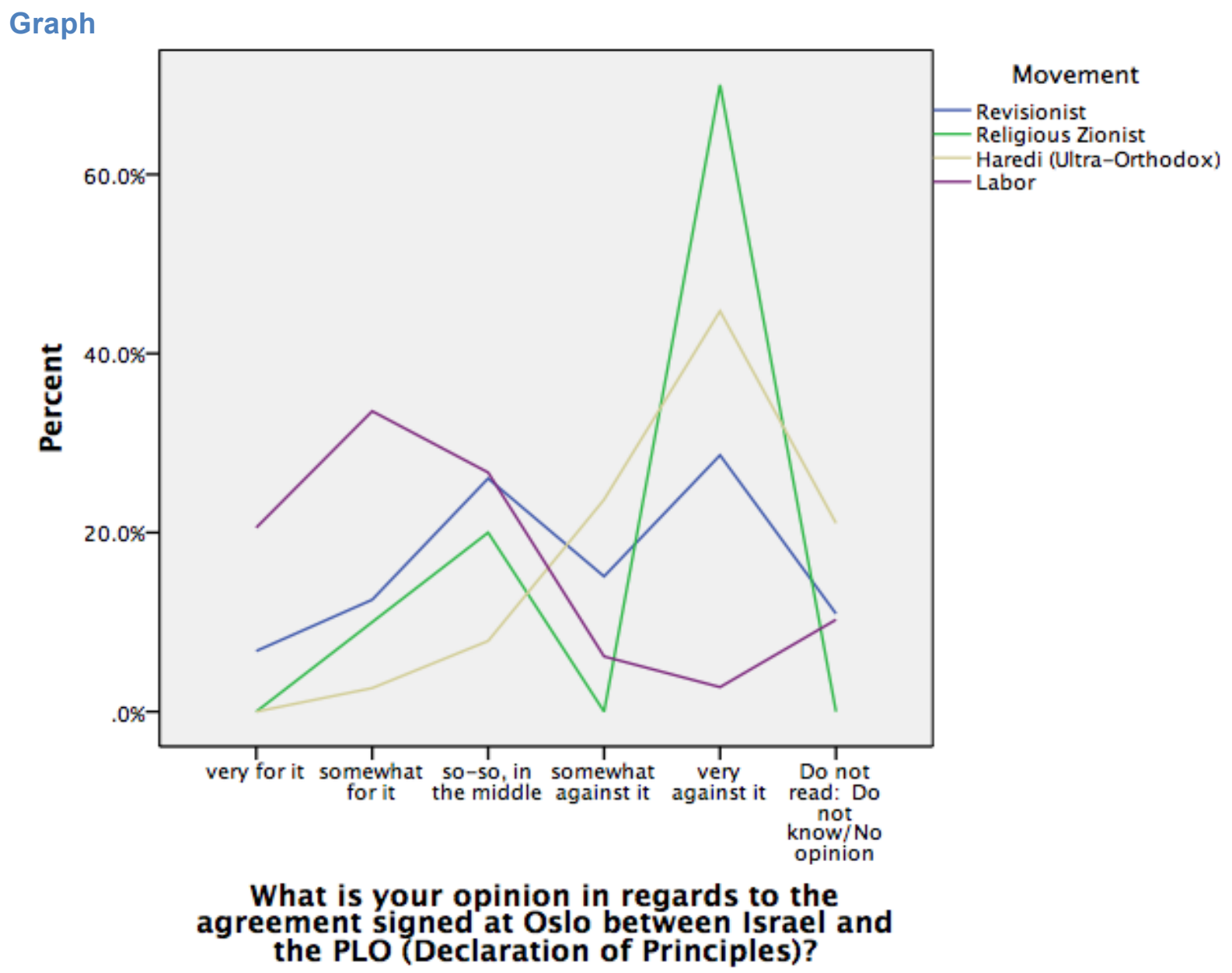

Nominal Regression

Model Fitting Information

\begin{tabular}{|l|r|r|r|r|}
\hline \multirow{2}{*}{} & \multicolumn{1}{|c|}{$\begin{array}{c}\text { Model Fitting } \\
\text { Criteria }\end{array}$} & \multicolumn{3}{|c|}{ Likelihood Ratio Tests } \\
\cline { 2 - 5 } & $\begin{array}{r}-2 \text { Log } \\
\text { Likelihood }\end{array}$ & Chi-Square & \multicolumn{1}{c|}{ df } & \multicolumn{1}{|c|}{ Sig. } \\
\hline Model & $\begin{array}{r}192.947 \\
62.031\end{array}$ & 130.916 & 15 & .000 \\
\hline
\end{tabular}

Goodness-of-Fit

\begin{tabular}{|l|r|r|r|}
\hline & Chi-Square & df & Sig. \\
\hline Pearson & .000 & & \\
Deviance & .000 & 0 &. \\
\hline
\end{tabular}

\section{Likelihood Ratio Tests}

\begin{tabular}{|l|r|r|r|r|}
\hline \multirow{2}{*}{} & \multicolumn{1}{|c|}{$\begin{array}{c}\text { Model Fitting } \\
\text { Criteria }\end{array}$} & \multicolumn{3}{|c|}{ Likelihood Ratio Tests } \\
\cline { 2 - 6 } & $\begin{array}{c}-2 \text { Log } \\
\text { Likelihood of } \\
\text { Reduced Model }\end{array}$ & Chi-Square & df & \multicolumn{1}{c|}{ Sig. } \\
\hline Intercept & $62.031^{\mathrm{a}}$ & .000 & 0 & \\
Movement & 192.947 & 130.916 & 15 & .000 \\
\hline
\end{tabular}


Parameter Estimates

\begin{tabular}{|c|c|c|c|c|c|c|c|c|c|}
\hline \multirow{2}{*}{\multicolumn{2}{|c|}{$\begin{array}{l}\text { What is your opinion in } \\
\text { regards to the agreement } \\
\text { signed at Oslo between } \\
\text { Israel and the PLO } \\
\text { (Declaration of } \\
\text { Principles)? }{ }^{\mathrm{a}}\end{array}$}} & \multirow[b]{2}{*}{ B } & \multirow[b]{2}{*}{$\begin{array}{l}\text { Std. } \\
\text { Error }\end{array}$} & \multirow[b]{2}{*}{ Wald } & \multirow[b]{2}{*}{ df } & \multirow[b]{2}{*}{ Sig. } & \multirow[b]{2}{*}{$\operatorname{Exp}(B)$} & \multicolumn{2}{|c|}{$\begin{array}{c}95 \% \text { Confidence } \\
\text { Interval for } \operatorname{Exp}(B)\end{array}$} \\
\hline & & & & & & & & $\begin{array}{l}\text { Lower } \\
\text { Bound }\end{array}$ & $\begin{array}{l}\text { Upper } \\
\text { Bound }\end{array}$ \\
\hline \multirow{5}{*}{$\begin{array}{l}\text { somewhat } \\
\text { for it }\end{array}$} & Intercept & .491 & .232 & 4.479 & 1 & .034 & & & \\
\hline & Revisionist & 122 & 415 & .087 & 1 & .768 & 1.130 & .501 & 2.550 \\
\hline & $\begin{array}{l}\text { Religious } \\
\text { Zionist }\end{array}$ & 18.551 & 1.189 & 243.514 & 1 & .000 & $\begin{array}{c}11395081 \\
5.903\end{array}$ & $\begin{array}{c}11086690 \\
.725\end{array}$ & $\begin{array}{c}11712050 \\
75.296\end{array}$ \\
\hline & $\begin{array}{l}\text { Haredi (ultra- } \\
\text { Orthodox) }\end{array}$ & 16.472 & 1.101 & 223.845 & 1 & .000 & $\begin{array}{c}14242117 \\
.419\end{array}$ & $\begin{array}{c}1646078 . \\
098\end{array}$ & $\begin{array}{c}12322496 \\
0.492\end{array}$ \\
\hline & Labor & $0^{\mathrm{b}}$ & & & 0 & & & & \\
\hline \multirow{4}{*}{$\begin{array}{l}\text { so-so, in the } \\
\text { middle }\end{array}$} & Intercept & .262 & 243 & 1.167 & 1 & .280 & & & \\
\hline & Revisionist & 1.085 & .395 & 7.547 & 1 & .006 & 2.959 & 1.365 & 6.415 \\
\hline & $\begin{array}{l}\text { Religious } \\
\text { Zionist }\end{array}$ & 19.473 & .958 & 412.832 & 1 & .000 & $\begin{array}{c}28633794 \\
7.654 \\
\end{array}$ & \begin{tabular}{|c|}
43762460 \\
.705 \\
\end{tabular} & $\begin{array}{c}18735102 \\
85.899 \\
\end{array}$ \\
\hline & $\begin{array}{l}\text { Haredi (ultra- } \\
\text { Orthodox) } \\
\text { Labor }\end{array}$ & $\begin{array}{c}17.799 \\
0^{\mathrm{b}}\end{array}$ & .742 & 575.311 & $\begin{array}{l}1 \\
0\end{array}$ & .000 & $\begin{array}{c}53681827 \\
.196\end{array}$ & $\begin{array}{c}12536940 \\
.537\end{array}$ & $\begin{array}{c}22985979 \\
4.154\end{array}$ \\
\hline \multirow{5}{*}{$\begin{array}{l}\text { somewhat } \\
\text { against it }\end{array}$} & Intercept & -1.204 & .380 & 10.035 & 1 & .002 & & & \\
\hline & Revisionist & 2.006 & .506 & 15.733 & 1 & .000 & 7.436 & 2.759 & 20.039 \\
\hline & $\begin{array}{l}\text { Religious } \\
\text { Zionist }\end{array}$ & 1.293 & .000 & & 1 & & 3.643 & 3.643 & 3.643 \\
\hline & $\begin{array}{l}\text { Haredi (ultra- } \\
\text { Orthodox) }\end{array}$ & 20.364 & 643 & $\begin{array}{c}1001.89 \\
6\end{array}$ & 1 & .000 & $\begin{array}{c}69786375 \\
3.553\end{array}$ & $\begin{array}{c}19776843 \\
0.176\end{array}$ & $\begin{array}{c}24625458 \\
07.187\end{array}$ \\
\hline & Labor & $0^{\mathrm{b}}$ & & & 0 & & & & \\
\hline \multirow{5}{*}{$\begin{array}{c}\text { very against } \\
\text { it }\end{array}$} & Intercept & -2.015 & .532 & 14.329 & 1 & .000 & & & \\
\hline & Revisionist & 3.457 & .615 & 31.585 & 1 & .000 & 31.731 & 9.503 & 105.954 \\
\hline & $\begin{array}{c}\text { Religious } \\
\text { Zionist }\end{array}$ & 23.003 & .000 & 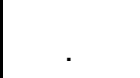 & 1 & & $\begin{array}{c}97712824 \\
63695\end{array}$ & 97712824 & 97712824 \\
\hline & Haredi (ultra- & 10 & & & & & 29659209 & 74126623 & 11867108 \\
\hline & $\begin{array}{l}\text { Orthodox) } \\
\text { Labor }\end{array}$ & $0^{\mathrm{b}}$ & .107 & 1950.460 & 0 & .000 & 52.598 & 4.996 & 849.369 \\
\hline \multirow{5}{*}{$\begin{array}{l}\text { Do not read: } \\
\text { Do not } \\
\text { know/No } \\
\text { opinion }\end{array}$} & Intercept & -.693 & .316 & 4.805 & 1 & .028 & & & \\
\hline & Revisionist & 1.173 & .474 & 6.125 & 1 & .013 & 3.231 & 1.276 & 8.178 \\
\hline & $\begin{array}{l}\text { Religious } \\
\text { Zionist }\end{array}$ & .716 & .000 & . & 1 & & 2.047 & 2.047 & 2.047 \\
\hline & Haredi (ultra- & 19.735 & .000 & & 1 & & $\begin{array}{c}37219400 \\
1895\end{array}$ & $\begin{array}{c}37219400 \\
1895\end{array}$ & 37219400 \\
\hline & Labor & $0^{\mathrm{b}}$ & & & 0 & & & & \\
\hline
\end{tabular}


July 2005

Crosstabs

Movement * What is your opinion in regards to the agreement signed at Oslo between Israel and the PLO (Declaration of Principles)? Crosstabulation

\begin{tabular}{|c|c|c|c|c|c|c|c|}
\hline & \multicolumn{5}{|c|}{$\begin{array}{l}\text { What is your opinion in regards to the agreement signed at } \\
\text { Oslo between Israel and the PLO (Declaration of Principles)? }\end{array}$} \\
\hline & & & very for it & $\begin{array}{l}\text { somewhat } \\
\text { for it }\end{array}$ & $\begin{array}{l}\text { so-so, in } \\
\text { the middle }\end{array}$ & $\begin{array}{l}\text { somewhat } \\
\text { against it }\end{array}$ & $\begin{array}{l}\text { very } \\
\text { against it }\end{array}$ \\
\hline \multirow{4}{*}{$\begin{array}{l}\text { Moveme } \\
\text { nt }\end{array}$} & Revisionist & $\begin{array}{c}\text { Count } \\
\% \text { within } \\
\text { Movement }\end{array}$ & $\begin{array}{c}7 \\
4.3 \%\end{array}$ & $\begin{array}{c}14 \\
8.5 \%\end{array}$ & $\begin{array}{c}25 \\
15.2 \%\end{array}$ & $\begin{array}{c}24 \\
14.6 \%\end{array}$ & $\begin{array}{c}66 \\
40.2 \%\end{array}$ \\
\hline & $\begin{array}{l}\text { Religious } \\
\text { Zionist }\end{array}$ & $\begin{array}{c}\text { Count } \\
\% \text { within } \\
\text { Movement }\end{array}$ & $\begin{array}{c}1 \\
4.8 \%\end{array}$ & $\begin{array}{c}0 \\
0.0 \%\end{array}$ & $\begin{array}{c}2 \\
9.5 \%\end{array}$ & $\begin{array}{c}0 \\
0.0 \%\end{array}$ & $\begin{array}{c}16 \\
76.2 \%\end{array}$ \\
\hline & $\begin{array}{l}\text { Haredi (Ultra- } \\
\text { Orthodox) }\end{array}$ & $\begin{array}{c}\text { Count } \\
\% \text { within } \\
\text { Movement }\end{array}$ & $\begin{array}{c}1 \\
2.7 \%\end{array}$ & $\begin{array}{c}1 \\
2.7 \%\end{array}$ & $\begin{array}{c}5 \\
13.5 \%\end{array}$ & $\begin{array}{c}9 \\
24.3 \%\end{array}$ & $\begin{array}{c}17 \\
45.9 \%\end{array}$ \\
\hline & Labor & $\begin{array}{c}\text { Count } \\
\% \text { within } \\
\text { Movement }\end{array}$ & $\begin{array}{c}46 \\
30.5 \%\end{array}$ & $\begin{array}{c}43 \\
28.5 \%\end{array}$ & $\begin{array}{c}27 \\
17.9 \%\end{array}$ & $\begin{array}{c}8 \\
5.3 \%\end{array}$ & $\begin{array}{c}13 \\
8.6 \%\end{array}$ \\
\hline \multicolumn{2}{|r|}{ Total } & $\begin{array}{c}\text { Count } \\
\% \text { within } \\
\text { Movement }\end{array}$ & $\begin{array}{c}55 \\
14.7 \%\end{array}$ & $\begin{array}{c}58 \\
15.5 \%\end{array}$ & $\begin{array}{c}59 \\
15.8 \%\end{array}$ & $\begin{array}{c}41 \\
11.0 \%\end{array}$ & $\begin{array}{c}112 \\
30.0 \%\end{array}$ \\
\hline
\end{tabular}




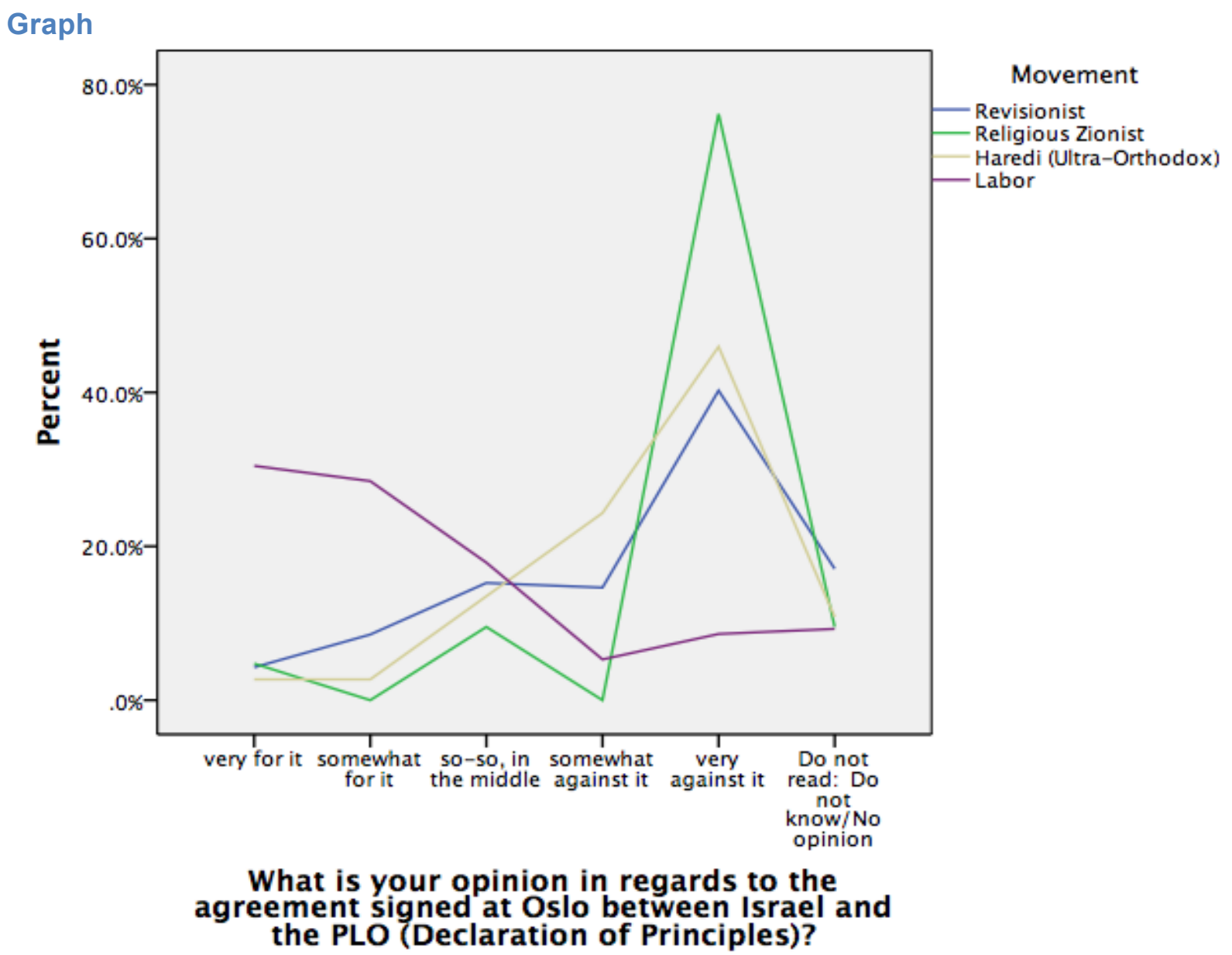

Nominal Regression

Model Fitting Information

\begin{tabular}{|l|r|r|r|r|}
\hline \multirow{2}{*}{} & \multicolumn{1}{|c|}{$\begin{array}{c}\text { Model Fitting } \\
\text { Criteria }\end{array}$} & \multicolumn{3}{|c|}{ Likelihood Ratio Tests } \\
\cline { 2 - 5 } & $\begin{array}{r}-2 \text { Log } \\
\text { Likelihood }\end{array}$ & Chi-Square & df & \multicolumn{1}{c|}{ Sig. } \\
\hline Intercept Only & $\begin{array}{r}213.544 \\
66.035\end{array}$ & 147.509 & 15 & .000 \\
\hline
\end{tabular}

Goodness-of-Fit

\begin{tabular}{|l|r|r|r|}
\hline & Chi-Square & df & Sig. \\
\hline Pearson & .000 & 0 & \\
Deviance & .000 & 0 &. \\
\hline
\end{tabular}

Likelihood Ratio Tests

\begin{tabular}{|l|r|r|r|r|}
\hline \multirow{2}{*}{} & \multicolumn{1}{|c|}{$\begin{array}{c}\text { Model Fitting } \\
\text { Criteria }\end{array}$} & \multicolumn{3}{|c|}{ Likelihood Ratio Tests } \\
\cline { 2 - 6 } & $\begin{array}{c}-2 \text { Log } \\
\text { Likelihood of } \\
\text { Reduced Model }\end{array}$ & Chi-Square & \multicolumn{1}{c|}{ df } & \multicolumn{1}{c|}{ Sig. } \\
\hline Intercept & $66.035^{\mathrm{a}}$ & .000 & 0 & \\
Movement & 213.544 & 147.509 & 15 & .000 \\
\hline
\end{tabular}


Parameter Estimates

\begin{tabular}{|c|c|c|c|c|c|c|c|c|c|}
\hline \multirow{2}{*}{\multicolumn{2}{|c|}{$\begin{array}{l}\text { What is your opinion in } \\
\text { regards to the agreement } \\
\text { signed at Oslo between } \\
\text { Israel and the PLO } \\
\text { (Declaration of Principles)? }\end{array}$}} & \multirow{2}{*}{ B } & \multirow{2}{*}{$\begin{array}{l}\text { Std. } \\
\text { Error }\end{array}$} & \multirow{2}{*}{ Wald } & \multirow{2}{*}{$d f$} & \multirow{2}{*}{ Sig. } & \multirow{2}{*}{$\operatorname{Exp}(B)$} & \multicolumn{2}{|c|}{$\begin{array}{l}95 \% \text { Confidence } \\
\text { Interval for Exp(B) }\end{array}$} \\
\hline & & & & & & & & $\begin{array}{l}\text { Lower } \\
\text { Bound }\end{array}$ & $\begin{array}{l}\text { Upper } \\
\text { Bound }\end{array}$ \\
\hline \multirow{4}{*}{$\begin{array}{l}\text { somewhat for } \\
\text { it }\end{array}$} & $\begin{array}{c}\text { Intercept } \\
\text { Revisionist }\end{array}$ & $\begin{array}{l}-.067 \\
761\end{array}$ & .212 & $\begin{array}{l}.101 \\
2231\end{array}$ & $\begin{array}{l}1 \\
1\end{array}$ & $\begin{array}{r}.751 \\
135\end{array}$ & 2110 & 789 & 5804 \\
\hline & Religious & -18.386 & .000 & 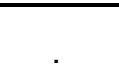 & 1 & & 1.035E- & $1.035 \mathrm{E}-8$ & $1.035 \mathrm{E}-8$ \\
\hline & $\begin{array}{l}\text { Haredi (ultra- } \\
\text { Orthodox) }\end{array}$ & .067 & 1.430 & .002 & 1 & .962 & 1.070 & .065 & \\
\hline & Labor & $0^{\mathrm{b}}$ & & & 0 & & & & \\
\hline \multirow{4}{*}{$\begin{array}{l}\text { so-so, in the } \\
\text { middle }\end{array}$} & Intercept & -.533 & .242 & 4.830 & 1 & .028 & & & \\
\hline & Revisionist & 1.806 & .492 & 13.495 & 1 & .000 & 6.085 & 2.322 & 15.946 \\
\hline & $\begin{array}{l}\text { Religious } \\
\text { Zionist }\end{array}$ & 1.226 & 1.249 & .964 & 1 & .326 & 3.407 & .295 & 39.369 \\
\hline & $\begin{array}{l}\text { Haredi (ultra- } \\
\text { Orthodox) } \\
\text { Labor }\end{array}$ & $\begin{array}{c}2.142 \\
0^{b}\end{array}$ & 1.122 & 3.646 & $\begin{array}{l}1 \\
0\end{array}$ & .056 & 8.519 & .945 & 76.802 \\
\hline \multirow{5}{*}{$\begin{array}{l}\text { somewhat } \\
\text { against it }\end{array}$} & Intercept & -1.749 & .383 & 20.851 & 1 & .000 & & & \\
\hline & Revisionist & 2.981 & .576 & 26.832 & 1 & .000 & 19.714 & 6.381 & 60.911 \\
\hline & $\begin{array}{l}\text { Religious } \\
\text { Zionist }\end{array}$ & -17.052 & .000 & & 1 & & $\begin{array}{l}3.932 \mathrm{E}- \\
\quad 8\end{array}$ & $3.932 E-8$ & 3.932E-8 \\
\hline & Haredi (ultra- & 3.946 & 1.122 & 12.382 & 1 & .000 & 51.750 & 5.745 & 466.194 \\
\hline & $\begin{array}{l}\text { Orthodox) } \\
\text { Labor }\end{array}$ & $0^{\mathrm{b}}$ & & & 0 & & & & \\
\hline \multirow{5}{*}{$\begin{array}{l}\text { very against } \\
\text { it }\end{array}$} & Intercept & -1.264 & .314 & 16.186 & 1 & .000 & & & \\
\hline & Revisionist & 3.507 & .507 & 47.930 & 1 & .000 & 33.363 & 12.360 & 90.054 \\
\hline & $\begin{array}{l}\text { Religious } \\
\text { Zionist }\end{array}$ & 4.036 & 1.078 & 14.030 & 1 & .000 & 56.615 & 6.850 & 467.914 \\
\hline & Haredi (ultra- & 4.097 & 1.076 & 14.501 & 1 & .000 & 60.154 & 7.303 & 495.497 \\
\hline & Labor & $0^{\mathrm{b}}$ & & & 0 & & & & \\
\hline \multirow{5}{*}{$\begin{array}{c}\text { Do not read: } \\
\text { Do not } \\
\text { know/No } \\
\text { opinion }\end{array}$} & Intercept & -1.190 & .305 & 15.189 & 1 & .000 & & & \\
\hline & Revisionist & 2.576 & .521 & 24.417 & 1 & .000 & 13.143 & 4.731 & 36.510 \\
\hline & $\begin{array}{l}\text { Religious } \\
\text { Zionist }\end{array}$ & 1.883 & 1.262 & 2.225 & 1 & .136 & 6.571 & .554 & 77.992 \\
\hline & Haredi (ultra- & 2.576 & 1.159 & 4.940 & 1 & .026 & 13.143 & 1.356 & 127.406 \\
\hline & Labor & $0^{\mathrm{b}}$ & & & 0 & & & & \\
\hline
\end{tabular}


January 2006

Crosstabs

Movement * What is your opinion in regards to the agreement signed at Oslo between Israel and the PLO (Declaration of Principles)? Crosstabulation

\begin{tabular}{|c|c|c|c|c|c|c|c|}
\hline & \multicolumn{5}{|c|}{$\begin{array}{l}\text { What is your opinion in regards to the agreement signed at } \\
\text { Oslo between Israel and the PLO (Declaration of Principles)? }\end{array}$} \\
\hline & & & very for it & $\begin{array}{l}\text { somewhat } \\
\text { for it }\end{array}$ & $\begin{array}{l}\text { so-so, in } \\
\text { the middle }\end{array}$ & $\begin{array}{l}\text { somewhat } \\
\text { against it }\end{array}$ & $\begin{array}{l}\text { very } \\
\text { against it }\end{array}$ \\
\hline \multirow{4}{*}{$\begin{array}{l}\text { Moveme } \\
\text { nt }\end{array}$} & Revisionist & $\begin{array}{c}\text { Count } \\
\% \text { within } \\
\text { Movement }\end{array}$ & $\begin{array}{c}14 \\
7.0 \%\end{array}$ & $\begin{array}{c}16 \\
8.0 \%\end{array}$ & $\begin{array}{c}43 \\
21.4 \%\end{array}$ & $\begin{array}{c}42 \\
20.9 \%\end{array}$ & $\begin{array}{c}54 \\
26.9 \%\end{array}$ \\
\hline & $\begin{array}{l}\text { Religious } \\
\text { Zionist }\end{array}$ & $\begin{array}{c}\text { Count } \\
\% \text { within } \\
\text { Movement }\end{array}$ & $\begin{array}{c}2 \\
11.1 \%\end{array}$ & $\begin{array}{c}1 \\
5.6 \%\end{array}$ & $\begin{array}{c}1 \\
5.6 \%\end{array}$ & $\begin{array}{c}5 \\
27.8 \%\end{array}$ & $\begin{array}{c}8 \\
44.4 \%\end{array}$ \\
\hline & $\begin{array}{l}\text { Haredi (Ultra- } \\
\text { Orthodox) }\end{array}$ & $\begin{array}{c}\text { Count } \\
\% \text { within } \\
\text { Movement }\end{array}$ & $\begin{array}{c}2 \\
6.1 \%\end{array}$ & $\begin{array}{c}2 \\
6.1 \%\end{array}$ & $\begin{array}{c}3 \\
9.1 \%\end{array}$ & $\begin{array}{c}8 \\
24.2 \%\end{array}$ & $\begin{array}{c}14 \\
42.4 \%\end{array}$ \\
\hline & Labor & $\begin{array}{c}\text { Count } \\
\% \text { within } \\
\text { Movement }\end{array}$ & $\begin{array}{c}37 \\
27.2 \%\end{array}$ & $\begin{array}{c}28 \\
20.6 \%\end{array}$ & $\begin{array}{c}33 \\
24.3 \%\end{array}$ & $\begin{array}{c}12 \\
8.8 \%\end{array}$ & $\begin{array}{c}8 \\
5.9 \%\end{array}$ \\
\hline \multicolumn{2}{|r|}{ Total } & $\begin{array}{c}\text { Count } \\
\% \text { within } \\
\text { Movement }\end{array}$ & $\begin{array}{c}55 \\
14.2 \%\end{array}$ & $\begin{array}{c}47 \\
12.1 \%\end{array}$ & $\begin{array}{c}80 \\
20.6 \%\end{array}$ & $\begin{array}{c}67 \\
17.3 \%\end{array}$ & $\begin{array}{c}84 \\
21.6 \%\end{array}$ \\
\hline
\end{tabular}




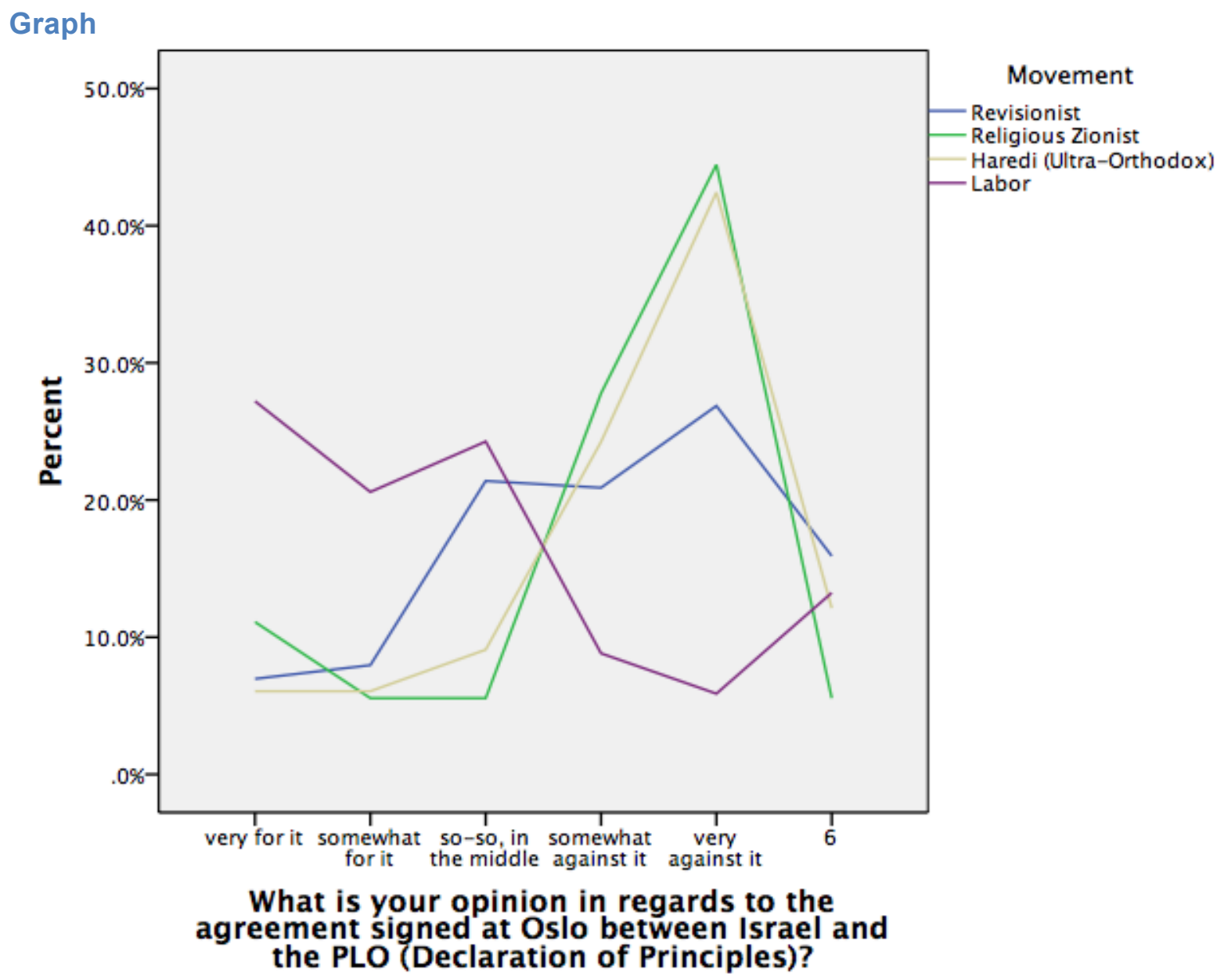

Nominal Regression

Model Fitting Information

\begin{tabular}{|c|c|c|c|c|}
\hline \multirow[b]{2}{*}{ Model } & \multirow{2}{*}{$\begin{array}{c}\begin{array}{c}\text { Model Fitting } \\
\text { Criteria }\end{array} \\
-2 \text { Log } \\
\text { Likelihood }\end{array}$} & \multicolumn{3}{|c|}{ Likelihood Ratio Tests } \\
\hline & & Chi-Square & $\mathrm{df}$ & Sig. \\
\hline $\begin{array}{l}\text { Intercept Only } \\
\text { Final }\end{array}$ & $\begin{array}{r}159.409 \\
72.386\end{array}$ & 87.023 & 15 & .000 \\
\hline
\end{tabular}

Goodness-of-Fit

\begin{tabular}{|c|c|c|c|}
\hline & Chi-Square & $\mathrm{df}$ & Sig. \\
\hline $\begin{array}{l}\text { Pearson } \\
\text { Deviance }\end{array}$ & $\begin{array}{l}.000 \\
.000\end{array}$ & $\begin{array}{l}0 \\
0\end{array}$ & \\
\hline
\end{tabular}

\section{Likelihood Ratio Tests}

\begin{tabular}{|l|r|r|r|r|}
\hline \multirow{2}{*}{} & \multicolumn{1}{|c|}{$\begin{array}{c}\text { Model Fitting } \\
\text { Criteria }\end{array}$} & \multicolumn{3}{|c|}{ Likelihood Ratio Tests } \\
\cline { 2 - 6 } & $\begin{array}{c}\text {-2 Log } \\
\text { Likelihood of } \\
\text { Reduced Model }\end{array}$ & Chi-Square & df & \multicolumn{1}{c|}{ Sig. } \\
\hline Intercept & $72.386^{2}$ & .000 & 0 & .000 \\
\hline Movement & 159.409 & 87.023 & 15 & .000 \\
\hline
\end{tabular}


Parameter Estimates

\begin{tabular}{|c|c|c|c|c|c|c|c|c|c|}
\hline \multirow{2}{*}{\multicolumn{2}{|c|}{$\begin{array}{l}\text { What is your opinion in } \\
\text { regards to the agreement } \\
\text { signed at Oslo between } \\
\text { Israel and the PLO } \\
\text { (Declaration of Principles)? }\end{array}$}} & \multirow[b]{2}{*}{ B } & \multirow{2}{*}{$\begin{array}{l}\text { Std. } \\
\text { Error }\end{array}$} & \multirow[b]{2}{*}{ Wald } & \multirow[b]{2}{*}{ df } & \multirow[b]{2}{*}{ Sig. } & \multirow{2}{*}{$\operatorname{Exp}(B)$} & \multicolumn{2}{|c|}{$\begin{array}{l}95 \% \text { Confidence } \\
\text { Interval for Exp(B) }\end{array}$} \\
\hline & & & & & & & & $\begin{array}{l}\text { Lower } \\
\text { Bound }\end{array}$ & $\begin{array}{l}\text { Upper } \\
\text { Bound }\end{array}$ \\
\hline \multirow{5}{*}{$\begin{array}{l}\text { somewhat for } \\
\text { it }\end{array}$} & $\begin{array}{l}\text { Intercept } \\
\text { Revisionist }\end{array}$ & $\begin{array}{c}-.279 \\
412\end{array}$ & $\begin{array}{l}.250 \\
443\end{array}$ & $\begin{array}{c}1.238 \\
864\end{array}$ & $\begin{array}{l}1 \\
1\end{array}$ & $\begin{array}{r}.266 \\
353\end{array}$ & 1510 & 633 & 3602 \\
\hline & Religious & -414 & 1250 & 110 & 1 & 740 & 661 & 057 & 7658 \\
\hline & Zionist & -.414 & 1.200 & .170 & 1 & .140 & 1 & r & 1.000 \\
\hline & $\begin{array}{l}\text { Haredi (ultra- } \\
\text { Orthodox) }\end{array}$ & .279 & 1.031 & .073 & 1 & .787 & 1.321 & .175 & 9.966 \\
\hline & Labor & $0^{\mathrm{b}}$ & & & 0 & & & & \\
\hline \multirow{4}{*}{$\begin{array}{l}\text { so-so, in the } \\
\text { middle }\end{array}$} & Intercept & -.114 & .239 & .228 & 1 & .633 & & & \\
\hline & Revisionist & 1.237 & .390 & 10.059 & 1 & .002 & \begin{tabular}{|l|}
3.444 \\
\end{tabular} & 1.604 & 7.394 \\
\hline & $\begin{array}{c}\text { Religious } \\
\text { Zionist }\end{array}$ & -.579 & 1.248 & .215 & 1 & .643 & .561 & .049 & 6.470 \\
\hline & $\begin{array}{l}\text { Haredi (ultra- } \\
\text { Orthodox) } \\
\text { Labor }\end{array}$ & $\begin{array}{l}.520 \\
0^{\mathrm{b}}\end{array}$ & .944 & .303 & $\begin{array}{l}1 \\
0\end{array}$ & .582 & 1.682 & .265 & 10.693 \\
\hline \multirow{5}{*}{$\begin{array}{l}\text { somewhat } \\
\text { against it }\end{array}$} & Intercept & -1.126 & .332 & 11.489 & 1 & .001 & & & \\
\hline & Revisionist & 2.225 & .453 & 24.071 & 1 & .000 & 9.250 & 3.803 & 22.496 \\
\hline & $\begin{array}{l}\text { Religious } \\
\text { Zionist }\end{array}$ & 2.042 & .900 & 5.147 & 1 & .023 & 7.708 & 1.320 & 45.000 \\
\hline & Haredi (ultra- & 2.512 & .858 & 8.583 & 1 & .003 & 12.333 & 2.297 & 66.224 \\
\hline & $\begin{array}{l}\text { Orthodox) } \\
\text { Labor }\end{array}$ & $0^{\mathrm{b}}$ & & & 0 & & & & \\
\hline \multirow{5}{*}{ very against it } & Intercept & -1.531 & .390 & 15.428 & 1 & .000 & & & \\
\hline & Revisionist & 2.881 & .492 & 34.311 & 1 & .000 & 17.839 & 6.802 & 46.783 \\
\hline & $\begin{array}{l}\text { Religious } \\
\text { Zionist }\end{array}$ & 2.918 & .881 & 10.956 & 1 & .001 & 18.500 & 3.287 & 104.111 \\
\hline & $\begin{array}{l}\text { Haredi (ultra- } \\
\text { Orthodox) }\end{array}$ & 3.477 & .851 & 16.715 & 1 & .000 & 32.375 & 6.112 & 171.478 \\
\hline & Labor & $0^{\mathrm{b}}$ & & & 0 & & & & \\
\hline \multirow{5}{*}{6} & Intercept & -.721 & .287 & 6.287 & 1 & .012 & & & \\
\hline & Revisionist & 1.547 & .430 & 12.922 & 1 & .000 & 4.698 & 2.021 & 10.923 \\
\hline & $\begin{array}{l}\text { Religious } \\
\text { Zionist }\end{array}$ & .027 & 1.258 & .000 & 1 & .983 & 1.028 & .087 & 12.098 \\
\hline & $\begin{array}{l}\text { Haredi (ultra- } \\
\text { Orthodox) }\end{array}$ & 1.414 & .912 & 2.400 & 1 & .121 & 4.111 & .687 & 24.584 \\
\hline & Labor & $0^{\mathrm{b}}$ & & & 0 & & & & \\
\hline
\end{tabular}


July 2006

Crosstabs

Movement * What is your position in regards to conducting peace negotiations between Israel and the Palestinian Authority? Crosstabulation

\begin{tabular}{|cc|c|c|c|c|c|}
\hline \multirow{2}{*}{} & & \multicolumn{2}{|c|}{ What is your position in regards to conducting peace } \\
negotiations between Israel and the Palestinian Authority?
\end{tabular}




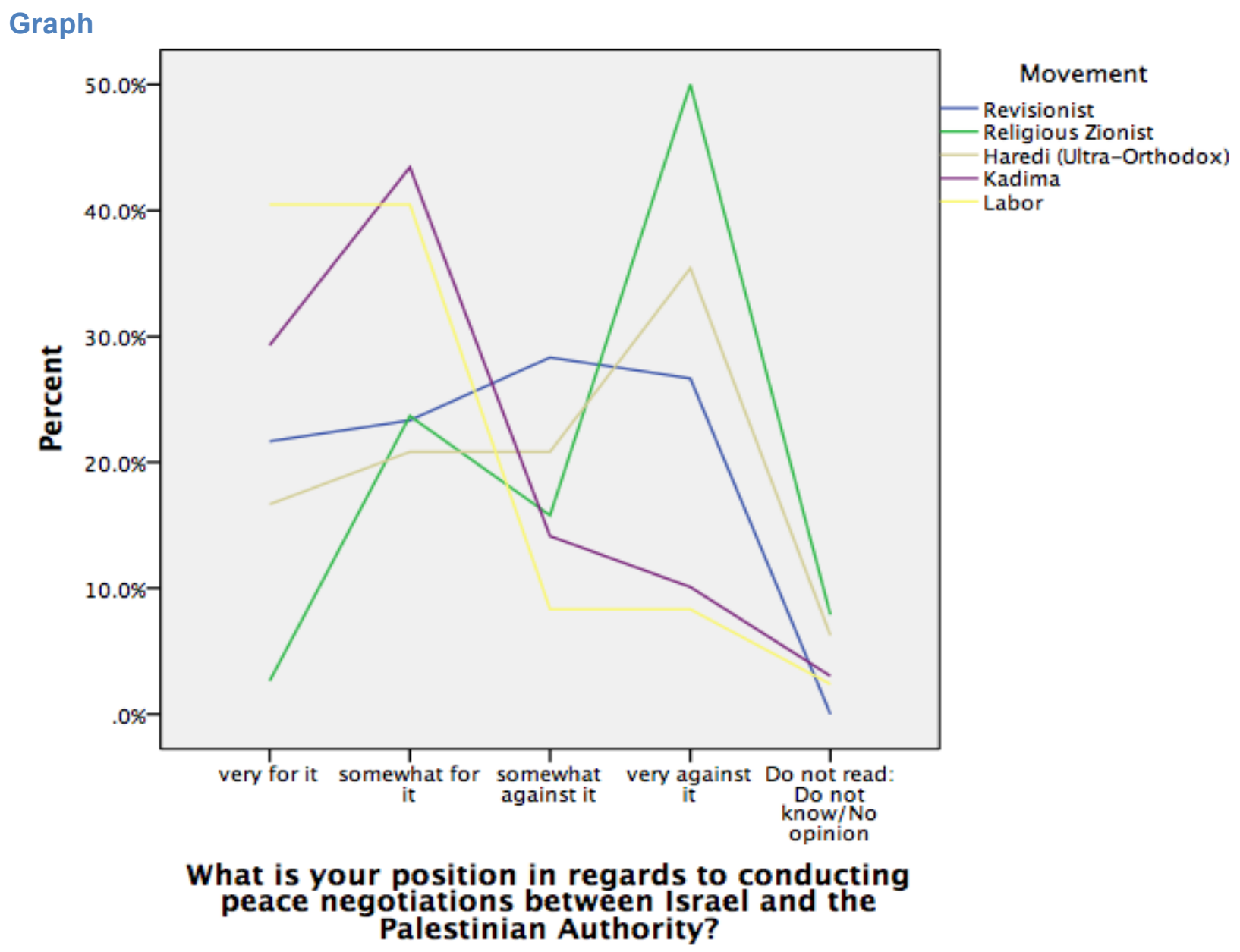

Nominal Regression

Model Fitting Information

\begin{tabular}{|c|c|c|c|c|}
\hline \multirow[b]{2}{*}{ Model } & $\begin{array}{l}\text { Model Fitting } \\
\text { Criteria }\end{array}$ & \multicolumn{3}{|c|}{ Likelihood Ratio Tests } \\
\hline & $\begin{array}{c}-2 \text { Log } \\
\text { Likelihood }\end{array}$ & Chi-Square & $\mathrm{df}$ & Sig. \\
\hline $\begin{array}{l}\text { Intercept Only } \\
\text { Final }\end{array}$ & $\begin{array}{r}147.774 \\
69.211\end{array}$ & 78.563 & 16 & .000 \\
\hline
\end{tabular}

Goodness-of-Fit

\begin{tabular}{|l|r|r|r|}
\hline & Chi-Square & df & Sig. \\
\hline Pearson & .000 & 0 & \\
Deviance & .000 & 0 &. \\
\hline
\end{tabular}

Likelihood Ratio Tests

\begin{tabular}{|l|r|r|r|r|}
\hline \multirow{2}{*}{} & \multicolumn{1}{|c|}{$\begin{array}{c}\text { Model Fitting } \\
\text { Criteria }\end{array}$} & \multicolumn{3}{|c|}{ Likelihood Ratio Tests } \\
\cline { 2 - 6 } & $\begin{array}{c}\text {-2 Log } \\
\text { Likelihood of } \\
\text { Eeffect }\end{array}$ & & & \\
\hline Reduced Model & Chi-Square & \multicolumn{1}{c|}{ df } & \multicolumn{1}{c|}{ Sig. } \\
Movement & $69.211^{2}$ & .000 & 0 & .000 \\
\hline
\end{tabular}


Parameter Estimates

\begin{tabular}{|c|c|c|c|c|c|c|c|c|c|}
\hline \multirow{2}{*}{\multicolumn{2}{|c|}{$\begin{array}{c}\text { What is your position in } \\
\text { regards to conducting } \\
\text { peace negotiations between } \\
\text { Israel and the Palestinian } \\
\text { Authority? }\end{array}$}} & \multirow[b]{2}{*}{ B } & \multirow{2}{*}{$\begin{array}{l}\text { Std. } \\
\text { Error }\end{array}$} & \multirow[b]{2}{*}{ Wald } & \multirow[b]{2}{*}{ df } & \multirow{2}{*}{ Sig. } & \multirow{2}{*}{$\operatorname{Exp}(B)$} & \multicolumn{2}{|c|}{$\begin{array}{l}95 \% \text { Confidence } \\
\text { Interval for } \operatorname{Exp}(\mathrm{B}) \\
\end{array}$} \\
\hline & & & & & & & & $\begin{array}{l}\text { Lower } \\
\text { Bound }\end{array}$ & $\begin{array}{l}\text { Upper } \\
\text { Bound }\end{array}$ \\
\hline \multirow{5}{*}{$\begin{array}{c}\text { somewhat for } \\
\text { it }\end{array}$} & Intercept & .000 & .243 & .000 & 1 & 1.000 & & & \\
\hline & Revisionist & .074 & .455 & .027 & 1 & .871 & 1.077 & .441 & 2.628 \\
\hline & $\begin{array}{l}\text { Religious } \\
\text { Zionist }\end{array}$ & 2.197 & 1.082 & 4.127 & 1 & .042 & 9.000 & 1.080 & 74.978 \\
\hline & $\begin{array}{l}\text { Haredi (ultra- } \\
\text { Orthodox) }\end{array}$ & .223 & .533 & .175 & 1 & .675 & 1.250 & .440 & 3.551 \\
\hline & $\begin{array}{c}\text { Kadima } \\
\text { Labor }\end{array}$ & $\begin{array}{l}.394 \\
0^{\mathrm{b}}\end{array}$ & .341 & 1.331 & $\begin{array}{l}1 \\
0\end{array}$ & .249 & 1.483 & .759 & 2.895 \\
\hline \multirow{4}{*}{$\begin{array}{l}\text { somewhat } \\
\text { against it }\end{array}$} & $\begin{array}{c}\text { Intercept } \\
\text { Revisionist }\end{array}$ & $\begin{array}{l}-1.580 \\
1.849 \\
\end{array}$ & $\begin{array}{l}.415 \\
.555 \\
\end{array}$ & $\begin{array}{l}14.500 \\
11.096 \\
\end{array}$ & $\begin{array}{l}1 \\
1 \\
\end{array}$ & $\begin{array}{l}.000 \\
.001\end{array}$ & 6.352 & 2.140 & 18.849 \\
\hline & $\begin{array}{l}\text { Religious } \\
\text { Zionist }\end{array}$ & 3.372 & 1.157 & 8.493 & 1 & .004 & 29.143 & 3.017 & 281.500 \\
\hline & $\begin{array}{l}\text { Haredi (ultra- } \\
\text { Orthodox) }\end{array}$ & 1.804 & .630 & 8.188 & 1 & .004 & 6.071 & 1.765 & 20.883 \\
\hline & $\begin{array}{l}\text { Kadima } \\
\text { Labor }\end{array}$ & $\begin{array}{l}.852 \\
0^{\mathrm{b}}\end{array}$ & .527 & 2.611 & $\begin{array}{l}1 \\
0\end{array}$ & .106 & 2.345 & .834 & 6.593 \\
\hline \multirow{5}{*}{$\begin{array}{l}\text { very against } \\
\text { it }\end{array}$} & Intercept & -1.580 & .415 & 14.500 & 1 & .000 & & & \\
\hline & Revisionist & 1.788 & .558 & 10.258 & 1 & .001 & 5.978 & 2.001 & 17.856 \\
\hline & $\begin{array}{c}\text { Religious } \\
\text { Zionist }\end{array}$ & 4.525 & 1.107 & 16.715 & 1 & .000 & 92.286 & 10.545 & 807.614 \\
\hline & $\begin{array}{l}\text { Haredi (ultra- } \\
\text { Orthodox) }\end{array}$ & 2.334 & .597 & 15.301 & 1 & .000 & 10.321 & 3.205 & 33.242 \\
\hline & $\begin{array}{l}\text { Kadima } \\
\text { Labor }\end{array}$ & $\begin{array}{l}.516 \\
0^{\mathrm{b}}\end{array}$ & .554 & .867 & $\begin{array}{l}1 \\
0\end{array}$ & .352 & 1.675 & .566 & 4.959 \\
\hline \multirow{5}{*}{$\begin{array}{l}\text { Do not read: } \\
\text { Do not } \\
\text { know/No } \\
\text { opinion }\end{array}$} & Intercept & -2.833 & .728 & 15.162 & 1 & .000 & & & \\
\hline & Revisionist & -19.134 & .000 & & 1 & & $\begin{array}{c}4.900 \mathrm{E}- \\
9\end{array}$ & $4.900 \mathrm{E}-9$ & $4.900 \mathrm{E}-9$ \\
\hline & $\begin{array}{l}\text { Religious } \\
\text { Zionist }\end{array}$ & 3.932 & 1.365 & 8.299 & 1 & .004 & 51.000 & 3.514 & 740.134 \\
\hline & $\begin{array}{l}\text { Haredi (ultra- } \\
\text { Orthodox) }\end{array}$ & 1.852 & .994 & 3.474 & 1 & .062 & 6.375 & .909 & 44.715 \\
\hline & $\begin{array}{l}\text { Kadima } \\
\text { Labor }\end{array}$ & $\begin{array}{l}.565 \\
0^{\mathrm{b}}\end{array}$ & .947 & .355 & $\begin{array}{l}1 \\
0\end{array}$ & .551 & 1.759 & .275 & 11.258 \\
\hline
\end{tabular}


January 2007

Crosstabs

Movement * What is your opinion in regards to the agreement signed at Oslo between Israel and the PLO (Declaration of Principles)? Crosstabulation

\begin{tabular}{|c|c|c|c|c|c|c|c|}
\hline & \multicolumn{5}{|c|}{$\begin{array}{l}\text { What is your opinion in regards to the agreement signed at } \\
\text { Oslo between Israel and the PLO (Declaration of Principles)? }\end{array}$} \\
\hline & & & very for it & $\begin{array}{l}\text { somewhat } \\
\text { for it }\end{array}$ & $\begin{array}{l}\text { so-so, in } \\
\text { the middle }\end{array}$ & $\begin{array}{l}\text { somewhat } \\
\text { against it }\end{array}$ & $\begin{array}{l}\text { very } \\
\text { against it }\end{array}$ \\
\hline \multirow{5}{*}{$\begin{array}{l}\text { Moveme } \\
\text { nt }\end{array}$} & Revisionist & $\begin{array}{c}\text { Count } \\
\% \text { within } \\
\text { Movement }\end{array}$ & $\begin{array}{c}1 \\
2.0 \%\end{array}$ & $\begin{array}{c}3 \\
6.1 \%\end{array}$ & $\begin{array}{c}7 \\
14.3 \%\end{array}$ & $\begin{array}{c}9 \\
18.4 \%\end{array}$ & $\begin{array}{c}20 \\
40.8 \%\end{array}$ \\
\hline & $\begin{array}{l}\text { Religious } \\
\text { Zionist }\end{array}$ & $\begin{array}{c}\text { Count } \\
\% \text { within } \\
\text { Movement }\end{array}$ & $\begin{array}{c}3 \\
11.5 \%\end{array}$ & $\begin{array}{c}1 \\
3.8 \%\end{array}$ & $\begin{array}{c}2 \\
7.7 \%\end{array}$ & $\begin{array}{c}3 \\
11.5 \%\end{array}$ & $\begin{array}{c}16 \\
61.5 \%\end{array}$ \\
\hline & $\begin{array}{l}\text { Haredi (Ultra- } \\
\text { Orthodox) }\end{array}$ & $\begin{array}{c}\text { Count } \\
\% \text { within } \\
\text { Movement }\end{array}$ & $\begin{array}{c}1 \\
2.6 \%\end{array}$ & $\begin{array}{c}1 \\
2.6 \%\end{array}$ & $\begin{array}{c}4 \\
10.3 \%\end{array}$ & $\begin{array}{c}5 \\
12.8 \%\end{array}$ & $\begin{array}{c}12 \\
30.8 \%\end{array}$ \\
\hline & Kadima & $\begin{array}{c}\text { Count } \\
\% \text { within } \\
\text { Movement }\end{array}$ & $\begin{array}{c}12 \\
11.7 \%\end{array}$ & $\begin{array}{c}19 \\
18.4 \%\end{array}$ & $\begin{array}{c}21 \\
20.4 \%\end{array}$ & $\begin{array}{c}20 \\
19.4 \%\end{array}$ & $\begin{array}{c}19 \\
18.4 \%\end{array}$ \\
\hline & Labor & $\begin{array}{c}\text { Count } \\
\% \text { within } \\
\text { Movement }\end{array}$ & $\begin{array}{c}26 \\
25.5 \%\end{array}$ & $\begin{array}{c}35 \\
34.3 \%\end{array}$ & $\begin{array}{c}21 \\
20.6 \%\end{array}$ & $\begin{array}{c}4 \\
3.9 \%\end{array}$ & $\begin{array}{c}4 \\
3.9 \%\end{array}$ \\
\hline \multicolumn{2}{|r|}{ Total } & $\begin{array}{c}\text { Count } \\
\% \text { within } \\
\text { Movement }\end{array}$ & $\begin{array}{c}43 \\
13.5 \%\end{array}$ & $\begin{array}{c}59 \\
18.5 \%\end{array}$ & $\begin{array}{c}55 \\
17.2 \%\end{array}$ & $\begin{array}{c}41 \\
12.9 \%\end{array}$ & $\begin{array}{c}71 \\
22.3 \%\end{array}$ \\
\hline
\end{tabular}




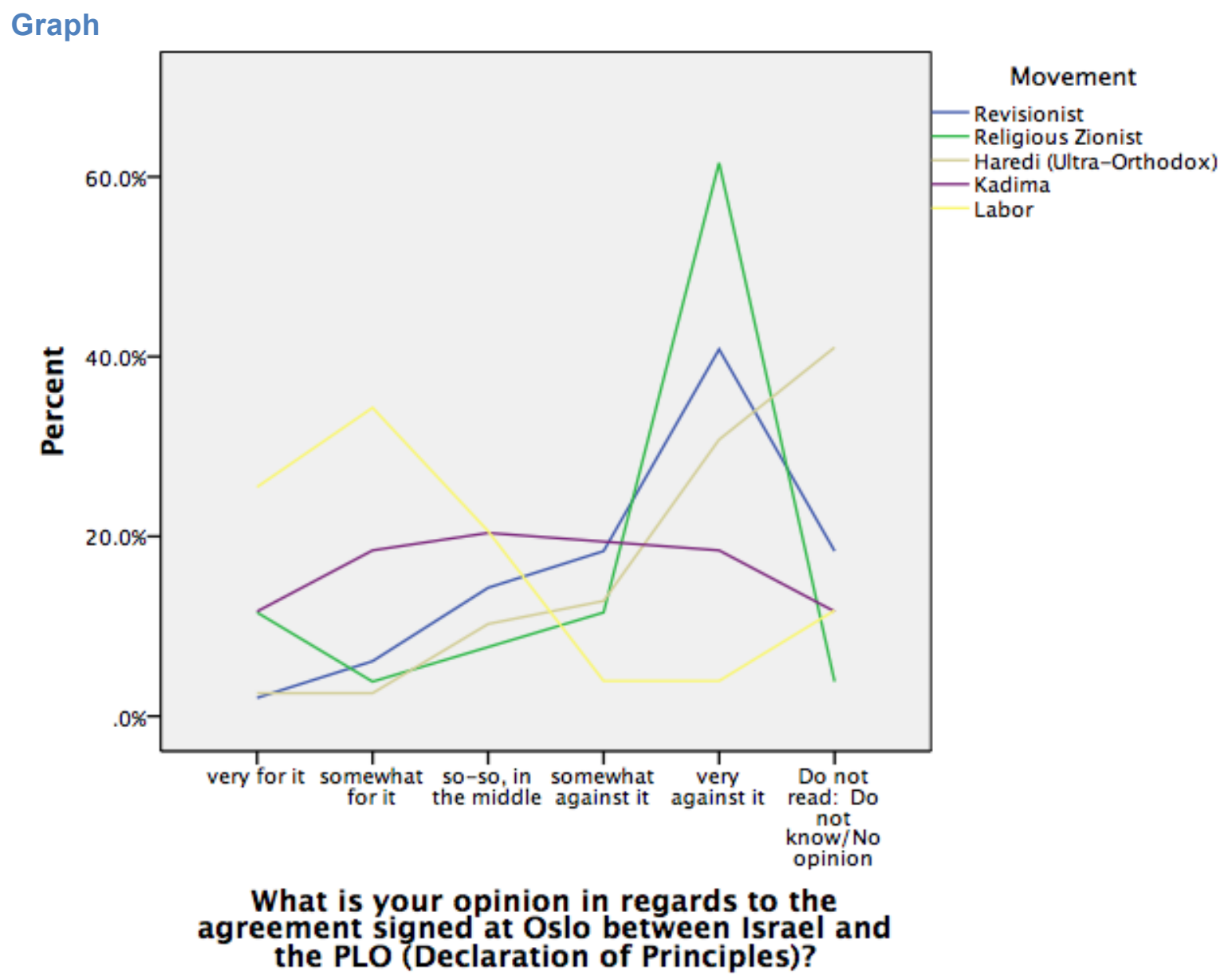

Nominal Regression

Model Fitting Information

\begin{tabular}{|c|c|c|c|c|}
\hline \multirow[b]{2}{*}{ Model } & $\begin{array}{c}\text { Model Fitting } \\
\text { Criteria }\end{array}$ & \multicolumn{3}{|c|}{ Likelihood Ratio Tests } \\
\hline & $\begin{array}{c}-2 \text { Log } \\
\text { Likelihood }\end{array}$ & Chi-Square & $d f$ & Sig. \\
\hline $\begin{array}{l}\text { Intercept Only } \\
\text { Final }\end{array}$ & $\begin{array}{r}212.292 \\
83.638\end{array}$ & 128.655 & 20 & .000 \\
\hline
\end{tabular}

Goodness-of-Fit

\begin{tabular}{|l|r|r|r|}
\hline & Chi-Square & df & Sig. \\
\hline Pearson & .000 & 0 & \\
Deviance & .000 & 0 & \\
\hline
\end{tabular}

\section{Likelihood Ratio Tests}

\begin{tabular}{|l|r|r|r|r|}
\hline \multirow{2}{*}{} & \multicolumn{1}{|c|}{$\begin{array}{c}\text { Model Fitting } \\
\text { Criteria }\end{array}$} & \multicolumn{3}{|c|}{ Likelihood Ratio Tests } \\
\cline { 2 - 5 } & $\begin{array}{c}-2 \text { Log } \\
\text { Likelihood of } \\
\text { Reduced Model }\end{array}$ & Chi-Square & df & \multicolumn{1}{c|}{ Sig. } \\
\hline Intercept & $83.638^{\mathrm{a}}$ & .000 & 0 & .000 \\
\hline Movement & 212.292 & 128.655 & 20 & .000 \\
\hline
\end{tabular}


Parameter Estimates

\begin{tabular}{|c|c|c|c|c|c|c|c|c|c|}
\hline \multirow{2}{*}{\multicolumn{2}{|c|}{$\begin{array}{l}\text { What is your opinion in } \\
\text { regards to the agreement } \\
\text { signed at Oslo between } \\
\text { Israel and the PLO } \\
\text { (Declaration of Principles)? }\end{array}$}} & \multirow[b]{2}{*}{ B } & \multirow{2}{*}{$\begin{array}{l}\text { Std. } \\
\text { Error }\end{array}$} & \multirow{2}{*}{ Wald } & \multirow[b]{2}{*}{$\mathrm{df}$} & \multirow[b]{2}{*}{ Sig. } & \multirow[b]{2}{*}{$\operatorname{Exp}(B)$} & \multicolumn{2}{|c|}{$\begin{array}{l}\text { 95\% Confidence } \\
\text { Interval for } \operatorname{Exp}(B)\end{array}$} \\
\hline & & & & & & & & $\begin{array}{l}\text { Lower } \\
\text { Bound }\end{array}$ & $\begin{array}{l}\text { Upper } \\
\text { Bound }\end{array}$ \\
\hline \multirow{5}{*}{$\begin{array}{l}\text { somewhat for } \\
\text { it }\end{array}$} & Intercept & .297 & .259 & 1.318 & 1 & .251 & & & \\
\hline & Revisionist & .801 & 1.183 & .459 & 1 & .498 & 2.229 & .219 & 22.663 \\
\hline & $\begin{array}{l}\text { Religious } \\
\text { Zionist }\end{array}$ & -1.396 & 1.183 & 1.391 & 1 & .238 & .248 & .024 & 2.518 \\
\hline & $\begin{array}{l}\text { Haredi (ultra- } \\
\text { Orthodox) }\end{array}$ & -.297 & 1.438 & .043 & 1 & .836 & .743 & .044 & 12.436 \\
\hline & $\begin{array}{l}\text { Kadima } \\
\text { Labor }\end{array}$ & $\begin{array}{c}.162 \\
0^{\mathrm{b}} \\
\end{array}$ & .451 & .130 & $\begin{array}{l}1 \\
0\end{array}$ & .719 & 1.176 & .486 & 2.844 \\
\hline \multirow{4}{*}{$\begin{array}{l}\text { so-so, in the } \\
\text { middle }\end{array}$} & $\begin{array}{c}\text { Intercept } \\
\text { Revisionist }\end{array}$ & $\begin{array}{l}-.214 \\
2.159 \\
\end{array}$ & $\begin{array}{l}.293 \\
1.109\end{array}$ & $\begin{array}{l}.530 \\
3.795\end{array}$ & $\begin{array}{l}1 \\
1\end{array}$ & $\begin{array}{l}.467 \\
.051\end{array}$ & 8.667 & .987 & 76.115 \\
\hline & $\begin{array}{l}\text { Religious } \\
\text { Zionist }\end{array}$ & & & & 1 & .841 & .825 & .126 & 5.406 \\
\hline & $\begin{array}{l}\text { Haredi (ultra- } \\
\text { Orthodox) }\end{array}$ & 1.600 & 1.156 & 1.916 & 1 & 166 & 4.952 & .514 & 47.721 \\
\hline & $\begin{array}{l}\text { Kadima } \\
\text { Labor }\end{array}$ & $\begin{array}{l}.773 \\
0^{\mathrm{b}}\end{array}$ & .466 & 2.755 & $\begin{array}{l}1 \\
0\end{array}$ & .097 & 2.167 & .869 & 5.399 \\
\hline \multirow{5}{*}{$\begin{array}{l}\text { somewhat } \\
\text { against it }\end{array}$} & Intercept & -1.872 & .537 & 12.146 & 1 & .000 & & & \\
\hline & Revisionist & 4.069 & 1.183 & 11.830 & 1 & .001 & 58.500 & 5.756 & 594.508 \\
\hline & $\begin{array}{l}\text { Religious } \\
\text { Zionist }\end{array}$ & 1.872 & .977 & 3.668 & 1 & .055 & 6.500 & .957 & 44.137 \\
\hline & $\begin{array}{l}\text { Haredi (ultra- } \\
\text { Orthodox) }\end{array}$ & 3.481 & 1.220 & 8.142 & 1 & .004 & 32.500 & 2.974 & 355.116 \\
\hline & $\begin{array}{c}\text { Kadima } \\
\text { Labor }\end{array}$ & $\begin{array}{c}2.383 \\
0^{\mathrm{b}}\end{array}$ & .649 & 13.459 & $\begin{array}{l}1 \\
0\end{array}$ & .000 & 10.833 & 3.033 & 38.688 \\
\hline \multirow{5}{*}{ very against it } & Intercept & -1.872 & .537 & 12.146 & 1 & .000 & & & \\
\hline & Revisionist & 4.868 & 1.157 & 17.702 & 1 & .000 & $\begin{array}{c}130.00 \\
0\end{array}$ & 13.464 & 1255.205 \\
\hline & $\begin{array}{l}\text { Religious } \\
\text { Zionist }\end{array}$ & 3.546 & .827 & 18.373 & 1 & .000 & 34.667 & 6.851 & 175.406 \\
\hline & $\begin{array}{l}\text { Haredi (ultra- } \\
\text { Orthodox) }\end{array}$ & 4.357 & 1.171 & 13.837 & 1 & .000 & 78.000 & 7.855 & 774.556 \\
\hline & $\begin{array}{c}\text { Kadima } \\
\text { Labor }\end{array}$ & $\begin{array}{c}2.331 \\
0^{\mathrm{b}}\end{array}$ & .651 & 12.806 & $\begin{array}{l}1 \\
0\end{array}$ & .000 & 10.292 & 2.870 & 36.900 \\
\hline \multirow{5}{*}{$\begin{array}{l}\text { Do not read: } \\
\text { Do not } \\
\text { know/No } \\
\text { opinion }\end{array}$} & Intercept & -.773 & .349 & 4.908 & 1 & .027 & & & \\
\hline & Revisionist & 2.970 & 1.110 & 7.157 & 1 & .007 & 19.500 & 2.213 & 171.861 \\
\hline & $\begin{array}{l}\text { Religious } \\
\text { Zionist }\end{array}$ & -.325 & 1.206 & .073 & 1 & .787 & .722 & .068 & 7.682 \\
\hline & $\begin{array}{l}\text { Haredi (ultra- } \\
\text { Orthodox) }\end{array}$ & 3.546 & 1.088 & 10.616 & 1 & .001 & 34.667 & 4.108 & 292.573 \\
\hline & $\begin{array}{l}\text { Kadima } \\
\text { Labor }\end{array}$ & $\begin{array}{c}.773 \\
0^{\mathrm{b}}\end{array}$ & .537 & 2.072 & $\begin{array}{l}1 \\
0\end{array}$ & .150 & 2.167 & .756 & 6.208 \\
\hline
\end{tabular}


July 2007

Crosstabs

Movement * What is your opinion in regards to the agreement signed at Oslo between Israel and the PLO (Declaration of Principles)? Crosstabulation

\begin{tabular}{|c|c|c|c|c|c|c|c|}
\hline & \multicolumn{5}{|c|}{$\begin{array}{l}\text { What is your opinion in regards to the agreement signed at } \\
\text { Oslo between Israel and the PLO (Declaration of Principles)? }\end{array}$} \\
\hline & & & very for it & $\begin{array}{l}\text { somewhat } \\
\text { for it }\end{array}$ & $\begin{array}{l}\text { so-so, in } \\
\text { the middle }\end{array}$ & $\begin{array}{l}\text { somewhat } \\
\text { against it }\end{array}$ & $\begin{array}{l}\text { very } \\
\text { against it }\end{array}$ \\
\hline \multirow{10}{*}{$\begin{array}{c}\text { Moveme } \\
\text { nt }\end{array}$} & \multirow[b]{2}{*}{ Revisionist } & Count & 1 & 5 & 7 & 11 & 24 \\
\hline & & $\begin{array}{l}\% \text { within } \\
\text { Movement }\end{array}$ & $1.7 \%$ & $8.5 \%$ & $11.9 \%$ & $18.6 \%$ & $40.7 \%$ \\
\hline & \multirow{2}{*}{$\begin{array}{l}\text { Religious } \\
\text { Zionist }\end{array}$} & Count & 0 & 0 & 2 & 6 & 21 \\
\hline & & $\begin{array}{l}\% \text { within } \\
\text { Movement }\end{array}$ & $0.0 \%$ & $0.0 \%$ & $6.5 \%$ & $19.4 \%$ & $67.7 \%$ \\
\hline & \multirow{2}{*}{$\begin{array}{l}\text { Haredi (Ultra- } \\
\text { Orthodox) }\end{array}$} & Count & 0 & 1 & 1 & 2 & 24 \\
\hline & & $\begin{array}{l}\text { \% within } \\
\text { Movement }\end{array}$ & $0.0 \%$ & $3.2 \%$ & $3.2 \%$ & $6.5 \%$ & $77.4 \%$ \\
\hline & \multirow[b]{2}{*}{ Kadima } & Count & 9 & 26 & 27 & 18 & 13 \\
\hline & & $\begin{array}{l}\% \text { within } \\
\text { Movement }\end{array}$ & $8.2 \%$ & $23.6 \%$ & $24.5 \%$ & $16.4 \%$ & $11.8 \%$ \\
\hline & \multirow[b]{2}{*}{ Labor } & Count & 18 & 32 & 13 & 3 & 3 \\
\hline & & $\begin{array}{l}\% \text { within } \\
\text { Movement }\end{array}$ & $23.7 \%$ & $42.1 \%$ & $17.1 \%$ & $3.9 \%$ & $3.9 \%$ \\
\hline \multirow{2}{*}{\multicolumn{2}{|c|}{ Total }} & Count & 28 & 64 & 50 & 40 & 85 \\
\hline & & $\begin{array}{l}\% \text { within } \\
\text { Movement }\end{array}$ & $9.1 \%$ & $20.8 \%$ & $16.3 \%$ & $13.0 \%$ & $27.7 \%$ \\
\hline
\end{tabular}




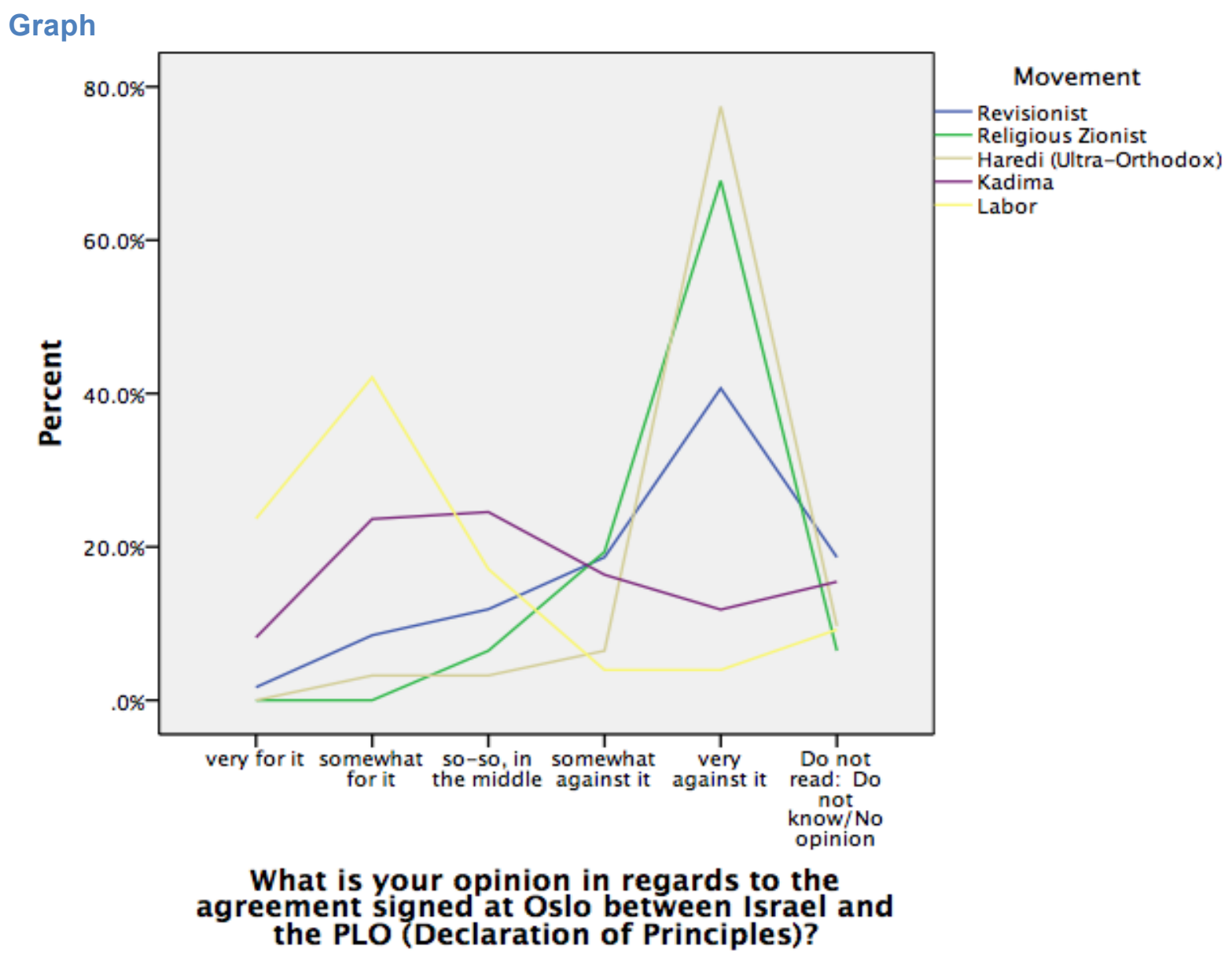

Nominal Regression

Model Fitting Information

\begin{tabular}{|l|r|r|r|r|}
\hline \multirow{2}{*}{ Model } & \multicolumn{1}{|c|}{$\begin{array}{c}\text { Model Fitting } \\
\text { Criteria }\end{array}$} & \multicolumn{3}{|c|}{ Likelihood Ratio Tests } \\
\cline { 2 - 5 } & $\begin{array}{r}-2 \text { Log } \\
\text { Likelihood }\end{array}$ & Chi-Square & df & Sig. \\
\hline $\begin{array}{l}\text { Intercept Only } \\
\text { Final }\end{array}$ & $\begin{array}{r}240.957 \\
74.416\end{array}$ & 166.540 & 20 & .000 \\
\hline
\end{tabular}

\section{Likelihood Ratio Tests}

\begin{tabular}{|l|r|r|r|r|}
\hline \multirow{2}{*}{} & \multicolumn{1}{|c|}{$\begin{array}{c}\text { Model Fitting } \\
\text { Criteria }\end{array}$} & \multicolumn{3}{|c|}{ Likelihood Ratio Tests } \\
\cline { 2 - 6 } & $\begin{array}{c}\text {-2 Log } \\
\text { Likelihood of } \\
\text { Reduced Model }\end{array}$ & Chi-Square & \multicolumn{1}{c|}{ df } & \multicolumn{1}{c|}{ Sig. } \\
\hline Intercept & $74.416^{a}$ & .000 & 0 & .000 \\
\hline Movement & 240.957 & 166.540 & 20 & .000 \\
\hline
\end{tabular}


Parameter Estimates

\begin{tabular}{|c|c|c|c|c|c|c|c|c|c|}
\hline \multirow{2}{*}{\multicolumn{2}{|c|}{$\begin{array}{l}\text { What is your opinion in } \\
\text { regards to the agreement } \\
\text { signed at Oslo between } \\
\text { Israel and the PLO } \\
\text { (Declaration of } \\
\text { Principles)? }{ }^{\text {a }}\end{array}$}} & \multirow[b]{2}{*}{ B } & \multirow[b]{2}{*}{$\begin{array}{l}\text { Std. } \\
\text { Error }\end{array}$} & \multirow[b]{2}{*}{ Wald } & \multirow[b]{2}{*}{ df } & \multirow[b]{2}{*}{ Sig. } & \multirow[b]{2}{*}{$\operatorname{Exp}(B)$} & \multicolumn{2}{|c|}{$\begin{array}{l}\text { 95\% Confidence } \\
\text { Interval for } \operatorname{Exp}(B)\end{array}$} \\
\hline & & & & & & & & $\begin{array}{l}\text { Lower } \\
\text { Bound }\end{array}$ & $\begin{array}{l}\text { Upper } \\
\text { Bound }\end{array}$ \\
\hline \multirow{4}{*}{$\begin{array}{l}\text { somewhat } \\
\text { for it }\end{array}$} & $\begin{array}{l}\text { Intercept } \\
\text { Revisionist }\end{array}$ & $\begin{array}{l}.575 \\
1.034\end{array}$ & $\begin{array}{l}.295 \\
1.134\end{array}$ & $\begin{array}{c}3.814 \\
.831\end{array}$ & $\begin{array}{l}1 \\
1\end{array}$ & $\begin{array}{l}.051 \\
.362\end{array}$ & 2.813 & .304 & 25.982 \\
\hline & $\begin{array}{l}\text { Religious } \\
\text { Zionist }\end{array}$ & .251 & $\begin{array}{c}7699.91 \\
4\end{array}$ & .000 & 1 & 1.000 & 1.286 & .000 & \\
\hline & $\begin{array}{l}\text { Haredi (ultra- } \\
\text { Orthodox) }\end{array}$ & 17.159 & 1.228 & $\begin{array}{c}195.30 \\
7 \\
\end{array}$ & 1 & .000 & $\begin{array}{c}28303613 \\
.611 \\
\end{array}$ & $\begin{array}{c}2551260 . \\
380\end{array}$ & $\begin{array}{c}31399952 \\
3.419\end{array}$ \\
\hline & $\begin{array}{l}\text { Kadima } \\
\text { Labor }\end{array}$ & $\begin{array}{l}.486 \\
0^{\mathrm{c}}\end{array}$ & .486 & .997 & $\begin{array}{l}1 \\
0\end{array}$ & .318 & 1.625 & .627 & 4.214 \\
\hline \multirow{4}{*}{$\begin{array}{l}\text { so-so, in the } \\
\text { middle }\end{array}$} & $\begin{array}{l}\text { Intercept } \\
\text { Revisionist }\end{array}$ & \begin{tabular}{|l|}
-.325 \\
2.271 \\
\end{tabular} & $\begin{array}{l}.364 \\
1.129 \\
\end{array}$ & $\begin{array}{l}.799 \\
4.045 \\
\end{array}$ & $\begin{array}{l}1 \\
1 \\
\end{array}$ & $\begin{array}{l}.371 \\
.044 \\
\end{array}$ & 9.692 & 1.060 & 88.653 \\
\hline & $\begin{array}{l}\text { Religious } \\
\text { Zionist }\end{array}$ & 18.554 & $\begin{array}{c}6422.17 \\
1\end{array}$ & .000 & 1 & .998 & $\begin{array}{c}11421513 \\
1.679\end{array}$ & & \\
\hline & $\begin{array}{l}\text { Haredi (ultra- } \\
\text { Orthodox) }\end{array}$ & 18.059 & 1.246 & $\begin{array}{c}209.99 \\
0\end{array}$ & 1 & .000 & $\begin{array}{c}69670433 \\
.504 \\
\end{array}$ & $\begin{array}{c}6056856 \\
752\end{array}$ & $\begin{array}{c}80140071 \\
0.590\end{array}$ \\
\hline & $\begin{array}{l}\text { Kadima } \\
\text { Labor }\end{array}$ & $\begin{array}{c}1.424 \\
0^{c}\end{array}$ & .530 & 7.226 & $\begin{array}{l}1 \\
0\end{array}$ & .007 & 4.154 & 1.471 & 11.732 \\
\hline \multirow{4}{*}{$\begin{array}{l}\text { somewhat } \\
\text { against it }\end{array}$} & Intercept & -1.792 & .624 & 8.255 & 1 & .004 & & & \\
\hline & $\begin{array}{c}\text { Revisionist } \\
\text { Religious } \\
\text { Zionist }\end{array}$ & $\begin{array}{l}4.190 \\
21.119\end{array}$ & $\begin{array}{c}1.216 \\
6422.17 \\
1\end{array}$ & $\begin{array}{c}11.862 \\
.000\end{array}$ & $\begin{array}{l}1 \\
1\end{array}$ & $\begin{array}{l}.001 \\
.997\end{array}$ & $\begin{array}{c}66.000 \\
14847967 \\
11.821\end{array}$ & $\begin{array}{c}6.083 \\
.000\end{array}$ & $\begin{array}{c}716.151 \\
b\end{array}$ \\
\hline & $\begin{array}{l}\text { Haredi (ultra- } \\
\text { Orthodox) }\end{array}$ & 20.219 & 1.144 & $\begin{array}{c}312.17 \\
4\end{array}$ & 1 & .000 & $\begin{array}{c}60381042 \\
3.705\end{array}$ & $\begin{array}{c}64096305 \\
.634\end{array}$ & $\begin{array}{c}56881129 \\
75.747\end{array}$ \\
\hline & $\begin{array}{c}\text { Kadima } \\
\text { Labor }\end{array}$ & $\begin{array}{c}2.485 \\
0^{c}\end{array}$ & .745 & 11.115 & $\begin{array}{l}1 \\
0\end{array}$ & .001 & 12.000 & 2.784 & 51.717 \\
\hline \multirow{5}{*}{$\begin{array}{l}\text { very against } \\
\text { it }\end{array}$} & Intercept & -1.792 & .624 & 8.255 & 1 & .004 & & & \\
\hline & Revisionist & 4.970 & 1.196 & 17.265 & 1 & .000 & 144.000 & 13.813 & 1501.237 \\
\hline & $\begin{array}{l}\text { Religious } \\
\text { Zionist }\end{array}$ & 22.371 & $\begin{array}{c}6422.17 \\
1\end{array}$ & .000 & 1 & .997 & $\begin{array}{c}51967884 \\
91.374\end{array}$ & .000 & $\mathrm{~b}$ \\
\hline & $\begin{array}{l}\text { Haredi (ultra- } \\
\text { Orthodox) }\end{array}$ & 22.704 & .923 & $\begin{array}{c}605.57 \\
2\end{array}$ & 1 & .000 & $\begin{array}{c}72457250 \\
84.465\end{array}$ & $\begin{array}{c}11878550 \\
30.496\end{array}$ & $\begin{array}{c}44197760 \\
376.296\end{array}$ \\
\hline & $\begin{array}{c}\text { Kadima } \\
\text { Labor }\end{array}$ & $\begin{array}{c}2.159 \\
0^{c}\end{array}$ & .760 & 8.083 & $\begin{array}{l}1 \\
0\end{array}$ & .004 & 8.667 & 1.956 & 38.405 \\
\hline \multirow{5}{*}{$\begin{array}{l}\text { Do not read: } \\
\text { Do not } \\
\text { know/No } \\
\text { opinion }\end{array}$} & Intercept & -.944 & .445 & 4.496 & 1 & .034 & & & \\
\hline & Revisionist & 3.342 & 1.135 & 8.665 & 1 & .003 & 28.286 & 3.055 & 261.874 \\
\hline & $\begin{array}{l}\text { Religious } \\
\text { Zionist }\end{array}$ & 19.173 & $\begin{array}{c}6422.17 \\
1\end{array}$ & .000 & 1 & .998 & $\begin{array}{c}21211381 \\
5.974\end{array}$ & .000 & b \\
\hline & $\begin{array}{l}\text { Haredi (ultra- } \\
\text { Orthodox) }\end{array}$ & 19.777 & .000 & & 1 & · & $\begin{array}{c}38816384 \\
3.811\end{array}$ & $\begin{array}{c}38816384 \\
3.811\end{array}$ & $\begin{array}{c}38816384 \\
3.811\end{array}$ \\
\hline & $\begin{array}{l}\text { Kadima } \\
\text { Labor }\end{array}$ & $\begin{array}{c}1.580 \\
0^{c}\end{array}$ & .607 & 6.781 & $\begin{array}{l}1 \\
0\end{array}$ & .009 & 4.857 & 1.478 & 15.958 \\
\hline
\end{tabular}


January 2008

Crosstabs

Movement * What is your opinion in regards to the agreement signed at Oslo between Israel and the PLO (Declaration of Principles)? Crosstabulation

\begin{tabular}{|c|c|c|c|c|c|c|c|}
\hline & \multicolumn{5}{|c|}{$\begin{array}{l}\text { What is your opinion in regards to the agreement signed at } \\
\text { Oslo between Israel and the PLO (Declaration of Principles)? }\end{array}$} \\
\hline & & & very for it & $\begin{array}{l}\text { somewhat } \\
\text { for it }\end{array}$ & $\begin{array}{l}\text { so-so, in } \\
\text { the middle }\end{array}$ & $\begin{array}{l}\text { somewhat } \\
\text { against it }\end{array}$ & $\begin{array}{l}\text { very } \\
\text { against it }\end{array}$ \\
\hline \multirow{5}{*}{$\begin{array}{l}\text { Moveme } \\
\mathrm{nt}\end{array}$} & Revisionist & $\begin{array}{c}\text { Count } \\
\% \text { within } \\
\text { Movement }\end{array}$ & $\begin{array}{c}1 \\
1.8 \%\end{array}$ & $\begin{array}{c}2 \\
3.6 \%\end{array}$ & $\begin{array}{c}9 \\
16.4 \%\end{array}$ & $\begin{array}{c}10 \\
18.2 \%\end{array}$ & $\begin{array}{c}25 \\
45.5 \%\end{array}$ \\
\hline & $\begin{array}{l}\text { Religious } \\
\text { Zionist }\end{array}$ & $\begin{array}{c}\text { Count } \\
\% \text { within } \\
\text { Movement }\end{array}$ & $\begin{array}{c}2 \\
8.0 \%\end{array}$ & $\begin{array}{c}0 \\
0.0 \%\end{array}$ & $\begin{array}{c}2 \\
8.0 \%\end{array}$ & $\begin{array}{c}4 \\
16.0 \%\end{array}$ & $\begin{array}{c}16 \\
64.0 \%\end{array}$ \\
\hline & $\begin{array}{l}\text { Haredi (Ultra- } \\
\text { Orthodox) }\end{array}$ & $\begin{array}{c}\text { Count } \\
\% \text { within } \\
\text { Movement }\end{array}$ & $\begin{array}{c}1 \\
2.8 \%\end{array}$ & $\begin{array}{c}4 \\
11.1 \%\end{array}$ & $\begin{array}{c}2 \\
5.6 \%\end{array}$ & $\begin{array}{c}8 \\
22.2 \%\end{array}$ & $\begin{array}{c}13 \\
36.1 \%\end{array}$ \\
\hline & Kadima & $\begin{array}{c}\text { Count } \\
\% \text { within } \\
\text { Movement }\end{array}$ & $\begin{array}{c}13 \\
11.8 \%\end{array}$ & $\begin{array}{c}19 \\
17.3 \%\end{array}$ & $\begin{array}{c}25 \\
22.7 \%\end{array}$ & $\begin{array}{c}19 \\
17.3 \%\end{array}$ & $\begin{array}{c}22 \\
20.0 \%\end{array}$ \\
\hline & Labor & $\begin{array}{c}\text { Count } \\
\% \text { within } \\
\text { Movement }\end{array}$ & $\begin{array}{c}28 \\
31.8 \%\end{array}$ & $\begin{array}{c}26 \\
29.5 \%\end{array}$ & $\begin{array}{c}9 \\
10.2 \%\end{array}$ & $\begin{array}{c}4 \\
4.5 \%\end{array}$ & $\begin{array}{c}8 \\
9.1 \%\end{array}$ \\
\hline \multicolumn{2}{|r|}{ Total } & $\begin{array}{c}\text { Count } \\
\% \text { within } \\
\text { Movement }\end{array}$ & $\begin{array}{c}45 \\
14.3 \%\end{array}$ & $\begin{array}{c}51 \\
16.2 \%\end{array}$ & $\begin{array}{c}47 \\
15.0 \%\end{array}$ & $\begin{array}{c}45 \\
14.3 \%\end{array}$ & $\begin{array}{c}84 \\
26.8 \%\end{array}$ \\
\hline
\end{tabular}




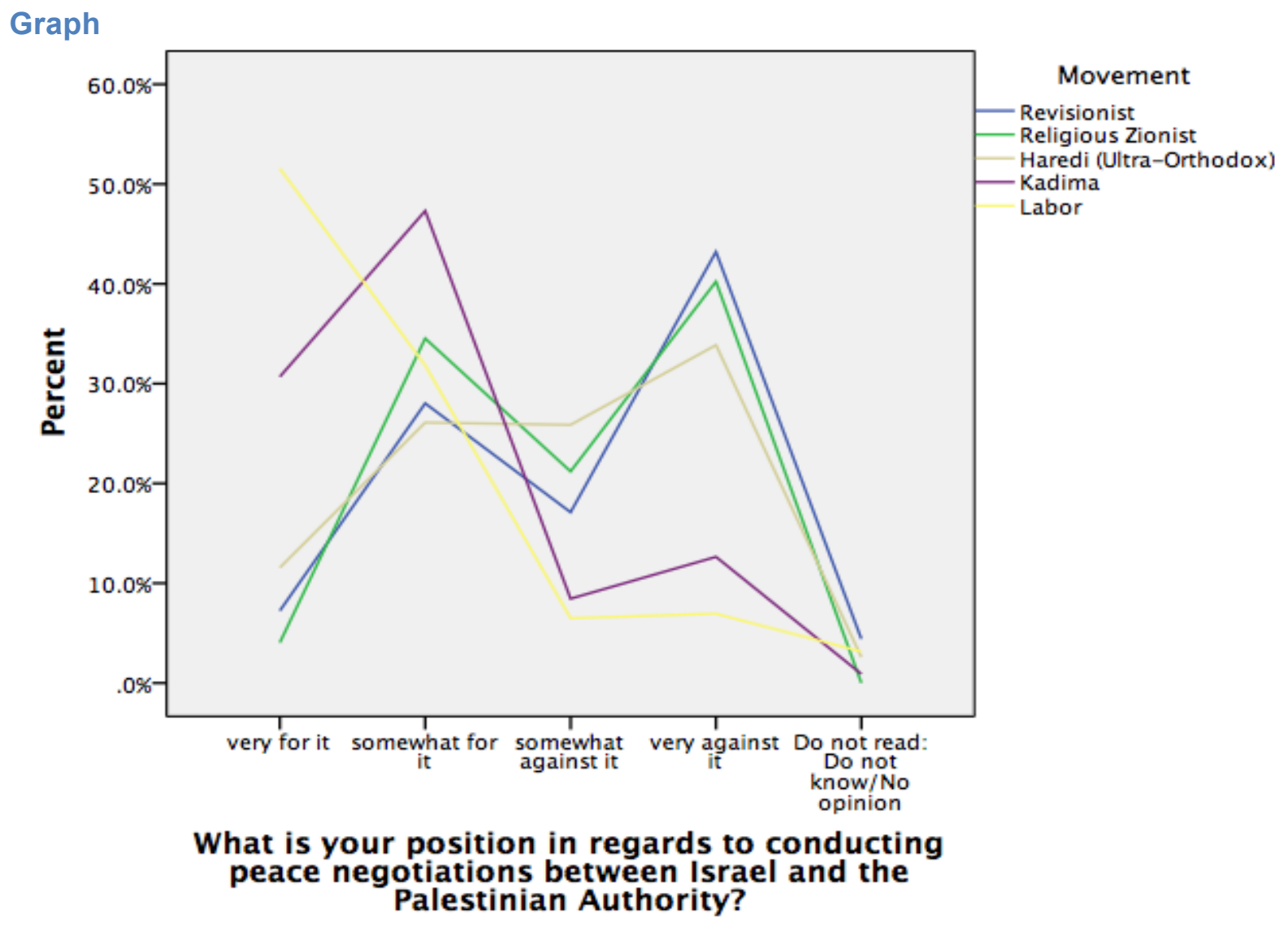

Cases weighted by w

Nominal Regression

Model Fitting Information

\begin{tabular}{|c|c|c|c|c|}
\hline \multirow[b]{2}{*}{ Model } & \multirow{2}{*}{$\begin{array}{c}\text { Model Fitting } \\
\text { Criteria }\end{array}$} & \multicolumn{3}{|c|}{ Likelihood Ratio Tests } \\
\hline & & Chi-Square & df & Sig. \\
\hline $\begin{array}{l}\text { Intercept Only } \\
\text { Final }\end{array}$ & $\begin{array}{r}191.247 \\
82.639\end{array}$ & 108.608 & 20 & .000 \\
\hline
\end{tabular}

Goodness-of-Fit

\begin{tabular}{|l|r|r|r|}
\hline & Chi-Square & df & Sig. \\
\hline Pearson & .000 & 0 & \\
Deviance & .000 & 0 &. \\
\hline
\end{tabular}

Likelihood Ratio Tests

\begin{tabular}{|l|r|r|r|r|}
\hline \multirow{2}{*}{} & \multicolumn{1}{|c|}{$\begin{array}{c}\text { Model Fitting } \\
\text { Criteria }\end{array}$} & \multicolumn{3}{|c|}{ Likelihood Ratio Tests } \\
\cline { 2 - 6 } & $\begin{array}{c}-2 \text { Log } \\
\text { Likelihood of } \\
\text { Reduced Model }\end{array}$ & Chi-Square & df & \multicolumn{1}{c|}{ Sig. } \\
\hline Effect & $82.639^{a}$ & .000 & 0 & .000 \\
\hline Intercept & 191.247 & 108.608 & 20 & .00 . \\
\hline
\end{tabular}


Parameter Estimates

\begin{tabular}{|c|c|c|c|c|c|c|c|c|c|}
\hline \multirow{2}{*}{\multicolumn{2}{|c|}{$\begin{array}{l}\text { What is your opinion in } \\
\text { regards to the agreement } \\
\text { signed at Oslo between } \\
\text { Israel and the PLO } \\
\text { (Declaration of Principles)? }\end{array}$}} & \multirow[b]{2}{*}{ B } & \multirow{2}{*}{$\begin{array}{l}\text { Std. } \\
\text { Error }\end{array}$} & \multirow[b]{2}{*}{ Wald } & \multirow[b]{2}{*}{$d f$} & \multirow[b]{2}{*}{ Sig. } & \multirow[b]{2}{*}{$\operatorname{Exp}(B)$} & \multicolumn{2}{|c|}{$\begin{array}{l}95 \% \text { Confidence } \\
\text { Interval for } \operatorname{Exp}(B)\end{array}$} \\
\hline & & & & & & & & $\begin{array}{l}\text { Lower } \\
\text { Bound }\end{array}$ & $\begin{array}{l}\text { Upper } \\
\text { Bound }\end{array}$ \\
\hline \multirow{4}{*}{$\begin{array}{c}\text { somewhat for } \\
\text { it }\end{array}$} & $\begin{array}{c}\text { Intercept } \\
\text { Revisionist }\end{array}$ & $\begin{array}{l}-.053 \\
.702\end{array}$ & $\begin{array}{c}.273 \\
1264\end{array}$ & $\begin{array}{l}.037 \\
309\end{array}$ & $\begin{array}{l}1 \\
1\end{array}$ & $\begin{array}{r}.847 \\
578\end{array}$ & 2018 & 170 & 24022 \\
\hline & Religious & $\begin{array}{l}-19.627 \\
\end{array}$ & .000 & 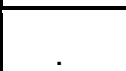 & 1 & & 2.993E- & 2.993E-9 & $2.993 E-9$ \\
\hline & $\begin{array}{l}\text { ZIonist } \\
\text { Haredi (ultra- } \\
\text { Orthodox) } \\
\end{array}$ & 1.181 & 1.012 & 1.361 & 1 & .243 & $\begin{array}{c}9 \\
3.256\end{array}$ & .448 & 23.660 \\
\hline & $\begin{array}{l}\text { Kadima } \\
\text { Labor }\end{array}$ & $\begin{array}{l}.438 \\
0^{\mathrm{b}} \\
\end{array}$ & .450 & .944 & $\begin{array}{l}1 \\
0 \\
\end{array}$ & .331 & 1.549 & .641 & 3.745 \\
\hline \multirow{4}{*}{$\begin{array}{l}\text { so-so, in the } \\
\text { middle }\end{array}$} & $\begin{array}{c}\text { Intercept } \\
\text { Revisionist }\end{array}$ & \begin{tabular}{|l|}
-1.157 \\
3.402 \\
\end{tabular} & $\begin{array}{l}.390 \\
1.121 \\
\end{array}$ & \begin{tabular}{|l|}
8.809 \\
9.203 \\
\end{tabular} & $\begin{array}{l}1 \\
1 \\
\end{array}$ & $\begin{array}{l}.003 \\
.002 \\
\end{array}$ & 30.029 & 3.334 & 270.483 \\
\hline & $\begin{array}{c}\text { Religious } \\
\text { Zionist }\end{array}$ & 1.377 & 1.038 & 1.759 & 1 & .185 & 3.963 & .518 & 30.333 \\
\hline & $\begin{array}{l}\text { Haredi (ultra- } \\
\text { Orthodox) }\end{array}$ & 1.516 & 1.170 & 1.679 & 1 & .195 & 4.556 & .460 & 45.148 \\
\hline & $\begin{array}{l}\text { Kadima } \\
\text { Labor }\end{array}$ & $\begin{array}{c}1.794 \\
0^{\mathrm{b}} \\
\end{array}$ & .518 & 11.994 & $\begin{array}{l}1 \\
0 \\
\end{array}$ & .001 & 6.016 & 2.179 & 16.610 \\
\hline \multirow{5}{*}{$\begin{array}{l}\text { somewhat } \\
\text { against it }\end{array}$} & Intercept & -1.964 & .544 & 13.062 & 1 & .000 & & & \\
\hline & Revisionist & 4.225 & 1.183 & 12.750 & 1 & .000 & 68.348 & 6.725 & 694.685 \\
\hline & $\begin{array}{l}\text { Religious } \\
\text { Zionist }\end{array}$ & 2.767 & 1.020 & 7.361 & 1 & .007 & 15.907 & 2.156 & 117.383 \\
\hline & $\begin{array}{l}\text { Haredi (ultra- } \\
\text { Orthodox) }\end{array}$ & 3.741 & 1.065 & 12.344 & 1 & .000 & 42.148 & 5.229 & 339.747 \\
\hline & $\begin{array}{c}\text { Kadima } \\
\text { Labor }\end{array}$ & $\begin{array}{c}2.325 \\
0^{\mathrm{b}}\end{array}$ & .652 & 12.725 & $\begin{array}{l}1 \\
0\end{array}$ & .000 & 10.230 & 2.851 & 36.708 \\
\hline \multirow{5}{*}{$\begin{array}{l}\text { very against } \\
\text { it }\end{array}$} & Intercept & -1.255 & .405 & 9.613 & 1 & .002 & & & \\
\hline & Revisionist & 4.454 & 1.098 & 16.471 & 1 & .000 & 85.981 & 10.005 & 738.935 \\
\hline & $\begin{array}{l}\text { Religious } \\
\text { Zionist }\end{array}$ & 3.345 & .861 & 15.092 & 1 & .000 & 28.360 & 5.246 & 153.322 \\
\hline & $\begin{array}{l}\text { Haredi (ultra- } \\
\text { Orthodox) }\end{array}$ & 3.525 & .977 & 13.009 & 1 & .000 & 33.939 & 4.999 & 230.412 \\
\hline & $\begin{array}{l}\text { Kadima } \\
\text { Labor }\end{array}$ & $\begin{array}{c}1.778 \\
0^{\mathrm{b}} \\
\end{array}$ & .534 & 11.077 & $\begin{array}{l}1 \\
0 \\
\end{array}$ & .001 & 5.916 & 2.077 & 16.853 \\
\hline \multirow{5}{*}{$\begin{array}{c}\text { Do not read: } \\
\text { Do not } \\
\text { know/No } \\
\text { opinion }\end{array}$} & Intercept & -.746 & .336 & 4.922 & 1 & .027 & & & \\
\hline & Revisionist & 2.776 & 1.115 & 6.194 & 1 & .013 & 16.055 & 1.804 & 142.909 \\
\hline & $\begin{array}{l}\text { Religious } \\
\text { Zionist }\end{array}$ & .111 & 1.264 & .008 & 1 & .930 & 1.117 & .094 & 13.295 \\
\hline & $\begin{array}{l}\text { Haredi (ultra- } \\
\text { Orthodox) }\end{array}$ & 2.468 & .979 & 6.356 & 1 & .012 & 11.796 & 1.732 & 80.340 \\
\hline & $\begin{array}{l}\text { Kadima } \\
\text { Labor }\end{array}$ & $\begin{array}{l}.673 \\
0^{\mathrm{b}}\end{array}$ & .521 & 1.671 & $\begin{array}{l}1 \\
0\end{array}$ & .196 & 1.960 & .706 & 5.441 \\
\hline
\end{tabular}


July 2008

Crosstabs

Movement * What is your position in regards to conducting peace negotiations between Israel and the Palestinian Authority? Crosstabulation

\begin{tabular}{|cc|c|c|c|c|c|}
\hline \multirow{2}{*}{} & & \multicolumn{2}{|c|}{ What is your position in regards to conducting peace } \\
negotiations between Israel and the Palestinian Authority?
\end{tabular}




\section{Graph}

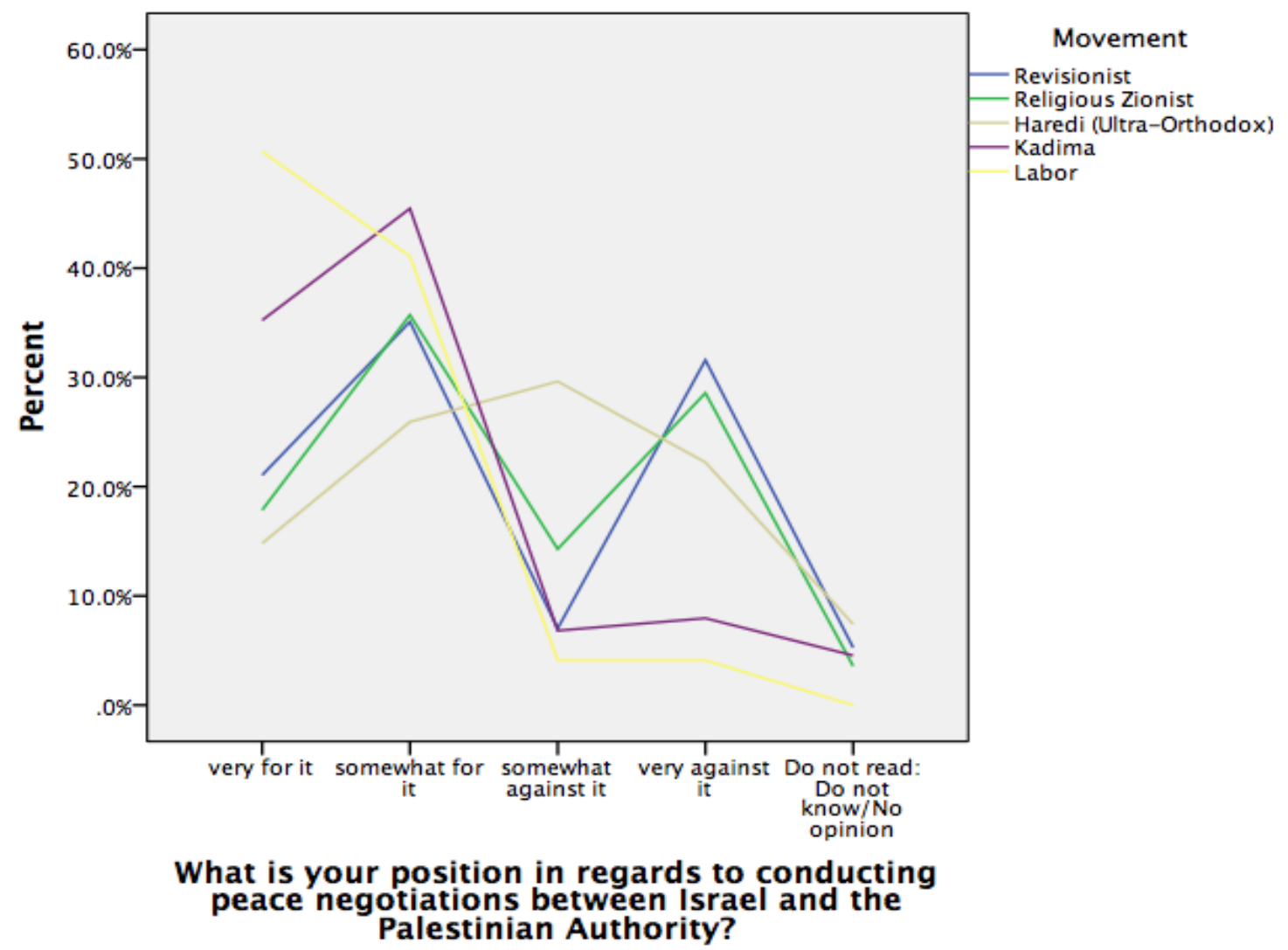

Nominal Regression

Model Fitting Information

\begin{tabular}{|l|r|r|r|r|}
\hline \multirow{4}{*}{ Model } & \multicolumn{2}{|c|}{$\begin{array}{l}\text { Model Fitting } \\
\text { Criteria }\end{array}$} & \multicolumn{3}{|c|}{ Likelihood Ratio Tests } \\
\cline { 2 - 5 } & $\begin{array}{c}-2 \text { Log } \\
\text { Likelihood }\end{array}$ & Chi-Square & \multicolumn{1}{c|}{ df } & \multicolumn{1}{c|}{ Sig. } \\
\hline Intercept Only & 122.718 & & & \\
Final & 63.871 & 58.847 & 16 & .000 \\
\hline
\end{tabular}

Goodness-of-Fit

\begin{tabular}{|l|r|r|r|}
\hline & Chi-Square & df & Sig. \\
\hline Pearson & .000 & 0 & \\
Deviance & .000 & 0 & \\
\hline
\end{tabular}

\section{Likelihood Ratio Tests}

\begin{tabular}{|l|r|r|r|r|}
\hline \multirow{2}{*}{} & \multicolumn{1}{|c|}{$\begin{array}{c}\text { Model Fitting } \\
\text { Criteria }\end{array}$} & \multicolumn{3}{|c|}{ Likelihood Ratio Tests } \\
\cline { 2 - 6 } & $\begin{array}{c}-2 \text { Log } \\
\text { Likelihood of } \\
\text { Reduced Model }\end{array}$ & Chi-Square & df & \multicolumn{1}{c|}{ Sig. } \\
\hline Intercept & $63.871^{\mathrm{a}}$ & .000 & 0 & .000 \\
\hline Movement & 122.718 & 58.847 & 16 & .000 \\
\hline
\end{tabular}




\section{Parameter Estimates}

\begin{tabular}{|c|c|c|c|c|c|c|c|c|c|}
\hline \multirow{2}{*}{\multicolumn{2}{|c|}{$\begin{array}{l}\text { What is your position in } \\
\text { regards to conducting } \\
\text { peace negotiations } \\
\text { between Israel and the } \\
\text { Palestinian Authority? }^{\text {a }}\end{array}$}} & \multirow{2}{*}{ B } & \multirow{2}{*}{$\begin{array}{l}\text { Std. } \\
\text { Error }\end{array}$} & \multirow{2}{*}{ Wald } & \multirow{2}{*}{$d f$} & \multirow{2}{*}{ Sig. } & \multirow{2}{*}{$\operatorname{Exp}(B)$} & \multicolumn{2}{|c|}{$\begin{array}{l}95 \% \text { Confidence } \\
\text { Interval for } \operatorname{Exp}(B)\end{array}$} \\
\hline & & & & & & & & $\begin{array}{l}\text { Lower } \\
\text { Bound }\end{array}$ & $\begin{array}{l}\text { Upper } \\
\text { Bound }\end{array}$ \\
\hline \multirow{4}{*}{$\begin{array}{l}\text { somewhat } \\
\text { for it }\end{array}$} & $\begin{array}{c}\text { Intercept } \\
\text { Revisionist }\end{array}$ & $\begin{array}{l}-.210 \\
.721\end{array}$ & $\begin{array}{l}.246 \\
.440\end{array}$ & $\begin{array}{l}.729 \\
2.680\end{array}$ & $\begin{array}{l}1 \\
1\end{array}$ & $\begin{array}{l}.393 \\
.102\end{array}$ & 2.056 & .868 & 4.870 \\
\hline & $\begin{array}{l}\text { Religious } \\
\text { Zionist }\end{array}$ & .903 & 600 & 2.262 & 1 & .133 & 2.467 & .761 & 8.000 \\
\hline & $\begin{array}{l}\text { Haredi (ultra- } \\
\text { Orthodox) }\end{array}$ & .769 & 673 & 1.306 & 1 & .253 & 2.158 & .577 & 8.075 \\
\hline & $\begin{array}{l}\text { Kadima } \\
\text { Labor }\end{array}$ & $\begin{array}{l}.465 \\
0^{\mathrm{b}}\end{array}$ & .343 & 1.835 & $\begin{array}{l}1 \\
0\end{array}$ & .176 & 1.591 & .813 & 3.117 \\
\hline \multirow{4}{*}{$\begin{array}{l}\text { somewhat } \\
\text { against it }\end{array}$} & $\begin{array}{c}\text { Intercept } \\
\text { Revisionist }\end{array}$ & \begin{tabular}{|l|}
-2.512 \\
1.414 \\
\end{tabular} & $\begin{array}{l}.600 \\
.833\end{array}$ & $\begin{array}{l}17.515 \\
2.881\end{array}$ & $\begin{array}{l}1 \\
1\end{array}$ & $\begin{array}{l}.000 \\
.090\end{array}$ & 4.111 & .804 & 21.033 \\
\hline & $\begin{array}{l}\text { Religious } \\
\text { Zionist }\end{array}$ & 2.289 & .900 & 6.467 & 1 & .011 & 9.867 & 1.690 & 57.600 \\
\hline & $\begin{array}{l}\text { Haredi (ultra- } \\
\text { Orthodox) }\end{array}$ & 3.205 & .858 & 13.973 & 1 & .000 & 24.667 & 4.594 & 132.447 \\
\hline & $\begin{array}{l}\text { Kadima } \\
\text { Labor }\end{array}$ & $\begin{array}{l}.870 \\
0^{\mathrm{b}}\end{array}$ & .748 & 1.354 & $\begin{array}{l}1 \\
0\end{array}$ & .245 & 2.387 & .551 & 10.338 \\
\hline \multirow{5}{*}{$\begin{array}{c}\text { very against } \\
\text { it }\end{array}$} & Intercept & -2.512 & .600 & 17.515 & 1 & .000 & & & \\
\hline & Revisionist & 2.918 & .707 & 17.052 & 1 & .000 & 18.500 & 4.632 & 73.894 \\
\hline & $\begin{array}{c}\text { Religious } \\
\text { Zionist }\end{array}$ & 2.982 & .828 & 12.977 & 1 & .000 & 19.733 & 3.895 & 99.972 \\
\hline & $\begin{array}{c}\text { Haredi (ultra- } \\
\text { Orthodox) }\end{array}$ & 2.918 & .881 & 10.956 & 1 & .001 & 18.500 & 3.287 & 104.111 \\
\hline & $\begin{array}{c}\text { Kadima } \\
\text { Labor }\end{array}$ & $\begin{array}{c}1.024 \\
0^{\mathrm{b}} \\
\end{array}$ & .732 & 1.959 & $\begin{array}{l}1 \\
0\end{array}$ & .162 & 2.785 & .664 & 11.687 \\
\hline \multirow{5}{*}{$\begin{array}{l}\text { Do not read: } \\
\text { Do not } \\
\text { know/No } \\
\text { opinion }\end{array}$} & Intercept & $20 . \overline{7}$ & .531 & $\begin{array}{c}1526.06 \\
4\end{array}$ & 1 & .000 & & & \\
\hline & Revisionist & 19.368 & .836 & 536.714 & 1 & .000 & $\begin{array}{l}25789843 \\
8.319\end{array}$ & $\begin{array}{c}50099062 \\
.264\end{array}$ & $\begin{array}{c}13276017 \\
84.963\end{array}$ \\
\hline & $\begin{array}{l}\text { Religious } \\
\text { Zionist }\end{array}$ & 19.145 & 1.217 & 247.277 & 1 & .000 & $\begin{array}{c}20631875 \\
0.653\end{array}$ & $\begin{array}{c}18976567 \\
.769\end{array}$ & $\begin{array}{c}22431573 \\
18.499\end{array}$ \\
\hline & $\begin{array}{l}\text { Haredi (ultra- } \\
\text { Orthodox) }\end{array}$ & 20.061 & 1.016 & 389.876 & 1 & .000 & $\begin{array}{l}51579687 \\
6.639\end{array}$ & $\begin{array}{c}70413685 \\
.543\end{array}$ & $\begin{array}{c}37783339 \\
40.303\end{array}$ \\
\hline & $\begin{array}{l}\text { Kadima } \\
\text { Labor }\end{array}$ & $\begin{array}{c}18.707 \\
0^{\mathrm{b}}\end{array}$ & .000 & & $\begin{array}{l}1 \\
0\end{array}$ & & $\begin{array}{c}13310887 \\
1.390\end{array}$ & $\begin{array}{c}13310887 \\
1.390\end{array}$ & $\begin{array}{c}13310887 \\
1.390\end{array}$ \\
\hline
\end{tabular}




\section{February 2009}

\section{Crosstabs}

Movement * What is your position in regards to conducting peace negotiations between Israel and the Palestinian Authority? Crosstabulation

\begin{tabular}{|cc|c|c|c|c|c|}
\hline \multirow{2}{*}{} & & \multicolumn{2}{|c|}{ What is your position in regards to conducting peace } \\
negotiations between Israel and the Palestinian Authority?
\end{tabular}




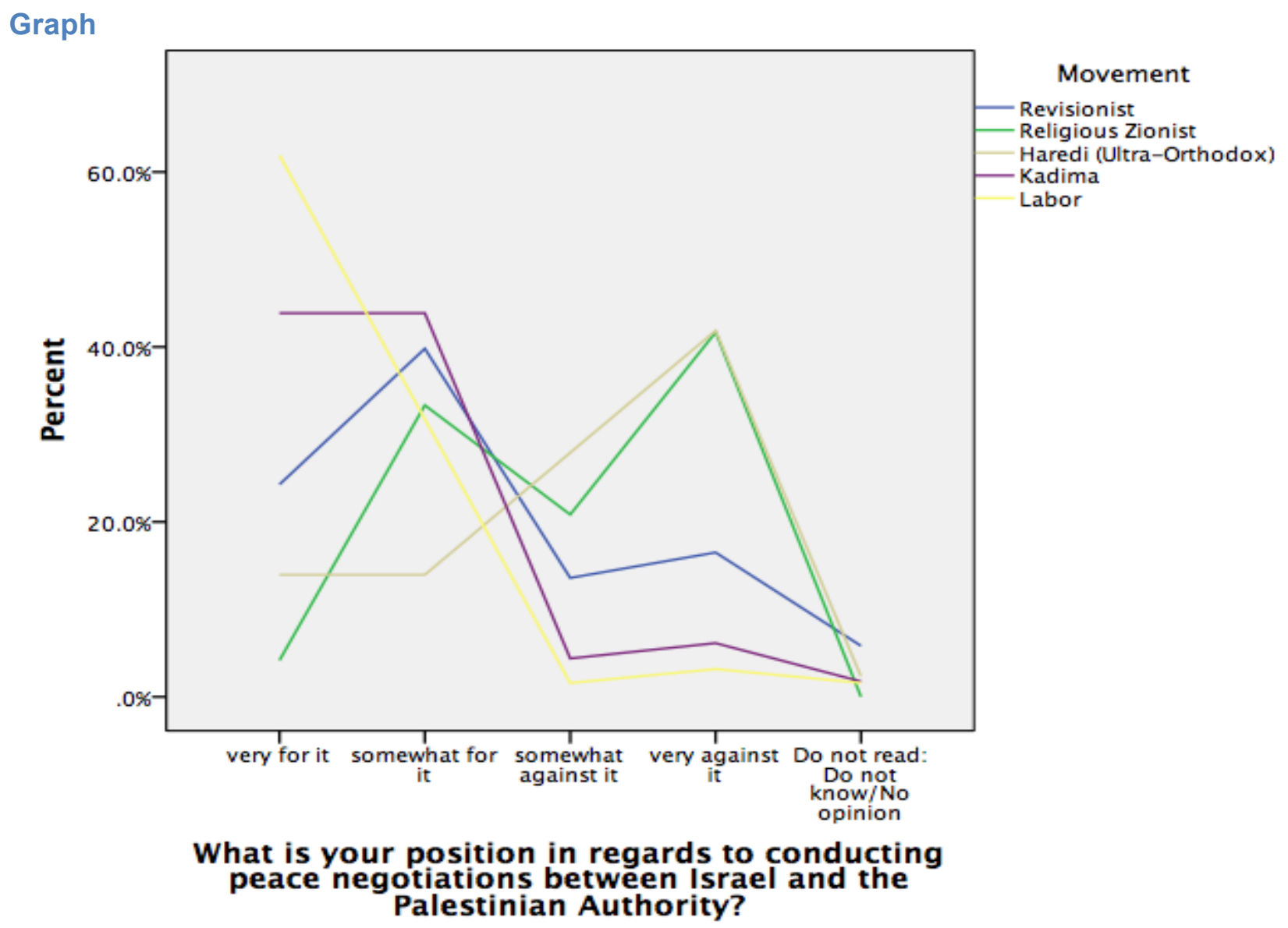

Nominal Regression

Model Fitting Information

\begin{tabular}{|l|r|r|r|r|}
\hline \multirow{2}{*}{ Model } & \multicolumn{1}{|c|}{$\begin{array}{c}\text { Model Fitting } \\
\text { Criteria }\end{array}$} & \multicolumn{3}{|c|}{ Likelihood Ratio Tests } \\
\cline { 2 - 5 } & $\begin{array}{r}\text {-2 Log } \\
\text { Likelihood }\end{array}$ & Chi-Square & \multicolumn{1}{c|}{ df } & Sig. \\
\hline Intercept Only & $\begin{array}{r}175.336 \\
64.121\end{array}$ & 111.215 & 16 & .000 \\
\hline
\end{tabular}

Goodness-of-Fit

\begin{tabular}{|l|r|r|r|}
\hline & Chi-Square & df & Sig. \\
\hline Pearson & .000 & 0 & \\
Deviance & .000 & 0 &. \\
\hline
\end{tabular}

\section{Likelihood Ratio Tests}

\begin{tabular}{|l|r|r|r|r|}
\hline \multirow{2}{*}{} & \multicolumn{1}{|c|}{$\begin{array}{c}\text { Model Fitting } \\
\text { Criteria }\end{array}$} & \multicolumn{3}{|c|}{ Likelihood Ratio Tests } \\
\cline { 2 - 6 } & $\begin{array}{c}\text {-2 Log } \\
\text { Likelihood of } \\
\text { Reduced Model }\end{array}$ & Chi-Square & \multicolumn{1}{c|}{ df } & \multicolumn{1}{c|}{ Sig. } \\
\hline Intercept & $64.121^{2}$ & .000 & 0 & \\
Movement & 175.336 & 111.215 & 16 & .000 \\
\hline
\end{tabular}


Parameter Estimates

\begin{tabular}{|c|c|c|c|c|c|c|c|c|c|}
\hline \multirow{2}{*}{\multicolumn{2}{|c|}{$\begin{array}{c}\text { What is your position in } \\
\text { regards to conducting } \\
\text { peace negotiations between } \\
\text { Israel and the Palestinian } \\
\text { Authority? }\end{array}$}} & \multirow[b]{2}{*}{ B } & \multirow{2}{*}{$\begin{array}{l}\text { Std. } \\
\text { Error }\end{array}$} & \multirow[b]{2}{*}{ Wald } & \multirow{2}{*}{$d f$} & \multirow[b]{2}{*}{ Sig. } & \multirow{2}{*}{$\operatorname{Exp}(B)$} & \multicolumn{2}{|c|}{$\begin{array}{l}95 \% \text { Confidence } \\
\text { Interval for Exp(B) }\end{array}$} \\
\hline & & & & & & & & $\begin{array}{l}\text { Lower } \\
\text { Bound }\end{array}$ & $\begin{array}{l}\text { Upper } \\
\text { Bound }\end{array}$ \\
\hline \multirow{4}{*}{$\begin{array}{l}\text { somewhat for } \\
\text { it }\end{array}$} & $\begin{array}{l}\text { Intercept } \\
\text { Revisionist }\end{array}$ & $\begin{array}{l}-.668 \\
1.163\end{array}$ & $\begin{array}{l}.275 \\
.374\end{array}$ & $\begin{array}{l}5.896 \\
9.651\end{array}$ & $\begin{array}{l}1 \\
1\end{array}$ & $\begin{array}{l}.015 \\
.002\end{array}$ & 3.198 & 1.536 & 6.659 \\
\hline & $\begin{array}{c}\text { Religious } \\
\text { Zionist }\end{array}$ & 2.747 & 1.096 & 6.286 & 1 & .012 & 15.600 & 1.822 & 133.604 \\
\hline & $\begin{array}{l}\text { Haredi (ultra- } \\
\text { Orthodox) }\end{array}$ & .668 & .640 & 1.091 & 1 & .296 & 1.950 & .557 & 6.829 \\
\hline & $\begin{array}{l}\text { Kadima } \\
\text { Labor }\end{array}$ & $\begin{array}{l}.668 \\
0^{\mathrm{b}}\end{array}$ & .340 & 3.857 & $\begin{array}{l}1 \\
0\end{array}$ & .050 & 1.950 & 1.001 & 3.797 \\
\hline \multirow{4}{*}{$\begin{array}{l}\text { somewhat } \\
\text { against it }\end{array}$} & $\begin{array}{c}\text { Intercept } \\
\text { Revisionist }\end{array}$ & \begin{tabular}{|c|}
-3.664 \\
3.084
\end{tabular} & $\begin{array}{l}1.013 \\
1.066\end{array}$ & $\begin{array}{l}13.086 \\
8.363\end{array}$ & $\begin{array}{l}1 \\
1\end{array}$ & $\begin{array}{l}.000 \\
.004\end{array}$ & 21.840 & 2.701 & 176.571 \\
\hline & $\begin{array}{c}\text { Religious } \\
\text { Zionist }\end{array}$ & 5.273 & 1.492 & 12.493 & 1 & .000 & 195.000 & 10.475 & 3630.000 \\
\hline & $\begin{array}{l}\text { Haredi (ultra- } \\
\text { Orthodox) }\end{array}$ & 4.357 & 1.129 & 14.880 & 1 & .000 & 78.000 & 8.525 & 713.638 \\
\hline & $\begin{array}{l}\text { Kadima } \\
\text { Labor }\end{array}$ & $\begin{array}{c}1.361 \\
0^{\mathrm{b}}\end{array}$ & 1.116 & 1.487 & $\begin{array}{l}1 \\
0\end{array}$ & .223 & 3.900 & .438 & 34.760 \\
\hline \multirow{5}{*}{$\begin{array}{l}\text { very against } \\
\text { it }\end{array}$} & Intercept & -2.970 & .725 & 16.786 & 1 & .000 & & & \\
\hline & Revisionist & 2.585 & .790 & 10.699 & 1 & .001 & 13.260 & 2.818 & 62.401 \\
\hline & $\begin{array}{c}\text { Religious } \\
\text { Zionist }\end{array}$ & 5.273 & 1.275 & 17.104 & 1 & .000 & 195.000 & 16.023 & 2373.132 \\
\hline & $\begin{array}{l}\text { Haredi (ultra- } \\
\text { Orthodox) }\end{array}$ & 4.069 & .865 & 22.139 & 1 & .000 & 58.500 & 10.741 & 318.616 \\
\hline & $\begin{array}{l}\text { Kadima } \\
\text { Labor }\end{array}$ & $\begin{array}{c}1.004 \\
0^{\mathrm{b}}\end{array}$ & .830 & 1.465 & $\begin{array}{l}1 \\
0\end{array}$ & .226 & 2.730 & .537 & 13.882 \\
\hline \multirow{5}{*}{$\begin{array}{l}\text { Do not read: } \\
\text { Do not } \\
\text { know/No } \\
\text { opinion }\end{array}$} & Intercept & -3.664 & 1.013 & 13.086 & 1 & .000 & & & \\
\hline & Revisionist & 2.236 & 1.110 & 4.059 & 1 & .044 & 9.360 & 1.063 & 82.450 \\
\hline & $\begin{array}{l}\text { Religious } \\
\text { Zionist }\end{array}$ & -15.248 & .000 & & 1 & & $\begin{array}{l}2.388 \mathrm{E}- \\
7\end{array}$ & 2.388E-7 & 2.388E-7 \\
\hline & $\begin{array}{l}\text { Haredi (ultra- } \\
\text { Orthodox) }\end{array}$ & 1.872 & 1.481 & 1.598 & 1 & .206 & 6.500 & .357 & 118.370 \\
\hline & $\begin{array}{l}\text { Kadima } \\
\text { Labor }\end{array}$ & $\begin{array}{l}.445 \\
0^{\mathrm{b}}\end{array}$ & 1.243 & .128 & $\begin{array}{l}1 \\
0\end{array}$ & .721 & 1.560 & .136 & 17.839 \\
\hline
\end{tabular}


July 2009

Crosstabs

Movement * What is your position in regards to conducting peace negotiations between Israel and the Palestinian Authority? Crosstabulation

\begin{tabular}{|cc|c|c|c|c|c|}
\hline \multirow{2}{*}{} & & \multicolumn{2}{|c|}{ What is your position in regards to conducting peace } \\
negotiations between Israel and the Palestinian Authority?
\end{tabular}




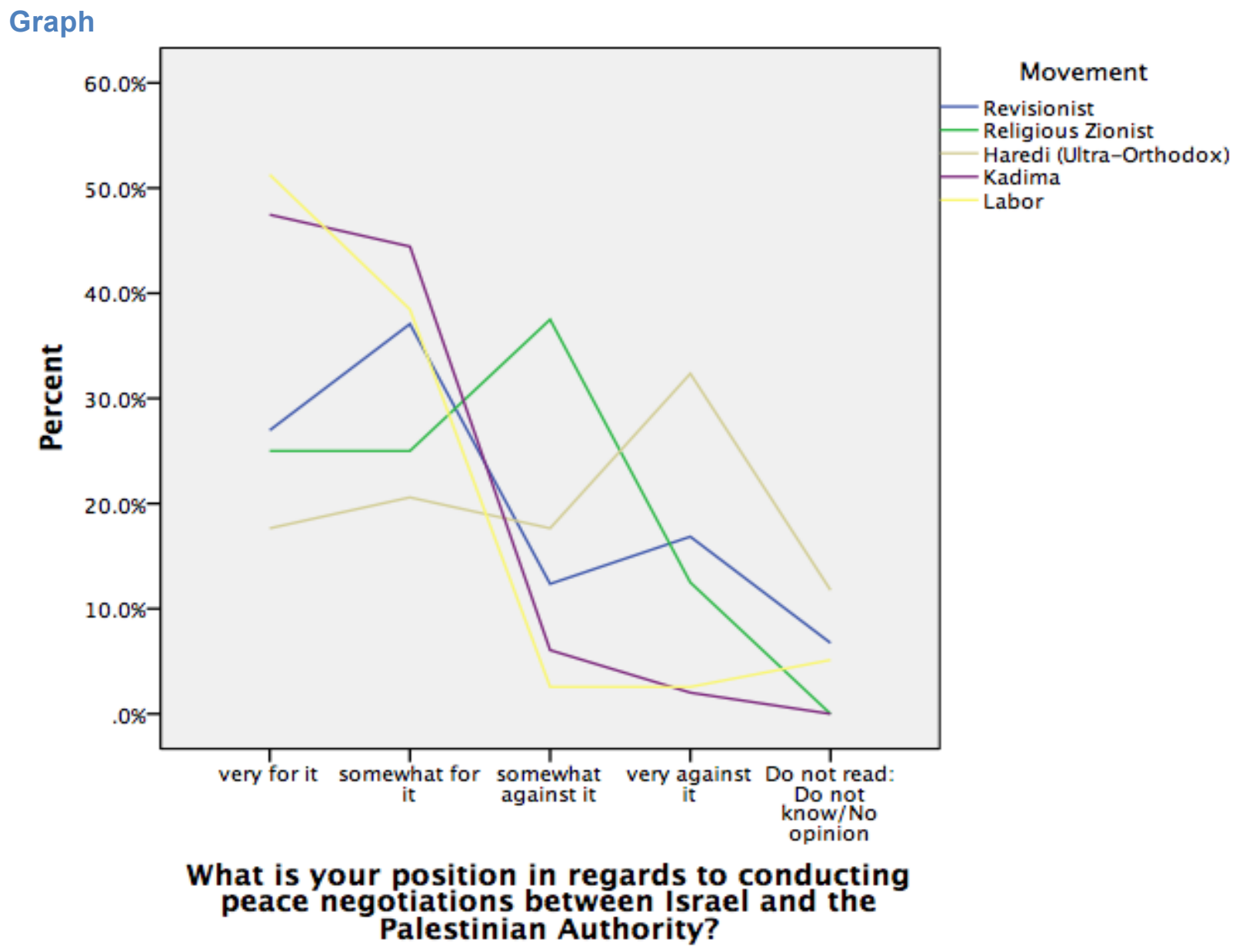

Nominal Regression

Model Fitting Information

\begin{tabular}{|c|c|c|c|c|}
\hline \multirow[b]{2}{*}{ Model } & \multirow{2}{*}{$\begin{array}{c}\text { Model Fitting } \\
\text { Criteria }\end{array}$} & \multicolumn{3}{|c|}{ Likelihood Ratio Tests } \\
\hline & & Chi-Square & $\mathrm{df}$ & Sig. \\
\hline $\begin{array}{l}\text { Intercept Only } \\
\text { Final }\end{array}$ & $\begin{array}{r}124.338 \\
57.711 \\
\end{array}$ & 66.627 & 16 & .000 \\
\hline
\end{tabular}

Goodness-of-Fit

\begin{tabular}{|l|r|r|r|}
\hline & Chi-Square & df & Sig. \\
\hline Pearson & .000 & 0 & \\
Deviance & .000 & 0 & \\
\hline
\end{tabular}

Likelihood Ratio Tests

\begin{tabular}{|l|r|r|r|r|}
\hline \multirow{2}{*}{} & \multicolumn{1}{|c|}{$\begin{array}{c}\text { Model Fitting } \\
\text { Criteria }\end{array}$} & \multicolumn{3}{|c|}{ Likelihood Ratio Tests } \\
\cline { 2 - 6 } & $\begin{array}{c}\text {-2 Log } \\
\text { Likelihood of } \\
\text { Reduced Model }\end{array}$ & Chi-Square & \multicolumn{1}{c|}{ df } & \multicolumn{1}{c|}{ Sig. } \\
\hline Intercept & $57.711^{\mathrm{a}}$ & .000 & 0 & \\
Movement & 124.338 & 66.627 & 16 & .000 \\
\hline
\end{tabular}


Parameter Estimates

\begin{tabular}{|c|c|c|c|c|c|c|c|c|c|}
\hline \multirow{2}{*}{\multicolumn{2}{|c|}{$\begin{array}{c}\text { What is your position in } \\
\text { regards to conducting } \\
\text { peace negotiations between } \\
\text { Israel and the Palestinian } \\
\text { Authority? }\end{array}$}} & \multirow[b]{2}{*}{ B } & \multirow{2}{*}{$\begin{array}{l}\text { Std. } \\
\text { Error }\end{array}$} & \multirow{2}{*}{ Wald } & \multirow{2}{*}{ df } & \multirow{2}{*}{ Sig. } & \multirow{2}{*}{$\operatorname{Exp}(B)$} & \multicolumn{2}{|c|}{$\begin{array}{l}95 \% \text { Confidence } \\
\text { Interval for } \operatorname{Exp}(\mathrm{B}) \\
\end{array}$} \\
\hline & & & & & & & & $\begin{array}{l}\text { Lower } \\
\text { Bound }\end{array}$ & $\begin{array}{l}\text { Upper } \\
\text { Bound }\end{array}$ \\
\hline \multirow{4}{*}{$\begin{array}{c}\text { somewhat for } \\
\text { it }\end{array}$} & $\begin{array}{c}\text { Intercept } \\
\text { Revisionist }\end{array}$ & $\begin{array}{l}-.288 \\
.606\end{array}$ & $\begin{array}{l}.342 \\
.434\end{array}$ & $\begin{array}{l}.709 \\
1.948\end{array}$ & $\begin{array}{l}1 \\
1\end{array}$ & $\begin{array}{l}.400 \\
.163\end{array}$ & 1.833 & .783 & 4.295 \\
\hline & $\begin{array}{c}\text { Religious } \\
\text { Zionist }\end{array}$ & .288 & 1.057 & .074 & 1 & .785 & 1.333 & .168 & 10.579 \\
\hline & $\begin{array}{l}\text { Haredi (ultra- } \\
\text { Orthodox) }\end{array}$ & .442 & .653 & .458 & 1 & .499 & 1.556 & .433 & 5.592 \\
\hline & $\begin{array}{l}\text { Kadima } \\
\text { Labor }\end{array}$ & $\begin{array}{l}.222 \\
0^{\mathrm{b}}\end{array}$ & .401 & .306 & $\begin{array}{l}1 \\
0\end{array}$ & .580 & 1.248 & .569 & 2.738 \\
\hline \multirow{4}{*}{$\begin{array}{l}\text { somewhat } \\
\text { against it }\end{array}$} & $\begin{array}{c}\text { Intercept } \\
\text { Revisionist }\end{array}$ & \begin{tabular}{|l}
-2.996 \\
2.216 \\
\end{tabular} & $\begin{array}{l}1.025 \\
1.087\end{array}$ & $\begin{array}{l}8.547 \\
4.151\end{array}$ & $\begin{array}{l}1 \\
1\end{array}$ & $\begin{array}{l}.003 \\
.042\end{array}$ & 9.167 & 1.088 & 77.243 \\
\hline & $\begin{array}{l}\text { Religious } \\
\text { Zionist }\end{array}$ & 3.401 & 1.372 & 6.142 & 1 & .013 & 30.000 & 2.037 & 441.839 \\
\hline & $\begin{array}{l}\text { Haredi (ultra- } \\
\text { Orthodox) }\end{array}$ & 2.996 & 1.176 & 6.488 & 1 & .011 & 20.000 & 1.995 & 200.527 \\
\hline & $\begin{array}{l}\text { Kadima } \\
\text { Labor }\end{array}$ & $\begin{array}{l}.937 \\
0^{\mathrm{b}}\end{array}$ & 1.113 & .710 & $\begin{array}{l}1 \\
0\end{array}$ & .400 & 2.553 & .288 & $\begin{array}{c}22.602 \\
.\end{array}$ \\
\hline \multirow{5}{*}{$\begin{array}{c}\text { very against } \\
\text { it }\end{array}$} & Intercept & -2.996 & 1.025 & 8.547 & 1 & .003 & & & \\
\hline & Revisionist & 2.526 & 1.076 & 5.507 & 1 & .019 & 12.500 & 1.516 & 103.044 \\
\hline & $\begin{array}{c}\text { Religious } \\
\text { Zionist }\end{array}$ & 2.303 & 1.597 & 2.079 & 1 & .149 & 10.000 & .437 & 228.697 \\
\hline & $\begin{array}{l}\text { Haredi (ultra- } \\
\text { Orthodox) }\end{array}$ & 3.602 & 1.143 & 9.922 & 1 & .002 & 36.667 & 3.899 & 344.837 \\
\hline & $\begin{array}{l}\text { Kadima } \\
\text { Labor }\end{array}$ & $\begin{array}{c}-.161 \\
0^{\mathrm{b}}\end{array}$ & 1.254 & .017 & $\begin{array}{l}1 \\
0\end{array}$ & .898 & .851 & .073 & 9.930 \\
\hline \multirow{6}{*}{$\begin{array}{l}\text { Do not read: } \\
\text { Do not } \\
\text { know/No } \\
\text { opinion }\end{array}$} & Intercept & -2.303 & .742 & 9.640 & 1 & .002 & & & \\
\hline & Revisionist & .916 & .871 & 1.107 & 1 & .293 & 2.500 & .454 & 13.778 \\
\hline & $\begin{array}{l}\text { Religious } \\
\text { Zionist }\end{array}$ & $\begin{array}{c}- \\
17.519\end{array}$ & .000 & . & 1 & . & $\begin{array}{c}2.463 \mathrm{E}- \\
8\end{array}$ & $2.463 \mathrm{E}-8$ & $2.463 \mathrm{E}-8$ \\
\hline & $\begin{array}{l}\text { Haredi (ultra- } \\
\text { Orthodox) }\end{array}$ & 1.897 & .983 & 3.723 & 1 & .054 & 6.667 & .971 & 45.793 \\
\hline & Kadima & $\begin{array}{l}- \\
17.152\end{array}$ & $\begin{array}{c}2446.18 \\
5\end{array}$ & .000 & 1 & .994 & $\begin{array}{c}3.556 \mathrm{E}- \\
8\end{array}$ & .000 &.${ }^{c}$ \\
\hline & Labor & $0^{\mathrm{b}}$ & & & 0 & & & & . \\
\hline
\end{tabular}


January 2010

Crosstabs

Movement * What is your position in regards to conducting peace negotiations between Israel and the Palestinian Authority? Crosstabulation

\begin{tabular}{|cc|c|c|c|c|c|}
\hline \multirow{2}{*}{} & & \multicolumn{2}{|c|}{ What is your position in regards to conducting peace } \\
negotiations between Israel and the Palestinian Authority?
\end{tabular}




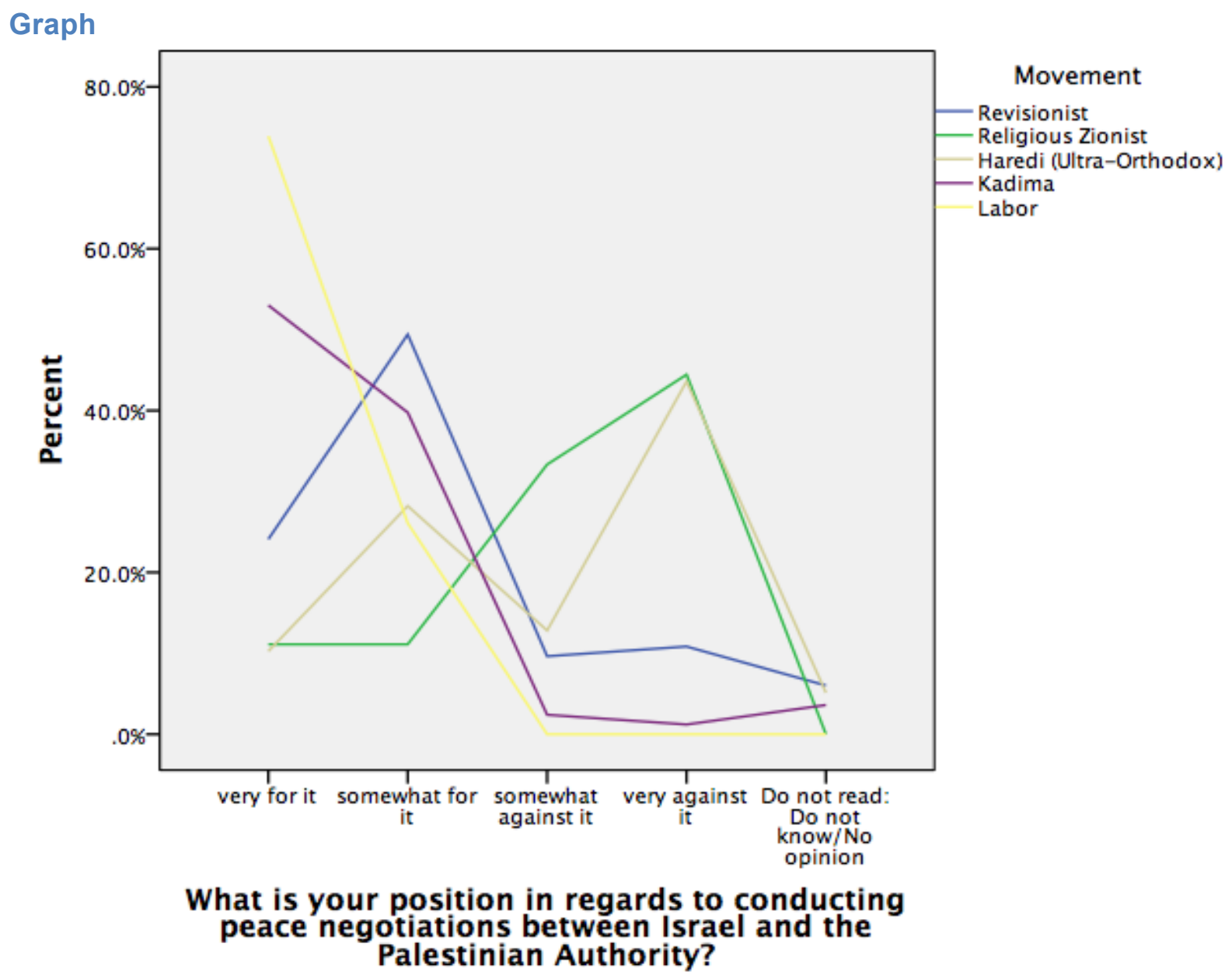

Nominal Regression

Model Fitting Information

\begin{tabular}{|l|r|r|r|r|}
\hline \multirow{2}{*}{ Model } & \multicolumn{2}{|c|}{$\begin{array}{c}\text { Model Fitting } \\
\text { Criteria }\end{array}$} & \multicolumn{3}{|c|}{ Likelihood Ratio Tests } \\
\cline { 2 - 5 } & $\begin{array}{c}-2 \text { Log } \\
\text { Likelihood }\end{array}$ & Chi-Square & \multicolumn{1}{|c|}{ df } & \multicolumn{1}{|c|}{ Sig. } \\
\hline Intercept Only & $\begin{array}{r}164.038 \\
\text { Final }\end{array}$ & 113.089 & 16 & .000 \\
\hline
\end{tabular}

Goodness-of-Fit

\begin{tabular}{|l|r|r|r|}
\hline & Chi-Square & df & Sig. \\
\hline Pearson & .000 & 0 & \\
Deviance & .000 & 0 &. \\
\hline
\end{tabular}

Likelihood Ratio Tests

\begin{tabular}{|l|r|r|r|r|}
\hline \multirow{2}{*}{} & \multicolumn{1}{|c|}{$\begin{array}{c}\text { Model Fitting } \\
\text { Criteria }\end{array}$} & \multicolumn{3}{|c|}{ Likelihood Ratio Tests } \\
\cline { 2 - 6 } & $\begin{array}{c}-2 \text { Log } \\
\text { Likelihood of } \\
\text { Reduced Model }\end{array}$ & Chi-Square & \multicolumn{1}{c|}{ df } & \multicolumn{1}{c|}{ Sig. } \\
\hline Intercept & $50.949^{2}$ & .000 & 0 & \\
Movement & 164.038 & 113.089 & 16 & .000 \\
\hline
\end{tabular}


Parameter Estimates

\begin{tabular}{|c|c|c|c|c|c|c|c|c|c|}
\hline \multirow{2}{*}{\multicolumn{2}{|c|}{$\begin{array}{l}\text { What is your position in } \\
\text { regards to conducting } \\
\text { peace negotiations } \\
\text { between Israel and the } \\
\text { Palestinian Authority? }\end{array}$}} & \multirow{2}{*}{ B } & \multirow{2}{*}{$\begin{array}{l}\text { Std. } \\
\text { Error }\end{array}$} & \multirow{2}{*}{ Wald } & \multirow{2}{*}{ df } & \multirow{2}{*}{ Sig. } & \multirow{2}{*}{$\operatorname{Exp}(B)$} & \multicolumn{2}{|c|}{$\begin{array}{l}95 \% \text { Confidence } \\
\text { Interval for } \operatorname{Exp}(\mathrm{B})\end{array}$} \\
\hline & & & & & & & & $\begin{array}{l}\text { Lower } \\
\text { Bound }\end{array}$ & $\begin{array}{l}\text { Upper } \\
\text { Bound }\end{array}$ \\
\hline \multirow{4}{*}{$\begin{array}{l}\text { somewhat } \\
\text { for it }\end{array}$} & $\begin{array}{c}\text { Intercept } \\
\text { Revisionist }\end{array}$ & $\begin{array}{r}-1.041 \\
1.759 \\
\end{array}$ & $\begin{array}{l}.336 \\
.433 \\
\end{array}$ & $\begin{array}{c}9.620 \\
16.539 \\
\end{array}$ & $\begin{array}{l}1 \\
1\end{array}$ & $\begin{array}{l}.002 \\
.000\end{array}$ & 5.808 & 2.488 & 13.560 \\
\hline & $\begin{array}{c}\text { Religious } \\
\text { Zionist }\end{array}$ & 1.041 & 1.454 & .513 & 1 & .474 & 2.833 & .164 & 48.926 \\
\hline & $\begin{array}{l}\text { Haredi (ultra- } \\
\text { Orthodox) } \\
\end{array}$ & 2.053 & .674 & 9.291 & 1 & .002 & 7.792 & 2.081 & 29.171 \\
\hline & $\begin{array}{c}\text { Kadima } \\
\text { Labor }\end{array}$ & $\begin{array}{l}.754 \\
0^{\mathrm{b}} \\
\end{array}$ & .407 & 3.427 & $\begin{array}{l}1 \\
0\end{array}$ & .064 & 2.125 & .957 & 4.720 \\
\hline \multirow{3}{*}{$\begin{array}{l}\text { somewhat } \\
\text { against it }\end{array}$} & $\begin{array}{l}\text { Intercept } \\
\text { Revisionist }\end{array}$ & $\begin{array}{c}- \\
18.675 \\
17.759\end{array}$ & \begin{tabular}{|c}
1947.35 \\
6 \\
1947.35 \\
6 \\
\end{tabular} & $\begin{array}{l}.000 \\
.000\end{array}$ & 1 & $\begin{array}{l}.992 \\
.993\end{array}$ & $\begin{array}{c}51573855 \\
.897 \\
\end{array}$ & .000 &.$^{c}$ \\
\hline & $\begin{array}{c}\text { Religious } \\
\text { Zionist } \\
\text { Haredi (ultra- } \\
\text { Orthodox) } \\
\end{array}$ & $\begin{array}{l}19.773 \\
18.898\end{array}$ & \begin{tabular}{|c|}
1947.35 \\
6 \\
1947.35 \\
6 \\
\end{tabular} & $\begin{array}{l}.000 \\
.000\end{array}$ & 1 & $\begin{array}{l}.992 \\
.992\end{array}$ & \begin{tabular}{|c|}
38680391 \\
9.226 \\
16116829 \\
9.677 \\
\end{tabular} & $\begin{array}{l}.000 \\
.000\end{array}$ & $\begin{array}{l}. \mathrm{c} \\
. \mathrm{c}\end{array}$ \\
\hline & $\begin{array}{c}\text { Kadima } \\
\text { Labor }\end{array}$ & $\begin{array}{c}15.584 \\
0^{\mathrm{b}} \\
\end{array}$ & $\begin{array}{c}1947.35 \\
6\end{array}$ & .000 & $\begin{array}{l}1 \\
0 \\
\end{array}$ & .994 & $\begin{array}{c}5860665 . \\
443\end{array}$ & .000 &.$^{\mathrm{c}}$ \\
\hline \multirow{6}{*}{$\begin{array}{l}\text { very against } \\
\text { it }\end{array}$} & Intercept & $18 . \overline{-}$ & $\begin{array}{c}1483.88 \\
7\end{array}$ & .000 & 1 & .990 & & & \\
\hline & Revisionist & 17.333 & $\begin{array}{c}1483.88 \\
7\end{array}$ & .000 & 1 & .991 & $\begin{array}{c}33689373 \\
.739\end{array}$ & .000 &.$^{\mathrm{c}}$ \\
\hline & $\begin{array}{l}\text { Religious } \\
\text { Zionist }\end{array}$ & 19.517 & $\begin{array}{c}1483.88 \\
7\end{array}$ & .000 & 1 & .990 & $\begin{array}{c}29946109 \\
9.906\end{array}$ & .000 &.$^{\mathrm{c}}$ \\
\hline & $\begin{array}{l}\text { Haredi (ultra- } \\
\text { Orthodox) }\end{array}$ & 19.578 & $\begin{array}{c}1483.88 \\
7\end{array}$ & .000 & 1 & .989 & $\begin{array}{c}31817741 \\
8.650\end{array}$ & .000 &.$^{c}$ \\
\hline & Kadima & 14.347 & $\begin{array}{c}1483.88 \\
7\end{array}$ & .000 & 1 & .992 & $\begin{array}{c}1701483 . \\
522\end{array}$ & .000 &.$^{c}$ \\
\hline & Labor & $0^{\mathrm{b}}$ & & & 0 & . & 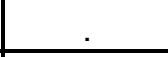 & . & . \\
\hline \multirow{6}{*}{$\begin{array}{l}\text { Do not read: } \\
\text { Do not } \\
\text { know/No } \\
\text { opinion }\end{array}$} & Intercept & $19 \overline{263}$ & $\begin{array}{c}2572.08 \\
3\end{array}$ & .000 & 1 & .994 & & & \\
\hline & Revisionist & 17.876 & $\begin{array}{c}2572.08 \\
3\end{array}$ & .000 & 1 & .994 & $\begin{array}{c}58020588 \\
.097\end{array}$ & .000 &.$^{c}$ \\
\hline & $\begin{array}{l}\text { Religious } \\
\text { Zionist }\end{array}$ & .078 & .000 & & 1 & & 1.081 & 1.081 & 1.081 \\
\hline & $\begin{array}{l}\text { Haredi (ultra- } \\
\text { Orthodox) }\end{array}$ & 18.569 & $\begin{array}{c}2572.08 \\
3\end{array}$ & .000 & 1 & .994 & $\begin{array}{c}11604117 \\
6.193\end{array}$ & .000 &.$^{\mathrm{c}}$ \\
\hline & Kadima & $\begin{array}{c}16.577 \\
0^{b}\end{array}$ & $\begin{array}{c}2572.08 \\
3\end{array}$ & .000 & 1 & .995 & $\begin{array}{c}15823796 \\
.754\end{array}$ & .000 &.$^{\mathrm{c}}$ \\
\hline & & $0^{\circ}$ & & & 0 & & & & \\
\hline
\end{tabular}


July 2010

Crosstabs

Movement * What is your position in regards to conducting peace negotiations between Israel and the Palestinian Authority? Crosstabulation

\begin{tabular}{|c|c|c|c|c|c|c|c|}
\hline & \multicolumn{5}{|c|}{$\begin{array}{l}\text { What is your position in regards to conducting peace } \\
\text { negotiations between Israel and the Palestinian Authority? }\end{array}$} \\
\hline & & & very for it & $\begin{array}{l}\text { somewhat } \\
\text { for it }\end{array}$ & $\begin{array}{l}\text { somewhat } \\
\text { against it }\end{array}$ & $\begin{array}{l}\text { very } \\
\text { against it }\end{array}$ & 5 \\
\hline \multirow{5}{*}{$\begin{array}{l}\text { Moveme } \\
\text { nt }\end{array}$} & Revisionist & $\begin{array}{c}\text { Count } \\
\% \text { within } \\
\text { Movement }\end{array}$ & $\begin{array}{c}32 \\
24.1 \%\end{array}$ & $\begin{array}{c}55 \\
41.4 \%\end{array}$ & $\begin{array}{c}23 \\
17.3 \%\end{array}$ & $\begin{array}{c}21 \\
15.8 \%\end{array}$ & $\begin{array}{c}2 \\
1.5 \%\end{array}$ \\
\hline & $\begin{array}{l}\text { Religious } \\
\text { Zionist }\end{array}$ & $\begin{array}{c}\text { Count } \\
\% \text { within } \\
\text { Movement }\end{array}$ & $\begin{array}{c}2 \\
13.3 \%\end{array}$ & $\begin{array}{c}3 \\
20.0 \%\end{array}$ & $\begin{array}{c}4 \\
26.7 \%\end{array}$ & $\begin{array}{c}5 \\
33.3 \%\end{array}$ & $\begin{array}{c}1 \\
6.7 \%\end{array}$ \\
\hline & $\begin{array}{l}\text { Haredi (Ultra- } \\
\text { Orthodox) }\end{array}$ & $\begin{array}{c}\text { Count } \\
\% \text { within } \\
\text { Movement }\end{array}$ & $\begin{array}{c}11 \\
25.0 \%\end{array}$ & $\begin{array}{c}14 \\
31.8 \%\end{array}$ & $\begin{array}{c}7 \\
15.9 \%\end{array}$ & $\begin{array}{c}10 \\
22.7 \%\end{array}$ & $\begin{array}{c}2 \\
4.5 \%\end{array}$ \\
\hline & Kadima & $\begin{array}{c}\text { Count } \\
\% \text { within } \\
\text { Movement }\end{array}$ & $\begin{array}{c}60 \\
55.6 \%\end{array}$ & $\begin{array}{c}36 \\
33.3 \%\end{array}$ & $\begin{array}{c}4 \\
3.7 \%\end{array}$ & $\begin{array}{c}6 \\
5.6 \%\end{array}$ & $\begin{array}{c}2 \\
1.9 \%\end{array}$ \\
\hline & Labor & $\begin{array}{c}\text { Count } \\
\% \text { within } \\
\text { Movement }\end{array}$ & $\begin{array}{c}39 \\
67.2 \%\end{array}$ & $\begin{array}{c}16 \\
27.6 \%\end{array}$ & $\begin{array}{c}1 \\
1.7 \%\end{array}$ & $\begin{array}{c}2 \\
3.4 \%\end{array}$ & $\begin{array}{c}0 \\
0.0 \%\end{array}$ \\
\hline \multicolumn{2}{|r|}{ Total } & $\begin{array}{c}\text { Count } \\
\% \text { within } \\
\text { Movement }\end{array}$ & $\begin{array}{c}144 \\
40.2 \%\end{array}$ & $\begin{array}{c}124 \\
34.6 \%\end{array}$ & $\begin{array}{c}39 \\
10.9 \%\end{array}$ & $\begin{array}{c}44 \\
12.3 \%\end{array}$ & $\begin{array}{c}7 \\
2.0 \%\end{array}$ \\
\hline
\end{tabular}




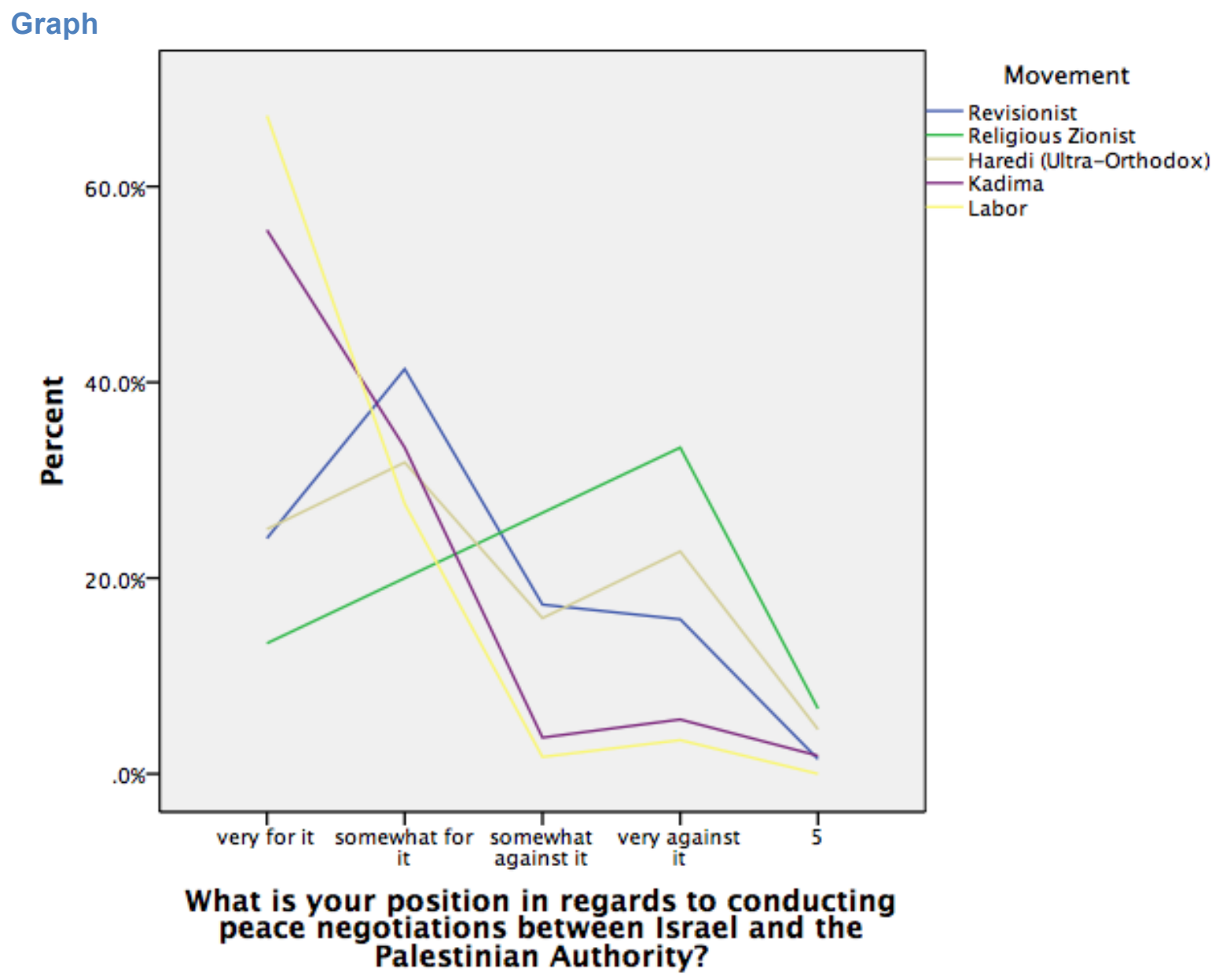

Nominal Regression

Model Fitting Information

\begin{tabular}{|l|r|r|r|r|}
\hline \multirow{2}{*}{ Model } & \multicolumn{1}{|c|}{$\begin{array}{c}\text { Model Fitting } \\
\text { Criteria }\end{array}$} & \multicolumn{3}{|c|}{ Likelihood Ratio Tests } \\
\cline { 2 - 5 } & $\begin{array}{r}-2 \text { Log } \\
\text { Likelihood }\end{array}$ & Chi-Square & df & Sig. \\
\hline Intercept Only & $\begin{array}{r}142.601 \\
63.615\end{array}$ & 78.986 & 16 & .000 \\
\hline
\end{tabular}

Goodness-of-Fit

\begin{tabular}{|c|c|c|c|}
\hline & Chi-Square & $\mathrm{df}$ & Sig. \\
\hline Pearson & .000 & 0 & \\
\hline Devi & .000 & 0 & \\
\hline
\end{tabular}

Likelihood Ratio Tests

\begin{tabular}{|l|r|r|r|r|}
\hline \multirow{2}{*}{} & \multicolumn{1}{|c|}{$\begin{array}{c}\text { Model Fitting } \\
\text { Criteria }\end{array}$} & \multicolumn{3}{|c|}{ Likelihood Ratio Tests } \\
\cline { 2 - 6 } & $\begin{array}{c}-2 \text { Log } \\
\text { Likelihood of } \\
\text { Reduced Model }\end{array}$ & Chi-Square & df & \multicolumn{1}{c|}{ Sig. } \\
\hline Effect & $63.615^{\text {a }}$ & .000 & 0 & .000 \\
\hline Movement & 142.601 & 78.986 & 16 & .000 \\
\hline
\end{tabular}


Parameter Estimates

\begin{tabular}{|c|c|c|c|c|c|c|c|c|c|}
\hline \multirow{2}{*}{\multicolumn{2}{|c|}{$\begin{array}{l}\text { What is your position in } \\
\text { regards to conducting } \\
\text { peace negotiations } \\
\text { between Israel and the } \\
\text { Palestinian Authority? }\end{array}$}} & \multirow[b]{2}{*}{ B } & \multirow{2}{*}{$\begin{array}{l}\text { Std. } \\
\text { Error }\end{array}$} & \multirow{2}{*}{ Wald } & \multirow[b]{2}{*}{ df } & \multirow{2}{*}{ Sig. } & \multirow{2}{*}{$\operatorname{Exp}(B)$} & \multicolumn{2}{|c|}{$\begin{array}{l}95 \% \text { Confidence } \\
\text { Interval for } \operatorname{Exp}(B) \\
\end{array}$} \\
\hline & & & & & & & & $\begin{array}{l}\text { Lower } \\
\text { Bound }\end{array}$ & $\begin{array}{l}\text { Upper } \\
\text { Bound }\end{array}$ \\
\hline \multirow{5}{*}{$\begin{array}{l}\text { somewhat } \\
\text { for it }\end{array}$} & Intercept & -.891 & $\begin{array}{l}.297 \\
271\end{array}$ & 9.006 & 1 & .003 & & & \\
\hline & Revisionist & 1.433 & .371 & 14.918 & 1 & .000 & 4.189 & 2.025 & 8.667 \\
\hline & $\begin{array}{l}\text { Religious } \\
\text { Zionist }\end{array}$ & 1.296 & .960 & 1.824 & 1 & .177 & 3.656 & .557 & 23.996 \\
\hline & $\begin{array}{l}\text { Haredi (ultra- } \\
\text { Orthodox) }\end{array}$ & 1.132 & .500 & 5.117 & 1 & .024 & 3.102 & 1.163 & 8.273 \\
\hline & $\begin{array}{l}\text { Kadima } \\
\text { Labor }\end{array}$ & $\begin{array}{l}.380 \\
0^{\mathrm{b}}\end{array}$ & .364 & 1.090 & $\begin{array}{l}1 \\
0 \\
\end{array}$ & .296 & 1.463 & .716 & 2.986 \\
\hline \multirow{4}{*}{$\begin{array}{l}\text { somewhat } \\
\text { against it }\end{array}$} & $\begin{array}{c}\text { Intercept } \\
\text { Revisionist }\end{array}$ & \begin{tabular}{|l|}
-3.664 \\
3.333 \\
\end{tabular} & $\begin{array}{l}1.013 \\
1.049 \\
\end{array}$ & $\begin{array}{l}13.086 \\
10.098 \\
\end{array}$ & $\begin{array}{l}1 \\
1 \\
\end{array}$ & $\begin{array}{l}.000 \\
.001 \\
\end{array}$ & 28.031 & 3.587 & 219.048 \\
\hline & $\begin{array}{l}\text { Religious } \\
\text { Zionist }\end{array}$ & 4.357 & 1.333 & 10.690 & 1 & .001 & 78.000 & 5.726 & 1062.546 \\
\hline & $\begin{array}{l}\text { Haredi (ultra- } \\
\text { Orthodox) }\end{array}$ & 3.212 & 1.122 & 8.190 & 1 & .004 & 24.818 & 2.751 & 223.881 \\
\hline & $\begin{array}{l}\text { Kadima } \\
\text { Labor }\end{array}$ & $\begin{array}{l}.956 \\
0^{\mathrm{b}}\end{array}$ & 1.137 & .706 & $\begin{array}{l}1 \\
0\end{array}$ & .401 & 2.600 & .280 & 24.133 \\
\hline \multirow{5}{*}{$\begin{array}{l}\text { very against } \\
\text { it }\end{array}$} & Intercept & -2.970 & .725 & 16.786 & 1 & .000 & & & \\
\hline & Revisionist & 2.549 & .778 & 10.750 & 1 & .001 & 12.797 & 2.788 & 58.737 \\
\hline & $\begin{array}{l}\text { Religious } \\
\text { Zionist }\end{array}$ & 3.887 & 1.107 & 12.325 & 1 & .000 & 48.750 & 5.567 & 426.902 \\
\hline & $\begin{array}{l}\text { Haredi (ultra- } \\
\text { Orthodox) }\end{array}$ & 2.875 & .846 & 11.536 & 1 & .001 & 17.727 & 3.374 & 93.149 \\
\hline & $\begin{array}{c}\text { Kadima } \\
\text { Labor }\end{array}$ & $\begin{array}{l}.668 \\
0^{\mathrm{b}} \\
\end{array}$ & .842 & .629 & $\begin{array}{l}1 \\
0 \\
\end{array}$ & .428 & 1.950 & .374 & 10.157 \\
\hline \multirow{6}{*}{ Do not read } & Intercept & $21 . \overline{7} 21$ & .719 & $\begin{array}{c}913.19 \\
6\end{array}$ & 1 & .000 & & & \\
\hline & Revisionist & 18.949 & 1.024 & $\begin{array}{c}342.63 \\
8\end{array}$ & 1 & .000 & $\begin{array}{c}16957148 \\
0.293\end{array}$ & $\begin{array}{c}22803237 \\
.564\end{array}$ & $\begin{array}{c}12609826 \\
49.851\end{array}$ \\
\hline & $\begin{array}{l}\text { Religious } \\
\text { Zionist }\end{array}$ & 21.028 & 1.420 & $\begin{array}{c}219.26 \\
6\end{array}$ & 1 & .000 & $\begin{array}{c}13565718 \\
42.375\end{array}$ & $\begin{array}{c}83879664 \\
.712\end{array}$ & $\begin{array}{c}21939610 \\
391.125\end{array}$ \\
\hline & $\begin{array}{l}\text { Haredi (ultra- } \\
\text { Orthodox) }\end{array}$ & 20.017 & 1.052 & $\begin{array}{c}361.75 \\
0\end{array}$ & 1 & .000 & $\begin{array}{c}49329885 \\
1.760\end{array}$ & $\begin{array}{c}62703743 \\
.677\end{array}$ & $\begin{array}{c}38808489 \\
39.443\end{array}$ \\
\hline & Kadima & 18.320 & .000 & $\cdot$ & 1 & . & $\begin{array}{c}90438122 \\
.823\end{array}$ & $\begin{array}{c}90438122 \\
.823\end{array}$ & $\begin{array}{c}90438122 \\
.823\end{array}$ \\
\hline & Labor & $0^{\mathrm{b}}$ & & & 0 & & & & \\
\hline
\end{tabular}


January 2011

Crosstabs

Movement * What is your position in regards to conducting peace negotiations between Israel and the Palestinian Authority? Crosstabulation

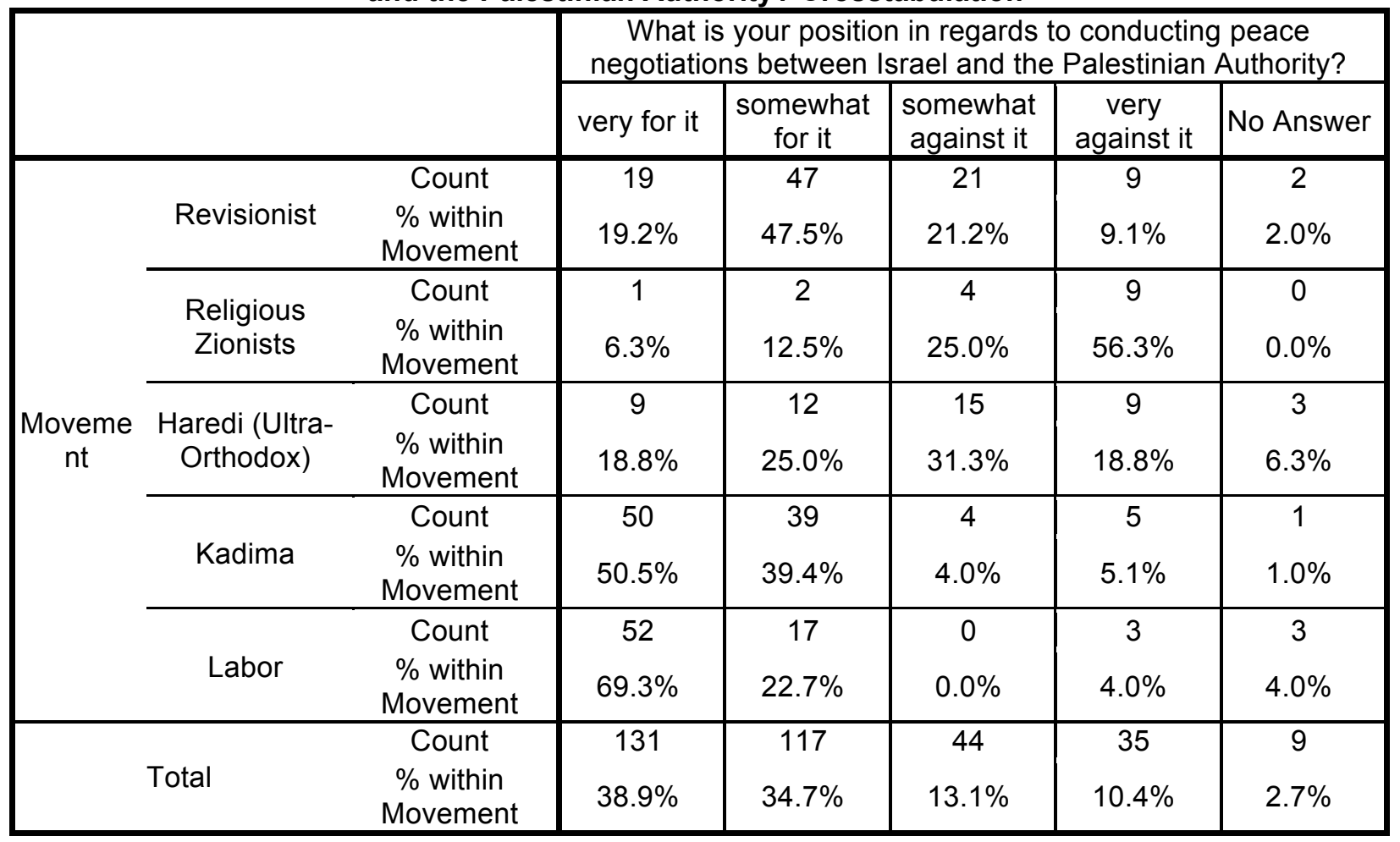




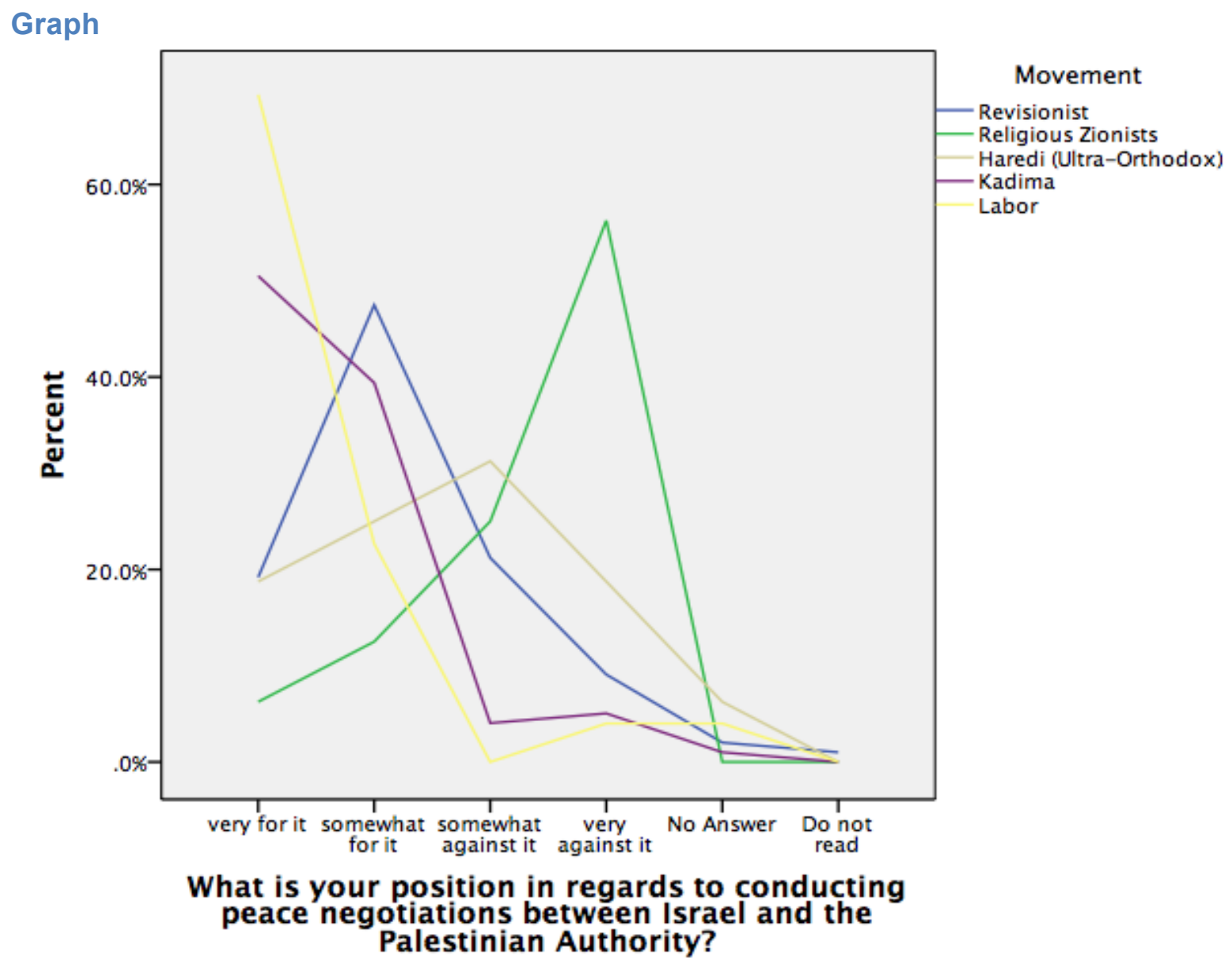

Nominal Regression

Model Fitting Information

\begin{tabular}{|l|r|r|r|r|}
\hline \multirow{2}{*}{ Model } & \multicolumn{1}{|c|}{$\begin{array}{c}\text { Model Fitting } \\
\text { Criteria }\end{array}$} & \multicolumn{3}{|c|}{ Likelihood Ratio Tests } \\
\cline { 2 - 5 } & $\begin{array}{c}\text {-2 Log } \\
\text { Likelihood }\end{array}$ & Chi-Square & df & \multicolumn{1}{c|}{ Sig. } \\
\hline Intercept Only & $\begin{array}{r}193.638 \\
63.068\end{array}$ & 130.569 & 20 & .000 \\
\hline
\end{tabular}

Goodness-of-Fit

\begin{tabular}{|l|r|r|r|}
\hline & Chi-Square & df & Sig. \\
\hline Pearson & .000 & 0 & \\
Deviance & .000 & 0 &. \\
\hline
\end{tabular}

Likelihood Ratio Tests

\begin{tabular}{|l|r|r|r|r|}
\hline \multirow{2}{*}{} & \multicolumn{1}{|c|}{$\begin{array}{c}\text { Model Fitting } \\
\text { Criteria }\end{array}$} & \multicolumn{3}{|c|}{ Likelihood Ratio Tests } \\
\cline { 2 - 6 } & $\begin{array}{c}\text {-2 Log } \\
\text { Likelihood of } \\
\text { Eeduced Model }\end{array}$ & Chi-Square & \multicolumn{1}{c|}{ df } & \multicolumn{1}{c|}{ Sig. } \\
\hline Intercept & $63.068^{\mathrm{a}}$ & .000 & 0 & .000 \\
\hline Movement & 193.638 & 130.569 & 20 & .000 \\
\hline
\end{tabular}


Parameter Estimates

\begin{tabular}{|c|c|c|c|c|c|c|c|c|c|}
\hline \multirow{2}{*}{\multicolumn{2}{|c|}{$\begin{array}{l}\text { What is your position in } \\
\text { regards to conducting } \\
\text { peace negotiations } \\
\text { between Israel and the } \\
\text { Palestinian Authority? }\end{array}$}} & \multirow[b]{2}{*}{ B } & \multirow{2}{*}{$\begin{array}{l}\text { Std. } \\
\text { Error }\end{array}$} & \multirow{2}{*}{ Wald } & \multirow{2}{*}{ df } & \multirow{2}{*}{ Sig. } & \multirow[b]{2}{*}{$\operatorname{Exp}(B)$} & \multicolumn{2}{|c|}{$\begin{array}{l}95 \% \text { Confidence } \\
\text { Interval for Exp(B) }\end{array}$} \\
\hline & & & & & & & & $\begin{array}{l}\text { Lower } \\
\text { Bound }\end{array}$ & $\begin{array}{l}\text { Upper } \\
\text { Bound }\end{array}$ \\
\hline \multirow{4}{*}{$\begin{array}{l}\text { somewhat } \\
\text { for it }\end{array}$} & $\begin{array}{c}\text { Intercept } \\
\text { Revisionist }\end{array}$ & $\begin{array}{c}-1.118 \\
2.024 \\
\end{array}$ & $\begin{array}{l}.279 \\
.390\end{array}$ & \begin{tabular}{|l|}
16.014 \\
26.951 \\
\end{tabular} & $\begin{array}{l}1 \\
1\end{array}$ & $\begin{array}{l}.000 \\
.000\end{array}$ & 7.567 & 3.524 & 16.245 \\
\hline & $\begin{array}{l}\text { Religious } \\
\text { Zionist }\end{array}$ & 1.811 & 1.256 & 2.079 & 1 & 149 & 6.118 & .522 & 71.758 \\
\hline & $\begin{array}{l}\text { Haredi (ultra- } \\
\text { Orthodox) }\end{array}$ & 1.406 & .522 & 7.252 & 1 & .007 & 4.078 & 1.466 & 11.346 \\
\hline & $\begin{array}{l}\text { Kadima } \\
\text { Labor }\end{array}$ & $\begin{array}{l}.870 \\
0^{\mathrm{b}}\end{array}$ & .352 & 6.113 & $\begin{array}{l}1 \\
0\end{array}$ & .013 & 2.386 & $\begin{array}{c}1.198 \\
.\end{array}$ & $\begin{array}{c}4.754 \\
.\end{array}$ \\
\hline \multirow{5}{*}{$\begin{array}{l}\text { somewhat } \\
\text { against it }\end{array}$} & Intercept & $14 . \overline{409}$ & 186.564 & .006 & 1 & .938 & & & \\
\hline & Revisionist & 14.509 & 186.564 & .006 & 1 & .938 & $\begin{array}{c}2000424 . \\
943\end{array}$ & $\begin{array}{c}3.146 \mathrm{E}- \\
153\end{array}$ & $\begin{array}{c}1.272 \mathrm{E}+1 \\
65\end{array}$ \\
\hline & $\begin{array}{c}\text { Religious } \\
\text { Zionist }\end{array}$ & 15.795 & 186.567 & .007 & 1 & .933 & $\begin{array}{c}7239633 . \\
126\end{array}$ & $\begin{array}{c}1.132 \mathrm{E}- \\
152\end{array}$ & $\begin{array}{c}4.632 \mathrm{E}+1 \\
65\end{array}$ \\
\hline & $\begin{array}{l}\text { Haredi (ultra- } \\
\text { Orthodox) }\end{array}$ & 14.920 & 186.564 & .006 & 1 & .936 & $\begin{array}{c}3016513 . \\
803\end{array}$ & $\begin{array}{l}4.741 \mathrm{E}- \\
153\end{array}$ & $\begin{array}{c}1.919 \mathrm{E}+1 \\
65\end{array}$ \\
\hline & $\begin{array}{l}\text { Kadima } \\
\text { Labor }\end{array}$ & $\begin{array}{c}11.883 \\
0^{b}\end{array}$ & 186.564 & .004 & $\begin{array}{l}1 \\
0\end{array}$ & .949 & $\begin{array}{c}144792.6 \\
63\end{array}$ & $\begin{array}{c}2.275 \mathrm{E}- \\
154\end{array}$ & $\begin{array}{c}9.216 \mathrm{E}+1 \\
63\end{array}$ \\
\hline \multirow{5}{*}{$\begin{array}{l}\text { very against } \\
\text { it }\end{array}$} & Intercept & -2.853 & .594 & 23.081 & 1 & .000 & & & \\
\hline & Revisionist & 2.105 & .719 & 8.586 & 1 & .003 & 8.211 & 2.008 & 33.574 \\
\hline & $\begin{array}{l}\text { Religious } \\
\text { Zionist }\end{array}$ & 5.050 & 1.210 & 17.423 & 1 & .000 & 156.000 & 14.565 & 1670.818 \\
\hline & $\begin{array}{l}\text { Haredi (ultra- } \\
\text { Orthodox) }\end{array}$ & 2.853 & .758 & 14.157 & 1 & .000 & 17.333 & 3.922 & 76.598 \\
\hline & $\begin{array}{c}\text { Kadima } \\
\text { Labor }\end{array}$ & $\begin{array}{c}.550 \\
0^{\mathrm{b}}\end{array}$ & .757 & .528 & $\begin{array}{l}1 \\
0\end{array}$ & .467 & 1.733 & .393 & 7.638 \\
\hline \multirow{5}{*}{ No Answer } & Intercept & -2.853 & .594 & 23.081 & 1 & .000 & & & \\
\hline & Revisionist & .601 & .951 & .399 & 1 & .527 & 1.825 & .283 & 11.776 \\
\hline & $\begin{array}{l}\text { Religious } \\
\text { Zionist }\end{array}$ & 13.422 & $\begin{array}{c}3419.63 \\
2\end{array}$ & .000 & 1 & .997 & $1.482 \mathrm{E}-6$ & .000 & c \\
\hline & $\begin{array}{c}\text { Haredi (ultra- } \\
\text { Orthodox) }\end{array}$ & 1.754 & .893 & 3.860 & 1 & .049 & 5.778 & 1.004 & 33.241 \\
\hline & $\begin{array}{l}\text { Kadima } \\
\text { Labor }\end{array}$ & $\begin{array}{c}-1.059 \\
0^{\mathrm{b}} \\
\end{array}$ & 1.172 & .818 & $\begin{array}{l}1 \\
0\end{array}$ & .366 & .347 & .035 & 3.445 \\
\hline \multirow{6}{*}{ Do not read } & Intercept & $\begin{array}{c}- \\
18.193\end{array}$ & $\begin{array}{c}1228.61 \\
6\end{array}$ & .000 & 1 & .988 & & & \\
\hline & Revisionist & 15.249 & $\begin{array}{c}1228.61 \\
6\end{array}$ & .000 & 1 & .990 & $\begin{array}{c}4191366 . \\
546\end{array}$ & .000 &.$^{c}$ \\
\hline & $\begin{array}{l}\text { Religious } \\
\text { Zionist }\end{array}$ & -.279 & .000 & & 1 & . & .757 & .757 & .757 \\
\hline & $\begin{array}{l}\text { Haredi (ultra- } \\
\text { Orthodox) }\end{array}$ & 1.233 & $\begin{array}{c}2021.72 \\
1\end{array}$ & .000 & 1 & 1.000 & 3.432 & .000 &.$^{c}$ \\
\hline & Kadima & .490 & $\begin{array}{c}1576.45 \\
5\end{array}$ & .000 & 1 & 1.000 & 1.632 & .000 &.$^{c}$ \\
\hline & Labor & $0^{\mathrm{b}}$ & & & 0 & & & & \\
\hline
\end{tabular}


July 2011

Crosstabs

Movement * What is your position in regards to conducting peace negotiations between Israel and the Palestinian Authority? Crosstabulation

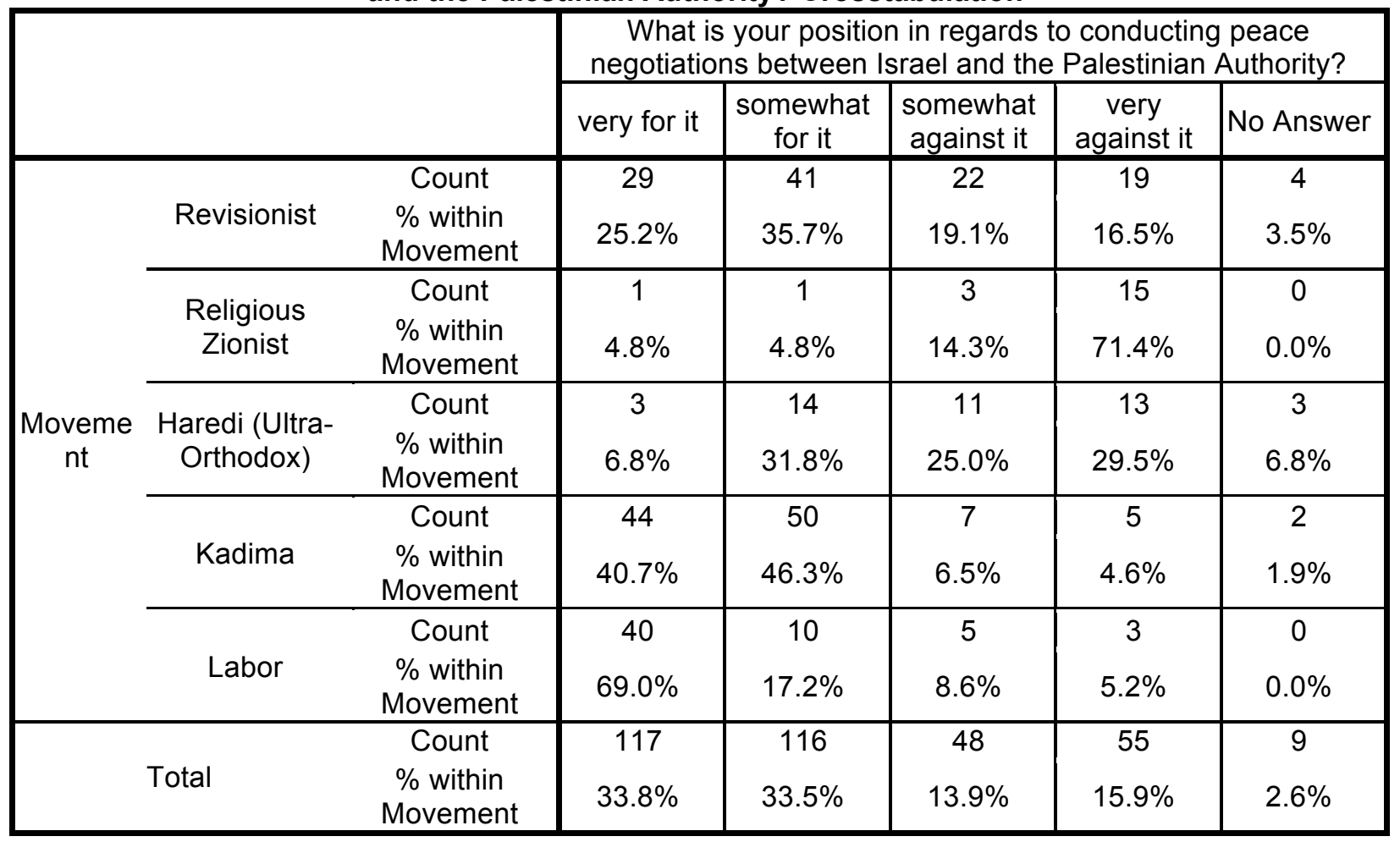




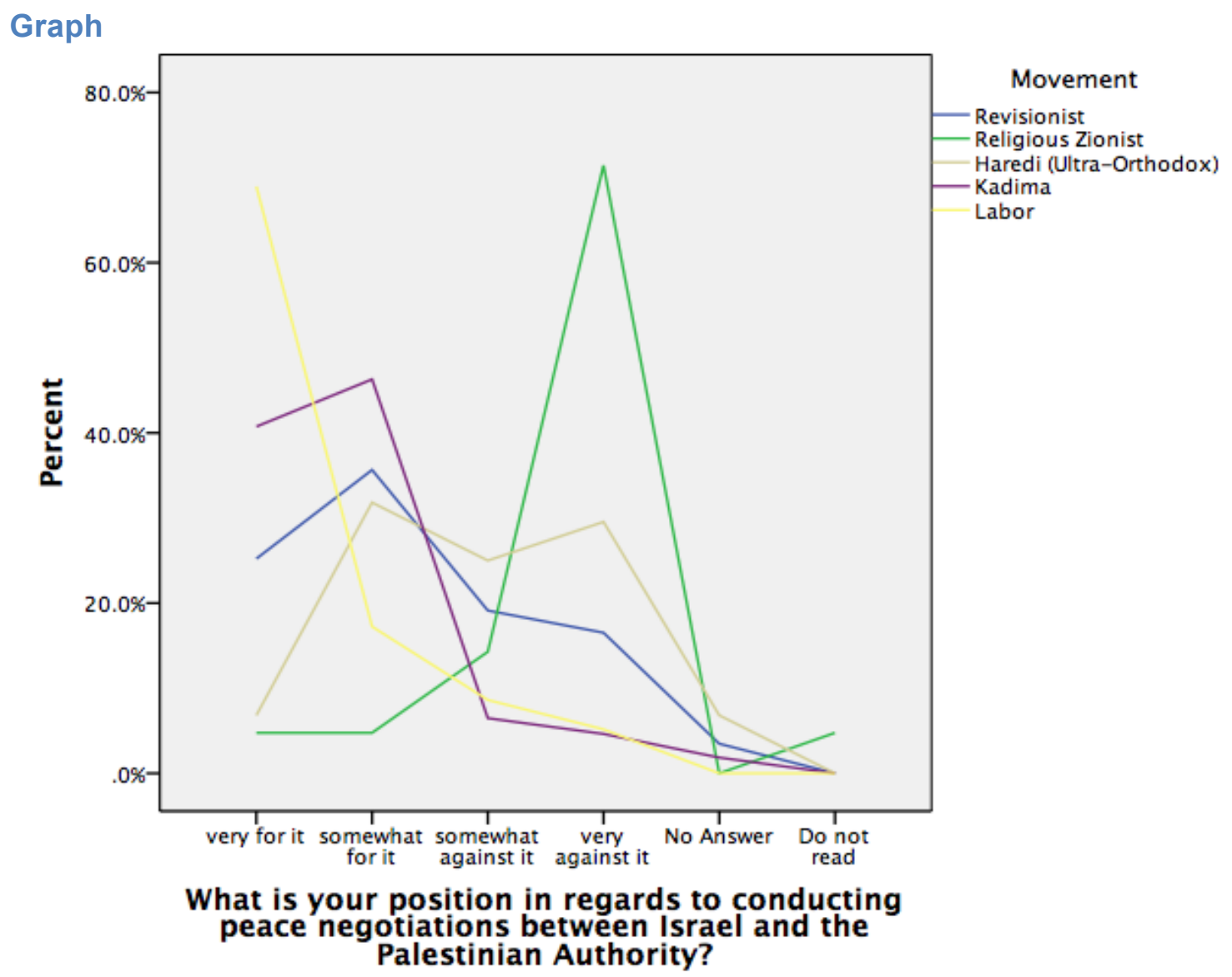

Nominal Regression

Model Fitting Information

\begin{tabular}{|l|r|r|r|r|}
\hline \multirow{2}{*}{} & \multicolumn{1}{|c|}{$\begin{array}{c}\text { Model Fitting } \\
\text { Criteria }\end{array}$} & \multicolumn{3}{|c|}{ Likelihood Ratio Tests } \\
\cline { 2 - 5 } & $\begin{array}{c}-2 \text { Log } \\
\text { Likelihood }\end{array}$ & Chi-Square & df & \multicolumn{1}{c|}{ Sig. } \\
\hline Intercept Only & $\begin{array}{r}193.686 \\
64.366\end{array}$ & 129.320 & 20 & .000 \\
\hline
\end{tabular}

Goodness-of-Fit

\begin{tabular}{|l|r|r|r|}
\hline & Chi-Square & df & Sig. \\
\hline Pearson & .000 & 0 & \\
Deviance & .000 & 0 &. \\
\hline
\end{tabular}

Likelihood Ratio Tests

\begin{tabular}{|l|r|r|r|r|}
\hline \multirow{2}{*}{} & \multicolumn{1}{|c|}{$\begin{array}{c}\text { Model Fitting } \\
\text { Criteria }\end{array}$} & \multicolumn{3}{|c|}{ Likelihood Ratio Tests } \\
\cline { 2 - 6 } & $\begin{array}{c}-2 \text { Log } \\
\text { Likelihood of } \\
\text { Reduced Model }\end{array}$ & Chi-Square & \multicolumn{1}{|c|}{ df } & \multicolumn{1}{c|}{ Sig. } \\
\hline Intercept & $64.366^{a}$ & .000 & 0 & .000 \\
\hline Movement & 193.686 & 129.320 & 20 & .000 \\
\hline
\end{tabular}




\section{Parameter Estimates}

\begin{tabular}{|c|c|c|c|c|c|c|c|c|c|}
\hline \multirow{2}{*}{\multicolumn{2}{|c|}{$\begin{array}{l}\text { What is your position in } \\
\text { regards to conducting } \\
\text { peace negotiations } \\
\text { between Israel and the } \\
\text { Palestinian Authority? }\end{array}$}} & \multirow{2}{*}{ B } & \multirow{2}{*}{$\begin{array}{l}\text { Std. } \\
\text { Error }\end{array}$} & \multirow{2}{*}{ Wald } & \multirow{2}{*}{$d f$} & \multirow{2}{*}{ Sig. } & \multirow{2}{*}{$\operatorname{Exp}(B)$} & \multicolumn{2}{|c|}{$\begin{array}{l}95 \% \text { Confidence } \\
\text { Interval for } \operatorname{Exp}(\mathrm{B}) \\
\end{array}$} \\
\hline & & & & & & & & $\begin{array}{l}\text { Lower } \\
\text { Bound }\end{array}$ & $\begin{array}{l}\text { Upper } \\
\text { Bound }\end{array}$ \\
\hline \multirow{4}{*}{$\begin{array}{l}\text { somewhat } \\
\text { for it }\end{array}$} & $\begin{array}{c}\text { Intercept } \\
\text { Revisionist }\end{array}$ & \begin{tabular}{|l|}
-1.386 \\
1.733
\end{tabular} & $\begin{array}{l}.354 \\
429\end{array}$ & \begin{tabular}{|l|}
15.374 \\
16.325
\end{tabular} & $\begin{array}{l}1 \\
1\end{array}$ & $\begin{array}{l}.000 \\
.000\end{array}$ & 5.655 & 2,440 & 13.105 \\
\hline & $\begin{array}{l}\text { Religious } \\
\text { Zionist }\end{array}$ & 1.386 & 1.458 & .904 & 1 & .342 & 4.000 & .230 & 69.645 \\
\hline & $\begin{array}{l}\text { Haredi (ultra- } \\
\text { Orthodox) }\end{array}$ & 2.927 & .728 & 16.169 & 1 & .000 & 18.667 & 4.483 & 77.734 \\
\hline & $\begin{array}{l}\text { Kadima } \\
\text { Labor }\end{array}$ & $\begin{array}{c}1.514 \\
0^{\mathrm{b}}\end{array}$ & .410 & 13.669 & $\begin{array}{l}1 \\
0\end{array}$ & .000 & 4.545 & 2.037 & $\begin{array}{c}10.143 \\
.\end{array}$ \\
\hline \multirow{4}{*}{$\begin{array}{l}\text { somewhat } \\
\text { against it }\end{array}$} & $\begin{array}{c}\text { Intercept } \\
\text { Revisionist }\end{array}$ & \begin{tabular}{|l|}
-2.079 \\
1.803 \\
\end{tabular} & $\begin{array}{l}.474 \\
.552\end{array}$ & \begin{tabular}{|l|}
19.218 \\
10.663 \\
\end{tabular} & $\begin{array}{l}1 \\
1\end{array}$ & $\begin{array}{l}.000 \\
.001\end{array}$ & 6.069 & 2.056 & 17.913 \\
\hline & $\begin{array}{l}\text { Religious } \\
\text { Zionist }\end{array}$ & 3.178 & 1.248 & 6.481 & 1 & .011 & 24.000 & 2.078 & 277.200 \\
\hline & $\begin{array}{l}\text { Haredi (ultra- } \\
\text { Orthodox) }\end{array}$ & 3.379 & .806 & 17.583 & 1 & .000 & 29.333 & 6.046 & 142.306 \\
\hline & $\begin{array}{l}\text { Kadima } \\
\text { Labor }\end{array}$ & $\begin{array}{c}.241 \\
0^{\mathrm{b}}\end{array}$ & .625 & .149 & $\begin{array}{l}1 \\
0\end{array}$ & .700 & 1.273 & .374 & 4.332 \\
\hline \multirow{5}{*}{$\begin{array}{l}\text { very against } \\
\text { it }\end{array}$} & Intercept & -2.590 & .599 & 18.724 & 1 & .000 & & & \\
\hline & Revisionist & 2.167 & .667 & 10.546 & 1 & .001 & 8.736 & 2.361 & 32.315 \\
\hline & $\begin{array}{l}\text { Religious } \\
\text { Zionist }\end{array}$ & 5.298 & 1.194 & 19.700 & 1 & .000 & 200.000 & 19.272 & 2075.573 \\
\hline & $\begin{array}{l}\text { Haredi (ultra- } \\
\text { Orthodox) }\end{array}$ & 4.057 & .877 & 21.411 & 1 & .000 & 57.778 & 10.364 & 322.109 \\
\hline & $\begin{array}{c}\text { Kadima } \\
\text { Labor }\end{array}$ & $\begin{array}{c}.416 \\
0^{\mathrm{b}} \\
\end{array}$ & .762 & .297 & $\begin{array}{l}1 \\
0 \\
\end{array}$ & .586 & 1.515 & .340 & 6.750 \\
\hline \multirow{5}{*}{ Do not read } & Intercept & $\begin{array}{c}- \\
17.233\end{array}$ & 873.057 & .000 & 1 & .984 & & & \\
\hline & Revisionist & 1.126 & $\begin{array}{c}1050.27 \\
9\end{array}$ & .000 & 1 & .999 & 3.084 & .000 & c \\
\hline & $\begin{array}{l}\text { Religious } \\
\text { Zionist }\end{array}$ & 17.233 & 873.059 & .000 & 1 & .984 & $\begin{array}{c}30489162 \\
.750\end{array}$ & .000 & c \\
\hline & $\begin{array}{l}\text { Haredi (ultra- } \\
\text { Orthodox) }\end{array}$ & 2.319 & $\begin{array}{c}1327.43 \\
2\end{array}$ & .000 & 1 & .999 & 10.165 & .000 &.$^{c}$ \\
\hline & Kadima & .605 & $\begin{array}{c}1067.93 \\
1\end{array}$ & .000 & 1 & 1.000 & 1.832 & .000 &.$^{c}$ \\
\hline
\end{tabular}


January 2012

Crosstabs

Movement * What is your position in regards to conducting peace negotiations between Israel and the Palestinian Authority? Crosstabulation

\begin{tabular}{|c|c|c|c|c|c|c|c|}
\hline & \multicolumn{5}{|c|}{$\begin{array}{l}\text { What is your position in regards to conducting peace } \\
\text { negotiations between Israel and the Palestinian Authority? }\end{array}$} \\
\hline & & & very for it & $\begin{array}{l}\text { somewhat } \\
\text { for it }\end{array}$ & $\begin{array}{l}\text { somewhat } \\
\text { against it }\end{array}$ & $\begin{array}{l}\text { very } \\
\text { against it }\end{array}$ & 5 \\
\hline \multirow{5}{*}{$\begin{array}{l}\text { Moveme } \\
\mathrm{nt}\end{array}$} & Revisionist & $\begin{array}{c}\text { Count } \\
\% \text { within } \\
\text { Movement }\end{array}$ & $\begin{array}{c}15 \\
12.2 \%\end{array}$ & $\begin{array}{c}68 \\
55.3 \%\end{array}$ & $\begin{array}{c}19 \\
15.4 \%\end{array}$ & $\begin{array}{c}17 \\
13.8 \%\end{array}$ & $\begin{array}{c}4 \\
3.3 \%\end{array}$ \\
\hline & $\begin{array}{l}\text { Religious } \\
\text { Zionist }\end{array}$ & $\begin{array}{c}\text { Count } \\
\% \text { within } \\
\text { Movement }\end{array}$ & $\begin{array}{c}3 \\
12.0 \%\end{array}$ & $\begin{array}{c}8 \\
32.0 \%\end{array}$ & $\begin{array}{c}2 \\
8.0 \%\end{array}$ & $\begin{array}{c}11 \\
44.0 \%\end{array}$ & $\begin{array}{c}1 \\
4.0 \%\end{array}$ \\
\hline & $\begin{array}{l}\text { Haredi (Ultra- } \\
\text { Orthodox) }\end{array}$ & $\begin{array}{c}\text { Count } \\
\% \text { within } \\
\text { Movement }\end{array}$ & $\begin{array}{c}6 \\
17.1 \%\end{array}$ & $\begin{array}{c}6 \\
17.1 \%\end{array}$ & $\begin{array}{c}13 \\
37.1 \%\end{array}$ & $\begin{array}{c}9 \\
25.7 \%\end{array}$ & $\begin{array}{c}1 \\
2.9 \%\end{array}$ \\
\hline & Kadima & $\begin{array}{c}\text { Count } \\
\% \text { within } \\
\text { Movement }\end{array}$ & $\begin{array}{c}30 \\
37.0 \%\end{array}$ & $\begin{array}{c}46 \\
56.8 \%\end{array}$ & $\begin{array}{c}2 \\
2.5 \%\end{array}$ & $\begin{array}{c}2 \\
2.5 \%\end{array}$ & $\begin{array}{c}1 \\
1.2 \%\end{array}$ \\
\hline & Labor & $\begin{array}{c}\text { Count } \\
\% \text { within } \\
\text { Movement }\end{array}$ & $\begin{array}{c}35 \\
59.3 \%\end{array}$ & $\begin{array}{c}20 \\
33.9 \%\end{array}$ & $\begin{array}{c}2 \\
3.4 \%\end{array}$ & $\begin{array}{c}1 \\
1.7 \%\end{array}$ & $\begin{array}{c}1 \\
1.7 \%\end{array}$ \\
\hline \multicolumn{2}{|r|}{ Total } & $\begin{array}{c}\text { Count } \\
\% \text { within } \\
\text { Movement }\end{array}$ & $\begin{array}{c}89 \\
27.6 \%\end{array}$ & $\begin{array}{c}148 \\
45.8 \%\end{array}$ & $\begin{array}{c}38 \\
11.8 \%\end{array}$ & $\begin{array}{c}40 \\
12.4 \%\end{array}$ & $\begin{array}{c}8 \\
2.5 \%\end{array}$ \\
\hline
\end{tabular}




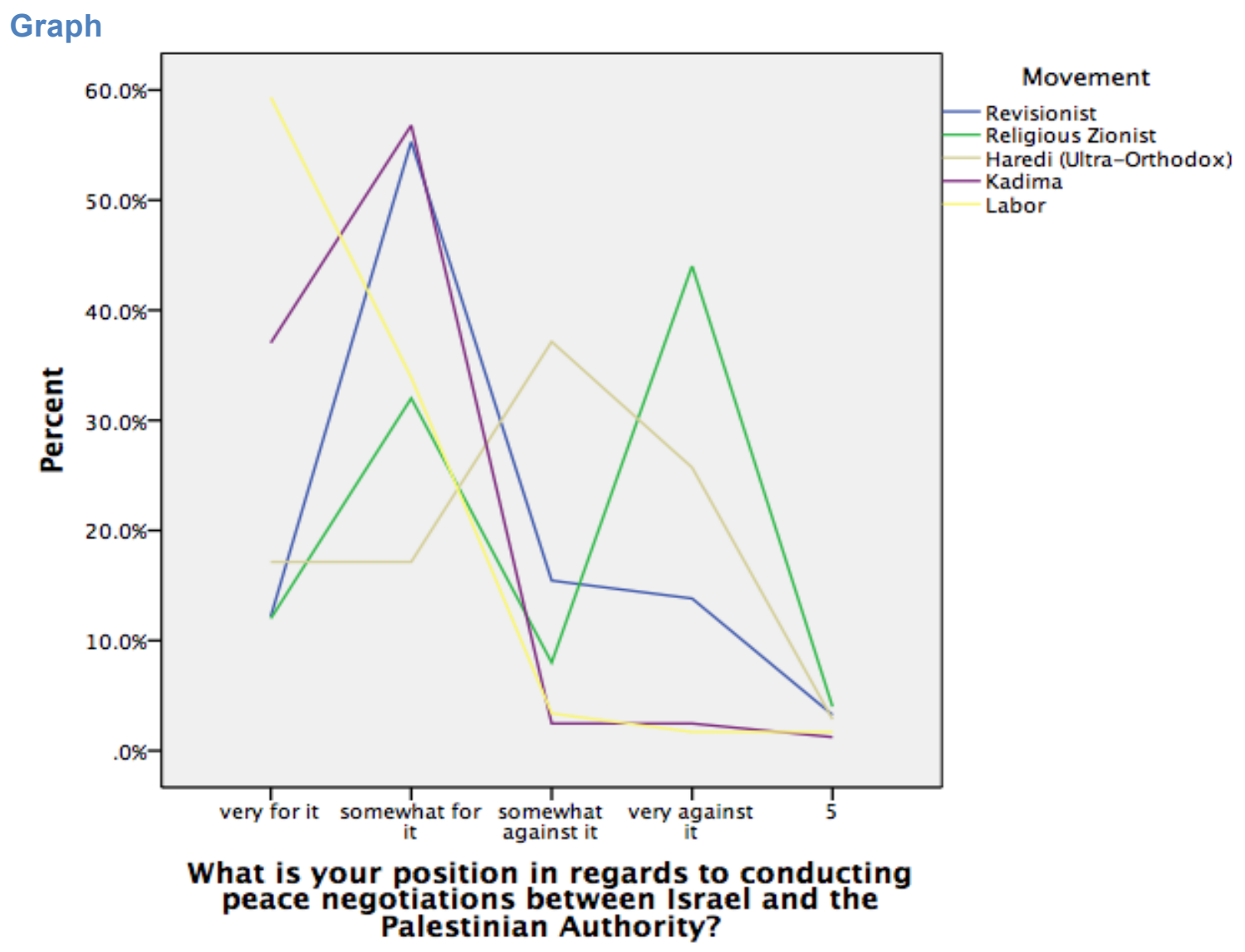

Nominal Regression

Model Fitting Information

\begin{tabular}{|l|r|r|r|r|}
\hline \multirow{2}{*}{} & \multicolumn{1}{|c|}{$\begin{array}{c}\text { Model Fitting } \\
\text { Criteria }\end{array}$} & \multicolumn{3}{|c|}{ Likelihood Ratio Tests } \\
\cline { 2 - 5 } & $\begin{array}{r}-2 \text { Log } \\
\text { Likelihood }\end{array}$ & Chi-Square & df & Sig. \\
\hline Model & $\begin{array}{r}177.732 \\
62.664\end{array}$ & 115.069 & 16 & .000 \\
\hline
\end{tabular}

Goodness-of-Fit

\begin{tabular}{|c|c|c|c|}
\hline & Chi-Square & $\mathrm{df}$ & Sig. \\
\hline Pearson & .000 & 0 & \\
\hline
\end{tabular}

Likelihood Ratio Tests

\begin{tabular}{|l|r|r|r|r|}
\hline \multirow{2}{*}{} & \multicolumn{1}{|c|}{$\begin{array}{c}\text { Model Fitting } \\
\text { Criteria }\end{array}$} & \multicolumn{3}{|c|}{ Likelihood Ratio Tests } \\
\cline { 2 - 6 } & $\begin{array}{c}-2 \text { Log } \\
\text { Likelihood of } \\
\text { Reduced Model }\end{array}$ & Chi-Square & df & \multicolumn{1}{c|}{ Sig. } \\
\hline Effect & $62.664^{\mathrm{a}}$ & .000 & 0 & .000 \\
\hline Movement & 177.732 & 115.069 & 16 & .000 \\
\hline
\end{tabular}


Parameter Estimates

\begin{tabular}{|c|c|c|c|c|c|c|c|c|c|}
\hline \multirow{2}{*}{\multicolumn{2}{|c|}{$\begin{array}{l}\text { What is your position in } \\
\text { regards to conducting peace } \\
\text { negotiations between Israel } \\
\text { and the Palestinian } \\
\text { Authority? }\end{array}$}} & \multirow[b]{2}{*}{ B } & \multirow{2}{*}{$\begin{array}{l}\text { Std. } \\
\text { Error }\end{array}$} & \multirow[b]{2}{*}{ Wald } & \multirow[b]{2}{*}{$\mathrm{df}$} & \multirow[b]{2}{*}{ Sig. } & \multirow[b]{2}{*}{$\operatorname{Exp}(B)$} & \multicolumn{2}{|c|}{$\begin{array}{c}95 \% \text { Confidence } \\
\text { Interval for } \operatorname{Exp}(B)\end{array}$} \\
\hline & & & & & & & & $\begin{array}{l}\text { Lower } \\
\text { Bound }\end{array}$ & $\begin{array}{l}\text { Upper } \\
\text { Bound }\end{array}$ \\
\hline \multirow{4}{*}{$\begin{array}{l}\text { somewhat for } \\
\text { it }\end{array}$} & $\begin{array}{c}\text { Intercept } \\
\text { Revisionist }\end{array}$ & \begin{tabular}{|l|}
-.560 \\
2.071
\end{tabular} & $\begin{array}{l}.280 \\
.400\end{array}$ & $\begin{array}{c}3.986 \\
26.818\end{array}$ & $\begin{array}{l}1 \\
1\end{array}$ & $\begin{array}{l}.046 \\
.000\end{array}$ & 7.933 & 3.623 & 17.373 \\
\hline & $\begin{array}{c}\text { Religious } \\
\text { Zionist }\end{array}$ & 1.540 & .733 & 4.420 & 1 & .036 & 4.667 & 1.110 & 19.621 \\
\hline & $\begin{array}{l}\text { Haredi (ultra- } \\
\text { Orthodox) } \\
\end{array}$ & .560 & .642 & .760 & 1 & .383 & 1.750 & .497 & 6.157 \\
\hline & $\begin{array}{l}\text { Kadima } \\
\text { Labor }\end{array}$ & $\begin{array}{l}.987 \\
0^{\mathrm{b}}\end{array}$ & .366 & 7.290 & $\begin{array}{l}1 \\
0\end{array}$ & .007 & 2.683 & 1.311 & 5.494 \\
\hline \multirow{4}{*}{$\begin{array}{l}\text { somewhat } \\
\text { against it }\end{array}$} & $\begin{array}{c}\text { Intercept } \\
\text { Revisionist } \\
\end{array}$ & $\begin{array}{l}-2.862 \\
3.099 \\
\end{array}$ & $\begin{array}{l}.727 \\
.805 \\
\end{array}$ & \begin{tabular}{|l|}
15.499 \\
14.820 \\
\end{tabular} & $\begin{array}{l}1 \\
1 \\
\end{array}$ & $\begin{array}{l}.000 \\
.000 \\
\end{array}$ & 22.167 & 4.577 & 107.358 \\
\hline & $\begin{array}{c}\text { Religious } \\
\text { Zionist }\end{array}$ & 2.457 & 1.167 & 4.432 & 1 & .035 & 11.667 & 1.185 & 114.896 \\
\hline & $\begin{array}{l}\text { Haredi (ultra- } \\
\text { Orthodox) }\end{array}$ & 3.635 & .879 & 17.116 & 1 & .000 & 37.917 & 6.774 & 212.229 \\
\hline & $\begin{array}{l}\text { Kadima } \\
\text { Labor }\end{array}$ & $\begin{array}{l}.154 \\
0^{\mathrm{b}} \\
\end{array}$ & 1.030 & .022 & $\begin{array}{l}1 \\
0 \\
\end{array}$ & .881 & 1.167 & .155 & 8.792 \\
\hline \multirow{5}{*}{ very against it } & Intercept & -3.555 & 1.014 & 12.289 & 1 & .000 & & & \\
\hline & Revisionist & 3.681 & 1.074 & 11.738 & 1 & .001 & 39.667 & 4.831 & 325.723 \\
\hline & $\begin{array}{l}\text { Religious } \\
\text { Zionist }\end{array}$ & 4.855 & 1.205 & 16.222 & 1 & .000 & $\begin{array}{c}128.33 \\
3\end{array}$ & 12.088 & 1362.435 \\
\hline & $\begin{array}{l}\text { Haredi (ultra- } \\
\text { Orthodox) }\end{array}$ & 3.961 & 1.143 & 12.009 & 1 & .001 & 52.500 & 5.588 & 493.225 \\
\hline & $\begin{array}{l}\text { Kadima } \\
\text { Labor }\end{array}$ & $\begin{array}{l}.847 \\
0^{\mathrm{b}}\end{array}$ & 1.250 & .460 & $\begin{array}{l}1 \\
0\end{array}$ & .498 & 2.333 & .201 & 27.026 \\
\hline \multirow{5}{*}{ Do not read } & Intercept & -3.555 & 1.014 & 12.289 & 1 & .000 & & & \\
\hline & Revisionist & 2.234 & 1.160 & 3.709 & 1 & .054 & 9.333 & .961 & 90.635 \\
\hline & $\begin{array}{l}\text { Religious } \\
\text { Zionist }\end{array}$ & 2.457 & 1.537 & 2.555 & 1 & .110 & 11.667 & .574 & 237.200 \\
\hline & $\begin{array}{l}\text { Haredi (ultra- } \\
\text { Orthodox) }\end{array}$ & 1.764 & 1.482 & 1.417 & 1 & .234 & 5.833 & .320 & 106.435 \\
\hline & $\begin{array}{l}\text { Kadima } \\
\text { Labor }\end{array}$ & $\begin{array}{l}.154 \\
0^{\mathrm{b}}\end{array}$ & 1.436 & .012 & $\begin{array}{l}1 \\
0\end{array}$ & .915 & 1.167 & .070 & 19.463 \\
\hline
\end{tabular}


July 2012

Crosstabs

Movement * What is your position in regards to conducting peace negotiations between Israel and the Palestinian Authority? Crosstabulation

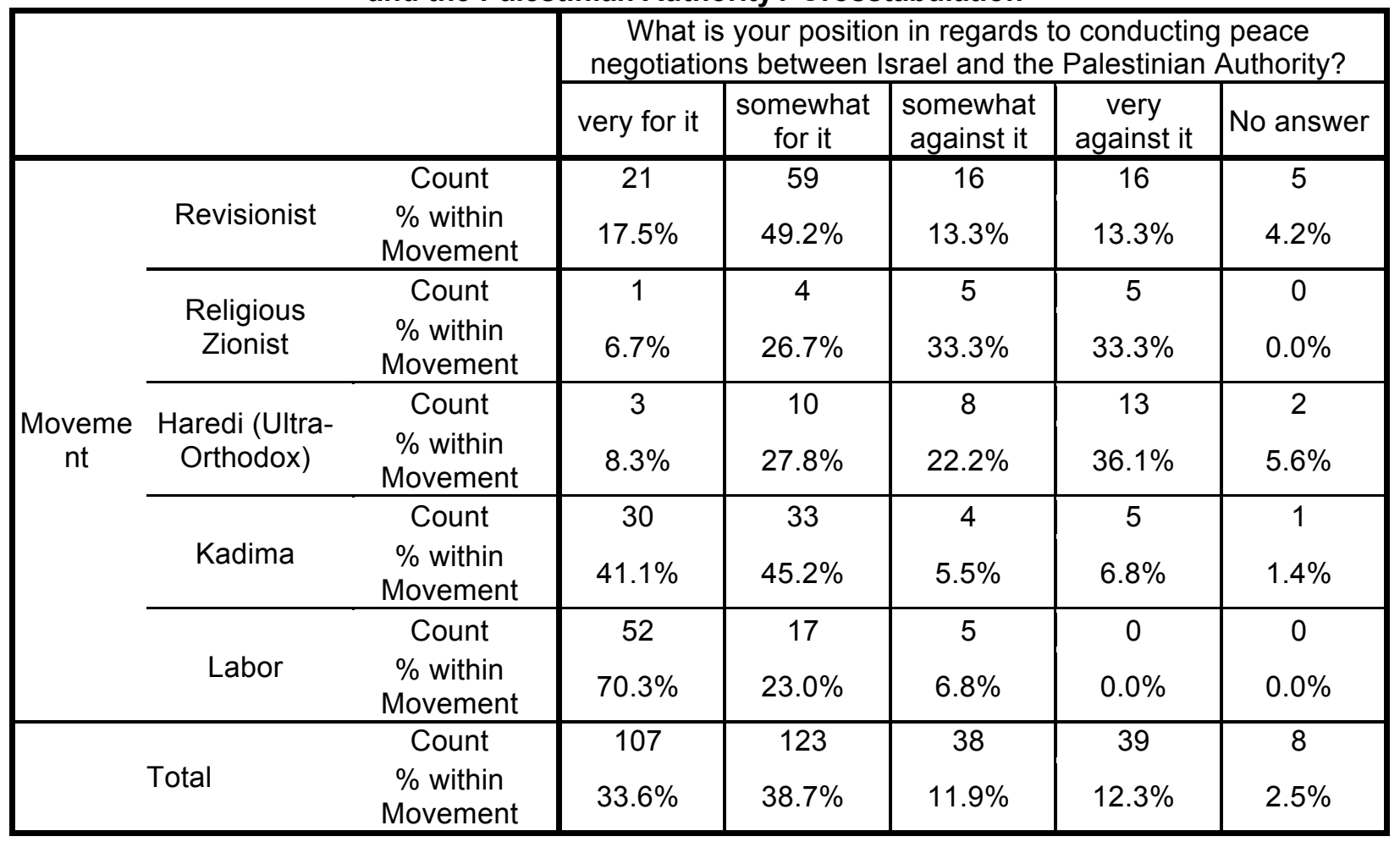




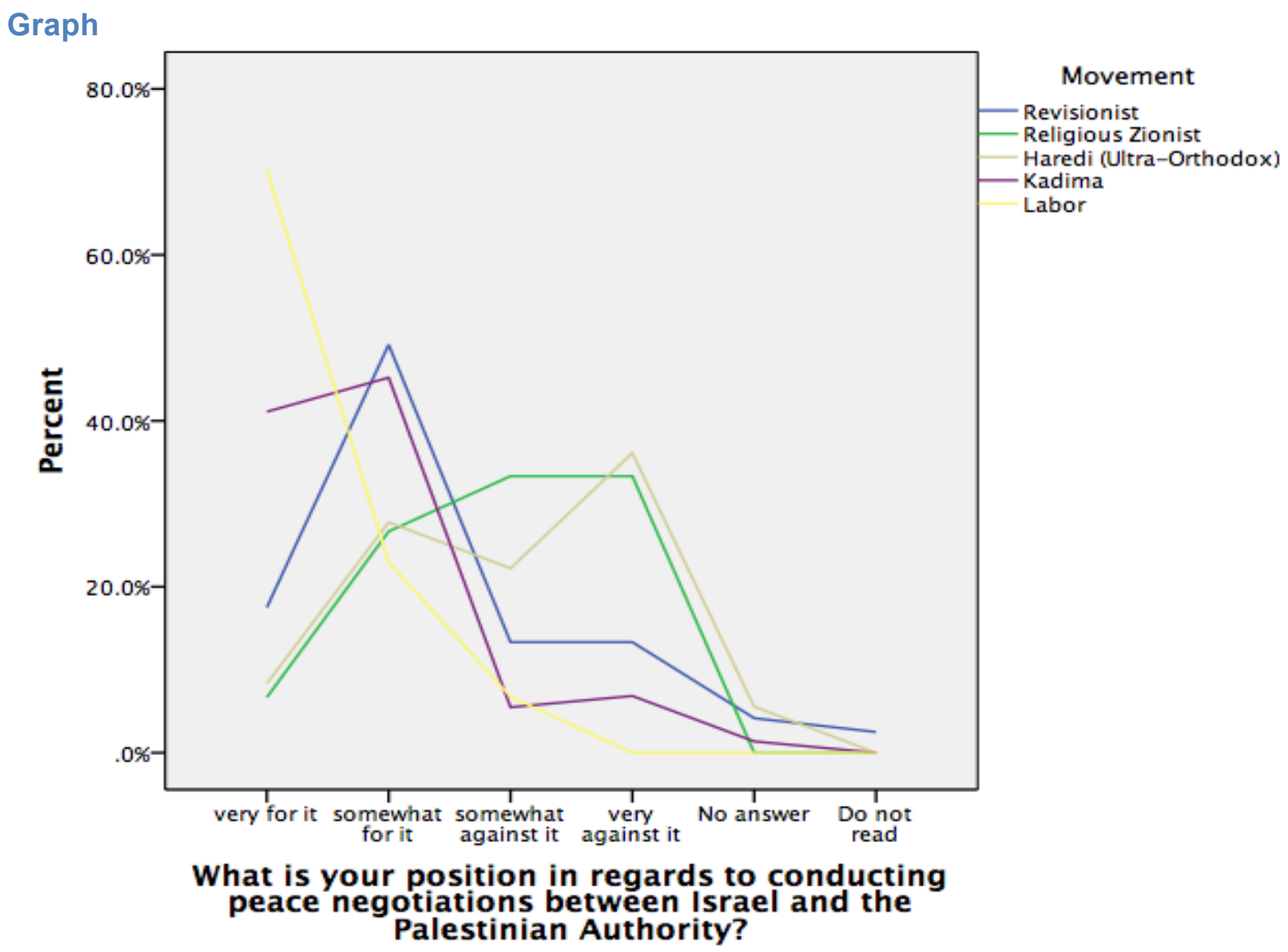

Nominal Regression

Model Fitting Information

\begin{tabular}{|c|c|c|c|c|}
\hline \multirow[b]{2}{*}{ Model } & $\begin{array}{l}\text { Model Fitting } \\
\text { Criteria }\end{array}$ & \multicolumn{3}{|c|}{ Likelihood Ratio Tests } \\
\hline & $\begin{array}{c}-2 \text { Log } \\
\text { Likelihood }\end{array}$ & Chi-Square & $d f$ & Sig. \\
\hline $\begin{array}{l}\text { Intercept Only } \\
\text { Final }\end{array}$ & $\begin{array}{r}181.594 \\
61.266\end{array}$ & 120.328 & 20 & .000 \\
\hline
\end{tabular}

Goodness-of-Fit

\begin{tabular}{|c|c|c|c|}
\hline & Chi-Square & $\mathrm{df}$ & Sig. \\
\hline Pearson & .000 & 0 & \\
\hline
\end{tabular}

Likelihood Ratio Tests

\begin{tabular}{|l|r|r|r|r|}
\hline \multirow{2}{*}{} & \multicolumn{1}{|c|}{$\begin{array}{c}\text { Model Fitting } \\
\text { Criteria }\end{array}$} & \multicolumn{3}{|c|}{ Likelihood Ratio Tests } \\
\cline { 2 - 6 } & $\begin{array}{c}\text {-2 Log } \\
\text { Likelihood of } \\
\text { Reduced Model }\end{array}$ & Chi-Square & \multicolumn{1}{c|}{ df } & \multicolumn{1}{c|}{ Sig. } \\
\hline Effect & $61.266^{a}$ & .000 & 0 & .000 \\
\hline Intercept & 181.594 & 120.328 & 20 & .000 . \\
\hline
\end{tabular}


Parameter Estimates

\begin{tabular}{|c|c|c|c|c|c|c|c|c|c|}
\hline \multirow{2}{*}{\multicolumn{2}{|c|}{$\begin{array}{l}\text { What is your position in } \\
\text { regards to conducting } \\
\text { peace negotiations } \\
\text { between Israel and the } \\
\text { Palestinian Authority? }\end{array}$}} & \multirow[b]{2}{*}{ B } & \multirow{2}{*}{$\begin{array}{l}\text { Std. } \\
\text { Error }\end{array}$} & \multirow[b]{2}{*}{ Wald } & \multirow[b]{2}{*}{ df } & \multirow{2}{*}{ Sig. } & \multirow{2}{*}{$\operatorname{Exp}(B)$} & \multicolumn{2}{|c|}{$\begin{array}{l}95 \% \text { Confidence } \\
\text { Interval for } \operatorname{Exp}(\mathrm{B}) \\
\end{array}$} \\
\hline & & & & & & & & $\begin{array}{l}\text { Lower } \\
\text { Bound }\end{array}$ & $\begin{array}{l}\text { Upper } \\
\text { Bound }\end{array}$ \\
\hline \multirow{5}{*}{$\begin{array}{l}\text { somewhat } \\
\text { for it }\end{array}$} & Intercept & -1.118 & .279 & 16.014 & 1 & .000 & & & \\
\hline & Revisionist & 2.151 & .378 & 32.442 & 1 & .000 & 8.594 & 4.099 & 18.016 \\
\hline & $\begin{array}{l}\text { Religious } \\
\text { Zionist }\end{array}$ & 2.504 & 1.152 & 4.722 & 1 & .030 & 12.235 & 1.278 & 117.098 \\
\hline & $\begin{array}{l}\text { Haredi (ultra- } \\
\text { Orthodox) }\end{array}$ & 2.322 & .715 & 10.543 & 1 & .001 & 10.196 & 2.510 & 41.413 \\
\hline & $\begin{array}{l}\text { Kadima } \\
\text { Labor }\end{array}$ & $\begin{array}{c}1.213 \\
0^{\mathrm{b}}\end{array}$ & .376 & 10.390 & $\begin{array}{l}1 \\
0\end{array}$ & .001 & 3.365 & $\begin{array}{c}1.609 \\
.\end{array}$ & $\begin{array}{c}7.036 \\
.\end{array}$ \\
\hline \multirow{4}{*}{$\begin{array}{l}\text { somewhat } \\
\text { against it }\end{array}$} & $\begin{array}{c}\text { Intercept } \\
\text { Revisionist }\end{array}$ & $\begin{array}{l}-2.342 \\
2.070\end{array}$ & $\begin{array}{l}.468 \\
.574\end{array}$ & \begin{tabular}{|l|}
25.015 \\
13.009
\end{tabular} & $\begin{array}{l}1 \\
1\end{array}$ & $\begin{array}{l}.000 \\
.000\end{array}$ & 7.924 & 2.573 & 24.402 \\
\hline & $\begin{array}{c}\text { Religious } \\
\text { Zionist }\end{array}$ & 3.951 & 1.191 & 11.001 & 1 & .001 & 52.000 & 5.034 & 537.096 \\
\hline & $\begin{array}{l}\text { Haredi (ultra- } \\
\text { Orthodox) }\end{array}$ & 3.323 & .823 & 16.294 & 1 & .000 & 27.733 & 5.525 & 139.207 \\
\hline & $\begin{array}{l}\text { Kadima } \\
\text { Labor }\end{array}$ & $\begin{array}{l}.327 \\
0^{\mathrm{b}}\end{array}$ & .709 & .213 & $\begin{array}{l}1 \\
0\end{array}$ & .645 & 1.387 & .346 & 5.564 \\
\hline \multirow{6}{*}{$\begin{array}{l}\text { very against } \\
\text { it }\end{array}$} & Intercept & $\begin{array}{c}- \\
18.108\end{array}$ & $\begin{array}{c}1185.89 \\
9\end{array}$ & .000 & 1 & .988 & & & \\
\hline & Revisionist & 17.836 & $\begin{array}{c}1185.89 \\
9\end{array}$ & .000 & 1 & .988 & $\begin{array}{c}55718497 \\
.483\end{array}$ & .000 & c \\
\hline & $\begin{array}{l}\text { Religious } \\
\text { Zionist }\end{array}$ & 19.717 & $\begin{array}{c}1185.89 \\
9\end{array}$ & .000 & 1 & .987 & $\begin{array}{c}36565263 \\
9.737\end{array}$ & .000 & c \\
\hline & $\begin{array}{l}\text { Haredi (ultra- } \\
\text { Orthodox) }\end{array}$ & 19.574 & $\begin{array}{c}1185.89 \\
9\end{array}$ & .000 & 1 & .987 & $\begin{array}{c}31689895 \\
4.438\end{array}$ & .000 & c \\
\hline & Kadima & 16.316 & $\begin{array}{c}1185.89 \\
9\end{array}$ & .000 & 1 & .989 & $\begin{array}{c}12188421 \\
.325\end{array}$ & .000 & c \\
\hline & Labor & $0^{\mathrm{b}}$ & & & 0 & . & & . & . \\
\hline \multirow{6}{*}{ Do not read } & Intercept & $\begin{array}{c}- \\
20.673\end{array}$ & $\begin{array}{c}3991.23 \\
8\end{array}$ & .000 & 1 & .996 & & & \\
\hline & Revisionist & 18.727 & $\begin{array}{c}3991.23 \\
8\end{array}$ & .000 & 1 & .996 & $\begin{array}{c}13581383 \\
8.053\end{array}$ & .000 & c \\
\hline & $\begin{array}{l}\text { Religious } \\
\text { Zionist }\end{array}$ & 2.039 & .000 & & 1 & & 7.680 & 7.680 & 7.680 \\
\hline & $\begin{array}{l}\text { Haredi (ultra- } \\
\text { Orthodox) }\end{array}$ & 1.908 & $\begin{array}{c}7933.22 \\
9\end{array}$ & .000 & 1 & 1.000 & 6.742 & .000 & c \\
\hline & Kadima & .850 & $\begin{array}{c}5428.62 \\
9\end{array}$ & .000 & 1 & 1.000 & 2.340 & .000 &.$^{c}$ \\
\hline & Labor & $0^{\mathrm{b}}$ & & & 0 & & & & . \\
\hline
\end{tabular}


January 2013

Crosstabs

Movement * What is your position in regards to conducting peace negotiations between Israel and the Palestinian Authority? Crosstabulation

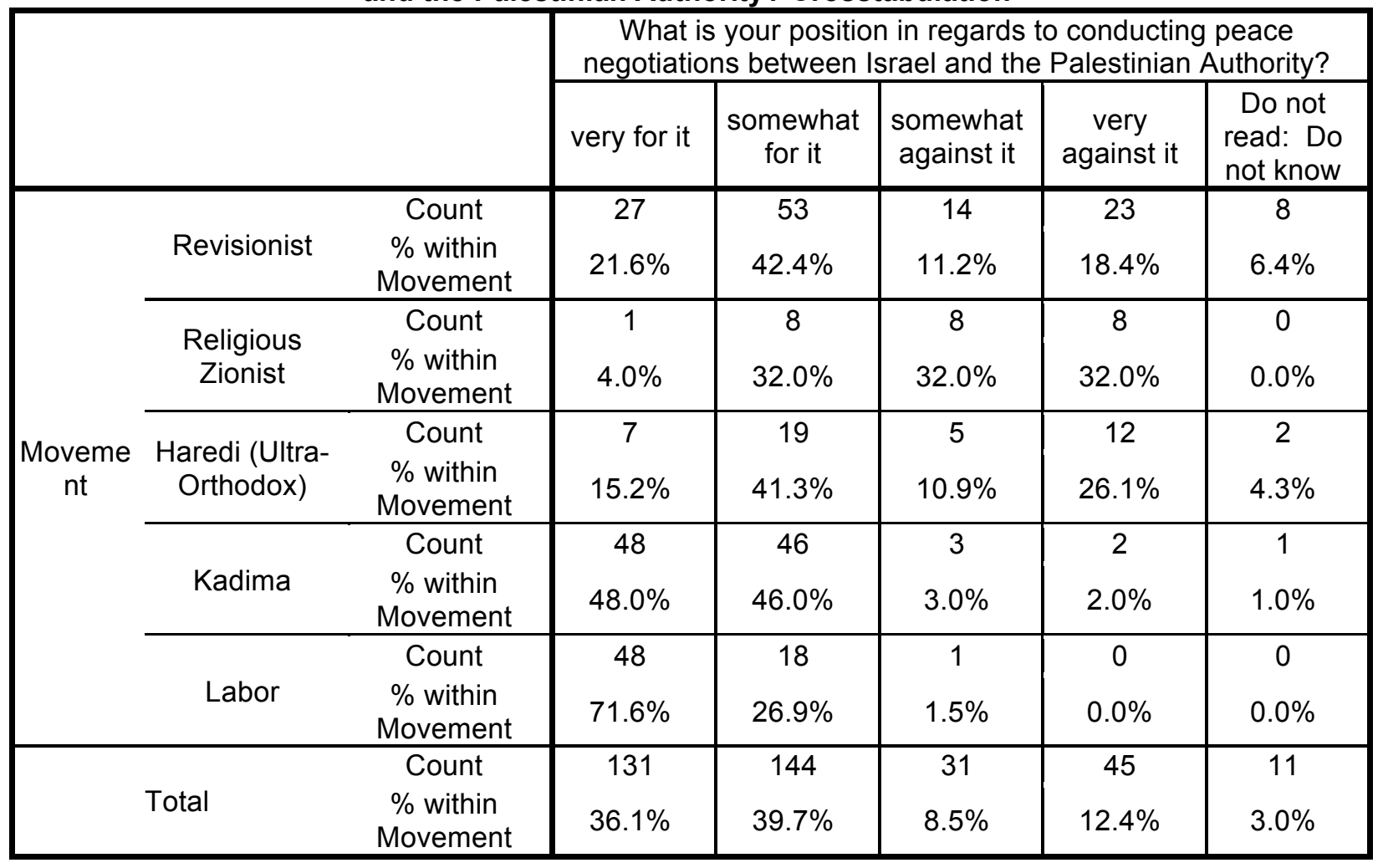




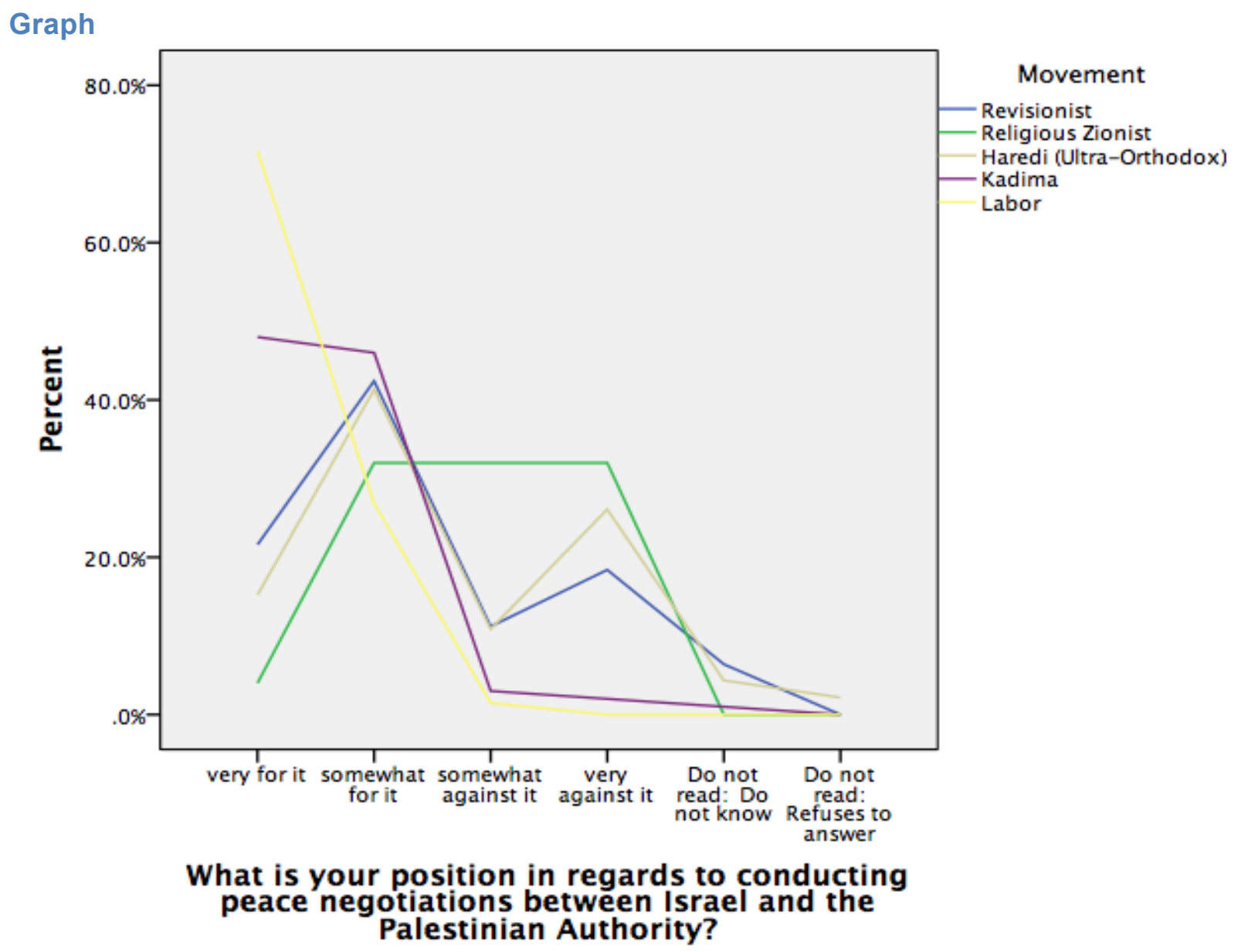

Nominal Regression

Model Fitting Information

\begin{tabular}{|l|r|r|r|r|}
\hline \multirow{2}{*}{ Model } & \multicolumn{1}{|c|}{$\begin{array}{c}\text { Model Fitting } \\
\text { Criteria }\end{array}$} & \multicolumn{3}{|c|}{ Likelihood Ratio Tests } \\
\cline { 2 - 5 } & $\begin{array}{r}\text {-2 Log } \\
\text { Likelihood }\end{array}$ & Chi-Square & df & \multicolumn{1}{c|}{ Sig. } \\
\hline Intercept Only & $\begin{array}{r}195.094 \\
60.750\end{array}$ & 134.344 & 20 & .000 \\
\hline
\end{tabular}

Goodness-of-Fit

\begin{tabular}{|l|r|r|r|}
\hline & Chi-Square & df & Sig. \\
\hline Pearson & .000 & 0 & \\
Deviance & .000 & 0 &. \\
\hline
\end{tabular}

\section{Likelihood Ratio Tests}

\begin{tabular}{|l|r|r|r|r|}
\hline \multirow{2}{*}{} & \multicolumn{1}{|c|}{$\begin{array}{c}\text { Model Fitting } \\
\text { Criteria }\end{array}$} & \multicolumn{3}{|c|}{ Likelihood Ratio Tests } \\
\cline { 2 - 6 } & $\begin{array}{c}\text {-2 Log } \\
\text { Likelihood of } \\
\text { Reduced Model }\end{array}$ & Chi-Square & df & \multicolumn{1}{c|}{ Sig. } \\
\hline Intercept & $60.750^{\mathrm{a}}$ & .000 & 0 & .000 \\
\hline Movement & 195.094 & 134.344 & 20 & .000 \\
\hline
\end{tabular}


Parameter Estimates

\begin{tabular}{|c|c|c|c|c|c|c|c|c|c|}
\hline \multirow{2}{*}{\multicolumn{2}{|c|}{$\begin{array}{l}\text { What is your position in } \\
\text { regards to conducting } \\
\text { peace negotiations } \\
\text { between Israel and the } \\
\text { Palestinian Authority? }\end{array}$}} & \multirow[b]{2}{*}{ B } & \multirow{2}{*}{$\begin{array}{l}\text { Std. } \\
\text { Error }\end{array}$} & \multirow[b]{2}{*}{ Wald } & \multirow[b]{2}{*}{ df } & \multirow[b]{2}{*}{ Sig. } & \multirow[b]{2}{*}{$\operatorname{Exp}(B)$} & \multicolumn{2}{|c|}{$\begin{array}{l}95 \% \text { Confidence } \\
\text { Interval for } \operatorname{Exp}(B)\end{array}$} \\
\hline & & & & & & & & $\begin{array}{l}\text { Lower } \\
\text { Bound }\end{array}$ & $\begin{array}{l}\text { Upper } \\
\text { Bound }\end{array}$ \\
\hline \multirow{5}{*}{$\begin{array}{l}\text { somewhat } \\
\text { for it }\end{array}$} & Intercept & -.981 & .276 & 12.594 & 1 & .000 & & & \\
\hline & Revisionist & 1.655 & .364 & 20.711 & 1 & .000 & 5.235 & 2.566 & 10.678 \\
\hline & $\begin{array}{l}\text { Religious } \\
\text { Zionist }\end{array}$ & 3.060 & 1.096 & 7.795 & 1 & .005 & 21.333 & 2.489 & 182.828 \\
\hline & $\begin{array}{l}\text { Haredi (ultra- } \\
\text { Orthodox) } \\
\end{array}$ & 1.979 & .521 & 14.410 & 1 & .000 & 7.238 & 2.605 & 20.112 \\
\hline & $\begin{array}{l}\text { Kadima } \\
\text { Labor }\end{array}$ & $\begin{array}{l}938 \\
0^{\mathrm{b}}\end{array}$ & .345 & 7.400 & $\begin{array}{l}1 \\
0\end{array}$ & .007 & 2.556 & 1.300 & $\begin{array}{c}5.024 \\
.\end{array}$ \\
\hline \multirow{4}{*}{$\begin{array}{l}\text { somewhat } \\
\text { against it }\end{array}$} & $\begin{array}{c}\text { Intercept } \\
\text { Revisionist }\end{array}$ & \begin{tabular}{|l|}
-3.871 \\
3.214 \\
\end{tabular} & $\begin{array}{l}1.010 \\
1.063 \\
\end{array}$ & \begin{tabular}{|c|}
14.680 \\
9.149 \\
\end{tabular} & $\begin{array}{l}1 \\
1 \\
\end{array}$ & $\begin{array}{l}.000 \\
.002 \\
\end{array}$ & 24.889 & 3.101 & 199.786 \\
\hline & $\begin{array}{l}\text { Religious } \\
\text { Zionist }\end{array}$ & 5.951 & 1.465 & 16.502 & 1 & .000 & 384.000 & 21.749 & 6779.969 \\
\hline & $\begin{array}{l}\text { Haredi (ultra- } \\
\text { Orthodox) }\end{array}$ & 3.535 & 1.168 & 9.162 & 1 & .002 & 34.286 & 3.476 & 338.160 \\
\hline & $\begin{array}{c}\text { Kadima } \\
\text { Labor }\end{array}$ & $\begin{array}{c}1.099 \\
0^{\mathrm{b}} \\
\end{array}$ & 1.173 & .878 & $\begin{array}{l}1 \\
0 \\
\end{array}$ & .349 & 3.000 & .301 & 29.871 \\
\hline \multirow{5}{*}{$\begin{array}{l}\text { very against } \\
\text { it }\end{array}$} & Intercept & 17.089 & 741.601 & .001 & 1 & .982 & & & \\
\hline & Revisionist & 16.928 & 741.601 & .001 & 1 & .982 & $\begin{array}{c}22487761 \\
.361\end{array}$ & .000 & ${ }^{c}$ \\
\hline & $\begin{array}{l}\text { Religious } \\
\text { Zionist }\end{array}$ & 19.168 & 741.602 & .001 & 1 & .979 & $\begin{array}{c}21118941 \\
1.043\end{array}$ & .000 & ${ }^{c}$ \\
\hline & $\begin{array}{l}\text { Haredi (ultra- } \\
\text { Orthodox) }\end{array}$ & 17.628 & 741.601 & .001 & 1 & .981 & $\begin{array}{c}45254873 \\
.795\end{array}$ & .000 & ${ }^{c}$ \\
\hline & $\begin{array}{c}\text { Kadima } \\
\text { Labor }\end{array}$ & $\begin{array}{c}13.911 \\
0^{b}\end{array}$ & 741.602 & .000 & $\begin{array}{l}1 \\
0\end{array}$ & .985 & $\begin{array}{c}1099944 . \\
849\end{array}$ & .000 & c \\
\hline \multirow{6}{*}{ Do not read } & Intercept & $\begin{array}{c}- \\
20.895\end{array}$ & $\begin{array}{c}4607.25 \\
9\end{array}$ & .000 & 1 & .996 & & & \\
\hline & Revisionist & 1.455 & $\begin{array}{c}5612.57 \\
6\end{array}$ & .000 & 1 & 1.000 & 4.282 & .000 &.$^{c}$ \\
\hline & $\begin{array}{l}\text { Religious } \\
\text { Zionist }\end{array}$ & 2.075 & .000 & & 1 & . & 7.964 & 7.964 & 7.964 \\
\hline & $\begin{array}{l}\text { Haredi (ultra- } \\
\text { Orthodox) }\end{array}$ & 18.950 & $\begin{array}{c}4607.25 \\
9\end{array}$ & .000 & 1 & .997 & $\begin{array}{c}16970577 \\
6.262\end{array}$ & .000 & ${ }^{c}$ \\
\hline & Kadima & .644 & $\begin{array}{c}5850.04 \\
1\end{array}$ & .000 & 1 & 1.000 & 1.904 & .000 &.$^{c}$ \\
\hline & Labor & $0^{\mathrm{b}}$ & & & 0 & & & & . \\
\hline
\end{tabular}




\section{Bibliography}

972Mag. "20 Years since Cave of the Patriarchs Massacre," February 25, 2014. http://972mag.com/photos-20-years-since-cave-of-the-patriarchsmassacre/87599/.

Abrams, Mitch. "Construction at Har Homa Could Begin in Two Weeks." JTA, June 5, 1997.

Address in the Knesset by Prime Minister-Elect Netanyahu Presenting His Government to the Knesset. Israel Ministry of Foreign Affairs, June 18, 1996.

http://www.mfa.gov.il/MFA/ForeignPolicy/MFADocuments/Yearbook11/Pa ges/4\%20Address $\% 20$ in $\% 20$ the $\% 20$ Knesset $\% 20$ by $\% 20$ Prime $\% 20$ Ministe r-elect\%20N.aspx.

“Adelsons Pledge \$25 Million to Ariel University." Israel Hayom, June 24, 2014.

Aderet, Ofer. "Former IDF General Israeli Icon Avraham Adan Dies at 86." Haaretz, September 29, 2012. http://www.haaretz.com/news/national/former-idf-general-israeli-iconavraham-adan-dies-at-86-1.467408.

AFP. "West Bank Jewish Settler Population Soars: Settlers," September 16, 2014. http://news.yahoo.com/west-bank-jewish-settler-population-soarssettlers-180527269.html.

Almagor, Dan. "The Commander Who Calls 'Follow Me!"." In Man at War: A Selection of Literary Chapters, 1975.

Almog, Oz. The Sabra: The Creation of the New Jew. Translated by Haim Watzman. Berkeley and Los Angeles: University of California Press, 2000.

Andoni, Lamis. "Searching for Answers: Gaza's Suicide Bombers." Journal of Palestine Studies 26, no. 4 (1997).

Arena, Philip, and Glenn Palmer. "Politics or the Economy? Domestic Correlates of Dispute Involvement in Developed Democracies." International Studies Quarterly 53 (2009): 955-75. 
Arian, Asher. Security Threatened: Surveying Israeli Opinion on Peace and War. New York: Cambridge University Press, 1995.

- The Elections in Israel -- 1969. Jerusalem: Jerusalem Academic Press, 1972.

Arian, Asher, and Michal Shamir. The Elections in Israel, 1992. Albany: State University of New York Press, 1995.

- The Elections in Israel, 1996. Albany: State University of New York Press, 1999.

—. "Two Reversals: Why 1992 Was Not 1977." In The Elections in Israel, 1992, n.d.

Aronoff, Myron. Power and Ritual in the Israel Labor Party. New York: M.E. Sharpe, 1993.

Aronoff, Myron J. Israeli Visions and Divisions. New Brunswick: Rutgers University Press, 2004.

Aronoff, Myron J., and Pierre M. Atlas. "The Peace Process and Competing Challenges to the Dominant Zionist Discourse." In The Middle East Peace Process: Interdisciplinary Perspectives, edited by Ilan Peleg. Albany: State University of New York Press, 1998.

Aronoff, Yael S. The Political Psychology of Israeli Prime Ministers. New York: Cambridge University Press, 2014.

Aruri, Naseer H. Dishonest Broker: The U.S. Role in Israel and Palestine. Massachusetts: South End Press, 2003.

Ashrawi, Hanan. This Side of Peace: A Personal Account. New York: Touchstone, 1995.

Atran, Scott. "Stones against the Iron Fist, Terror within the Nation: Alternating Structures of Violence and Cultural Identity in the Israeli-Palestinian Conflict." Politics and Society 18 (1990): 481-526.

Avineri, Shlomo. The Making of Modern Zionism: Intellectual Origins of the Jewish State. New York: Basic Books, 1981. 
Avishai, Bernard. "Netanyahu's Inflammatory New Bill." The New Yorker, December 2, 2014.

Balaban, Oded. Politics and Ideology: A Philosophical Approach. London: Avebury, 1995.

Barari, Hassan A. Israeli Politics and the Middle East Peace Process, 1988-2002. New York: Routledge, 2005.

Barkin, Samuel. "Realist Constructivism." International Studies Review 5, no. 3 (2003): 325-42.

- Realist Constructivism: Rethinking International Relations Theory. Cambridge: Cambridge University Press, 2010.

Barnett, Michael. "Culture, Strategy and Foreign Policy Change: Israel's Road to Oslo." European Journal of International Relations 5 (1999): 5-36.

Barnett, Michael, and Shibley Telhami. "The Israeli Identity and the Peace Process." In In Identity and Foreign Policy in the Middle East, 58-87. Ithaca: Cornell University Press, 2002.

Bartels, Larry. "PartisanshipandVotingBehavior,1952-1996." American Journal of Political Science 44 (2000): 35-50.

Barth, Hans. Truth and Ideology. Berkeley: University of California Press, 1976.

Baumgart-Ochse, Claudia. "Democratization in Israel, Politicized Religion and the Failure of the Oslo Peace Process." Democratization 16, no. 6 (2009): 1115-42.

Behrendt, Sven. The Secret Israeli-Palestinian Negotiations in Oslo: Their Success and Why The Process Ultimately Failed. New York: Routledge, 2007.

Beinart, Peter. The Crisis of Zionism. New York: Times Books, 2012.

Beinin, Joel. Was the Red Flag Flying There? Marxist Politics and the Arab-Isræli Conflict in Eqypt and Isræl 1948-1965. Berkeley: University of California Press, 1990. 
Bell, Michael. "Netanyahu's 'Jewish State' Bill Would Be a Crippling Blow to Israel." The Globe and Mail, December 5, 2014.

Ben Ami, Shlomo. Scars of War, Wounds of Peace: The Israeli-Arab Tragedy: The Israeli-Arab Tragedy. Oxford: Oxford University Press, 2006.

Bennett, Naftali. "For Israel, Two-State Is No Solution." New York Times, November 5, 2014.

Ben-Yehuda, Nachman. Masada Myth: Collective Memory and Mythmaking in Israel. Madison: The University of Wisconsin Press, 1995.

Ben Zion, Ilan. "Netanyahu Fires Lapid, Livni from Ministerial Posts." The Times of Israel, December 2, 2014.

Berman, Lazar. " 5 of Ovadia Yosef's Most Controversial Quotations." The Times of Israel, October 9, 2013.

Bokser, Ben Zion. The Essential Writings of Abraham Isaac Kook. Teaneck: Ben Yehuda Press, 2006.

Bowman, Glenn. "A Place for Palestinians in the Altneuland: Herzl, AntiSemitism, and the Jewish State." In In Surveillance and Control in Israel/Palestine: Population, Territory and Power, by David Lyon, Elia Zureik, and Yasmeen Abu-Laban, 65-79. New York: Routledge, 2010.

Boyle, Kevin, and Juliet Sheen. Freedom of Religion and Belief: A World Report. London: Routledge, 1997.

Brecher, Michael. Decisions in Israel's Foreign Policy. London: Oxford University Press, 1974.

- The Foreign Policy System of Israel: Setting, Images, Process. New Haven: Yale University Press, 1972.

Bregman, Ahron. Cursed Victory: A History of Israel and the Occupied Territories. London: Allen Lane, 2014.

Brenner, Lenni. The Iron Wall: Zionist Revisionism From Jabotinsky to Shamir. London: Zed Books, 1984. 
Brynen, Rex. "The State of the Art in Middle Eastern Studies: A Research Note on Inquiry and the American Empire." Arab Studies Quarterly 8 (1986): 404-19.

Brynen, Rex, and Neil Caplan. "The Palestinian Uprising." In Echoes of the Intifada: Regional Repercussions of the Palestinian-Israeli Conflict, edited by Rex Brynen. Boulder, Colorado: Westview Press, 1991.

Brzezinski, Zbigniew K. Ideology and Power in Soviet Politics. Westport: Greenwood Press, 1976.

"Cabinet Picks Israeli Arabs for High Posts: Mideast: Two Are Named Deputy Ministers. Appointments Are First of Their Kind in 19 Years." Los Angeles Times, August 3, 1992.

Calin, Costel. "Hawks versus Doves: The Influence of Political Ideology on the Foreign Policy Behavior of Democratic States." PhD Dissertation, University of Tennessee., 2010.

Carr, Edward Hallett. The Twenty Years' Crisis, 1919-1939: An Introduction to the Study of International Relations. Harper Perennial, 1964.

Chomsky, Noam. The Fateful Triangle: The United States, Israel and the Palestinians. London: Pluto Press, 1999.

Chowers, Eyal. "Peel Back Time: Should Israelis Revisit the Partition Plan of 1937?" Haaretz, September 6, 2012.

Christenson, Reo M., Alan S. Engel, Dan N. Jacobs, Rejai Mostafa, and Herbert Waltzer. Ideologies and Modern Politics. New York: Harper Collins, 1975.

Cohen-Almagor, Raphael. Liberal Democracy and the Limits of Tolerance: Essays in Honor and Memory of Yitzhak Rabin. Ann Arbor: University of Michigan Press, 2000.

Cohen, Raymond. "Israel's Starry-Eyed Foreign Policy." Middle East Quarterly 1, no. 2 (June 1994).

Cordesman, Anthony H., and Jennifer Moravitz. The Israeli-Palestinian War: Escalating to Nowhere. Westport: Praeger, 2005. 
Dar, Yael. "The Militarization of the Sabra: Hebrew Children's Literature Mobilized to Militarizing Its Readers." In Battle Cry and Morning After: Representations of the War of Independence in Israeli Literature, by Oded Menda-Levy and Hanna Naveh. Tel Aviv University, 2002.

Declaration of Establishment of State of Israel. Israel Ministry of Foreign Affairs, May 14, 1948. http://www.mfa.gov.il/mfa/foreignpolicy/peace/guide/pages/declaration $\% 20$ of $\% 20$ establishment $\% 20$ of\%20state $\% 20$ of\%20israel.aspx.

Deeb, Dennis J. Israel, Palestine, \& the Quest for Middle East Peace. Lanham: University Press of America, 2013.

Delaet, James C., and James M. Scott. "Treaty-Making and Partisan Politics: Arms Control and the U.S. Senate, 1960-2001." Foreign Policy Analysis 2, no. 3 (2006): 177-200.

Derfler, Leslie. Yitzhak Rabin: A Political Biography. New York: Palgrave Macmillan, 2014.

Dermer, Ron. Why the Likud Voted No to Sharon's Disengagement Plan. Jerusalem Issue Brief, May 3, 2004.

Doron, Gideon, and Rebecca Kook. "Religion and the Politics of Inclusion: The Success of the Ultra-Orthodox Parties." In The Elections in Israel, 1996, by Asher Arian and Michal Shamir. Albany: State University of New York Press, 1999.

Drory, Ze'ev. The Israel Defence Force and the Foundation of Israel:Utopia in Uniform. New York: Routledge, 2005.

Duffield, John S. "Political Culture and State Behavior: Why Germany Confounds Neorealism." International Organization 53, no. no. 4 (1999): 765-803.

Eaton, Joseph W., and Michael Chen. Influencing Youth Culture: Study Youth Organizations in Israel. Beverly Hills: SAGE Publications, 1970.

Elazar, Daniel J., and Shmuel Sandler. Israel At The Polls, 1992. Lanham: Rowmand \& Littlefield Publishers, 1995.

_. Israel at the Polls, 1996. New York: Routledge, 2013. 
Eldar, Akiva. "Peace Is Israel's Best Security Guarantee." Almonitor, August 19, 2013.

Elmer, Jon. "Remembering the Second Intifada." Aljazeera, 2011. http://www.aljazeera.com/photo_galleries/middleeast/2010103132115872 256.html.

Ettinger, Yair. "Shas Official Tells Haaretz: We're Ready to Evacuate Settlements, Back Mideast Talks." Haaretz, March 3, 2013.

Etzioni-Halevy, Eva, and Rina Shapira. Political Culture in Israel: Cleavage and Integration among Israeli Jews. London and New York: Praeger, 1977.

Farrell, William E. "Israelis, at Huge Rally in Tel Aviv, Demand Begin and Sharon Resign.” The New York Times, September 26, 1982.

Firer, Ruth. Agents of Zionist Education. Oranim, 1985.

Firestone, Reuven. "Holy War in Modern Judaism? 'Mitzvah War' and the Problem of the 'Three Vows." Journal of the American Academy of Religion 74, no. 4 (December 2006): 954-82.

Fisk, Robert. "Ariel Sharon.” The Independent, January 6, 2006.

Fordham, Benjamin. "Partisanship, Macroeconomic Policy, and the U.S. Uses of Force, 1949-1994." Journal of Conflict Resolution 42 (1998): 418-39.

Foster, Dennis M., and Glenn Palmer. "Presidents, Public Opinion, and Diversionary Behavior: The Role of Partisan Support Reconsidered." Foreign Policy Analysis 2 (2006): 269-87.

Frankel, Glenn. Beyond the Promised Land: Jews and Arabs on the Hard Road to a New Israel. New York: Touchstone, 1994.

Freedman, Samuel G. Jew Vs. Jew: The Struggle for the Soul of American Jewry. New York: Simon \& Schuster, 2000.

Friedgut, Theodor H. "Immigrants from the Former Soviet Union: Their Influence and Identity." In Israeli Identity in Transition, by Anita Shapira. Westport: Praeger, 2004. 
Friedland, Roger, and Richard Hecht. To Rule Jerusalem. Berkeley: University of California Press, 2000.

Friedman, Menachem. "Jewish Zealots: Conservative and." In Religious Radicalism and Politics in the Middle East, by Emmanuel Sivan and Menachem Friedman. New York: State University of New York Press, 1990.

- "The Structural Foundation for Religio Political Accomodation in Israel: Fallacy and Reality." In Israel: The First Decade of Independence, by Ilan Troen and Noah Lucas, 51-82. Albany: State University of New York Press, 1995.

Friedman, Robert I. Zealots for Zion: Inside Israel's West Bank Settlement Movement. New Brunswick: Rutgers University Press, 1994.

Friedman, Thomas L. "Foreign Affairs; A River Runs Through It." The New York Times, May 25, 1999.

Gabay, Nadav. "Peace Begins at Home: Toleration, Identity Politics and the Changing Conception of Peacemaking in Israel after Yitzhak Rabin's Assassination." Social Identities 12, no. 3 (May 2006).

Gal, Allon. Socialist Zionism. Cambridge, Massachusetts: Schenkman Publishing Company, 1973.

Gellman, Ezra. Essays on the Thought and Philosophy of Rabbi Kook. London: Cornwall Book, 1991.

Gelvin, James. The Israel-Palestine Conflict: One Hundred Years of War. Third Edition. Cambridge: Cambridge University Press, 2014.

Gertz, Nurith. Myths in Israeli Culture: Captives of a Dream. London: Valentine Mitchell, 2000.

Ghanem, As'ad. Ethnic Politics in Israel: The Margins and the Ashkenazi Centre. New York: Routledge, 2010.

Goddard, Stacie E. Indivisible Territory and the Politics of Legitimacy: Jerusalem and Northern Ireland. New York: Cambridge University Press, 2010. 
Goldberg, Elisheva. "Likud: The Party of Annexation." The Daily Beast, November 27, 2012.

Graebner, Norman A. America As a World Power: A Realist Appraisal from Wilson to Reagan. Lanham: Rowman \& Littlefield Publishers, 1984.

Guidelines of the Government of Israel, 17 June 1996. Israel Ministry of Foreign Affairs, June 17 , 1996. http://www.mfa.gov.il/mfa/foreignpolicy/mfadocuments/yearbook11/pages/ $2 \% 20$ address $\% 20$ in $\% 20$ the $\% 20$ knesset $\% 20$ by $\% 20$ president $\% 20$ weizman $\% 20$ on\%20t.aspx.

Gutwein, Daniel. "From Melting Pot to Multiculturalism; Or, the Privatization of Israeli Identity." In Israeli Identity in Transition, 215-33. Westport: Praeger, 2004.

Hall-Cathala, David. The Peace Movement in Israel, 1967-1987. Houndmills: Macmillan, 1990.

Halpern, Ben, and Jehuda Reinharz. Zionism and the Creation of a New Society. New York: Oxford University Press, 1998.

Hansen, Lene. Security as Practice: Discourse Analysis and the Bosnian War. London: Routledge, 2006.

Harrow, Ari. "The PM's Speech: History in the Making?" The Jerusalem Post, May 21, 2011.

Hasson, Nir. "Despite It All, Most Israelis Still Support the Two-State Solution." Haaretz, July 7, 2014.

Hauser, Emily L. "Netanyahu's Fake Jerusalem Stalls Peace." The Forward, March 24, 2014.

Hazan, Reuven Y. "The Electoral Consequences of Political Reform: In Search of the Center of the Israeli Party System." In The Elections in Israel, 1996. Albany: State University of New York Press, 1999.

Hazaz, Haim. The Sermon and Other Stories. Toby Press, 2005.

Hazony, Yoram. The Jewish State: The Struggle for Israel's Soul. New York: Basic Books, 2001. 
__. "The Zionist Idea and Its Enemies." Commentary, May 1, 1996.

Heller, Joseph. The Stern Gang: Ideology, Politics and Terror, 1940-1949. Abingdon: Routledge, 1995.

Hermann, Tamar. The Israeli Peace Movement: A Shattered Dream. Cambridge: Cambridge University Press, 2009.

Hermann, Tamar, and Yuchtman-Yaar Ephraim. "Divided yet United: IsraeliJewish Attitudes Toward the Oslo Process." Journal of Peace Research 39, no. 5 (2002).

Hersh, Seymour M. The Samson Option: Israel's Nuclear Arsenal and American Foreign Policy. New York: Random House, 2013.

Hertzberg, Arthur. The Zionist Idea: A Historical Analysis and Reader. Philadelphia: Jewish Publication Society, 1997.

Herzl, Theodor. The Jewish State. New York: Dover Publications, 1896.

Heywood, Andrew. Political Ideologies: An Introduction. Fifth. New York: Palgrave Macmillan, 2012.

Hoch, Richard L. "Sovereignty, Sanctity, and Salvation: The Theology of Rabbi Tzvi Yehudah Ha-Kohen Kook and the Actions of Gush Emunim." Shofar: An Interdisciplinary Journal of Jewish Studies 13, no. 1 (Fall 1994): 90118.

Holsti, Ole R. Public Opinion and American Foreign Policy. Ann Arbor: University of Michigan Press, 2004.

Holsti, Ole R., and James N. Rosenau. "The Domestic and Foreign Policy Beliefs of American Leaders." The Journal of Conflict Resolution 32, no. 2 (1988): 248-94.

- "The Structure of Foreign Policy Attitudes among American Leaders." The Journal of Politics 52, no. 1 (1990): 94-125.

Hopf, Ted. Social Construction of International Politics: Identities \& Foreign Policies, Moscow, 1955 and 1999. Ithaca: Cornell, 2002. 
Horovitz, David. Shalom, Friend: The Life and Legacy of Yitzhak Rabin. New York: Newmarket Press, 1996.

Hughes, Libby. Yitzhak Rabin: From Soldier to Peacemaker. Lincoln: iUniverse, 2005.

Hundley, Tom. "2 Views Of A Horror Jews In US, Israel Split Over Holocaust Lesson." Chicago Tribune, May 9, 1993.

Hunt, Michael. Ideology and U. S. Foreign Policy. New Haven: Yale University Press, 1987.

Ichilov, Orit. The Retreat from Public Education: Global and Israeli Perspectives. New York: Springer, 2009.

Ichilov, Orit, Dan Inbar, and Avriel Salomon. "Citizenship Education in Israel - A Jewish-Democratic State." Israel Affairs 11, no. 2 (April 2005).

Inbar, Efraim. "Israeli National Security, 1973-96." Annals of the American Academy of Political and Social Science 555 (1998): 62-81.

—. "Labor's Return to Power." In Israel at the Polls, 1992, by Daniel J. Elazar and Shmuel Sandler. Lanham: Rowmand \& Littlefield Publishers, 1995.

- Rabin and Israel's National Security. Washington D.C.: The Woodrow Wilson Center Press, 1999.

Inbari, Motti. Messianic Religious Zionism Confronts Israeli Territorial Compromises. Cambridge: Cambridge University Press, 2012.

Independence Day Message by Prime Minister Shamir- 7 May 1992. Volume 1112: 1988-1992. Israel Ministry of Foreign Affairs, May 7, 1992. http://mfa.gov.il/MFA/ForeignPolicy/MFADocuments/Yearbook8/Pages/27 $1 \% 20$ Independence $\% 20$ Day $\% 20$ Message $\% 20$ by $\% 20$ Prime $\% 20$ Minister $\%$ 20Sha.aspx.

"Interview with Prime Minister Netanyahu in Ha'aretz." Israeli Ministry of Foreign Affairs, November 22, 1996, Historical Documents, Volume 16: 19961997 edition. http://www.mfa.gov.il/MFA/ForeignPolicy/MFADocuments/Yearbook11/Pa 
ges/38\%20Interview\%20with\%20Prime\%20Minister\%20Netanyahu\%20in $\% 20$ Haa.aspx.

Isaac, Rael Jean. Israel Divided: Ideological Politics in the Jewish State. Baltimore: Johns Hopkins University Press, 1976.

Jabotinsky, Ze'ev. "Sha'atnez Lo Yalle Alekha." The Jewish Herald, January 21, 1938, 6.

—. The Iron Wall. Translated by Lenni Brenner, 1923.

-Writings: On the Road To Statehood. Jerusalem, 1959.

Jackson, Patrick Thaddeus, and Daniel H. Nexon. "Constructivist Realism or Realist-Constructivism?” International Studies Review 6 (2004).

Jackson, Robert, and Satoko Fujiwara. Peace Education and Religious Plurality: International Perspectives. New York: Routledge, 2008.

Jefferis, Jennifer L. Religion and Political Violence: Sacred Protest in the Modern World. New York: Routledge, 2010.

Jewish Virtual Library. CHMIELNICKI (Khmelnitski), BOGDAN. Accessed September 20 , 2014. http://www.jewishvirtuallibrary.org/jsource/judaica/ejud_0002_0004_0_042 59.html.
- http://www.jewishvirtuallibrary.org/jsource/judaica/ejud_0002_0008_0_086 55.html.

Johnston, Larry. Ideologies: An Analytic and Contextual Approach. Peterborough, Ontario: Broadview Press, 1995.

Kacowicz, Arie M. "Rashomon in the Middle East: Clashing Narratives, Images, and Frames in the Israeli-Palestinian Conflict." Cooperation and Conflict 40, no. 3 (2005): 343-60.

Kalpowitz, Noel. "Psycho Political Dimensions of the Middle East Conflict." Journal of Conflict Resolution 20 (1976). 
Kaplan, Eran. The Jewish Radical Right Revisionist Zionism and Its Ideological Legacy. Madison: The University of Wisconsin Press, 2005.

Karpin, Michael, and Ina Friedman. Murder in the Name of God: The Plot to Kill Yitzhak Rabin. New York: Henry Holt and Company, 1998.

Karsh, Efraim. From Rabin to Netanyahu: Israel's Troubled Agenda. Abingdon: Frank Cass and Co., 2004.

Katzenstein, Peter J. ed. The Culture of National Security. Norms and Identity in World Politics. New York: Columbia University Press, 1996.

Katz, Shmuel. Lone Wolf: A Biography of Vladimir (Ze'Ev) Jabotinsky. New Jersey: Barricade Books, 1996.

Kennan, George F. American Diplomacy. Chicago: University of Chicago Press, 1985.

Kifner, John. "Hussein Surrenders Claims on West Bank to the PLO; US Peace Plan in Jeopardy." The New York Times, August 1, 1988.

Kimmerling, Baruch. "The Elections as a Battleground over Collective Identity." In The Elections in Israel, 1996, by Asher Arian and Michal Shamir. New York: State University of New York Press, 1999.

- The Invention and Decline of Israeliness: State, Society, and the Military. Berkeley: University of California Press, 2001.

Kipnis, Yigal. The Golan Heights: Political History, Settlement and Geography since 1949. New York: Routledge, 2013.

Klein, Uta. "Our Best Boys': The Gendered Nature of Civil-Military Relations in Israel." Men and Masculinities 2, no. 47 (1999).

Klein, Zeev. "Report: More than Half of New Pupils Will Be Haredi or Arab by 2019." Israel Hayom, August 7, 2013.

Klingemann, Hans-Dieter, Richard Hofferbert, and lan Budge. Parties, Policies, and Democracy. Boulder: Westview, 1994.

Kramer, Michael. "The Political Interest Nobody Does Nothing Better Than Shamir." Time Magazine, September 30, 1991. 
Krauthammer, Charles. "Momentous Move By Netanyahu's Likud Government Is Largely Ignored By The West Some Say The Plan Is Not Forthcoming Enough. But They Miss The Principles Conceded." Philly.com, June 16, 1997. http://articles.philly.com/1997-06-16/news/25526459_1_netanyahuplan-land-of-israel-party-benjamin-netanyahu.

Laqueur, Walter. A History of Zionism: From the French Revolution to the Establishment of the State of Israel. New York: Tauris Parke Paperbacks, 2003.

Lazaroff, Tovah. "More Settlers Voted for Bayit Yehudi, Data Shows." The Jerusalem Post, March 22, 2015.

Levin, Kenneth. The Os/o Syndrome: Delusions of a People Under Siege. Smith and Kraus, 2005.

Levinson, Chaim. "Former Jewish Underground Convict Receives More than NIS 1.3 Million from State." Haaretz, February 13, 2013.

Levinson, Chaim, and Yair Ettinger. "Rabbi Kook's Followers Are Still Debating His Legacy." Haaretz, March 11, 2012. http://www.haaretz.com/printedition/features/rabbi-kook-s-followers-are-still-debating-his-legacy1.417753 .

Levy, Gideon. "Shulamit Aloni: The Great Woman of the Dreams." Haaretz, January 26, 2014.

Lewis, Samuel W., and Yoram Peri. "Generals in the Cabinet Room: Foreword." In Generals in the Cabinet Room. Washington: United States Institute of Peace Press, 2006.

Lippmann, Walter. The Cold War: A Study In U.S. Foreign Policy. New York: Harper, 1947.

Lobell, Steven E., Norrin M. Ripsman, and Jeffrey W. Taliaferro. Neoclassical Realism, the State, and Foreign Policy. Cambridge: Cambridge University Press, 2009.

Lochery, Neill. The Israeli Labor Party: In the Shadow of the Likud. Berkshire: Ithaca Press, 1997. 
Lockman, Zachary. Comrades and Enemies: Arab and Jewish Workers in Palestine, 1906-1948. Berkeley: University of California Press, 1996.

Lockman, Zachary, and Joel Beinin, eds. Intifada. Cambridge, Massachusetts: South End Press, 1989.

Lustick, Ian. For the Land and the Lord: Jewish Fundamentalism in Israel. New York: Council on Foreign Relations Press, 1988.

Maoz, Zeev. Defending the Holy Land: A Critical Analysis of Israel's Security \& Foreign Policy. Ann Arbor: University of Michigan Press, 2009.

Martin, Patrick. "We Are the Only Country That Is Threatened to Be Destroyed." The Globe and Mail, May 5, 2012.

Marx, Karl, and Friedrich Engels. The Communist Manifesto. New York: Penguin Classics, 2011.

Masalha, Nur. Expulsion of the Palestinians: The Concept of "Transfer" in Zionist Political Thought, 1882-1948. Washington D.C.: Institute for Palestine Studies, 1992.

Mazal, Mualem. "Israel Mourns Shulamit Aloni, Champion of Feminism in Israeli Politics.” Al-Monitor, January 24, 2014.

McCormick, James M., and Eugene R. Wittkopf. "Bipartisanship, Partisanship, and Ideology in Congressional-Executive Foreign Policy Relations, 19471988." Journal of Politics 52 (1990): 1077-1100.

Mearsheimer, John, and Stephen M. Walt. The Israel Lobby and US Foreign Policy. London: Allen Lane Books, 2007.

Medding, Peter Y. Mapai in Israel: Political Organisation and Government in a New Society. Cambridge: Cambridge University Press, 1972.

Mendilow, Jonathan. Ideology, Party Change, and Electoral Campaigns in Israel, 1965-2001. Albany: State University of New York Press, 2003.

—. "The Likud's Double Campaign: Between the Devil and the Deep Blue Sea." In The Elections in Israel, 1996. Albany: State University of New York Press, 1999. 
Meydani, Assaf. Political Transformations and Political Entrepreneurs: Israel in Comparative Perspective. New York: Palgrave Macmillan, 2009.

Miller, Elhanan. "Two Decades after Massacre, Hebron Is Still Hurting Read More: Two Decades after Massacre, Hebron Is Still Hurting | The Times of Israel." The Times of Israel, February 25, 2014.

Mirsky, Yehudah. Rav Kook: Mystic in a Time of Revolution. New Haven: Yale University Press, 2014.

Mordechai, Sarig, Shimshon Feder, and Daniel Carpi. The Political and Social Philosophy of Ze'ev Jabotinsky: Selected Writings. Portland: Vallentine Mitchell, 1999.

Morgenthau, Hans. Politics Among Nations: The Struggle for Power and Peace. 6th ed. New York: McGraw Hill, 1948.

Morley, Jefferson. "Israeli Withdrawal From Gaza Explained." The Washington Post, August 10, 2005.

Morris, Benny. Righteous Victims: A History of the Zionist-Arab Conflict 18812001. New York: Vintage Books, 2001.

"Moser." Jewish Encyclopedia. Accessed October 25, 2014. http://www.jewishencyclopedia.com/articles/11047-moser.

Naor, Mordecai. Zionism The First 120 Years 1882 - 2002. The Jewish Agency, 2014.

http://www.jafi.org.il/JewishAgency/English/Jewish+Education/Compelling +Content/Eye+on+Israel/120/Chapter+Three+From+Political+Zionism+to+ +Synthetic+Zionism.htm.

Narang, Vipin. Nuclear Strategy in the Modern Era: Regional Powers and International Conflict. Princeton: Princeton University Press, 2014.

Nativ. Volume 19, Number 6 (113). Ariel Center for Policy Research, November 2006. www.acpr.org.il/nativ_e/113-nativ-toc.htm.

Netanyahu, Benjamin. A Place Among the Nations: Israel and the World. New York: Bantam Books, 1993. 
Newman, David. Impact of Gush Emunim: Politics and Settlement in the West Bank. London: Croom Helm, 1985.

- "Territorial Discontinuity and Palestinian Autonomy: Implementing the Oslo II Agreement." IBRU Boundary and Security Bulletin, Winter -1996 1995.

Newman, Louis E. Jewish Choices, Jewish Voices: War and National Security. Philadelphia: Jewish Publication Society, 2010.

Omer-Man, Michael. "This Week in History: Israel's Last Direct Election." The Jerusalem Post, February 5, 2012.

Oz, Amos. In the Land of Israel. Orlando: Harcourt Book, 1993.

Palmer, Glenn H., Tamar R. London, and Patrick M. Regan. "What's Stopping You?: The Sources of Political Constraints on International Conflict Behavior in Parliamentary Democracies." International Interactions 30 (2004): 1-24.

Pappe, Ilan. The Ethnic Cleansing of Palestine. Oxford: Oneworld Publications, 2007.

Parks, Michael. "Israel's Rabin Scolds Official for Call to Give Up Golan : Politics: To Retain Parliamentary Majority, Prime Minister Stops Short of Firing Education Minister." Los Angeles Times, September 28, 1992.

Pedahzur, Ami, and Arie Perliger. Jewish Terrorism in Israel. New York: Columbia University Press, 2009.

Peleg, Ilan. "The Peace Process and Israel's Political Kulturkampf." In In The Middle East Peace Process: Interdisciplinary Perspectives, 237-63. New York: SUNY Press, 1998.

Peleg, Ilan, and Dov Waxman. Israel's Palestinians: The Conflict Within. Cambridge: Cambridge University Press, 2011.

Peleg, Samuel. Zealotry and Vengeance: Quest of a Religious Identity Group. Lanham: Lexington Books, 2002.

Peres, Shimon. Ben-Gurion: A Political Life. New York: Schocken Book, 2011. 
Peres, Shimon, and Robert Littell. For the Future of Israel. Baltimore: Johns Hopkins University Press, 1998.

Peri. The Assassination of Yitzhak Rabin. Stanford: Stanford University Press, 2000.

Peri, Yoram. Between Battles and Ballots: Israeli Military in Politics. Cambridge: Cambridge University Press, 1983.

—. "The Assassination: Causes, Meaning, Outcomes." In The Assassination of Yitzhak Rabin. Stanford: Stanford University Press, 2000.

Petraeus, David. Statement of General David H. Petraeus, Before the Senate Armed Services Committee. Senate Armed Services Committee, March 16, 2010.

Pinsker, Leon. Auto-Emancipation, 1882. https://www.jewishvirtuallibrary.org/jsource/Zionism/pinsker.html.

Plamenatz, John Petrov. Ideology. London: Macmillan, 1971.

Prittie, Terence. Eshkol; the Man and the Nation. New York: Putman, 1969.

"Rabbi Calls for Annihilation of Arabs." BBC News, April 10, 2001.

Rabinovich, Itamar, and Jehuda Reinharz. Israel in the Middle East: Documents and Readings on Society, Politics, and Foreign Relations, Pre-1948 to the Present. Lebanon: Brandeis University Press, 2008.

Rabin, Yitzhak. Address to the Knesset by Prime Minister Rabin Presenting His Government- 13 July 1992. Israel Ministry of Foreign Affairs, July 13, 1992.

http://www.mfa.gov.il/mfa/foreignpolicy/mfadocuments/yearbook9/pages/1 $\% 20 \% 20$ address $\% 20$ to $\% 20$ the $\% 20$ knesset $\% 20$ by $\% 20$ prime $\% 20$ minister $\% 20$ rabin.aspx.

- Policy Statement by Prime Minister Yitzhak Rabin to the Knesset Oct 3, 94. Israel Ministry of Foreign Affairs, October 3, 1994. http://mfa.gov.il/MFA/PressRoom/1994/Pages/POLICY\%20STATEMENT \%20BY\%20PRIME\%20MINISTER\%20YITZHAK\%20RABIN\%20T.aspx. 
- Statement in the Knesset by Prime Minister Rabin on the Hebron Murders- 28 February 1994. Israel Ministry of Foreign Affairs, February 28, 1994. http://www.mfa.gov.il/MFA/ForeignPolicy/MFADocuments/Yearbook9/Pag es $/ 168 \% 20$ Statement $\% 20$ in $\% 20$ the $\% 20$ Knesset $\% 20$ by $\% 20$ Prime $\% 20$ Mini ster\%20Rab.aspx.

—. The Rabin Memoirs. Berkeley: University of California Press, 1996.

Rachlevsky, Sefi. "The Extremist Rabbi Who Reigns Unobstructed." Haaretz, May 11, 2013.

Rathbun, Brian. "A Rose by Any Other Name: Neoclassical Realism as the Logical and Necessary Extension of Structural Realism." Security Studies 17 (2008): 294-321.

—. "Contesting the National Interest." PhD Dissertation, University of California at Berkeley, 2002.

Ravitzky, Aviezer. "Let Us Search Our Path': Religious Zionism After the Assassination." In The Assassination of Yitzhak Rabin, by Yoram Peri. Stanford: Stanford University Press, 2000.

—. Messianism, Zionism, and Jewish Religious Radicalism. Translated by Michael Swirsky and Jonathan Chipman. Chicago: University Of Chicago Press, 1996.

Ripsman, Norrin M. "Neoclassical Realism and Domestic Interest Groups." In Neoclassical Realism, the State, and Foreign Policy, by Steven E. Lobell, Norrin M. Ripsman, and Jeffrey W. Taliaferro, 170-93. Cambridge: Cambridge University Press, 2009.

Rose, Gideon. "Neoclassical Realism and Theories of Foreign Policy." World Politics 51 (1998): 144-72.

Rosen, Steven J. "Israeli Settlements, American Pressure, and Peace." The Jerusalem Center for Public Affairs, May 4, 2012.

Rosman-Stollman, Elisheva. For God and Country?: Religious Student-Soldiers in the Israel Defense Forces. Austin: University of Texas, 2014. 
Rosner, Shmuel. "Children of Israel." The New York Times, August 28, 2013.

Rubin, Barry. Israel: An Introduction. New Haven: Yale University Press, 2012.

Rubinstein, Amnon. From Herzl to Rabin: The Changing Image of Zionism. New York: Holmes \& Meier Publishers, 2000.

—_. "Post-Zionism." Commentary, October 1, 1996.

Russett, Bruce. "Doves, Hawks, and U.S. Public Opinion." Political Science Quarterly 105, no. 4 (1990): 515-38.

Rynhold, Jonathan. "Cultural Shift and Foreign Policy Change: Israel and the Making of the Oslo Accords." Cooperation and Conflict 42 (2007): 419-40.

Rynhold, Jonathan, and Dov Waxman. "Ideological Change and Israel's Disengagement from Gaza." Political Science Quarterly 123, no. 1 (2008): $11-37$.

Saad, Lydia, and Elizabeth Mendes. "Israelis, Palestinians Pro Peace Process, but Not Hopeful." Gallup, March 21, 2013.

Sachar, Howard M. A History of Israel: From the Rise of Zionism to Our Time. 3rd ed. Alfred A. Knopf, 2007.

Said, Edward W. Peace and Its Discontents: Essays on Palestine in the Middle East Peace Process. London: Vintage Books, 1996.

Samet, Gideon. "The Collapse of the Common Denominator." Haaretz, April 10, 1998.

Saposnik, Arieh Bruce. Becoming Hebrew: The Creation of a Jewish National Culture in Ottoman Palestine. Oxford: Oxford University Press, 2008.

Sarfati, Yusuf. Mobilizing Religion in Middle East Politics: A Comparative Study of Israel. Routledge, 2014.

Sasley, Brent E. "Israel's Tangled Democracy Why Governments Will Keep Falling." Foreign Affairs, December 3, 2014.

Scheindlin, Dahlia. "Are Israelis Ready for a Confederated Two-State Solution?" +972 Magazine, January 4, 2015. 
Schlesinger, Arthur. "Foreign Policy and the American Character." Foreign Affairs 62, no. 1 (Fall 1983).

Schonberg, Karl K . Constructing 21st Century U.S. Foreign Policy. New York: Palgrave Macmillan, 2009.

Schultz, Kenneth. Democracy and Coercive Diplomacy. Cambridge: Cambridge University Press, 2001.

- "The Politics of Risking Peace: Do Hawks or Doves Deliver the Olive Branch?” International Organization 59 (2005): 1-38.

Schwartz, Barry, Yael Zerubavel, and Bernice Barnett. "The Recovery of Masada: A Study in Collective Memory." Sociological Quarterly 27, no. 2 (1986): 147-64.

Schwartz, Dov. Religious Zionism: History and Ideology. Boston: Academic Studies Press, 2009.

Segev, Tom. One Palestine, Complete: Jews and Arabs Under the British Mandate. New York: Holt Paperbacks, 2001.

- The Seventh Million: The Israelis and the Holocaust. Translated by Haim Watzman. New York: Holt Paperbacks, 1991.

Seliktar, Ofira. New Zionism and the Foreign Policy System of Israel. Carbondale: Southern Illinois University Press, 1986.

- "Socialization of National Ideology: The Case of Zionist Attitudes among Young Israelis." Political Psychology 2, no. 3-4 (1980): 66-94.

Settlement Populations in the Occupied Territories, 1972-2000. Foundation for Middle East Peace. Accessed June 2, 2014. http://www.fmep.org/settlement_info/settlement-info-and-tables/statsdata/settlement-populations-in-the-occupied-territories-1972-2000.

Shalev, Michael. Labor and the Political Economy in Israel. Oxford: Oxford University Press, 1992.

- "The Labor Movement in Israel Ideology and Political Economy." In The Social History of Labor in the Middle East, Edited by Ellis J. Goldberg., 131-61. Boulder Colorado: Westview, 1996. 
Shalom Chetrit, Sami. Intra-Jewish Conflict in Israel: White Jews, Black Jews. New York: Routledge, 2010.

Shamir, Yitzhak. Summing Up: An Autobiography. London: Weidenfeld and Nicholson, 1994.

Shapira, Anita. Land and Power: The Zionist Resort to Force, 1881-1948. Stanford: Stanford University Press, 1999.

—. "Whatever Became of 'Negating Exile'?." In Israeli Identity in Transition. Westport: Praeger, 2004.

Shapiro, Yonathan. The Formative Years of the Israeli Labour Party: The Organization of Power, 1919-1930. New York: SAGE Publications, 1976.

- The Road to Power: Herut Party in Israel. Albany: State University of New York Press, 1991.

Sharon, Jeremy. "UTJ Weighs Backing Aggressive Peace Agenda." The Jerusalem Post, February 17, 2013.

"Shas Spiritual Leader: Abbas and Palestinians Should Perish." Haaretz, August 29, 2010.

Shavit, Yaacov. Jabotinsky and the Revisionist Movement 1925-1948. London: Frank Cass and Co., 1988.

Sheffer, Gabi. In the Wake of the Peace Process: Changes in Ideology and Political Orientation in Israel and the Palestinian Community. Tel-Aviv: Tami Steinmetz Center for Peace Research. Tel-Aviv University., 2000.

Shehadeh, Raja. "Israel and the Palestinians: Human Rights in the Occupied Territories." In Echoes of the Intifada: Regional Repercussions of the Palestinian-Israeli Conflict, edited by Rex Brynen. Boulder Colorado: Westview Press, 1991.

Shelef, Nadav. Evolving Nationalism: Homeland, Identity, and Religion in Israel, 1925-2005. Ithaca: Cornell University Press, 2010.

Sheleg, Yair. The Political and Social Ramifications of Evacuating Settlements in Judea, Samaria and the Gaza Strip. The Israel Democracy Institute, October 2004. 
Sherwood, Harriet. "Likud Members Call for Israeli Annexation of West Bank Territories." The Guardian, January 2, 2013.

Shindler, Colin. The Land Beyond Promise: Israel, Likud and the Zionist Dream. London and New York: I.B. Tauris, 2002.

- Triumph of Military Zionism: Nationalism and the Origins of the Israeli Right. London: I.B. Tauris, 2006.

Shlaim, Avi. Collusion Across the Jordan: King Abdullah, the Zionist Movement, and the Partition of Palestine. New York: Columbia University Press, 1988.

- The Iron Wall: Israel and the Arab World. New York: Norton and Company, 2001.

- The Iron Wall: Israel and the Arab World (Updated and Expanded). New York: W.W. Norton, 2014.

Silverstein, Richard. Emil Grunzweig's Assassin: "I Killed the Israeli Left." Tikun Olam, July 26, 2011.

"Sixth Zionist Congress: Basel 23 - 28 August 1903." Herzl Museum, n.d. http://www.herzl.org/english/Article.aspx?ltem=543.

Smith, Lee. "Have Obama and Bibi Made Up?," December 5, 2012. http://www.tabletmag.com/jewish-news-and-politics/118288/have-obamaand-bibi-made-up.

Sofer, Sasson. "International Relations and the Invisibility of Ideology." Millennium: Journal of International Studies 16, no. 3 (1987): 489-521.

- Zionism and the Foundation of Israeli Diplomacy. Cambridge: Cambridge University Press, 1998.

Spiegel, Steven L. The Other Arab-Israeli Conflict: Making America's Middle East Policy, from Truman to Reagan. Chicago: University Of Chicago Press, 1986.

Sprinzak, Ehud. "Israel's Radical Right and the Countdown to the Rabin Assassination." In The Assassination of Yitzhak Rabin. Stanford: Stanford University Press, 2000. 
- The Ascendance of Israel's Radical Right. Oxford: Oxford University Press, 1991.

Steinberg, Gerald M. "A Nation That Dwells Alone? Foreign Policy in the 1992 Elections." In Israel at the Polls, 1992, by Daniel J. Elazar and Shmuel Sandler. Lanham: Rowmand \& Littlefield Publishers, 1995.

Sternhell, Zeev. The Founding Myths of Israel: Nationalism, Socialism, and the Making of the Jewish State. Princeton: Princeton University Press, 1998.

Stone, Russell A, Louis Guttman, and Levy Shlomit. Social Change in Israel: Attitudes and Events, 1967-1979. New York: Praeger, 1982.

Sucharov, Mira. The International Self. Albany: State University of New York Press, 2005.

Sulfaro, Valerie A. "The Role of Ideology and Political Sophistication in the Structure of Foreign Policy Attitudes." American Politics Research 24 (1996): 303.

Swisher, Clayton E. The Truth About Camp David: The Untold Story About the Collapse of the Middle East Peace Process. New York: Nation Books, 2004.

Tauber, Daniel. "The Rise and Fall of Kadima: A Cautionary Tale." The Jerusalem Post, October 31, 2012.

Taub, Gadi. The Settlers and the Struggle over the Meaning of Zionism. New Haven: Yale University Press, 2011.

Tessler, Mark A. A History of the Israeli-Palestinian Conflict. Bloomington: Indiana University Press, 1994.

- "The Intifada and Political Discourse in Israel." Journal of Palestine Studies 19, no. 2 (Winter 1990): 43-61.

The Central Elections Committee. Final Official Results of the Elections for the Nineteenth Knesset, 2013. http://www.bechirot.gov.il/elections19/eng/list/results_eng.aspx.

The Israel Democracy Institute. The Peace Index Report: April 2012, April 2012. 
The Knesset. Elections to the Fourteenth Knesset, May 29, 1996. http://knesset.gov.il/description/eng/eng_mimshal_res14.htm.

- Elections to the Nineteenth Knesset, January 22, 2013. http://knesset.gov.il/description/eng/eng_mimshal_res19.htm.

- Elections to the Thirteenth Knesset, June 23, 1992. http://knesset.gov.il/description/eng/eng_mimshal_res13.htm.

- Elections to the Twelfth Knesset, November 1, 1988. http://knesset.gov.il/description/eng/eng_mimshal_res12.htm.

- Knesset Elections Results, 2013. http://knesset.gov.il/description/eng/eng_mimshal_res.htm.

“The Officers' Letter - March 1978." Peace Now. Accessed September 22, 2014. http://peacenow.org.il/eng/content/officers-letter-march-1978.

Thérien, Jean P., and Alain Noel. "Political Parties and Foreign Aid." The American Political Science Review 94, no. 1 (2000): 151-62.

Torrance, John. Karl Marx's Theory of Ideas. Cambridge: Cambridge University Press, 2008.

Trabelsi-Hadad, Tamar. "Israeli Classrooms among World's Most Crowded." Ynet News, May 10, 2009.

United Nations Office for the Coordination of Humanitarian Affairs. IsraeliPalestinian Fatalities Since 2000 - Key Trends. United Nations Office for the Coordination of Humanitarian Affairs, August 2007. http://unispal.un.org/UNISPAL.NSF/0/BE07C80CDA45794685257348005 00272.

Van Der Vyver, Johan D., and John Witte. Religious Human Rights in Global Perspective: Religious Perspectives, Volume 1. Cambridge: Kluwer Law International, 1996.

Vital, David. Origins of Zionism. New York: Oxford University Press, 1980.

_. Zionism: The Formative Years. New York: Oxford University Press, 1989. 
Walt, Stephen M. "News Flash: WINEP Defends the 'Special Relationship." Foreign Policy, November 9, 2011. November 28, 2012. http://walt.foreignpolicy.com/posts/2011/11/08/news_flash_winep_defends _the_special_relationship.

Waxman, Dov. The Pursuit of Peace and the Crisis of Israeli Identity. New York: Palgrave, 2006.

Weinberg, Leonard, and Ami Pedahzur. Religious Fundamentalism and Political Extremism. London: Frank Cass and Co., 2004.

Weiner, Rex. "Extradited to L.A., the Abergils Get Ready To Face the Music." Forward, March 2, 2011.

Weissbrod, Lilly. "Gush Emunim Ideology: From Religious Doctrine to Political Action." Middle Eastern Studies 18, no. 3 (1982).

Wendt, Alexander. Social Theory of International Politics. Cambridge: Cambridge University Press, 1999.

Wittkopf, Eugene R. Faces of Internationalism: Public Opinion and American Foreign Policy. Duke University Press, 1990.

Yablonka, Hanna, and Zvi Zameret. The first decade - 1948-1958. Jerusalem: Yad Ben-Zvi, 1997.

Yellen-Shtaklis, Miriam. "Prayer." Davar Le-Yeladim 10, no. 8 (1940): 9.

Yishai, Yael. Land or Peace: Whither Israel?. Stanford: Hoover Institution Press, 1987.

"Youth Movements." Israeli Ministry of Foreign Affairs, August 4, 1998. http://mfa.gov.il/mfa/aboutisrael/history/pages/youth\%20movements.aspx.

Zanotti, Jim. Israel: Background and U.S. Relations. Congressional Research Service, 2012.

Zelikovich, Yaheli Moran. "OCED Report Paints Bleak Picture of Israeli Education." Ynet News, 09/092008.

Zertal, Idith. Israel's Holocaust and the Politics of Nationhood. Cambridge: Cambridge University Press, 2005. 
Zertal, Idith, and Akiva Eldar. Lords of the Land: The War Over Israel's Settlements in the Occupied Territories, 1967-2007. New York: Nation Books, 2007.

Zerubavel, Yael. Recovered Roots: Collective Memory and the Making of Israeli National Tradition. Chicago: University Of Chicago Press, 1997.

Zieve, Tamara. "This Week In History: Masses Protest Sabra, Shatila." The Jerusalem Post, September 23, 2012.

Zohar, Zion. Sephardic and Mizrahi Jewry: From the Golden Age of Spain to Modern Times. New York: New York University Press, 2005. 